راطاساتواوكتوروزارت

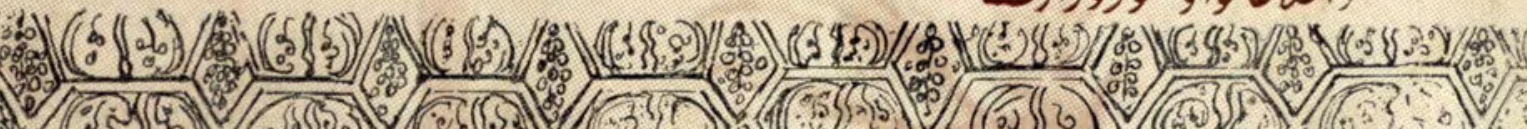

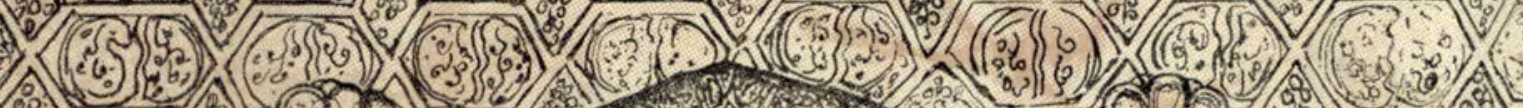

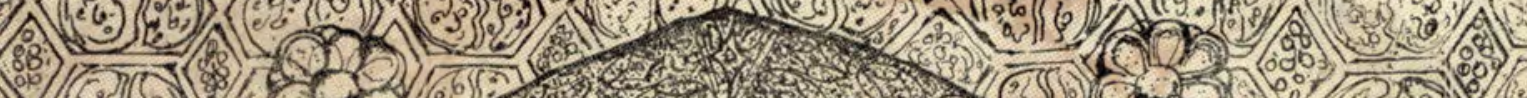
(165) 30$)(0.6)$ (i) (6) (2. (1) (1) (3) sere (6)

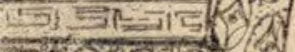
$0.0003 \%$

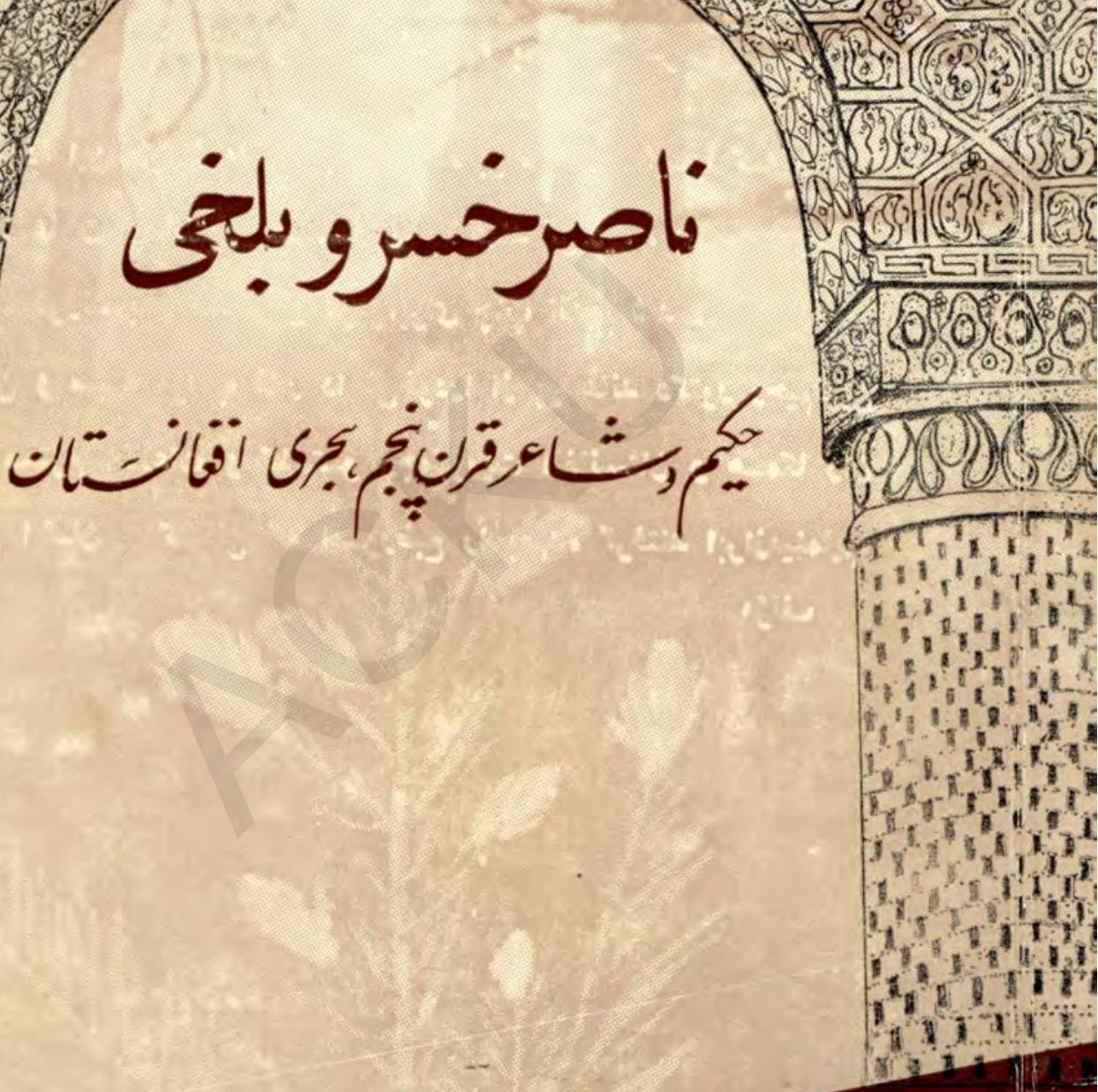
1) $9: 0.9$

) 00 (1) $3 x^{2}+17 \%$ $e^{2} x^{3} x^{2} x_{1}, 1$

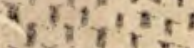

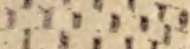
$2, \frac{3}{8}, 2^{2}, 3,3$

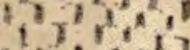

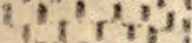

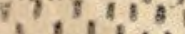

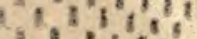
$8^{3} y^{2}+2,8,3$ $\left(x^{3} y^{3}+x^{8}\right)^{2} a^{2}=$

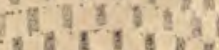

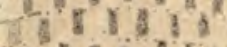
$80_{0} b_{4}+21$

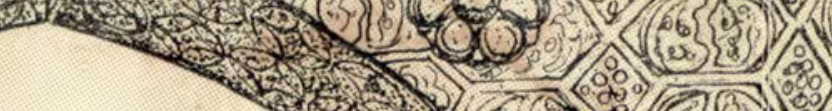
8. (cos)

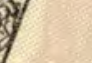


بنامخداو نل بخشاينده بخشايشكر.

مسودة اين اثر از مدتى تهــيه شمده بود، ولسى اخيسراً كـه وزارت

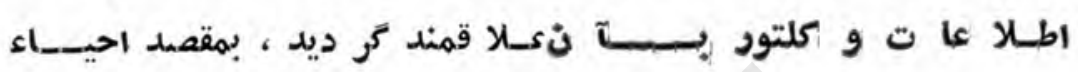

$$
\text { نام يك فرزند برو مند وطن عزيز،براى حاب تقديم شد . }
$$

باين و سيله مراتب قدر دا نىخودرا از يو هاند دكتود رحيمنوين وزير مجترم اطلاعات و كلـتسو رجمهوريت افغانستان و هــمكا ران كرامى ايشان و كسانى كه امسورطبع را بعهده كرفتند ابرازمينمايم. مؤلف

تذكر: ترسيم صمفحة اول هشتىاز روى بقا ياى مس-جد ح-ج يباده

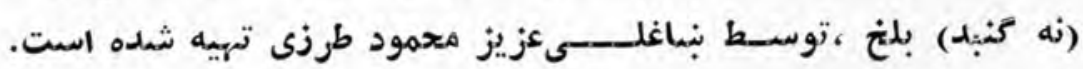
(اين مسجد جامع در زمان ناصـــر خسرو بلخى آباد بوده است ). 
AFGHANISTAN CENTRE AT KABUL UNIVERSTY
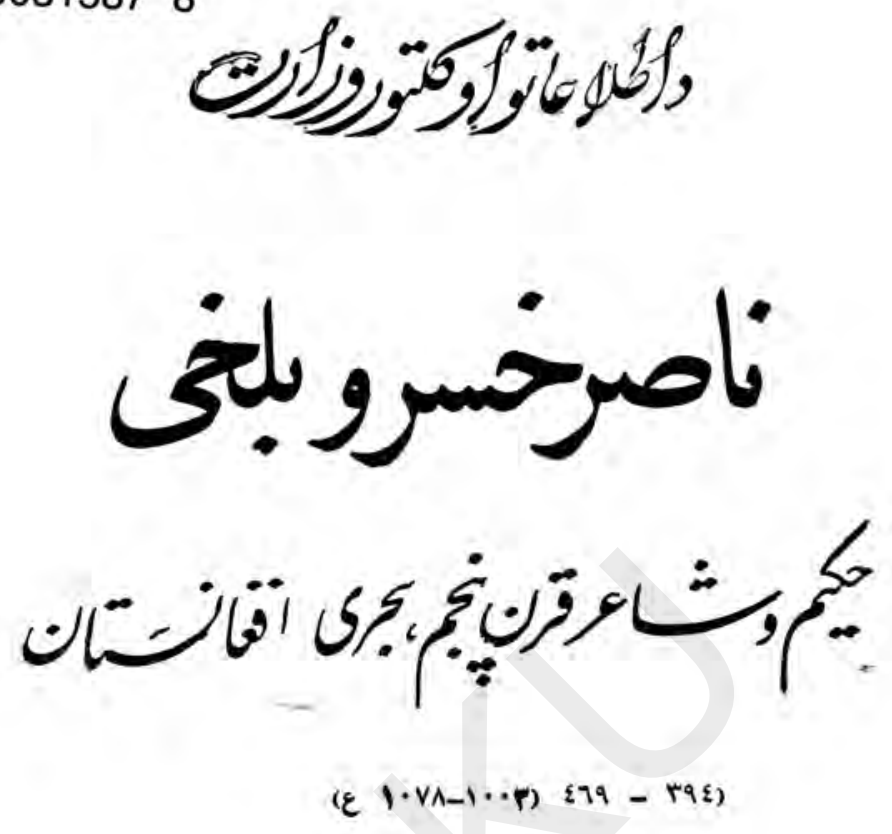

$$
\text { ( } \varepsilon 1 \cdot v \Lambda-1 \cdot \cdots) \varepsilon 79-r q \varepsilon)
$$

$$
\begin{aligned}
& \text { 'ئل } \\
& \text { عبّال بإمحورطزى }
\end{aligned}
$$


ائباد عصر تر كدوىبر ديار بلـن بكذربهخانة منوآنجا بجوىحال

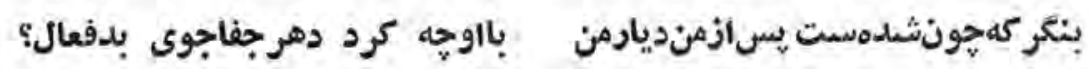
(ناصر خسرو بلخى) 


\section{زفز}

وزارت اطلاعات وكلتور مسرت دارد، براى نخستين بار كتابى دادربارة

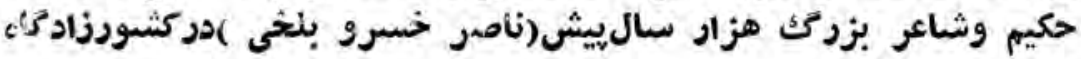

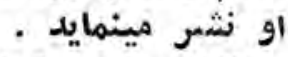

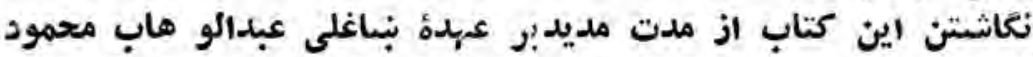

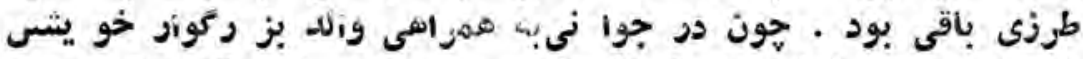

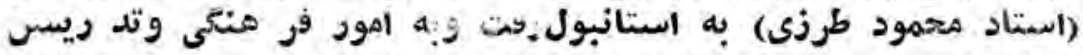

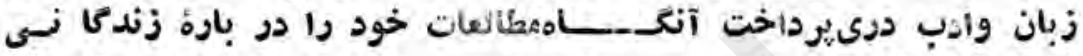

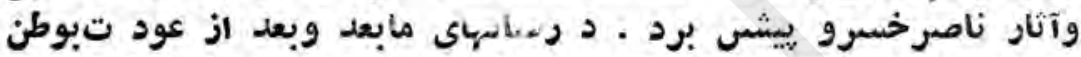

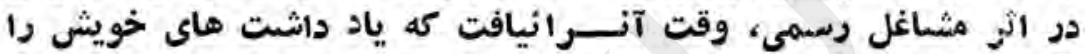

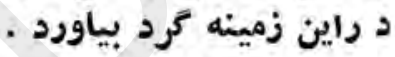

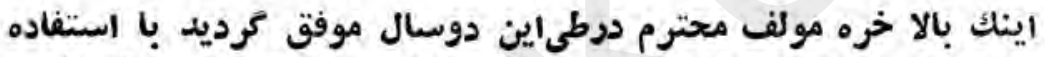

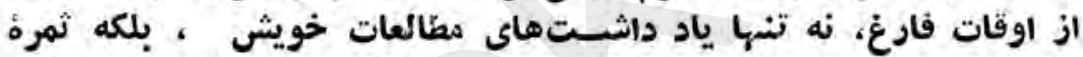

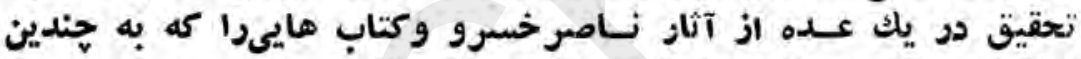

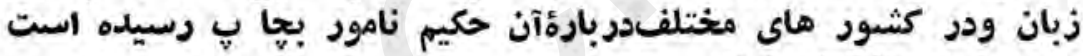

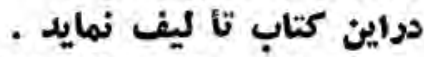

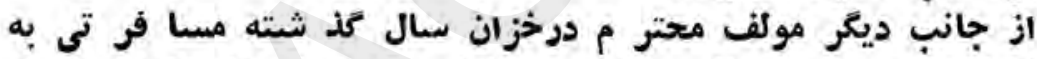

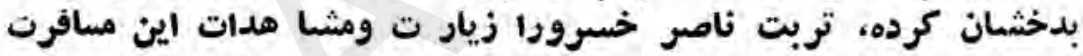

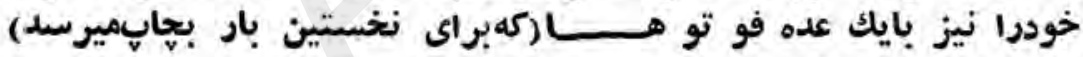

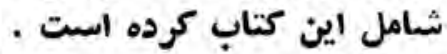

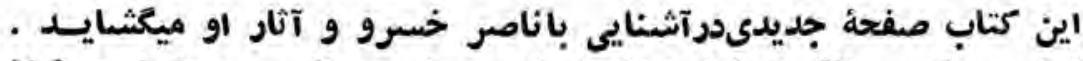

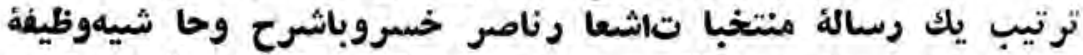

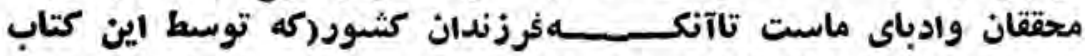

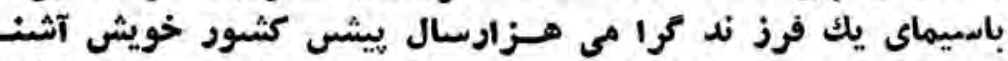

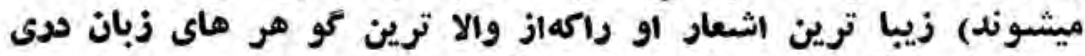

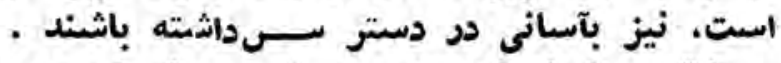

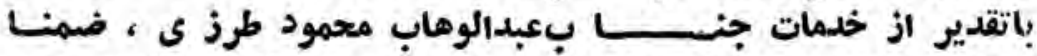

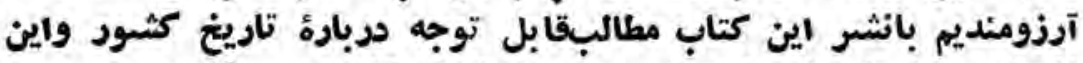

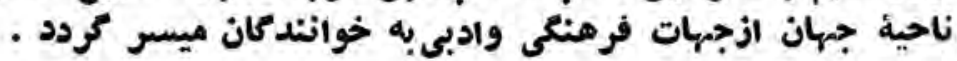

( يوهاند دكتورنوين) (ئن) 


\section{فهرست سفمرجات}

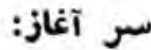

فصل اول: نكا هير زند كا نىناصر خسروبلغى : ا-روايات متداو ل درين باره

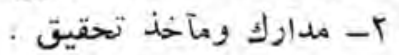

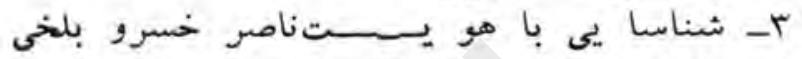

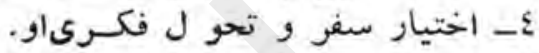

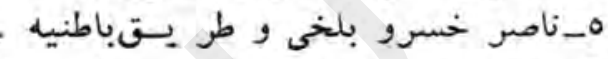

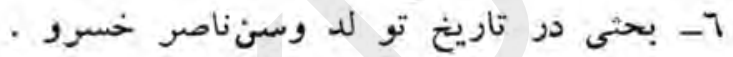

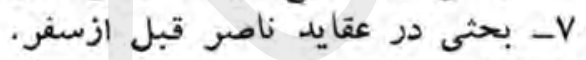

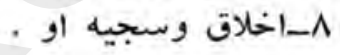

فصل دو م :جريان فكر ىباطنيانوطريق اسماعيليه :

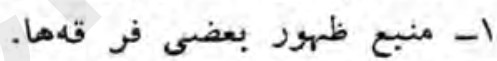

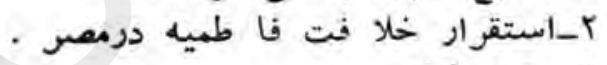

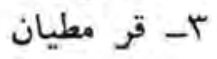

(صفت لحسا، اقتباس از سفـر نامه ) .

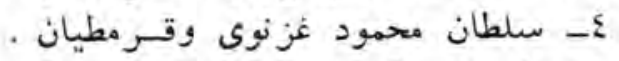

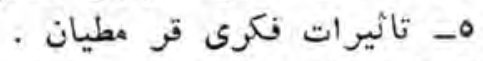

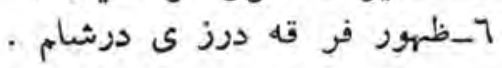

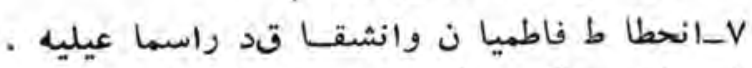

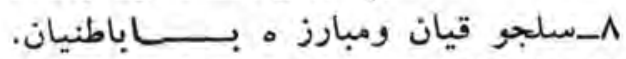

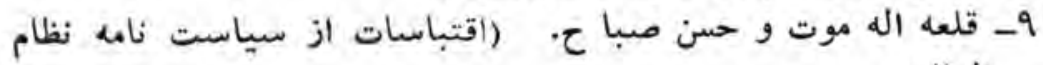
الملك)

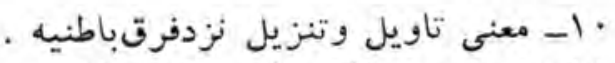

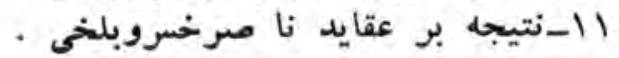


فصل سوم: مؤلفات ناصر خسروبلغى :

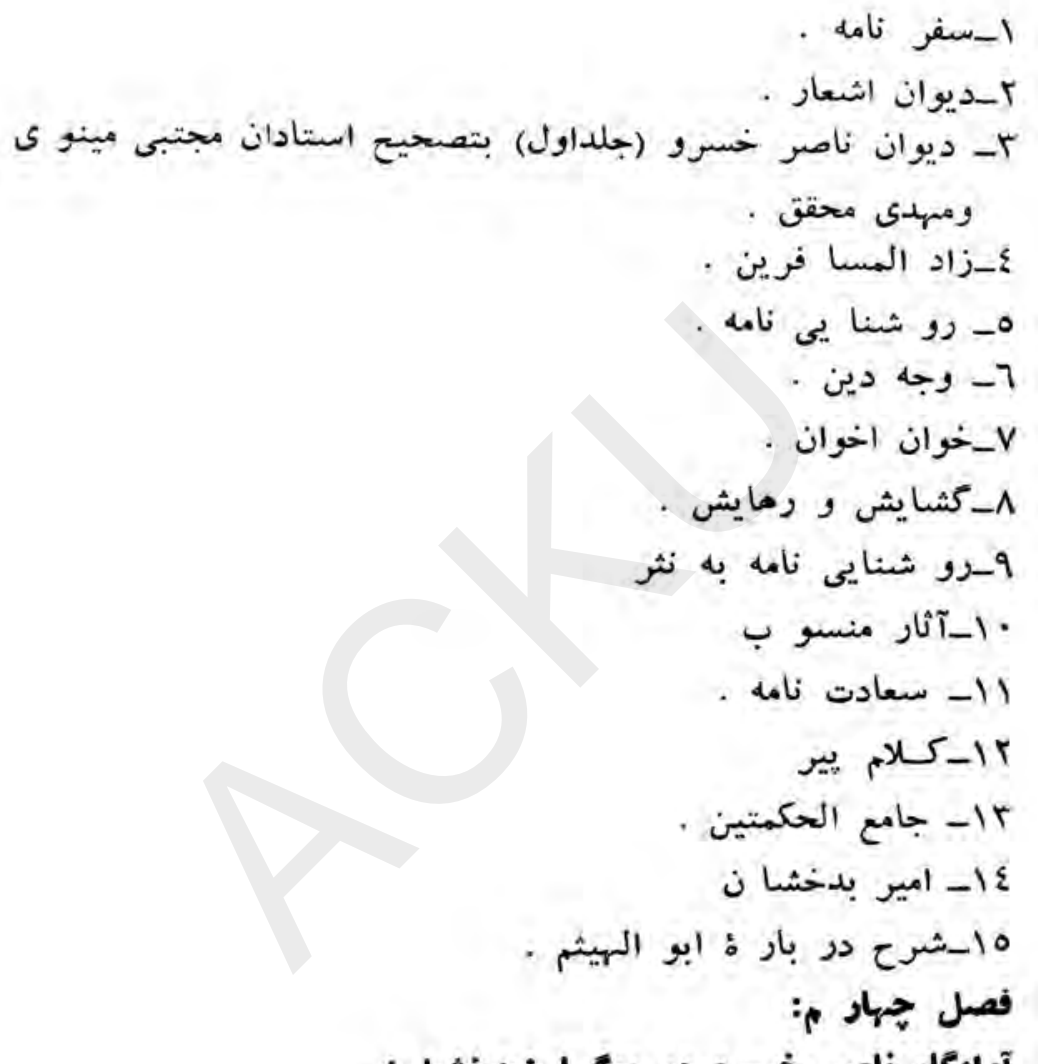

آرامكاه ناصر خسرو در يمكـ نبدخشا ن

فصل ينجم : درخاتهه كتاب:

ا-افغانستا ن ونا صر خسر وبلخى .

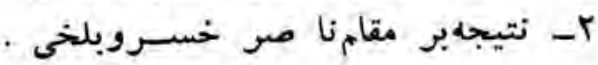




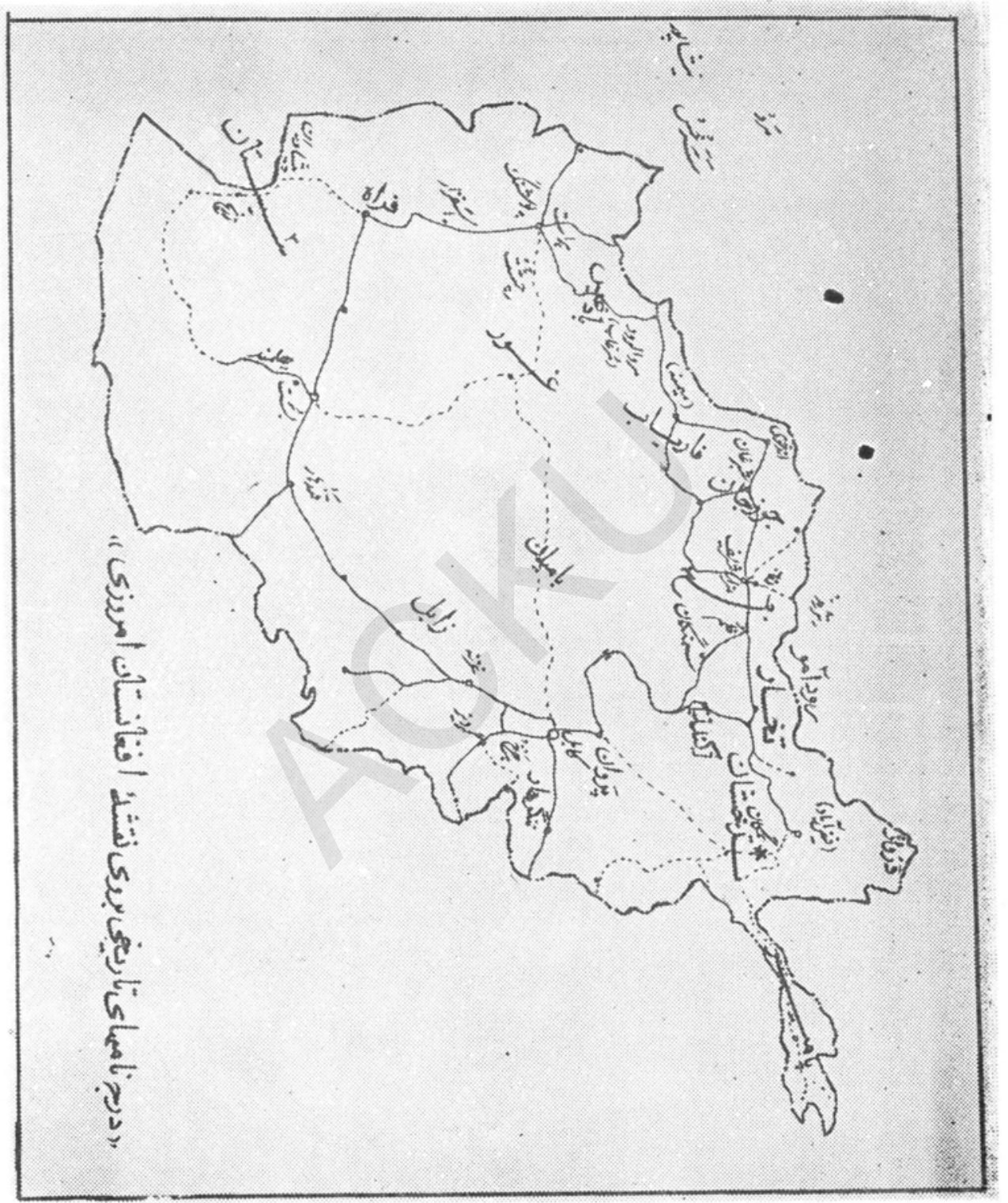




\section{يك دو ستخن}

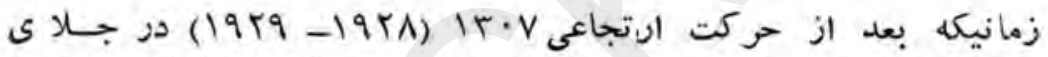

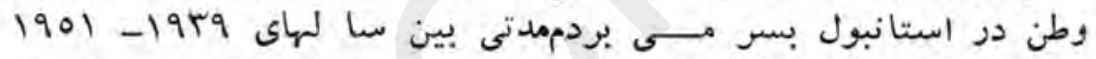

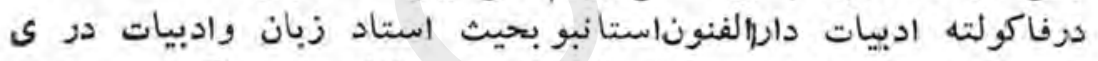

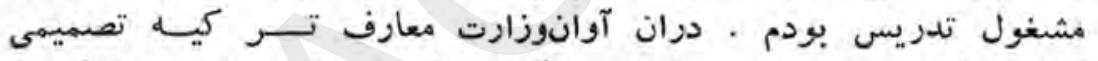

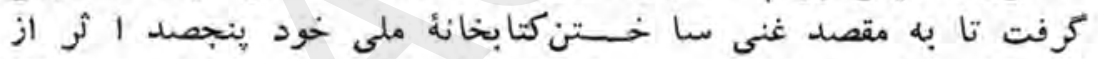

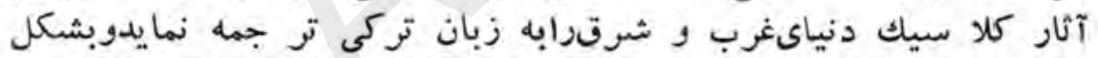

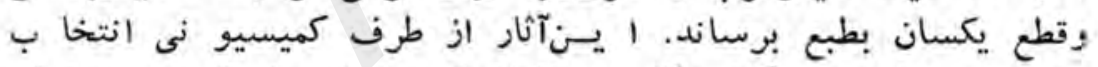

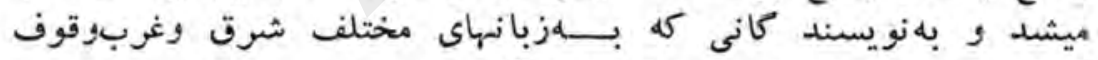

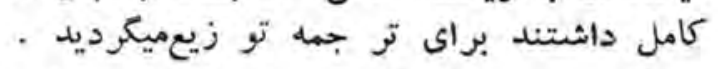

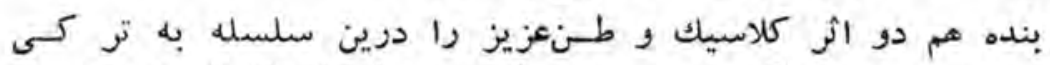

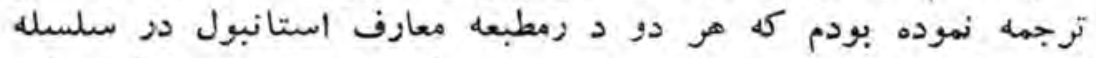

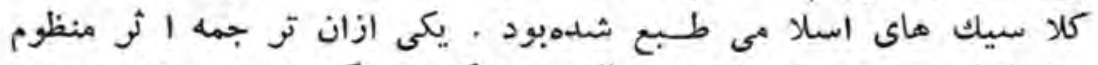

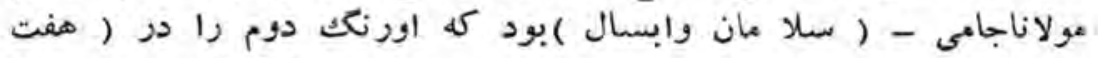

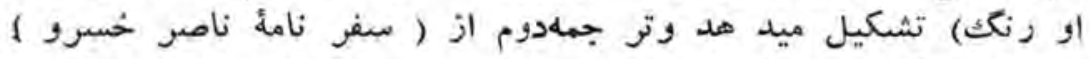

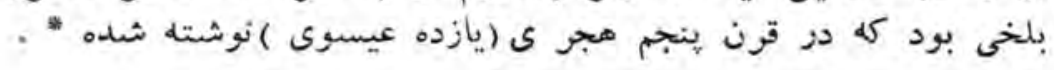




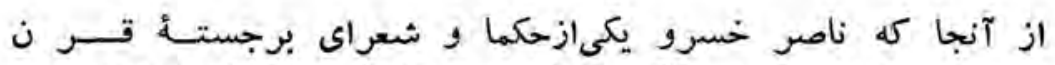

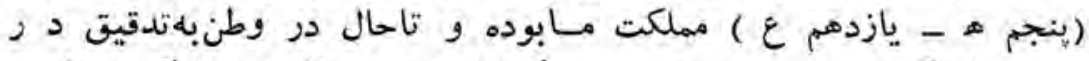

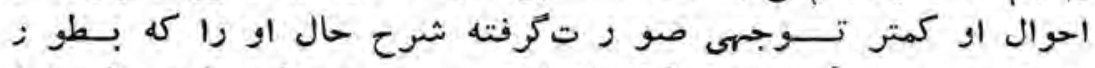

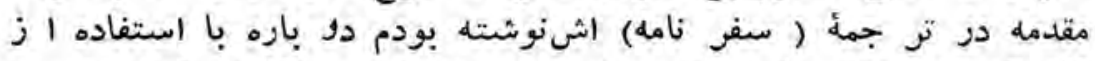

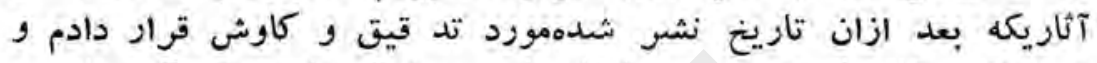

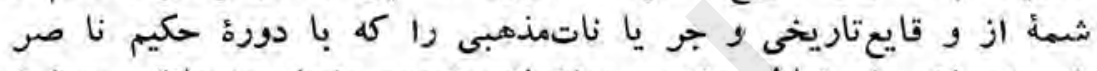

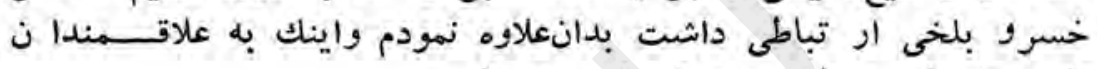

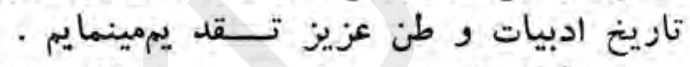

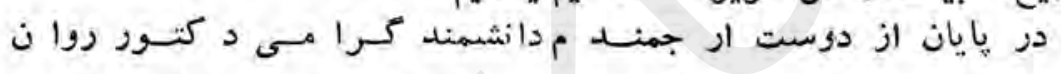
فـرهادى ا ظـهار سيا سكزا ز عميكنم كه به اين اثر علاقمندىنشان داده ودر ابراز نظر ها هـر ارزشخود مساعدت فواوان نمود . 


\section{فصل اول}

\section{نَا هي بر زندكانى ناصرخسرو بلخخى}

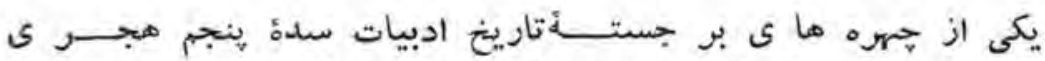

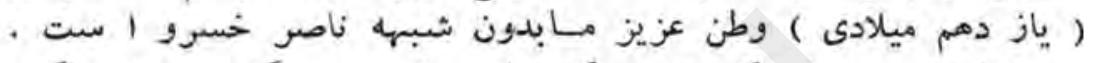

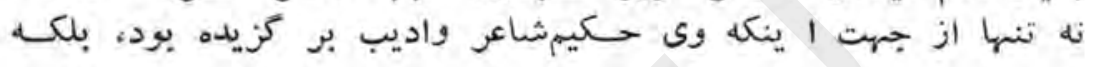

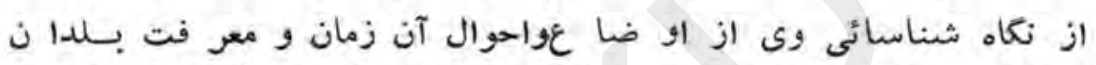

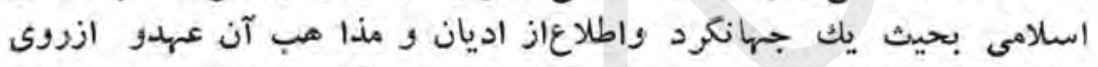

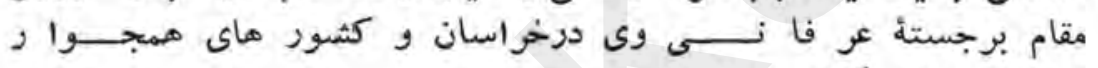

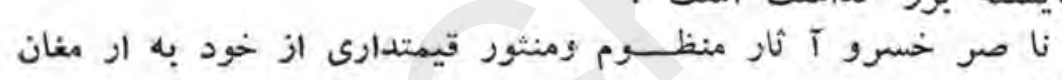
كذاشته است . ماست

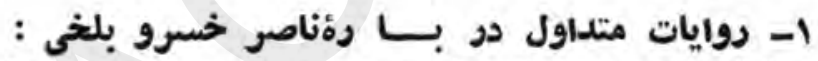

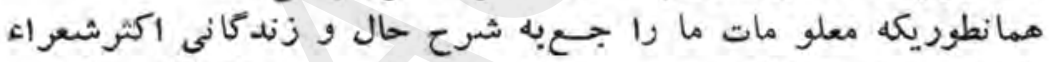

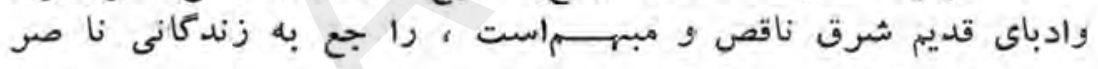

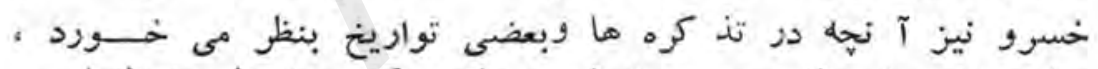

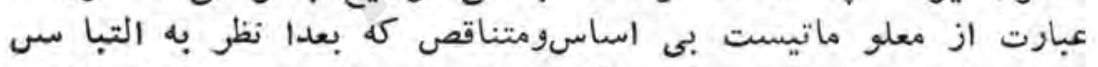

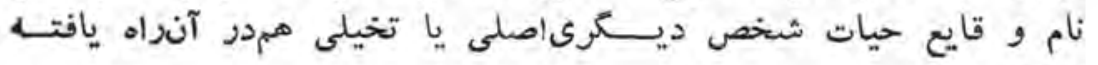

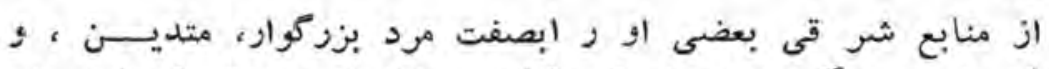

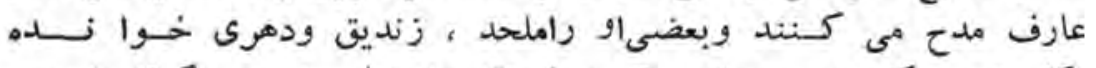

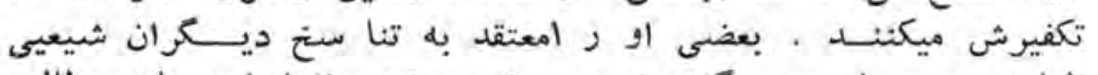

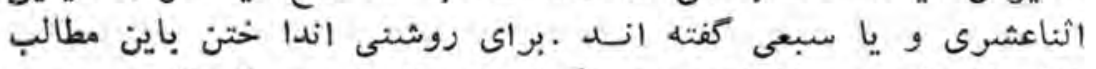

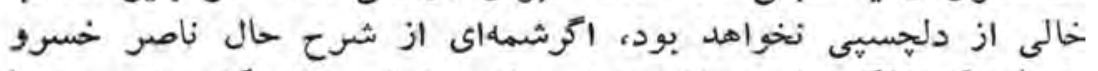

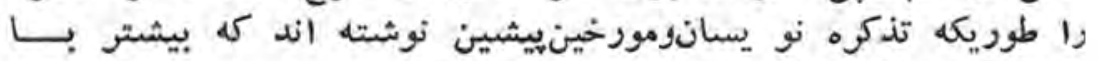

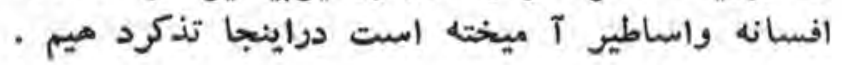




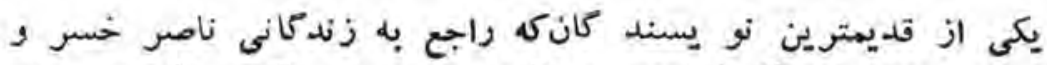

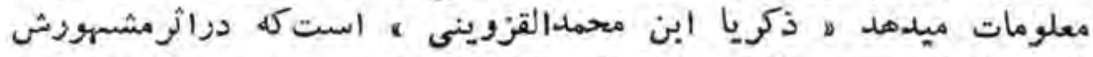

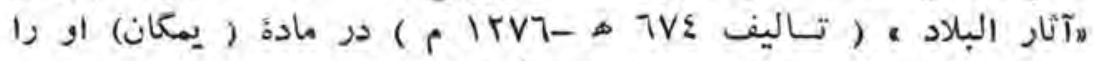

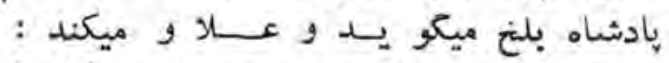

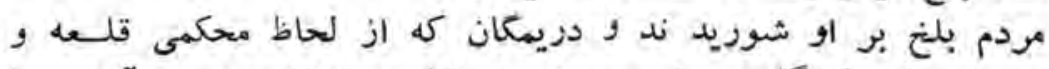

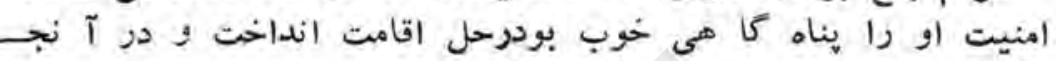

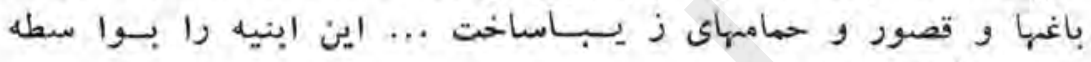

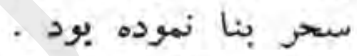

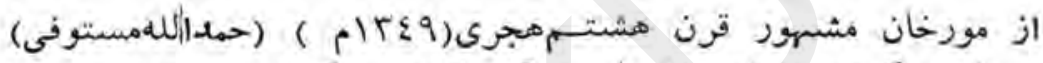

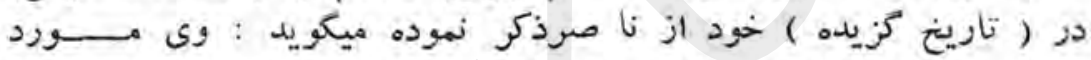

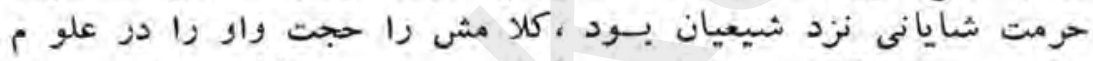

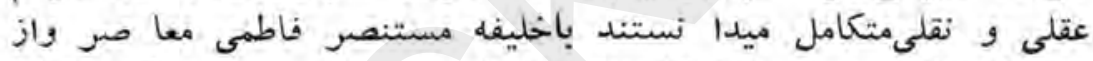

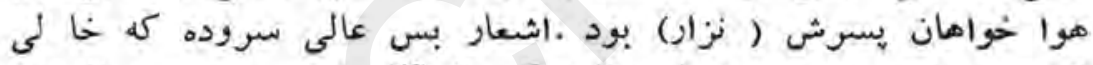

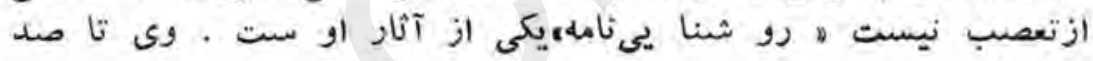
مال زيست

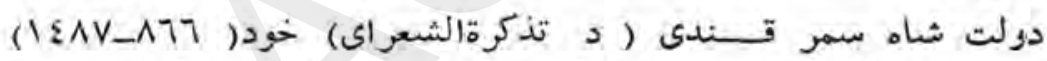

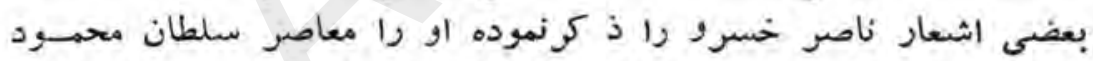

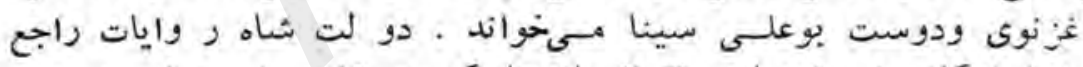

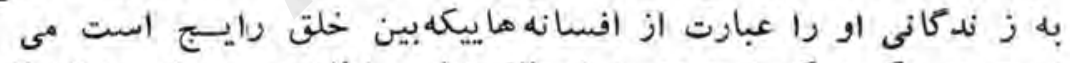

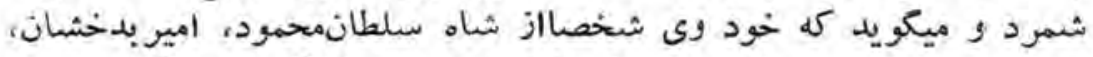

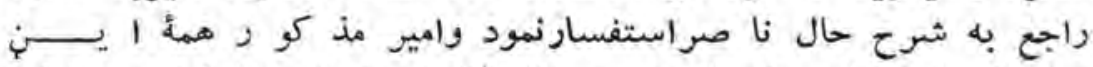

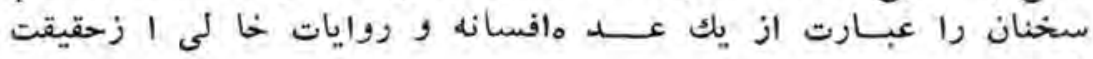

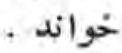

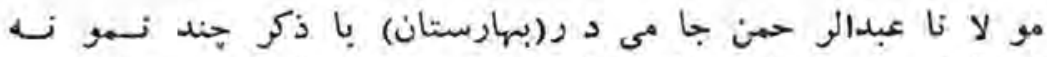

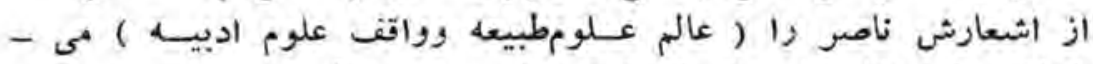

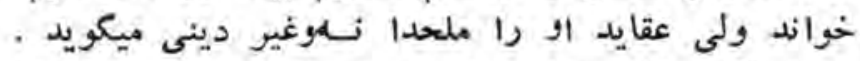

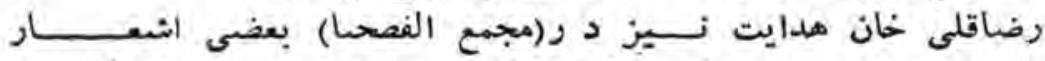

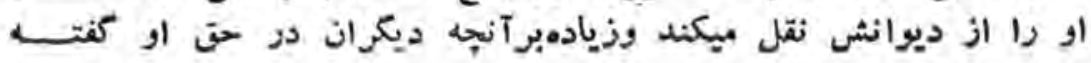




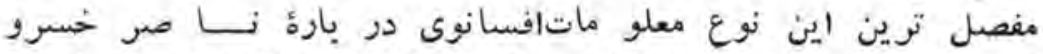

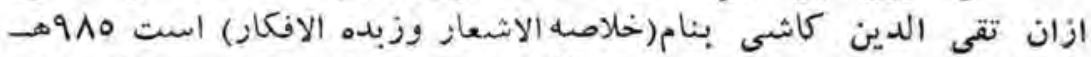

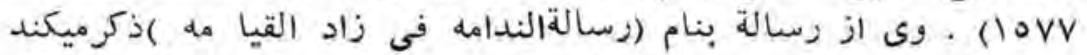

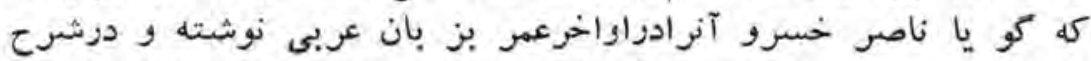

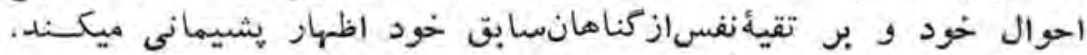

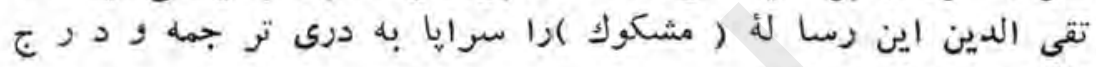

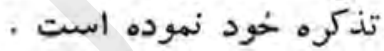

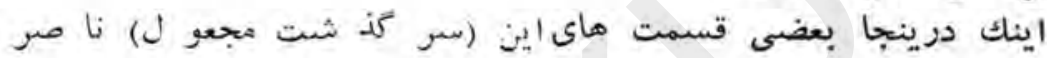
را نقل مينماييم

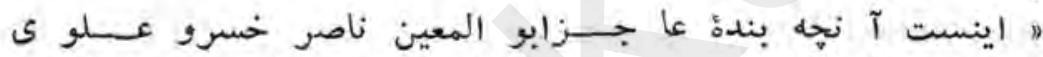

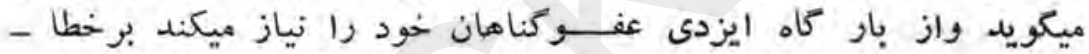

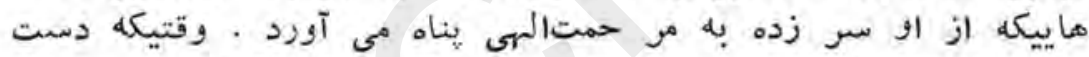

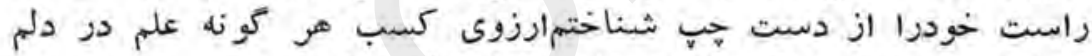

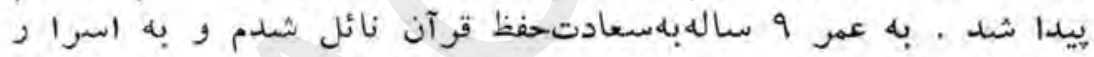

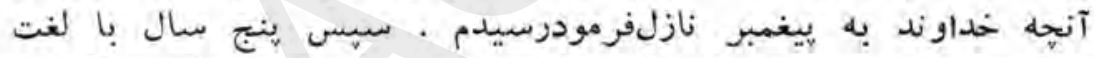

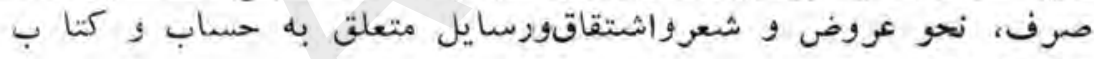

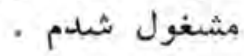

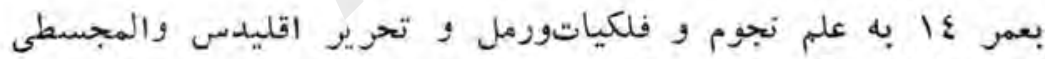

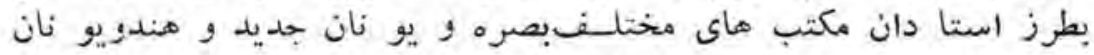

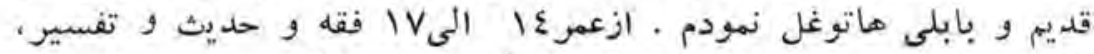

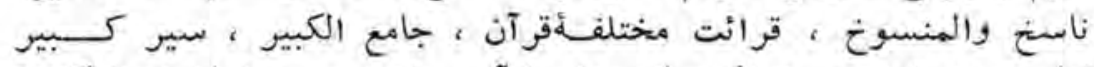

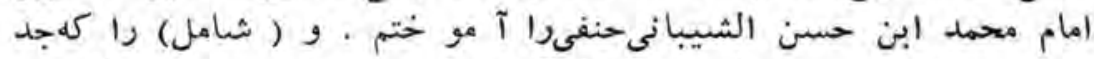

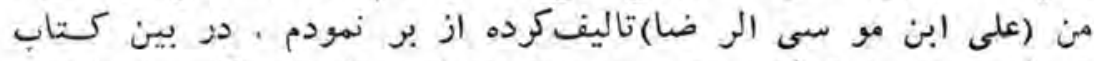

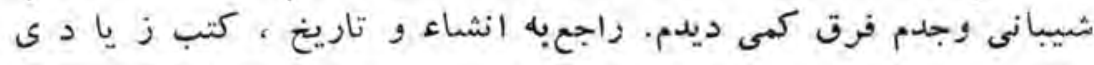

1) از مقدمة فرانسوى (شسارل شيسلفر)بر(سفرنامة ناصر خسرو). متن فسارسسي 2

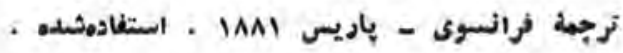


خواندم وكاه نزد استادى و كاه بهتنها نهصد تفسير قرآن را مطالعه

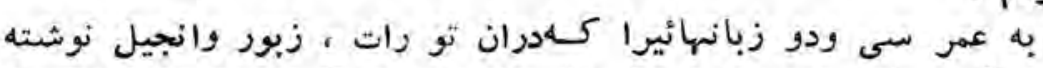

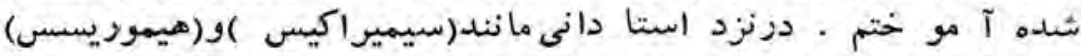

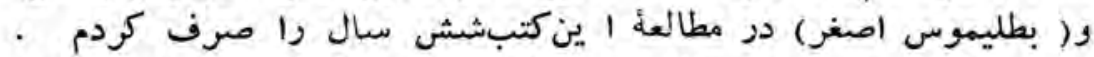

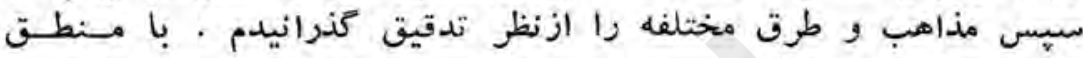

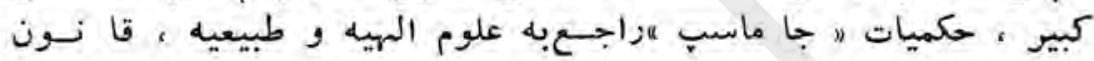

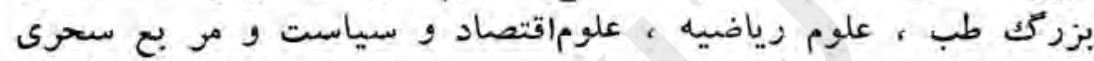

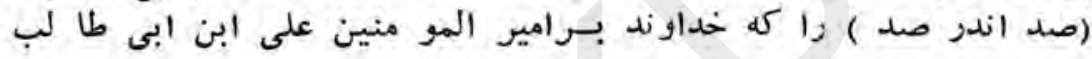

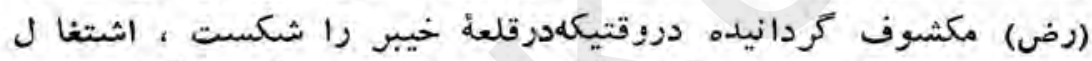

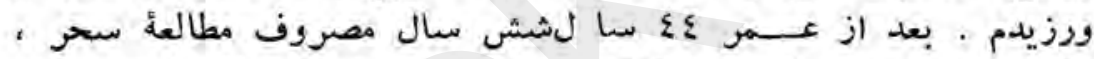

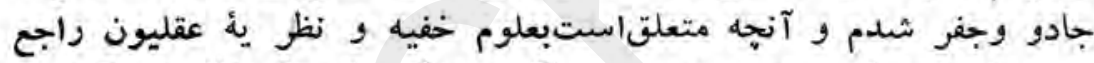

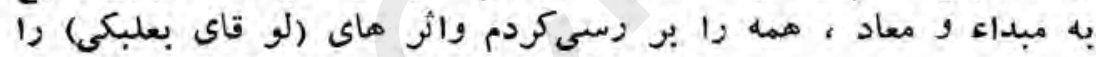

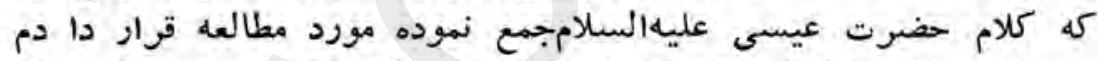

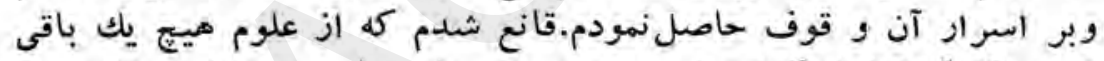

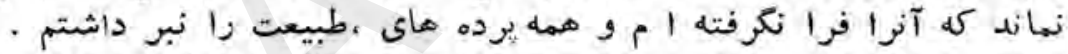

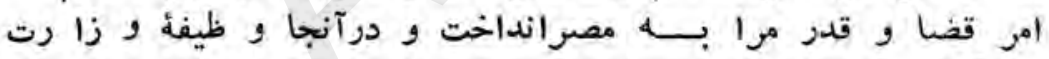

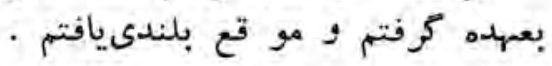

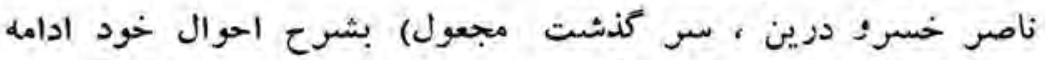

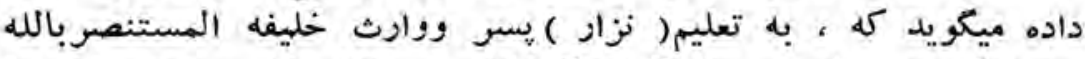

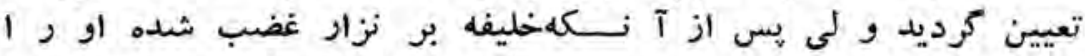

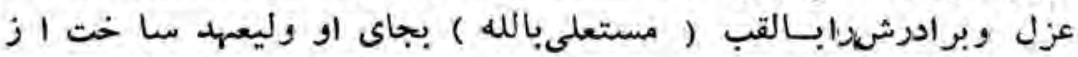

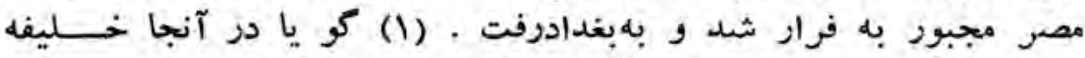

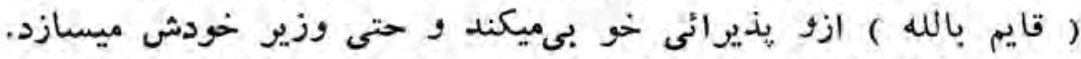

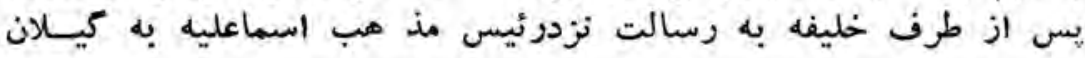

1) ناصر خسرو درزمان خلافت الهستضرازمصر ديدن نموده بوداختلاف بيسنيسرانش

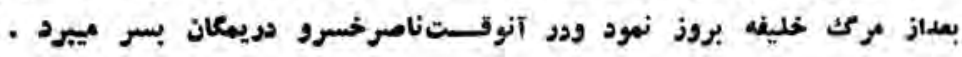




\section{نوايات شتداول}

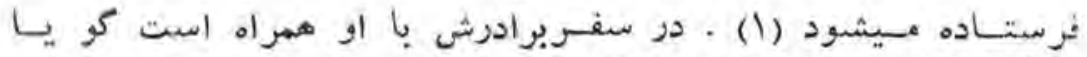

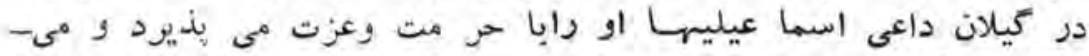

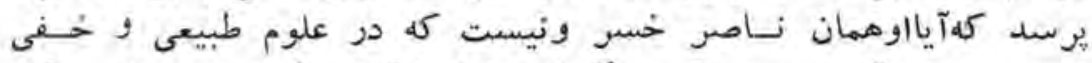

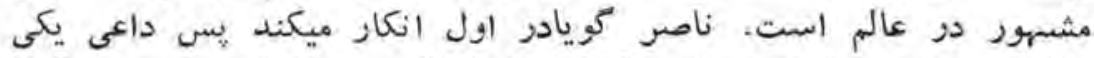

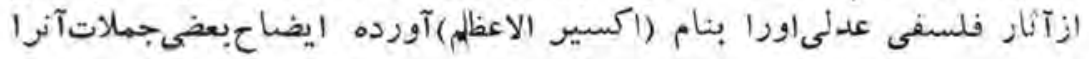

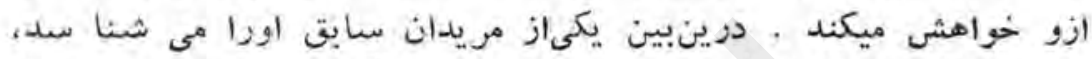

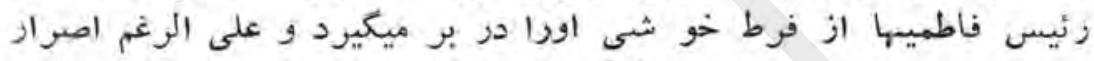

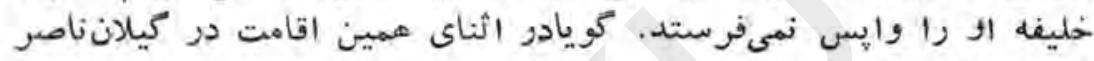

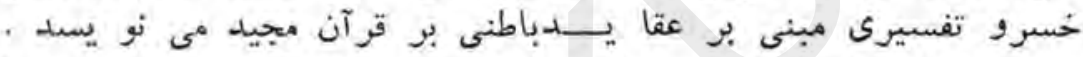

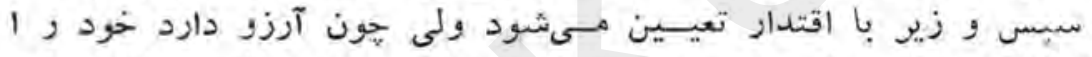

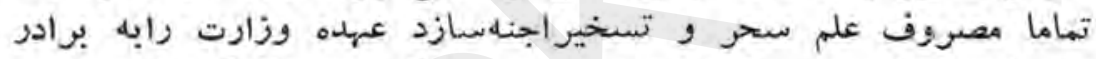

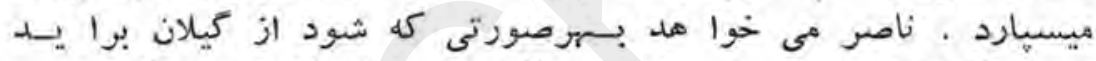

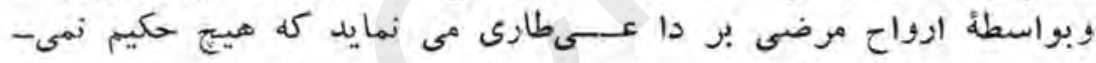

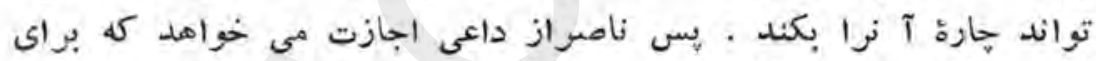

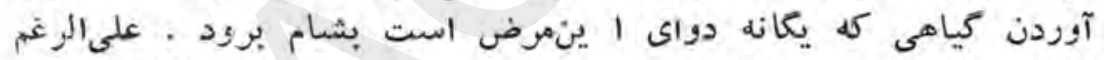

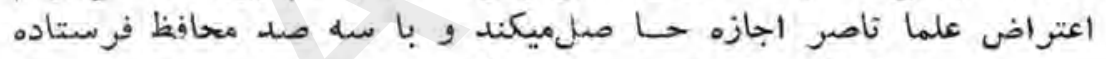

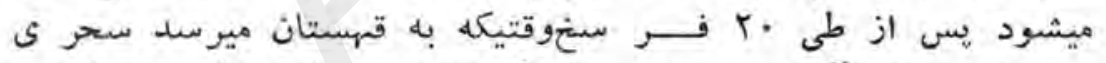

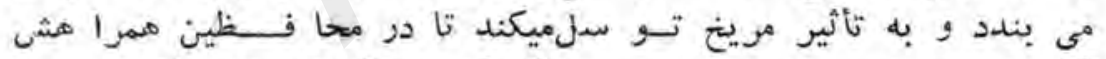

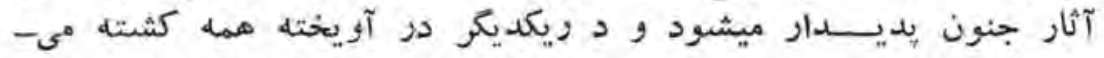

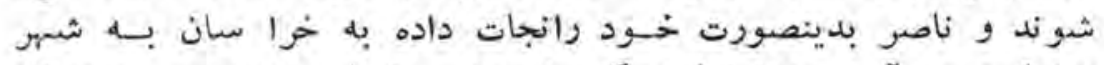

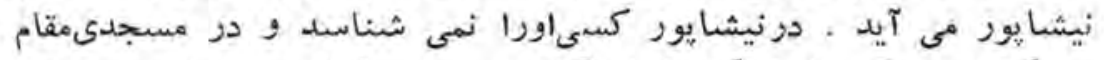

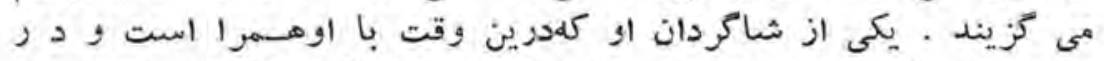

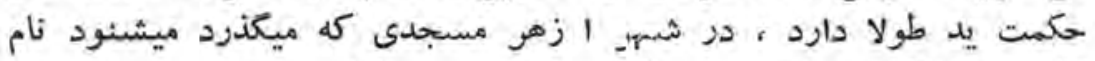

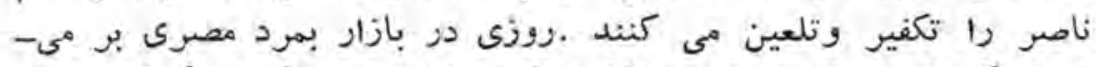

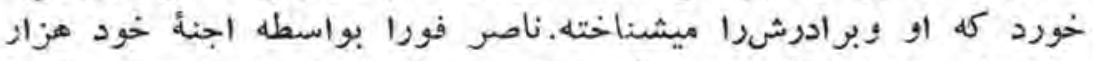

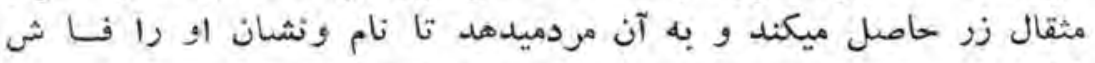


نسازد . يس با برادر بدكان كفشدوزى ميروند وكفش خود رو را براي

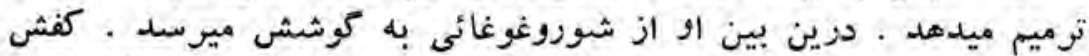

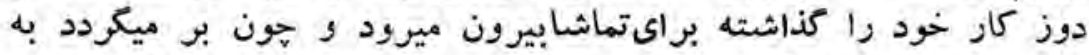

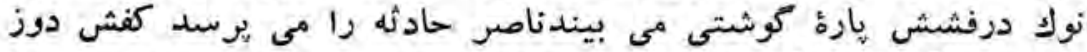

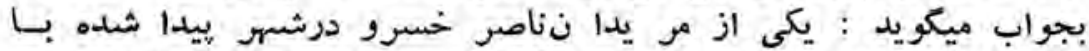

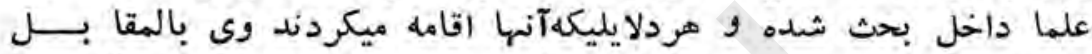

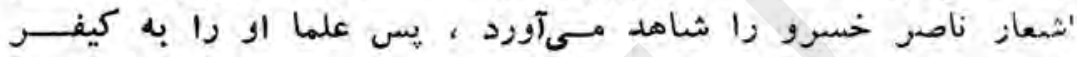

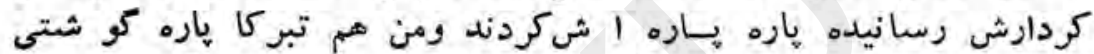

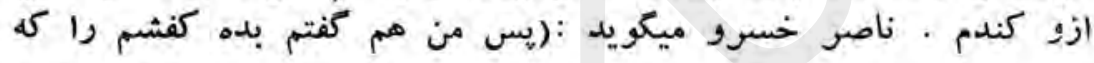

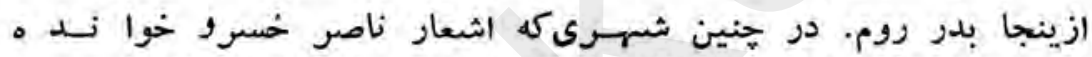

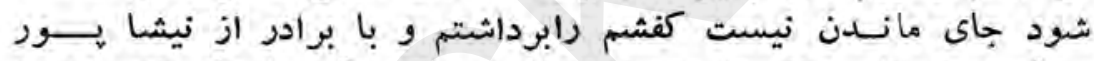

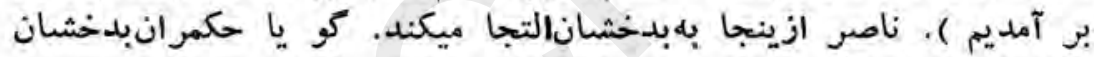

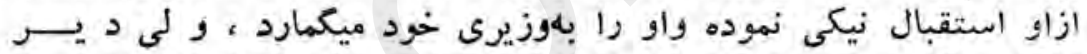

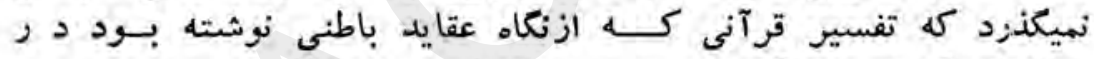

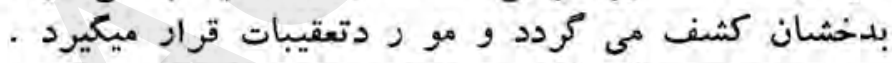

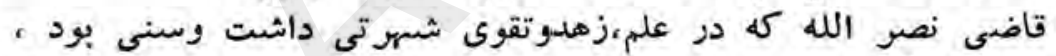

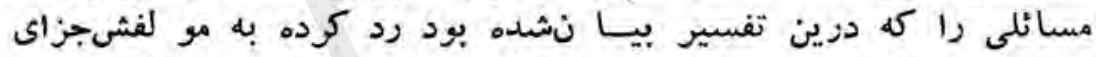

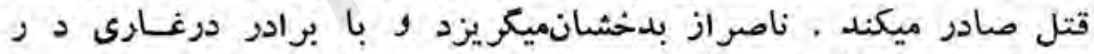

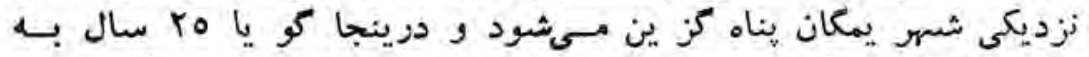

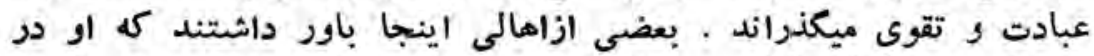

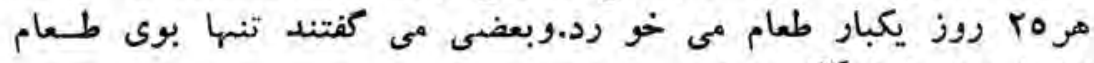

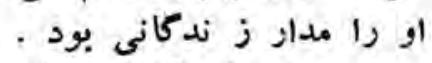

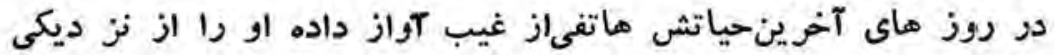

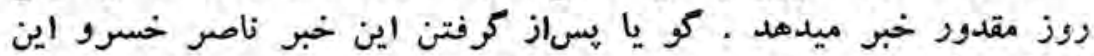

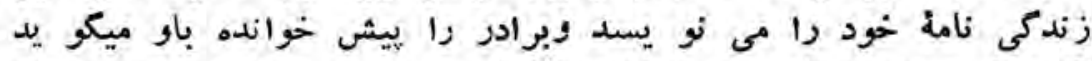

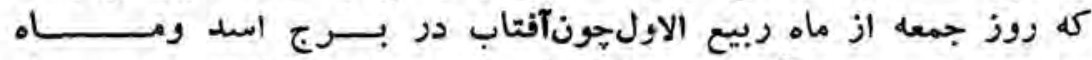

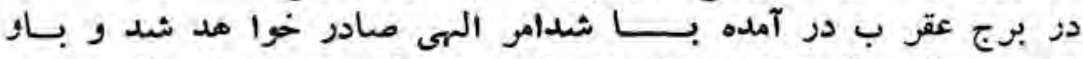

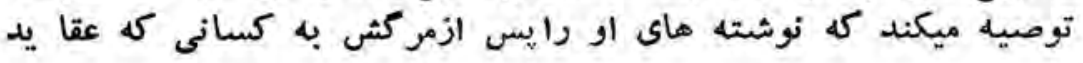




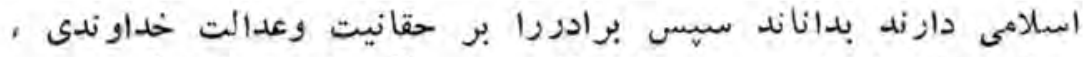

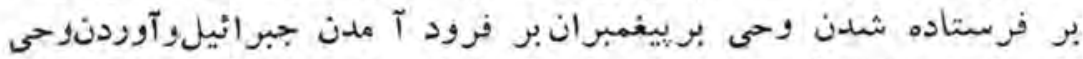

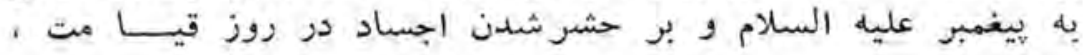

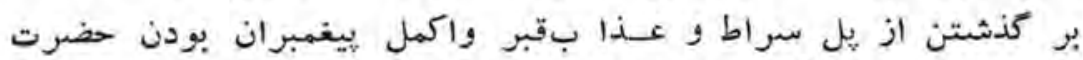

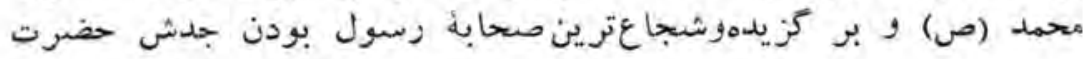

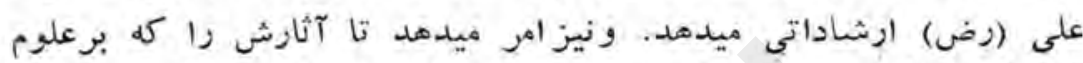

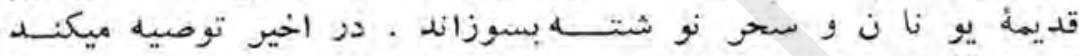

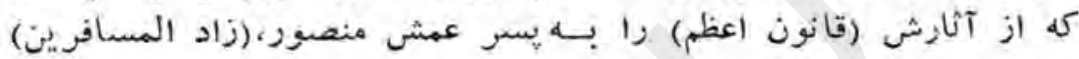

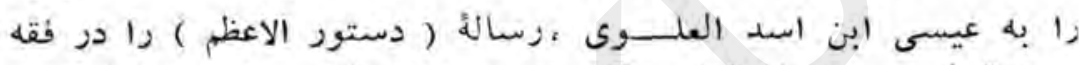

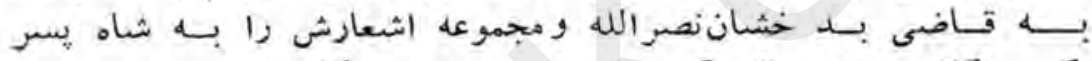

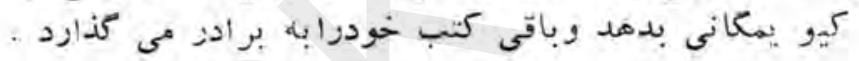

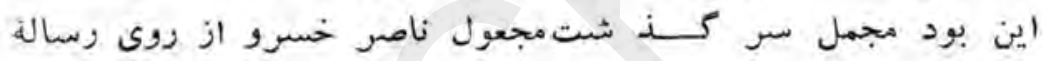

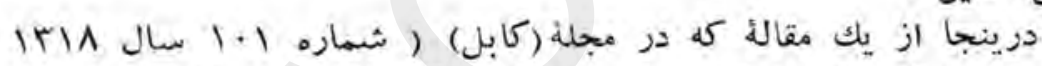

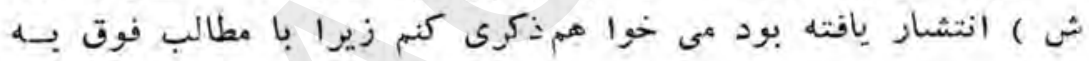

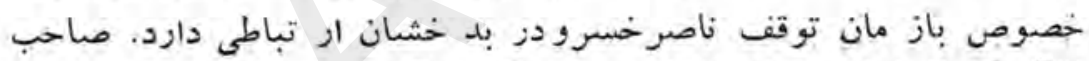

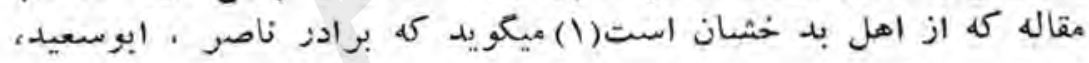

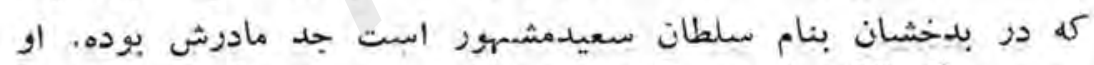

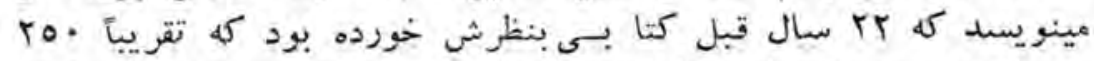

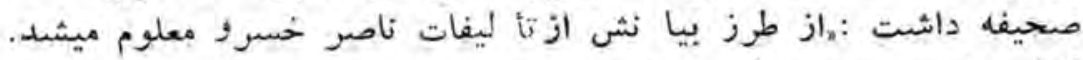

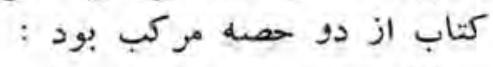

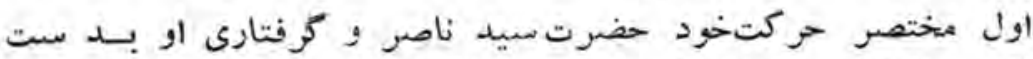

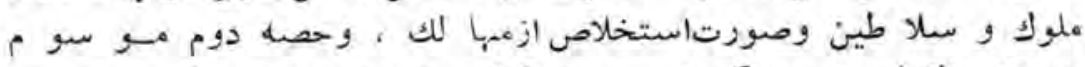

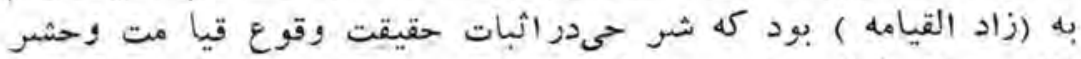

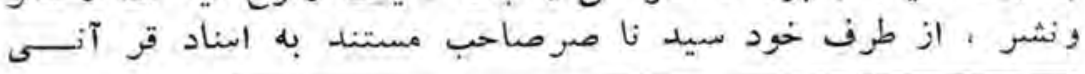


ومتكى به ادلات فلسفى ار قاميافته.اين كتاب قلمى و به به خط جلى درى آنى

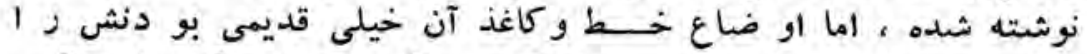

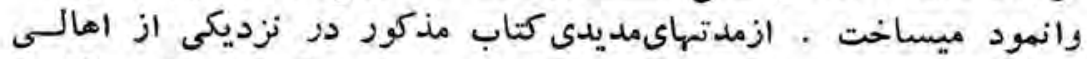

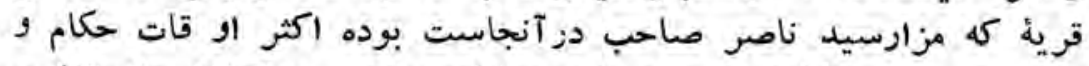

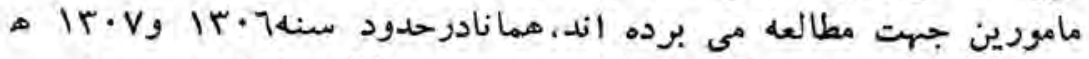

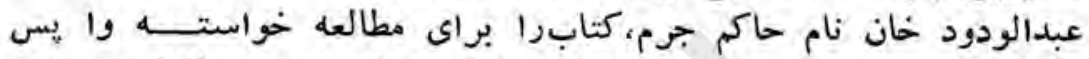

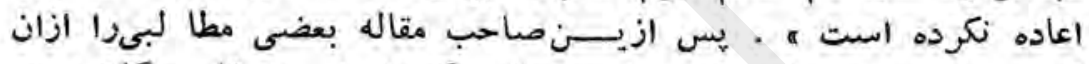

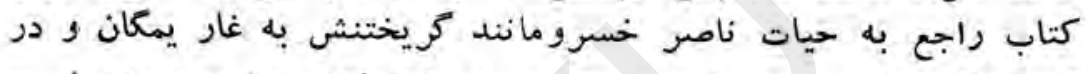

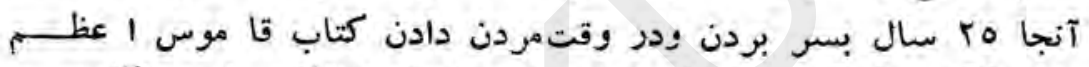

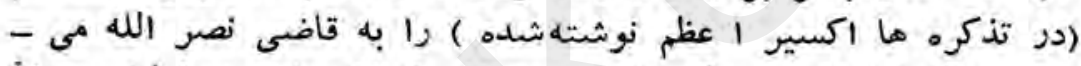

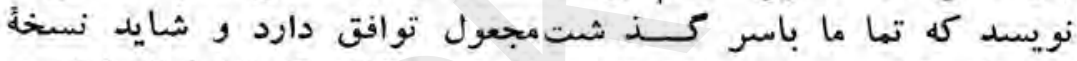

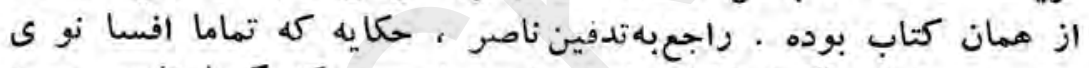

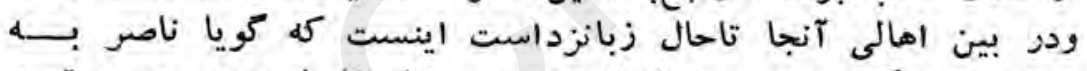

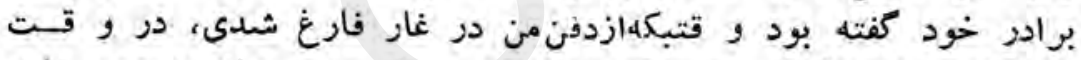

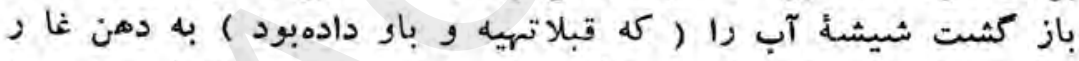

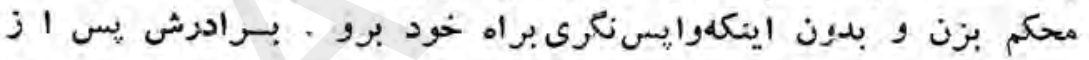

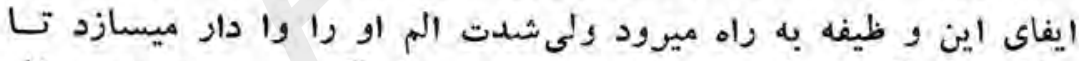

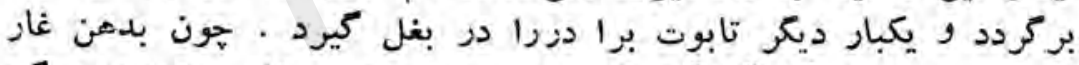

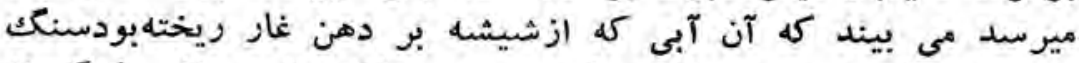

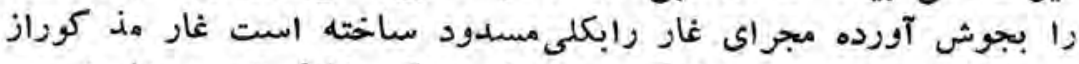

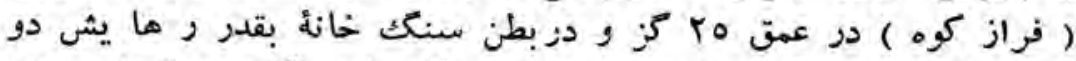

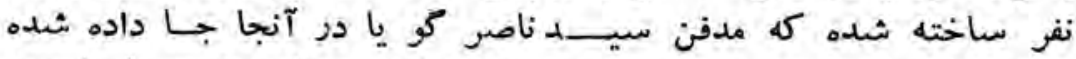

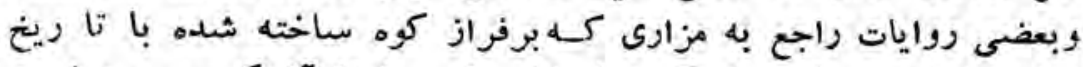

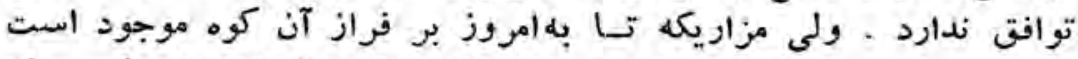

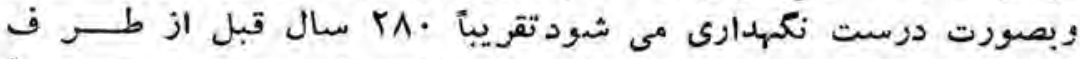

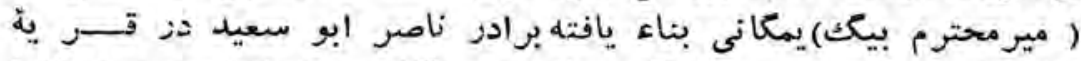

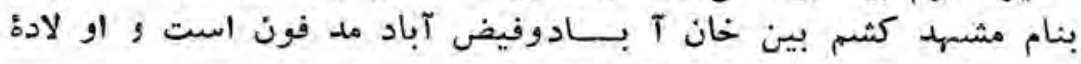
او تا امروز صاحب آن اراضیى الند. 
مقصد ما ازين نقل سر كز شتمجعول ناصر خسرو درين آ غنساز

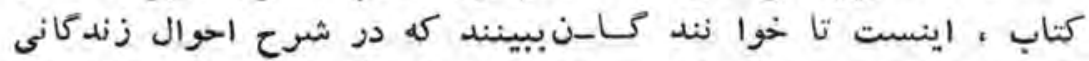

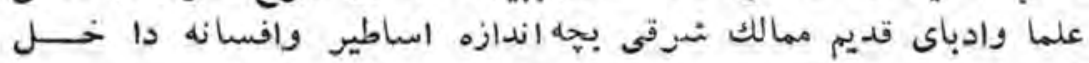

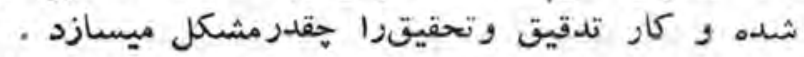

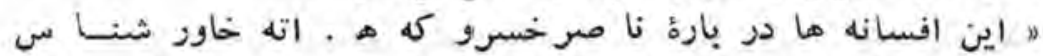

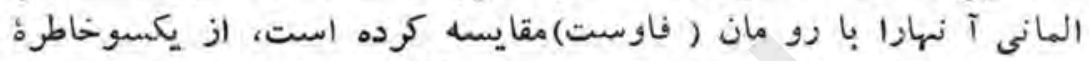

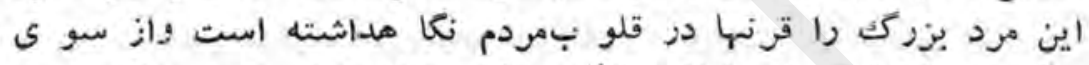

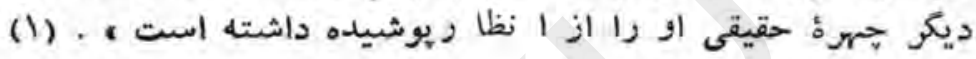

\section{r- مدارك و مآخذ تحقيق}

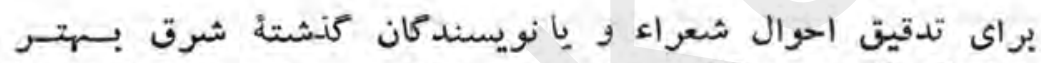

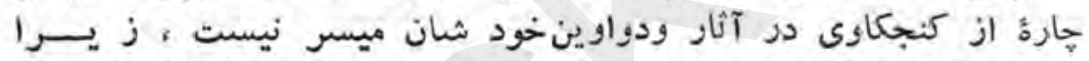

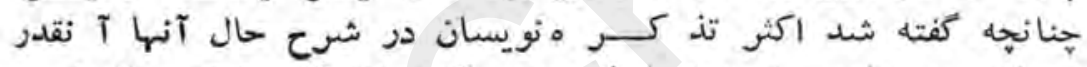

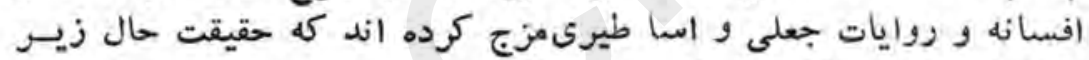

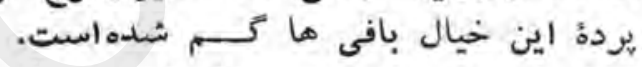

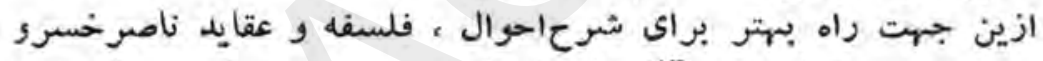

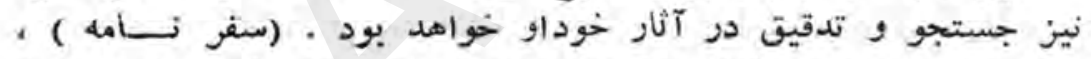

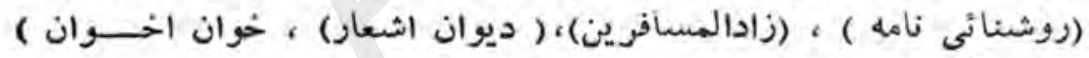

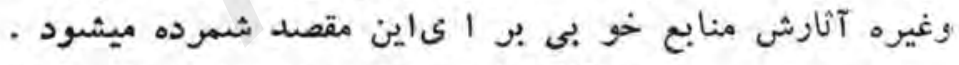

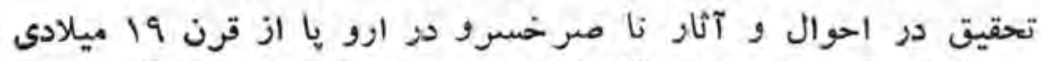

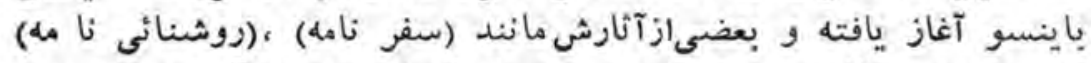

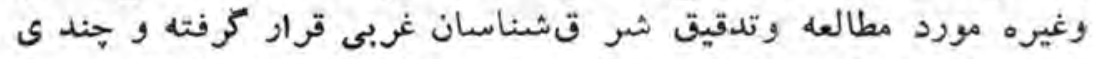

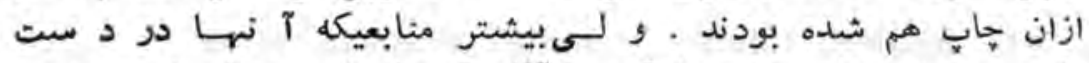

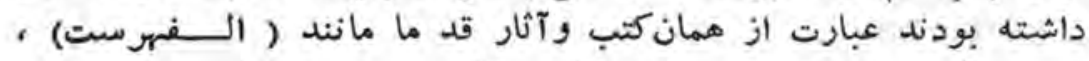

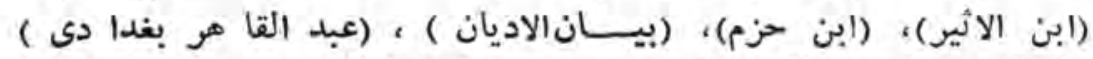

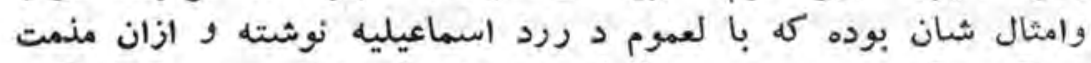

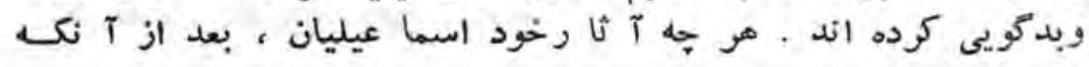




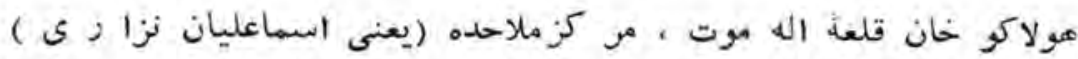

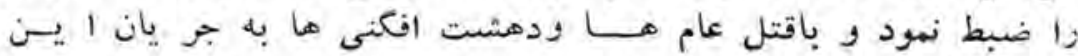

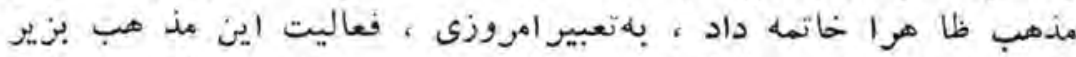

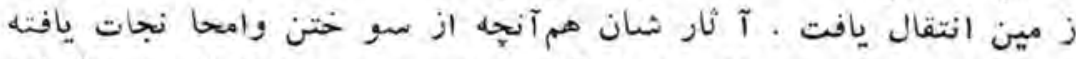

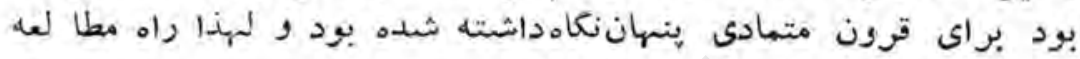

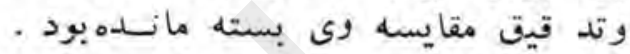

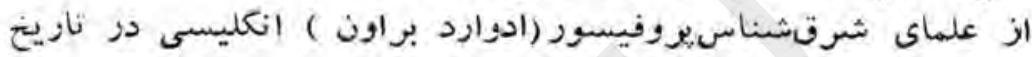

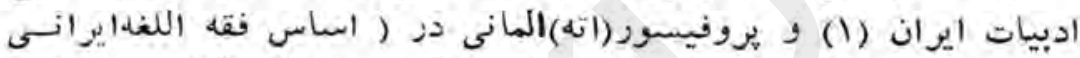

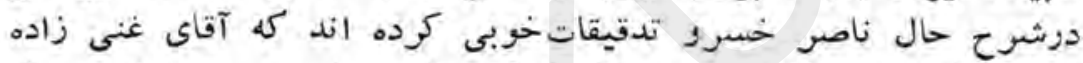

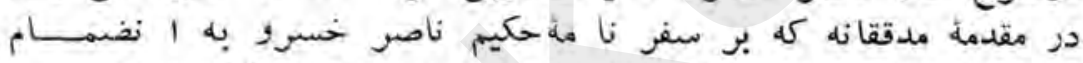

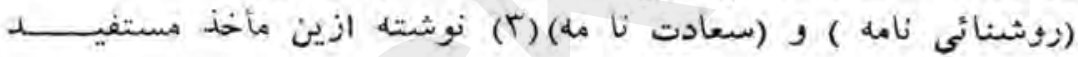
كردبده

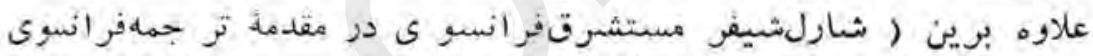

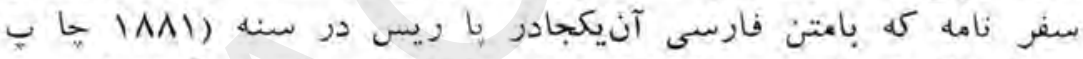

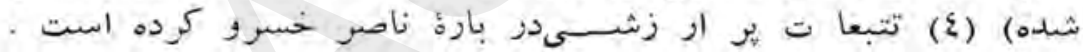

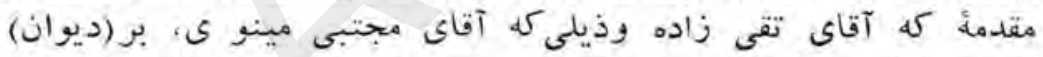

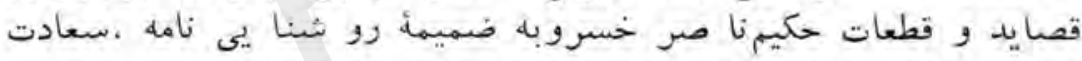

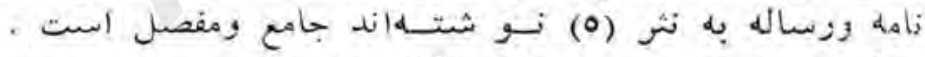

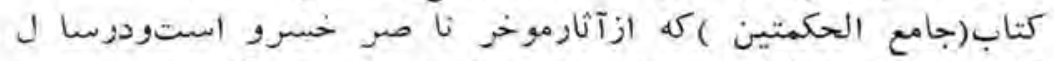
(190r_lrtr) CORBIU

E.G. BROWN. Literary History of Persia vol. II p. $222-246$. 
(تفصيل آن درفصلمولفاتناصرخسرو آمده است ) از هر حيثاز تحقيقات

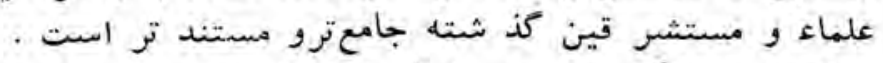

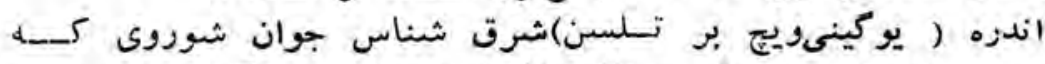

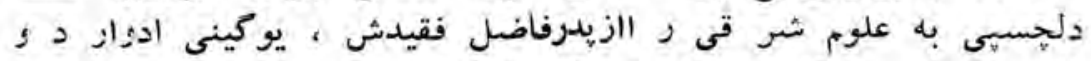

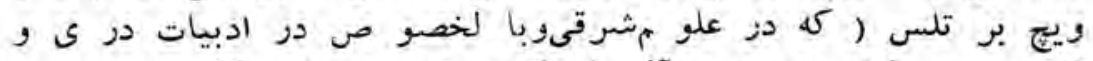

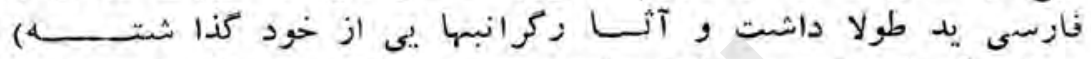

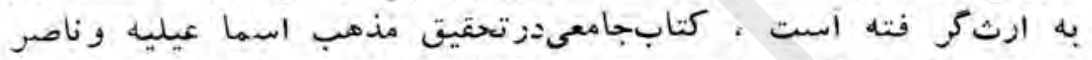

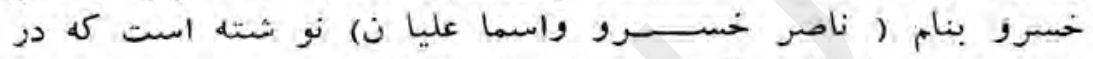

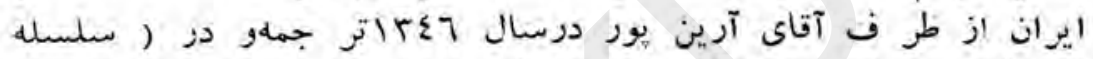

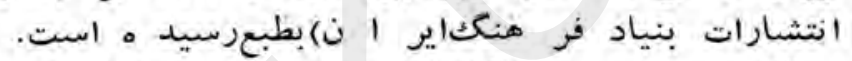

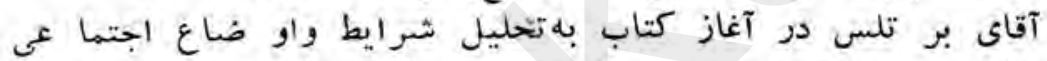

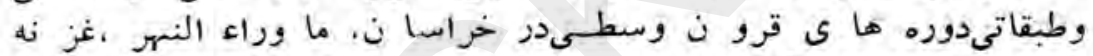

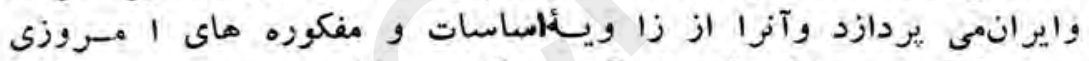

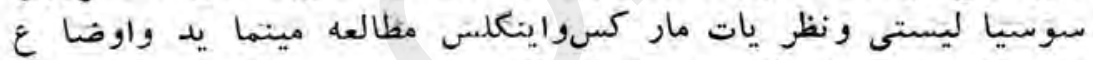

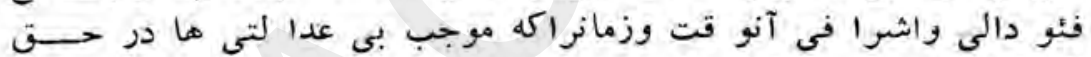

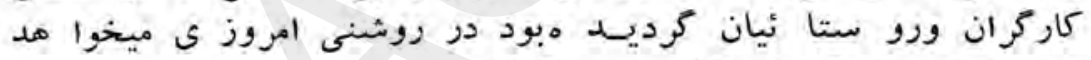

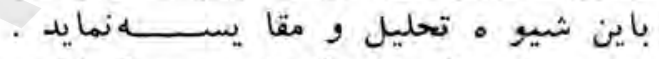

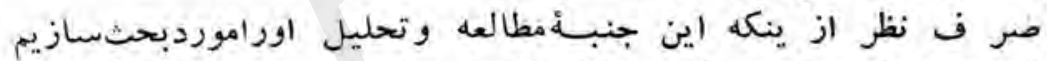

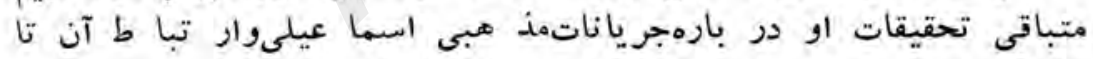

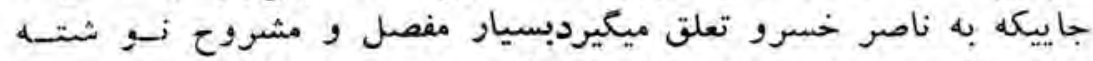

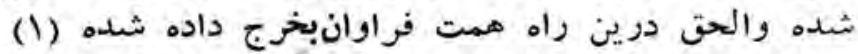

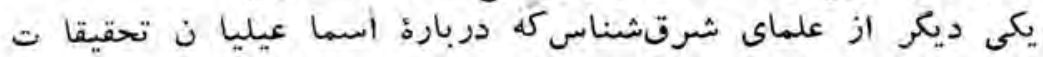

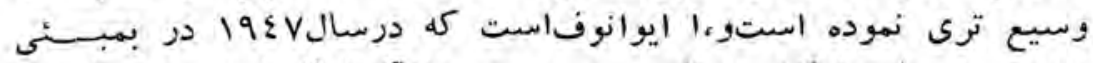

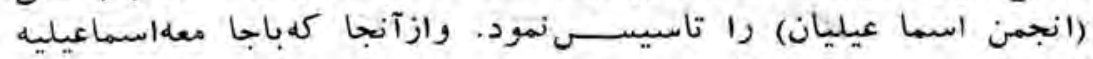

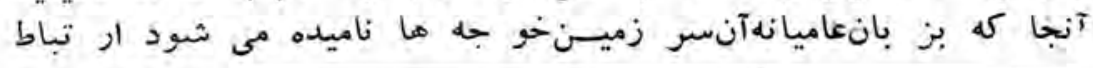

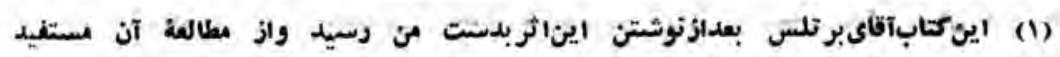

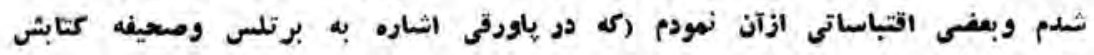

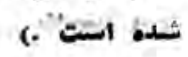




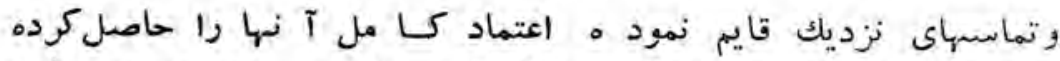

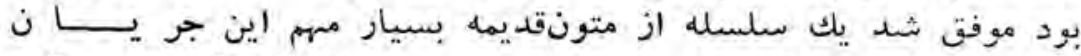

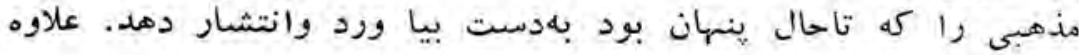

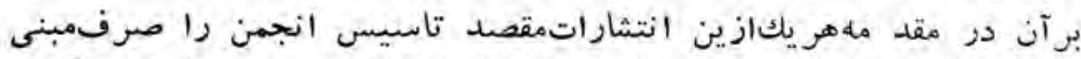

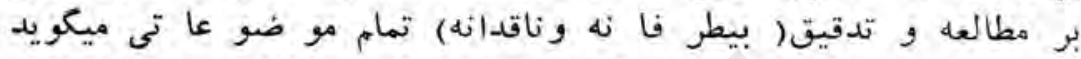

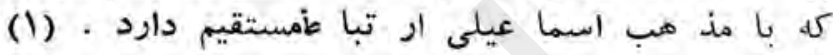

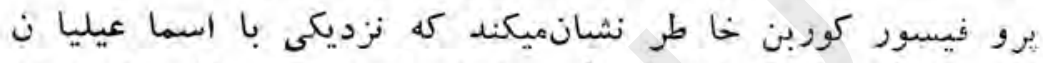

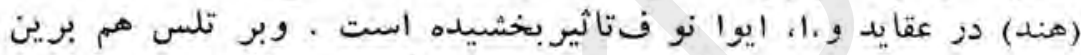

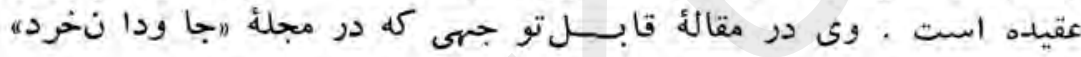

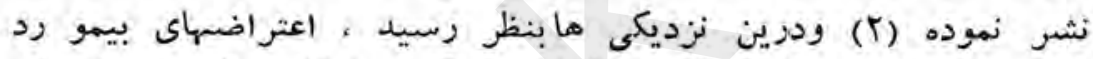

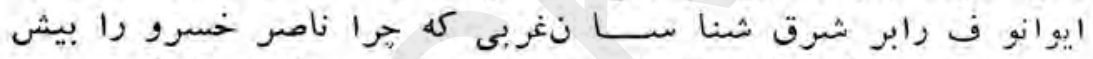

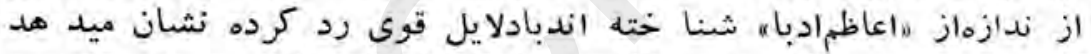

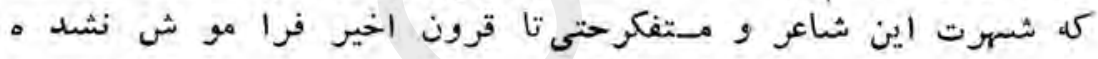

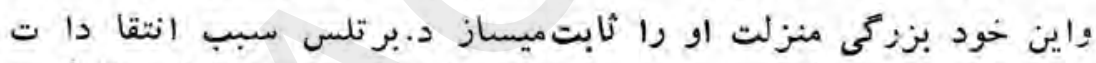

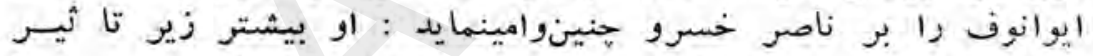

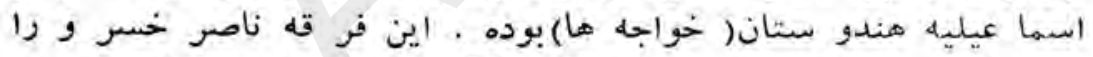

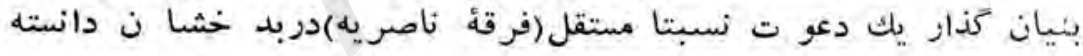

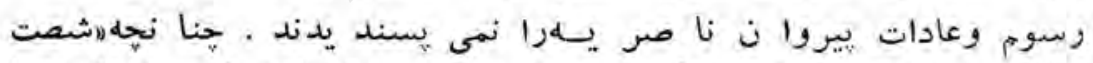

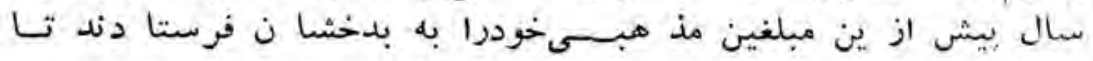

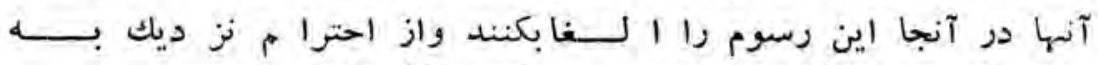

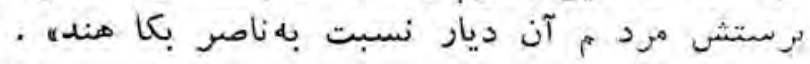

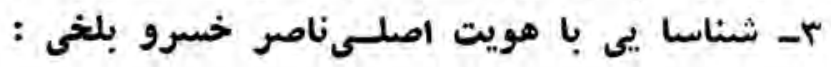

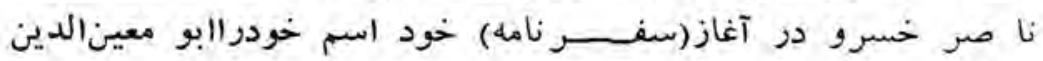

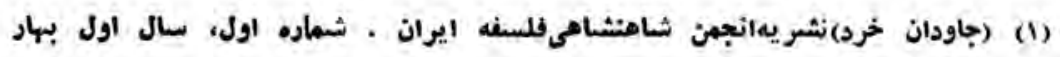




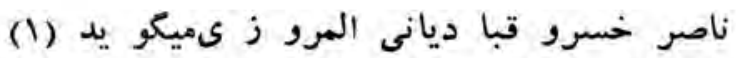

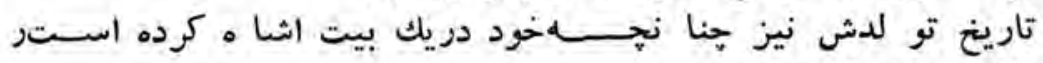

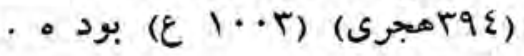
بكذ شته زهجر تيس سيصـــن بونود وجار

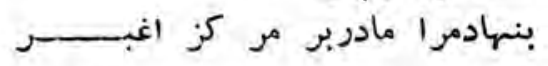

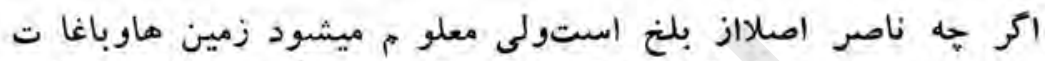

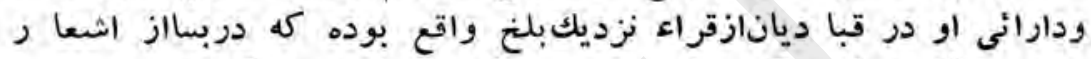

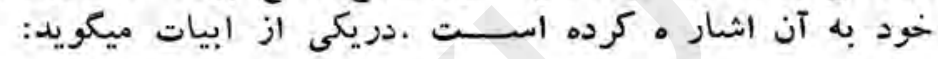

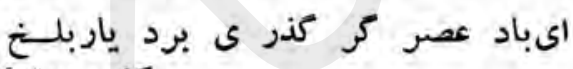

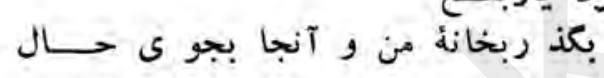
بنكر كه جون شده است بيسسئز من ديا رمن

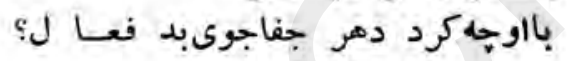

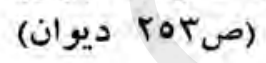

اينكه آقاى بر تلس(ص 179 )فباديان را :مواقع در ناحيه ختلانه

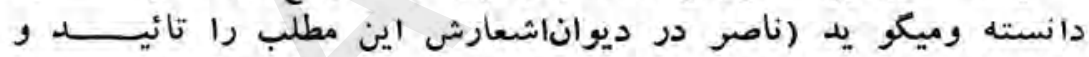

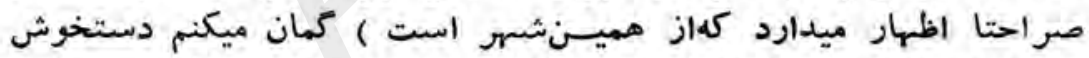

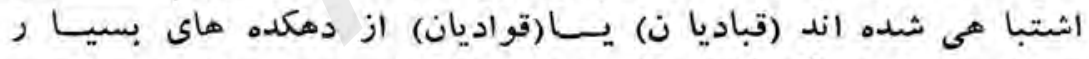

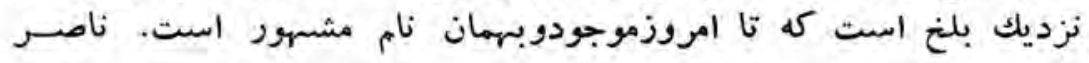

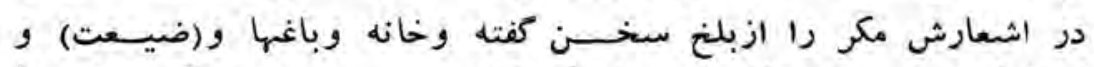

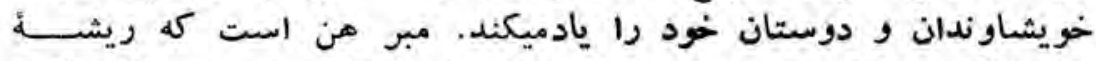

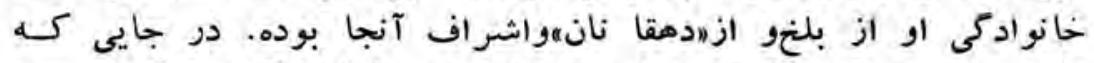

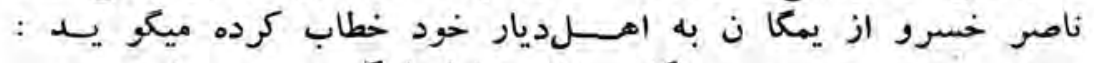

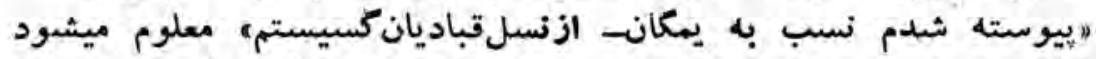
كه قباديان را به معنى قوموشا يدهم به معنى مسكن بكار بكار بردهباشيد

(1) دوكتاب جامع العمتين اسم خود را(ابوعيز نامربن خسروبن العارث) ميعويد. 


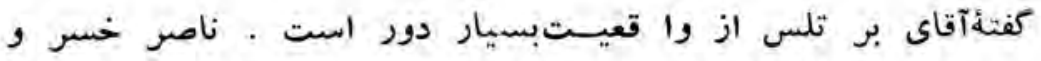

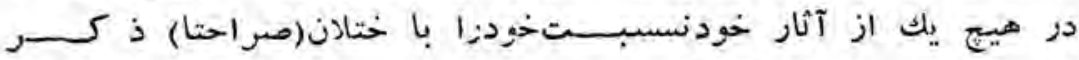

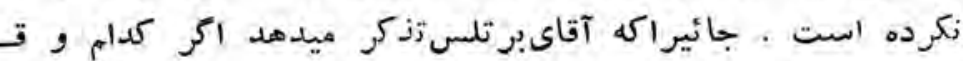

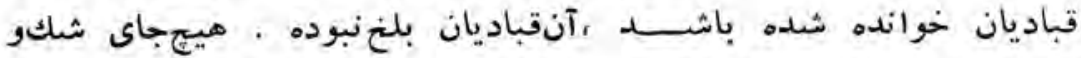

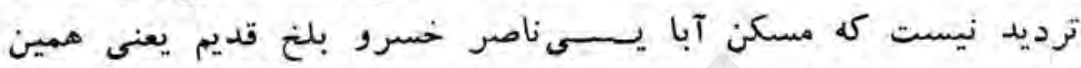

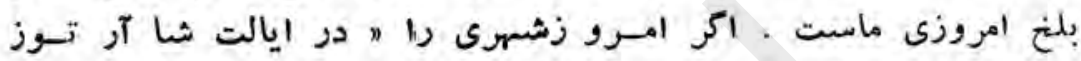

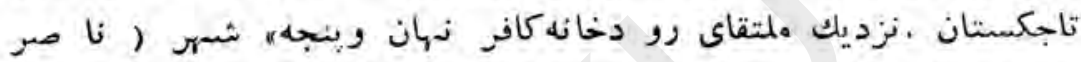

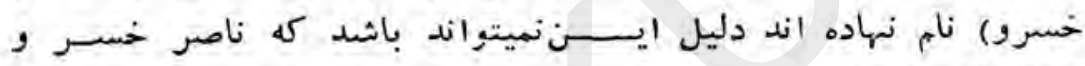

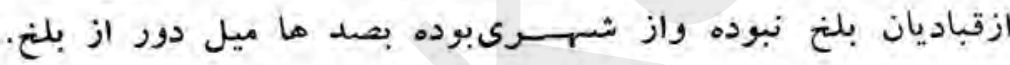

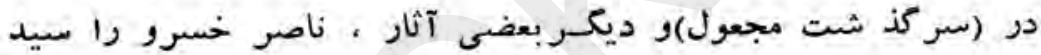
واز دود مان حضر ت على (رضس)كفته اند، و شيفر هم در رسيدن او اونار

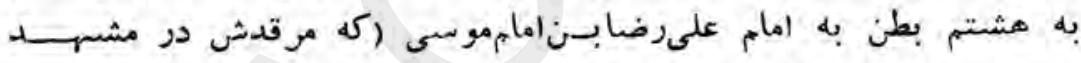

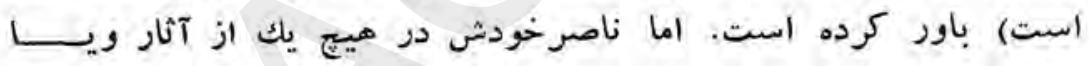

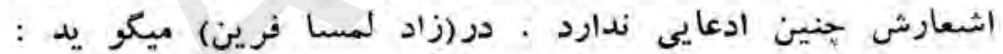

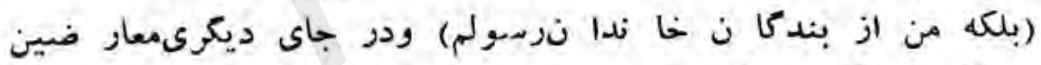
خود راخطاب كرده ميكو يد : زبندان

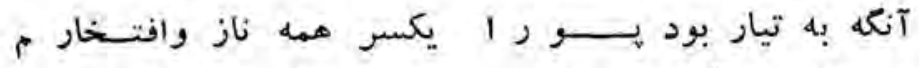

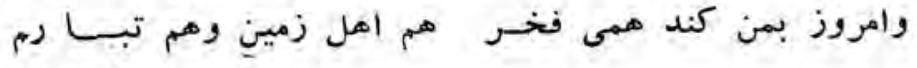

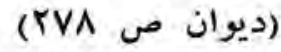

من شرف و فخرآل خويشوتبارمكرد كرى راشر فبهآلوتبارست

$$
\text { (2) (م-2) }
$$

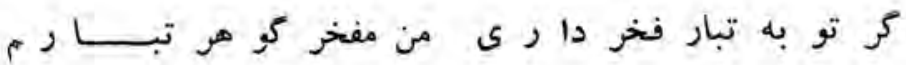
(TAV D-2) 


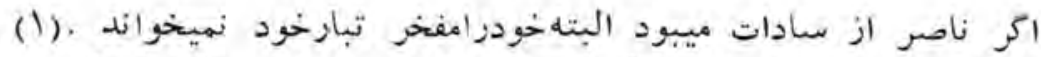

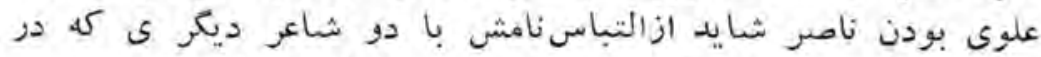

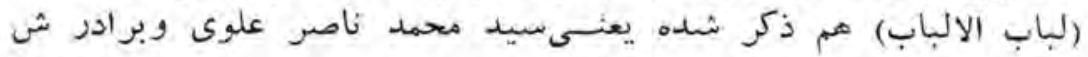

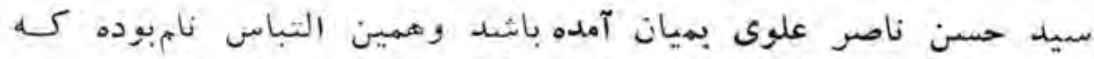

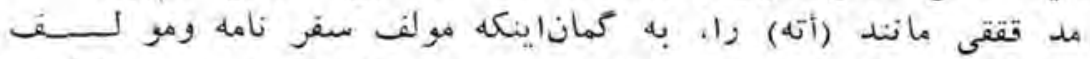

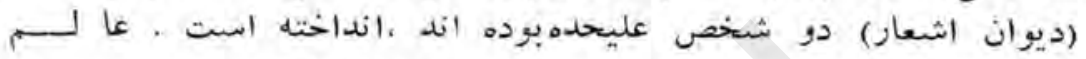

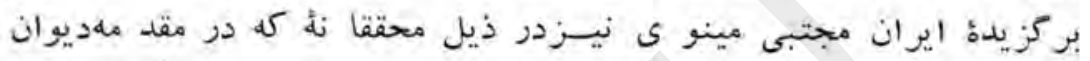

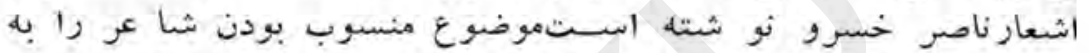

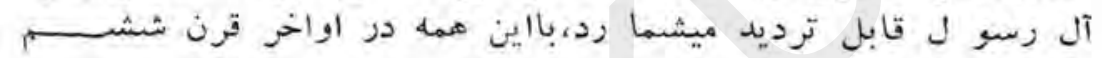

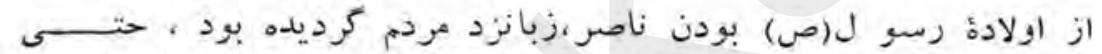

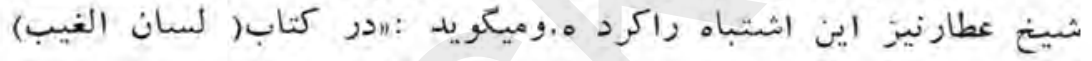

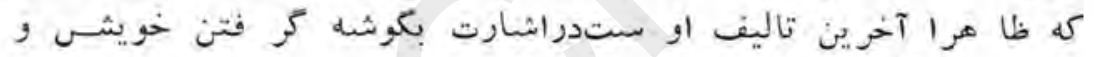

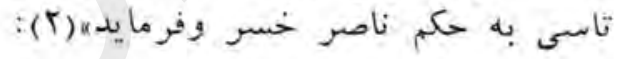

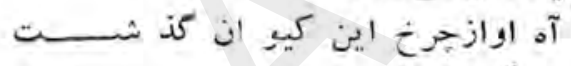

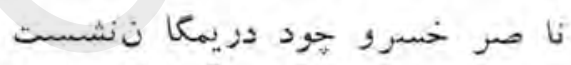

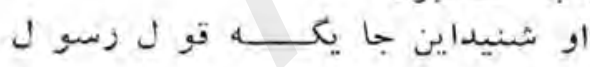

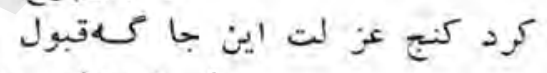

$$
\begin{aligned}
& \text { بود فرزند رسب آن هـر ددين }
\end{aligned}
$$

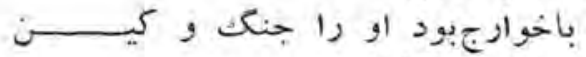

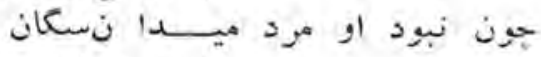

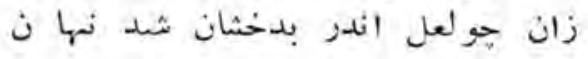

(1) برتلس ازقول ايوانوف كهفته است:اكر شها يبك اسهاعيلى كهيسار بكوئيدناصر

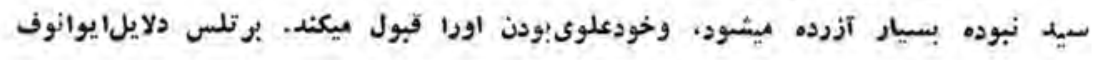

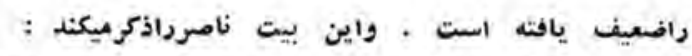

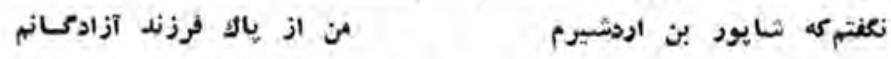

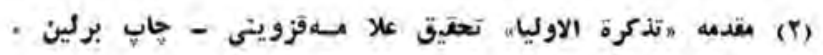




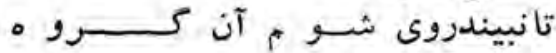

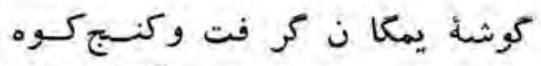

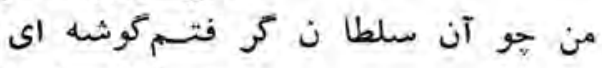

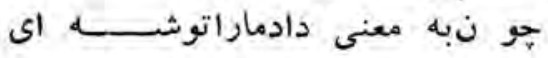

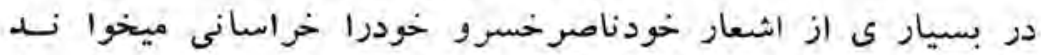

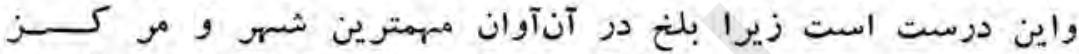

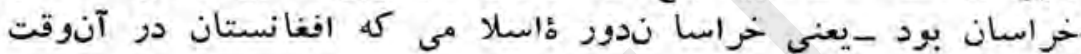

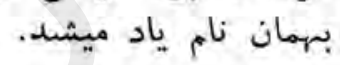

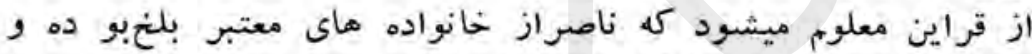

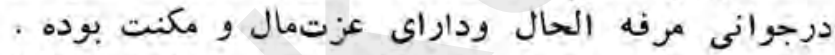

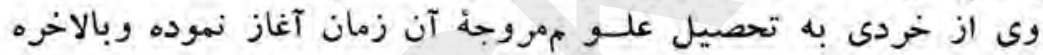

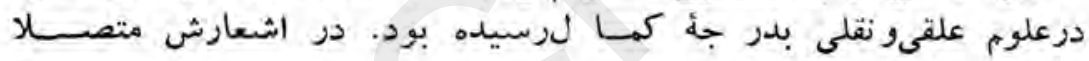

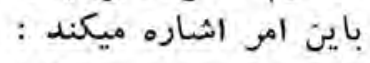

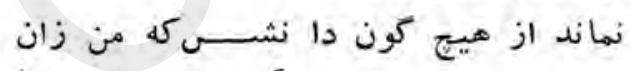

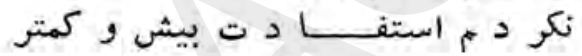

$$
\text { (1/10 د-2 }
$$

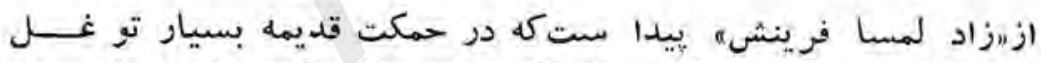

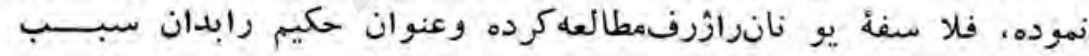

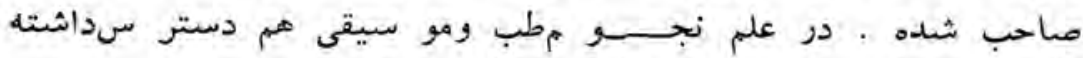

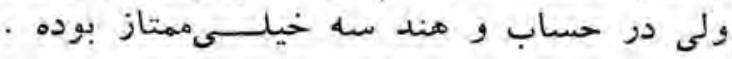
بعلم هندسه سر بو بر كشيدى

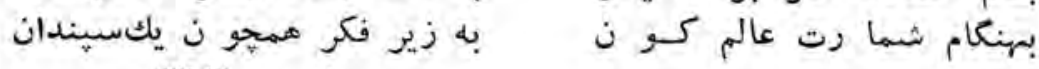

(rit

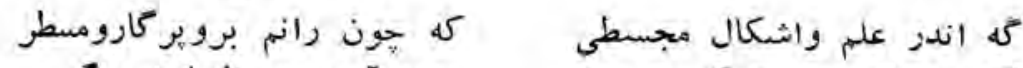

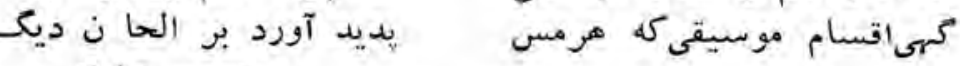
(ص) 


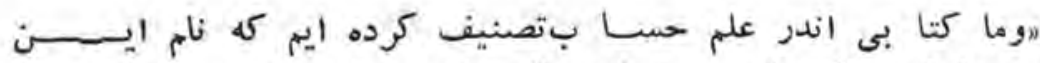

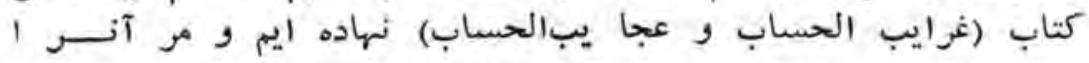

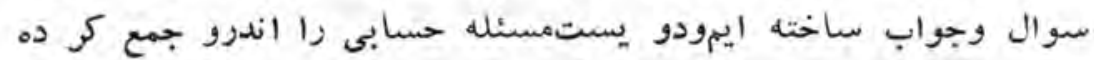

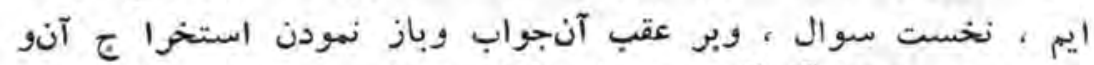

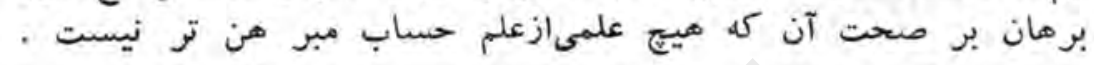

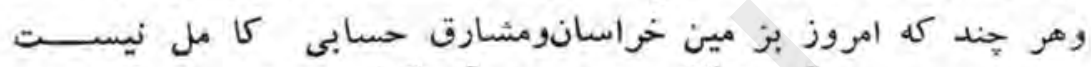

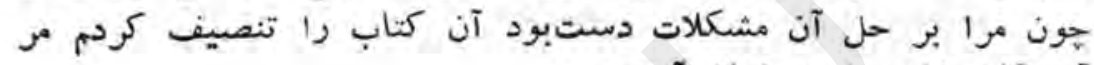

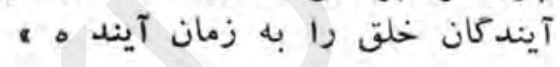

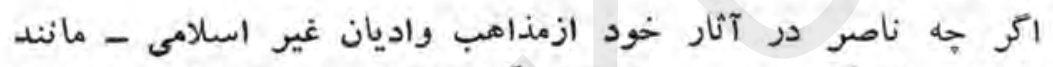

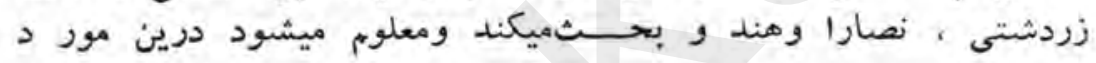

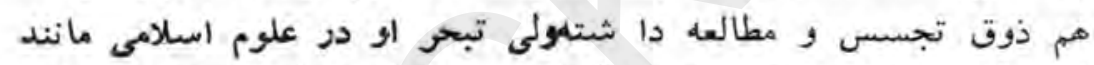

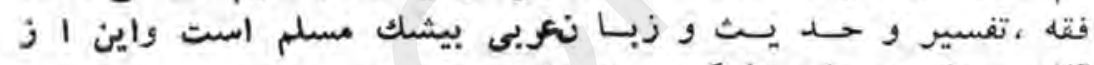

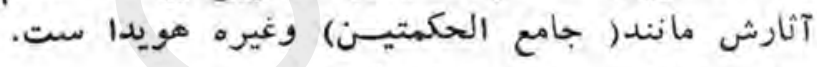

\section{ع- اختيار سفر وتحول فكرىاو}

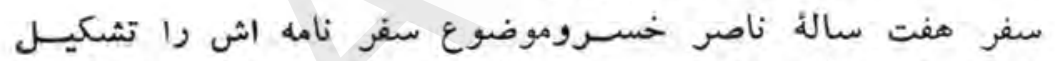

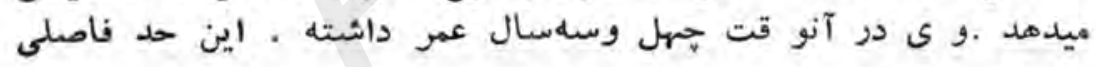

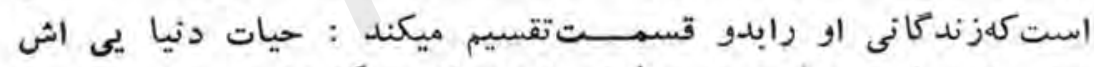

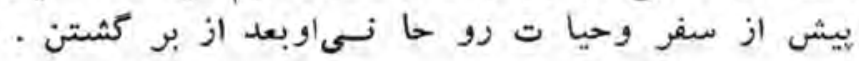

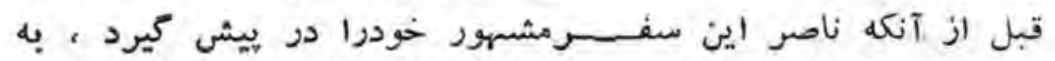

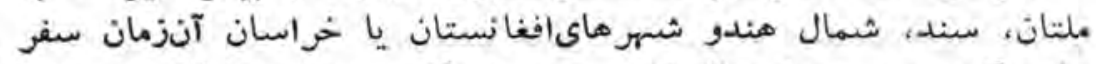

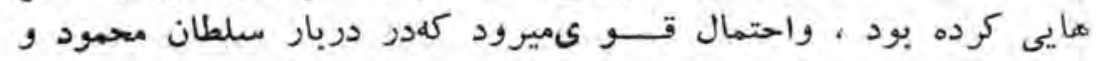

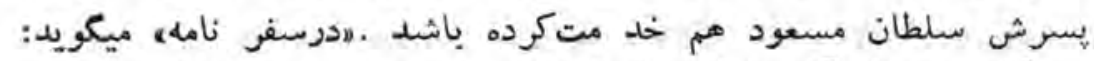
ب....

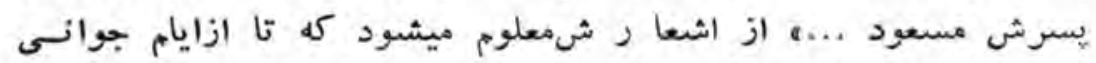

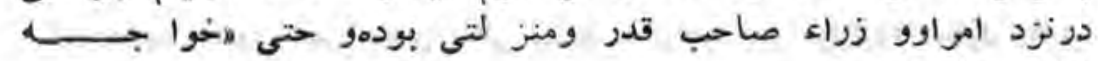




\section{r. \\ نامر خسرو بلنى}

بى منقدحبدست كمئ نكيرد همى اميسر

دستم رسيده بر مهاز يرا كهميح و قت من بلت

بيش وزير با خطل و خشمتمبدا نك من بلك

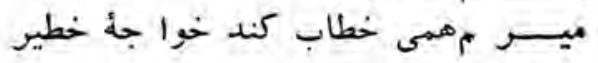

$$
\text { (107 ص (2) }
$$

زمنمجلس ميرو صدر و زئس زيسـ

$$
\text { همان نا صر م من كى خا ليىنبود }
$$

$$
\text { بنامم نخوا ندى كس ا زبسشر في زئس }
$$

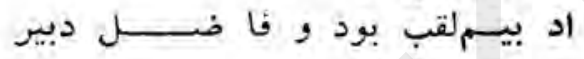

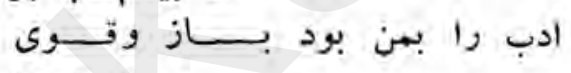

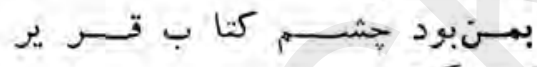

$$
\text { به تحرير الفـا ط من فخــركرد }
$$

همبـ كاغذ از دست من بر بر حر يسر

$$
\text { (ص) }
$$

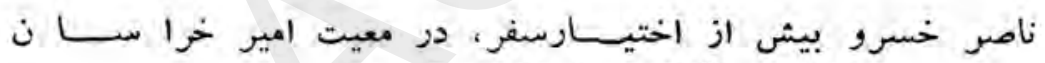

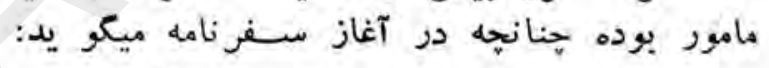

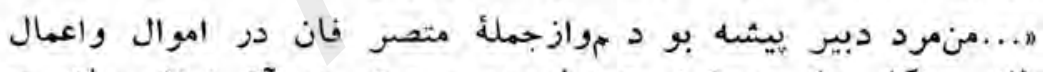

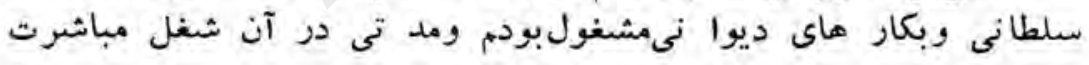

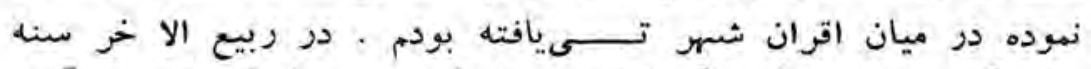

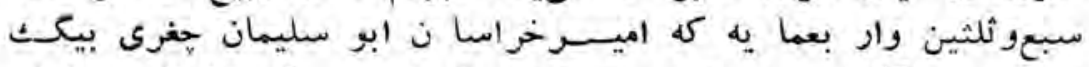

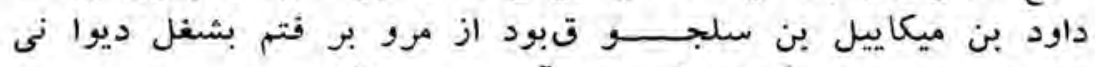

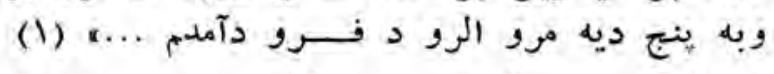

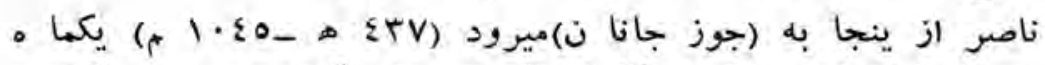

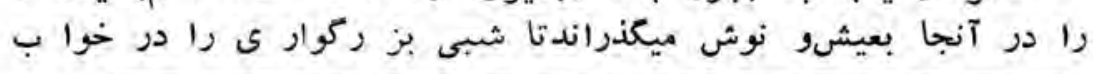

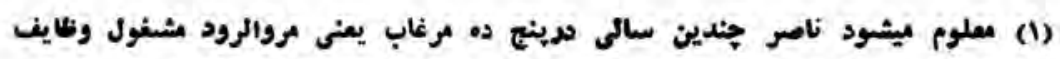

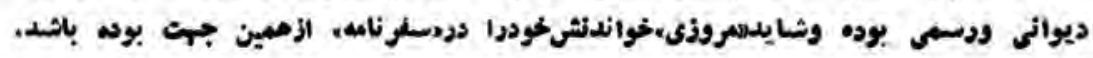


ميبيند كه اوراازحيات بيهودة كلصرف لهو ولعب كرده وبمادياتو

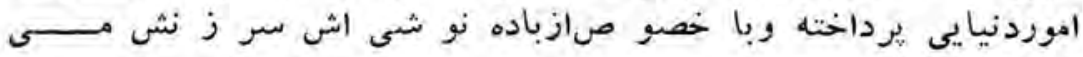
كند :

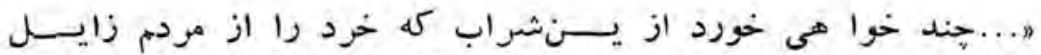

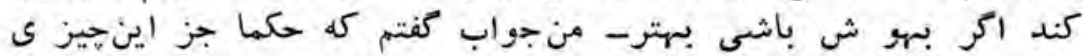

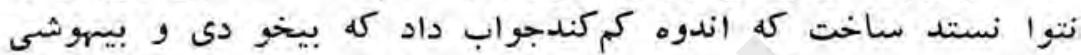

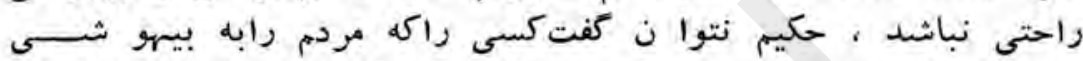

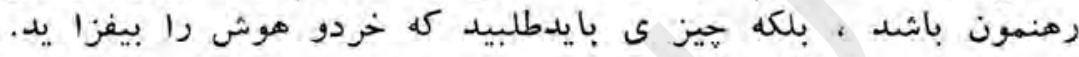

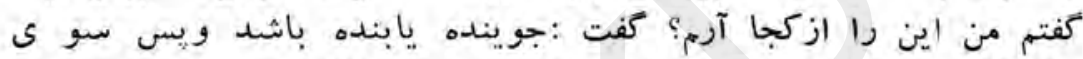

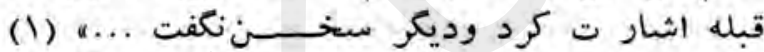

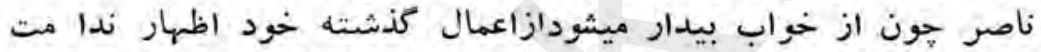

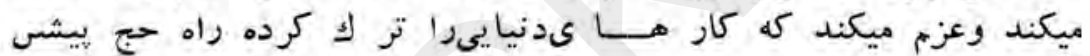
كيرد.

\section{جنانهه ميكو يد:}

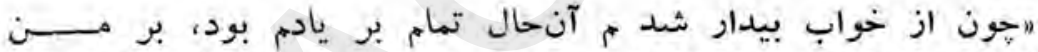

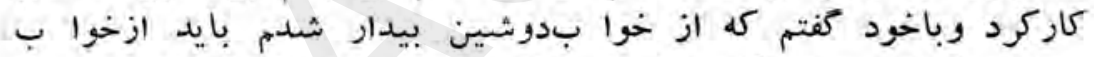

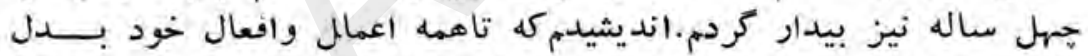

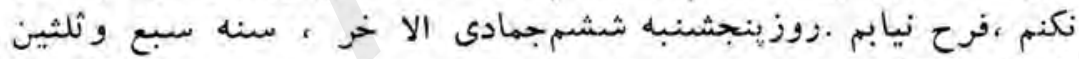

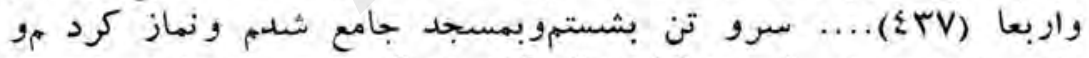

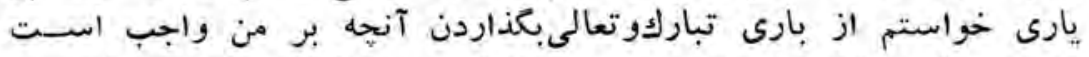

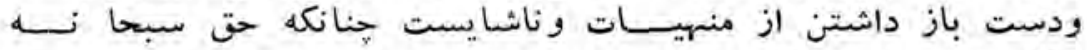

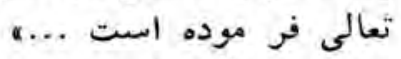

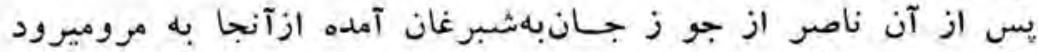

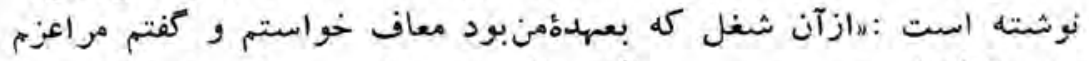

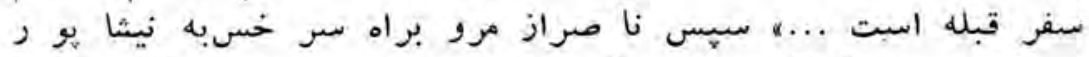

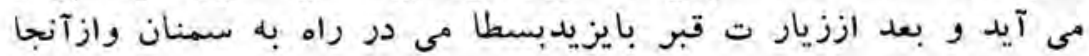




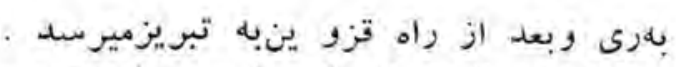

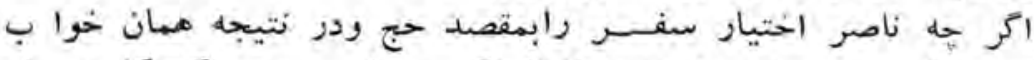

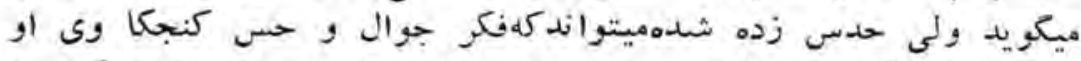

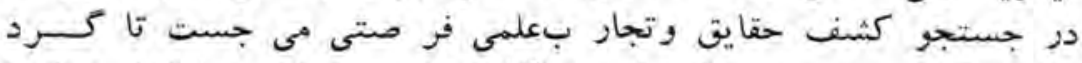

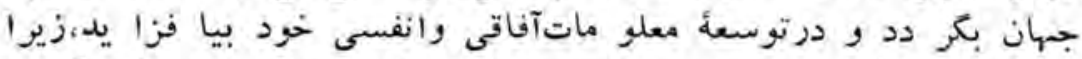

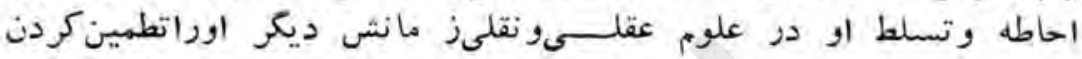

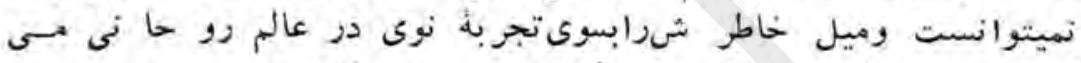

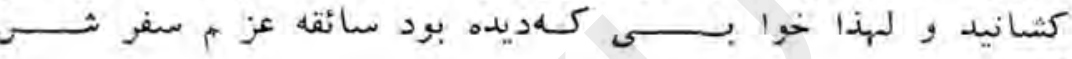
كرديد

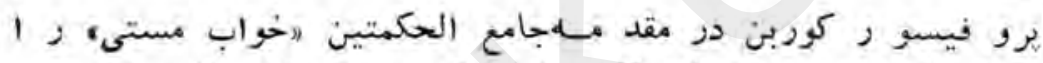

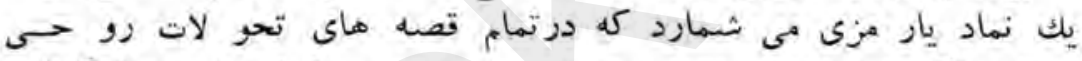

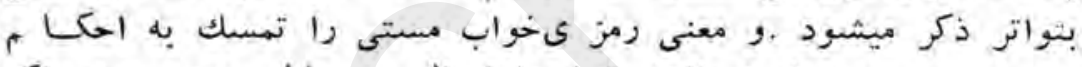

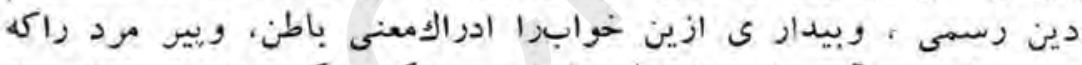

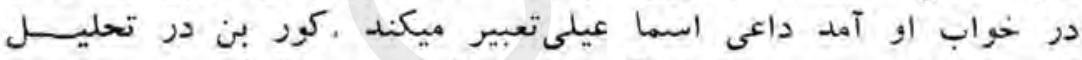

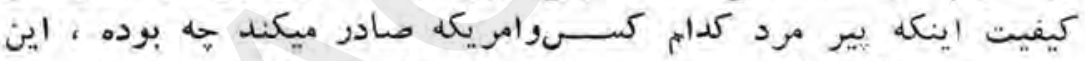

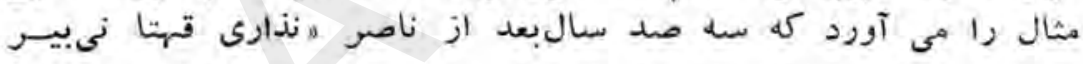

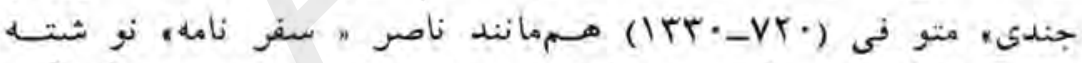

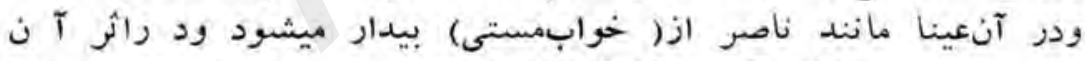

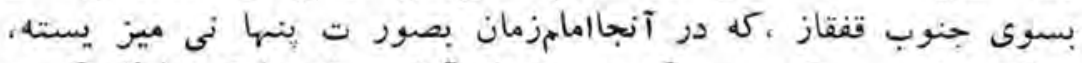

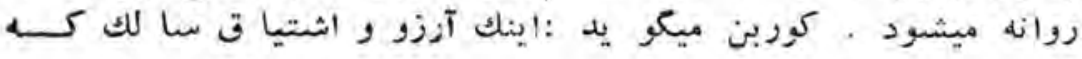

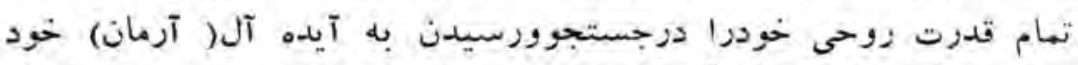

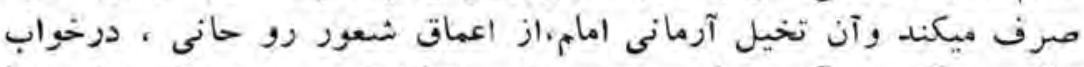

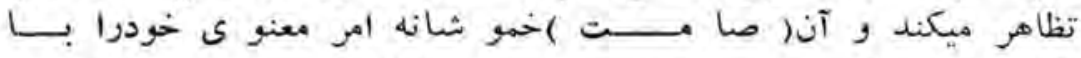

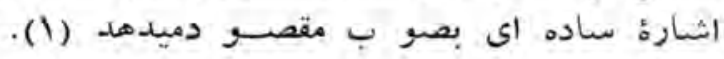

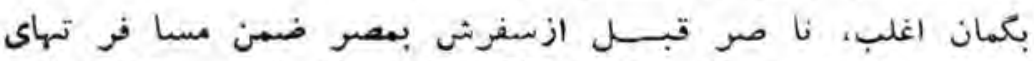

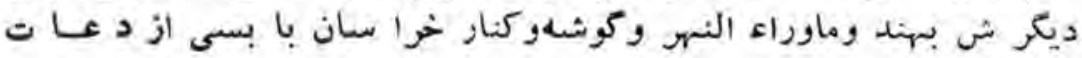


و بيروانكيش باطنى بر خـورده ومعلو مات زياد ازآث مذ هب بدست آوزده بودان.

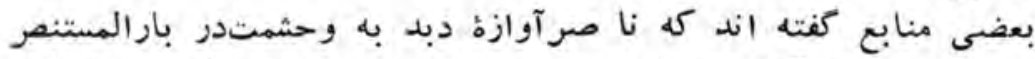

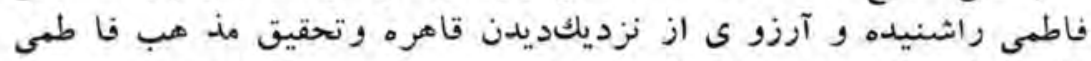

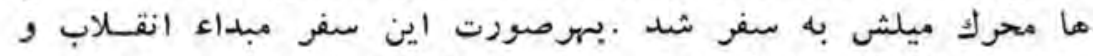

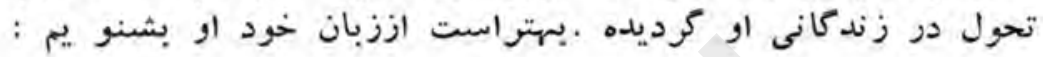

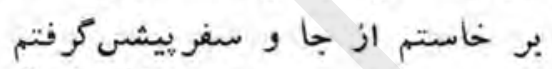

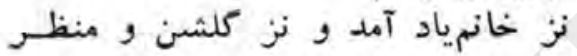

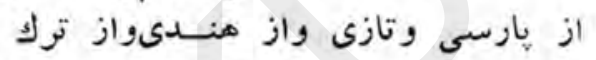

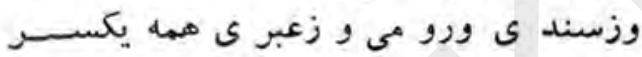

$$
\text { وز فلسفى و ما نو ى وصابىودهرى وزينا ورو }
$$

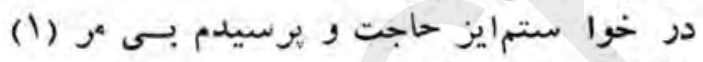

$$
\text { از سنكث بسى ساخته ام بستروبالين }
$$

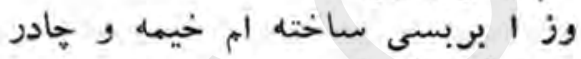

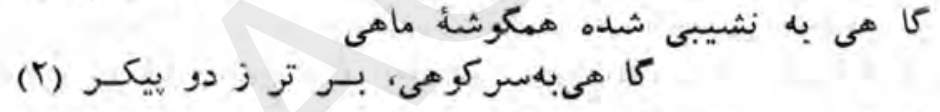

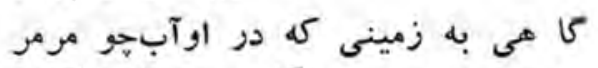

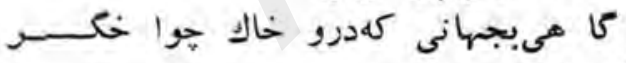

$$
\text { كه دريا كه بالا كه رفتن.بسىراه }
$$

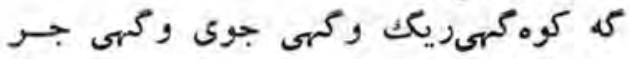

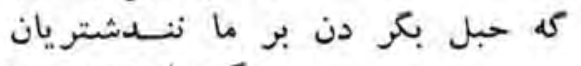

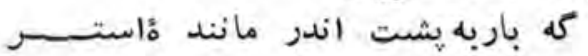

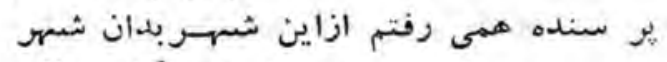

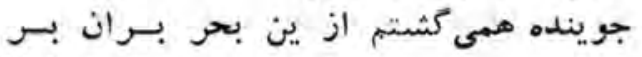

(IV乏

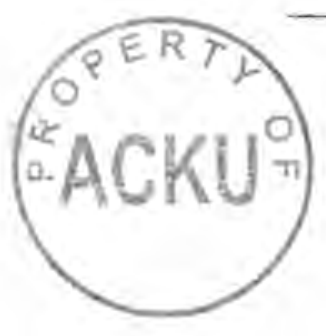

(1)

(r) 


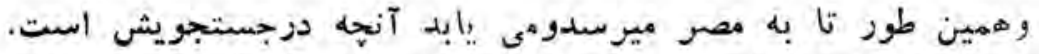

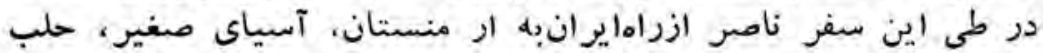

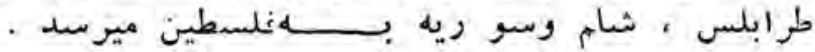

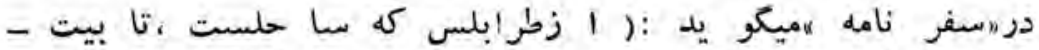

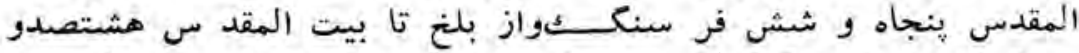

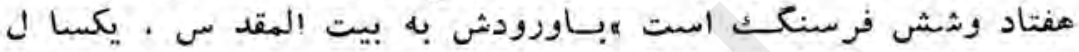

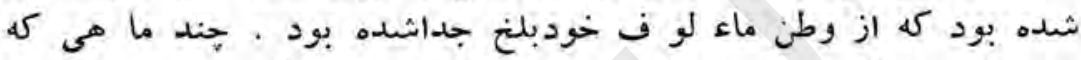

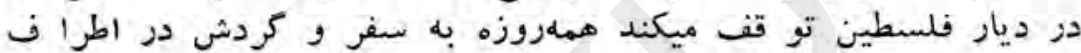

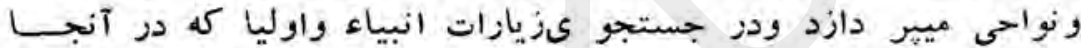

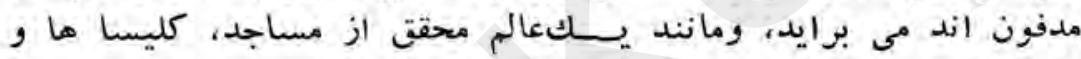

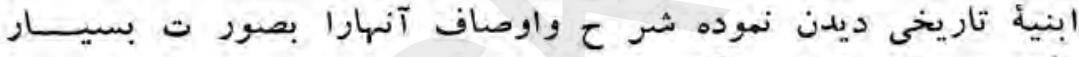

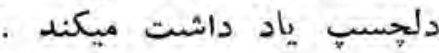

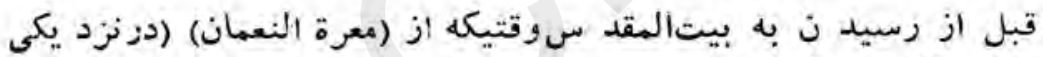

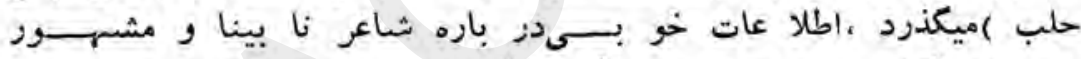

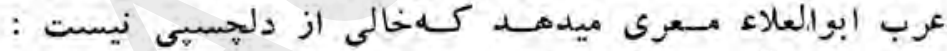

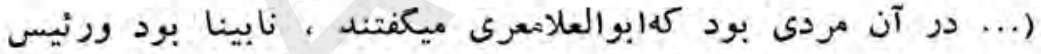

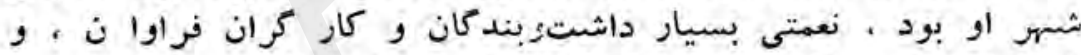

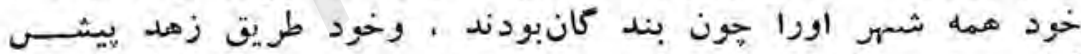

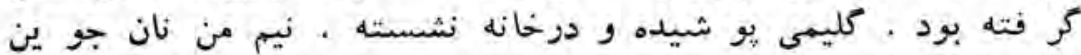

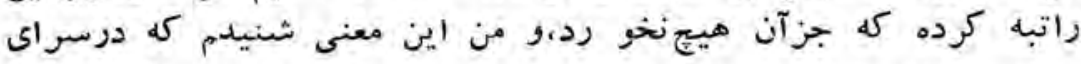

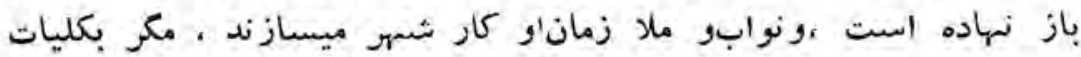

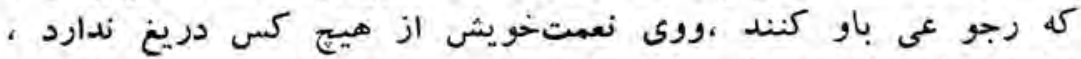

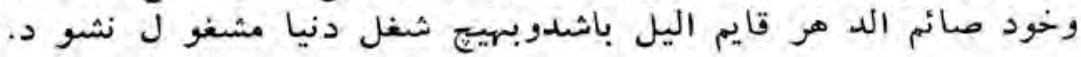

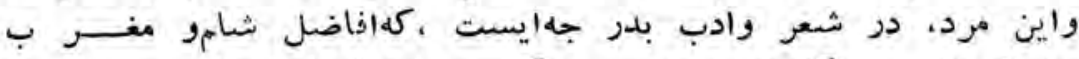

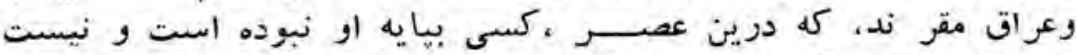

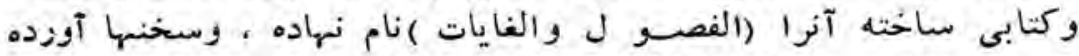

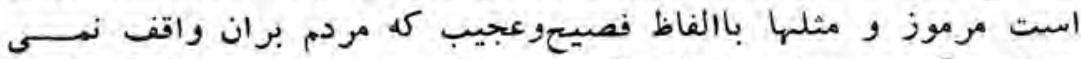

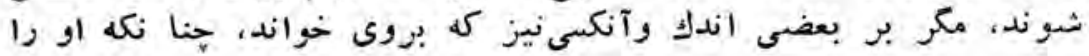




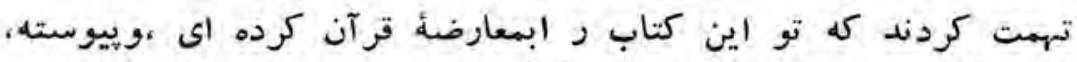

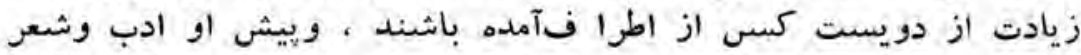

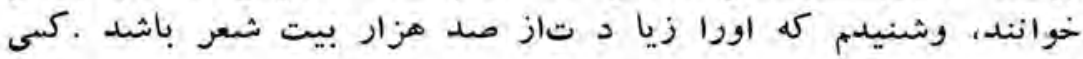

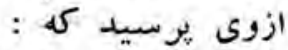

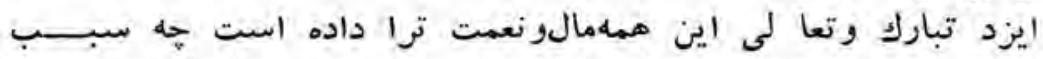

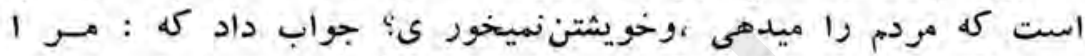

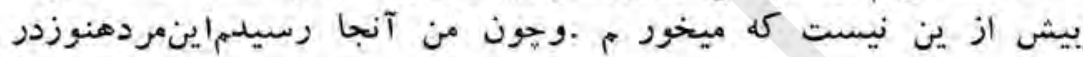
جيات بود . ناصن

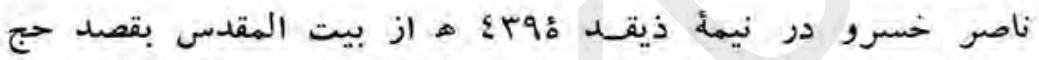

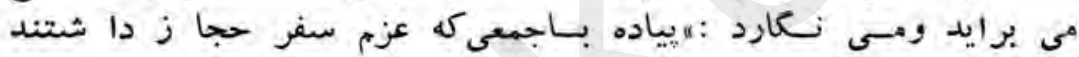

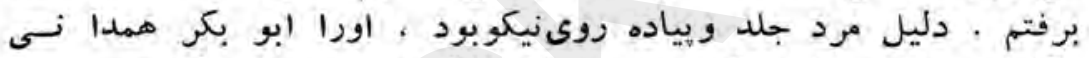

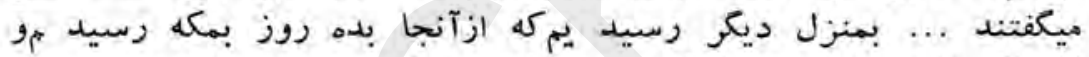

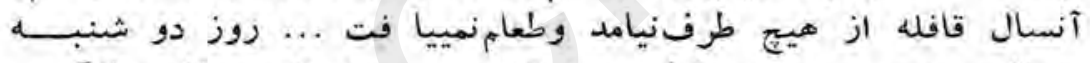

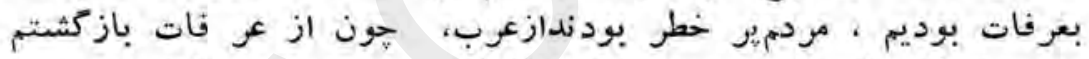

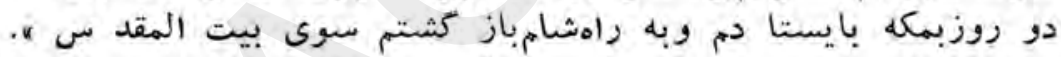

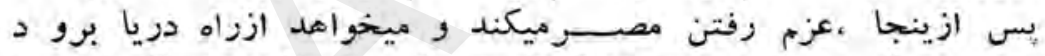

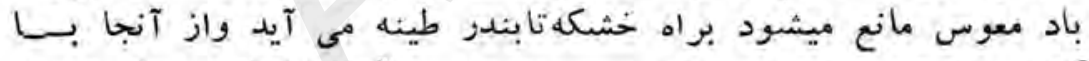

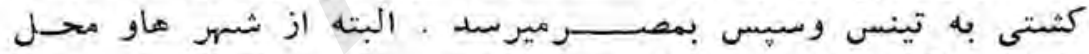

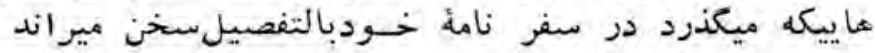

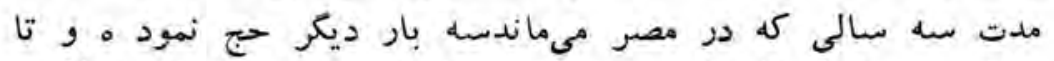

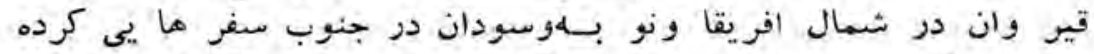

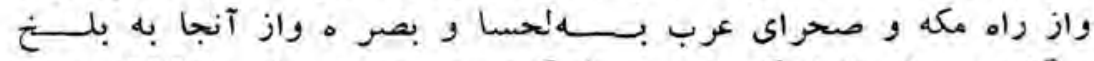

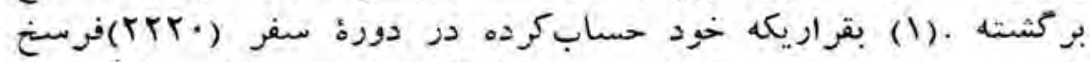

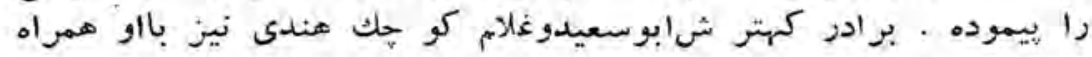
بوده اند بوده

در مصر- كه درين و قت زيسرحممرا نى خلفاى فاطمى بود تحول 


\section{หา}

بزركى در زندكانى ناصر رخميدهدكه اوجسفر ش را تشكيل ميدهدو

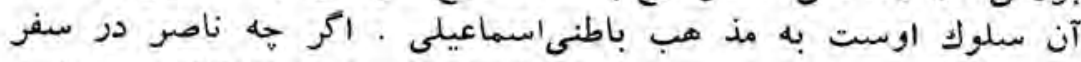

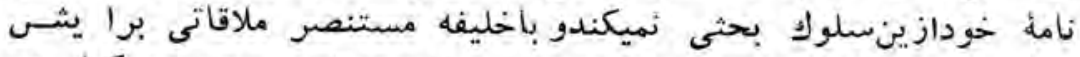

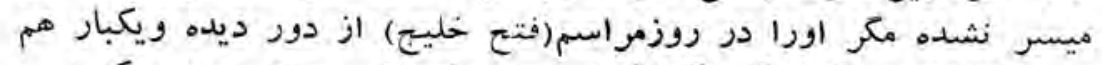

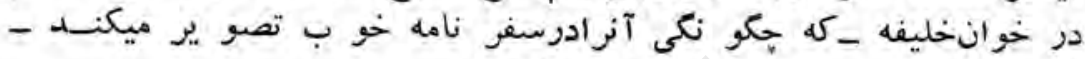

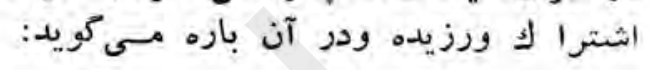

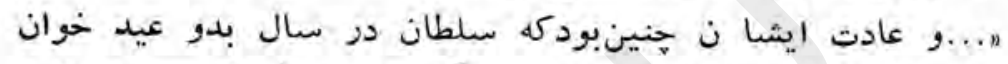

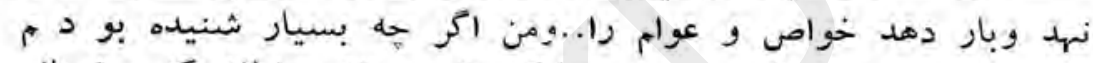

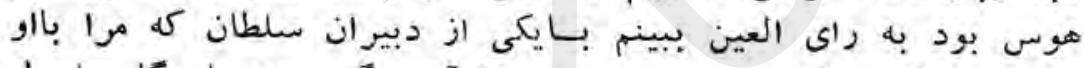

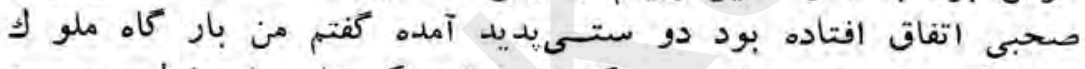

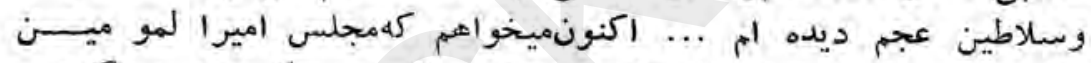

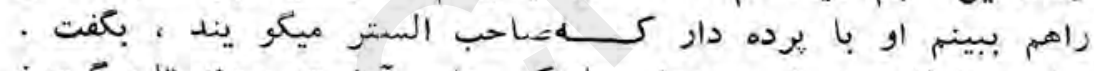

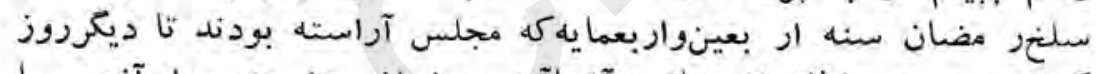

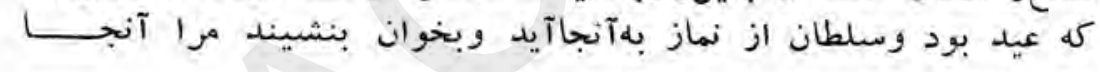

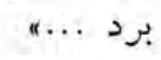

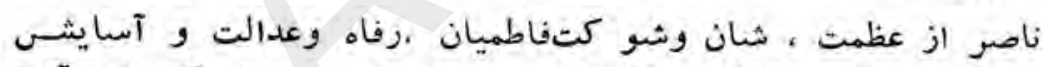

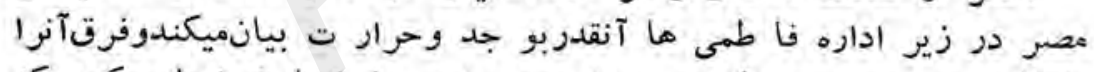

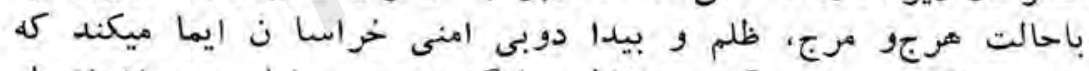

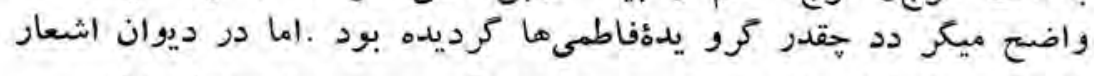

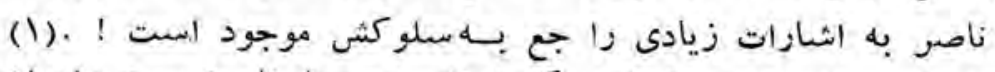

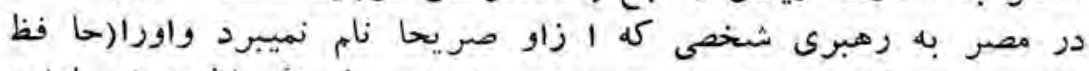

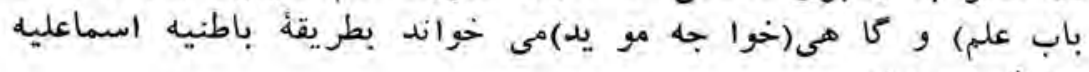

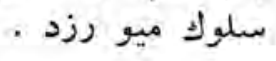

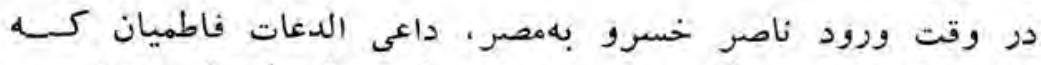

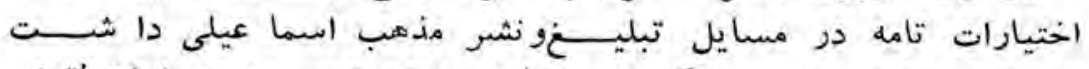

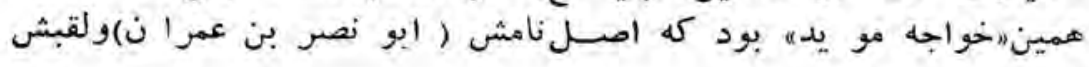




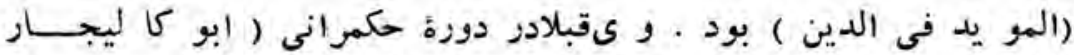

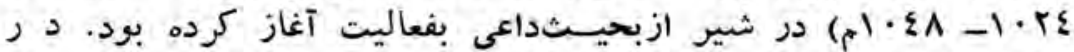

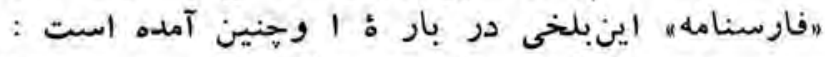

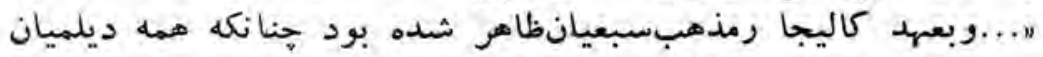

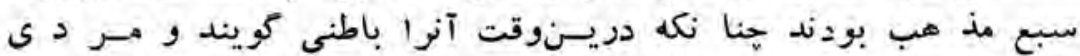

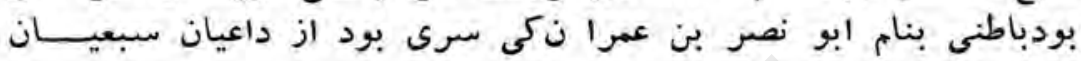

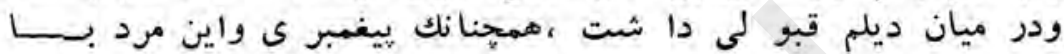

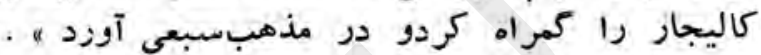

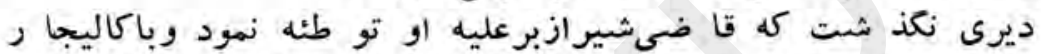

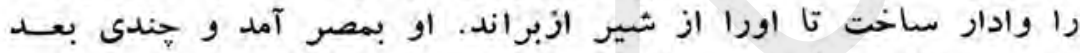

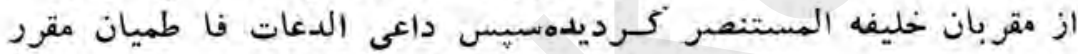

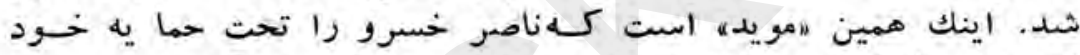

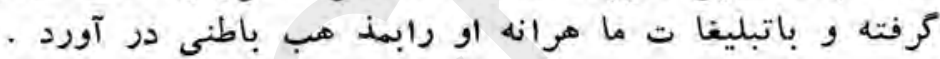

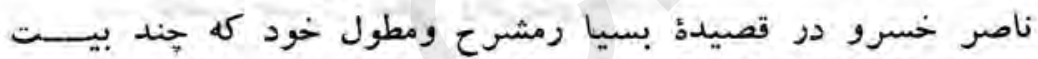

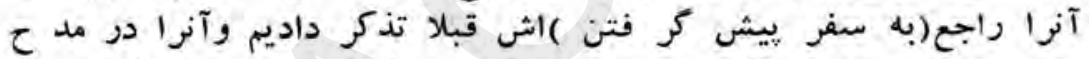

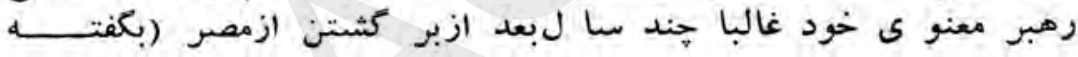

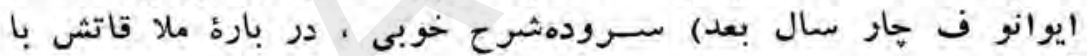

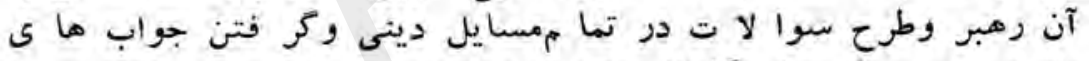

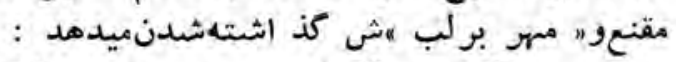

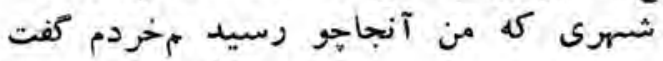

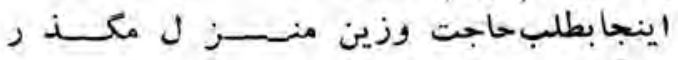

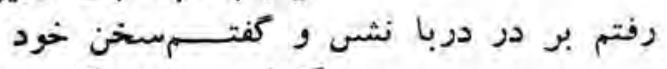

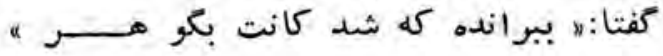

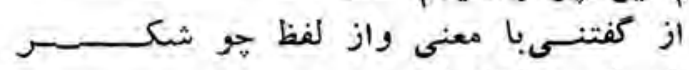

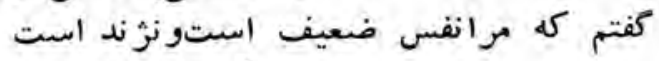

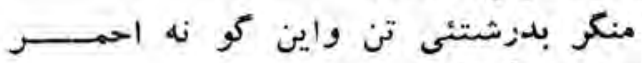

$$
\text { سوالا تشى هفده بيت را دربومى ميرد وسيسى : }
$$


كفتا "بد هم دارو ى با حجـتوبر هان

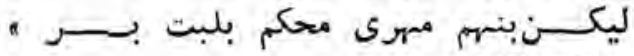

$$
\text { زآفاق وز انفس دو كواحاضركردش لئ }
$$

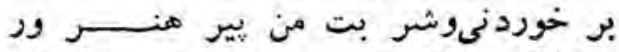

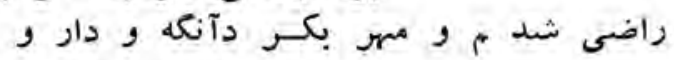

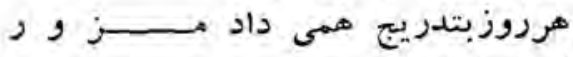

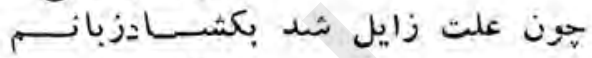

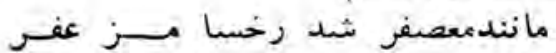

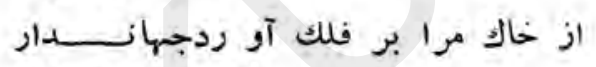

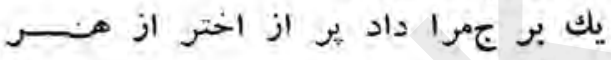

$$
\text { دستم بكف دبست نبى داد بهبيعـــت فمراد }
$$

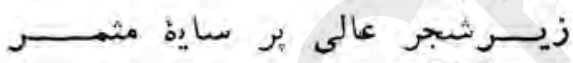

\section{0ـ ناصر خسزو بلخى وطريـقباطنيه}

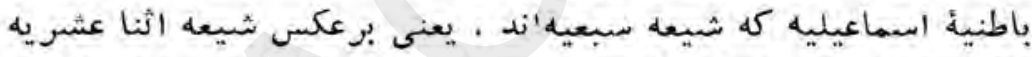

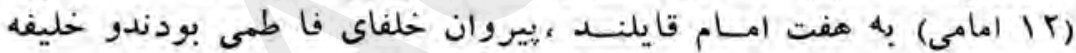

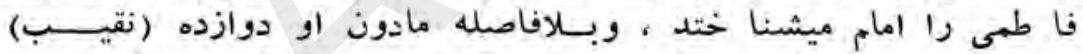

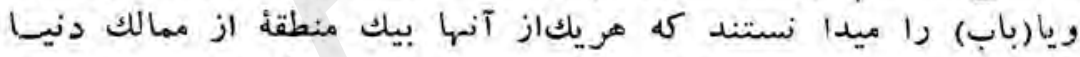

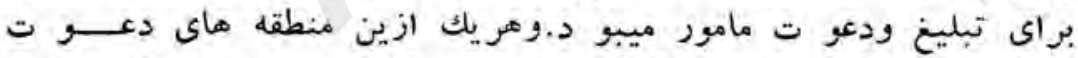

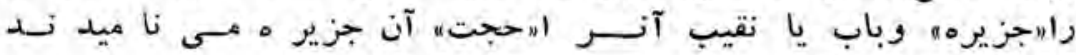

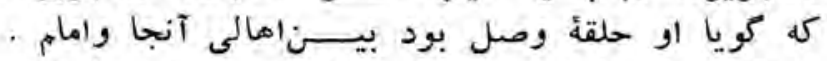

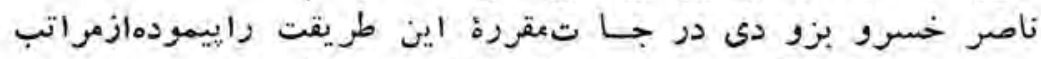

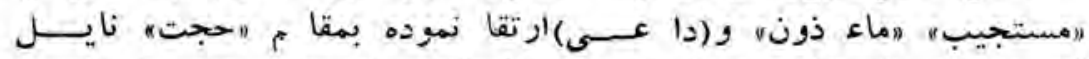

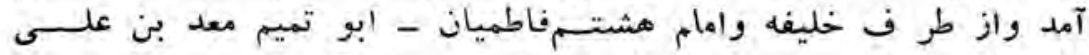

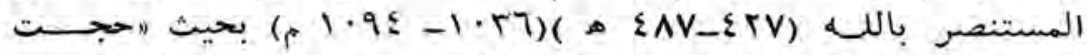

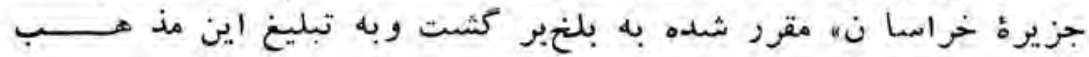

(1). آغاز نمودة

(1) 
دزبلخ ديرى نكذ شت كه ناصر هدف تير ملا مت و تعقيب علما و و

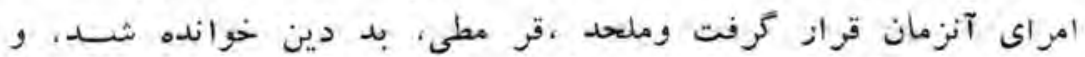

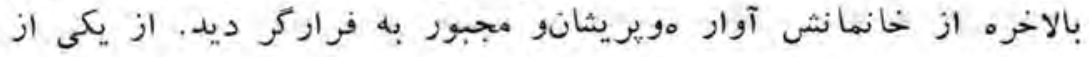

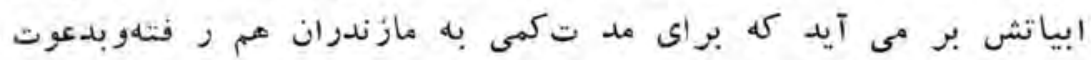

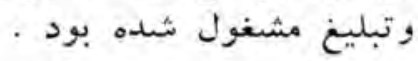

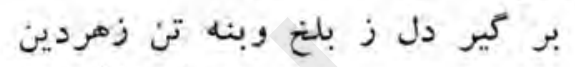

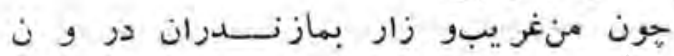

$$
\text { (0.7- (2) }
$$

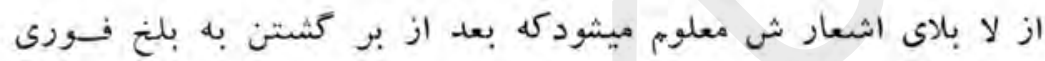

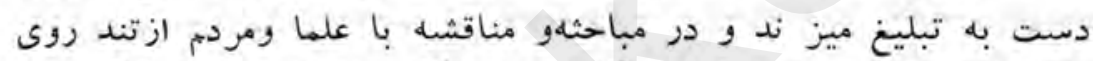

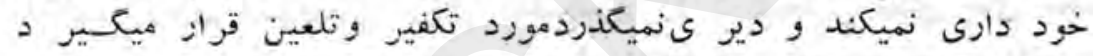

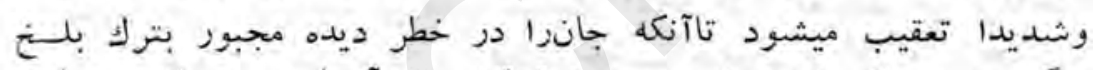

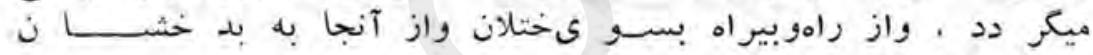

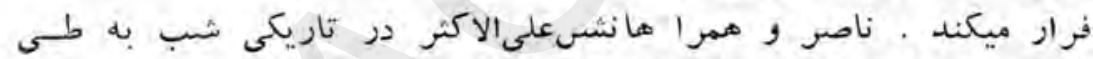

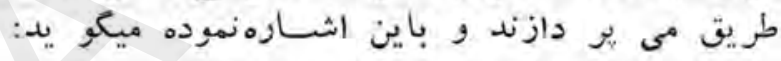

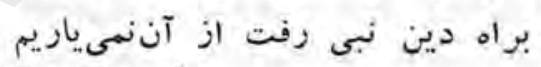

كه راهير خطر وماضعيف وبنى يار يم يم

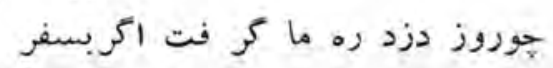

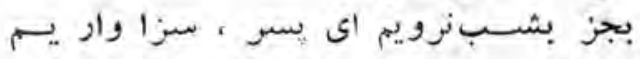

$$
\text { ازين بسان ستار ه بـسـرو زينهانيم }
$$

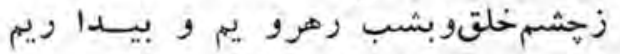

(

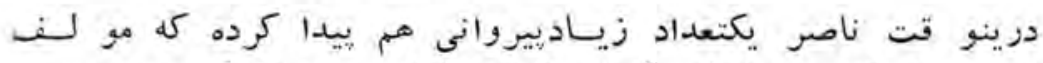

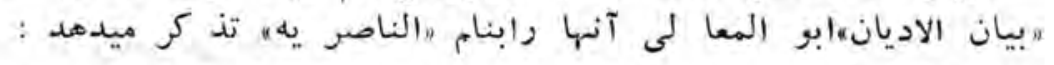

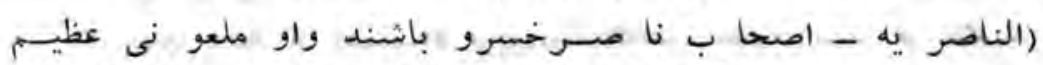

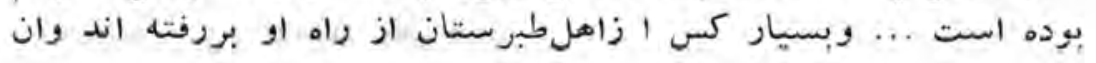




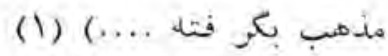

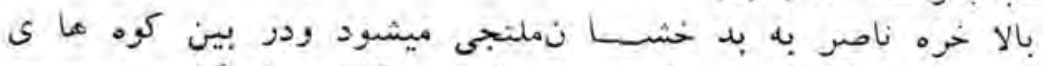

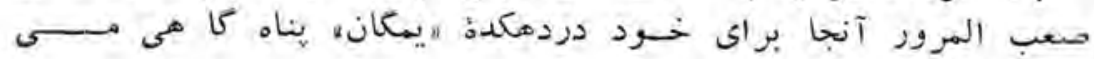
(T) .

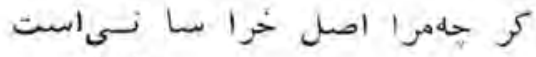

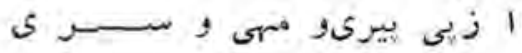

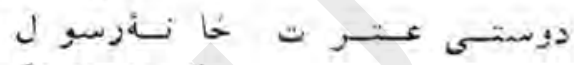

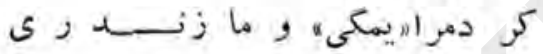

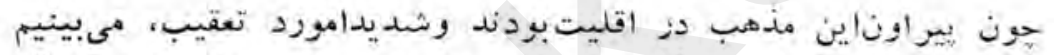

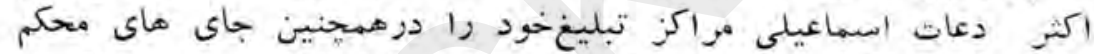

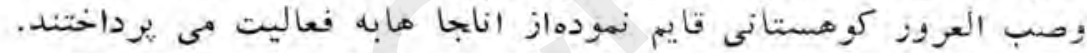

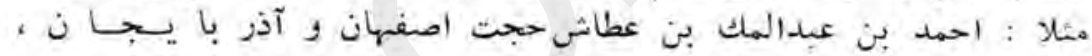

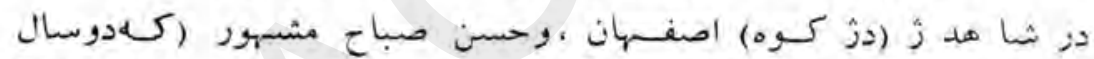

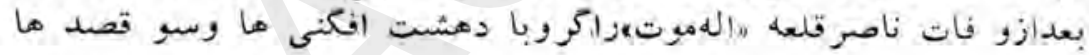

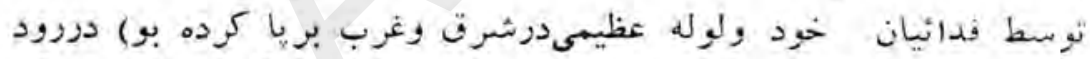

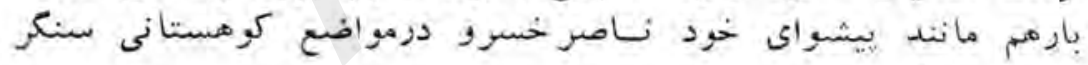

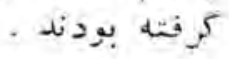

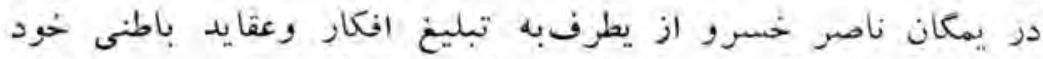

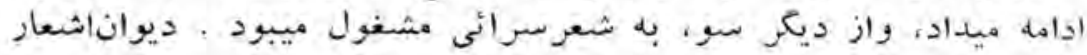

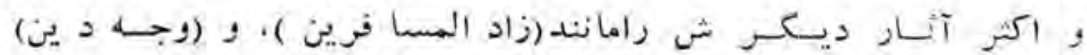

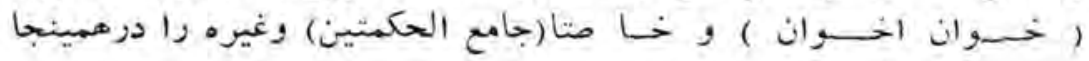

تموين كرده است احتوان

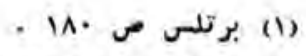

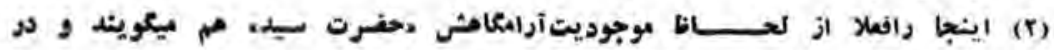

2اكيلومترى جرم بذخشان واقع است. 
در شبر يكه باين عطلع آغاز هىيابد:

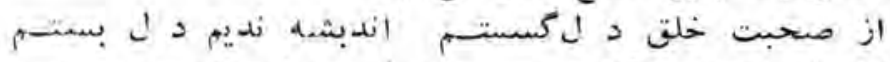

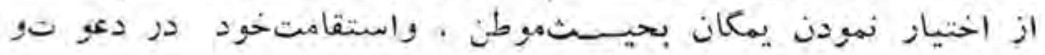

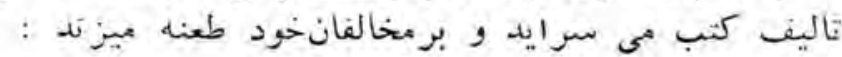

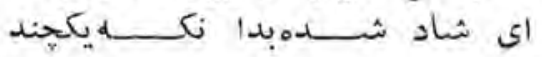

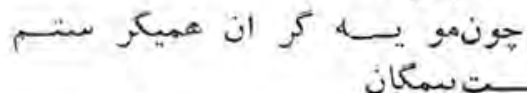

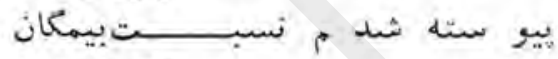

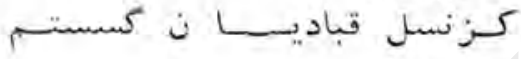

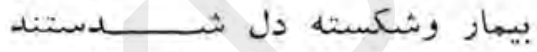

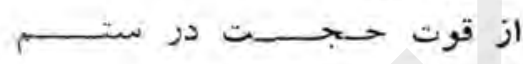

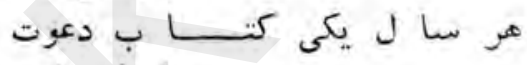

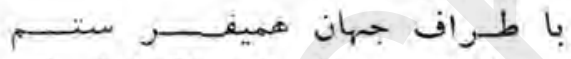

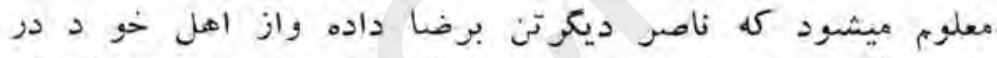

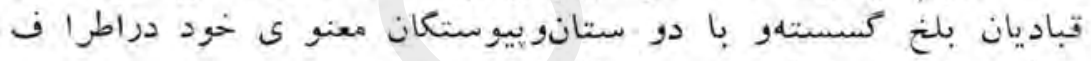

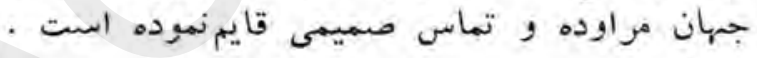

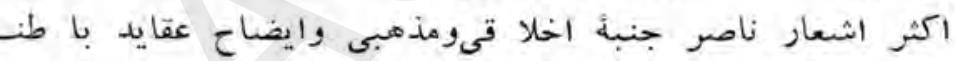

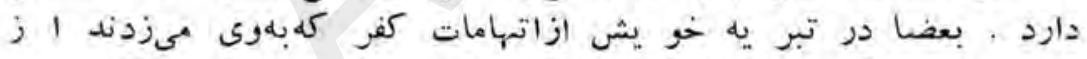

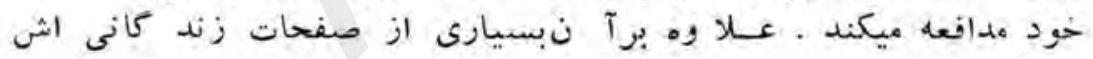

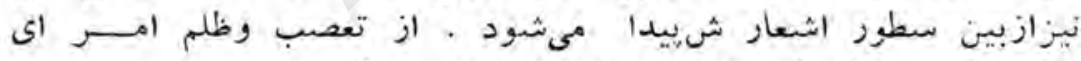

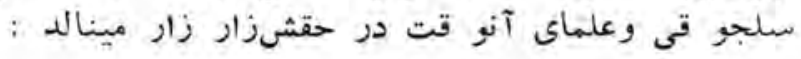

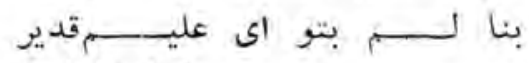

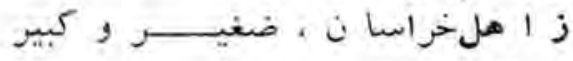

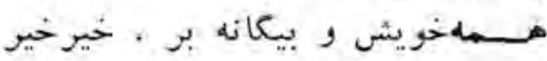

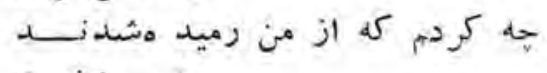

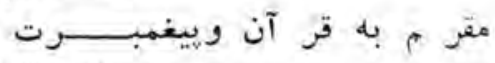

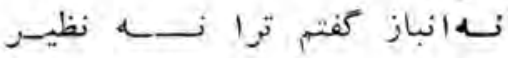

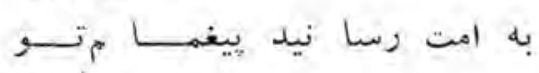

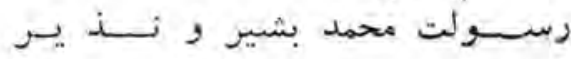


مكسرجبر ائيل ، آن مبار لـ سفير؟

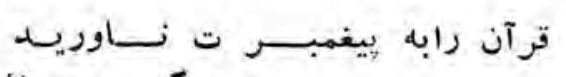

مقر م به مركث و بحشبر وحساب ائبل

كتا بتزير دار م انســــــ ر ضميــر

$$
\text { (ص. (19) }
$$

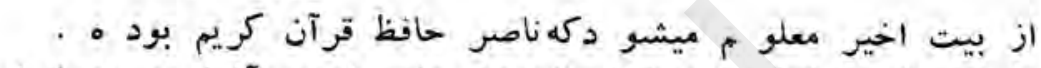

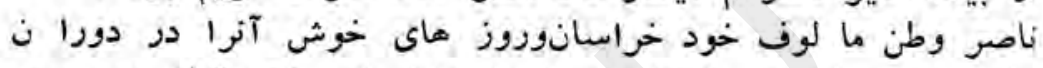

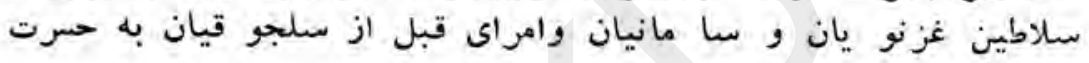

خلفاى عباسى وسلا طينسلجوقىزا ديوو فر عو ن ميخواند .

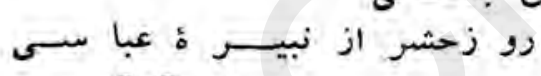

$$
\text { ( }
$$

ناصر خسرو در اشتيا ت وطنخودبلخ وخراسا ن هم بسيار شعر

$$
\begin{aligned}
& \text { هاى بر سوز مى سر ايد : }
\end{aligned}
$$

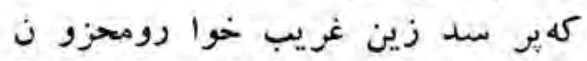

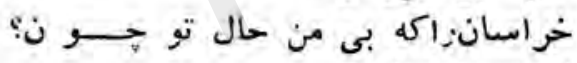

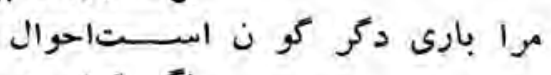

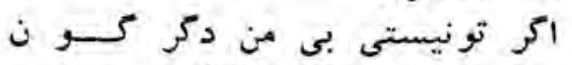

$$
\text { ( }
$$

$$
\text { بكذر اى باد دل افرو زخــراسانى }
$$

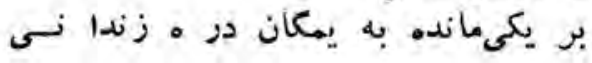

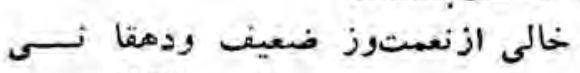

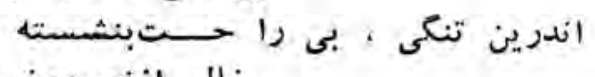

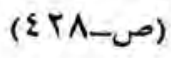

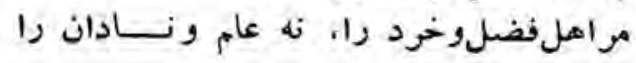


ناصر خسووطريق باطنيه

rr

بكو يشان كه جهان سرو من خو جمبر كرد

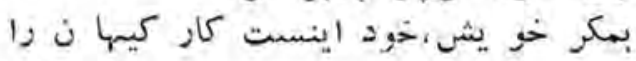
(ص-ص)

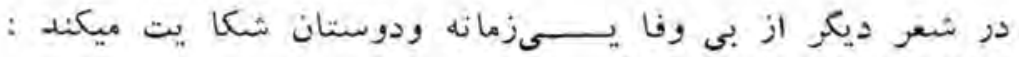

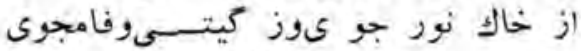

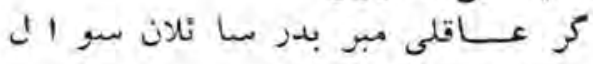

آنروز كار جون شد و, آن دوستان كجا؟

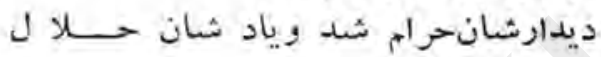

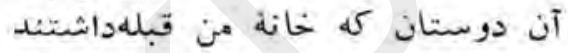

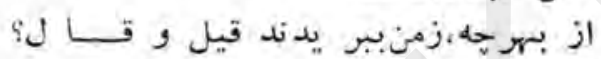

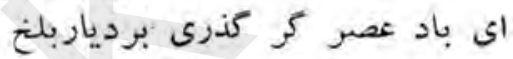

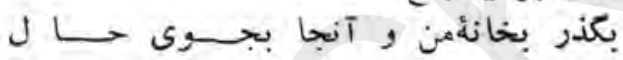

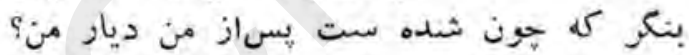

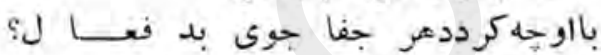

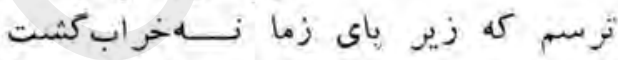

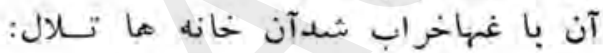

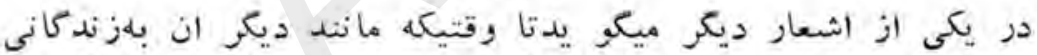

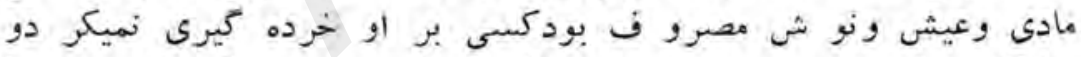

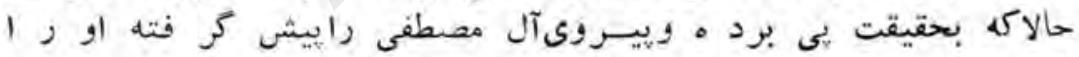

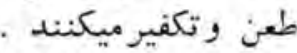

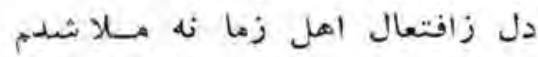

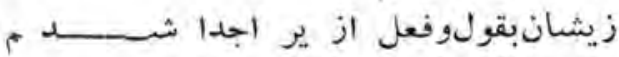

تا هميجو عمر و زيد مرا كوربوددل

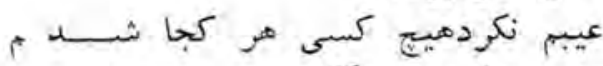

كا هى ز درد عشق يس خوبيهير كان

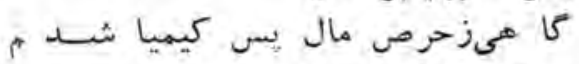

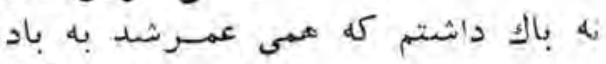

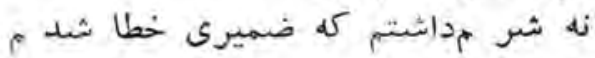




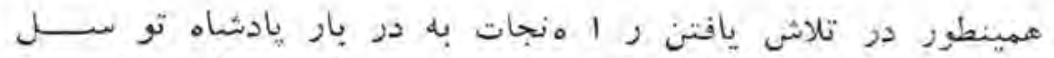

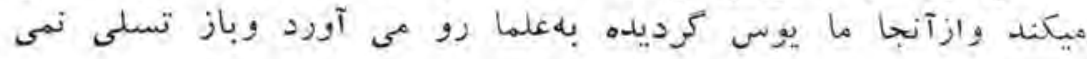

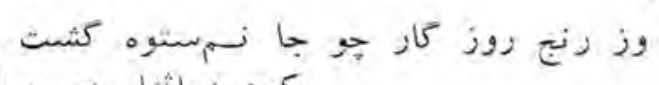

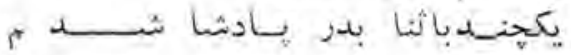

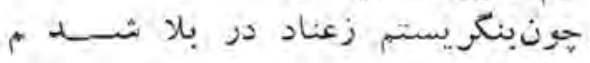

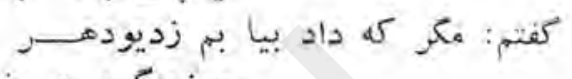

$$
\text { صد بند كى شاه بيـ يست كردنم }
$$

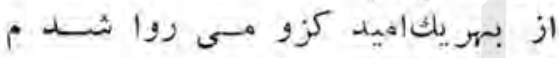

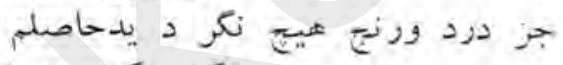

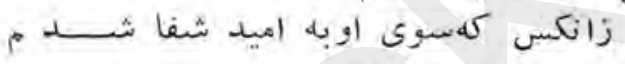

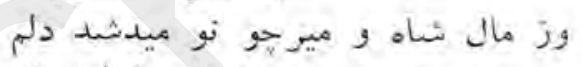

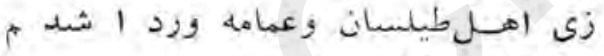

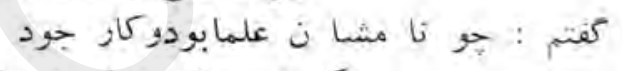

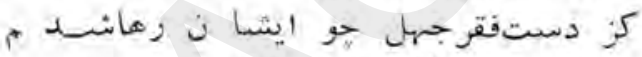

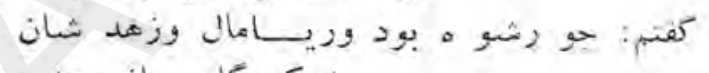

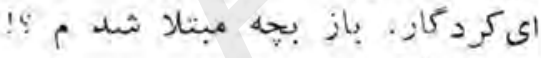

$$
\text { از تشاه زيفقيه جنان بودرفنم }
$$

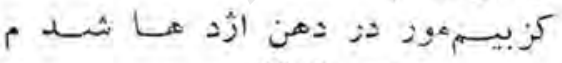

$$
\text { (TVT صن 2) }
$$

\section{T- بحثى در تاريخ تولد وســـن كندر خسرو}

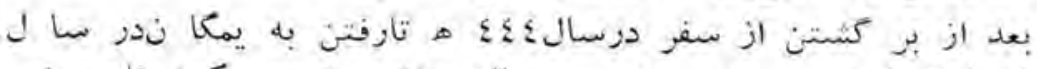

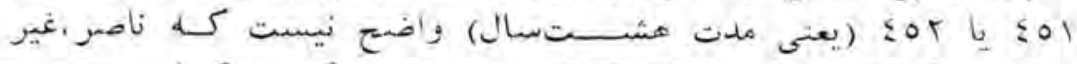

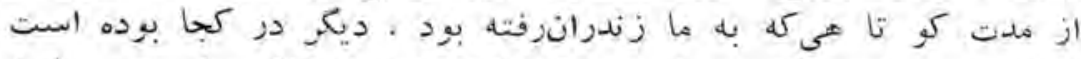

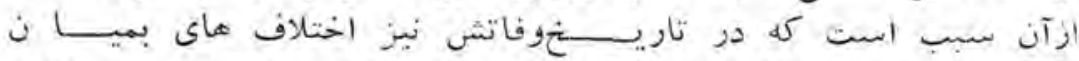

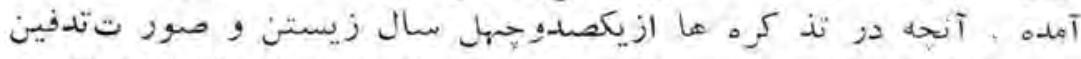

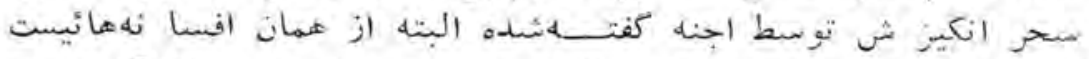

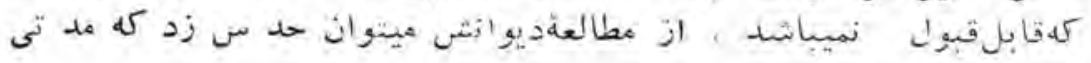




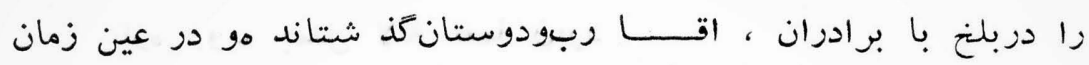

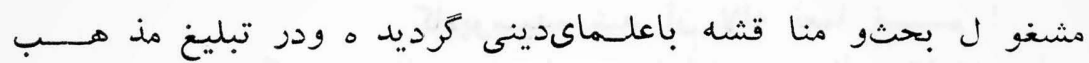

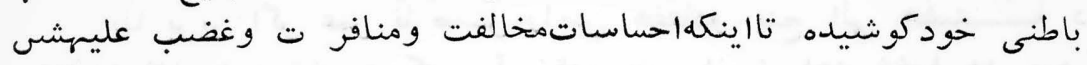

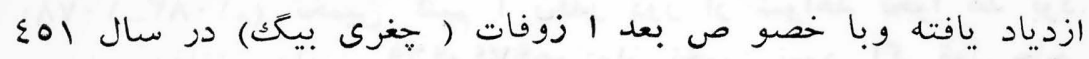

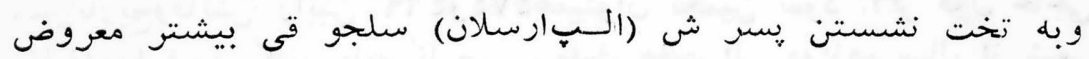

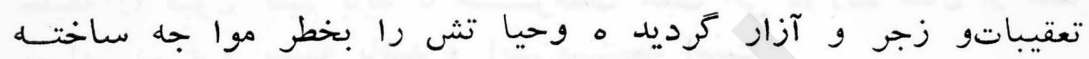

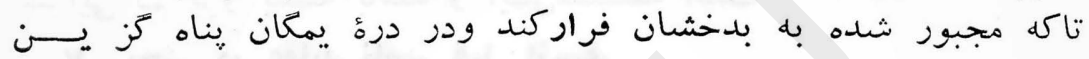

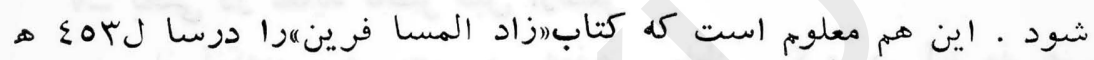

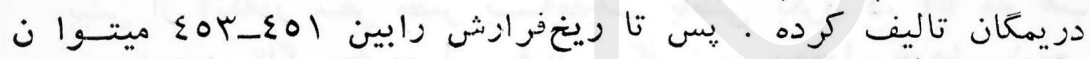

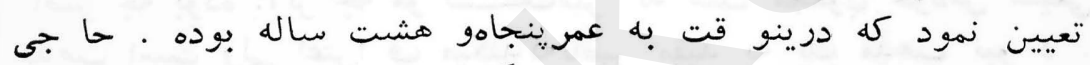

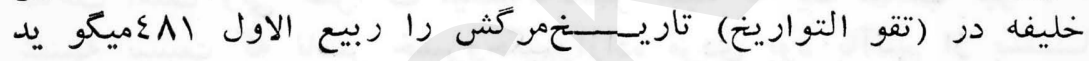

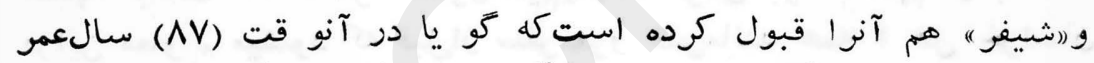

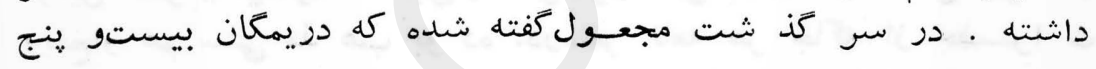

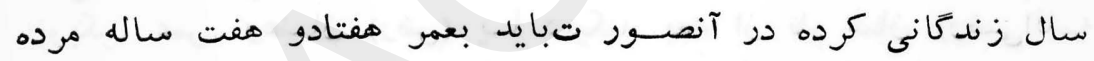

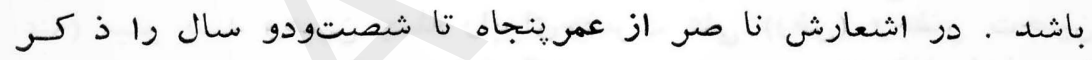
كرده است . كاشن

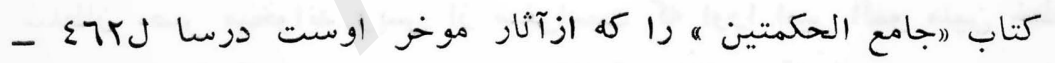

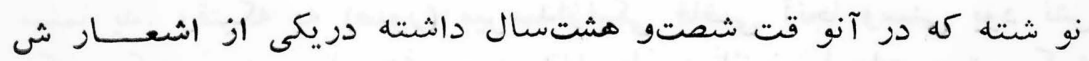

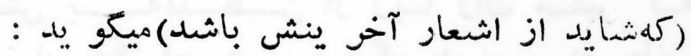

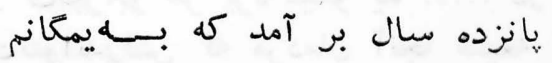

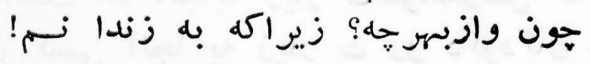

$$
\text { (ص^) }
$$

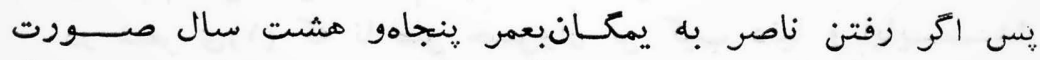

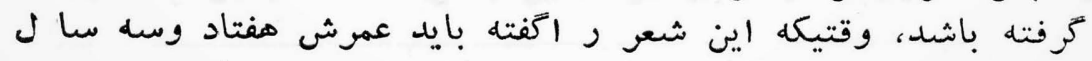

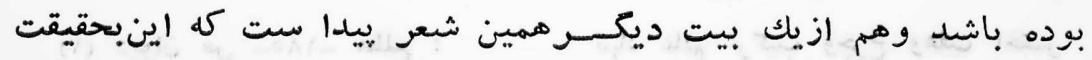




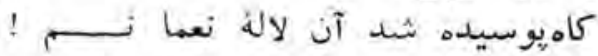

تازه رويم بمثل لاله نعما نبود

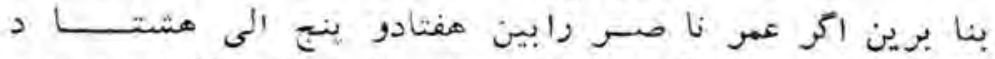

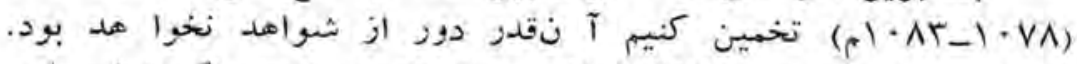

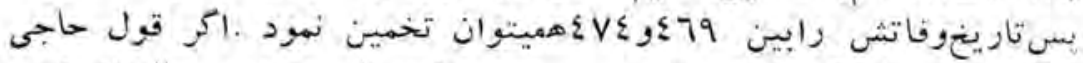

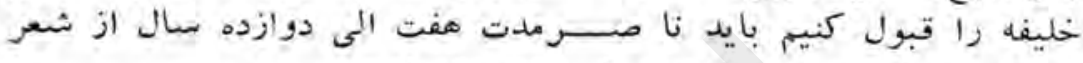

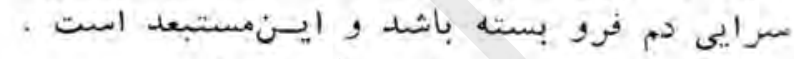

\section{V- بحثى در عقايد ناصر قبل ازسفر باثل}

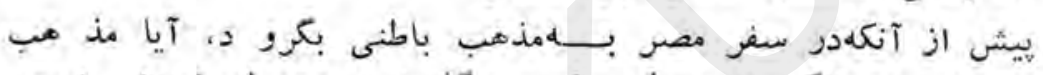

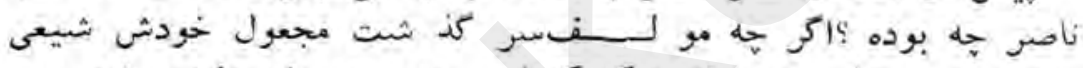

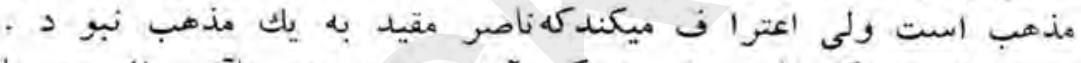

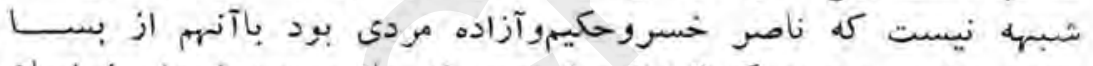

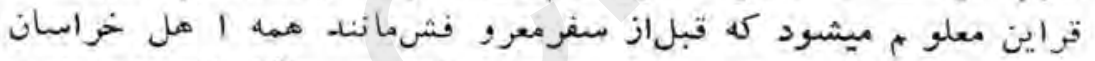

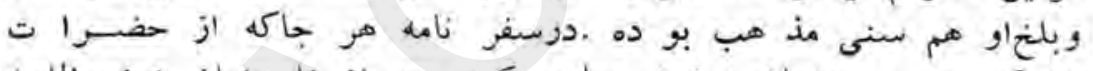

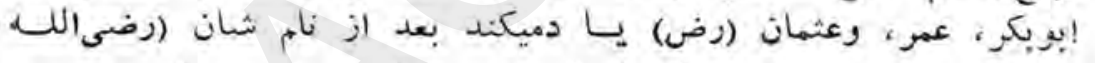

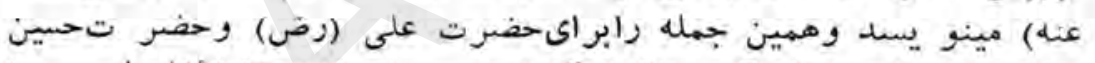

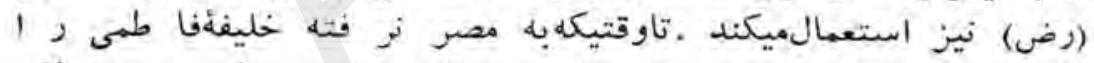

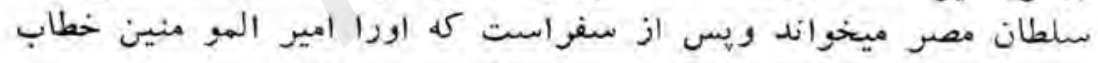

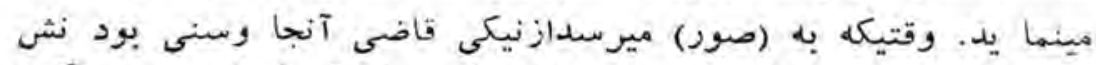

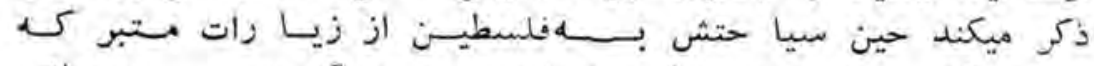

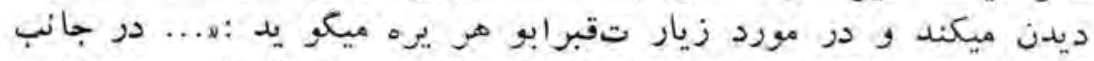

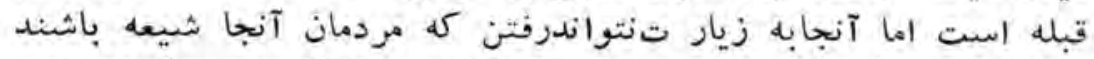

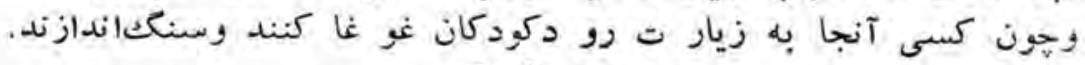

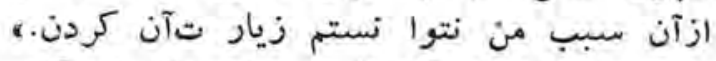

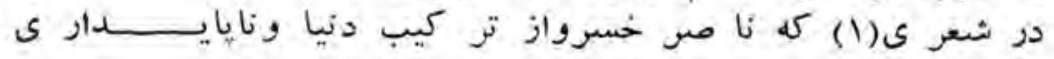


زندكانى بشر سخن ميراندوسيساز حضرت آدم كر فته همه ريبغمبران

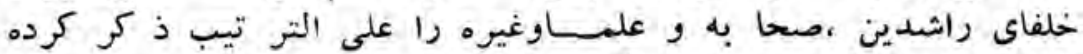

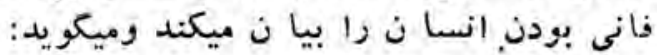

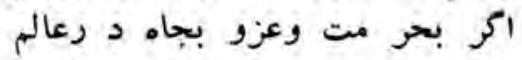

كسىبماندى، ماندى رو سول تامحشر

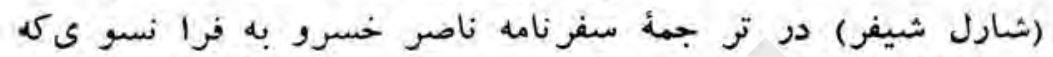

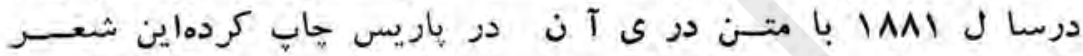

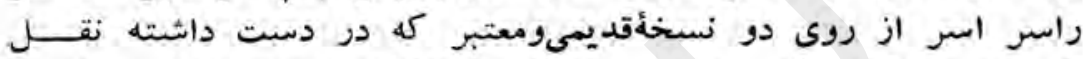

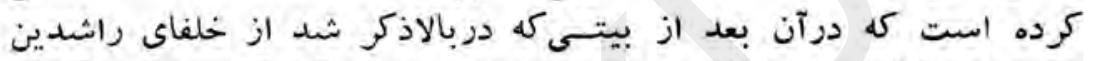

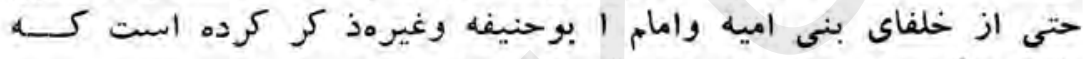

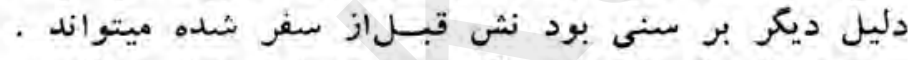

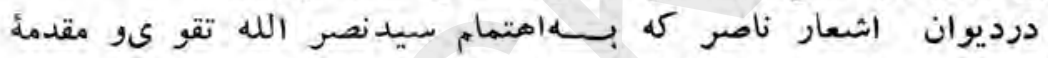

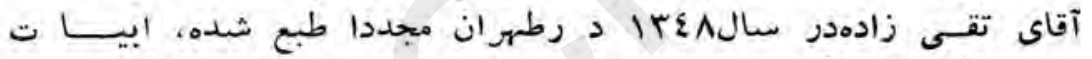

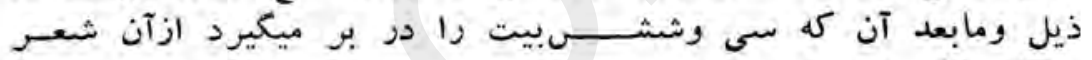

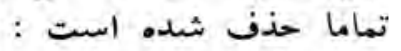
وكر بصدقبهاندى كسى بدى بديت وكربعدل بهاندى كسى بدى بدى عيتسر وكر بشرم بماندى كسى بدىعثمان و كربجودوسخا وت كسى بدى حيـــ ر

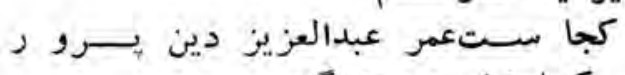

كجا معاو يه وكو يز يد كسوهشام زعا لمان جهان هر كجا زخورد وبزركى صغير بوده و شيهره ابو حنيفه كبــر

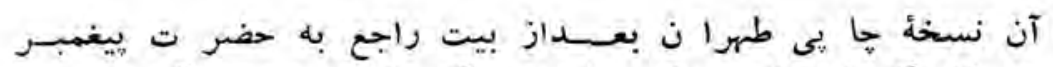

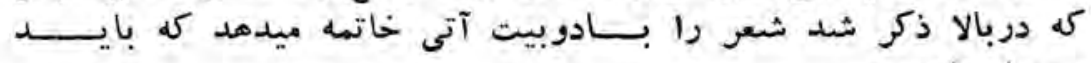
مجعول بكاثد : 


$$
\begin{aligned}
& \text { ورى بجود وسخا وشجا عتو مردى ندي }
\end{aligned}
$$

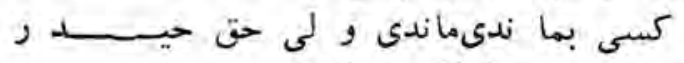

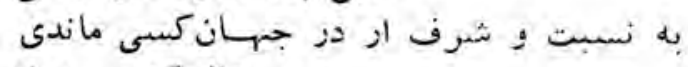

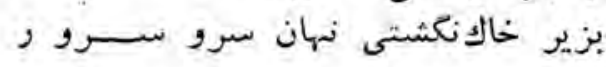

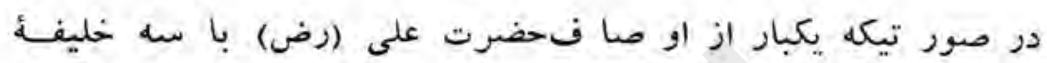

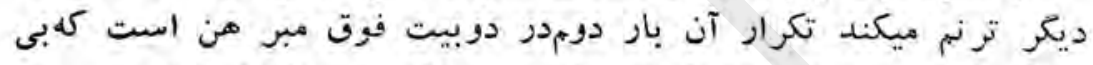

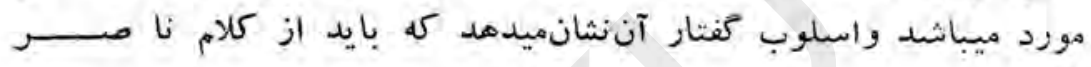

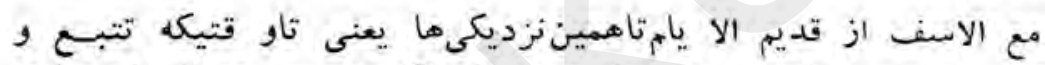

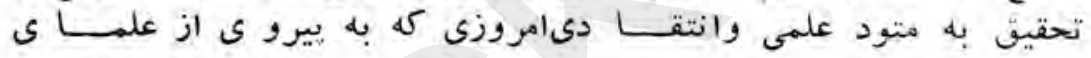

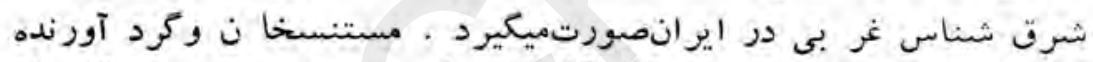

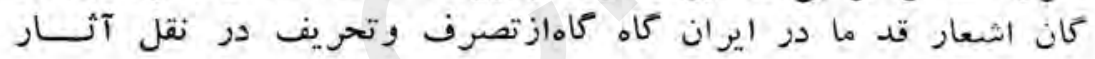

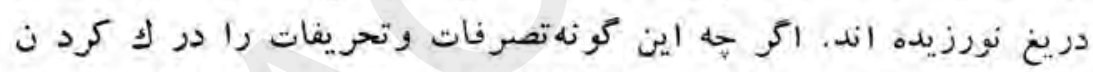

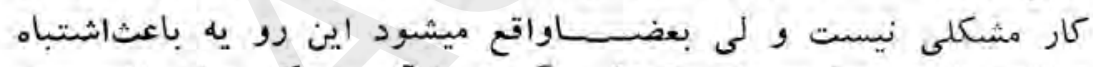

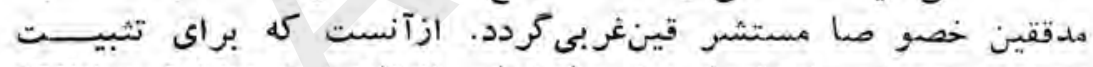

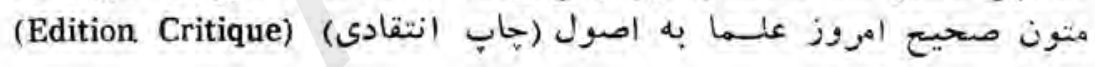

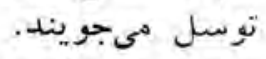

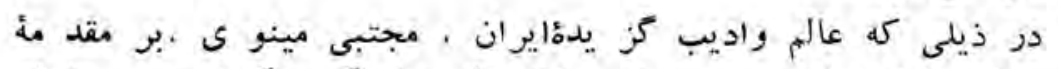

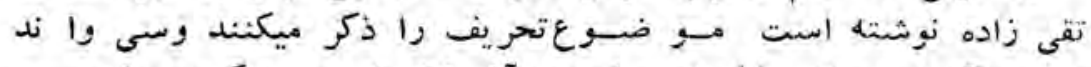

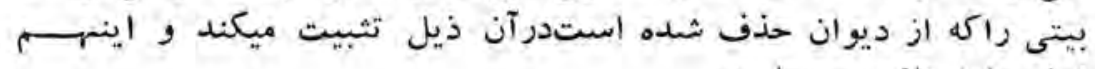

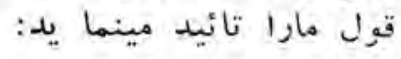

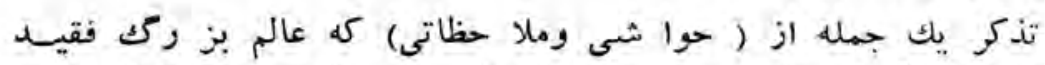

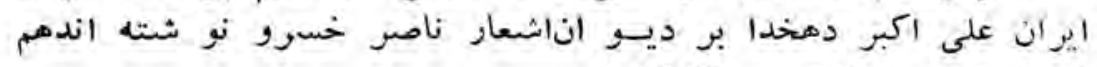

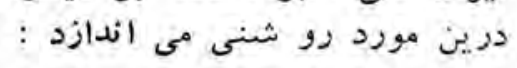

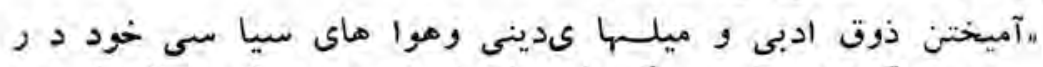

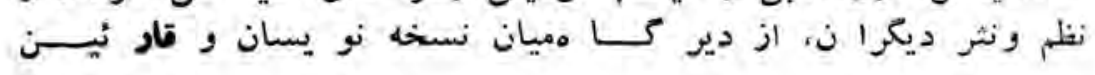




\section{بعشى از عقا يد ناقبل ازمسفر}

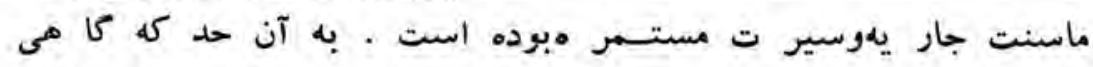
تنها از متن نسخه هاى متعدديك كتاب ، بـى هيج اماره واشار مأديكر.

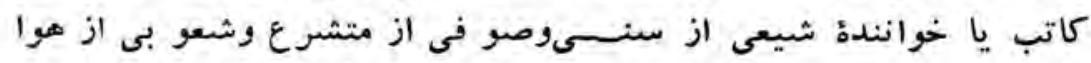

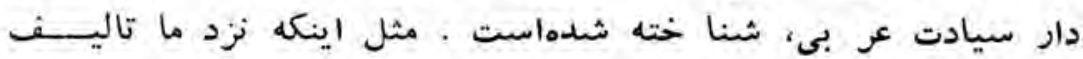
نو عى از تمليكنبوده و, كتابماننديافتهها ى خرابه هاو مفا و زجبالما

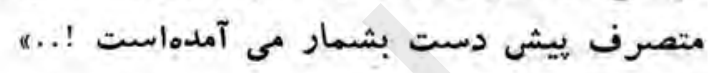

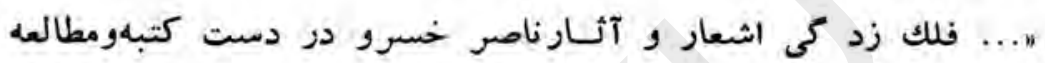

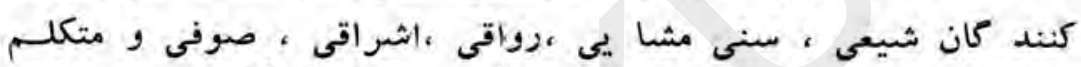

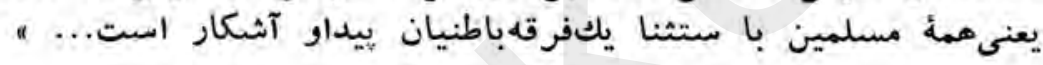
درين كه ناصر خسرو در بار مسه خليفه از خلفاى راشد ين حس

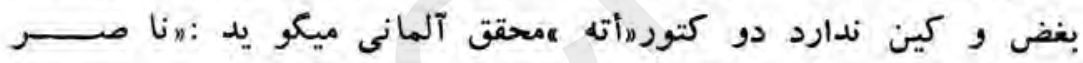

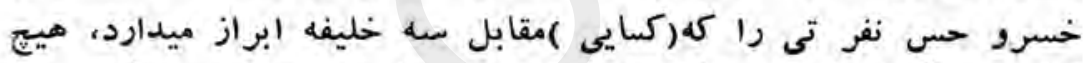

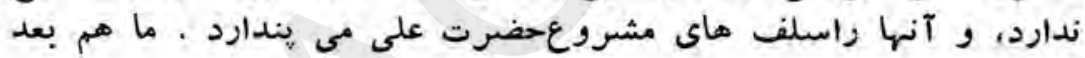

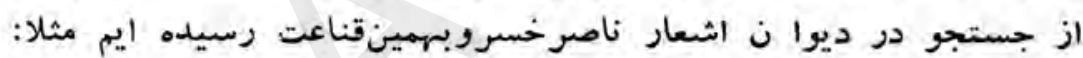

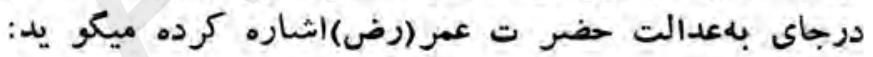

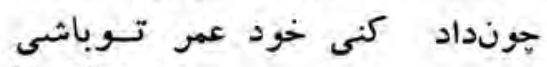

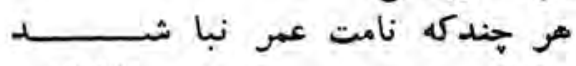
(I乏)-ص)

به طاعت بكن شكر حسب ناو

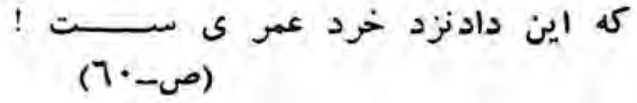

$$
\begin{aligned}
& \text { به احتر ام شيخين مى كويد : }
\end{aligned}
$$

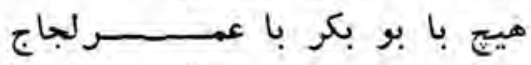

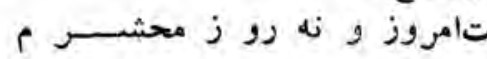
( 


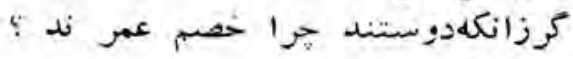

$$
\text { وينها كل دم زدند به حبعلى معمى }
$$

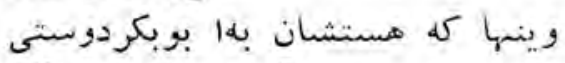

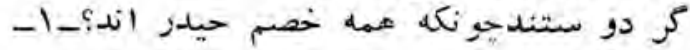

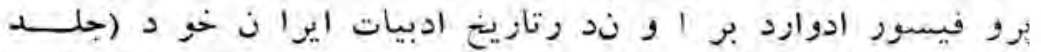

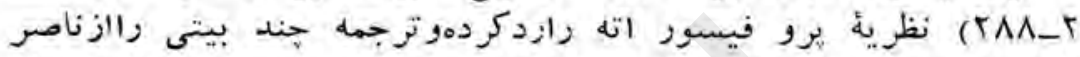

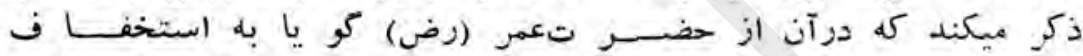

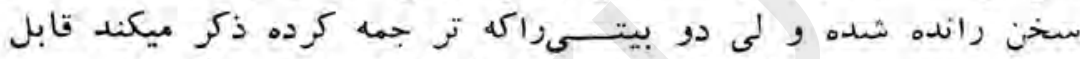

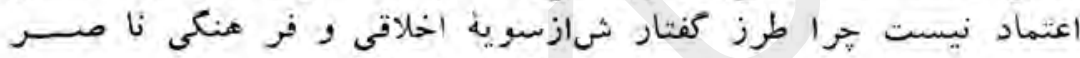

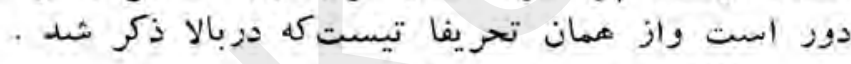

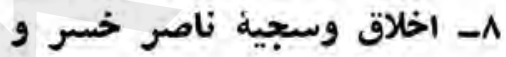

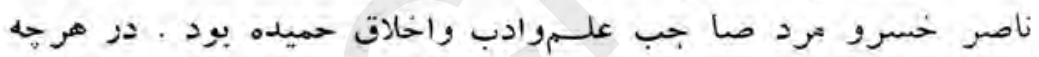

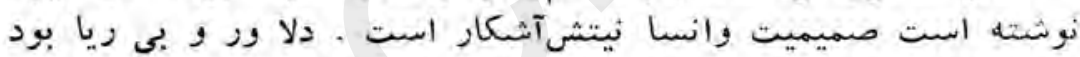

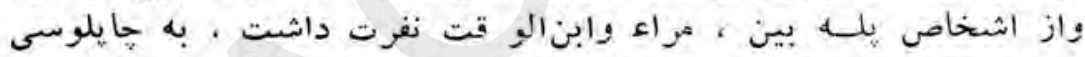

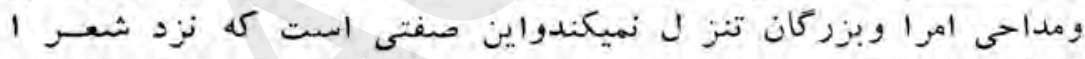

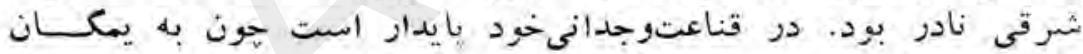

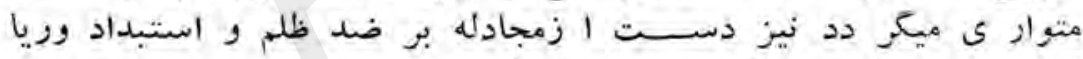

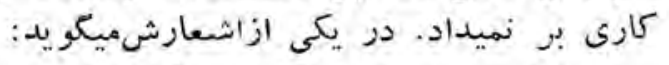

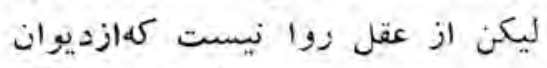

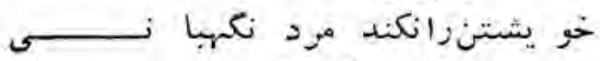

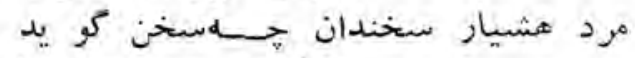

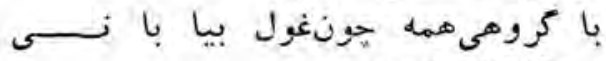

$$
\begin{aligned}
& \text { از اعترا ضا تيكه بر او ميكردندواورا: }
\end{aligned}
$$

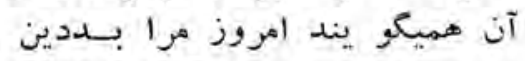

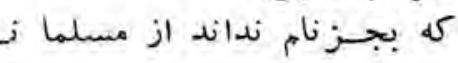




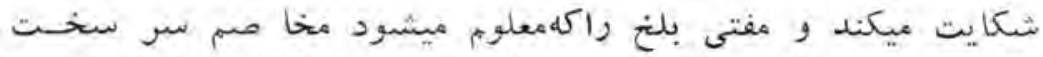

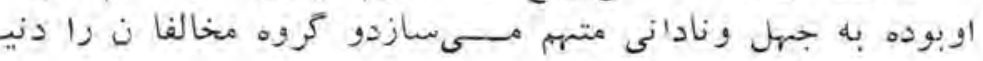

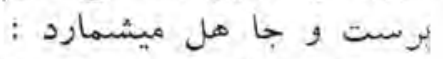

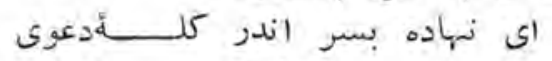

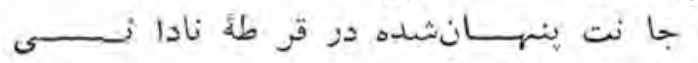

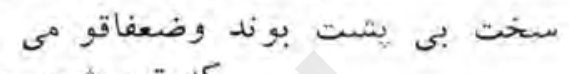

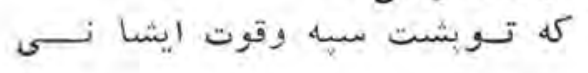

\section{سيرت را هر نان دار ىليكنتسو}

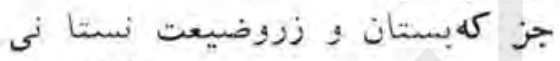
( $\Sigma$ rq-ص)

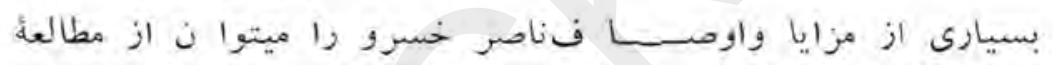

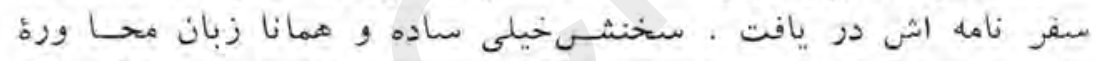

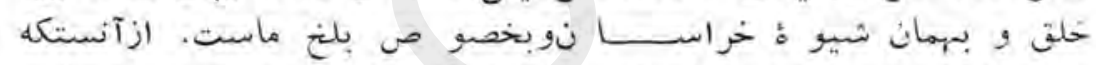

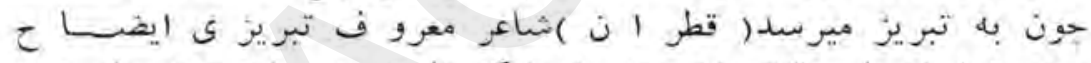

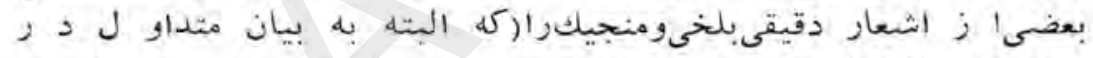

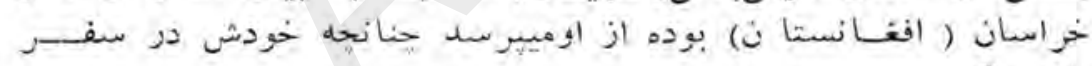

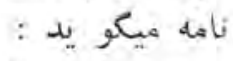

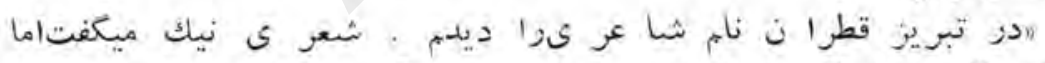

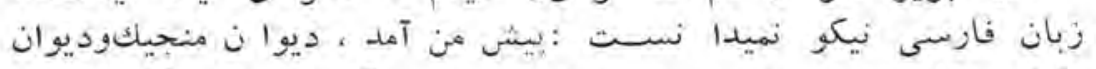

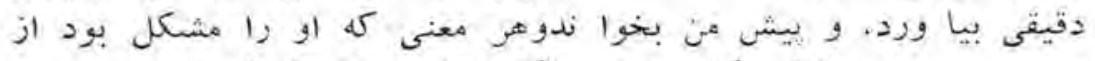

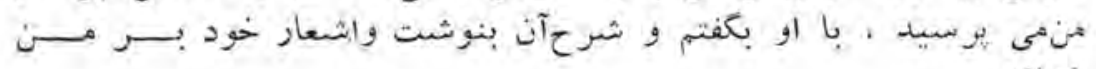

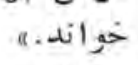

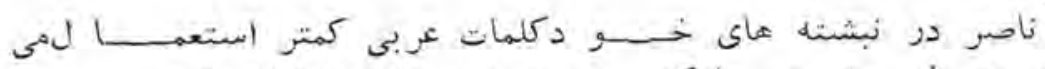

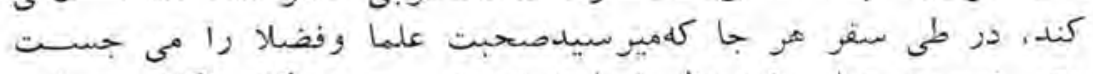

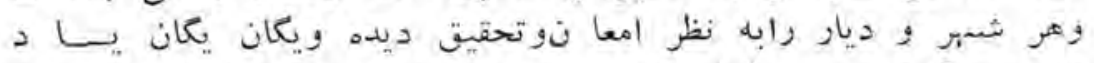

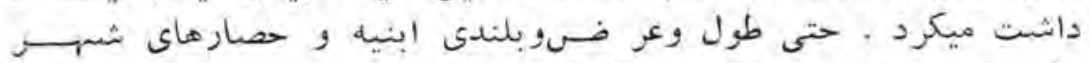

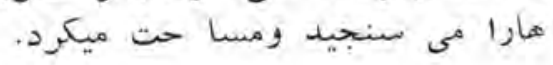




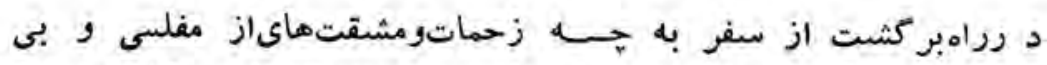

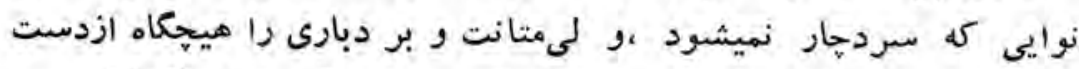

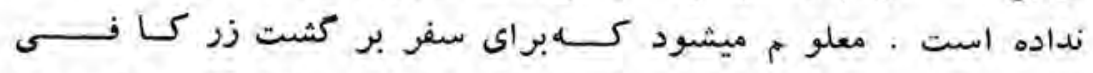

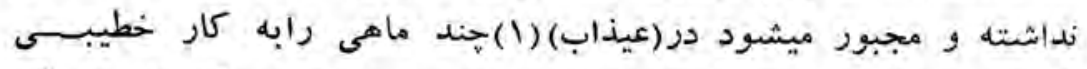

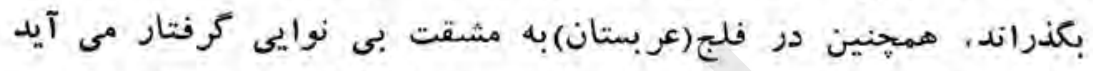

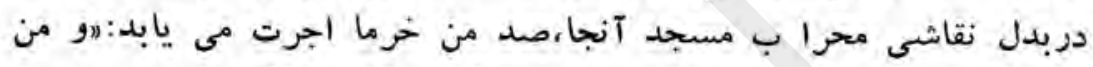

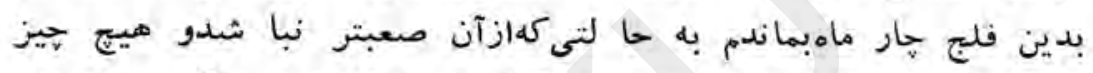

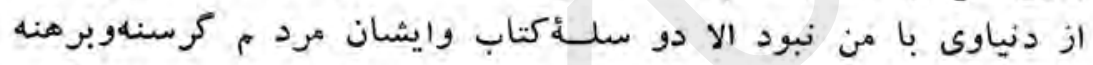

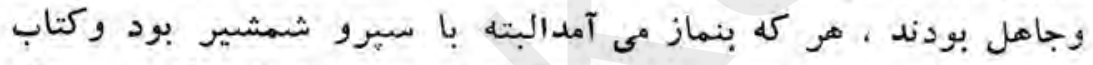

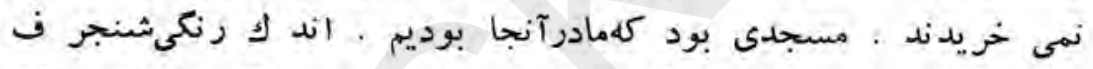

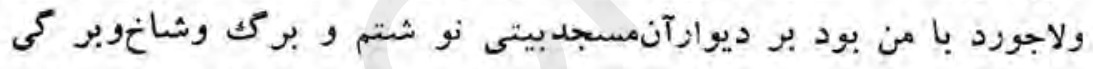

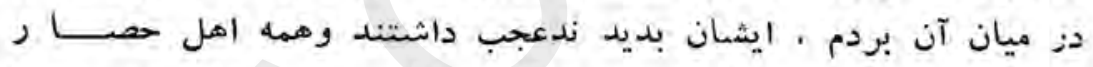

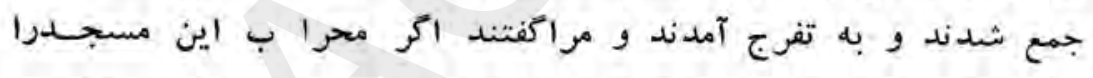

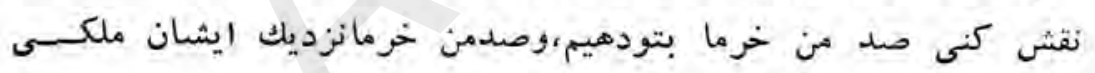
بود...)

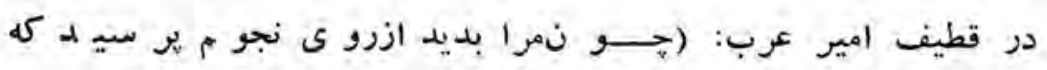

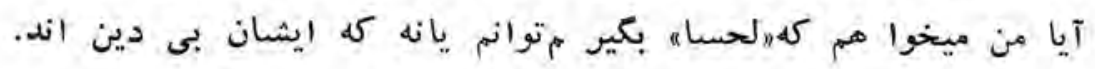

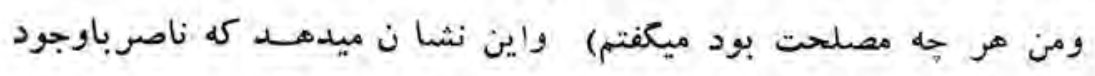

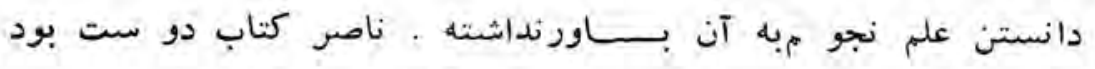

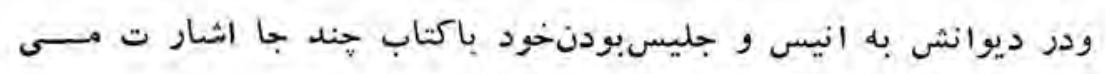




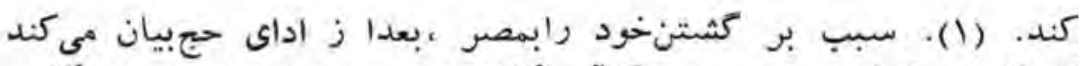

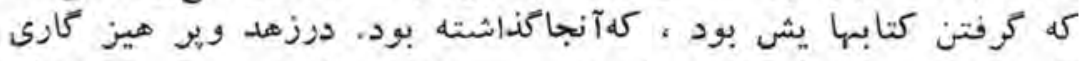

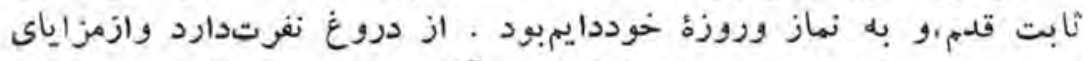

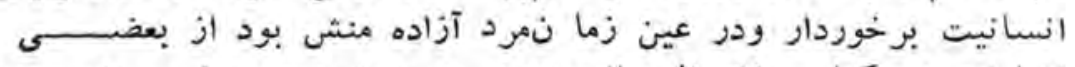

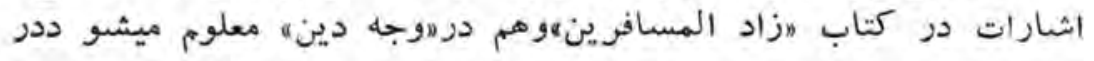

$$
\text { ص-ع إع وصف كتاب راجهزيبا كفته : }
$$

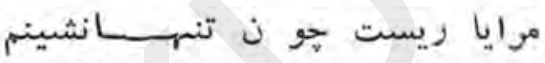

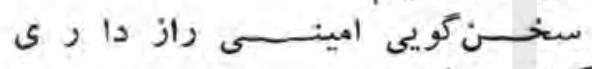

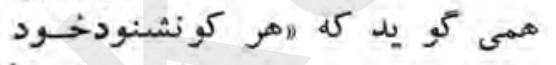

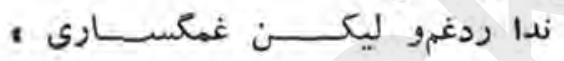

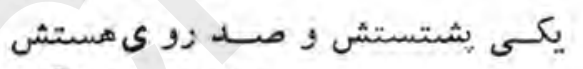

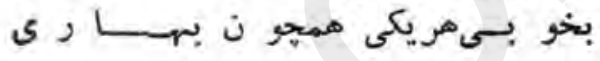

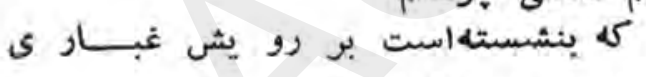

$$
\text { به يشتش بر زنم دستى جودانم }
$$

سخن كو يى بى او از ى وليكن

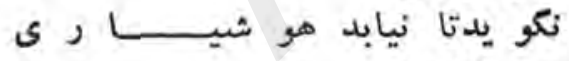

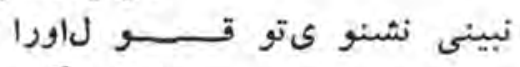

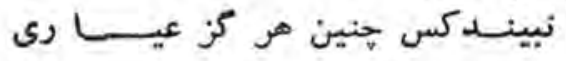

$$
\text { به هروقت از سخنهــ ىحكيمان }
$$

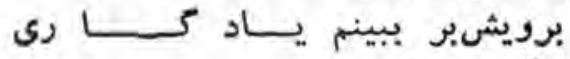

$$
\text { نكويد تا بور يشس ننسكر ممهن برين }
$$

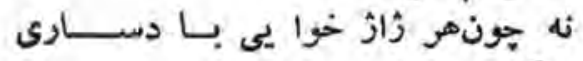

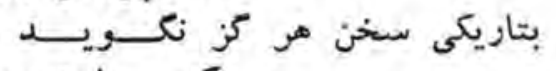

كه بـــاحشهت مشنهر شهر يـا

$$
\text { بصحبـت با جنين يارى بـــيسكان }
$$

به سربردم به بيرى روز كـــان رى 


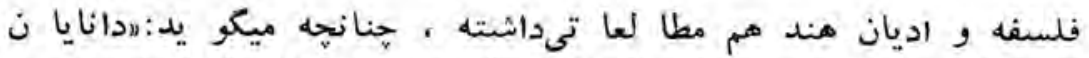

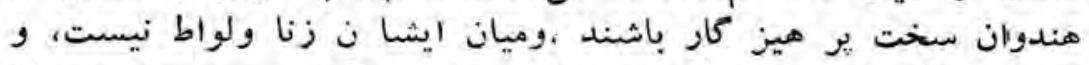

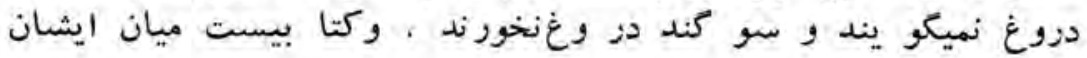

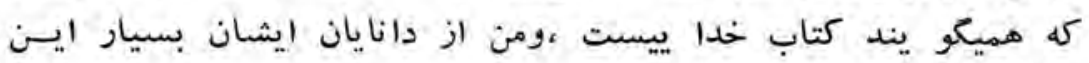

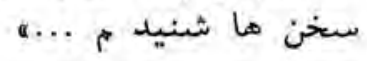

د د ديوانشباين ابياتبر مخوريـمكه آزاده منشى اورا نشان ميدهد : فضل تو جيست بن بنكر بوتسرسا؟

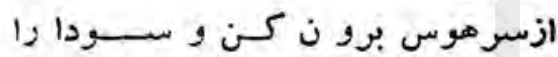

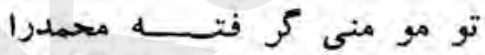

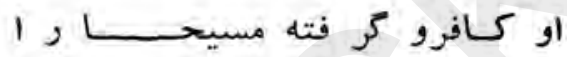

ايشان ييمبرا ن و رفيقــــاند

جو ندشمنى تو بيههد تر سا را؟

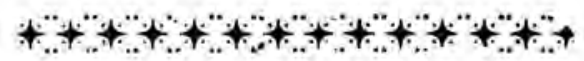




\section{فصل دوم}

\section{جريانفكرى باطنيان وطريق اسماعيايه}

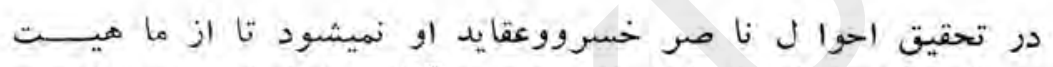

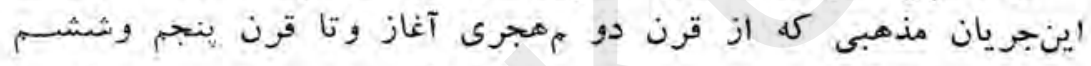

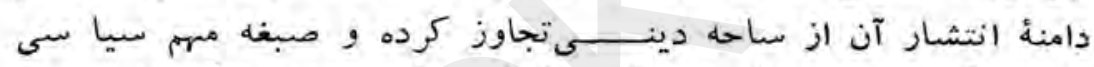

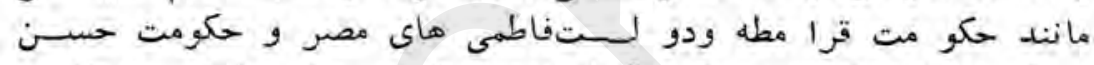

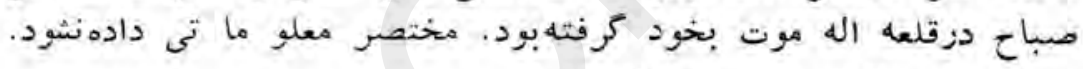

\section{ا- منبع ظهودبعضى فر قه هـ}

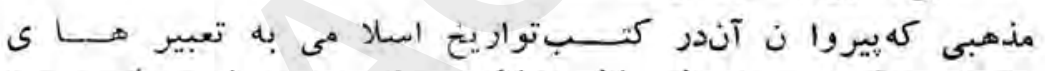

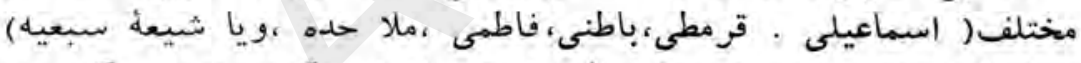

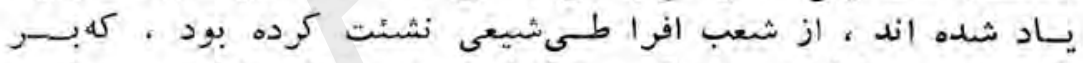

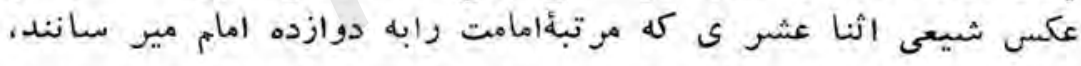

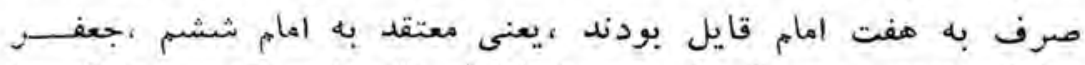

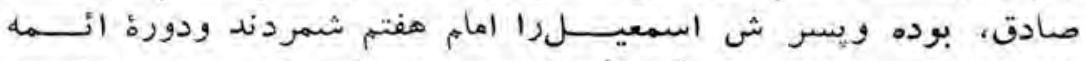

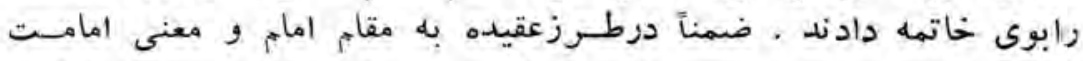

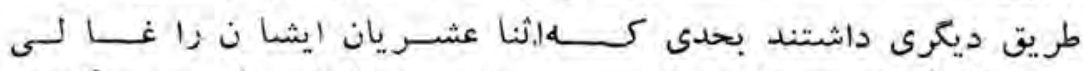

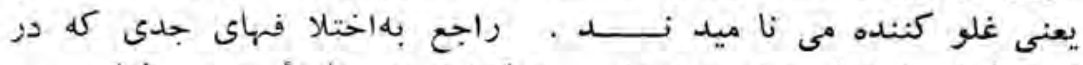

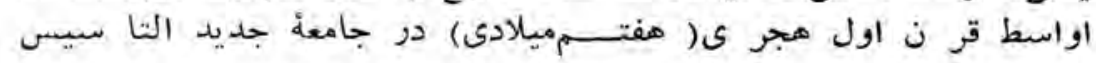

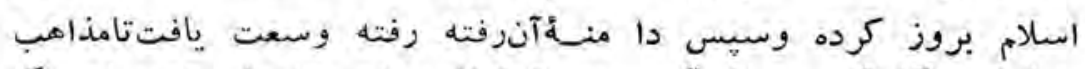

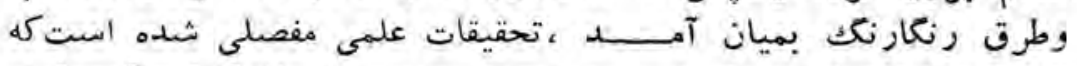

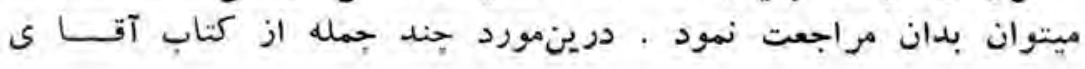




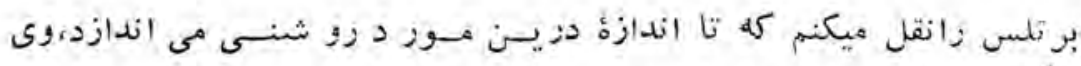

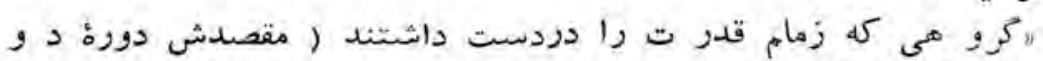

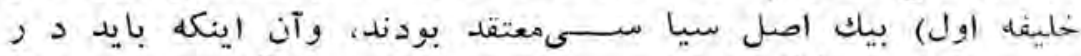

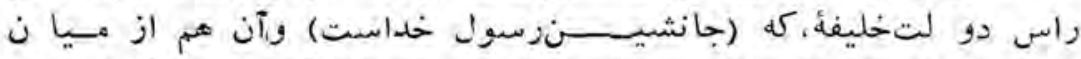

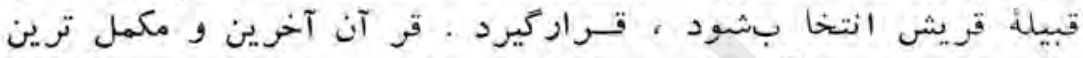

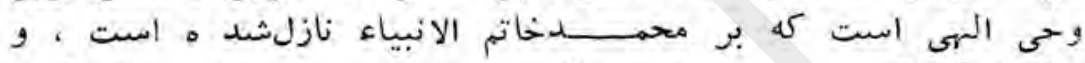

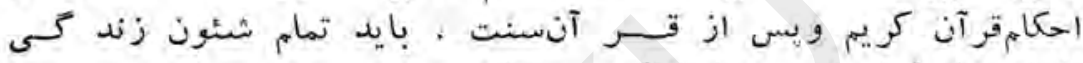

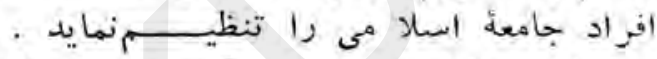

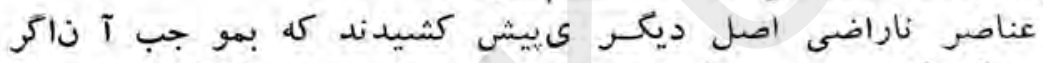

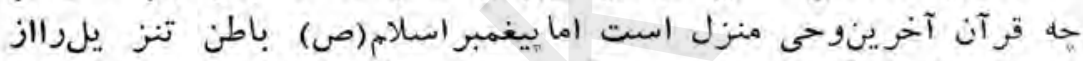

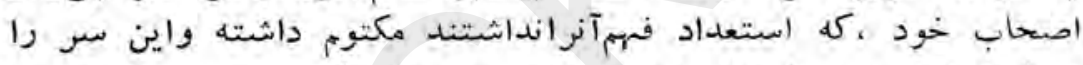

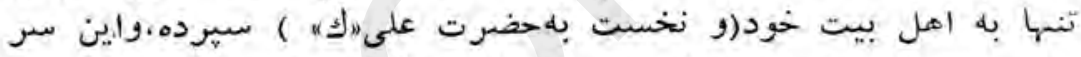

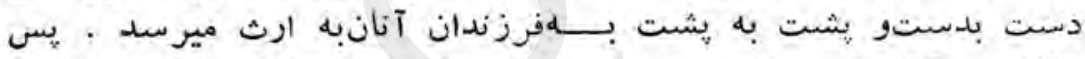

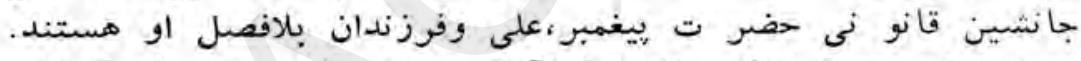

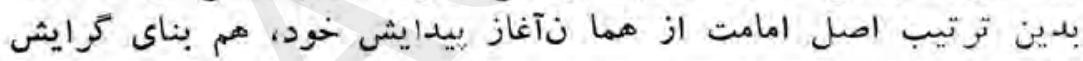

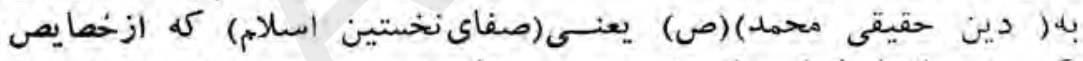

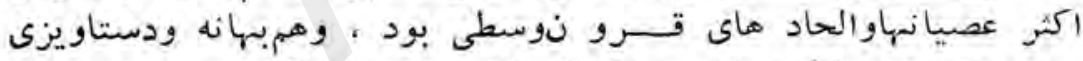

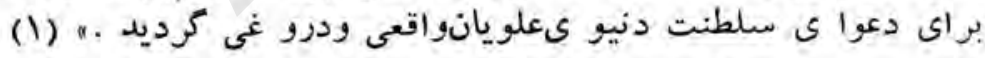

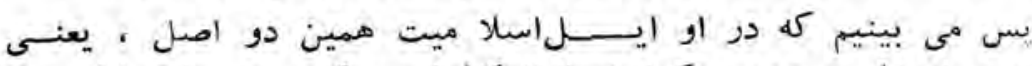

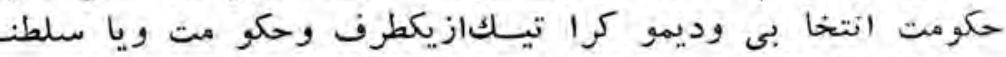

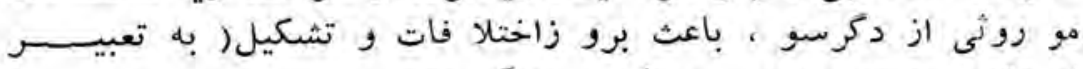

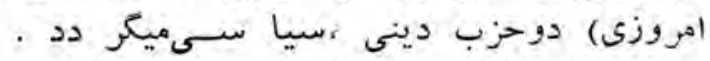

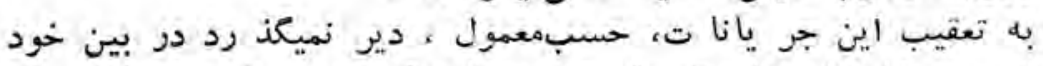

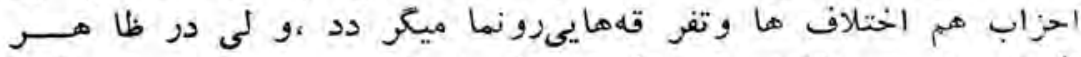

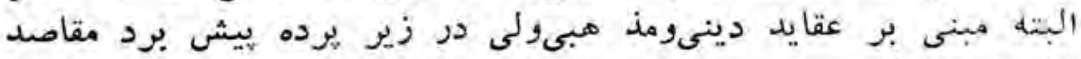
دنيوى وسيا سنى 


\section{$46 a 1$}

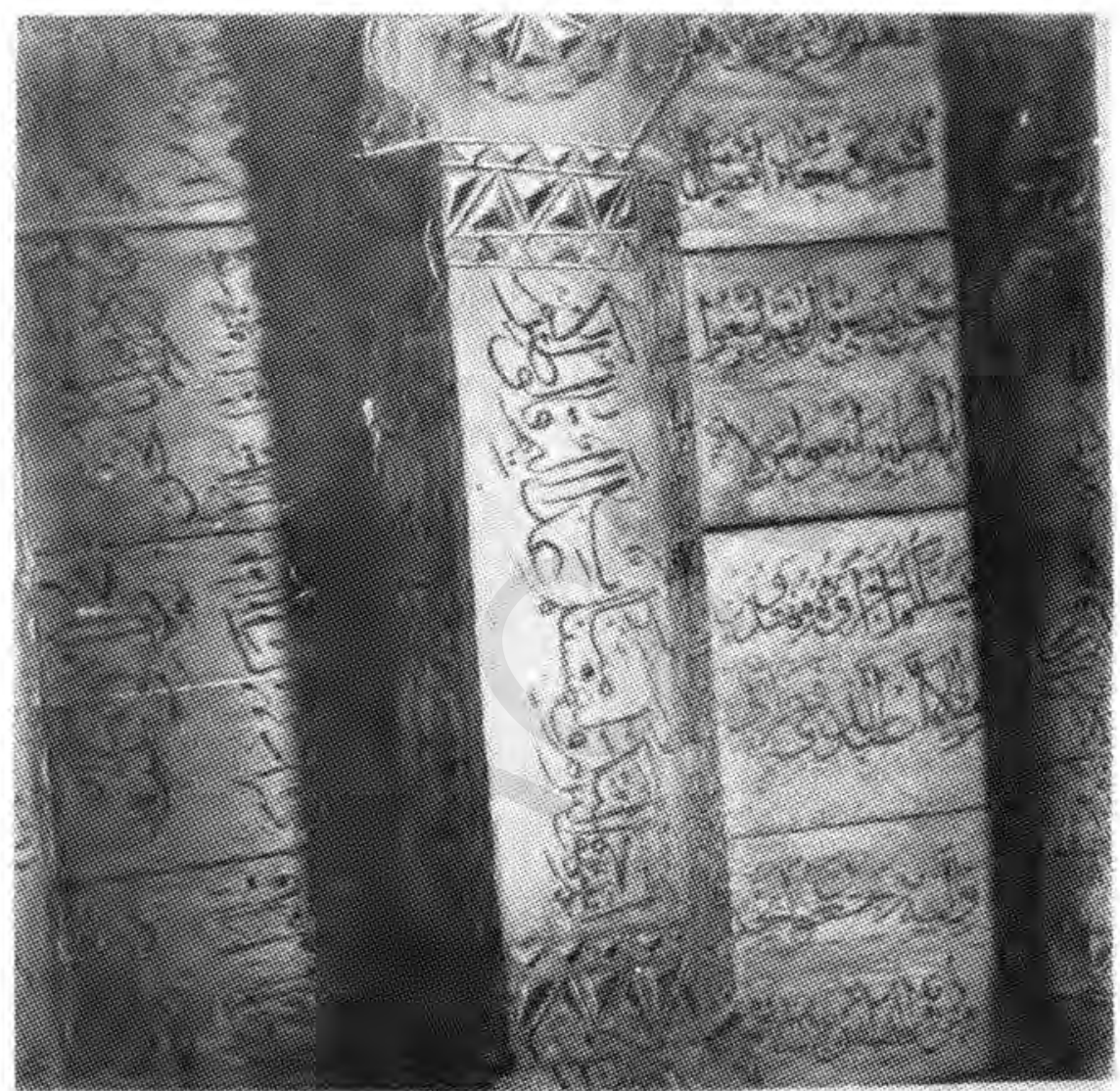

\section{نهونة از آيات قرآنكريم روىستونبا}




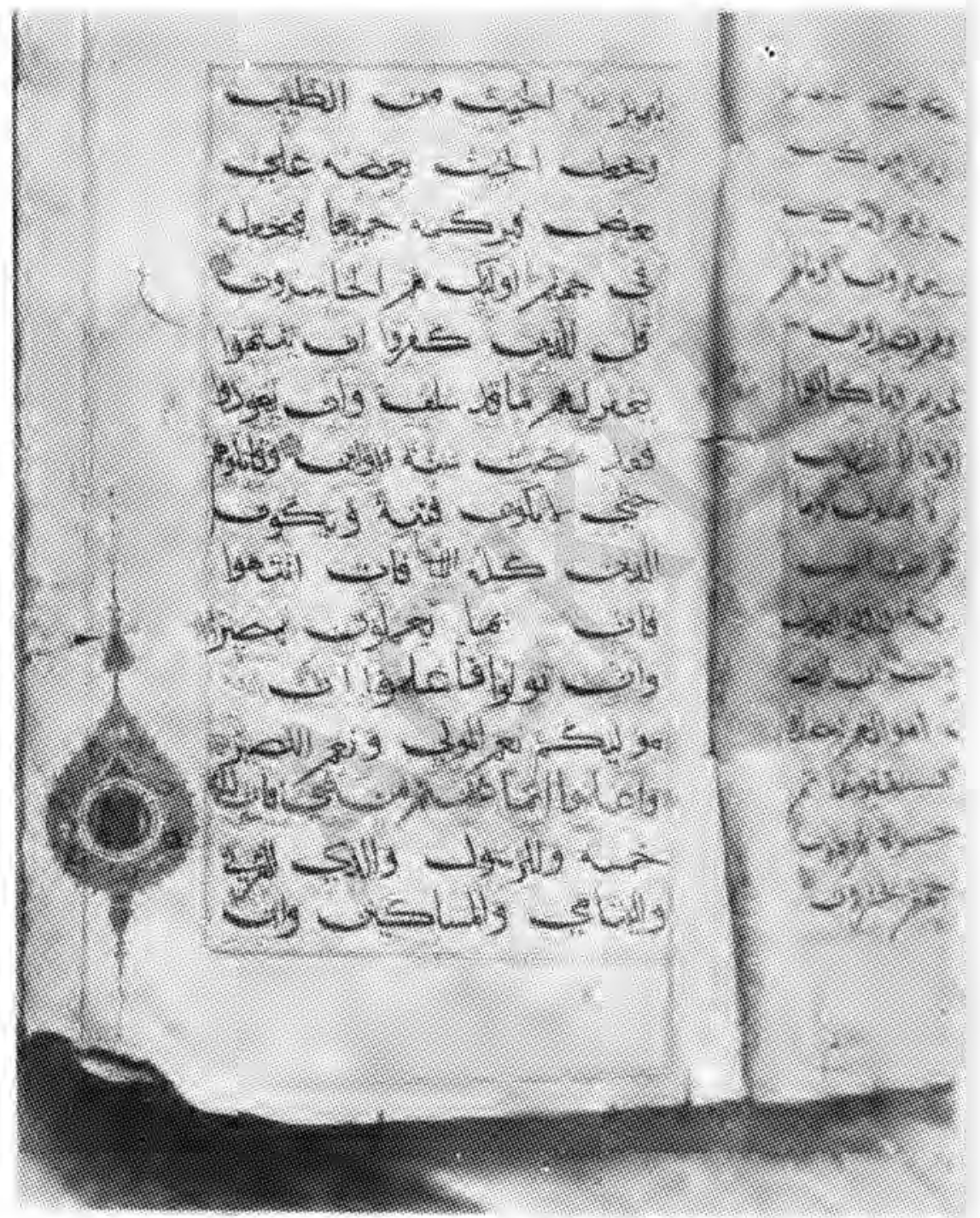

عكس يكصفحه ازقرآن كريم قديمى،متعلق بزيارتكاه ناصر خسرو 


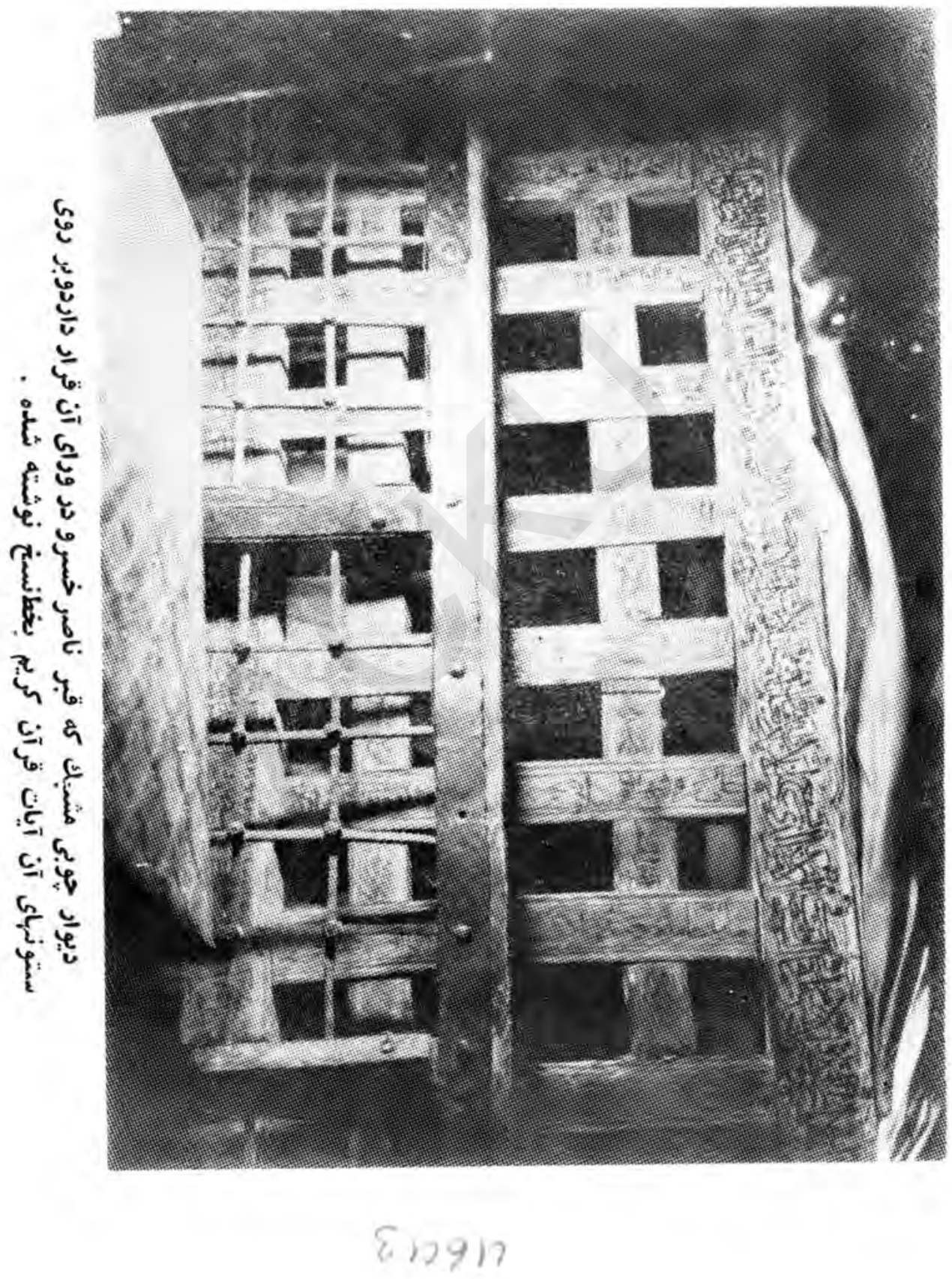




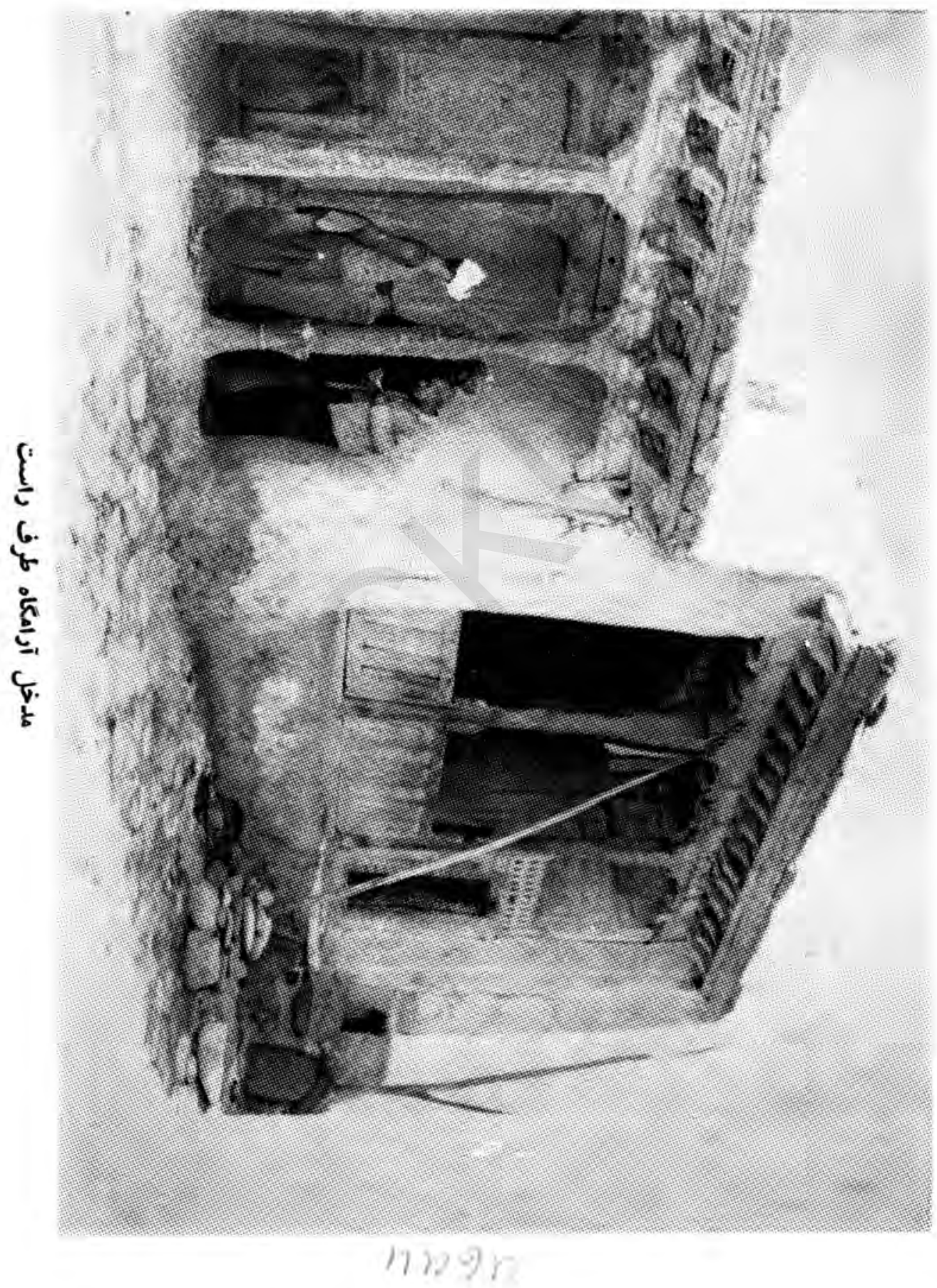


منبع ظهود بعفى فرقه .

EV

يرو فيسور براون ميـكويد :مطالعه تاريخجه بميان آمدن مذاهب

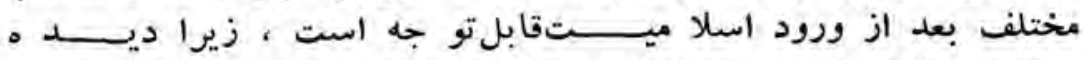

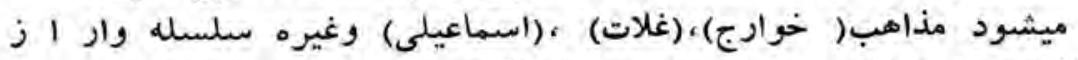

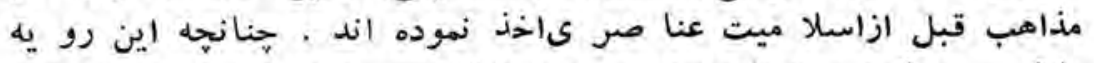

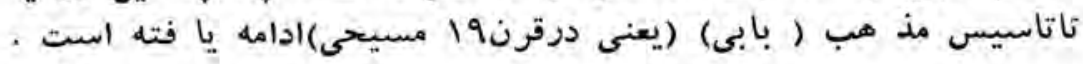
(r)

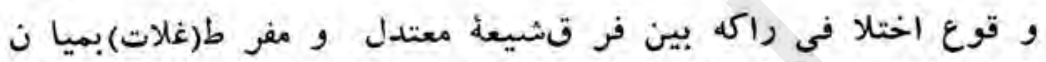

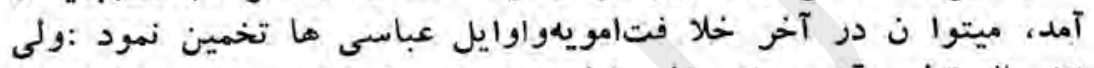

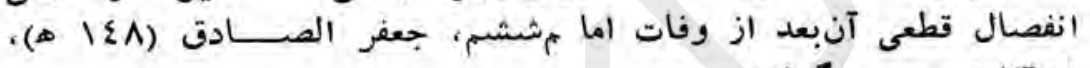

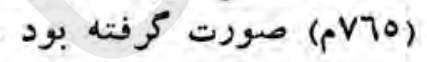

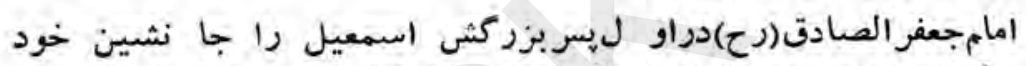

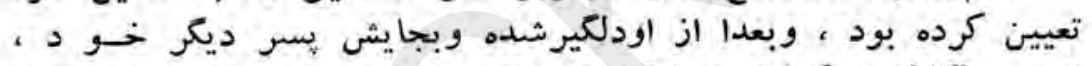

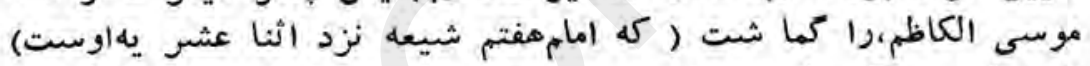

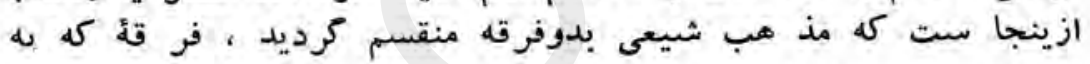

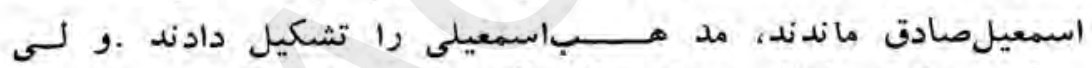

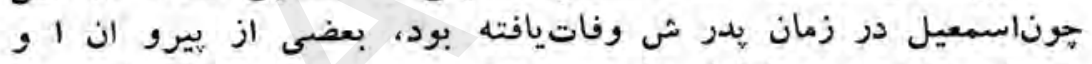

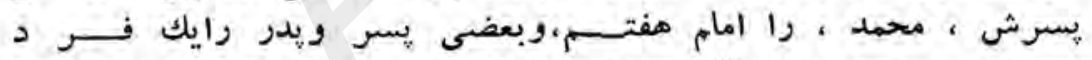

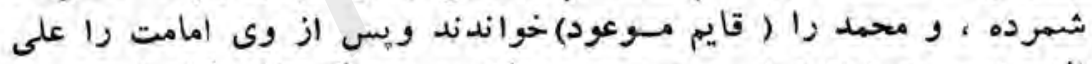

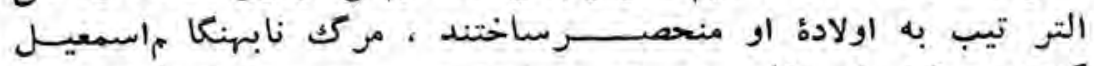

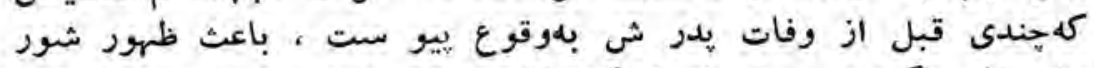

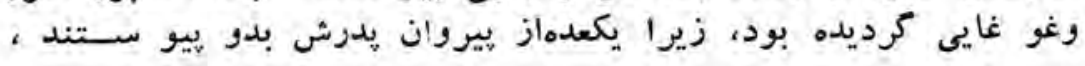

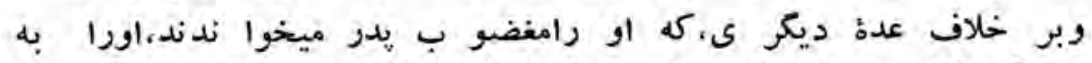

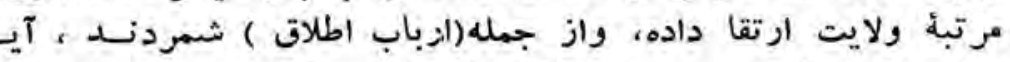

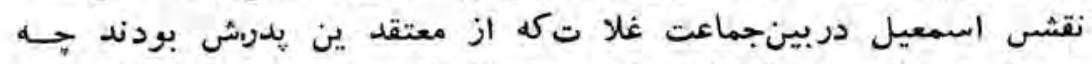

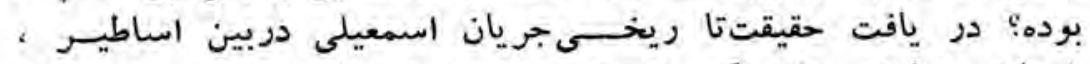

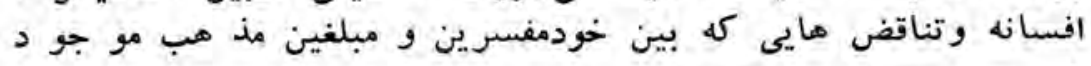

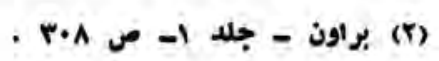




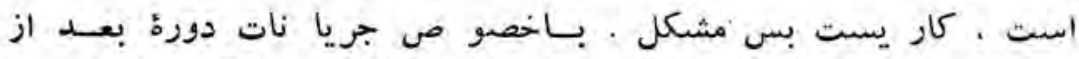

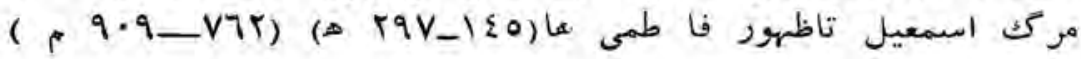

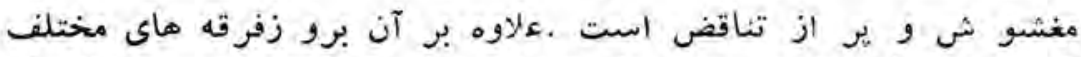

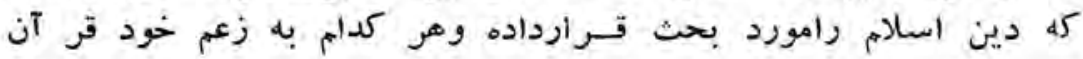

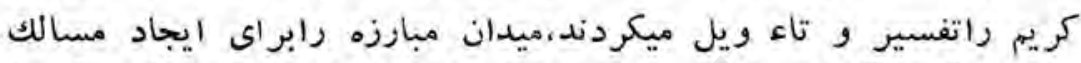

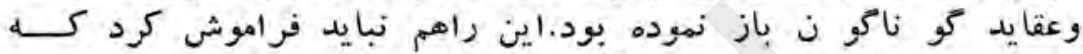

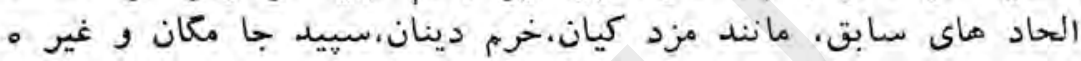

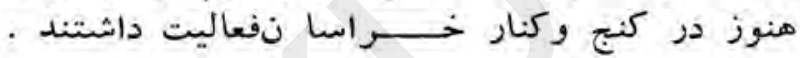

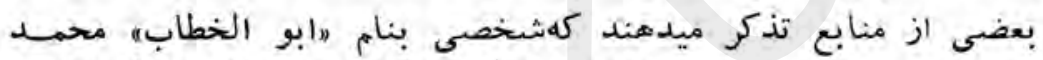
ابن ابى زينب الا سـلى (

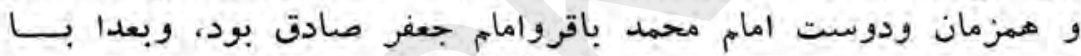

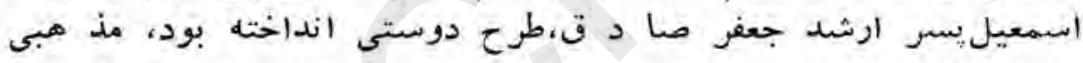

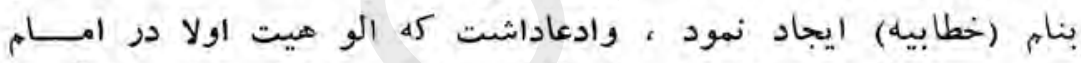

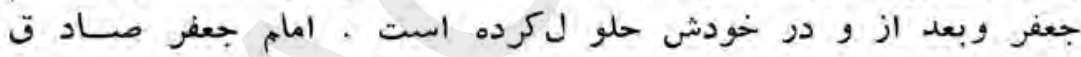

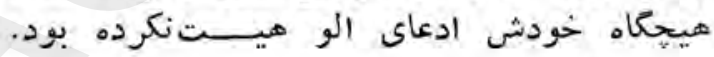

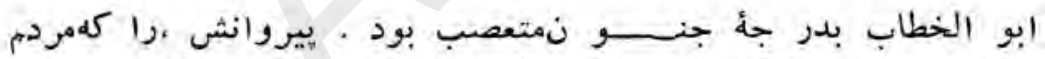

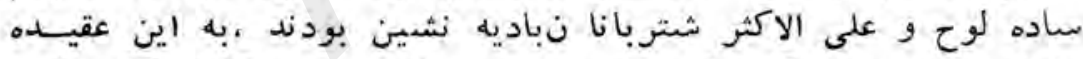

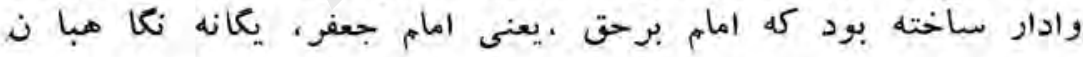

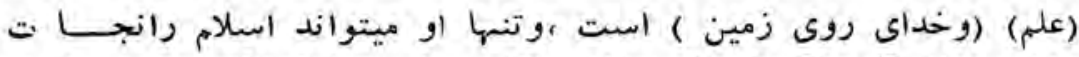

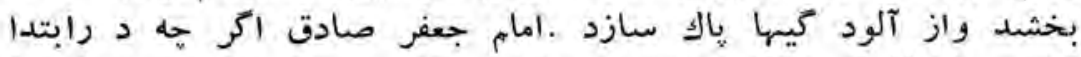

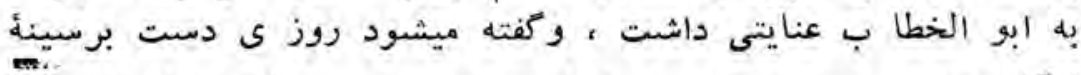

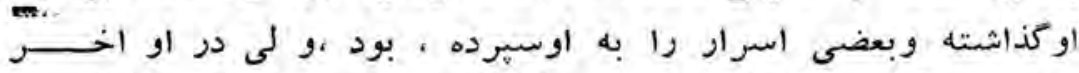

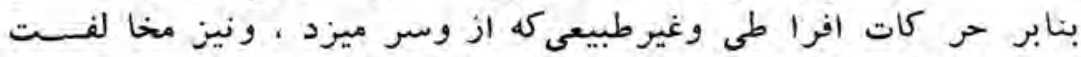

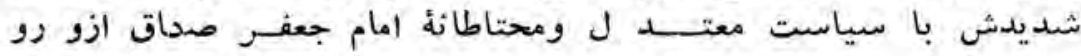

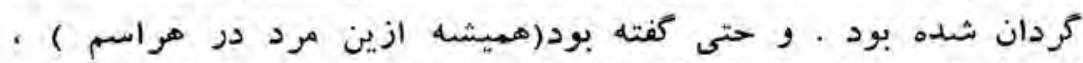

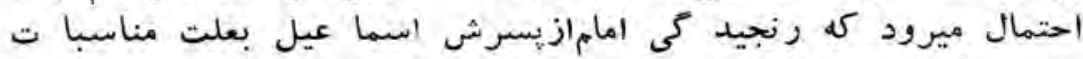

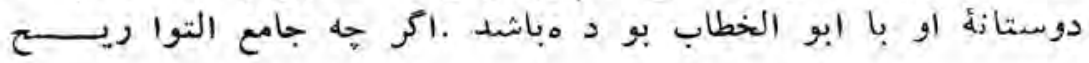


سبب دلكير ىرا هنين تذكرميدهدابعضى كويند اورا در شراب نوشى نور

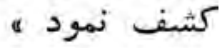

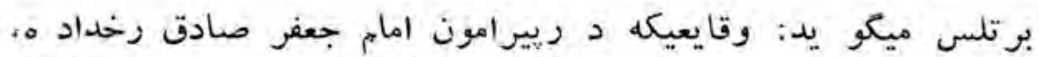

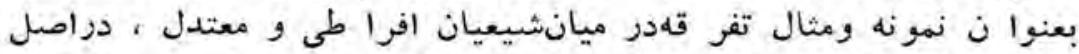

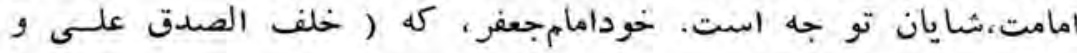

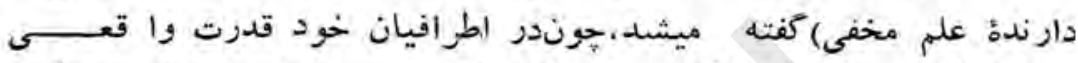

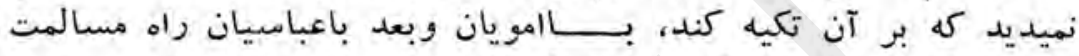

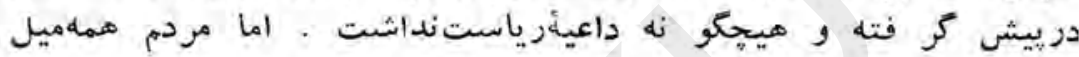

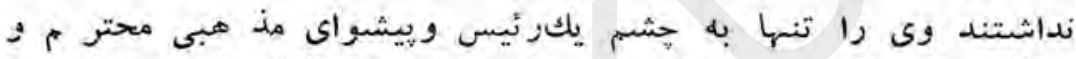

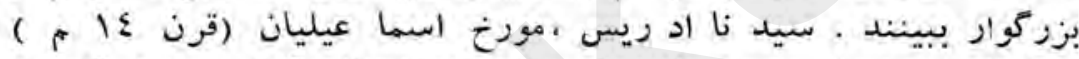

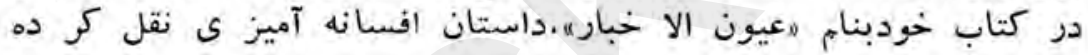

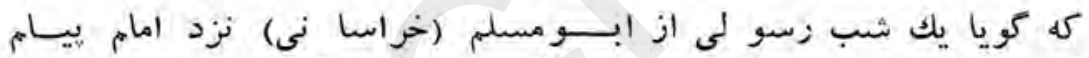

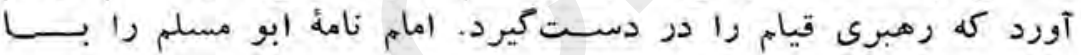

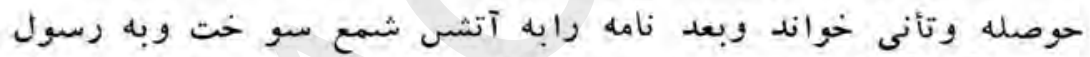

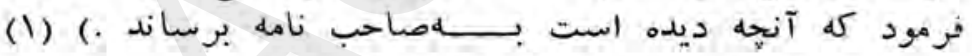

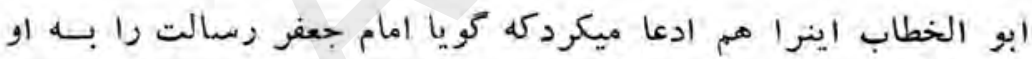

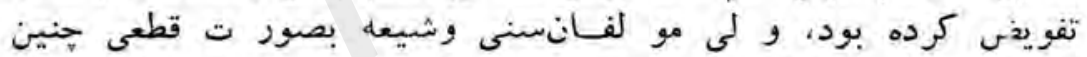

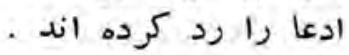

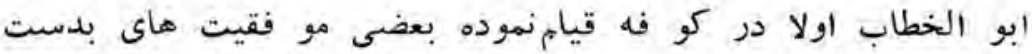

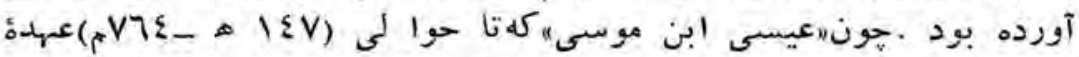

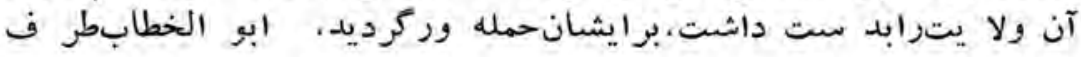

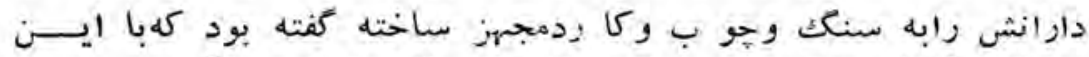

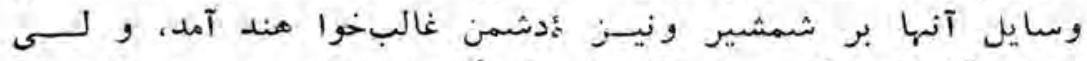

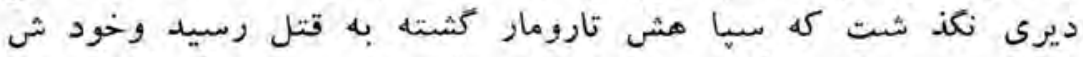

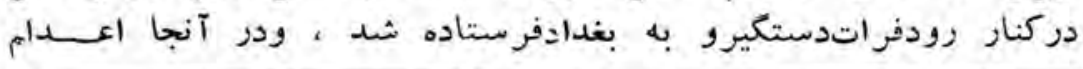

Founde of Ismailism 


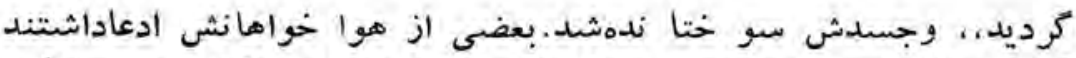

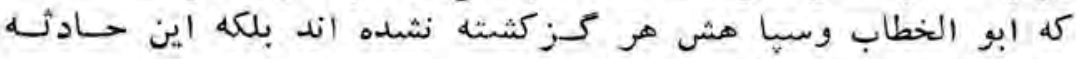

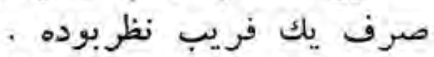

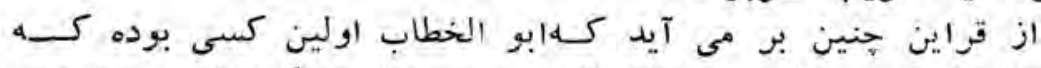

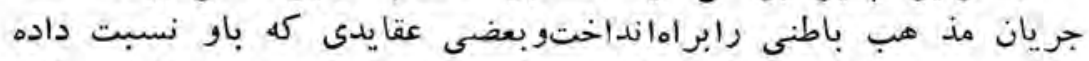

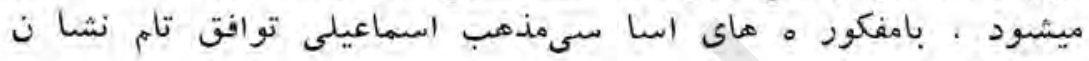

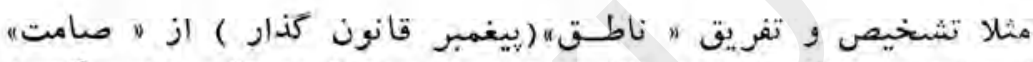

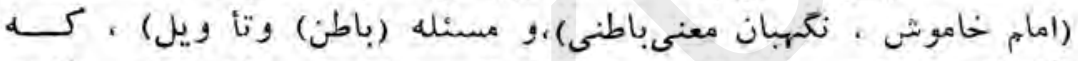

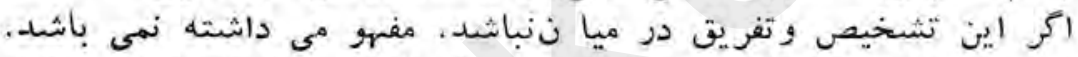

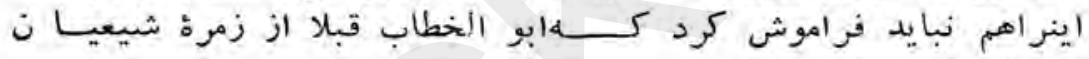

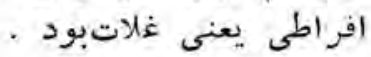

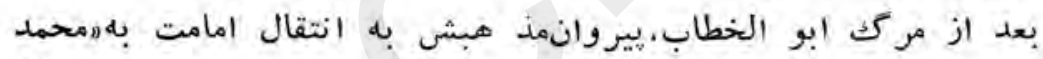

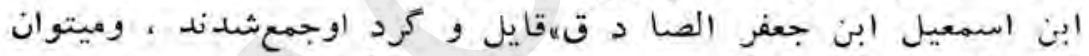

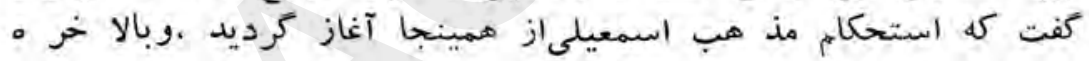

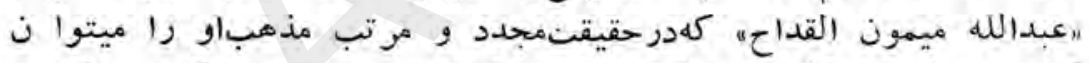

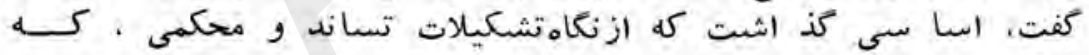

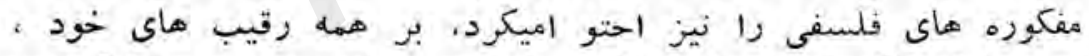

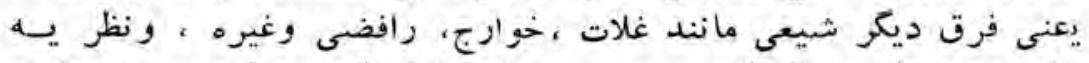

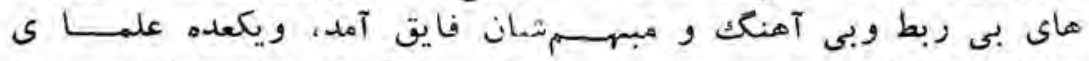

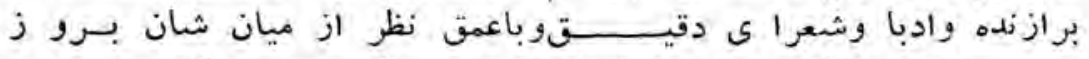

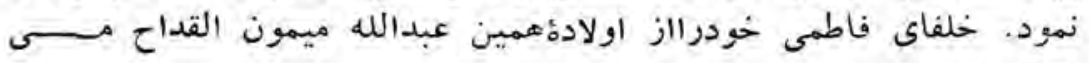
شمارند. تمود.

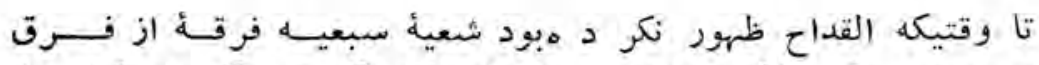

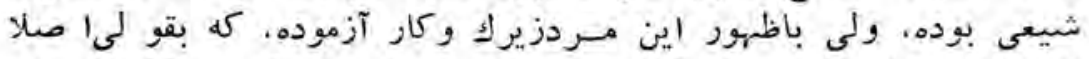

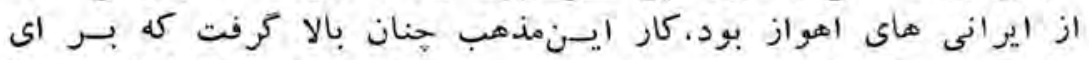

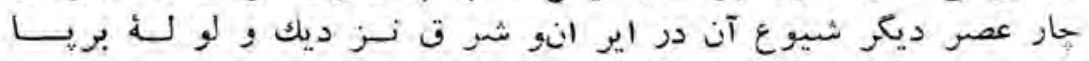

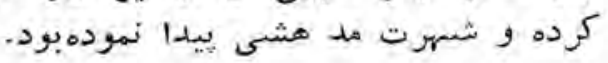




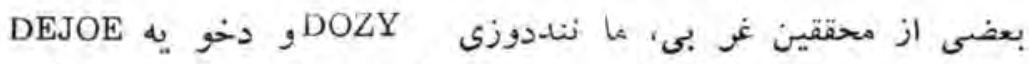

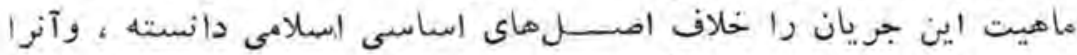

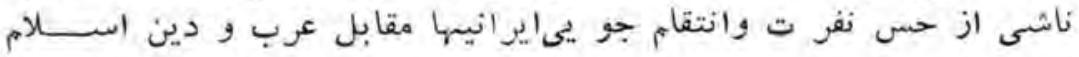

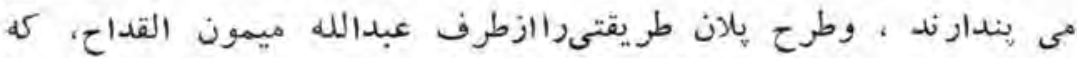

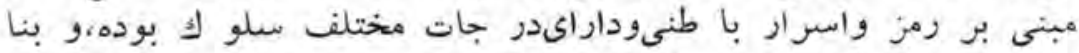

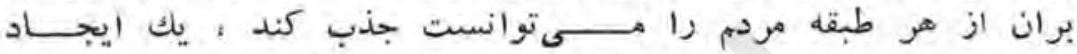

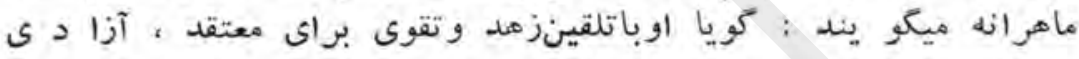

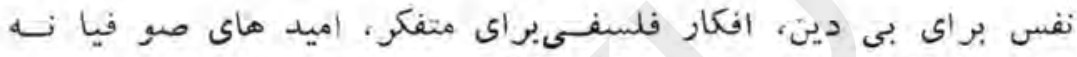

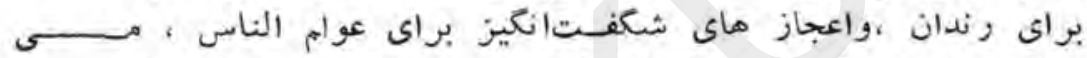

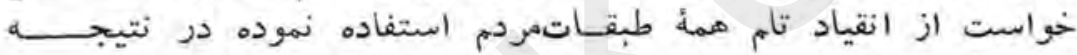

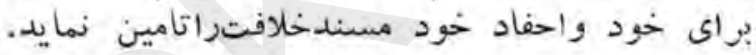

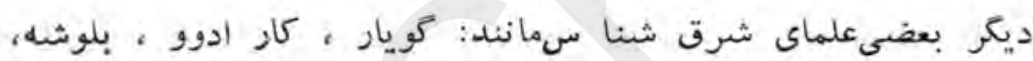

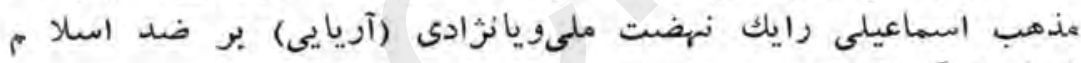

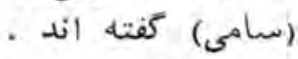

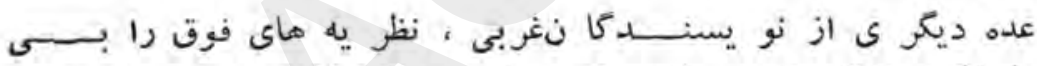

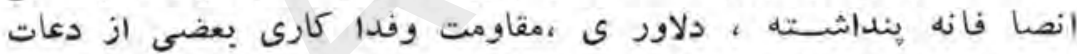

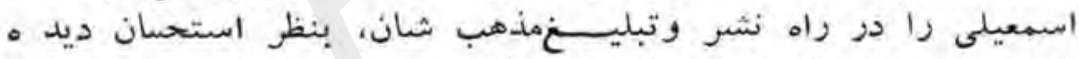

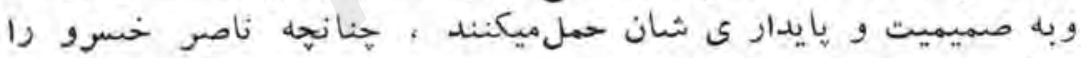

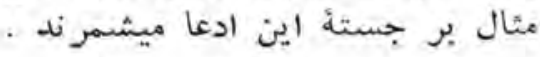

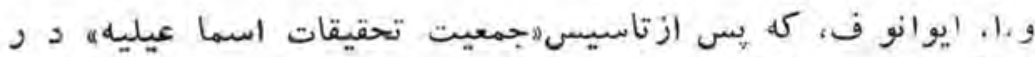

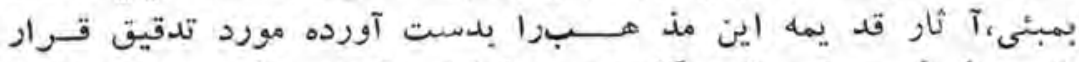

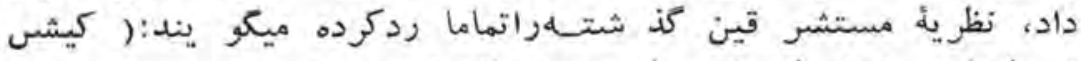

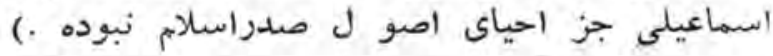

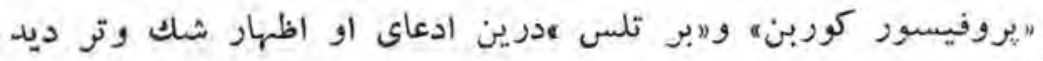

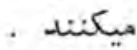

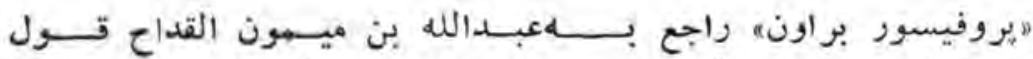

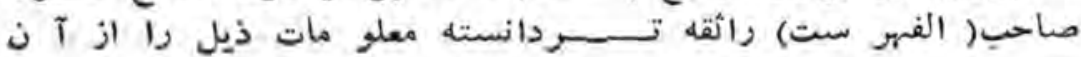


(1) (1)

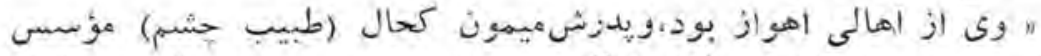

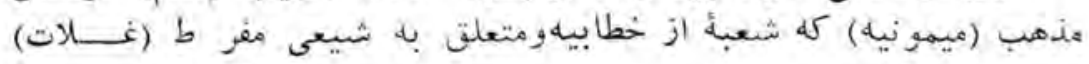

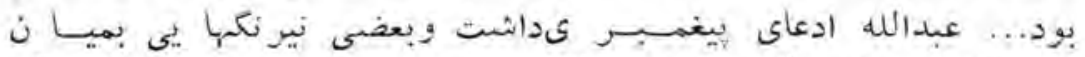

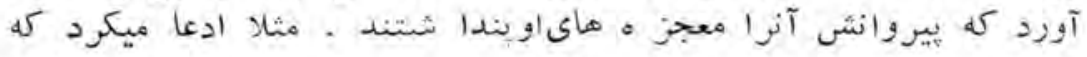

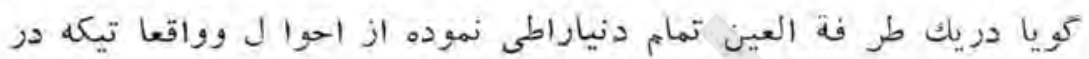

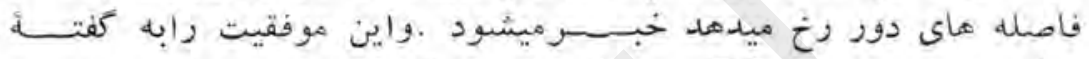

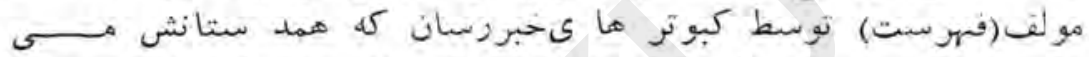

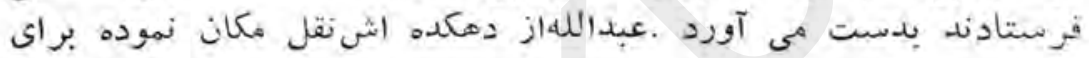

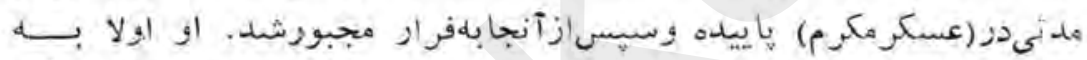

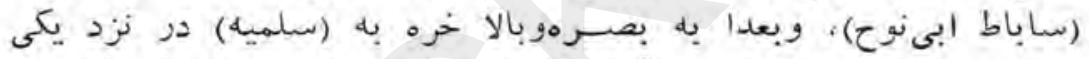

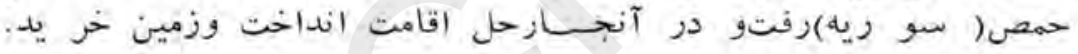

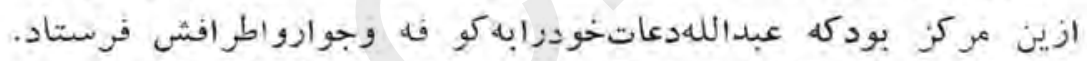

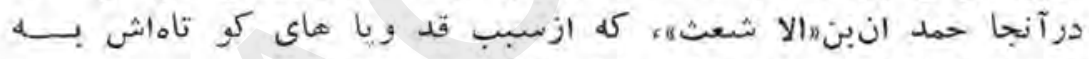

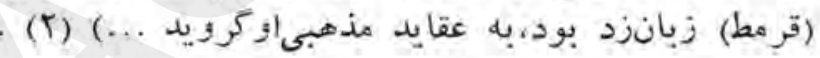

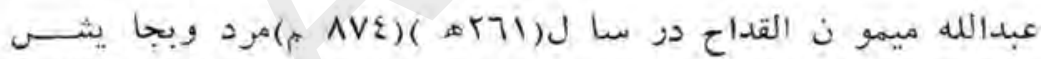

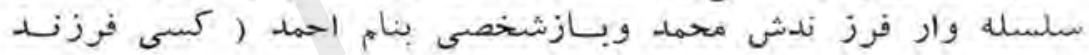

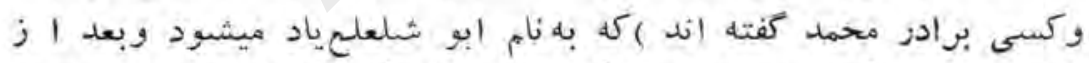

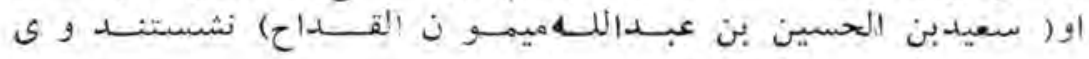

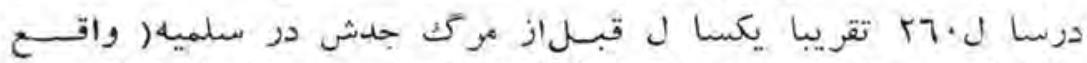

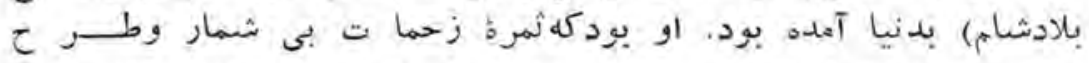

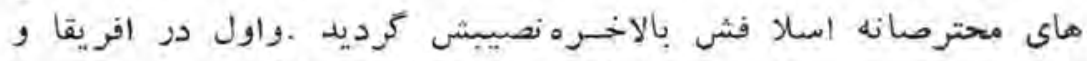

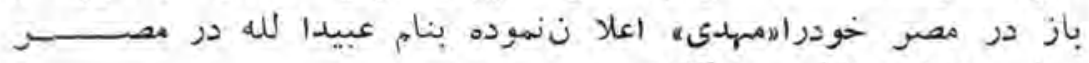

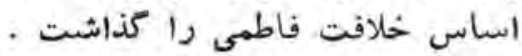


r- استقرار خلافت فاطميه درهصر و بيشبر فت هذهب اسمعيلسى

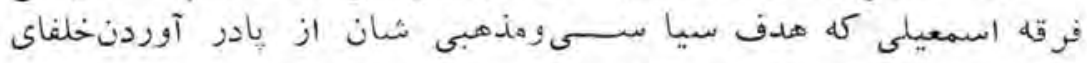

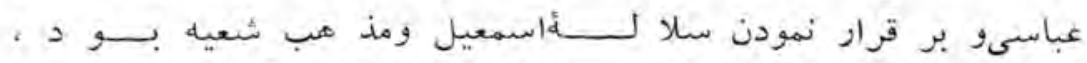

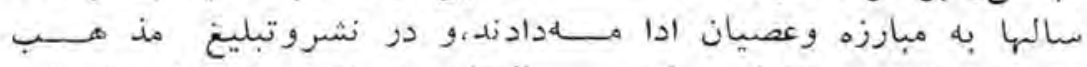

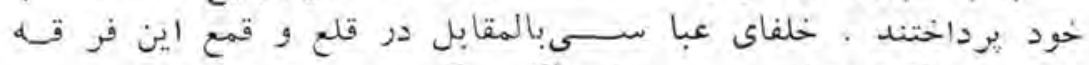

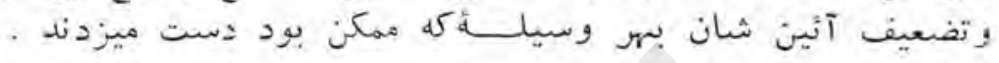

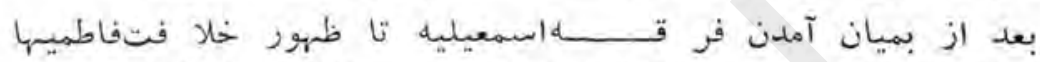

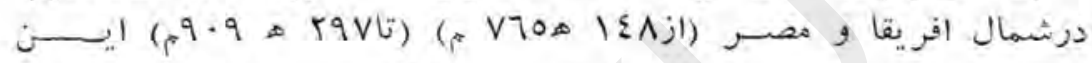

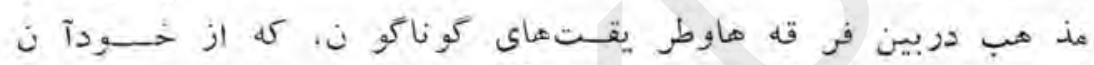

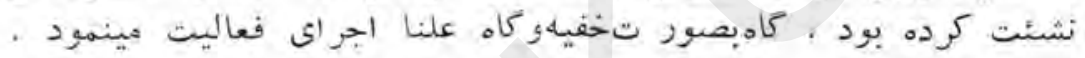

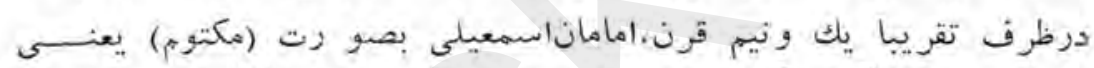

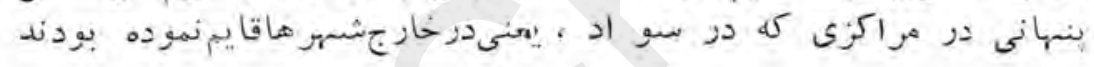

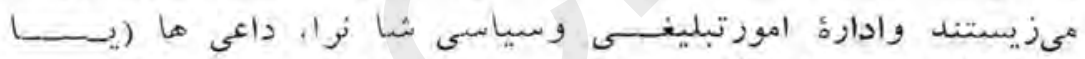

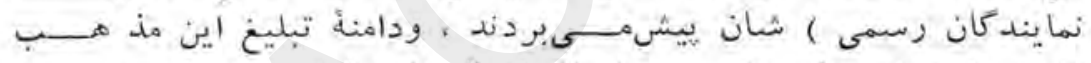

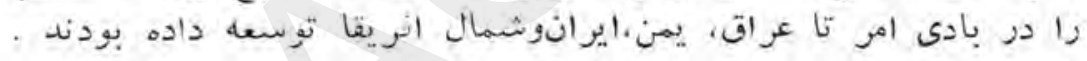

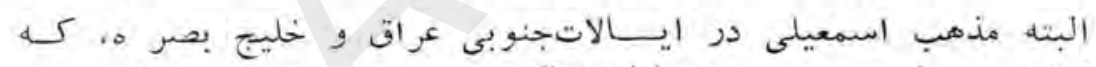

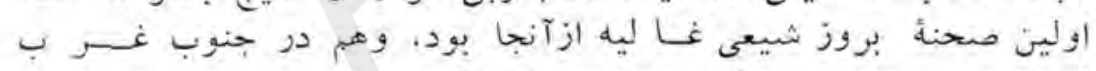

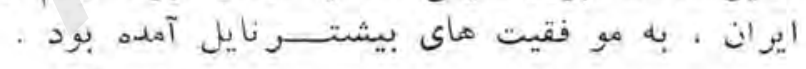

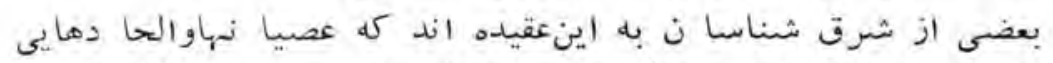

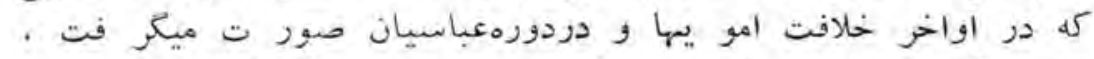

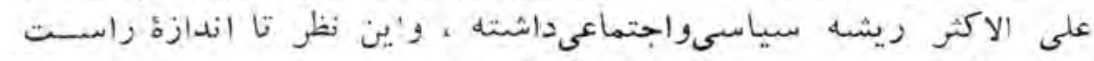

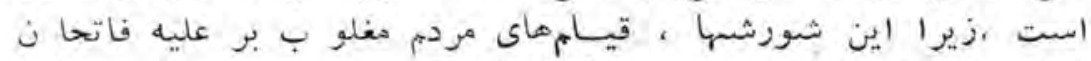

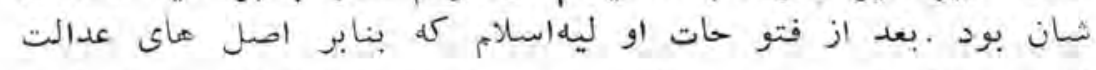

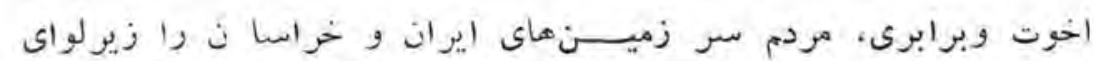

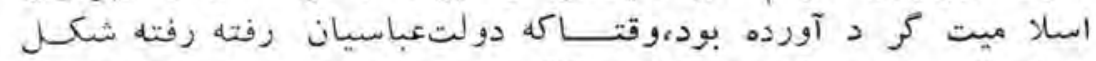

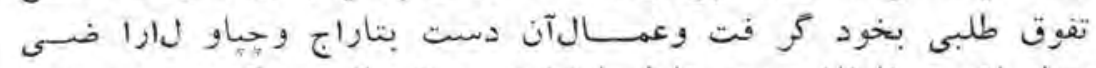

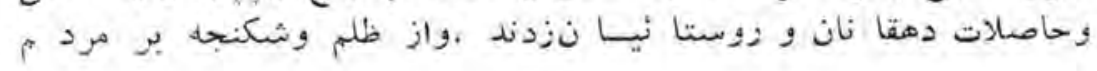




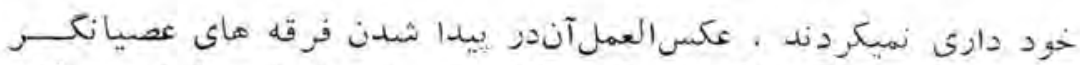

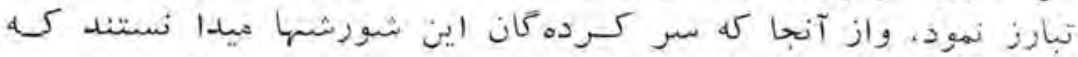

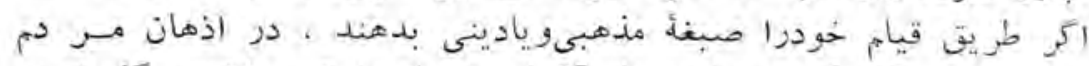

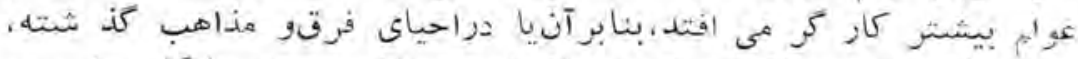

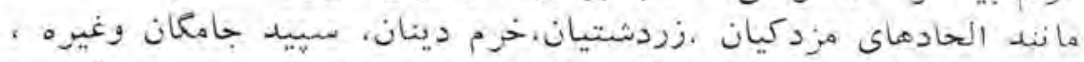

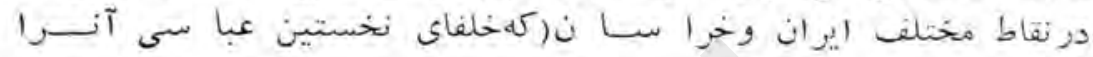

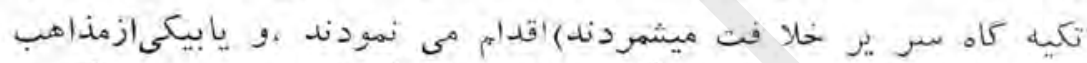

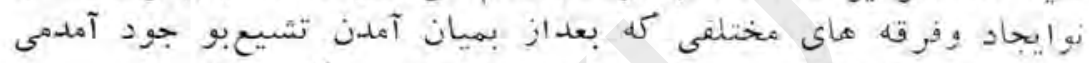

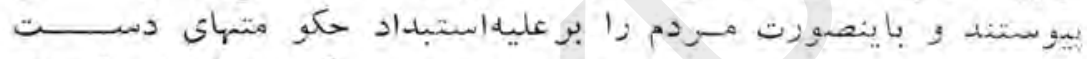

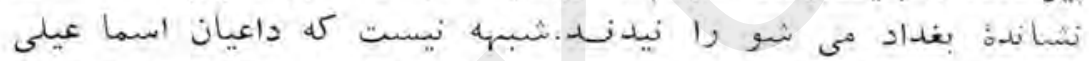

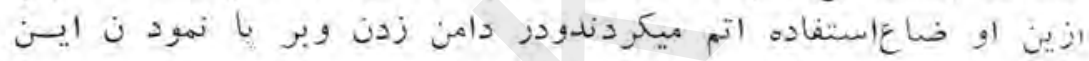

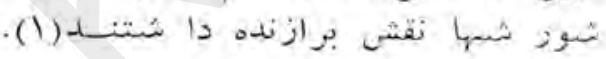

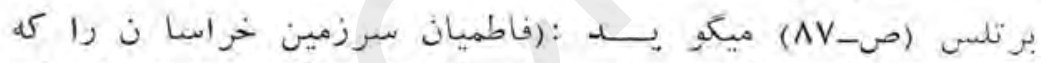

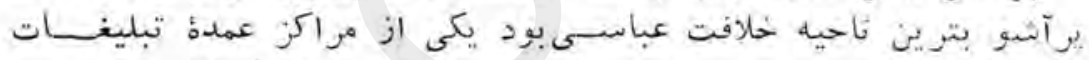

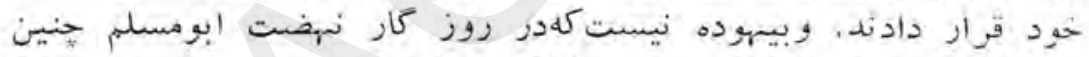

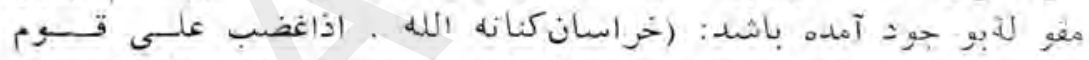

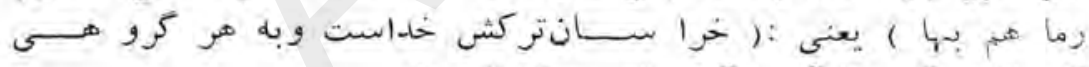

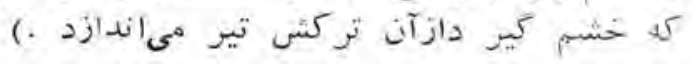

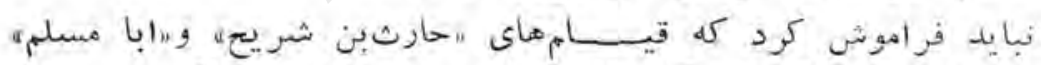

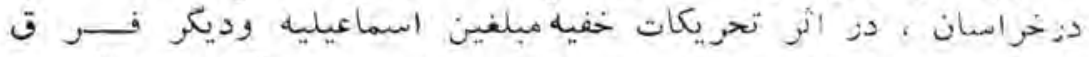

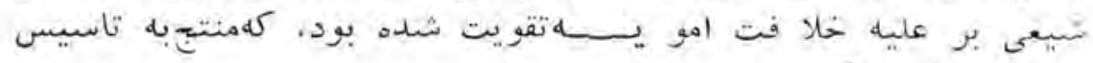
حلافت عباسنى كرديد.

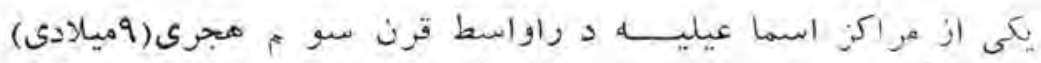

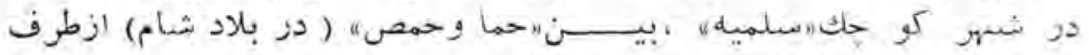

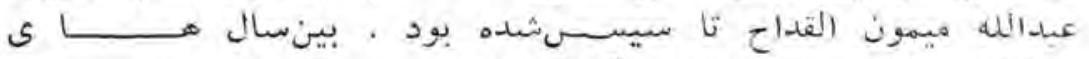

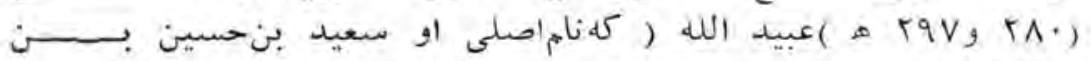


عبدالله واز احقاد ميهون القـدا حبود) دزين هركز بحميث داعى كبير

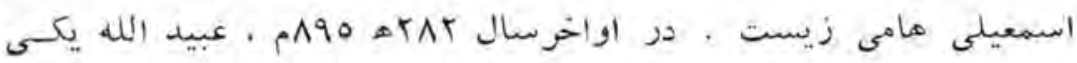

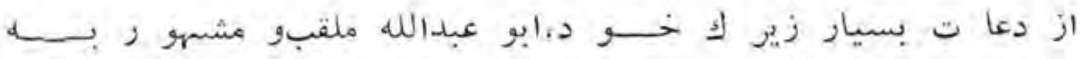
(الشيعى) رابه المغر ب ( شمه لافريقا) فرسناده بود .او در بيــن قبيلة بربر ى هاي (كتامه ) اقامستاختياز كرد وبه نشر وتبليغ مذهب اسمعيلى آغاز نمود . ديرىنكذشتدزآنايالات (طر ابلس ، مغرب،تونس،

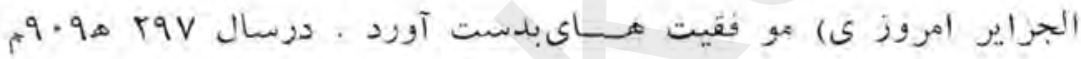
"الشيعى"به عبيدا لله بيا مىفرستادكه زهينه براي اعلان املمت آمـاده كرديده ، و آمدن اورايكآن او لتربه المغرب در خواست . 2ريبــن زمان افريقاى شما لى زيرحكمر انىسلالة بنى اغلب بود ،وحيطه اقتماز شان حتى جزاير سيسليا ( يعنسـىصقليه )، ساردينيا و ها لتيا(مالطل) را دربر كر فنه بودد .

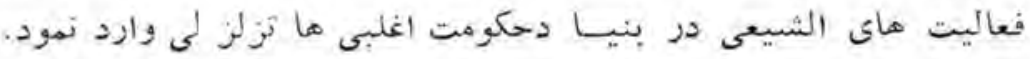

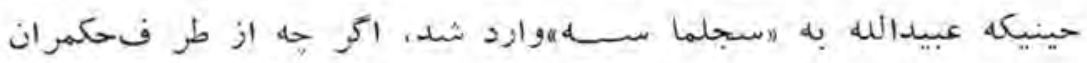
اغلبى ، زيادت الله، زندانى كرديد،ولى درين وقت كه الشيعى بر شهر

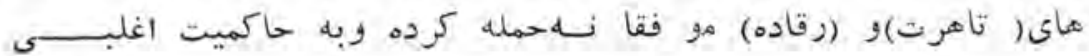
ها خاتهل داده بود ، عبيدا لله رالز حبسى رها كرح و عر(زقاده) اورا هم بحيث المهادى وهم به صفــتاعير المو منين اعلان نمودوحكومت

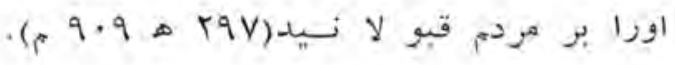




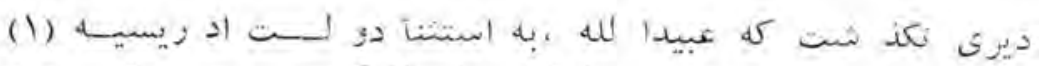

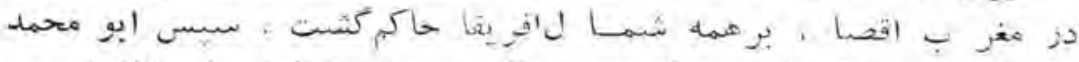

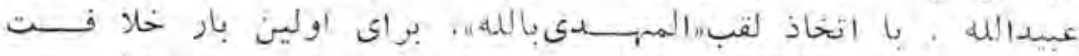

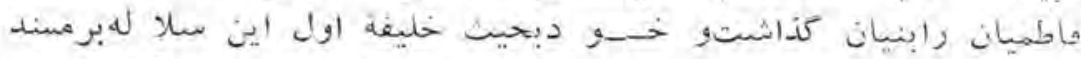

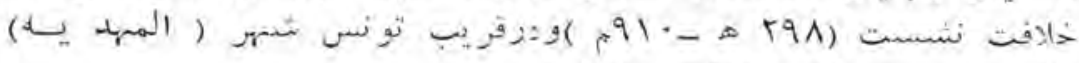
رابا نهو

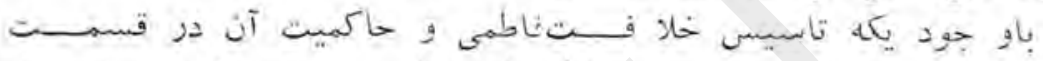

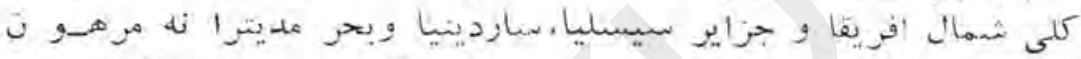

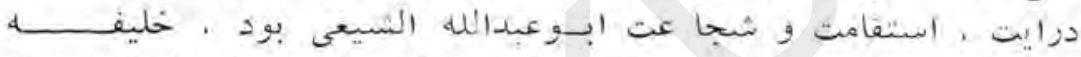

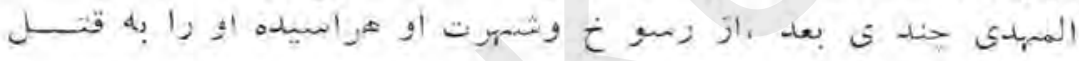
intivg

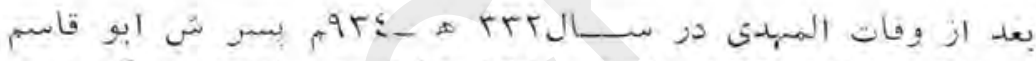

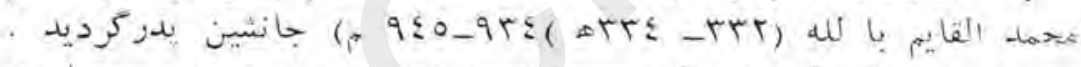

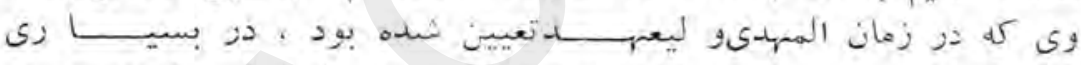

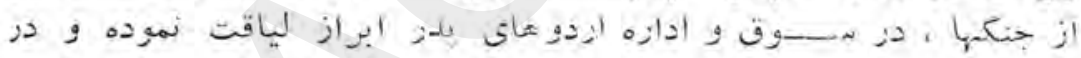

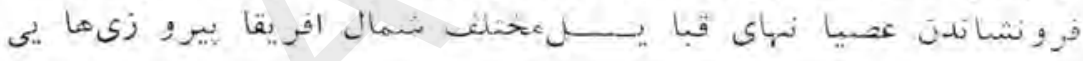

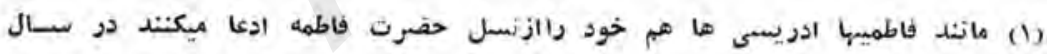

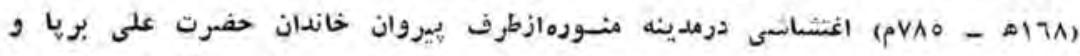

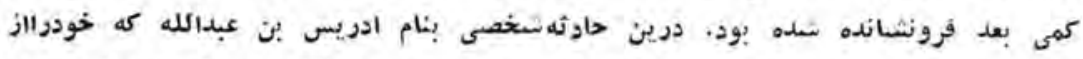

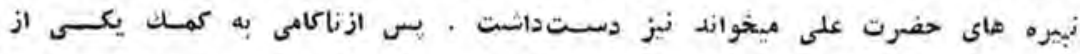

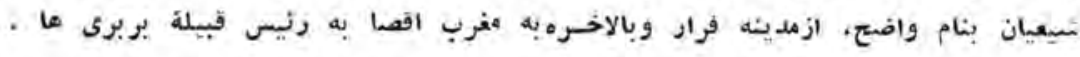

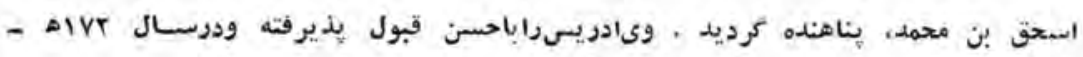
FVA

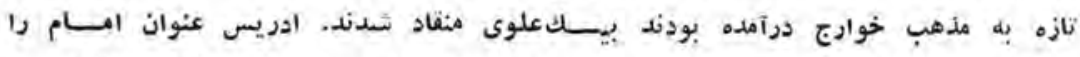

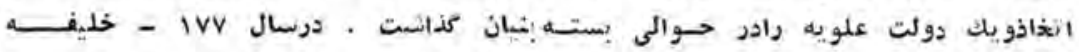

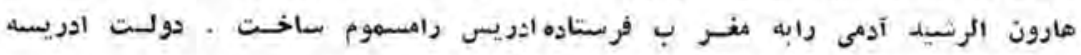

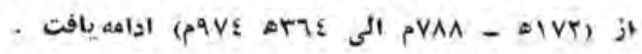




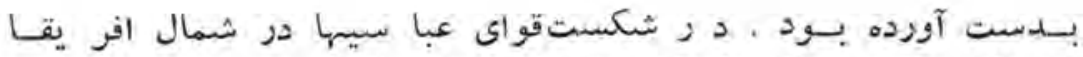

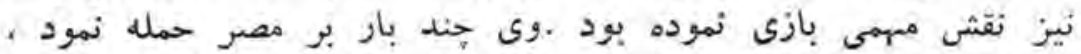

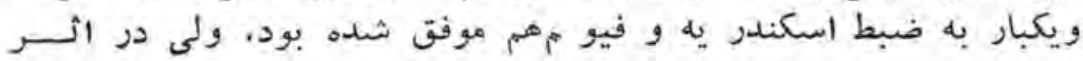

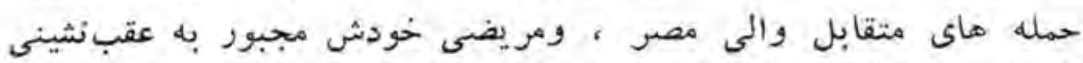

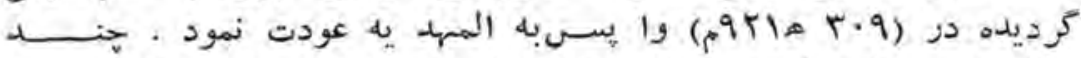

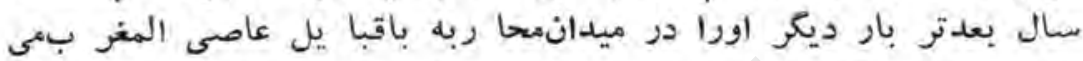

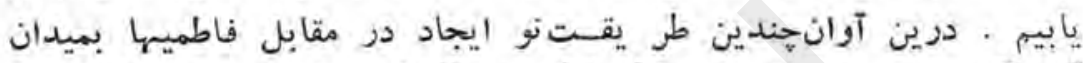

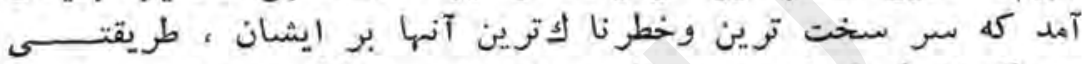

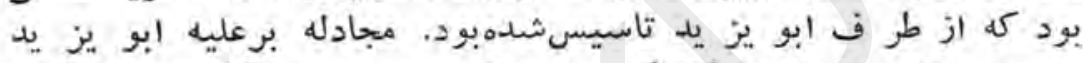

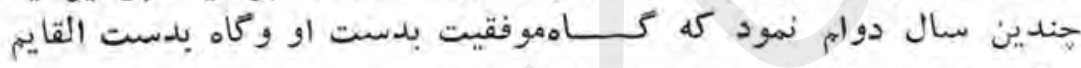

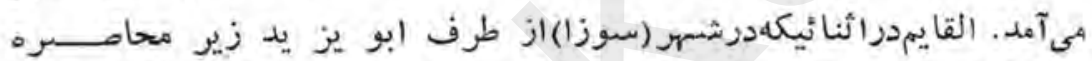

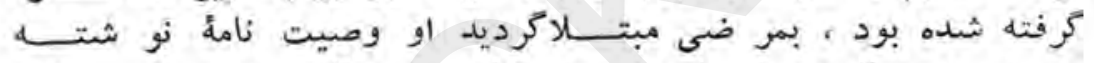

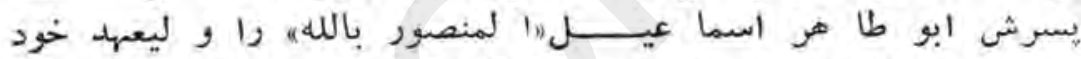

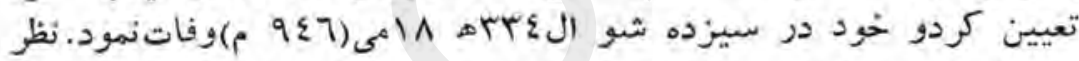

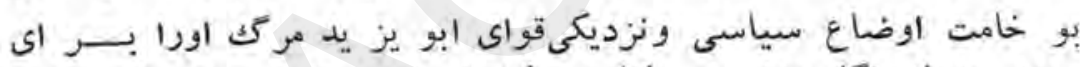

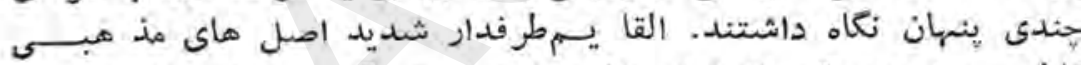

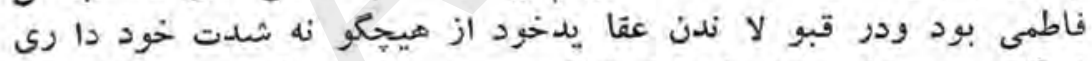

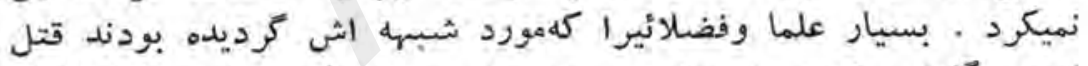

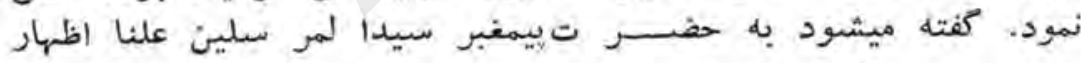

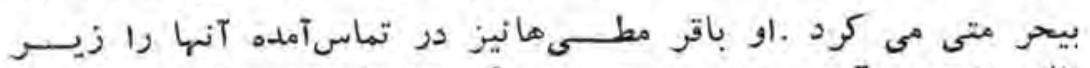

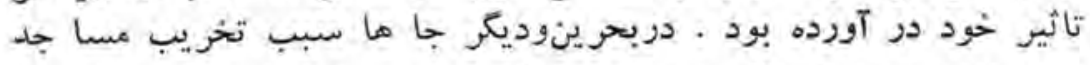

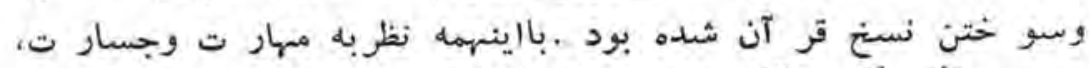

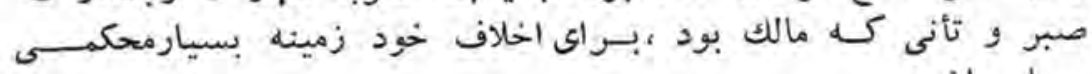

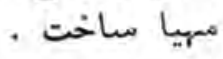

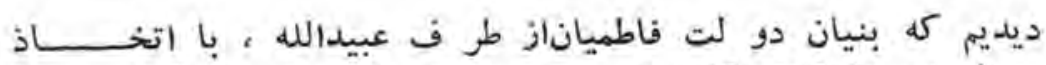

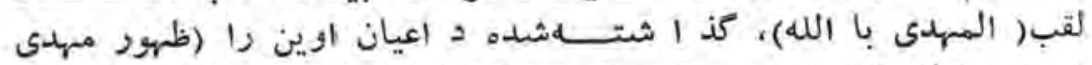

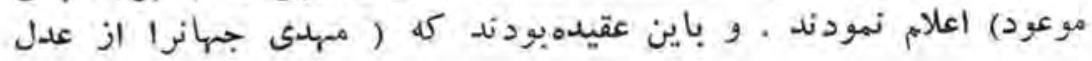




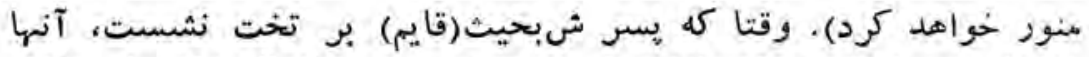

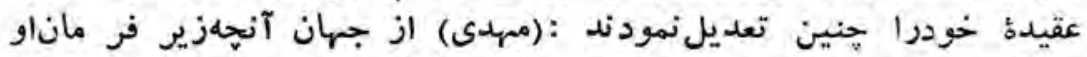

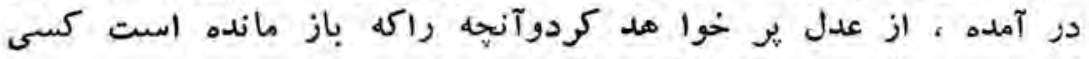

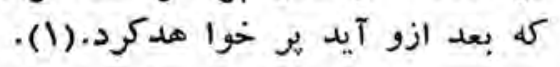

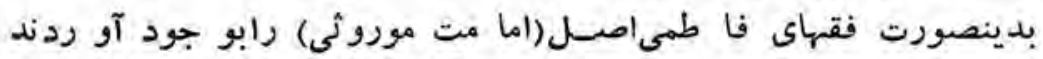

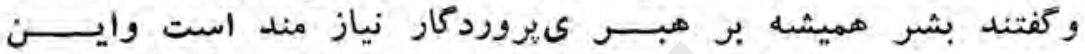

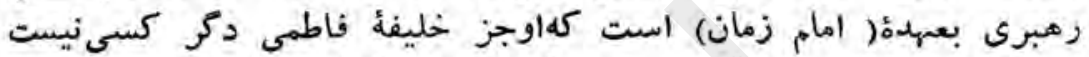

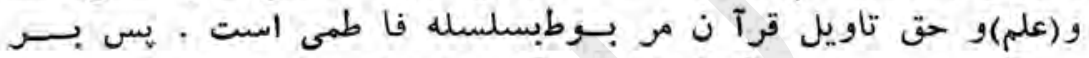

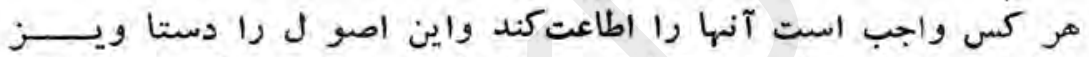

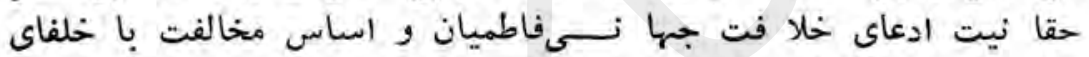

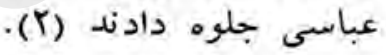

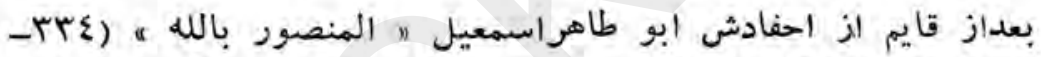

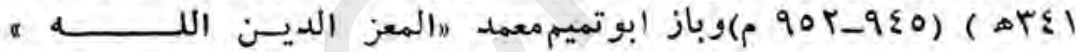

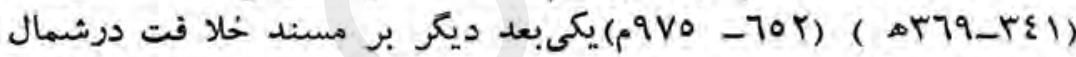

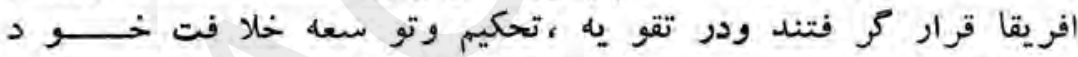

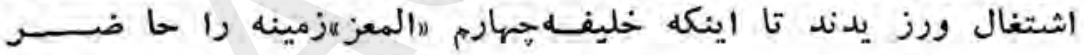

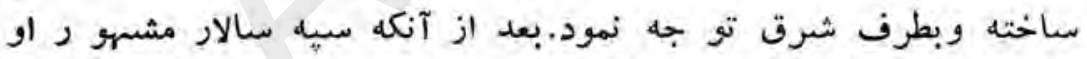

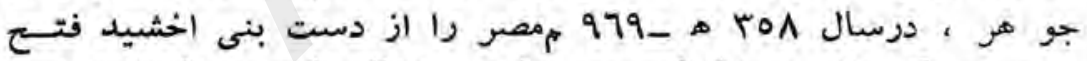

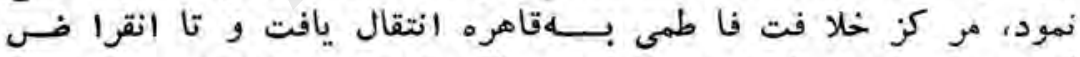

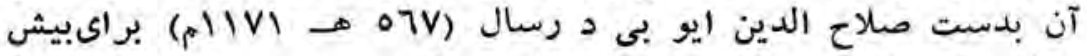

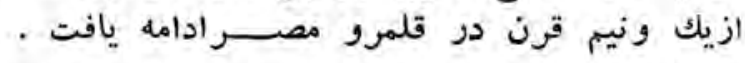

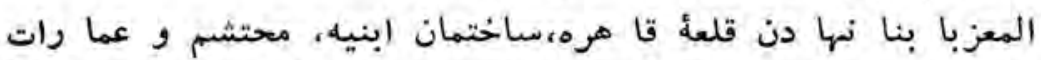

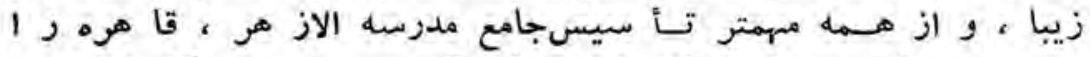

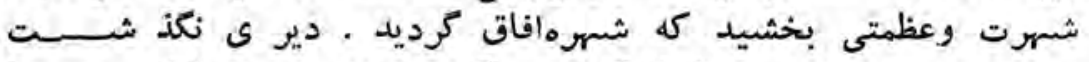

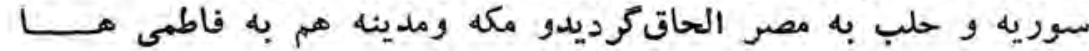




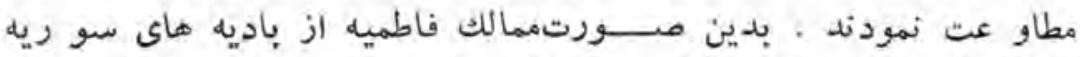

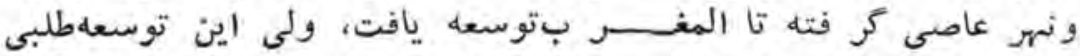

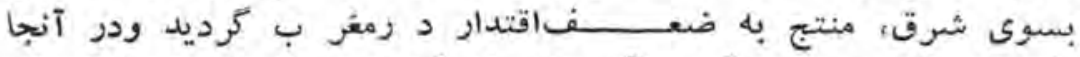

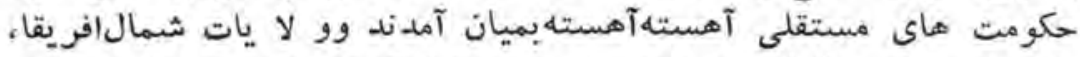

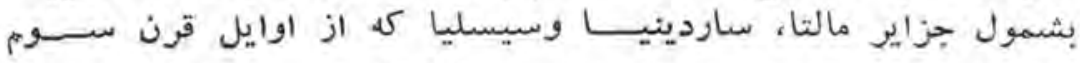

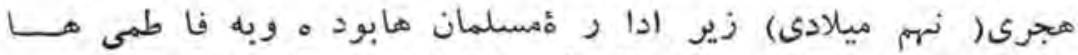

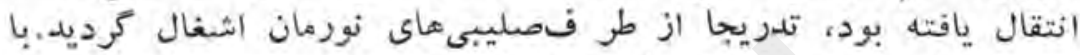

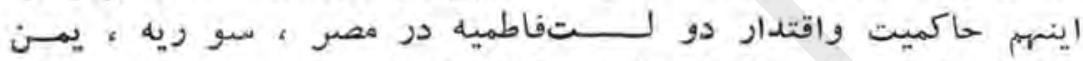

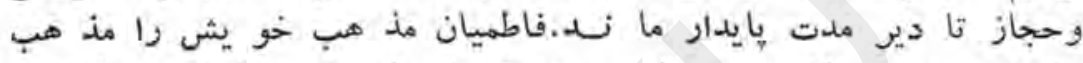

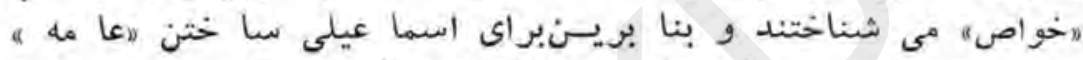

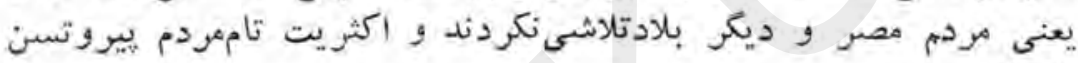
هاندند . معند

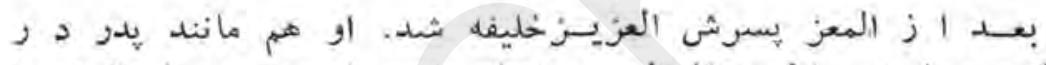

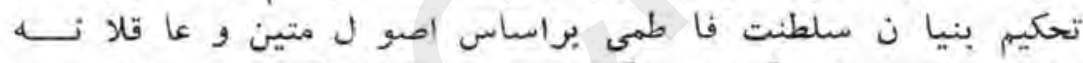

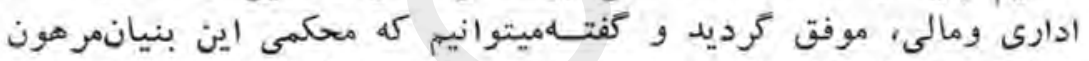

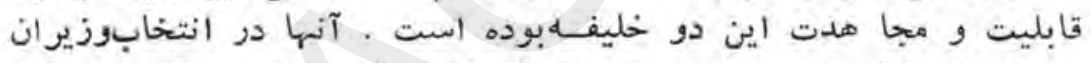

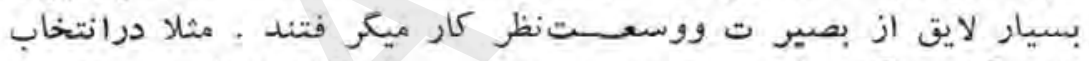

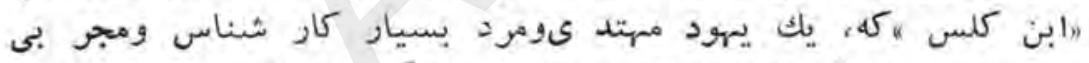

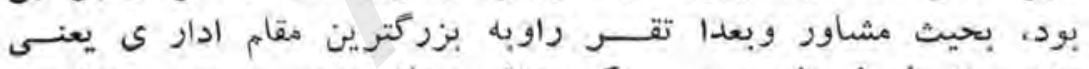

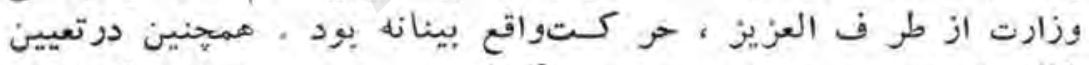

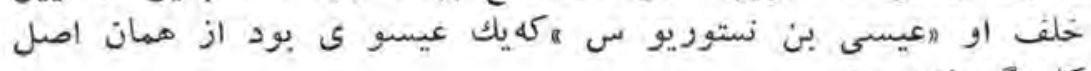

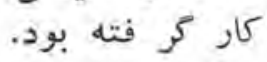

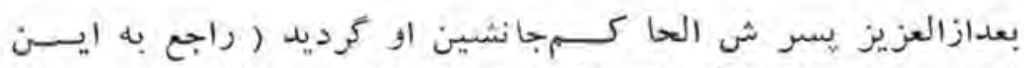

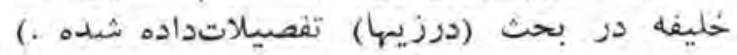

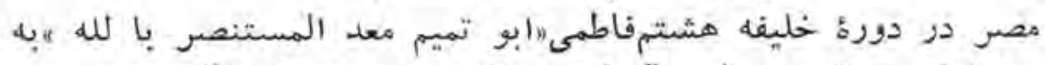

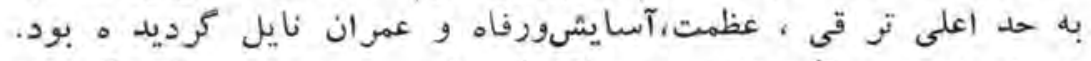

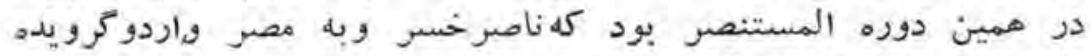

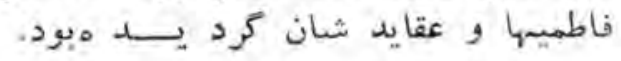


در بسا از اشعار خود ازالمستنصمدلح ميكند و تخلص خودرا كاه كاه

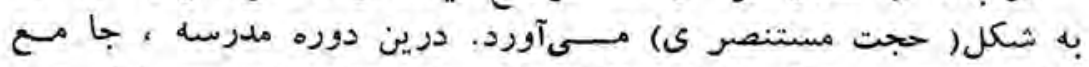

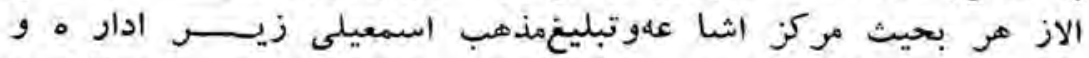

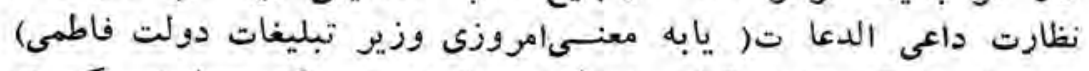

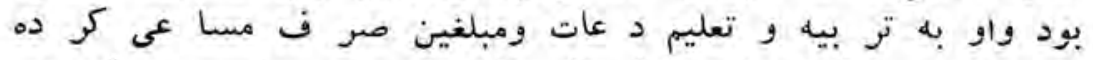

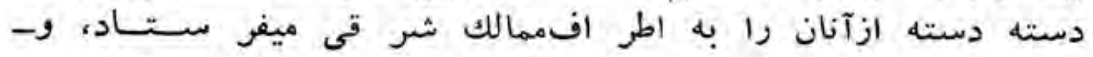

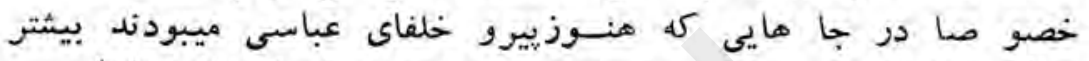

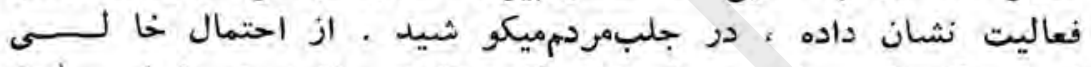

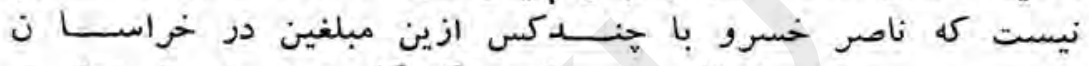

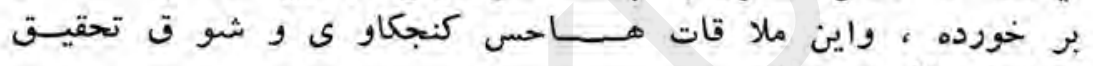

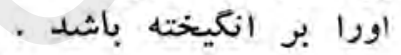

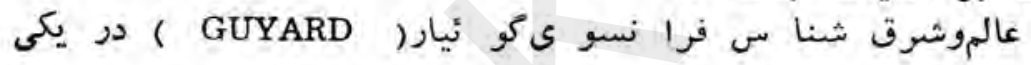

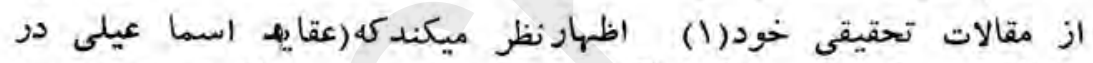

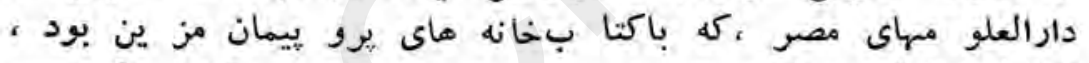

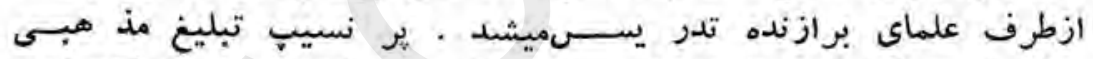

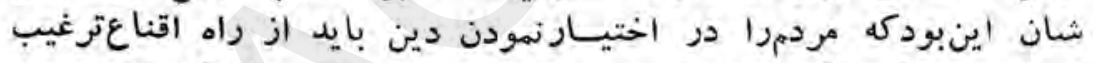

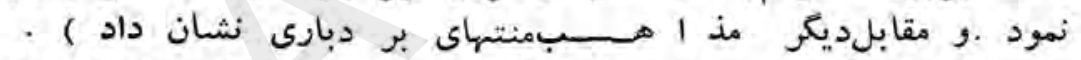

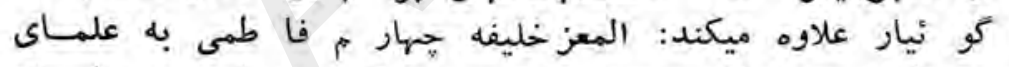

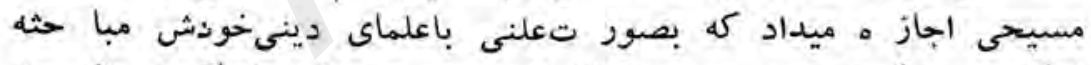

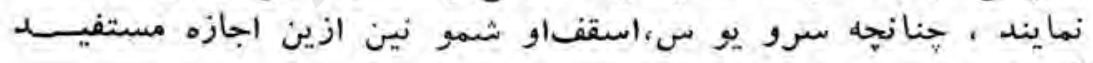

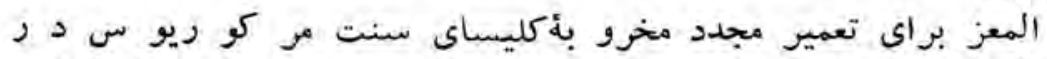

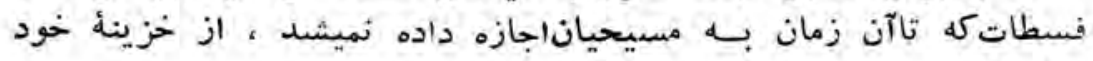
يول داد.

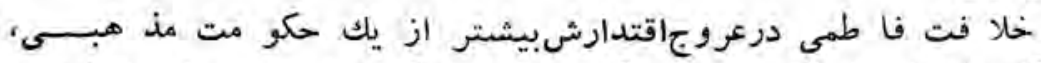

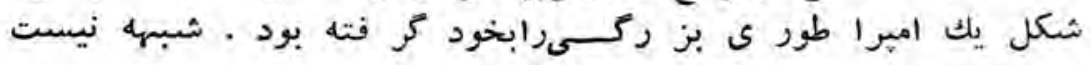

"UN GRAND MAITREDES ASSASSINS" JOURNAL ASIATIQUE' PARIS 1877 


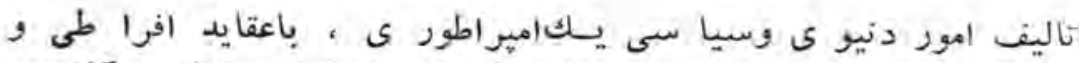

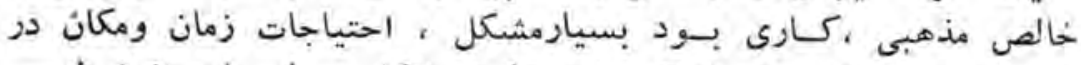

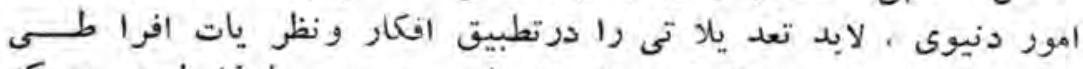

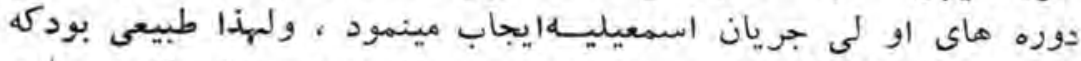

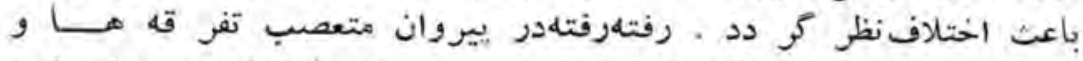

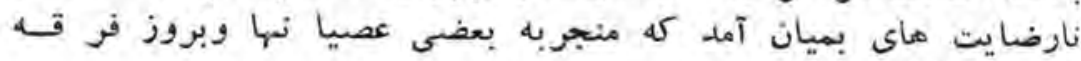

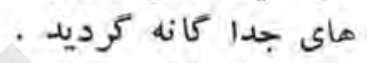

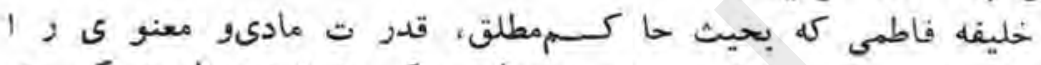

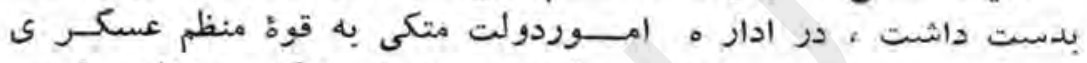

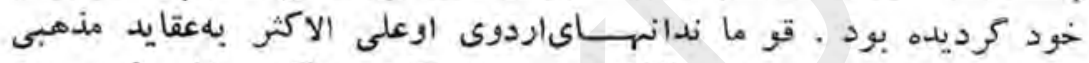

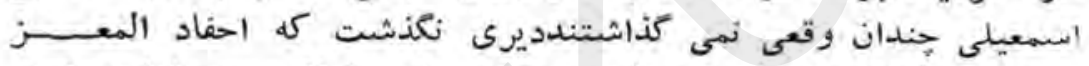

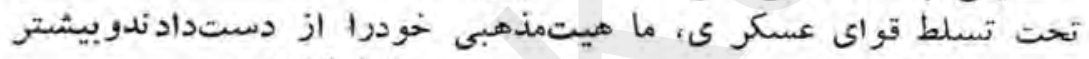

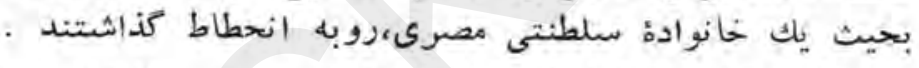

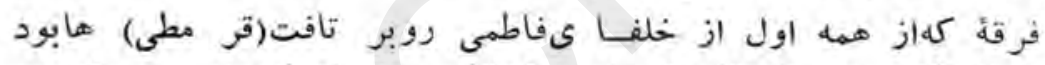

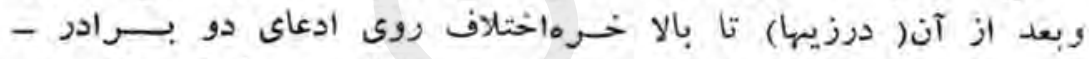

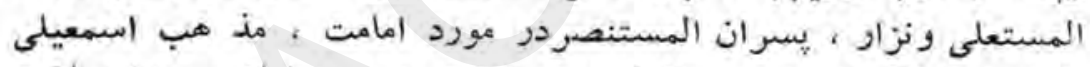

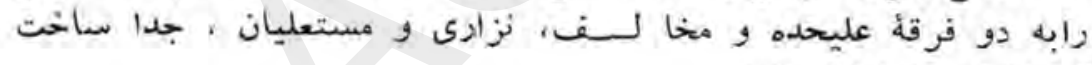

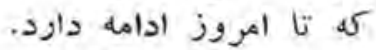

بهتر است ، كمى دعلو مات دربارة اين فر قه هما وطرز تفكســ وفعاليت شان بد هيم .

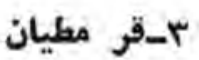

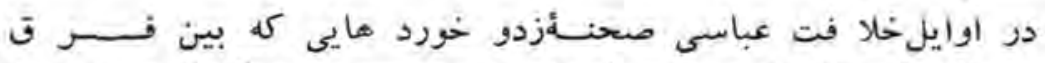

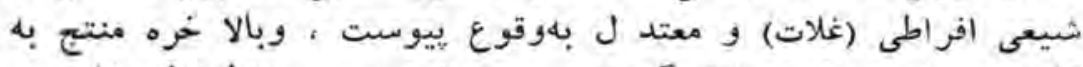

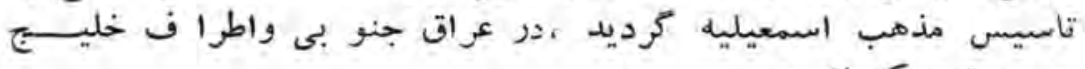

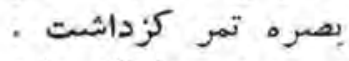

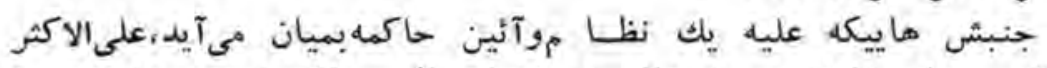
بوقشر هاى ناراضى واصناف زيرفشار تالثير جاذب توى ميدا شيتـــ 


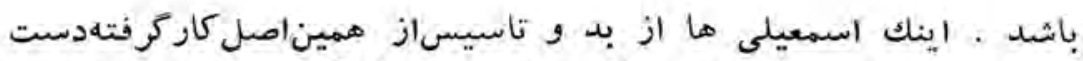

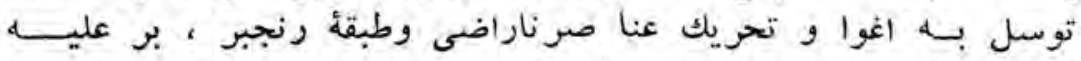

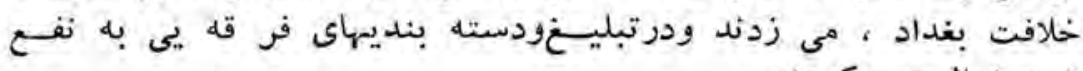

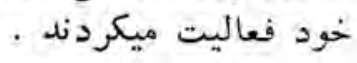

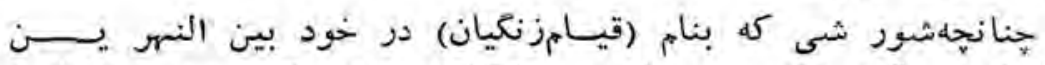

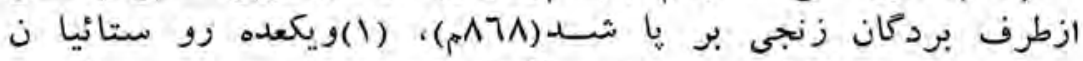

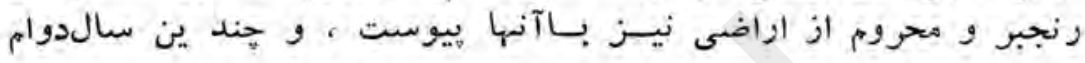

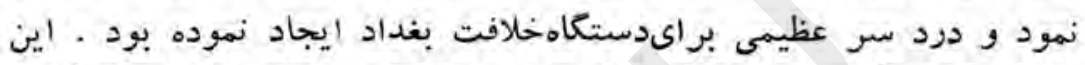

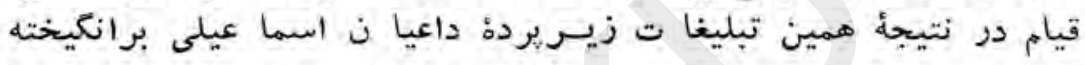

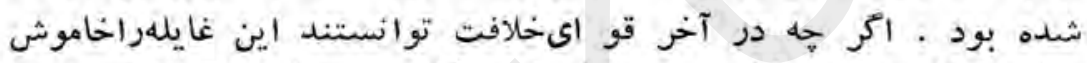

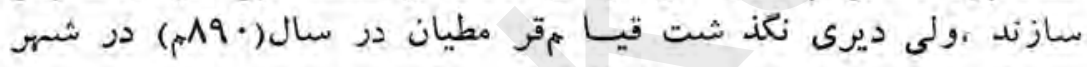

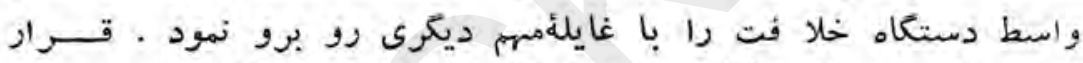

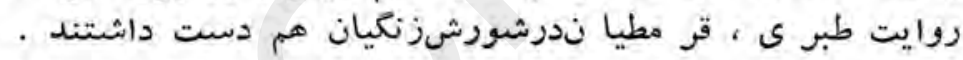

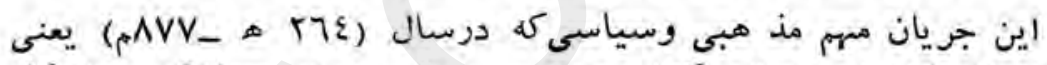

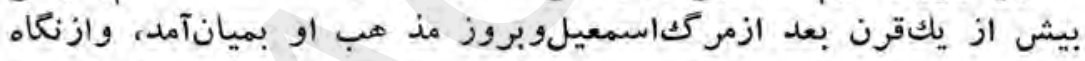

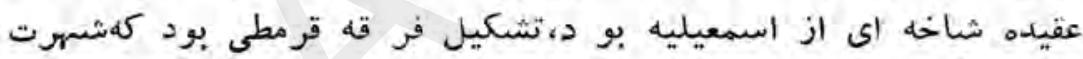

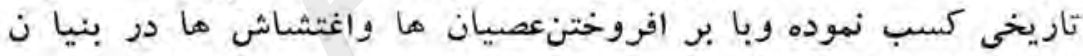

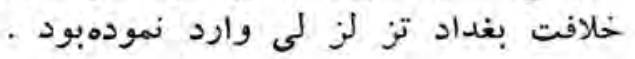

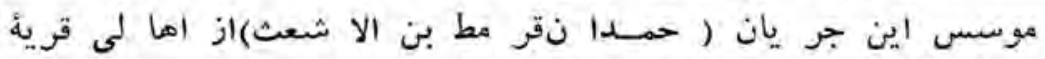

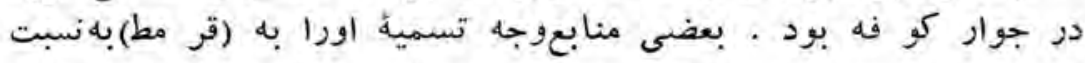

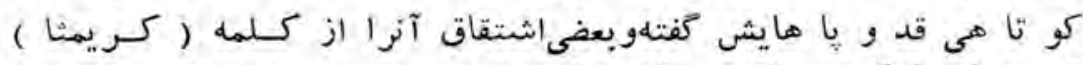

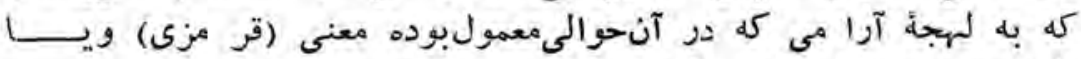

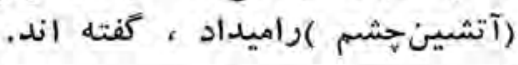

(1)

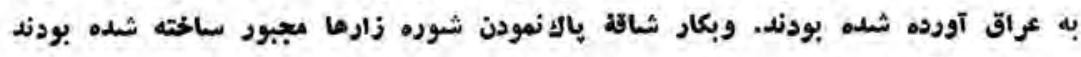
درشُرايط طاقت فرسا لورده شعده بودند. 


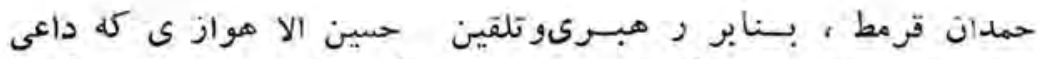

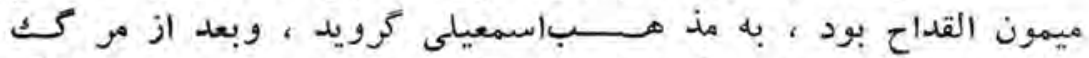

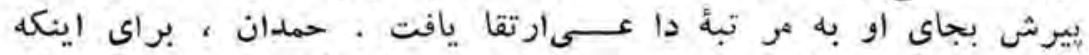

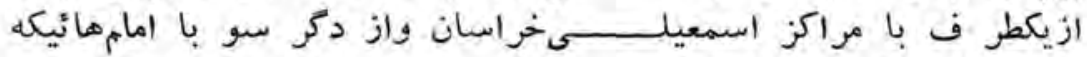

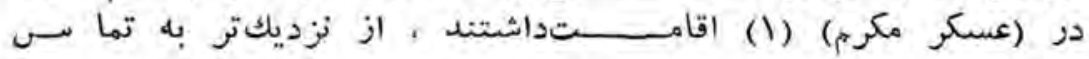

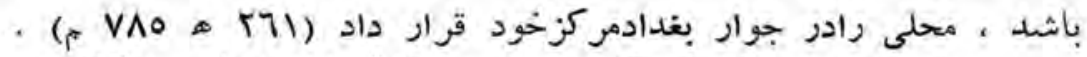

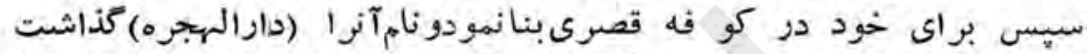

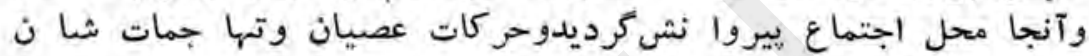

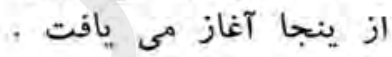

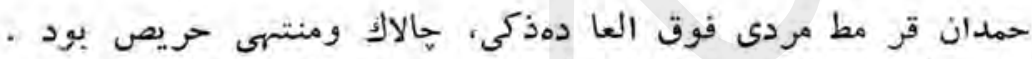

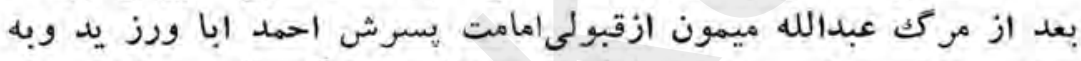

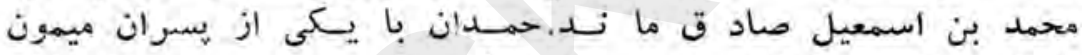

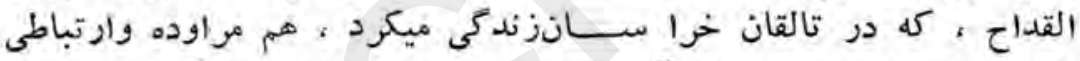

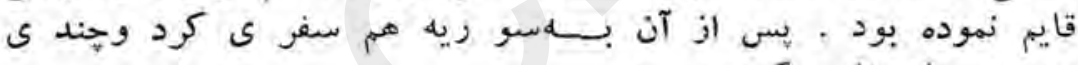

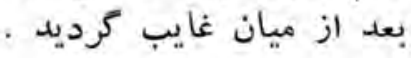

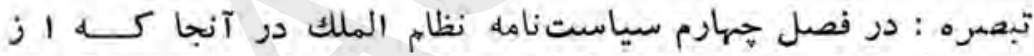

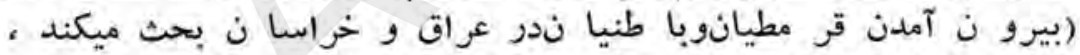

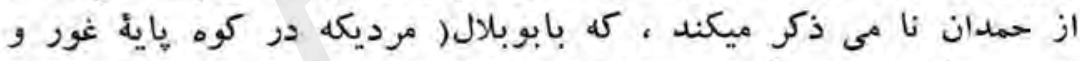

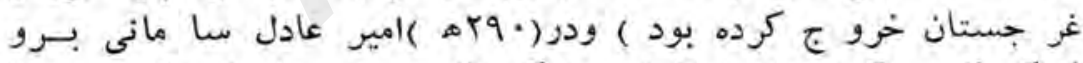

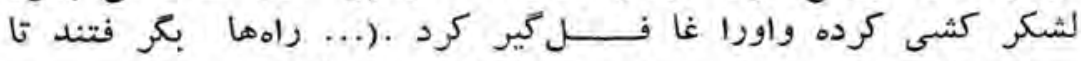

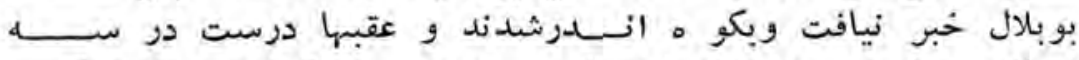

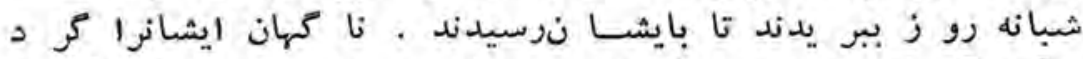

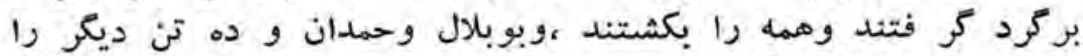

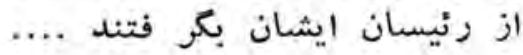

(1) يعنى "اردوكاه مكرم" - يكىازاردوكاه هاييكه اهويها دراهواز (خوزستان) تاسيس

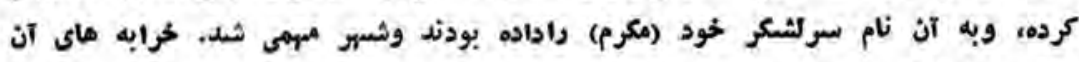

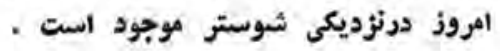




\section{$7 \varepsilon$}

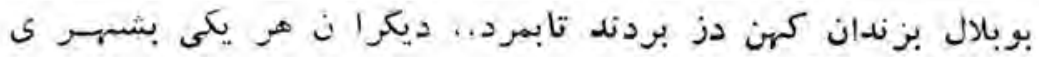

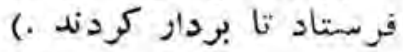

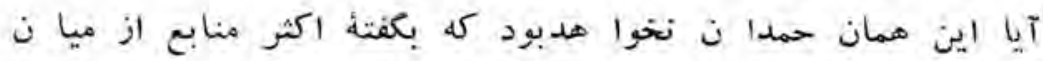

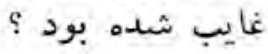

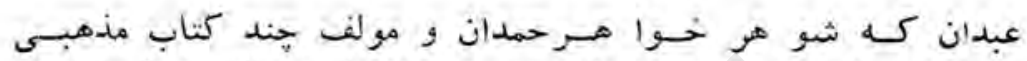

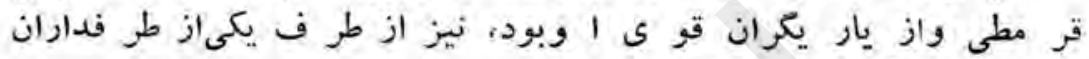

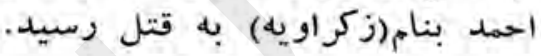

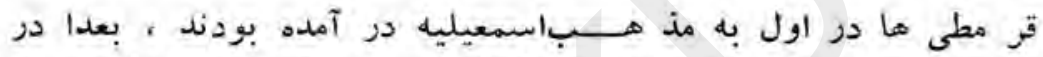

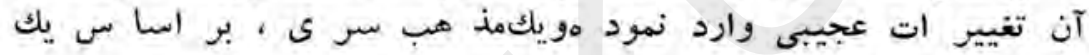

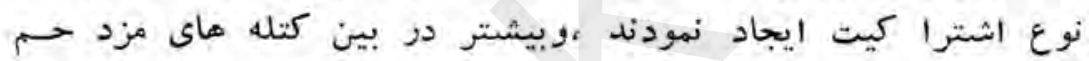

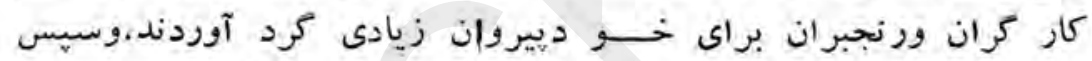

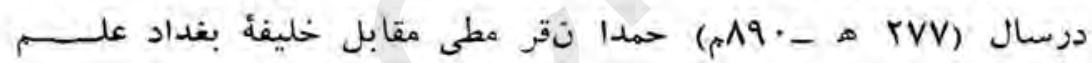

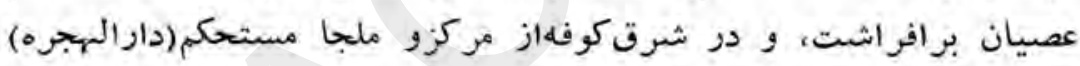

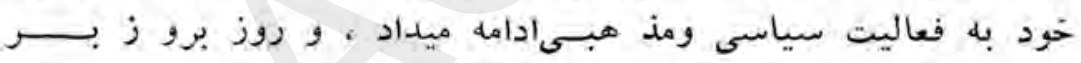

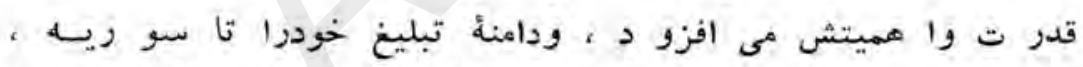

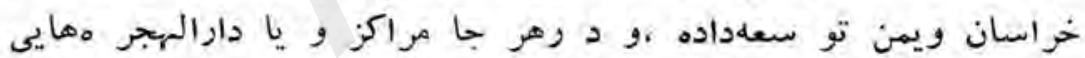

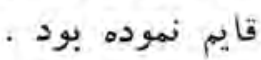

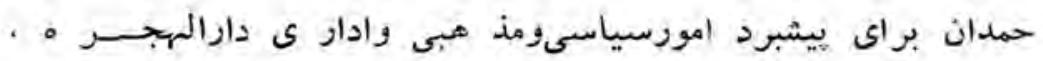

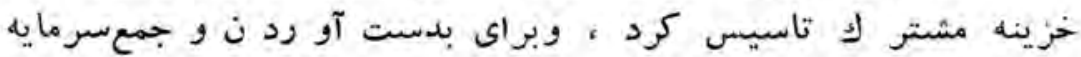

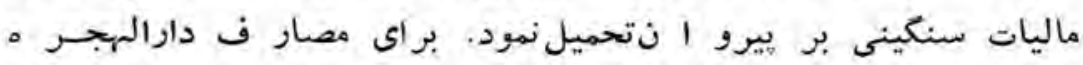

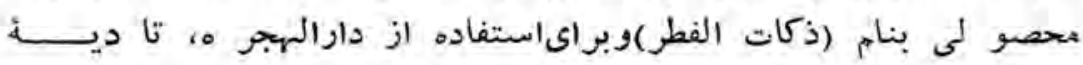

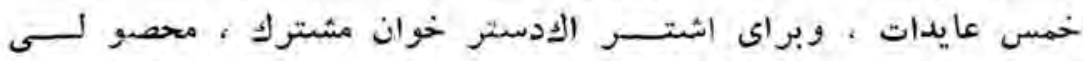

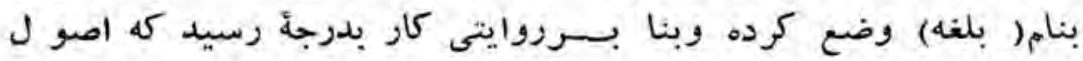

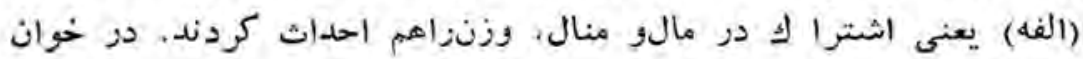




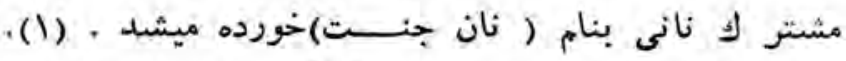

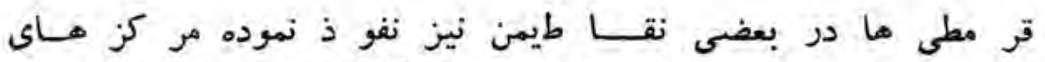

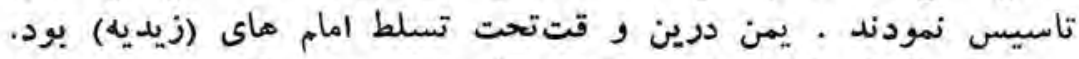

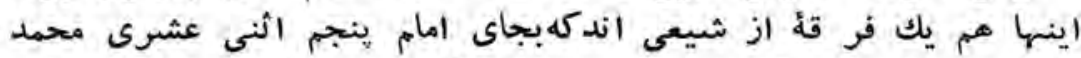

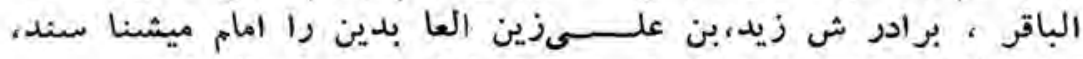

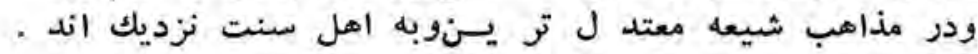

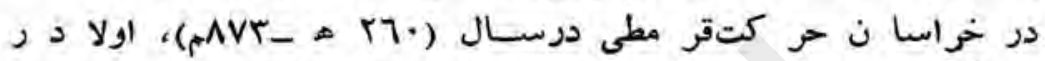

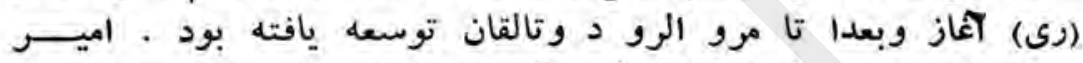

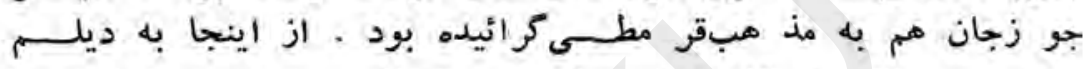

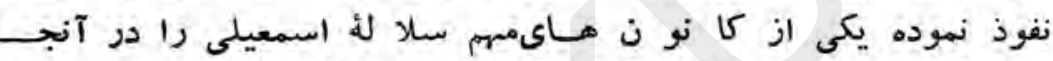

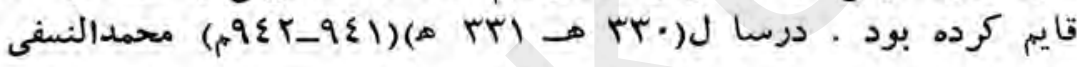

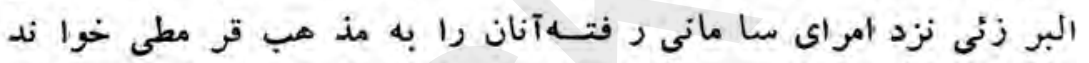

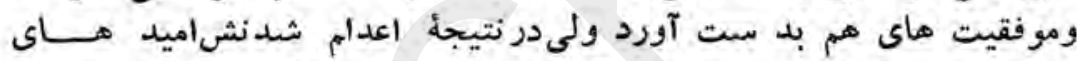

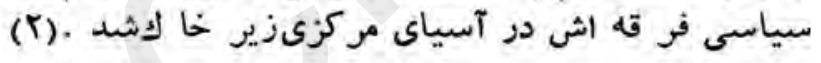

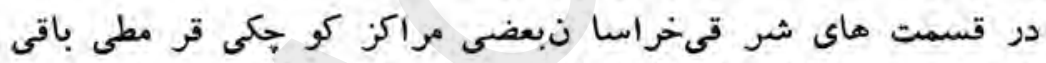

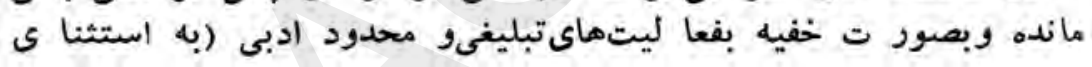

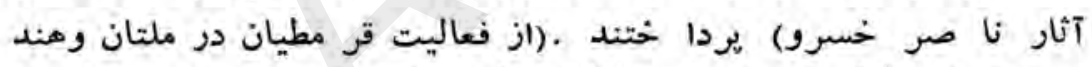

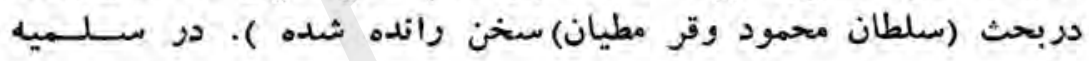

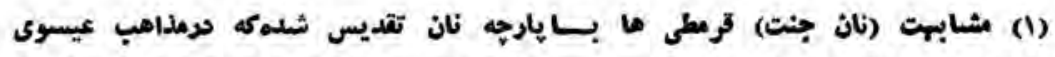

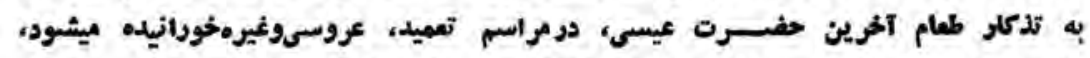

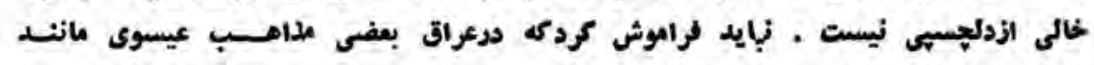

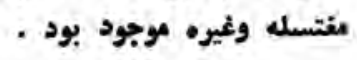

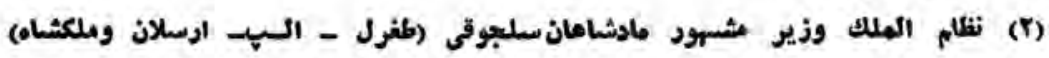

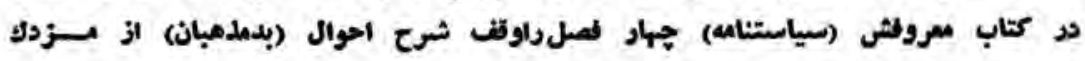

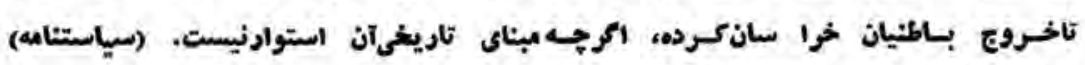

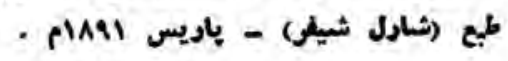




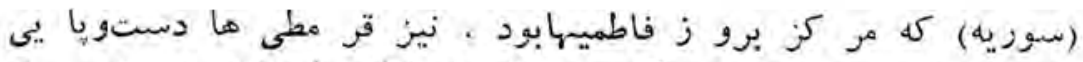

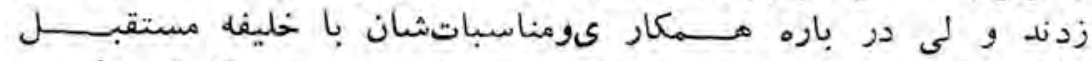

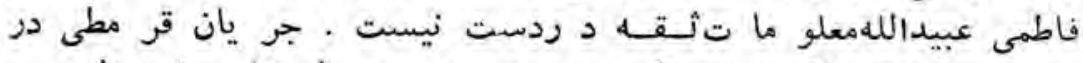

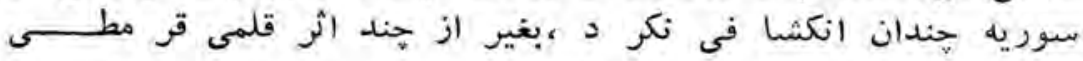

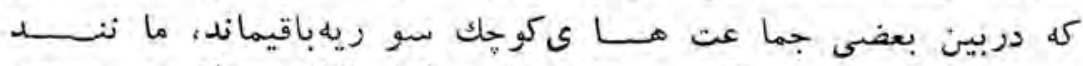

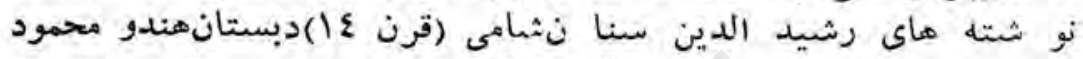

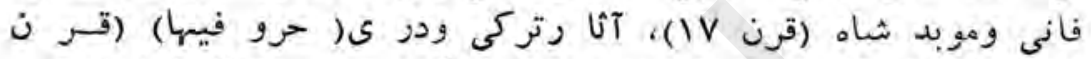

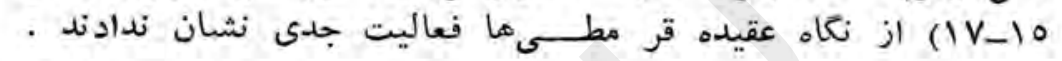

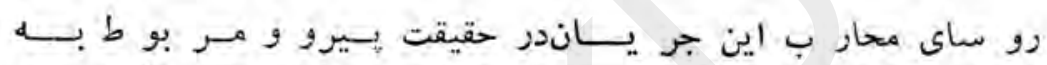

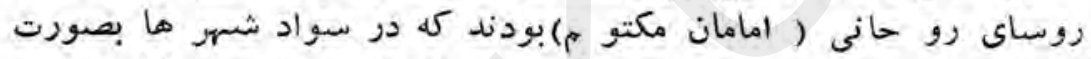

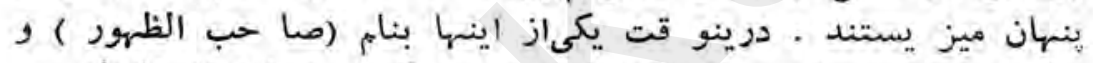

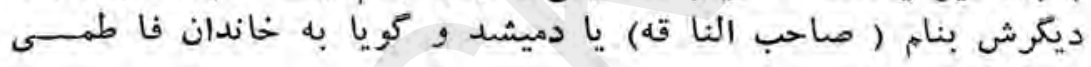

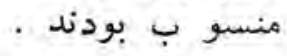

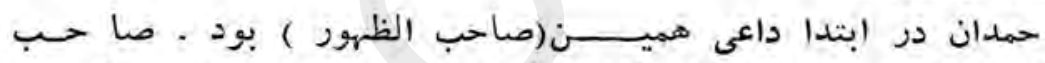

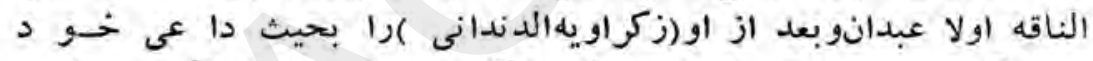

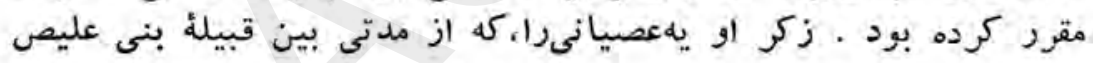

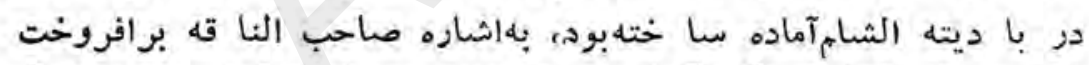

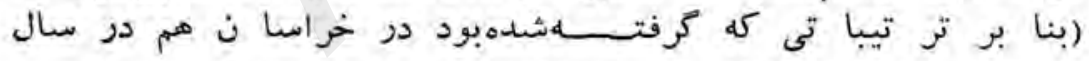

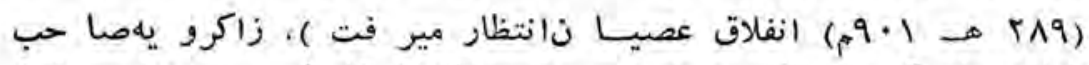

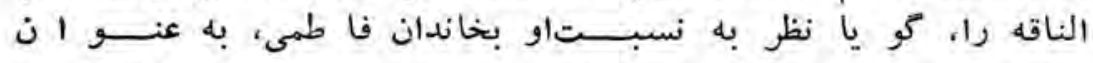

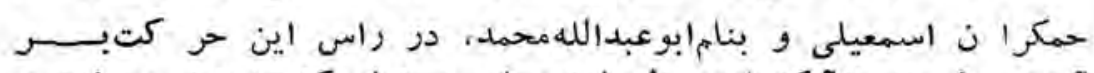

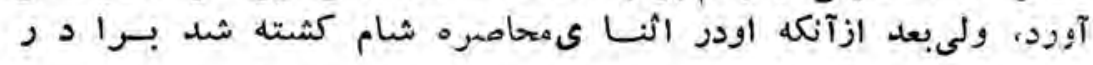

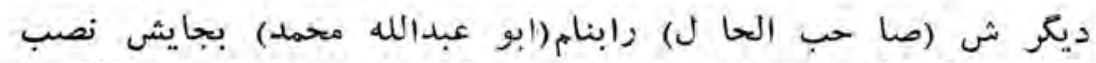

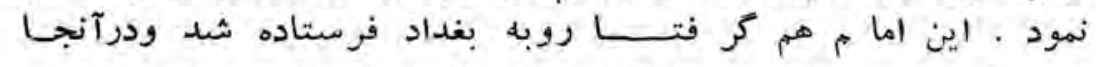

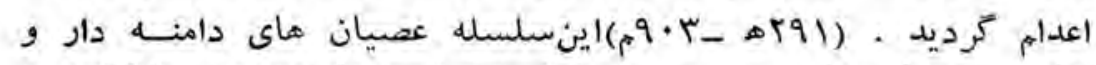

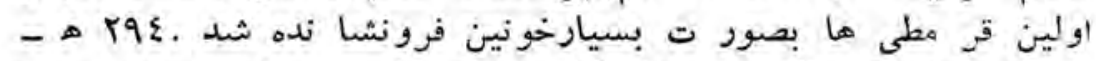

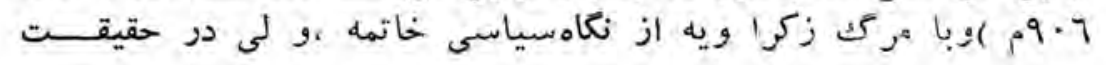


ساحهٔ فعاليت آن در بحر يسـن،بخصوص در (لحسا)، انتسقا ل و

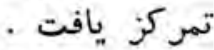

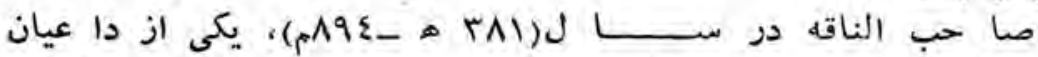

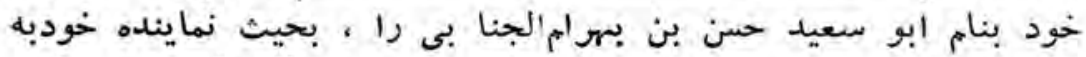

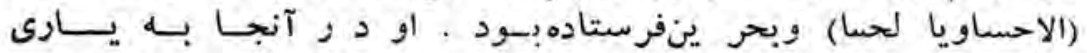

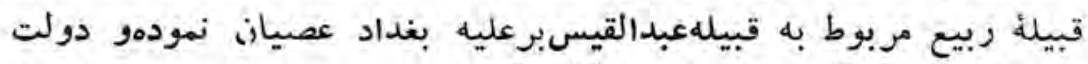

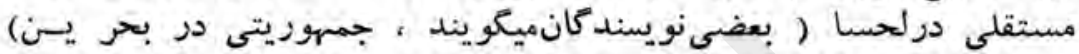

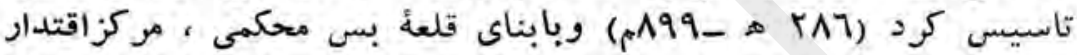

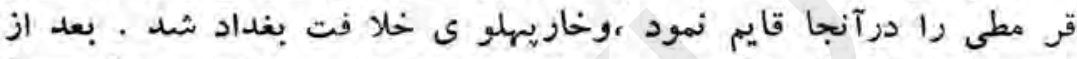

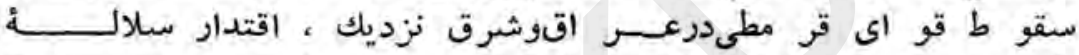

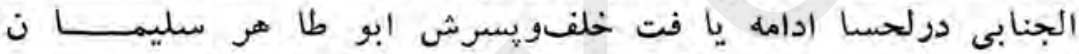

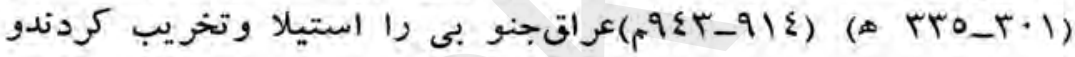

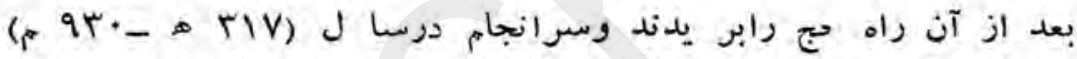

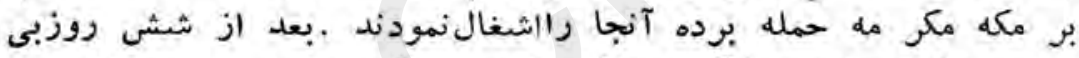

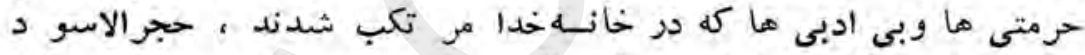

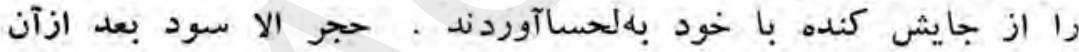

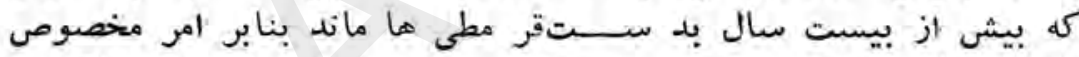

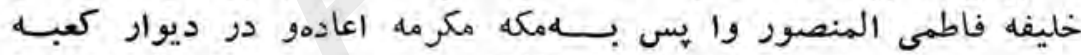

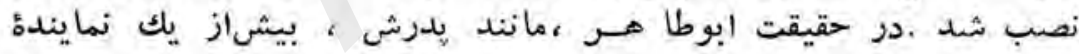

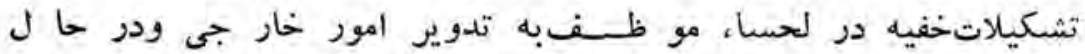

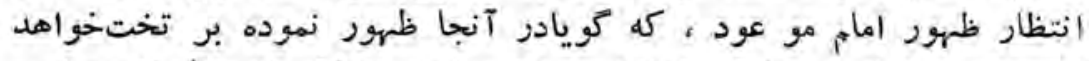

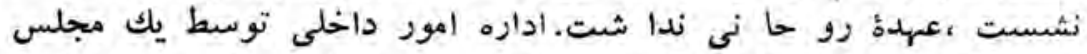

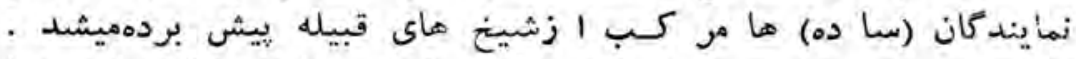

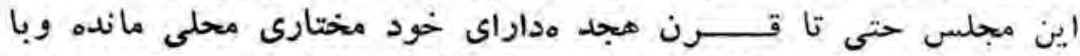

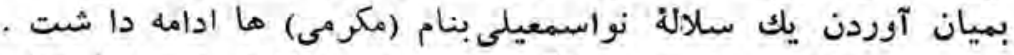

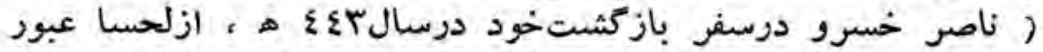

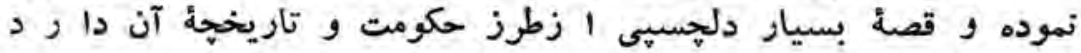

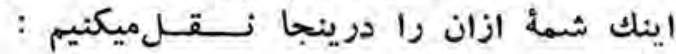




\section{صفت لحسا :}

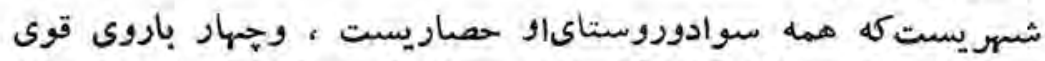

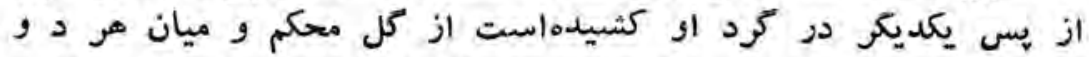

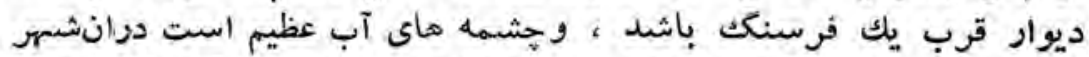

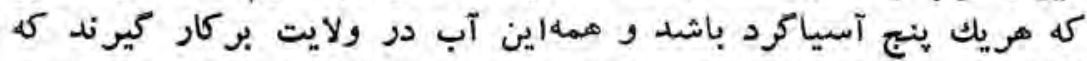

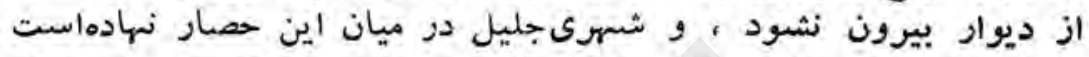

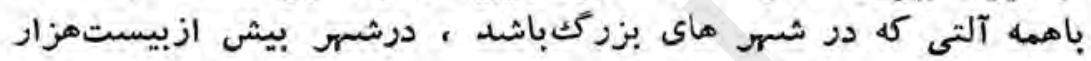

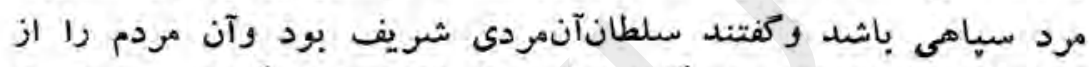

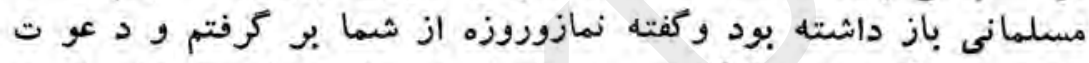

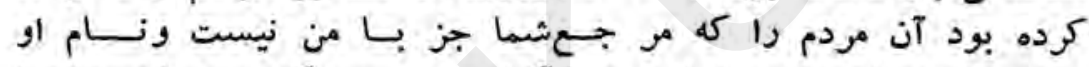

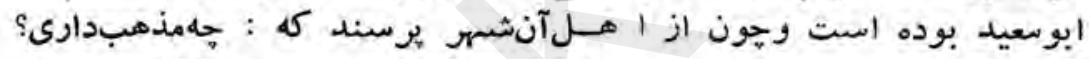

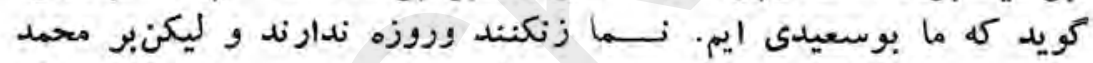

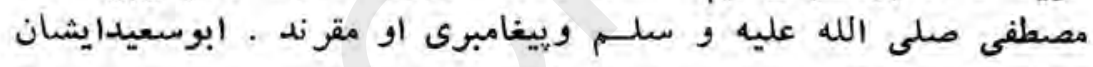

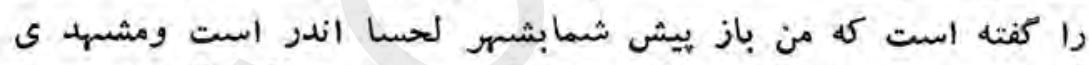

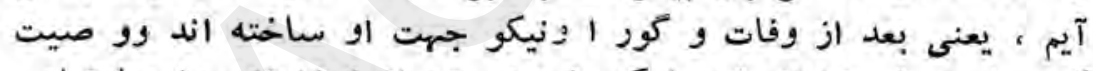

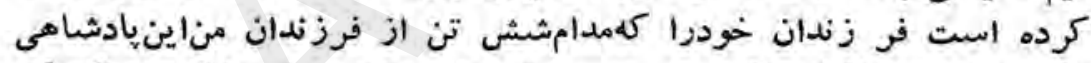

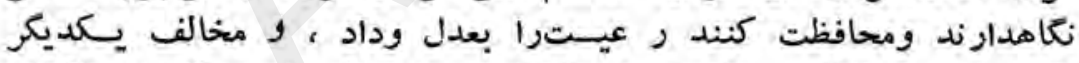

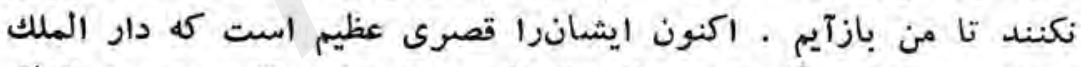

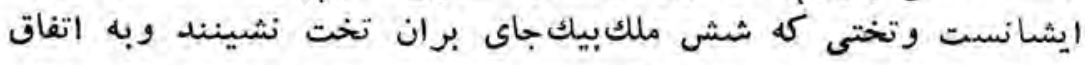

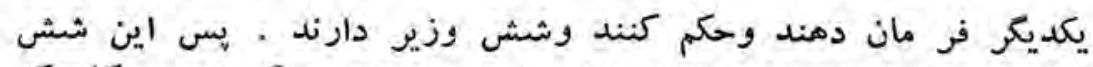

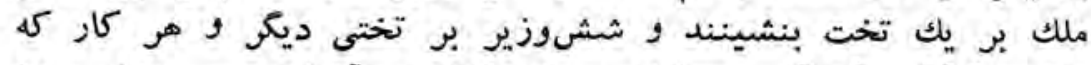

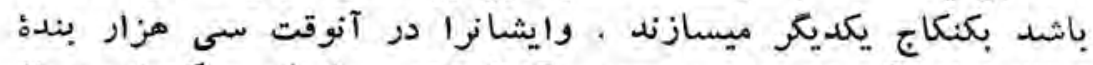

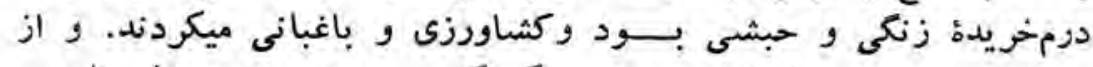

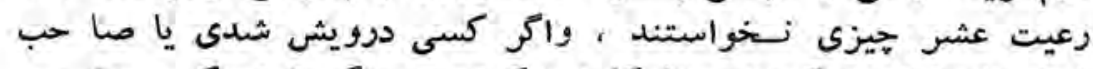

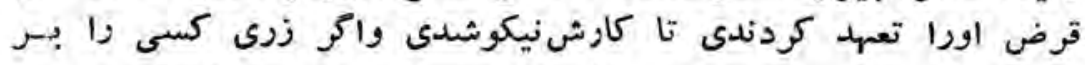

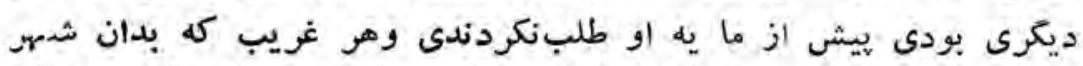

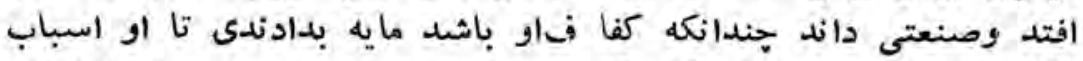

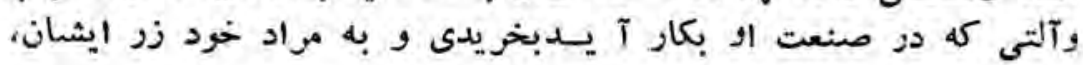




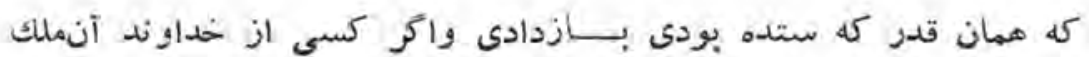

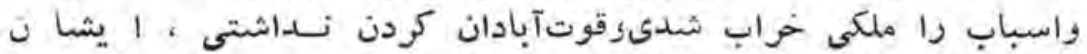

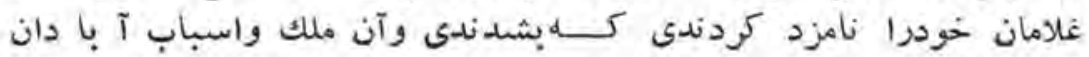

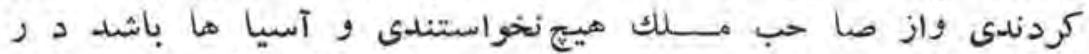

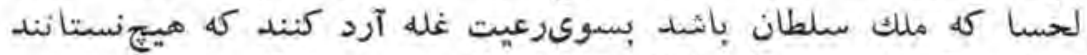

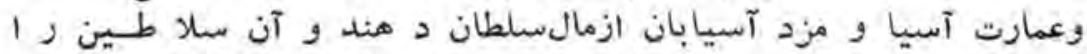

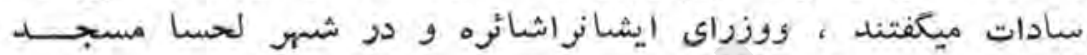

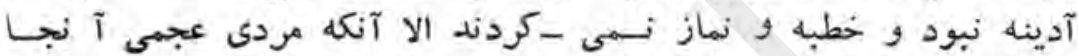

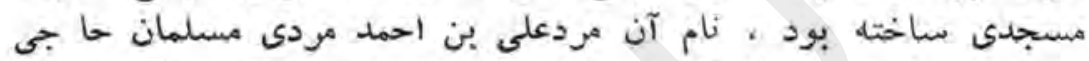

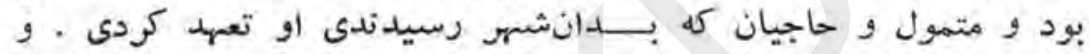

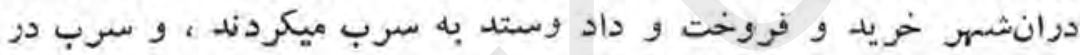

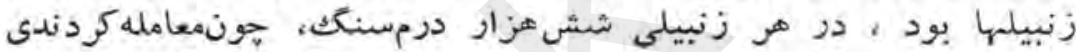

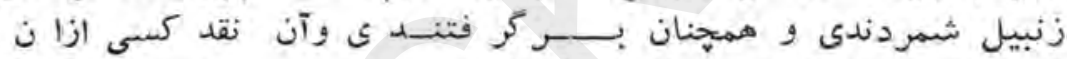

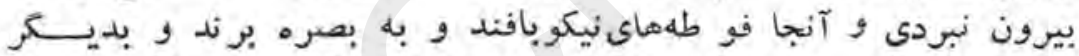

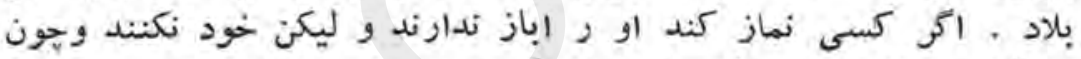

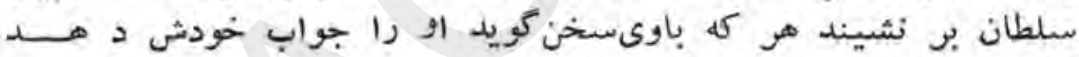

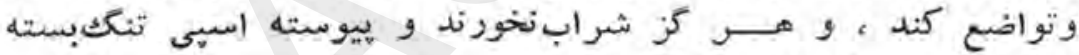

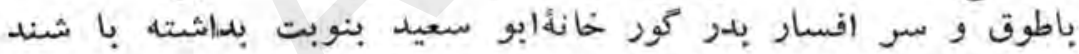

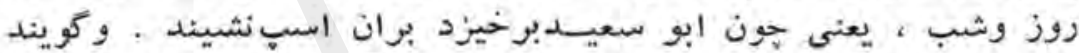

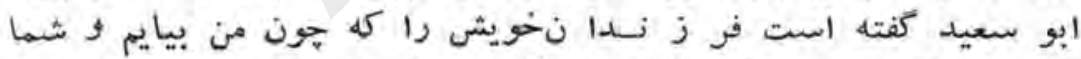

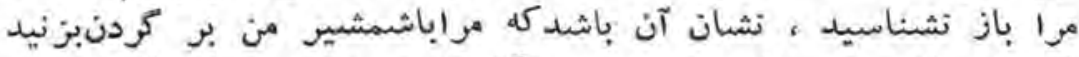

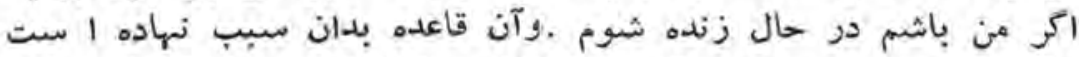

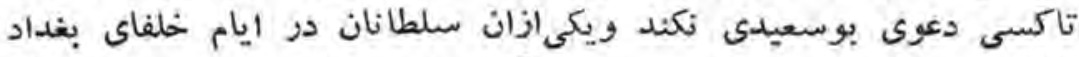

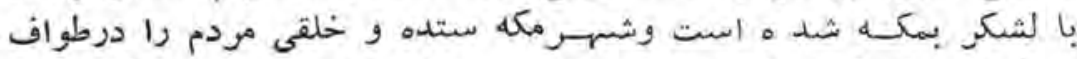

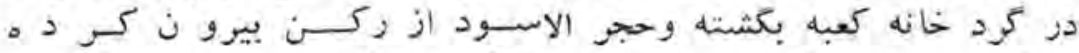

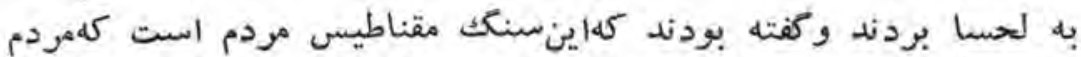

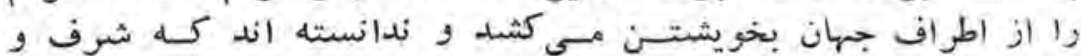

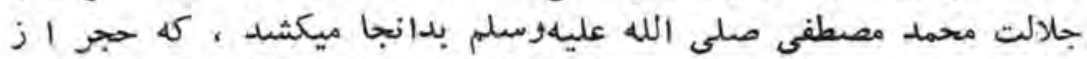

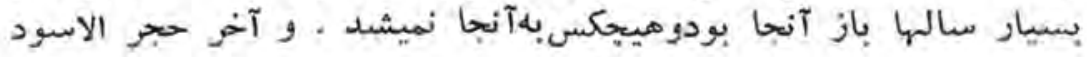




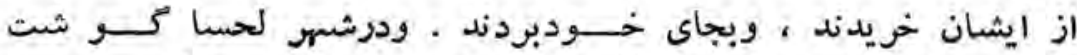

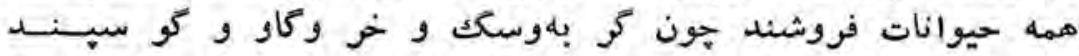

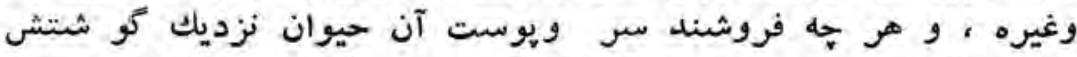

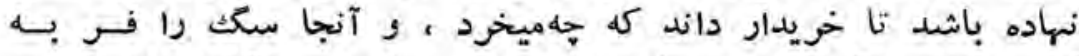

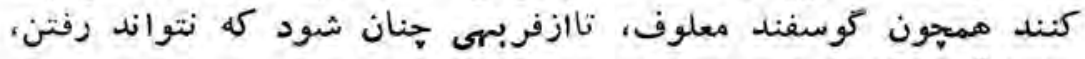
بعد ازآن ميكشند و ميخورند

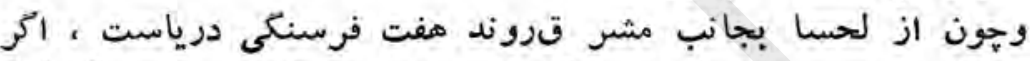

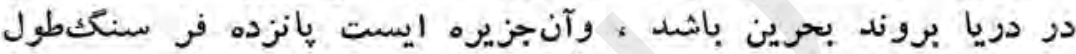

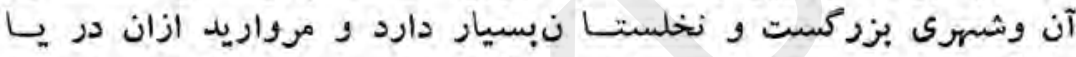

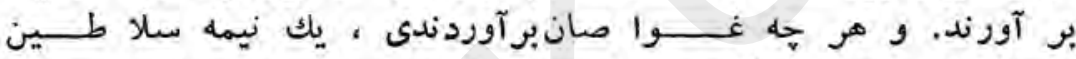

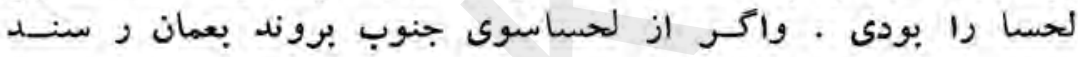

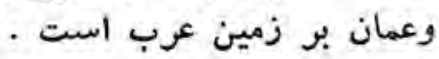

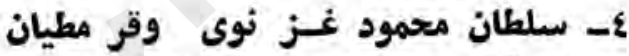

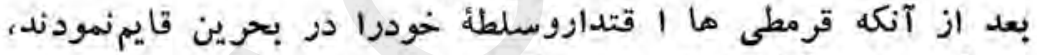

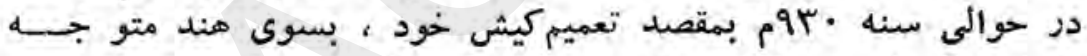

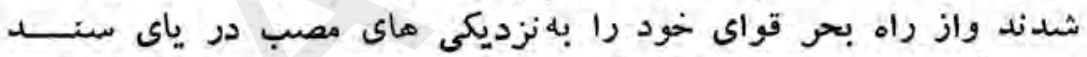

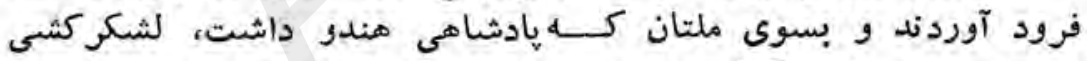

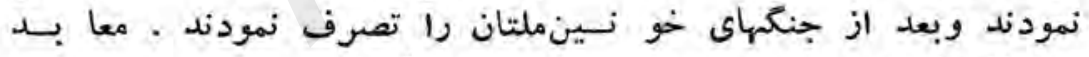

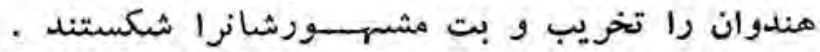

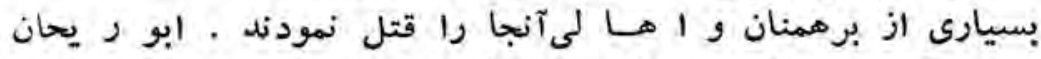

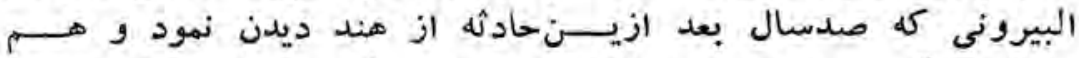

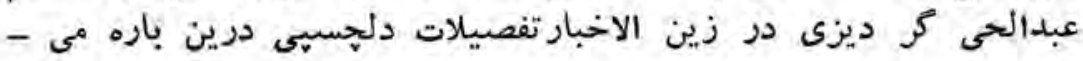
sol

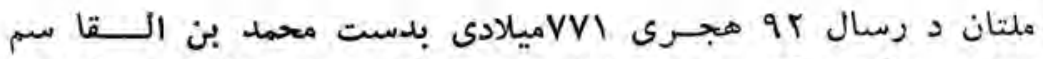

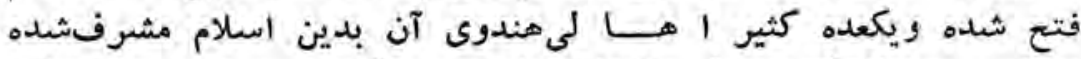

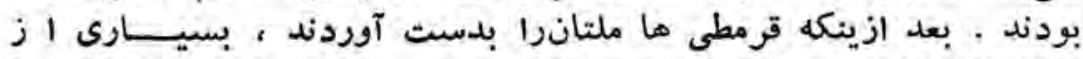

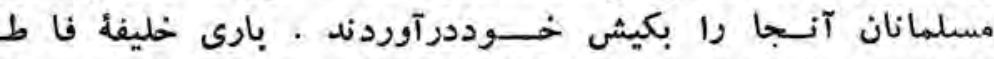

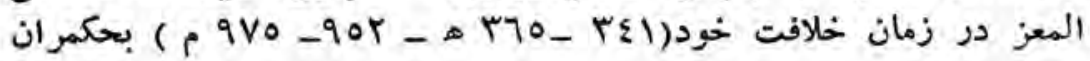


قرمطى ملتان ، حكيي بن شيبان ،نامه اى فرستاده او و بييروانش را باند

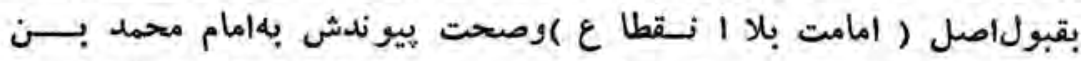

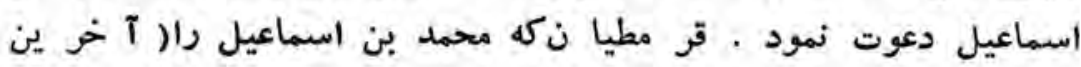

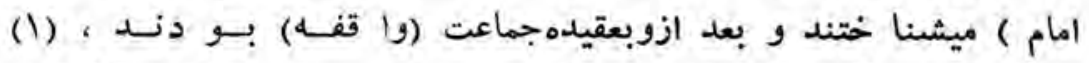

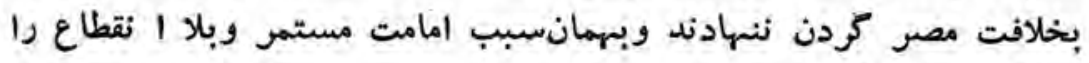

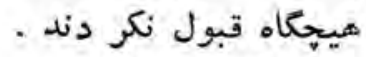

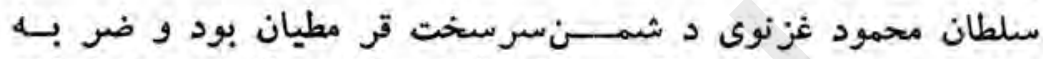

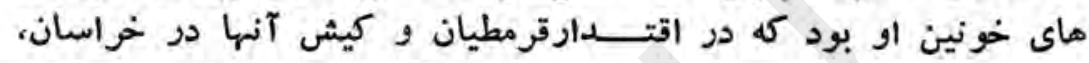

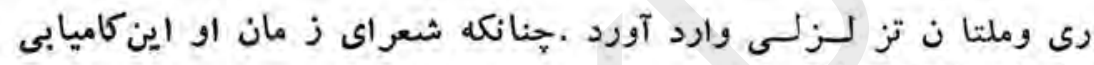

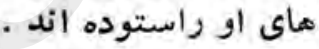

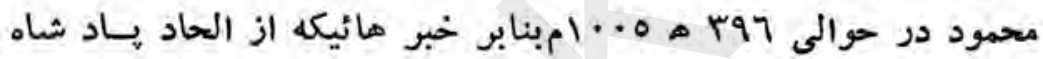

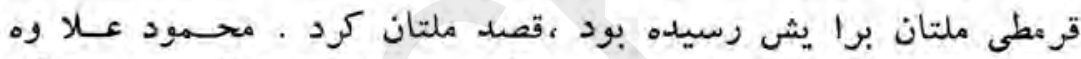

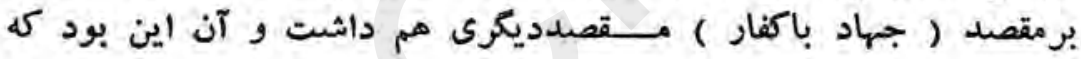

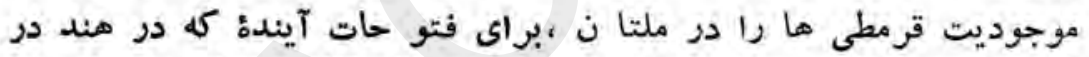

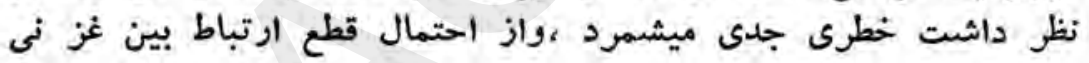

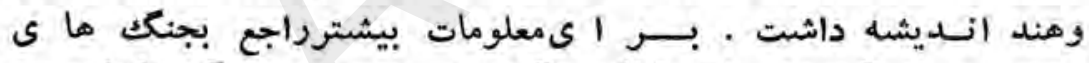
محمود ، به البيرونى ابن الاثير ،كرديزى ، عبتى و ديكر مانذاجرجوع

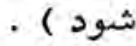

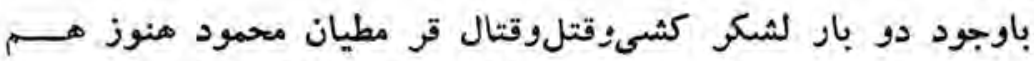

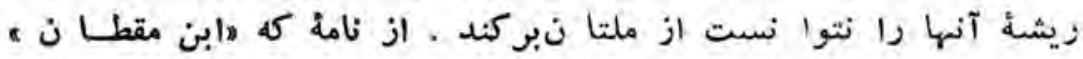

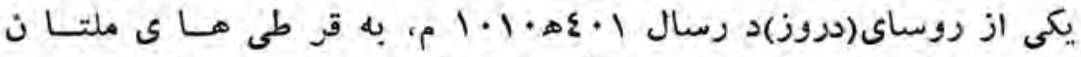

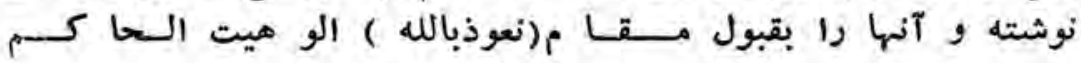

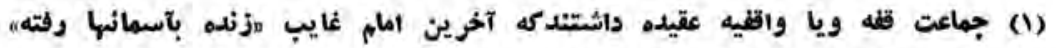

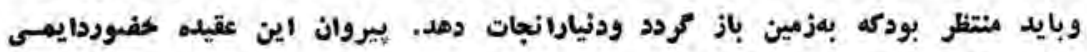

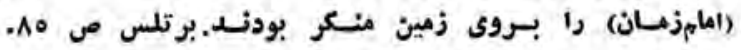




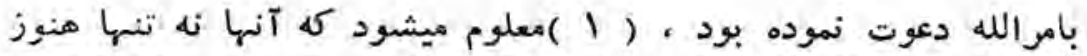

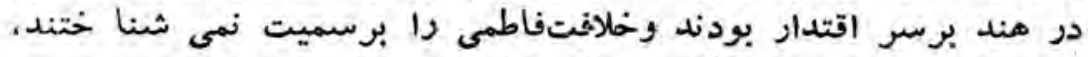

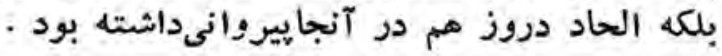

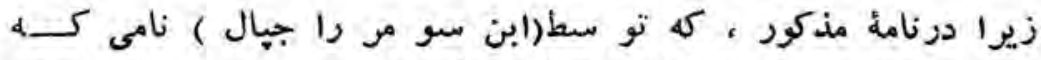

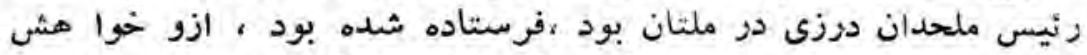

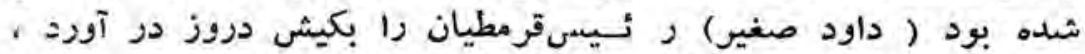

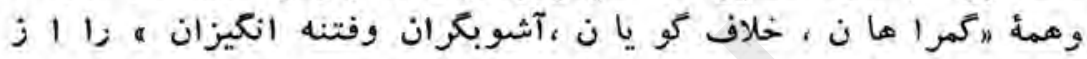

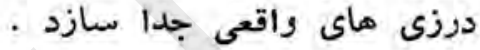

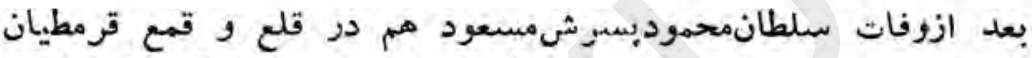

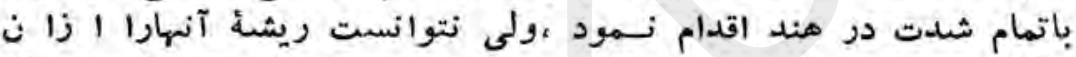

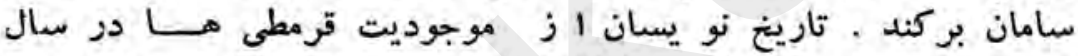

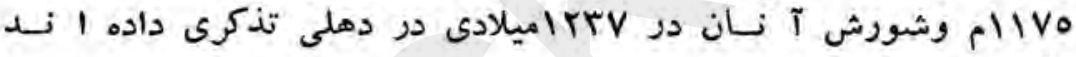

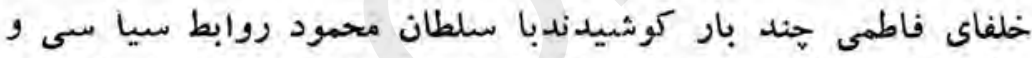

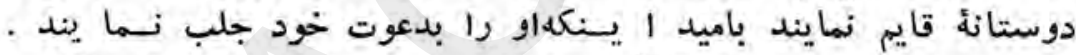

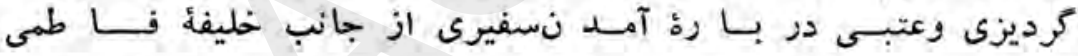

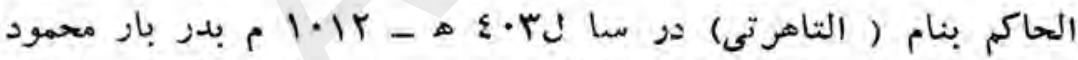

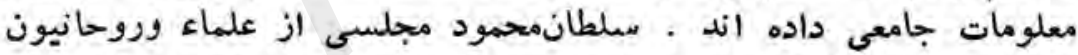

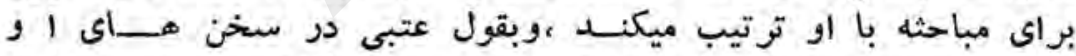

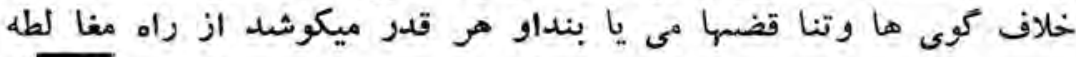

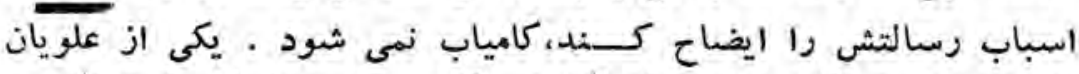

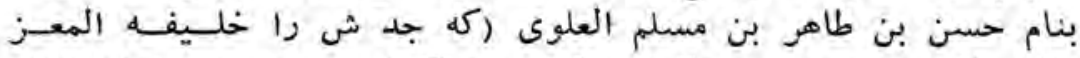

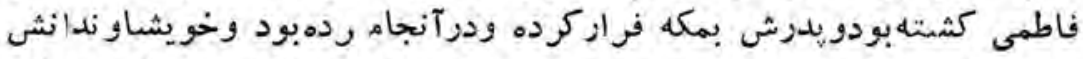

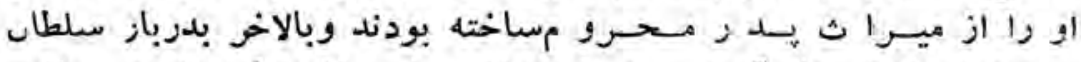
محمود در غزنه يناه آورده بود )نيزدران مجلس اشتران الك داثته ميباشيد

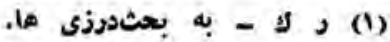

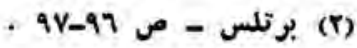




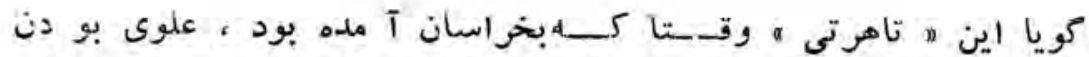

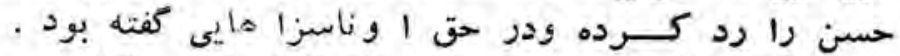

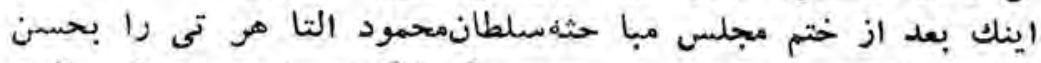

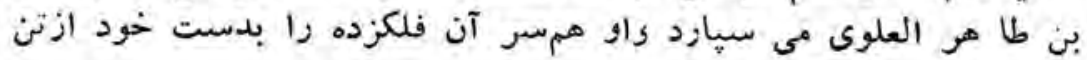
جدا ميكند طن العلور

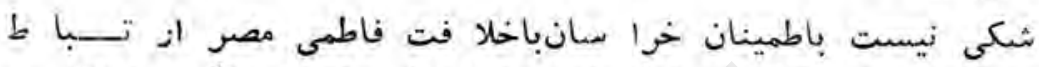

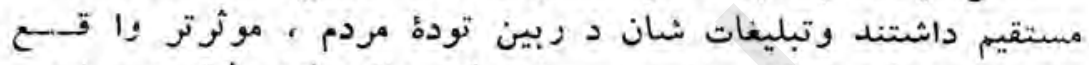

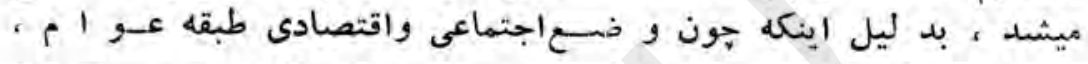

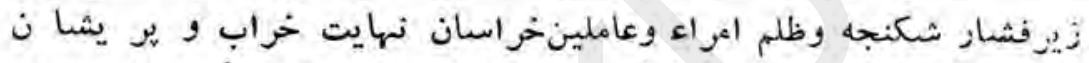

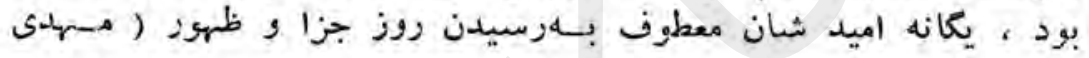

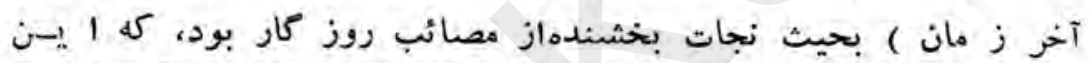

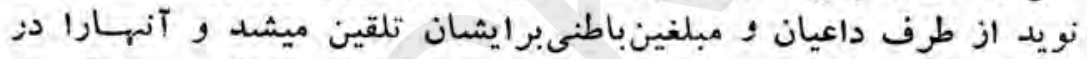

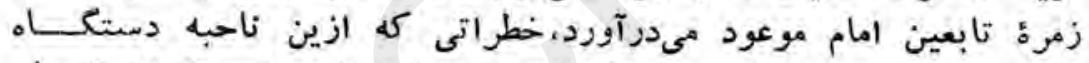

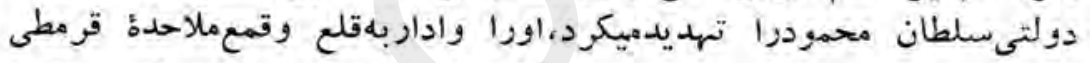

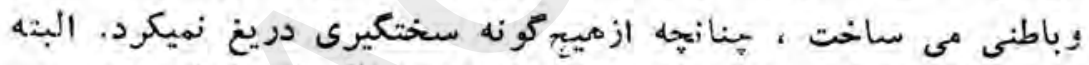

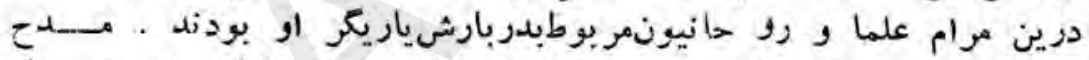

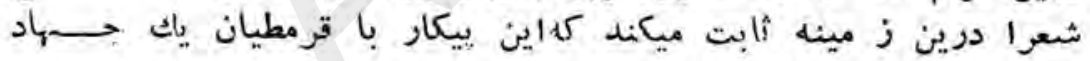
عمده بشمار ميرفت دون مينا

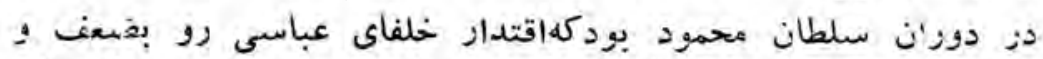

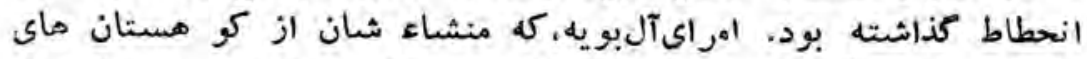

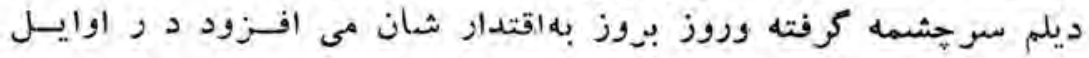

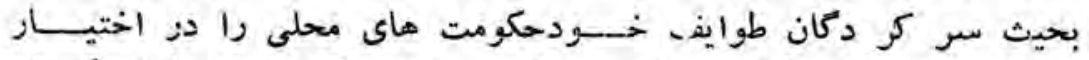

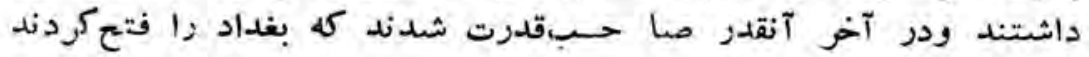

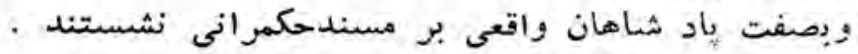

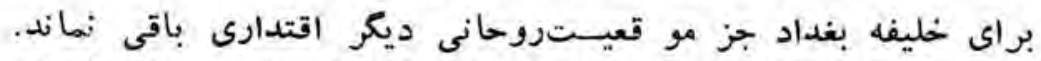

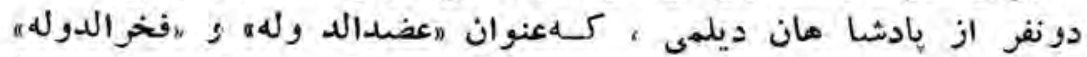

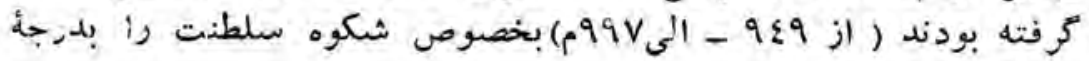




\section{VE}

اعلى ربطانيده و در بارشان يوورشكاه علما ، ادبا وازباب دانشكريديده

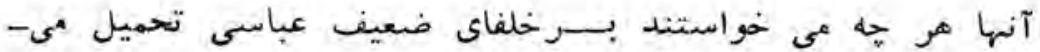

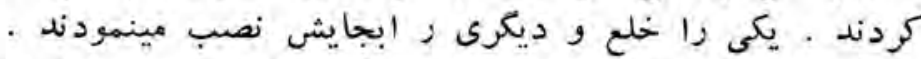

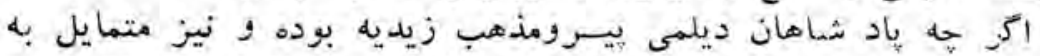

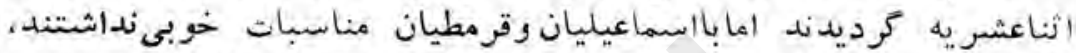

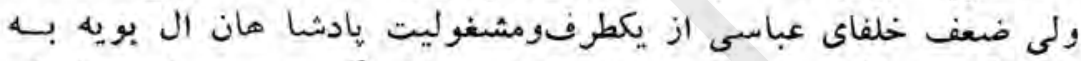

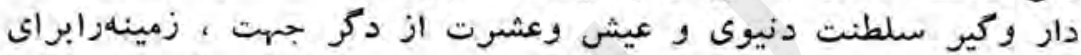

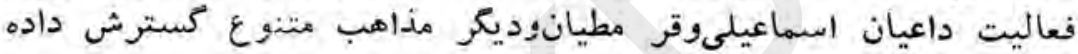

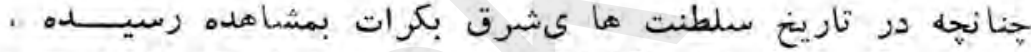

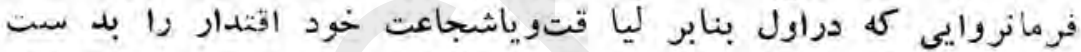

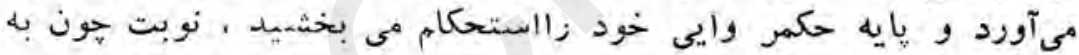

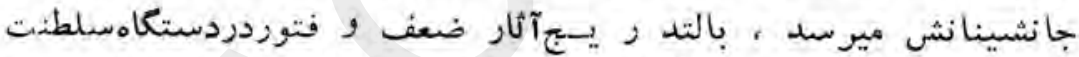

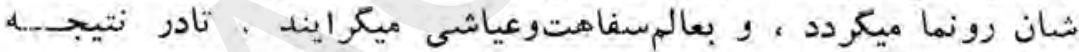

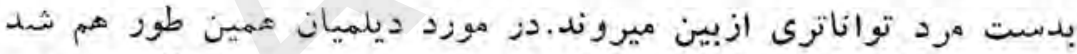

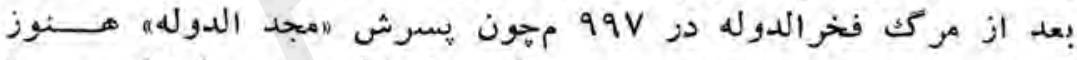

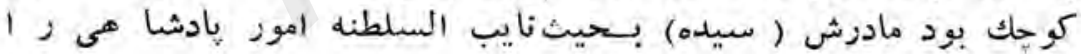

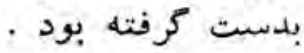

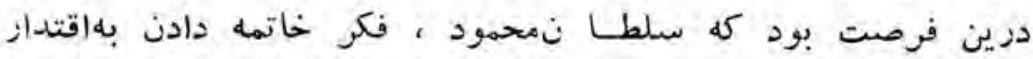

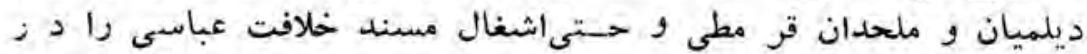

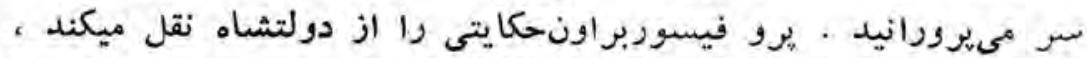

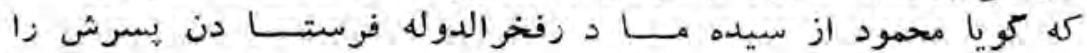

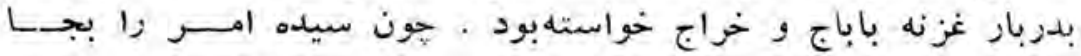

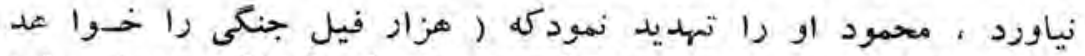

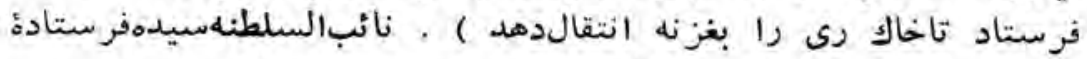

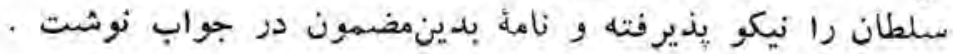




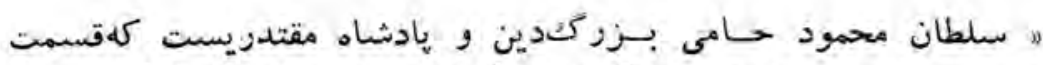

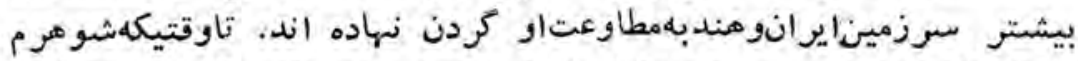

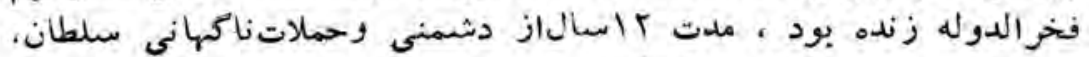

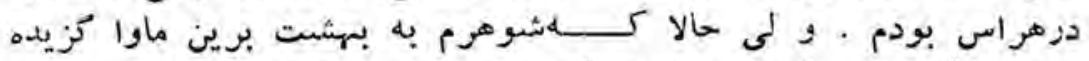

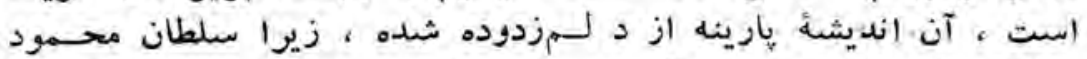

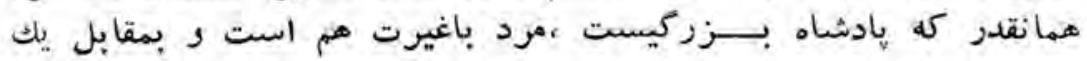

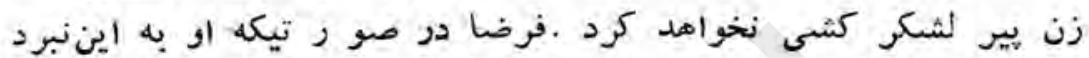

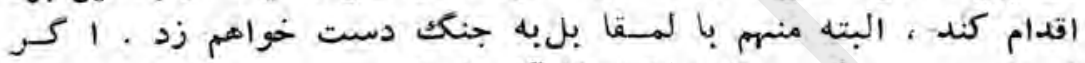

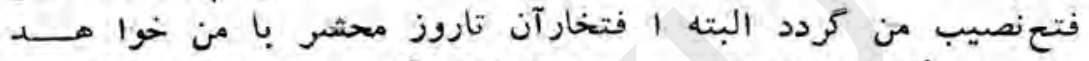

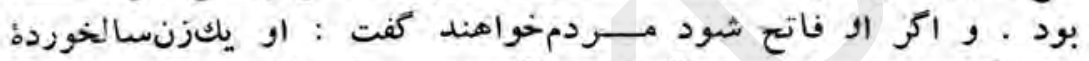

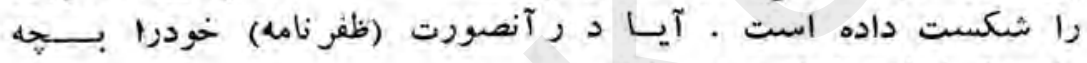

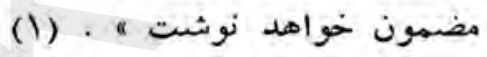

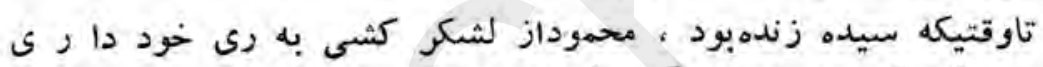

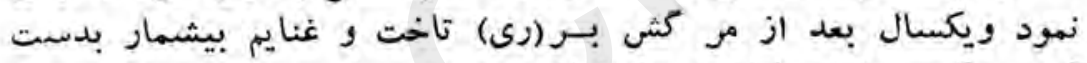

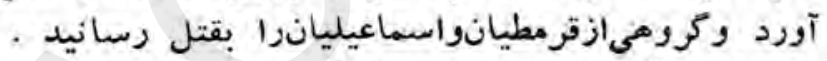

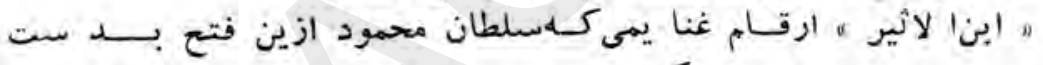

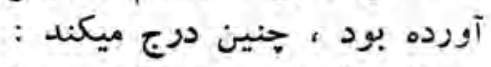

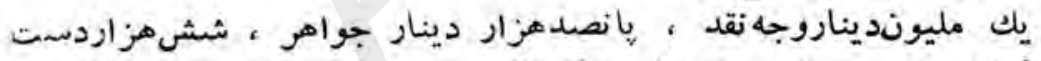

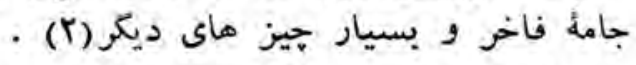

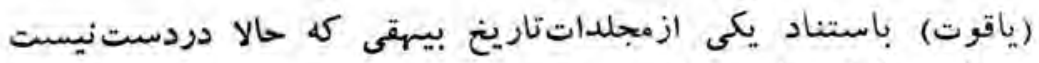

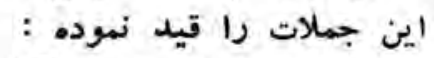

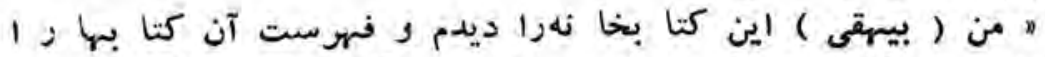

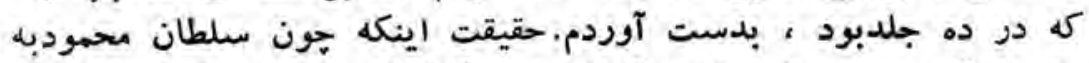

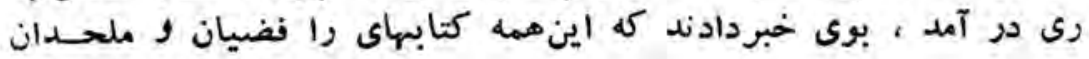

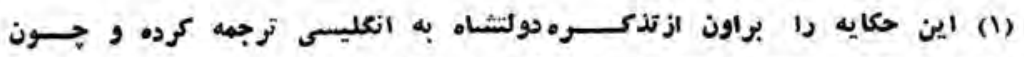

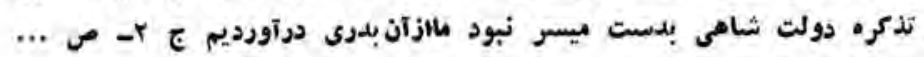

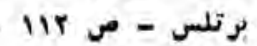


است ، واو از ميان آ نها آ نسـهـدينى بود جدا كرد و فـر مـــو د

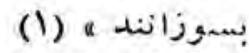

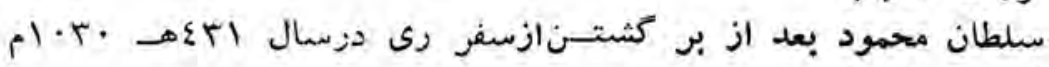

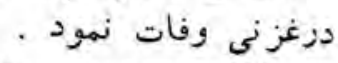

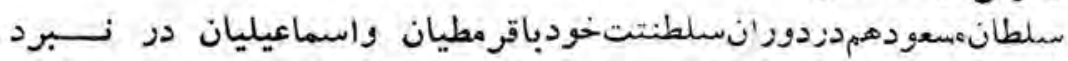

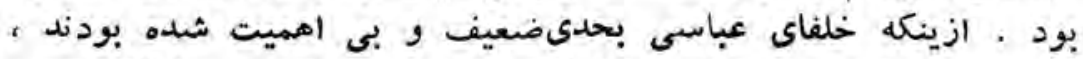

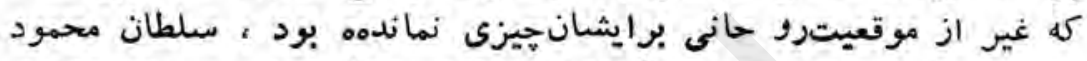

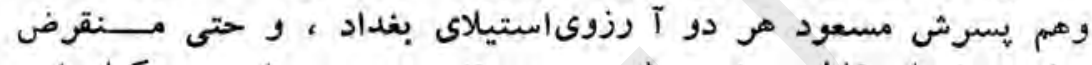

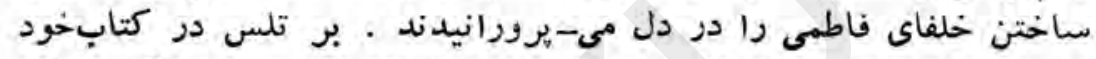

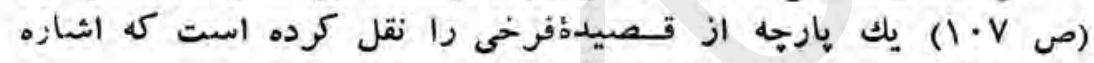

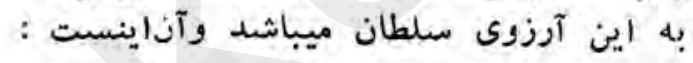

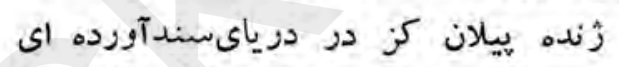

سال ديكر بكذرانى از لب درد دزي

$$
\text { قرمطى هندان كشى كز خونشان تاجند سال }
$$

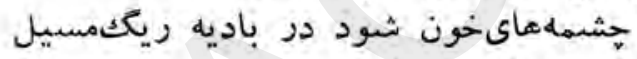

$$
\text { تازجامه سبو كواران بر زنانمصريان }
$$

همجو زربخشش تو مست كرداند

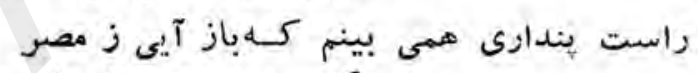

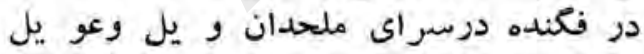

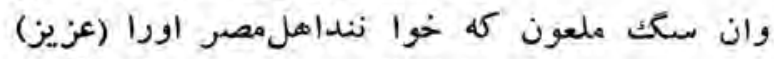

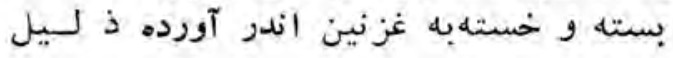

$$
\text { دارا و بر بإى كرده در ميانمرغزار }
$$

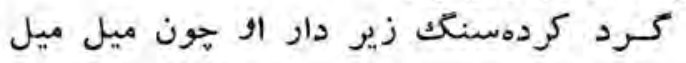

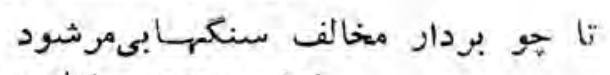

اهل بد عتسر بنتابند ازمخالف قالود قيل 


\section{๑ـ تاثيرات فكرى قر مطيان}

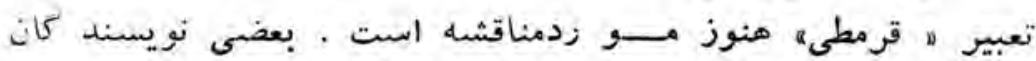

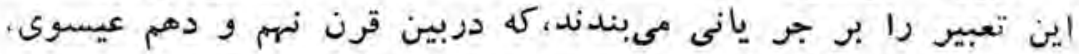

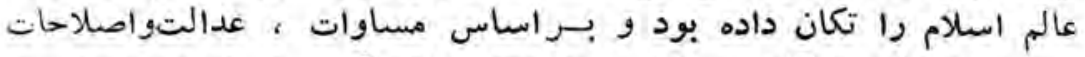

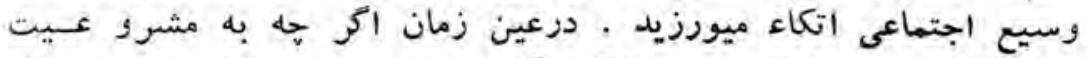

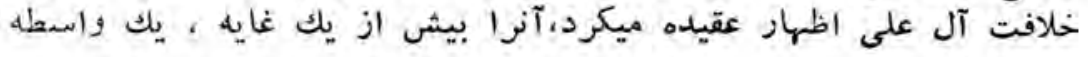

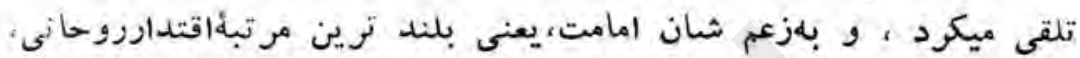

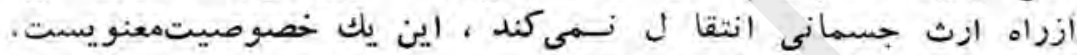

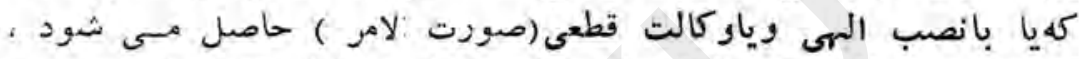

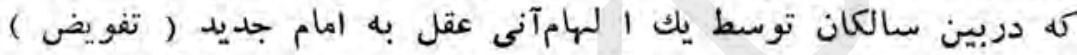

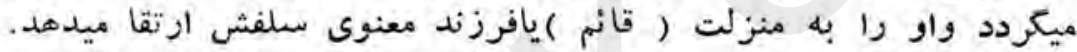

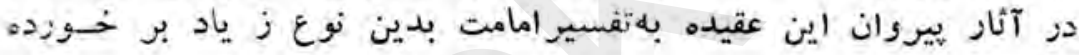

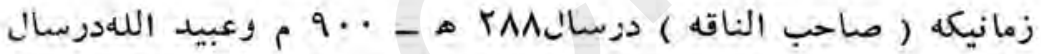
كام

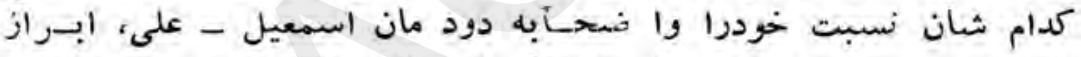

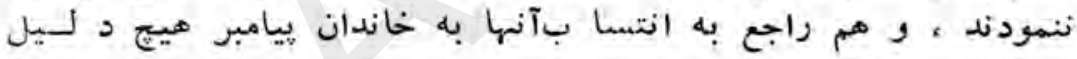

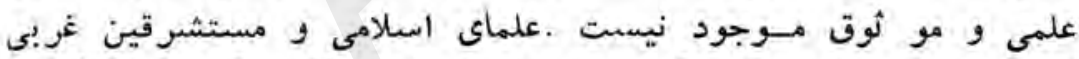

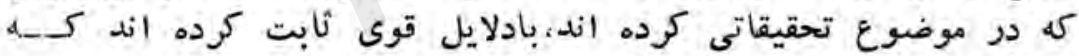

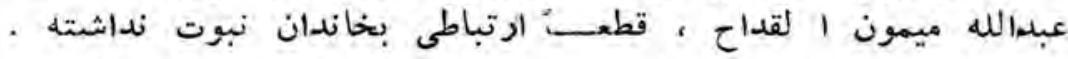

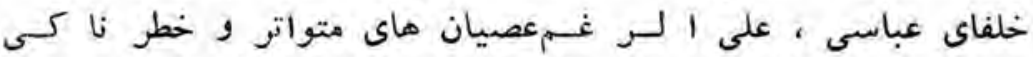

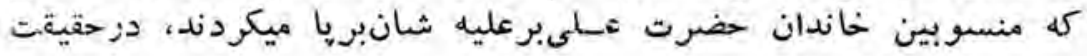

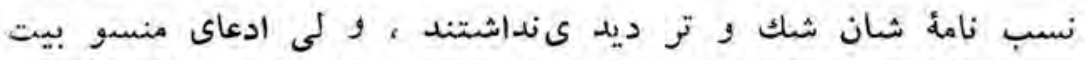

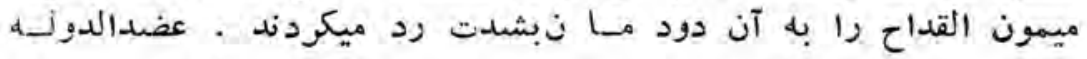

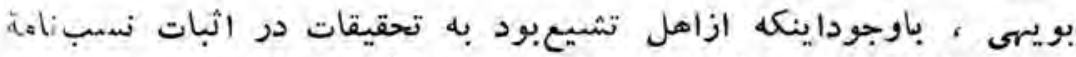

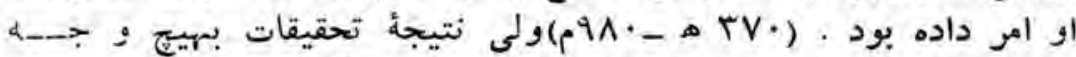

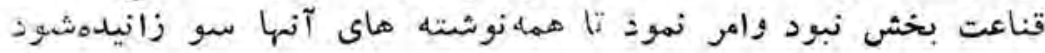




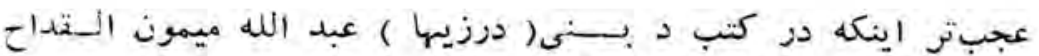

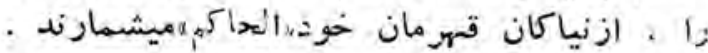

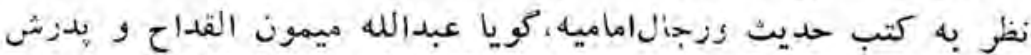

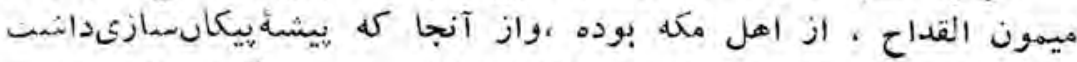

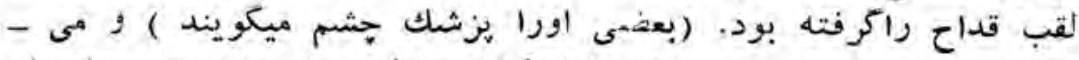

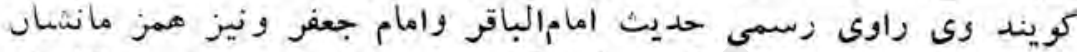

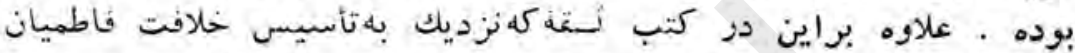

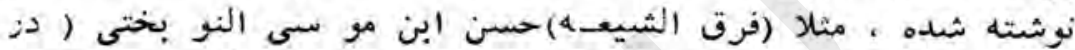

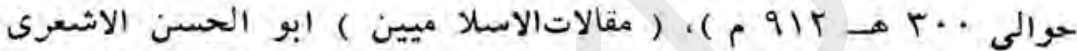

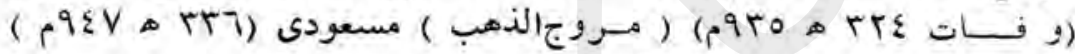

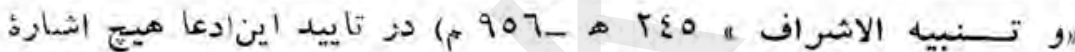

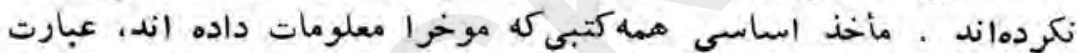

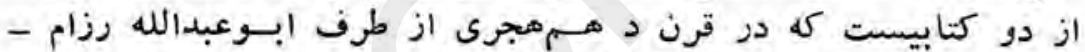

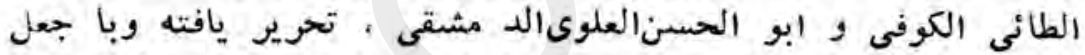

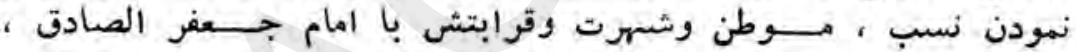

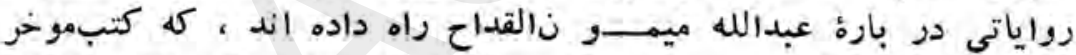

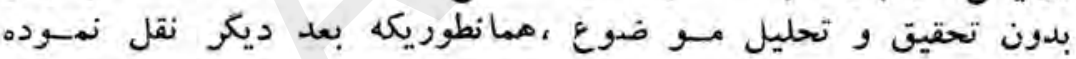
آهده اند : (1)

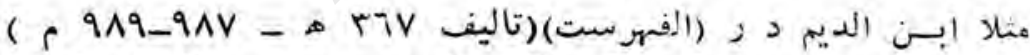

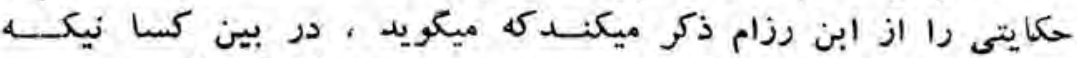

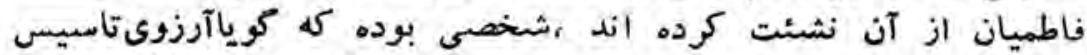

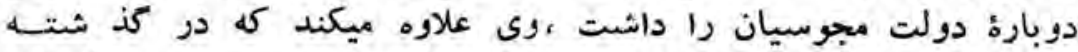

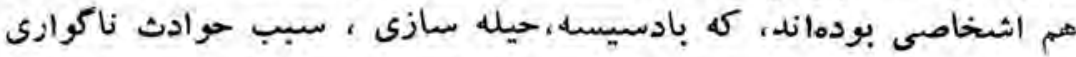

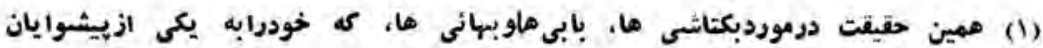

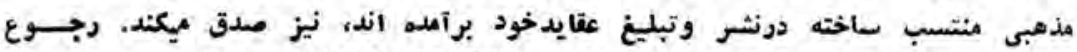

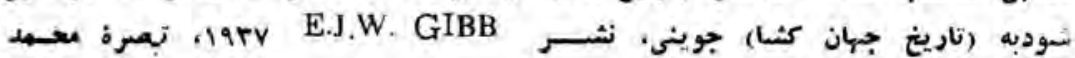

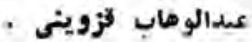


در عالم السلام شله بودند ، و ابوهسلم خراسانى را نيز ازهواخواهله

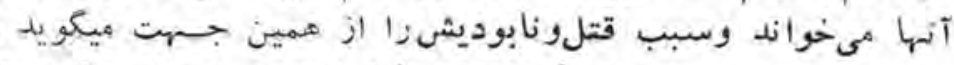

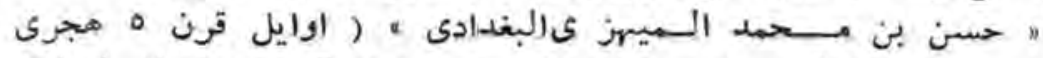

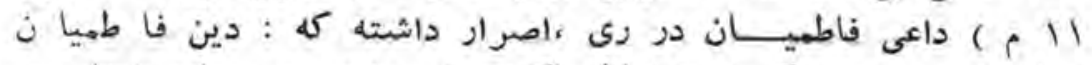

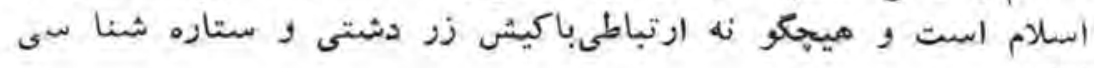
ندارد

هرو فيسور ايوانوف ، كه با نىمركز تحقيقات اسمعيليه در بمبئيى

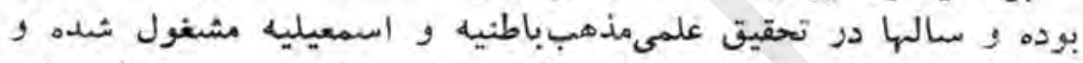

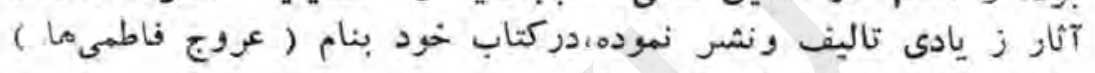

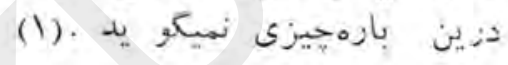

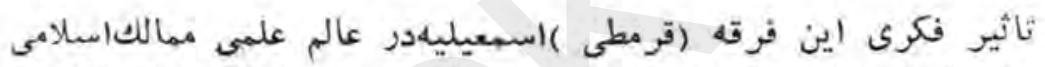

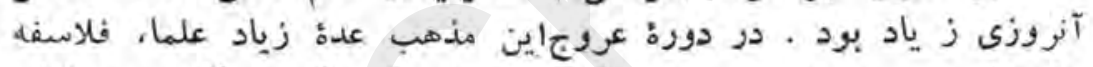

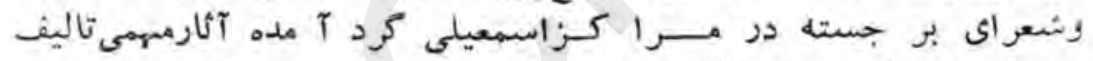

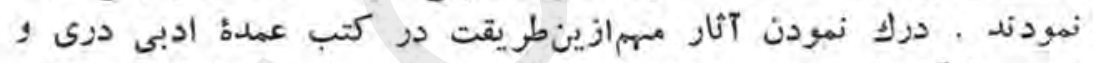

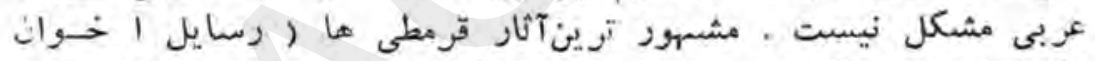

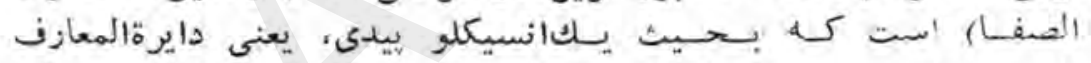

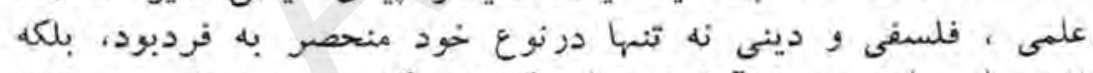

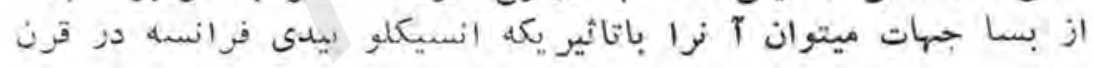

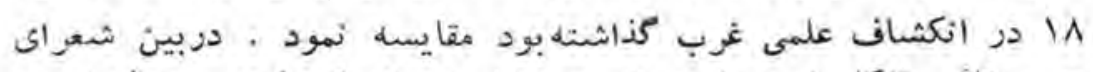

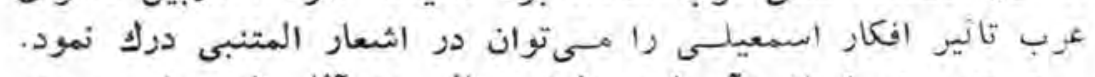

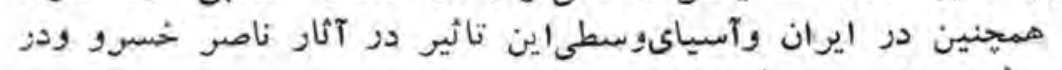

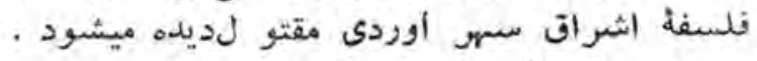

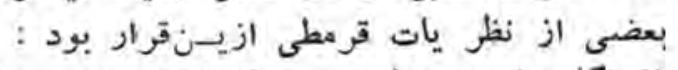

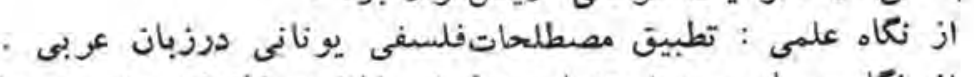

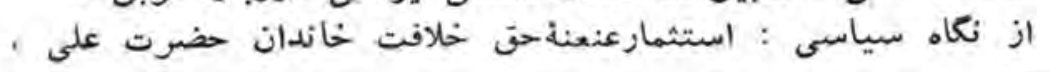

Ivanov, The rise of the Fatimids - 1) 


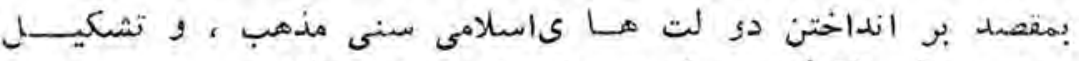

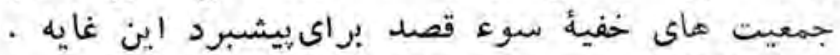

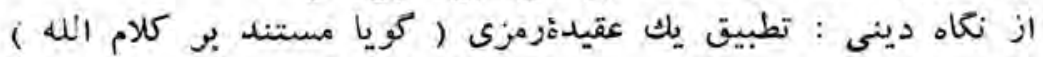

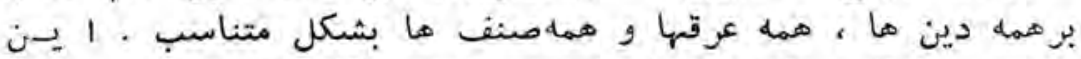

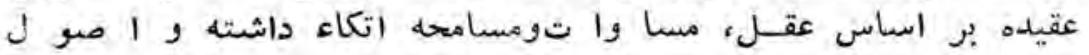

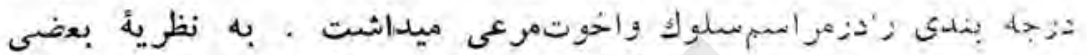

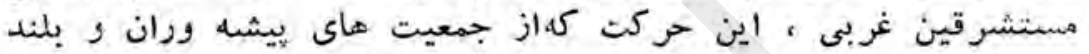

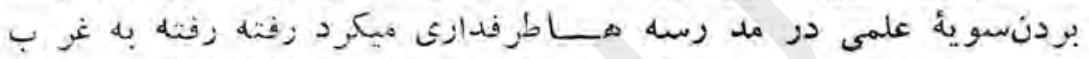

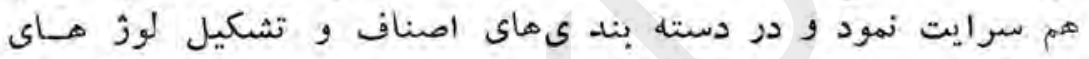

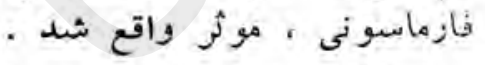

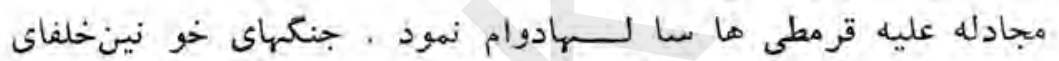

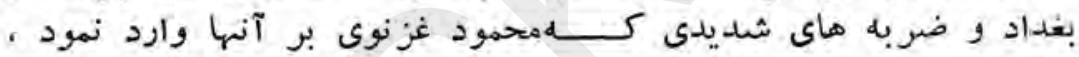

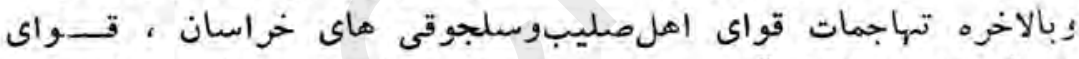

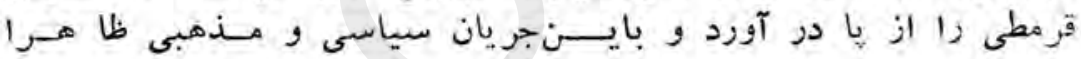

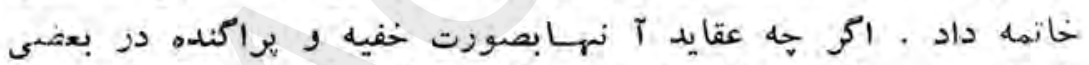

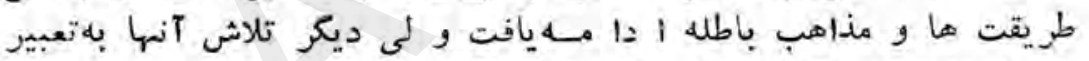

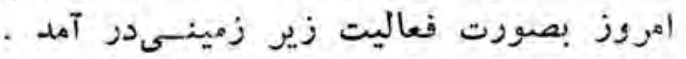

\section{T- ظهور فرقه درزى درثيام}

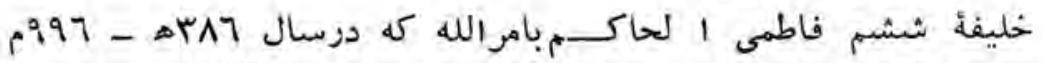

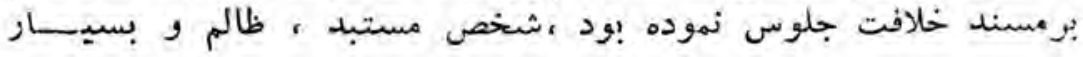

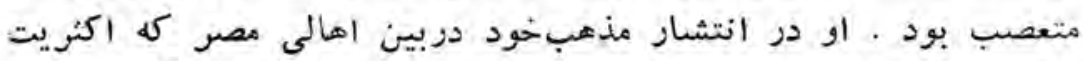

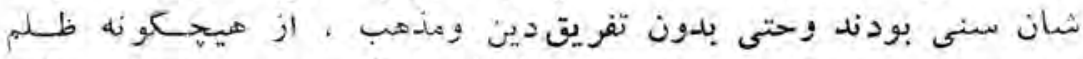

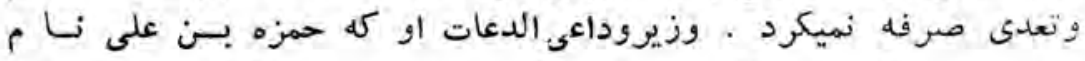

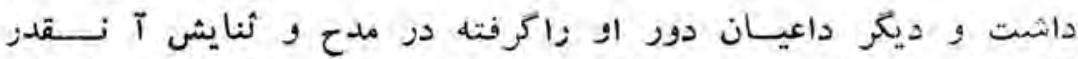

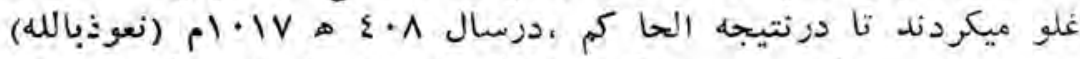

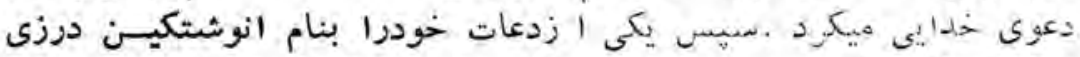

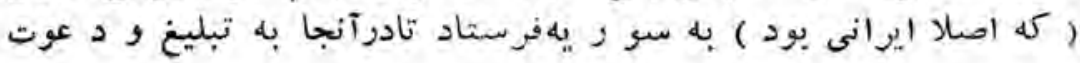


بيردازد ـ درزيدربعضى قسمتهايسوريه ولبنان مو فق شه يكعـــهـ مردم را به مذهب نو ايجادش بيروالحاكم بسازد ، وبا نهادن نامخـود برين جريان ، آنرا مذ هب ه درزىهواند . اين نام بعدا بر مههييرواث

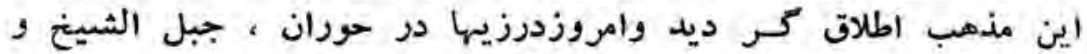
جبل دروز ، درسوريه و لبنان بودوباش دارند و مذهب خودرا بيسن خود مكتوم نكهميدارند مورن هردم مصر از ظلم و جور الحاكيجان آ مدهبوو شوريد ند. د ريسن بين الحاكم بصورت اسرار انكيزىبغتتأ از ميان غايب كرديد ر شايد از طرف دشمنانش بقتل رسيد )اصدةقا و بيروانش كه تعداد ثيا ن زياد نبود ، مركث او را فطعا باورنكرده ، به ادامه حيات او بصورت (امام عستور ) وبالاخره به رجعتوبميدان بر آمدن او ايمان دا شتند اين عقيده تا امروز در بين دز زيهاى لبنان باقيمانده والحاكيم بـنام

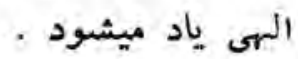
بعد از غيب شدن الحاكي، اكرجه بسرش " الظاهــر لاعزاز دينالله " جانثين او شد ، ولى اقتدار وادارةاموز دز دست وزير حمزه باقيماند. وى كه مرد حريص و زيركى بـردزود باانشتكين سر مخالفت كرفت واو را متهم به عصيــان و غصبامامت كه حق خود ميــــانست ، ساخته ودرسال •|عهـ - 19+1 متوطيه بو بيد كه بقتل دززى هايان 


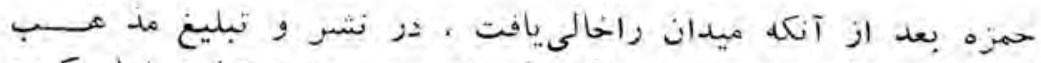

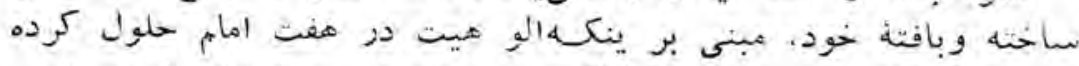

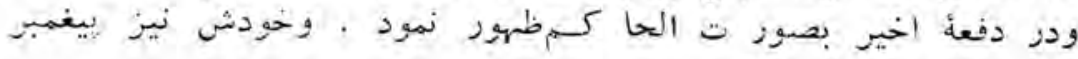

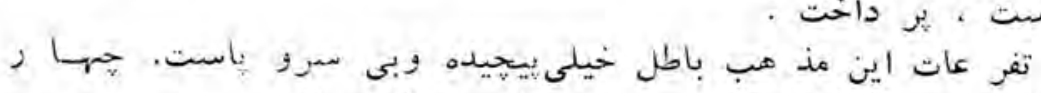

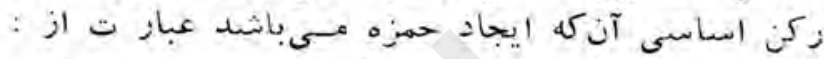

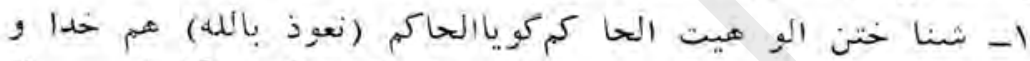

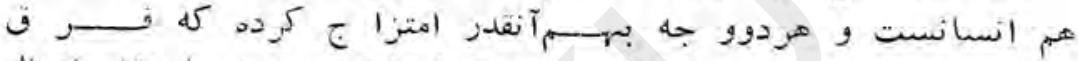

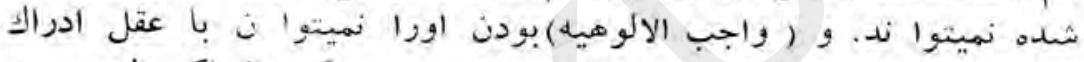

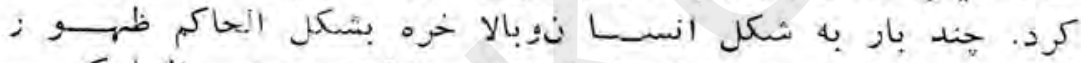

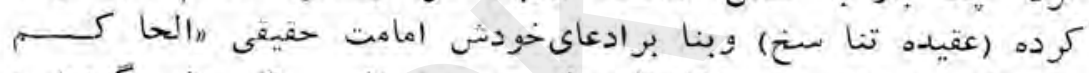

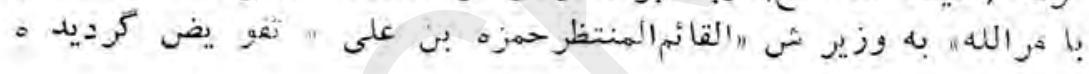

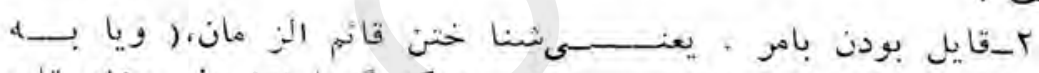

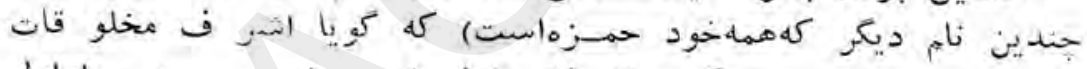

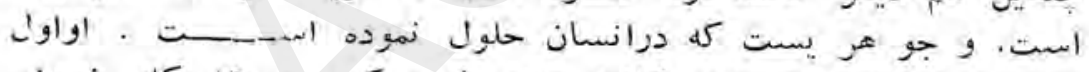

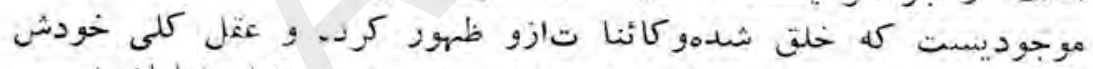

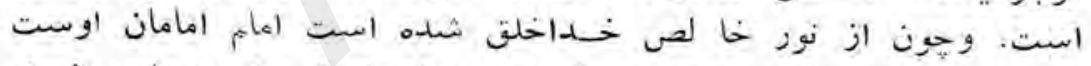

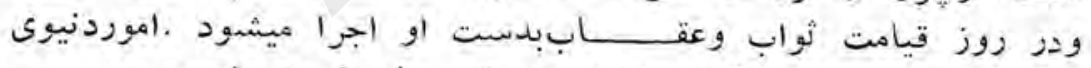

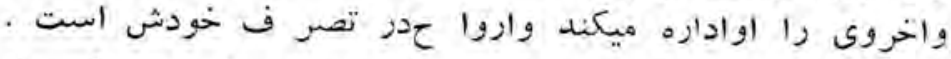

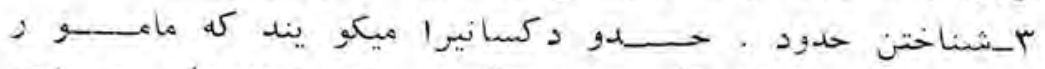

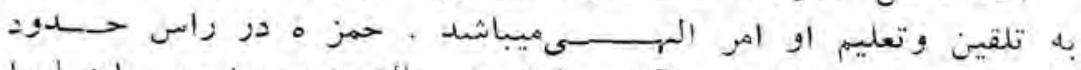

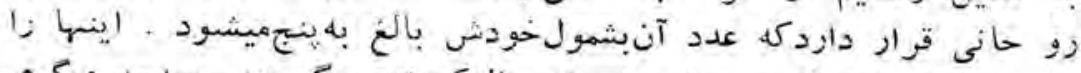

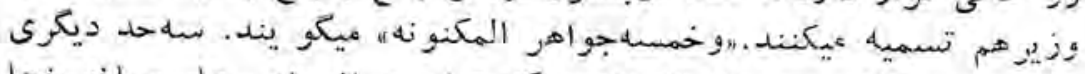

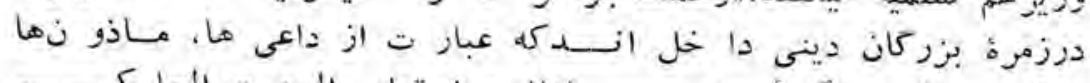

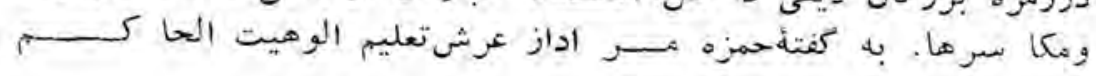

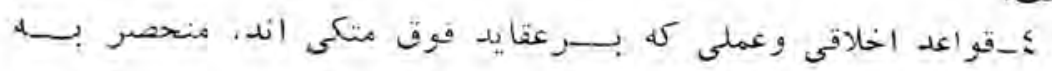


هفت وظيفه وبعضى تكا ليف ديكراست، كه آنها را وصايا وياوطايف

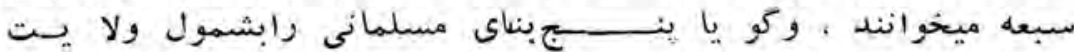

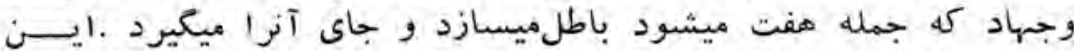

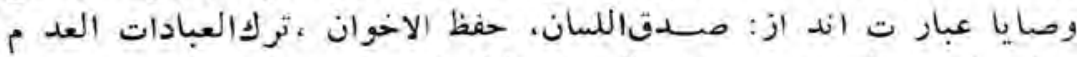

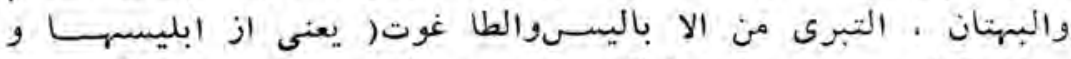

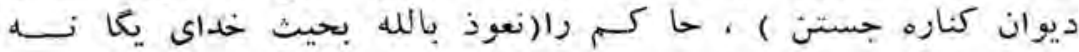

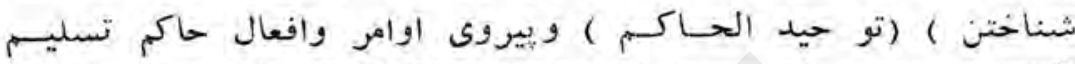

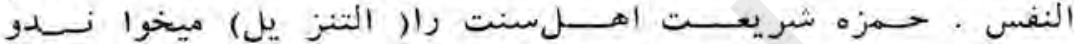

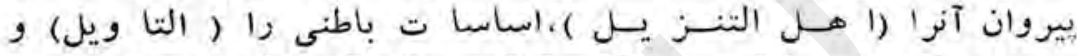

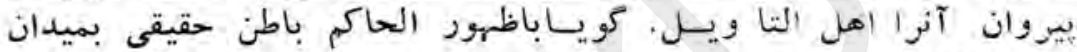

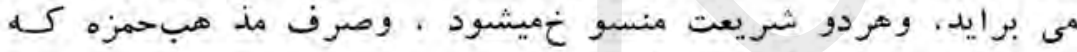

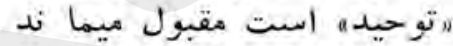

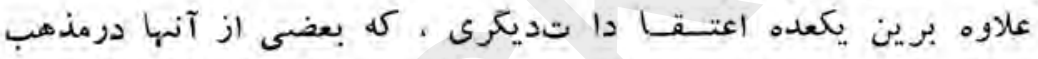

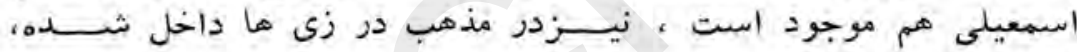

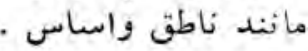

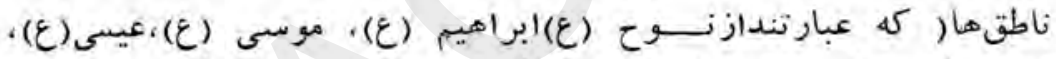

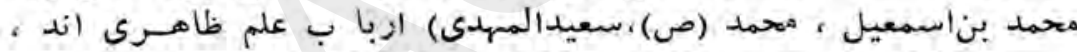

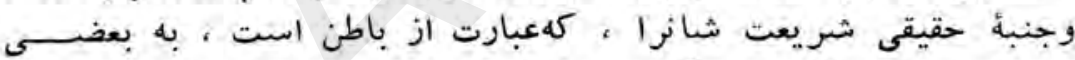

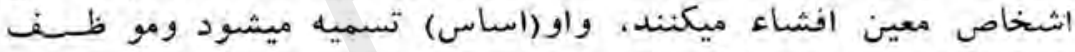

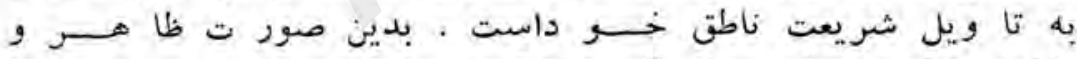

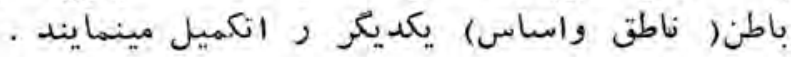

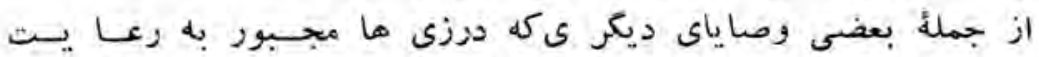

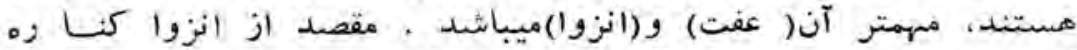

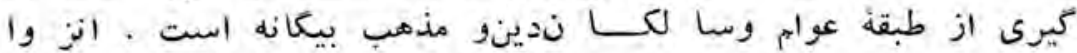

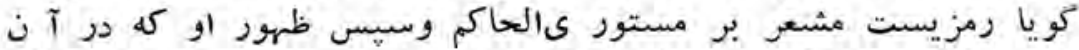

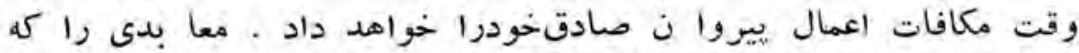

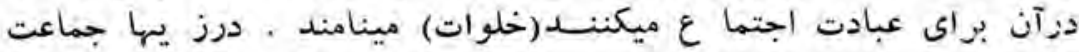

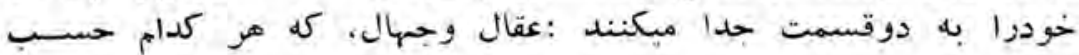




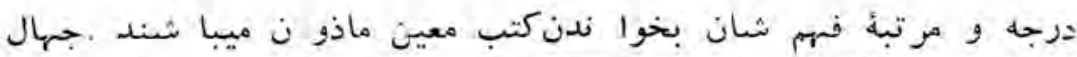

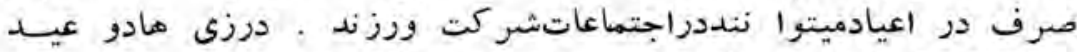

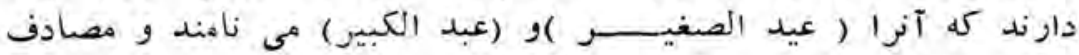

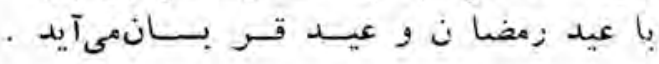

\section{- V انحطاط فاطميان وانشاق دراسما عيليه}

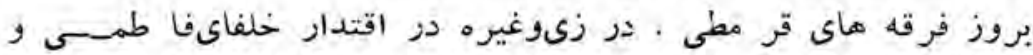

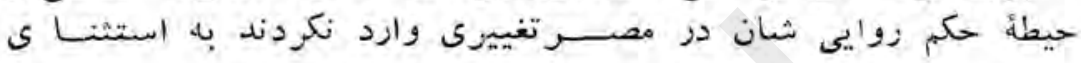

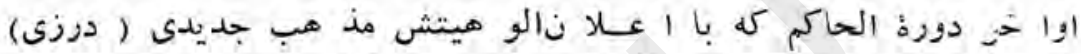

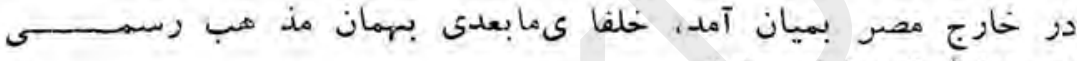

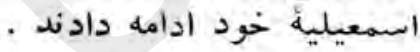

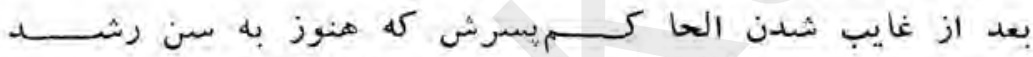

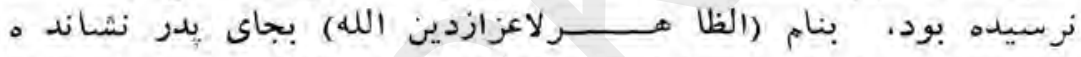

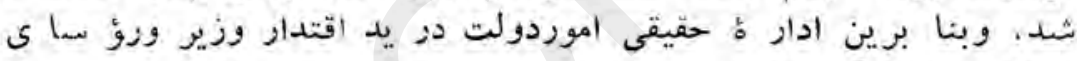

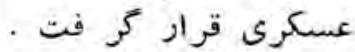

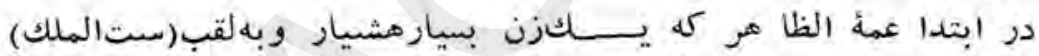

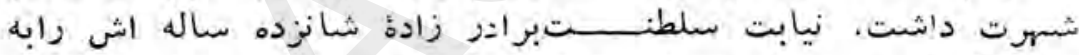

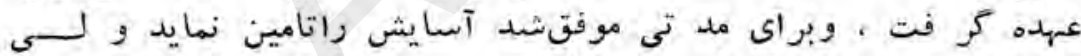

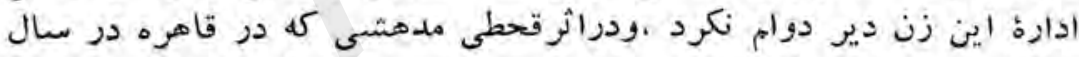

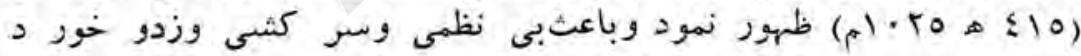

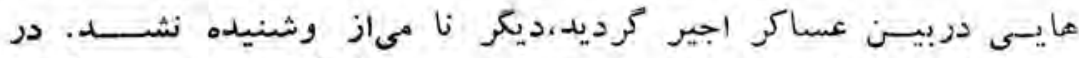

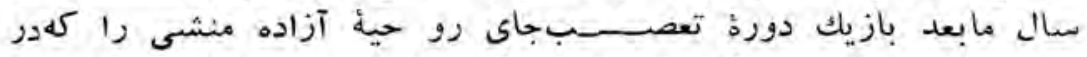

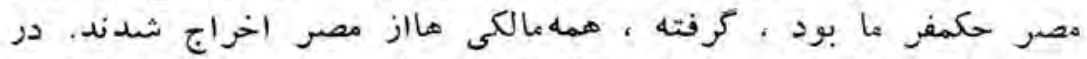

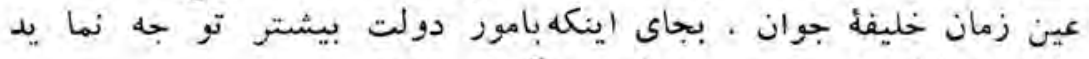

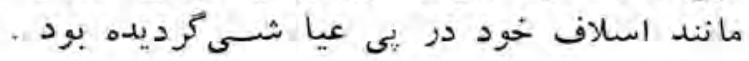

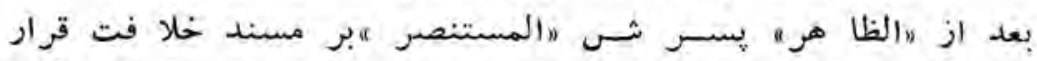

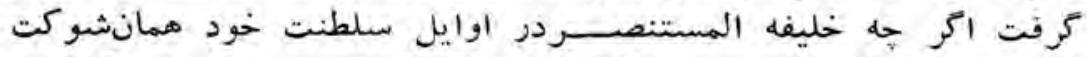

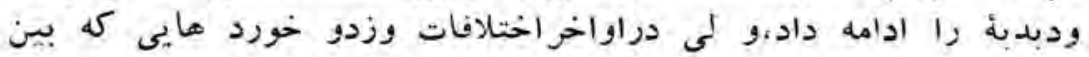




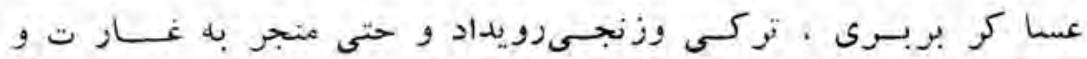

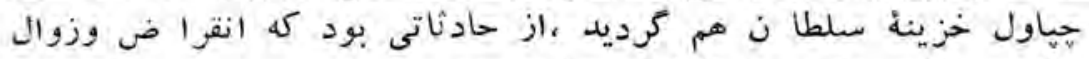

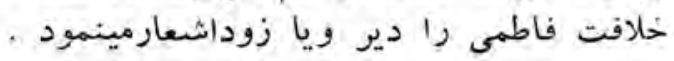

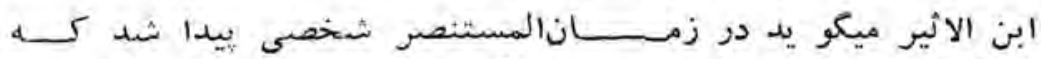

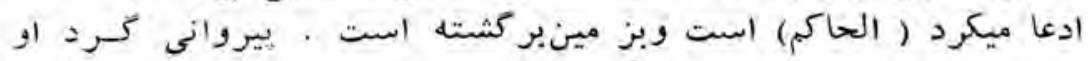

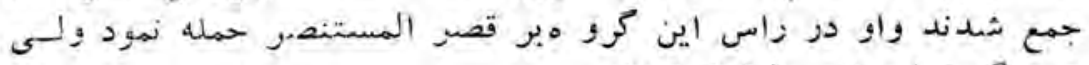

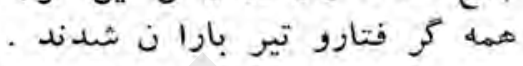

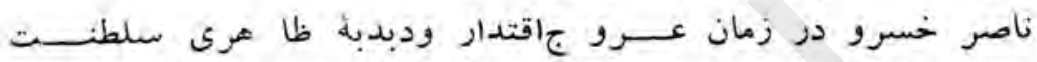

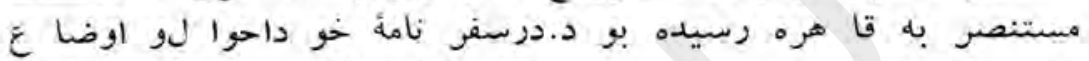

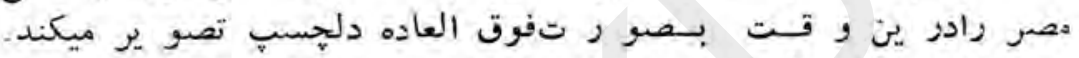

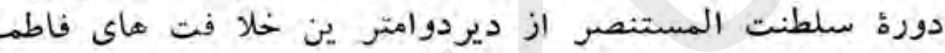

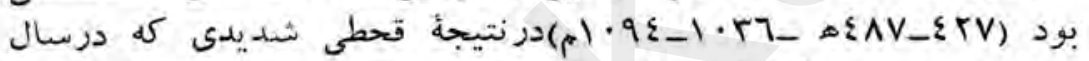
EOV

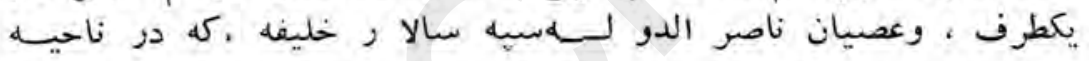

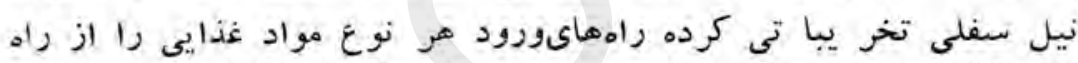

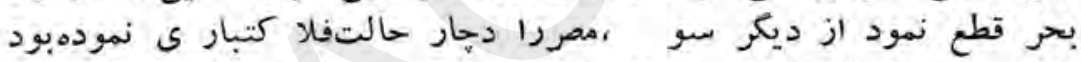

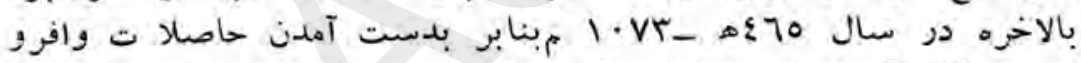

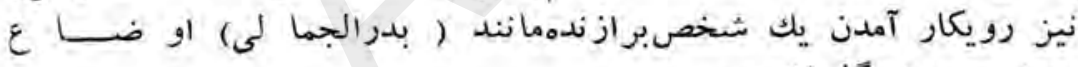

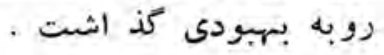

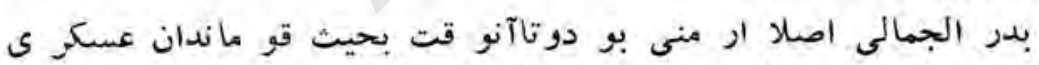

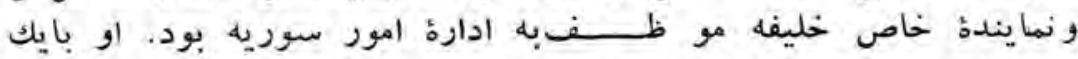

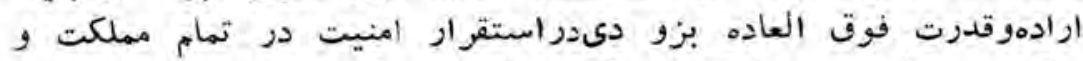

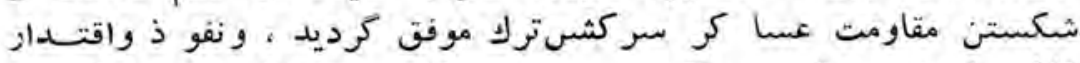

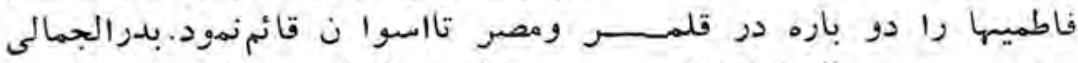

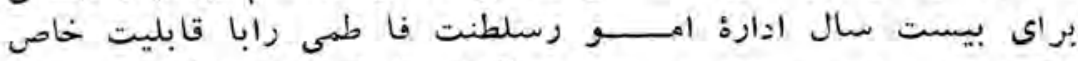

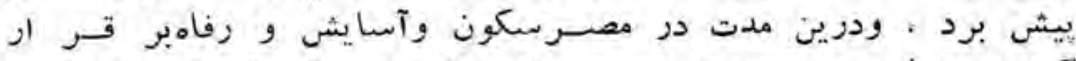

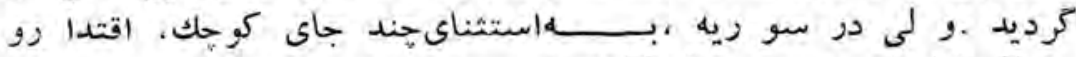

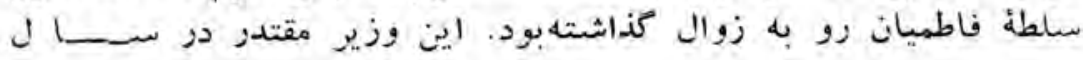




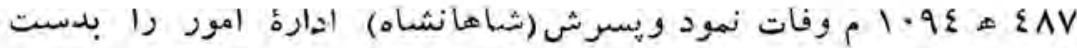

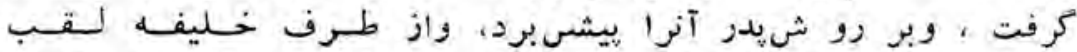

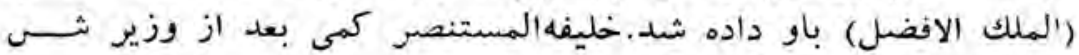

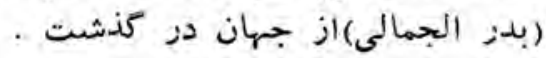

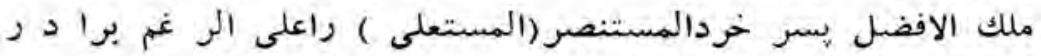

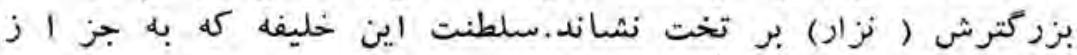

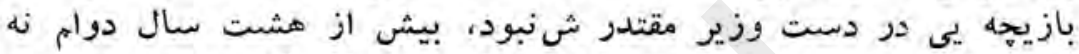

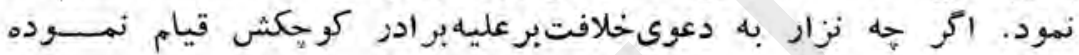

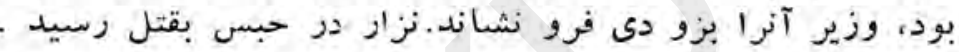

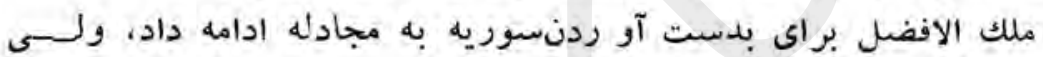

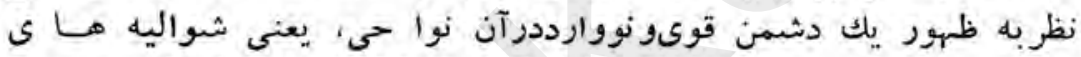

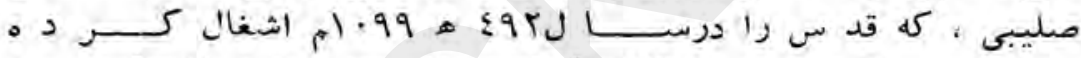

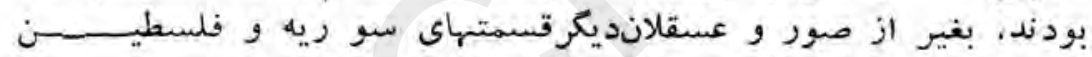

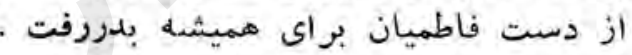

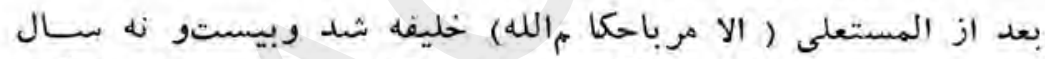

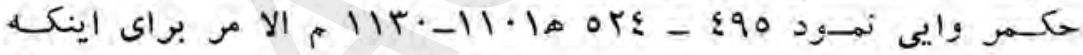

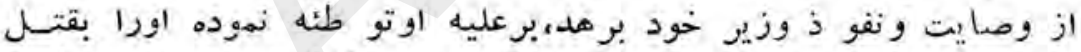

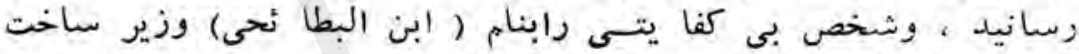

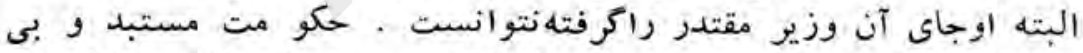

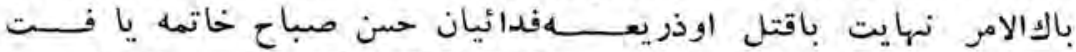

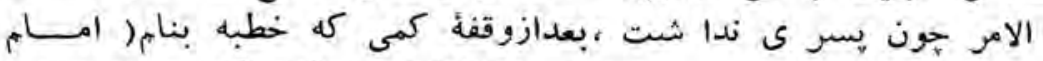

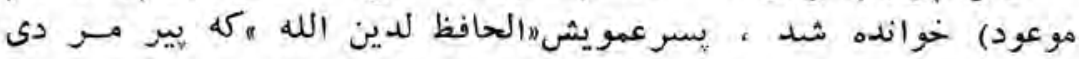

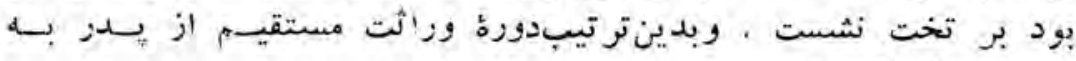

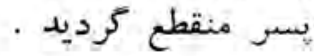

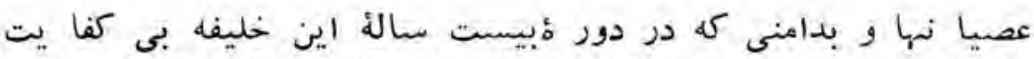

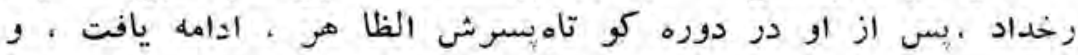

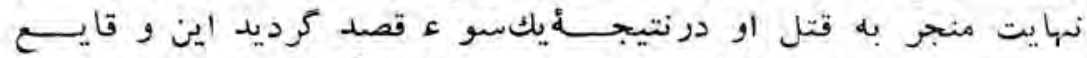

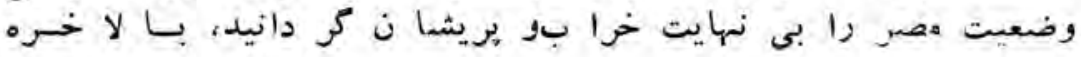




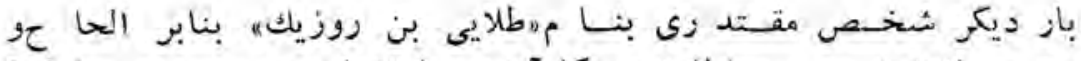

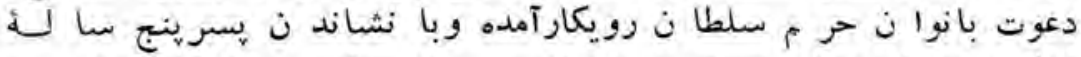

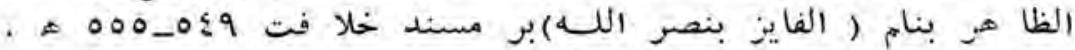

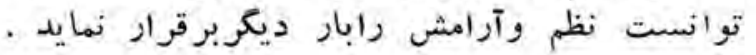

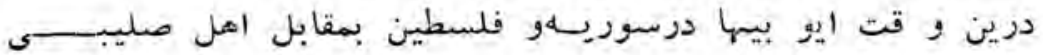

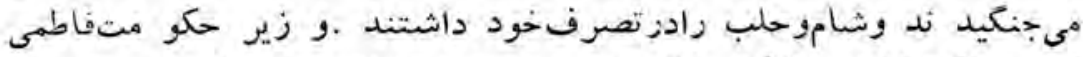

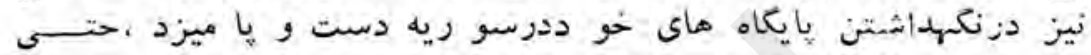

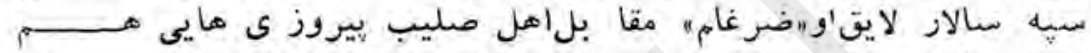

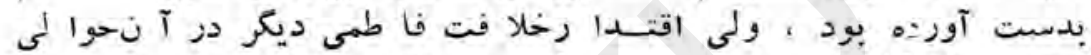

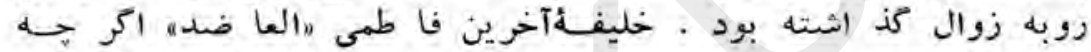

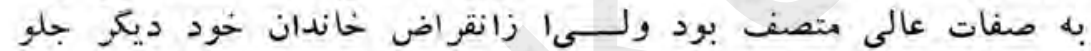

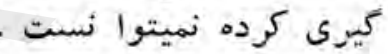

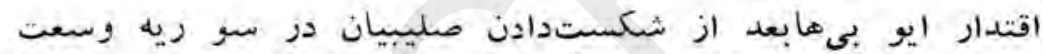

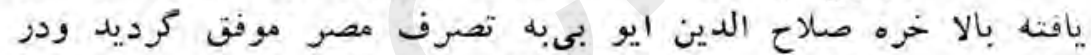

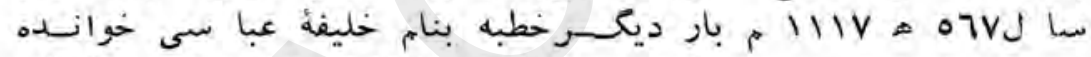

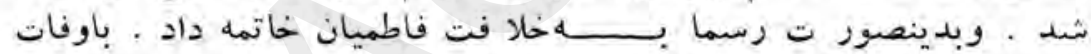

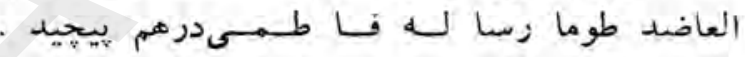

جنانكه قبلاتذكر يافت دعاتومبلغيناسمعيلى از بلدو تاسيس همجنـان

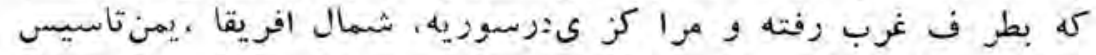

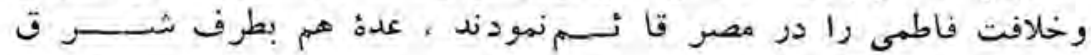

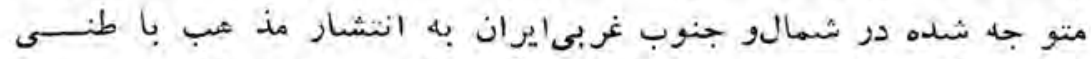

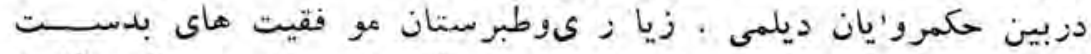

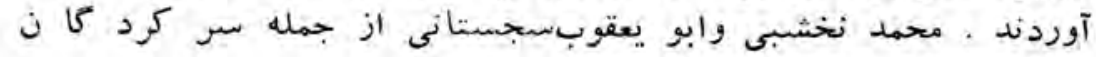

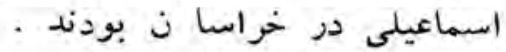

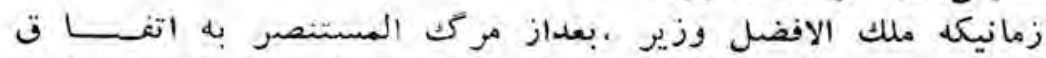

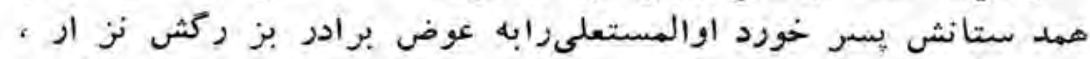

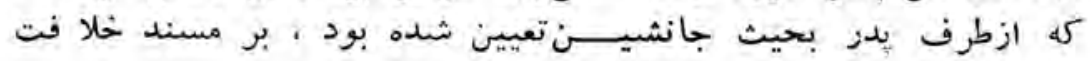


نشا ند ، اين حر كت باعث اختلا فـ نارضا يتى ييروا ن متعصب ترفرقة

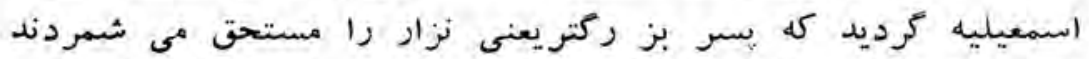

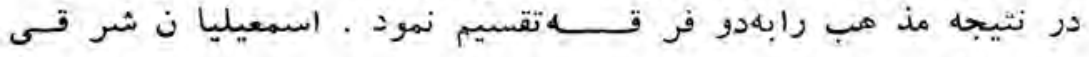
بطر فدار ى نزار بر خا ستند،درصورتيكه مصر ويمن وشمال افريقا

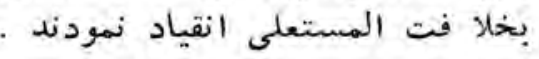

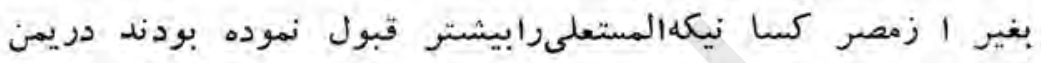

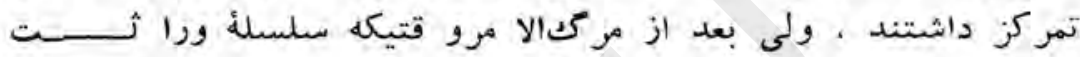

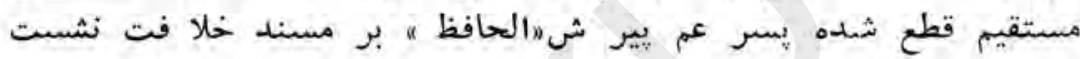

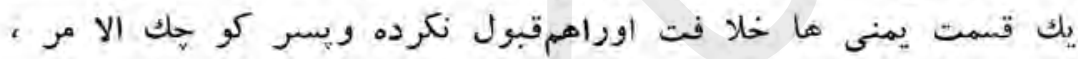

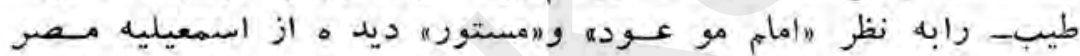
جدا شدند

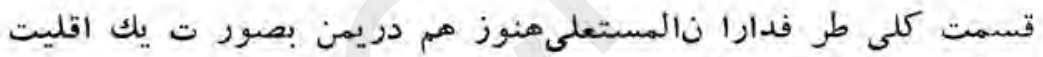

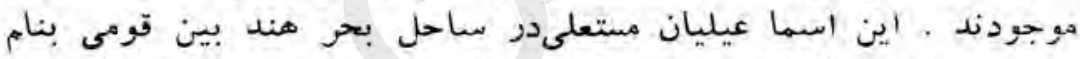

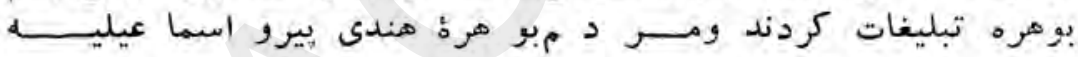

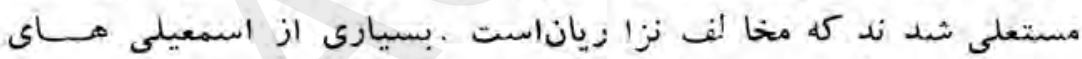

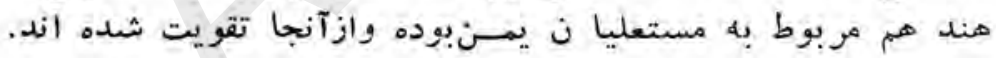

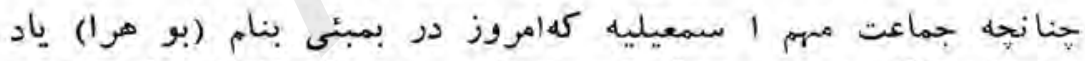

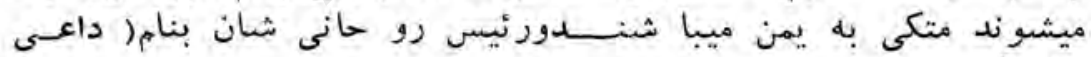

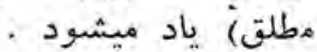

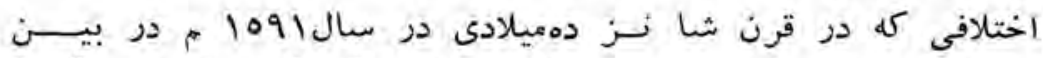

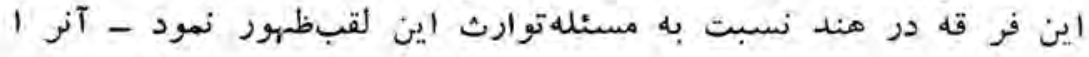

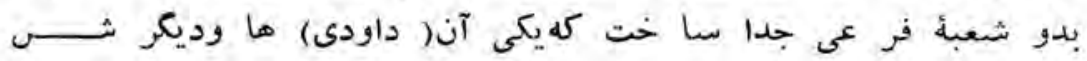

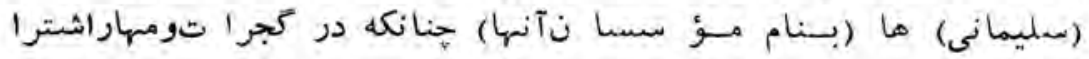

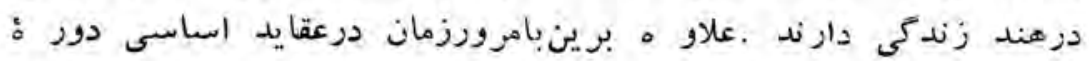

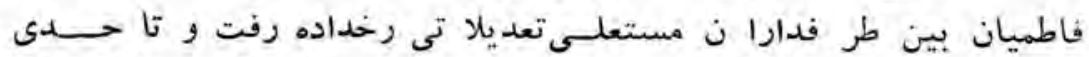

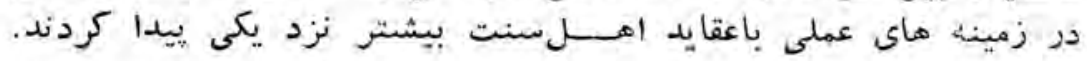




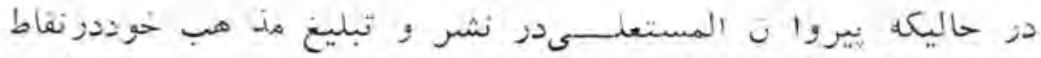

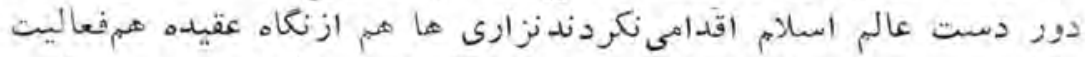

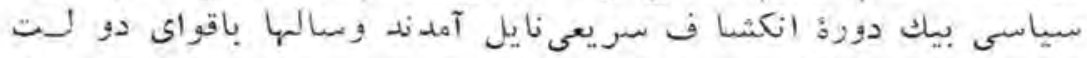

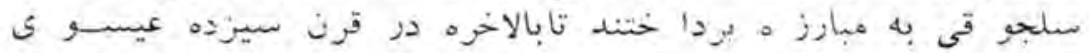

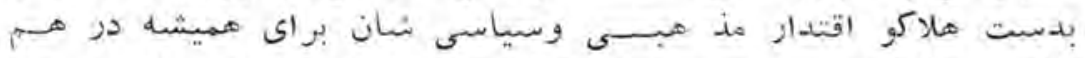

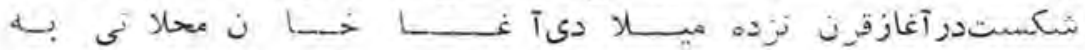

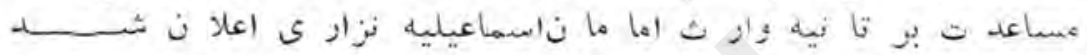

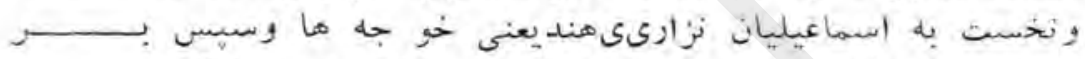

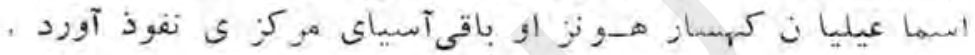

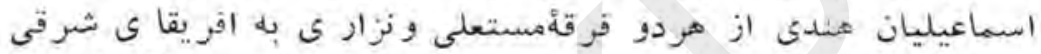

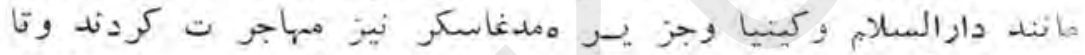

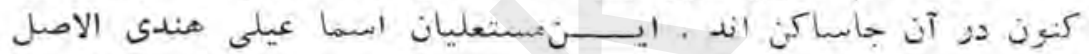

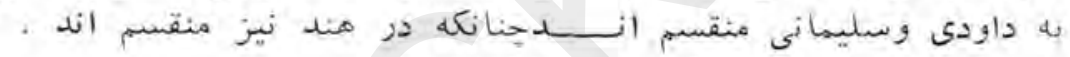

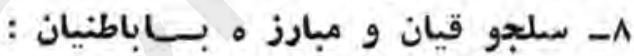

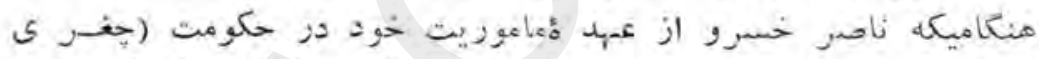

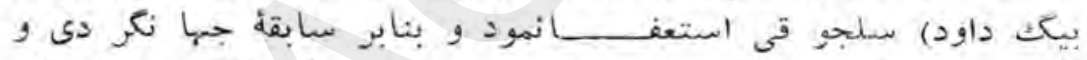

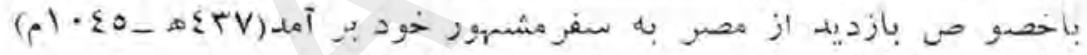

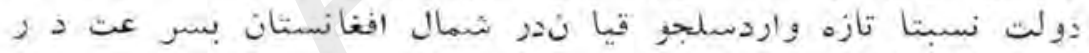

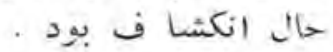

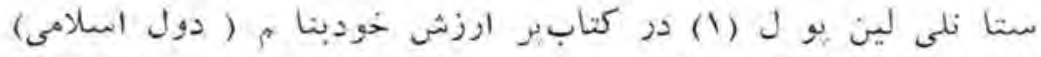

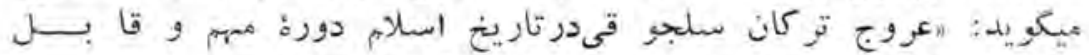

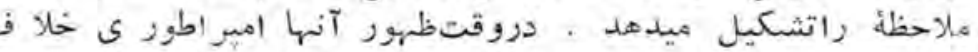

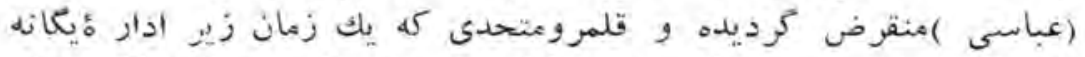

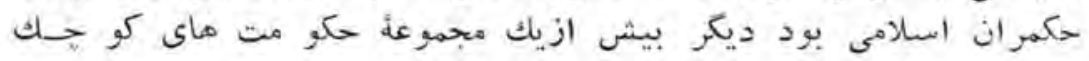

Stanley Iane-Pool: Mohammad an dynasties.

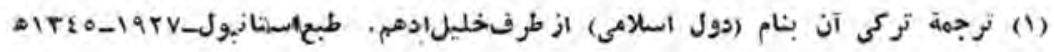




\section{9.}

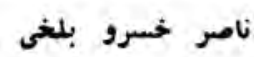

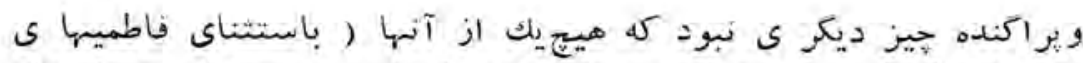

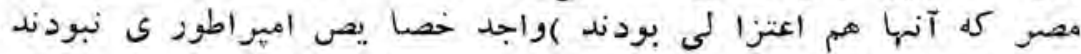

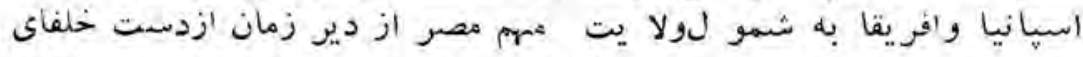

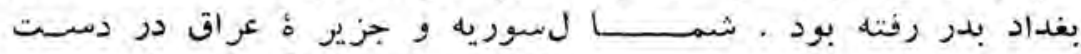

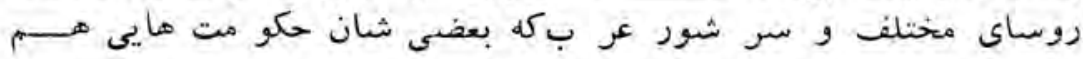

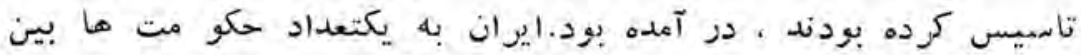

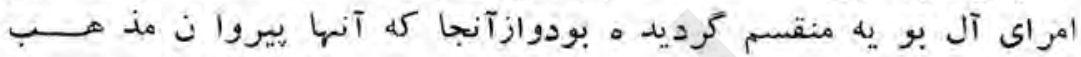

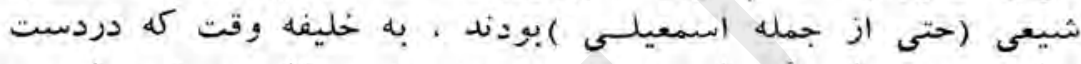

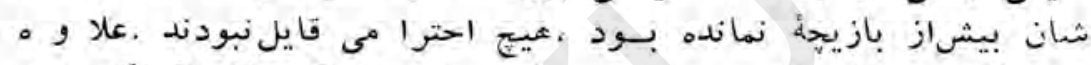

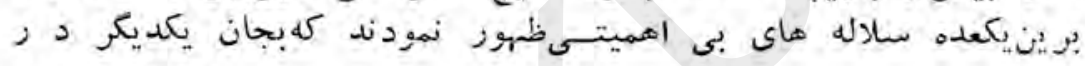

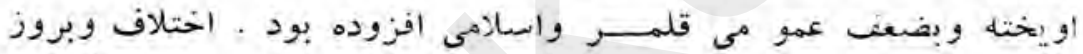

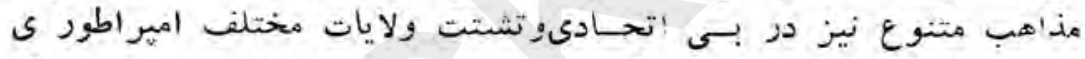

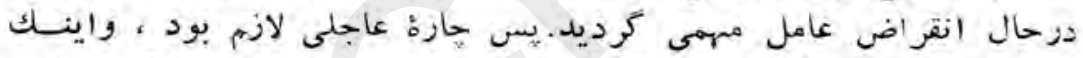

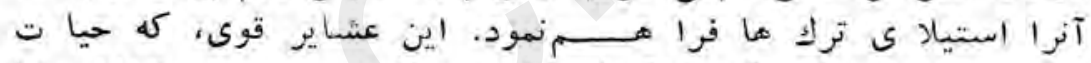

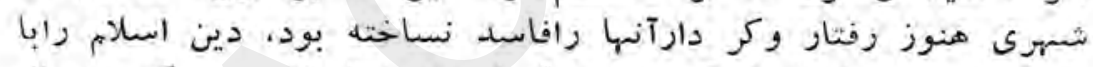

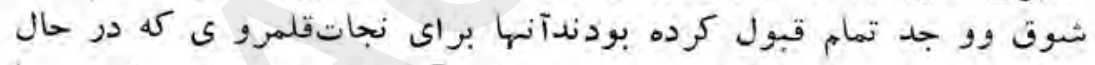

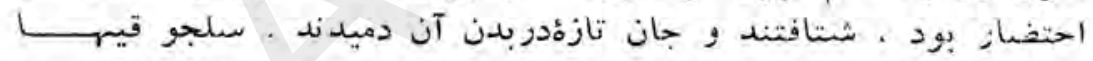

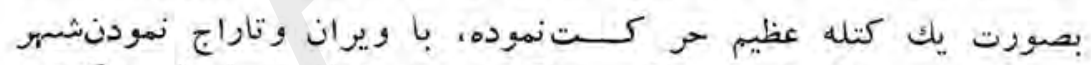

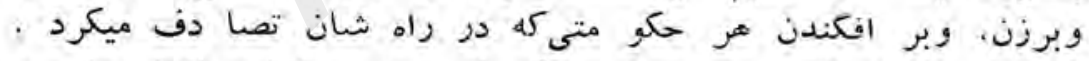

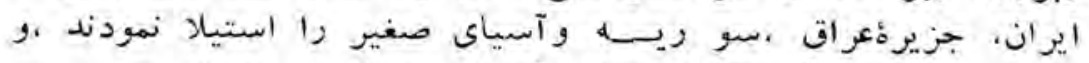

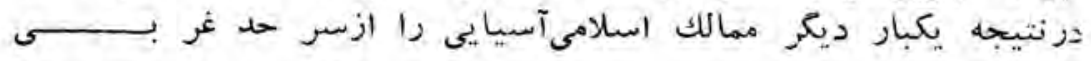

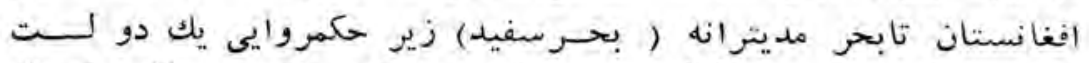

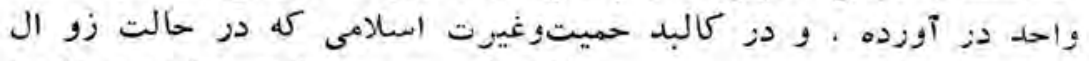

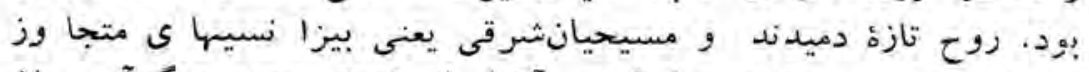

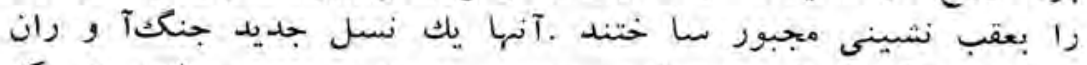

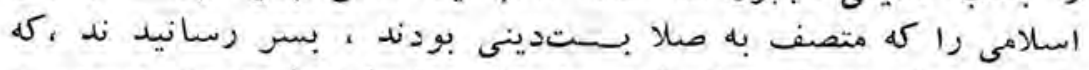

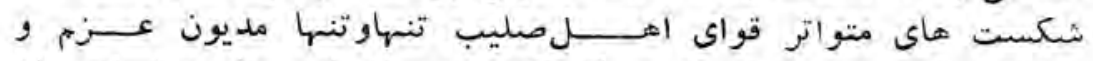

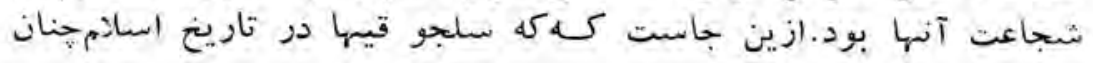




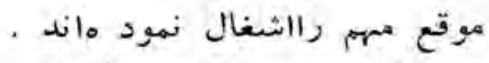

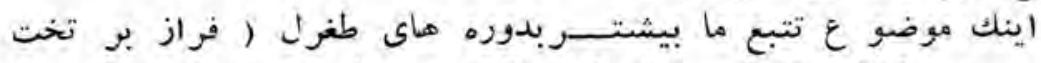

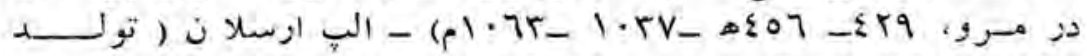

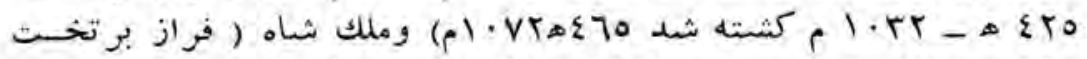

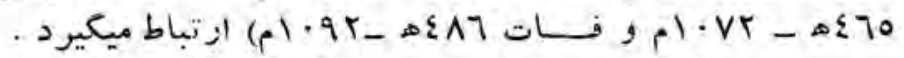

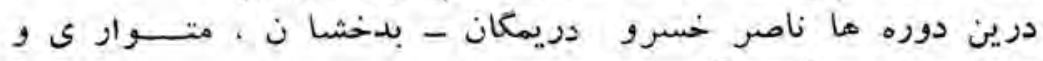

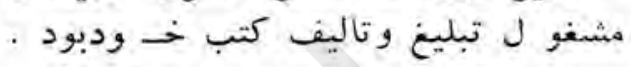

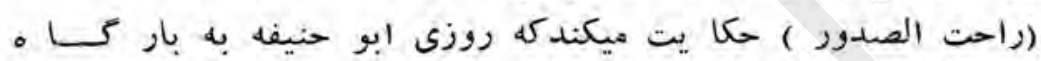

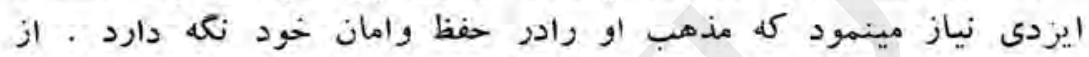

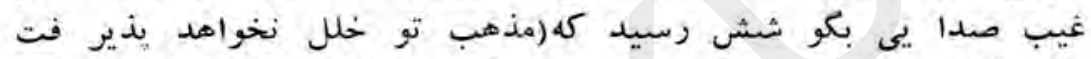

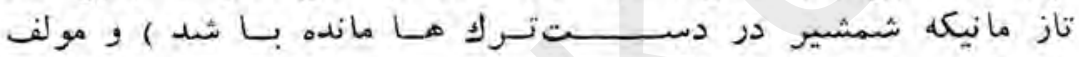

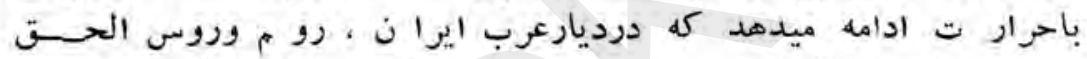

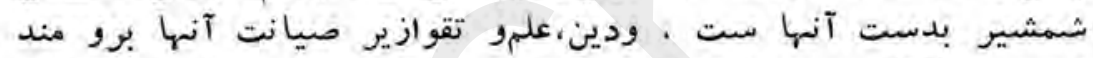

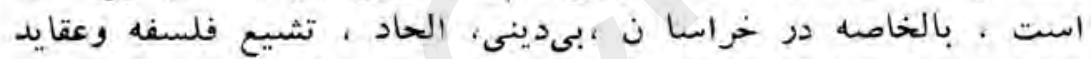

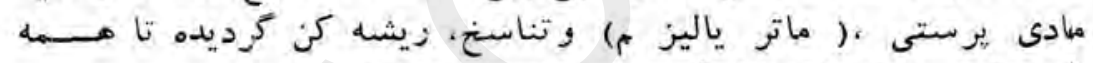

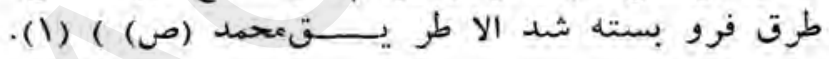

\section{9-قلعه اله موت و حسن صباح}

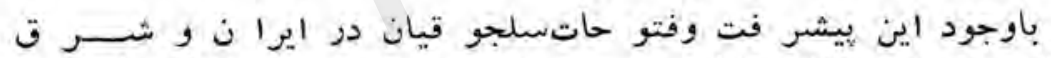

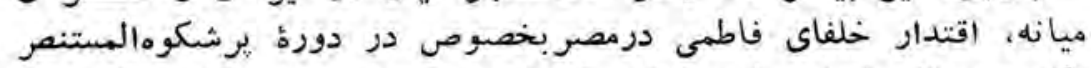

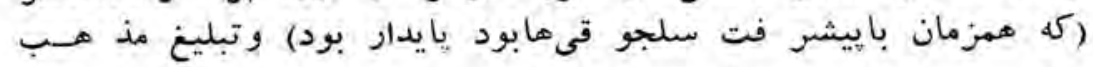

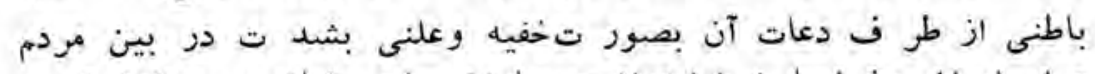

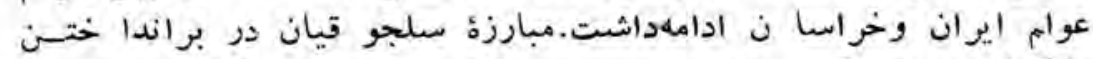

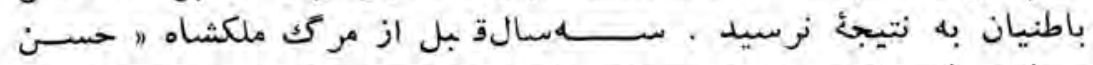

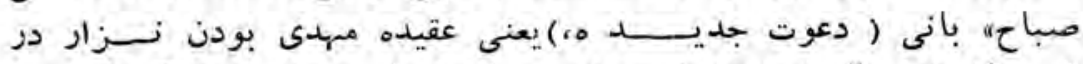

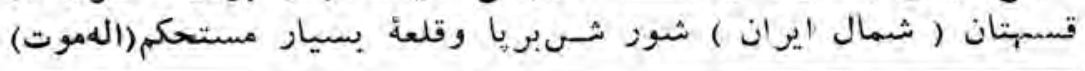


تسخير و جمعيت خفيه و, مشهه رخود بعنى (فدانيان) راتاسيسنمود

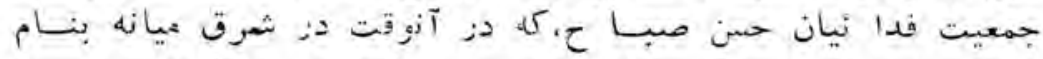

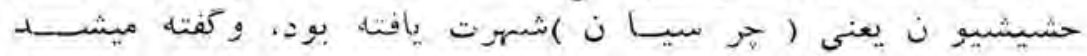

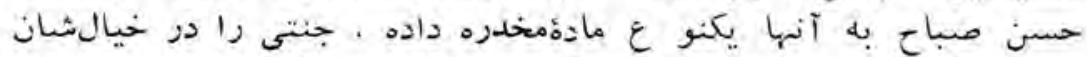

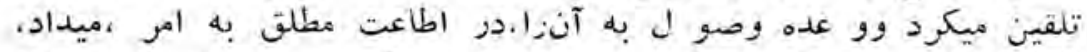

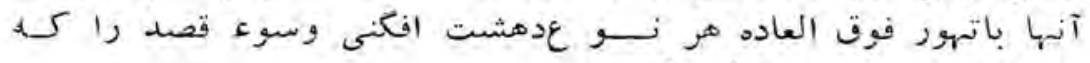

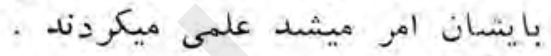

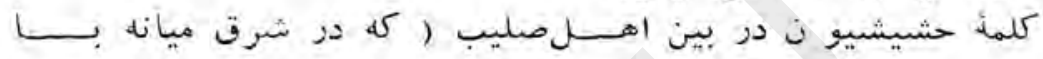

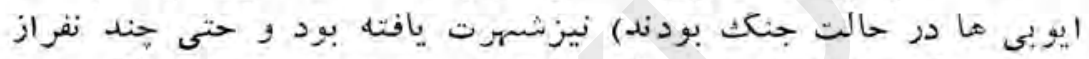

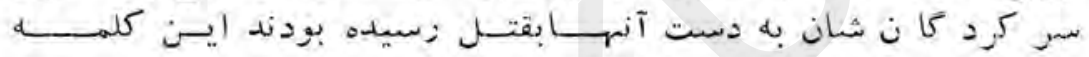

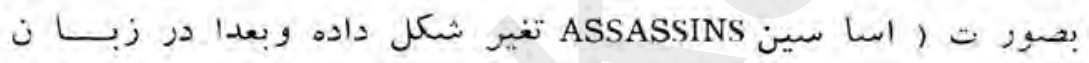

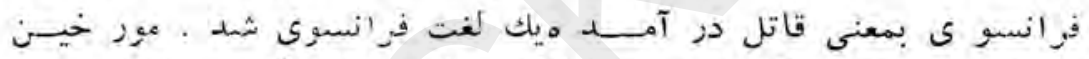

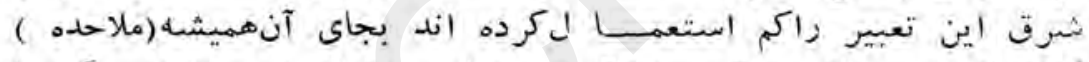

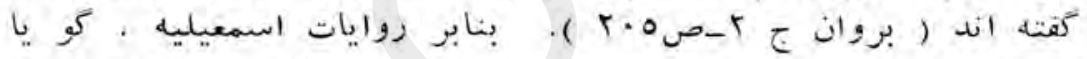

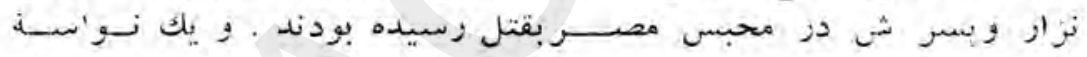

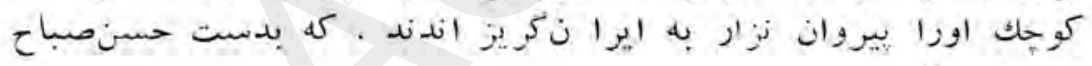

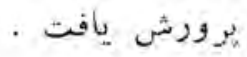

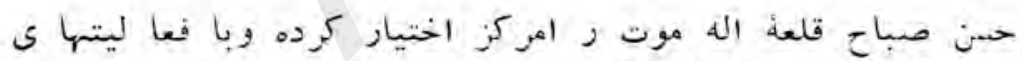

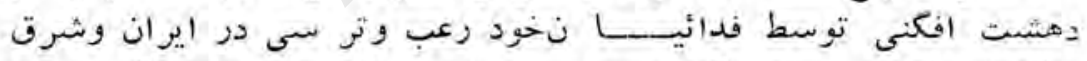

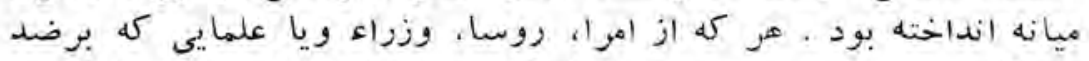

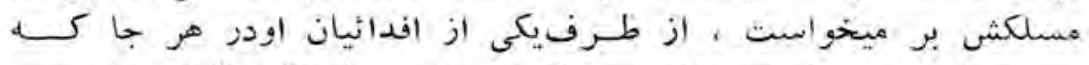

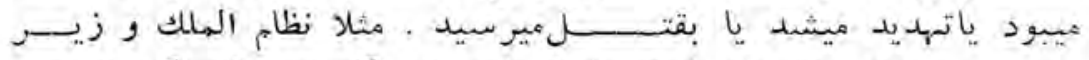

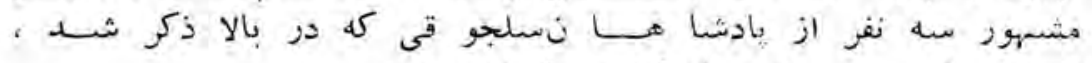

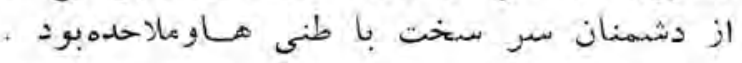

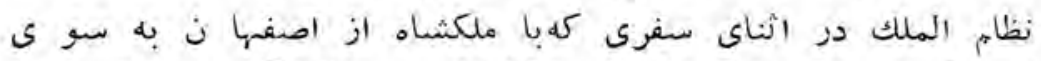

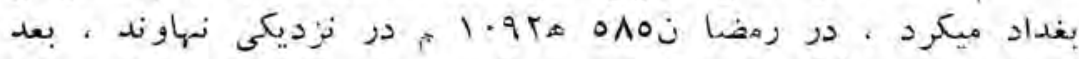

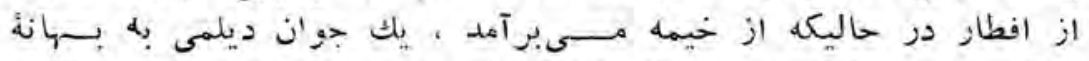

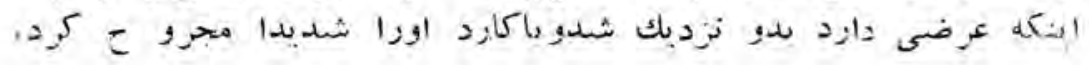




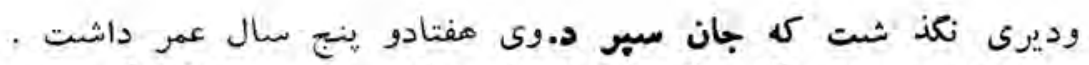

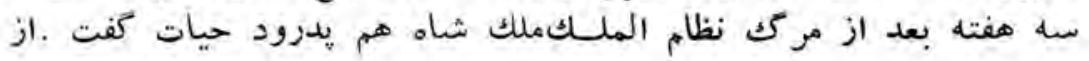

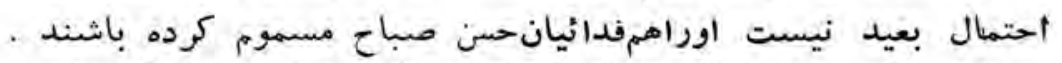

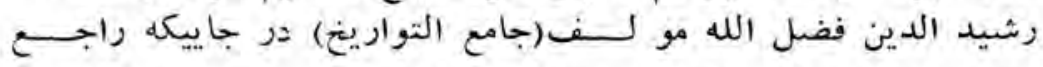

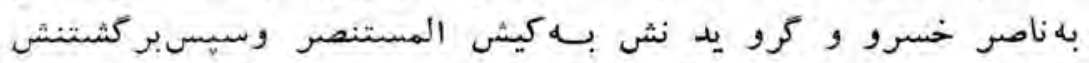

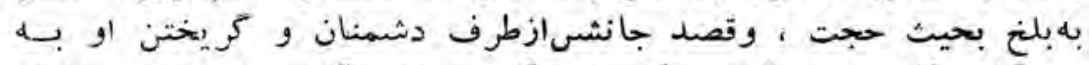

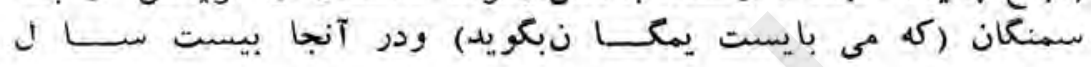

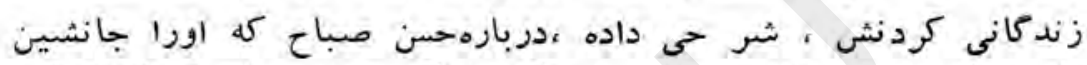

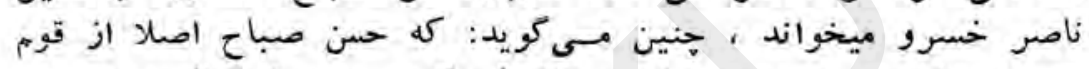

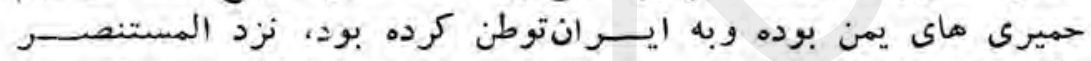

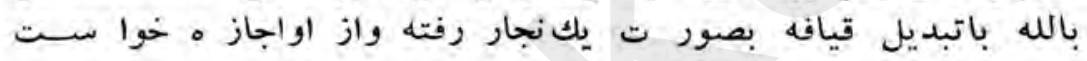

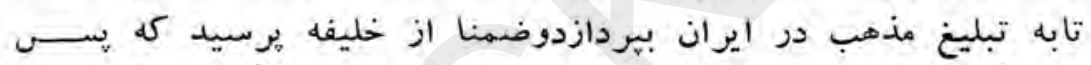

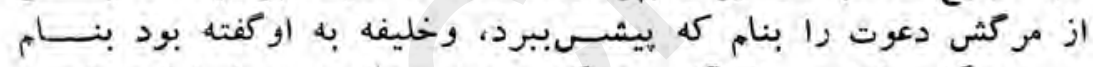

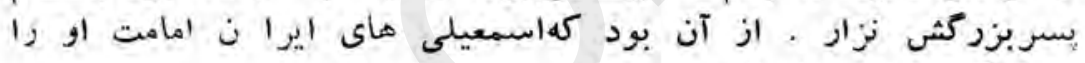

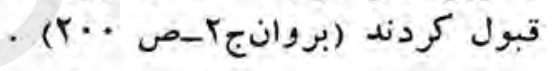

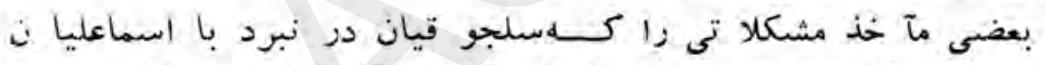

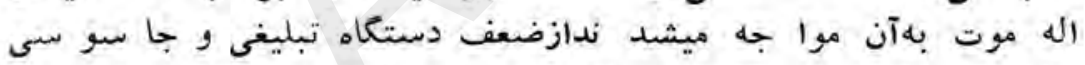

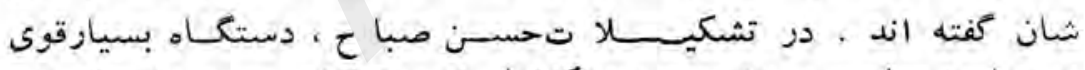

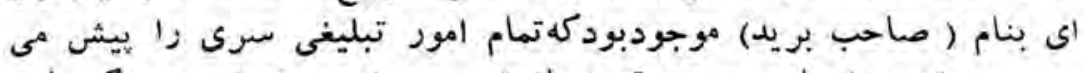

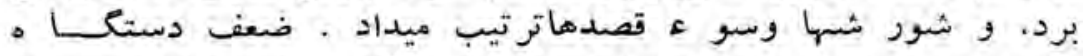

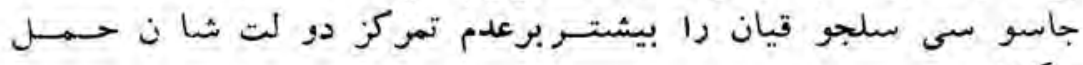
ميكند

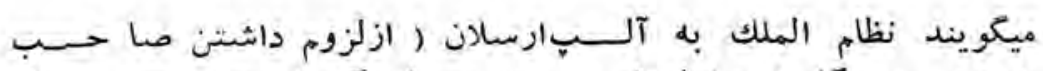

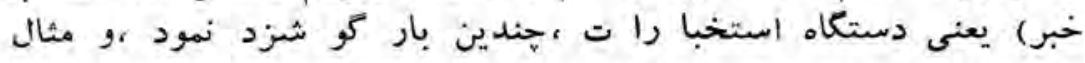

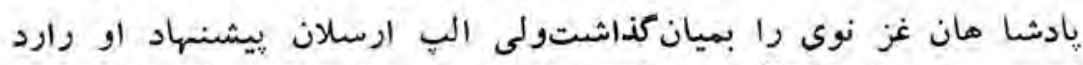

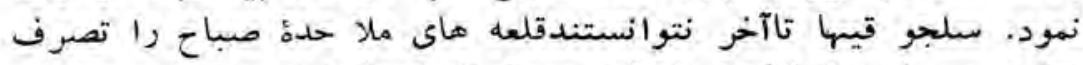

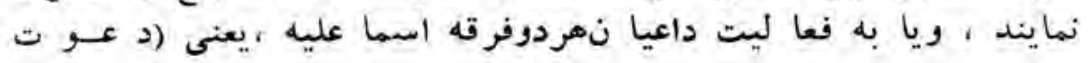




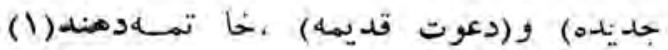

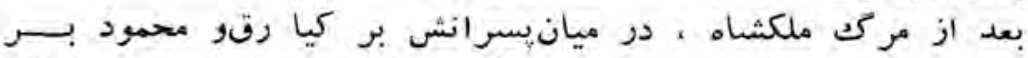

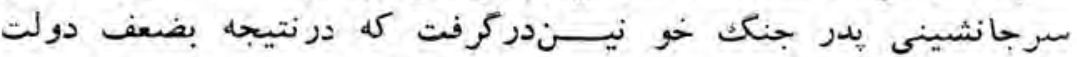

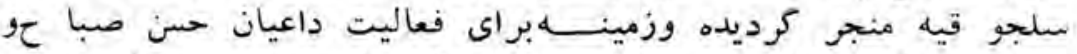

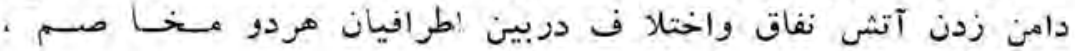

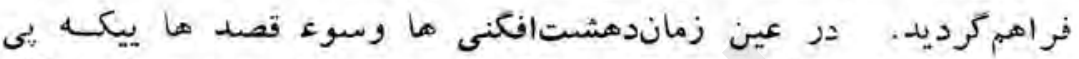

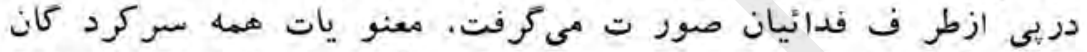

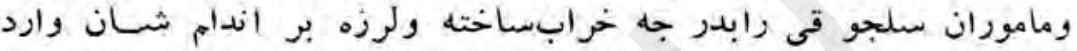

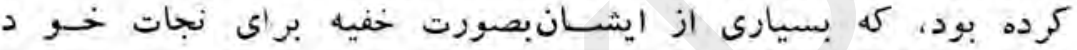

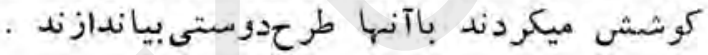

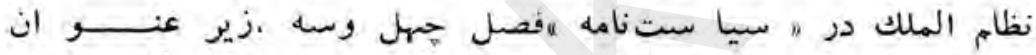

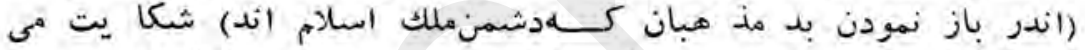

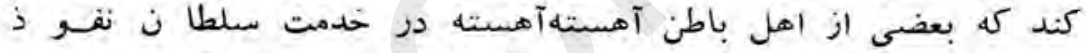

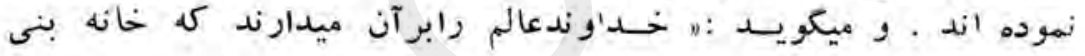

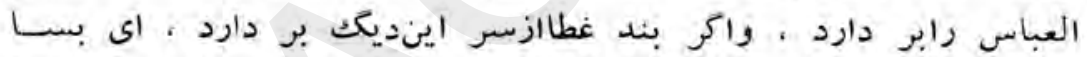

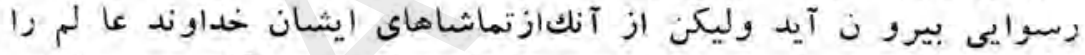

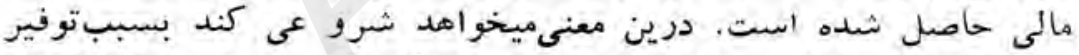

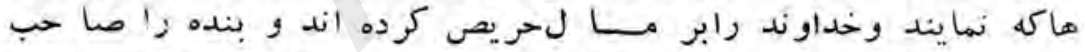

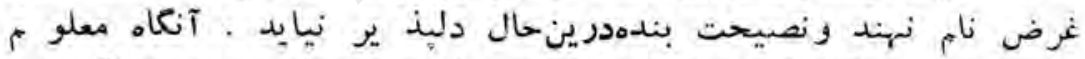

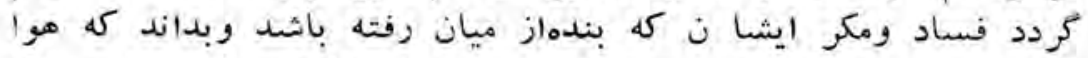

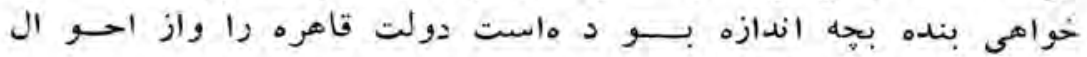

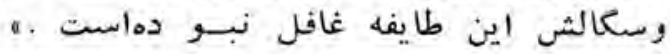

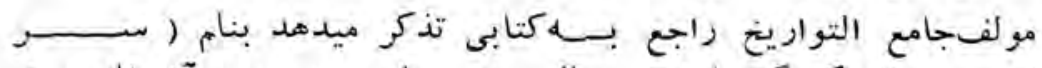

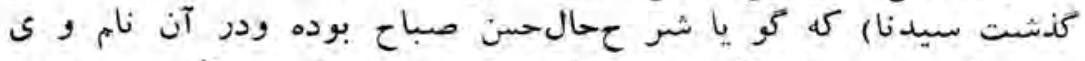

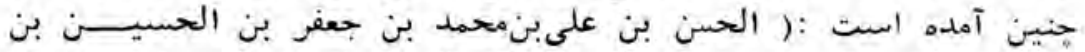

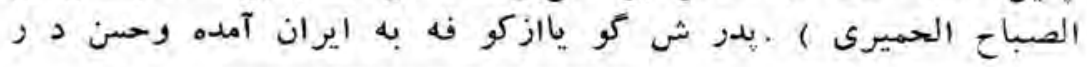




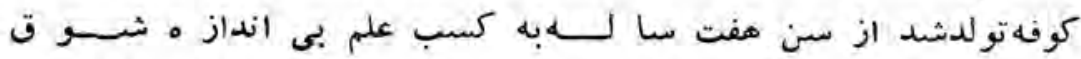

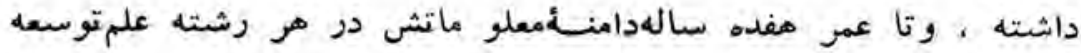

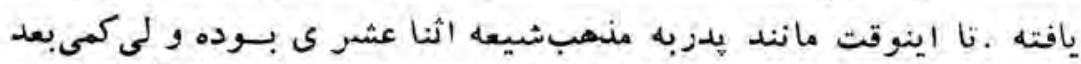

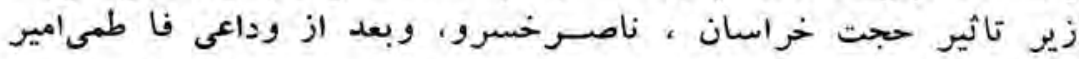

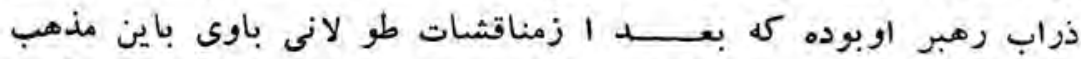

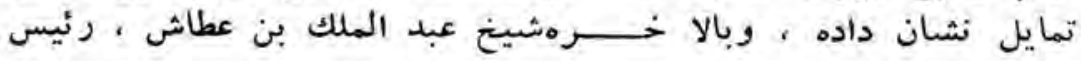

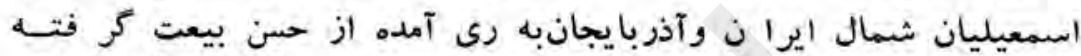

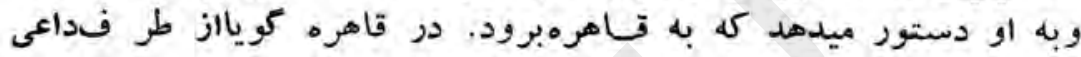

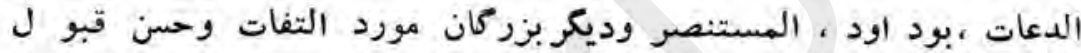

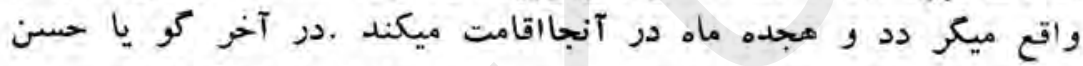

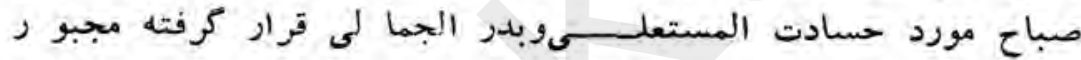

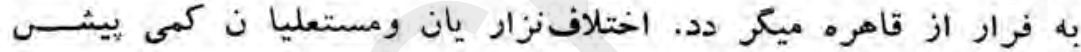

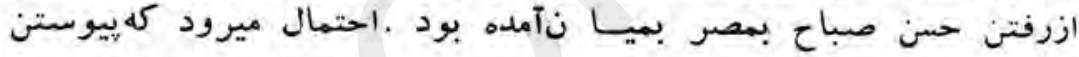

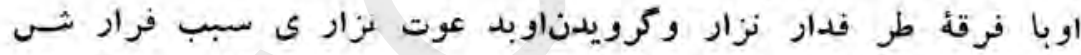
از مصر شده باشد ، كه بعد ازبركشتنبهاصفهان (

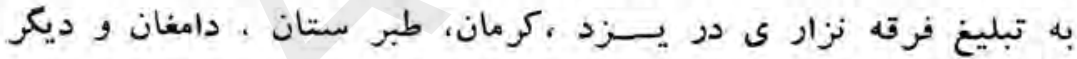

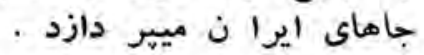
حسئ از ترس نظام الملك كلدرصدد كرفتارى اوبوده ، ، به دامـاد

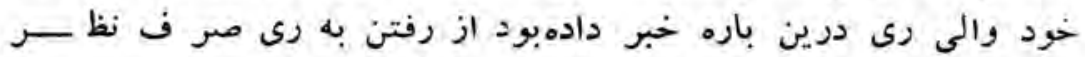

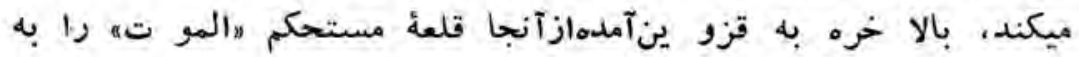

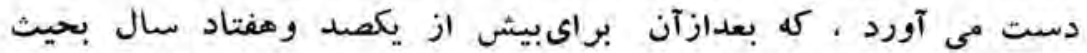

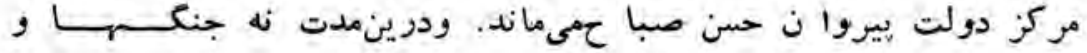

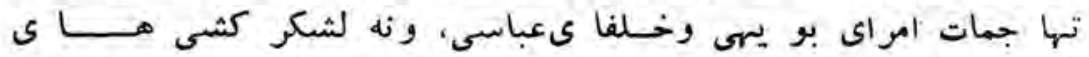

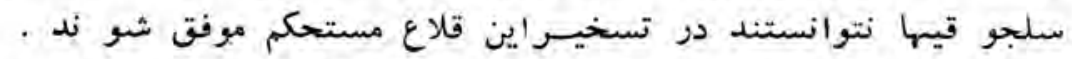

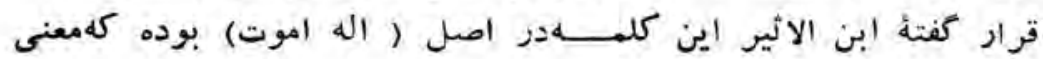




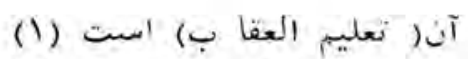

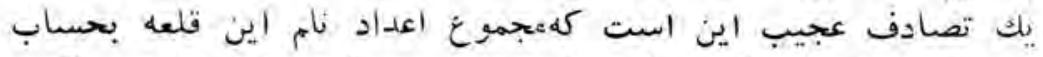

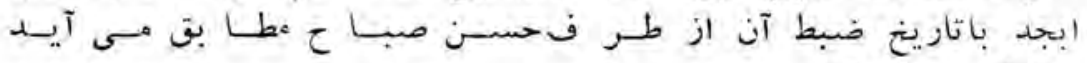

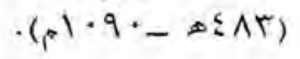

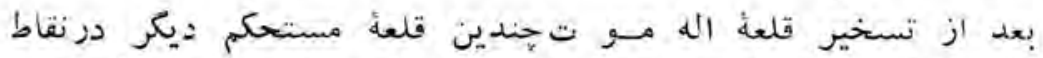

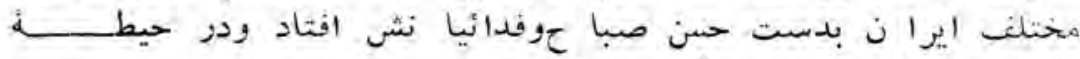

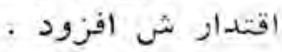

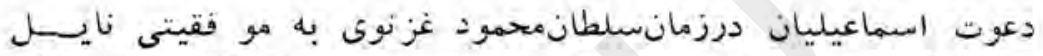

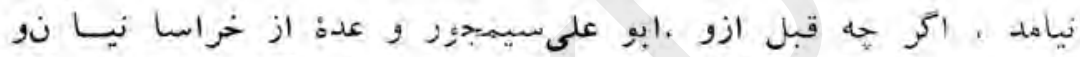

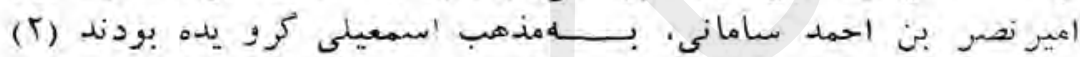

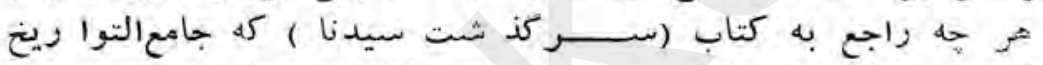

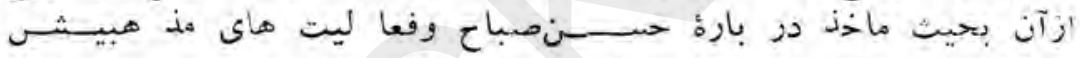

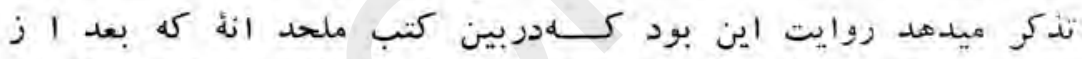

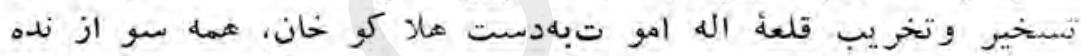

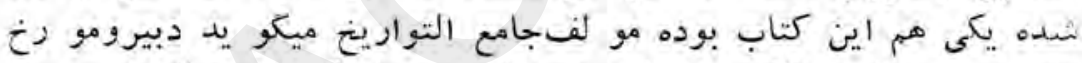

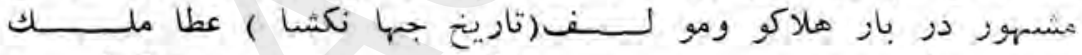

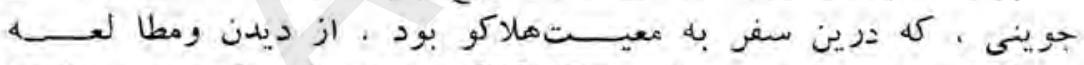

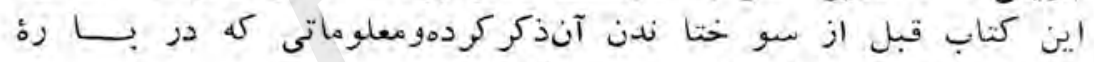

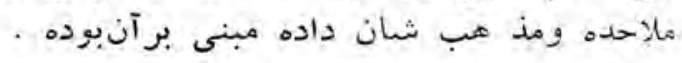

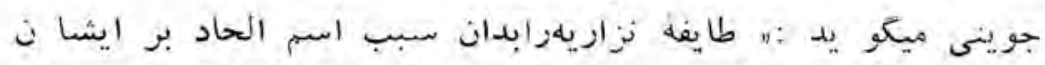

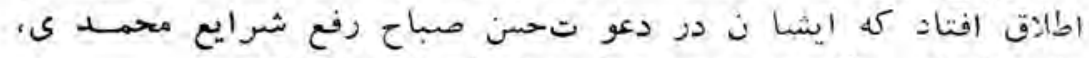

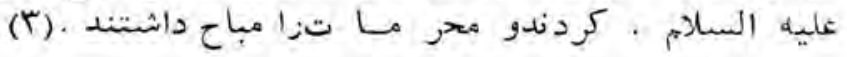

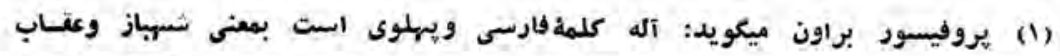

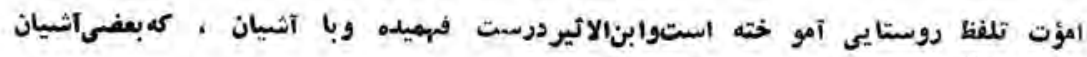

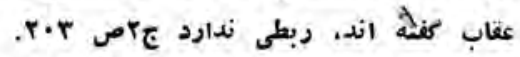

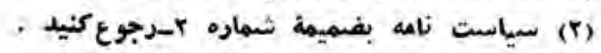
م برتلس - Irv 


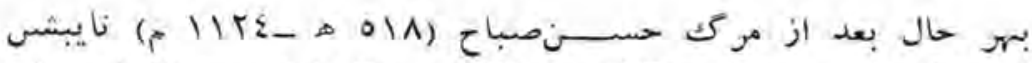

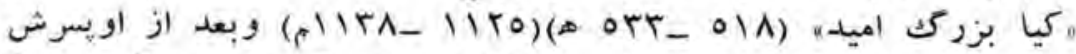

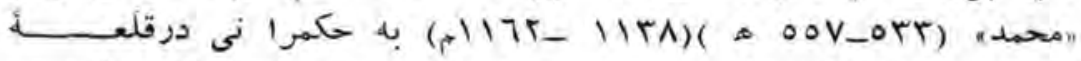

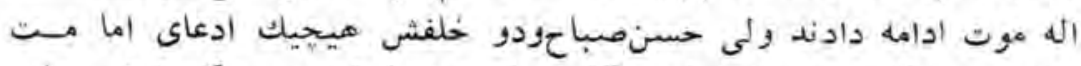

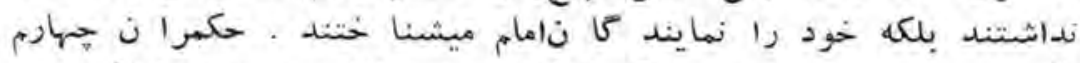

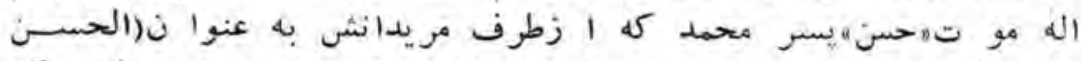

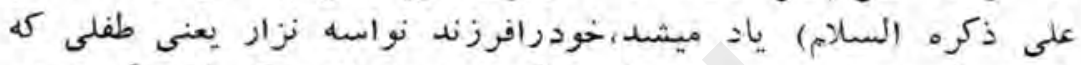

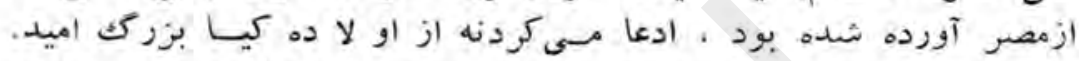

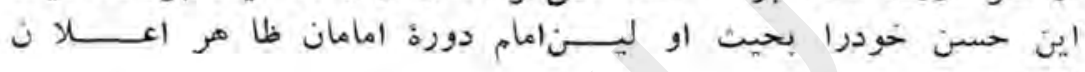
نمبود - نمي

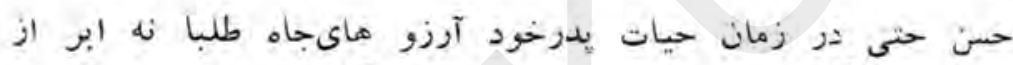

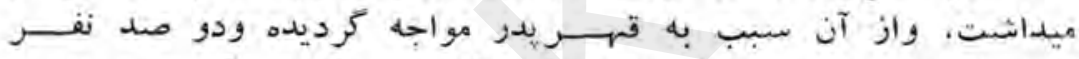

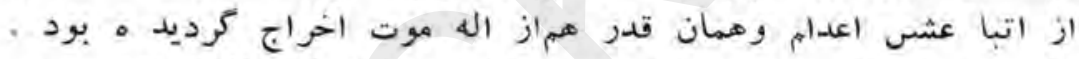

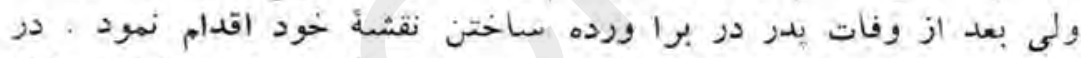

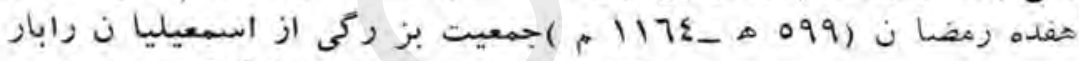

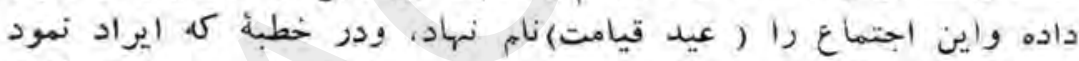

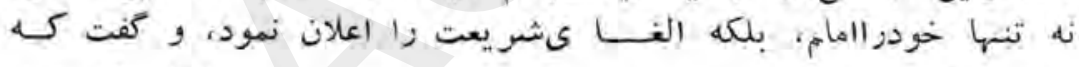

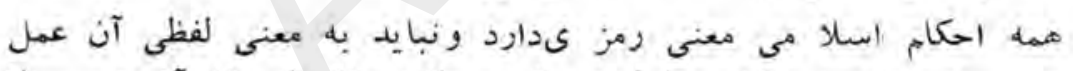

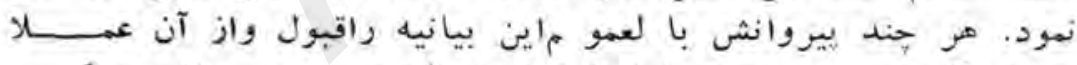

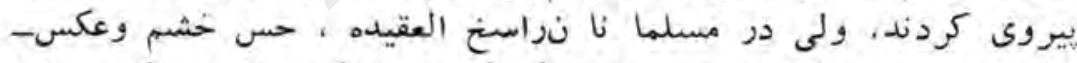

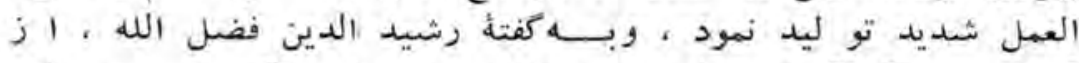

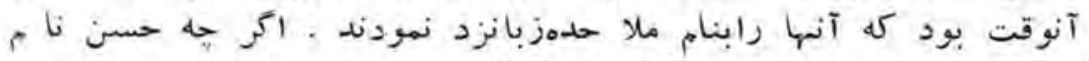

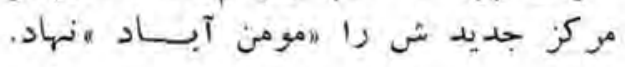

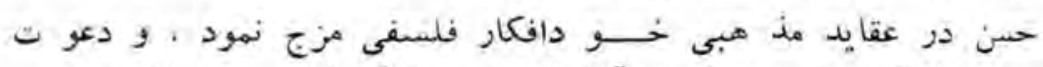

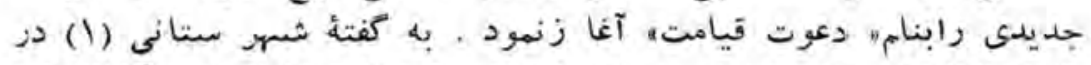

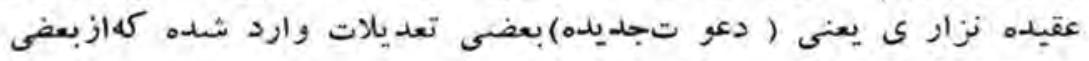

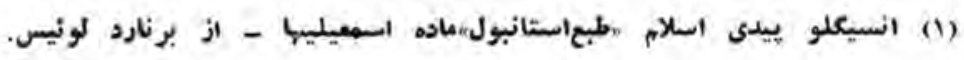




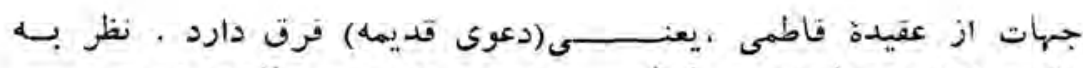

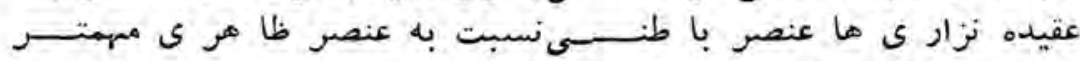

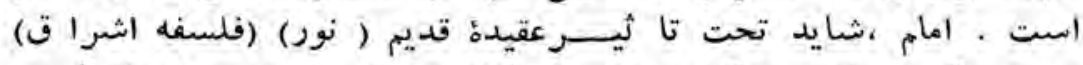

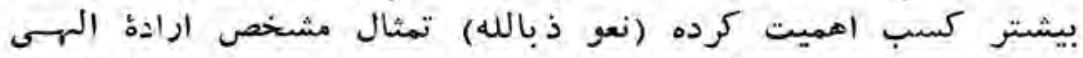

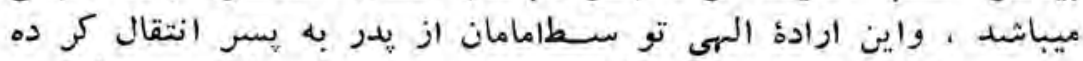

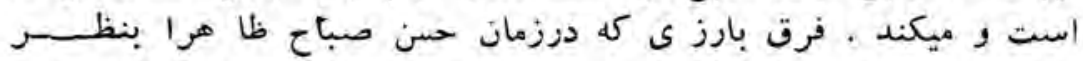

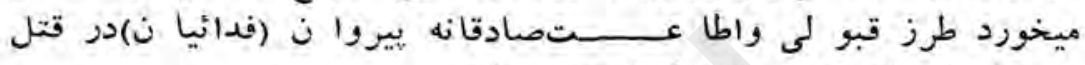

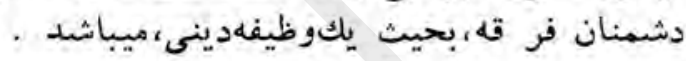

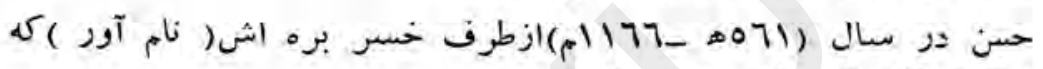

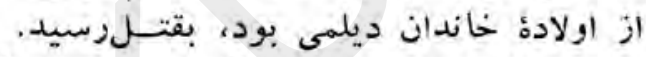

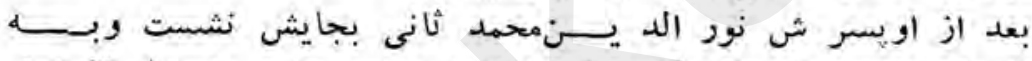

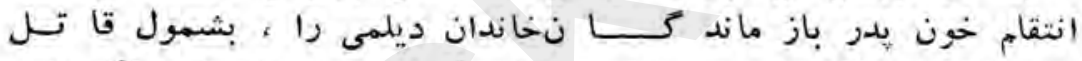

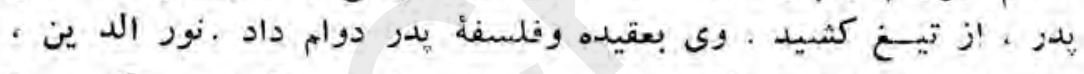

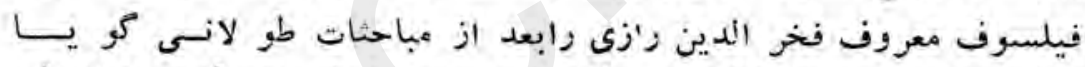

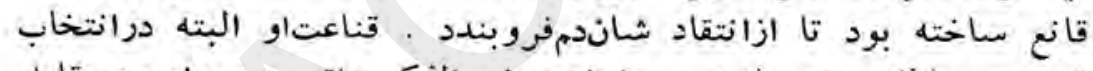

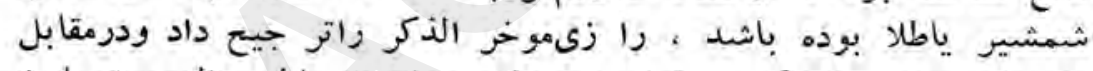

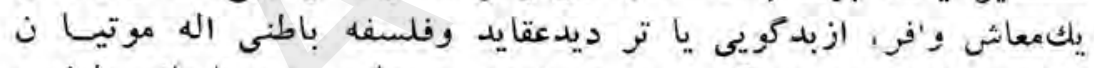

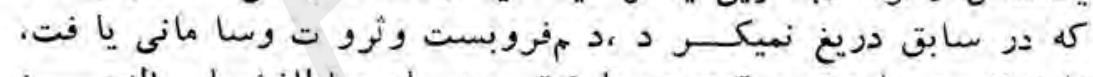

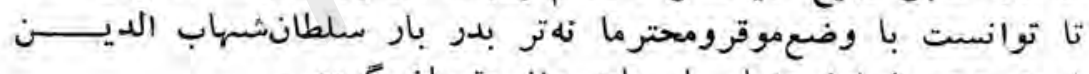

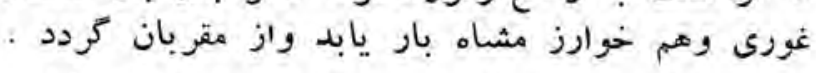

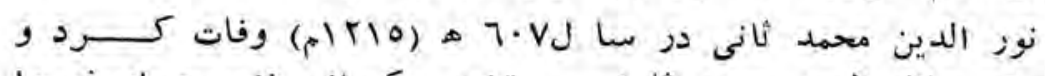

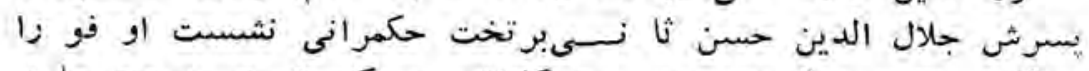

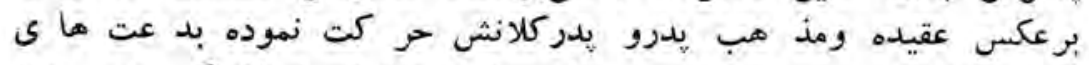

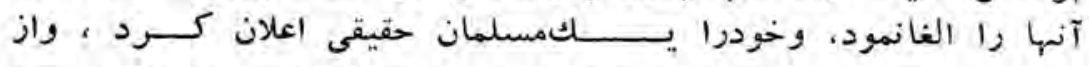

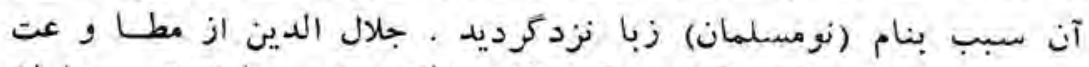

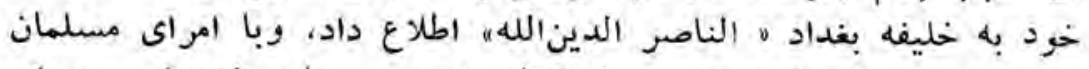

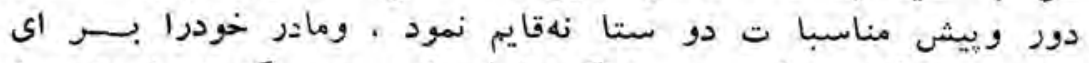

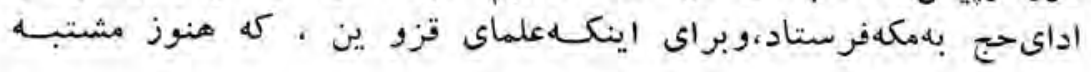




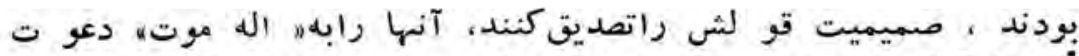

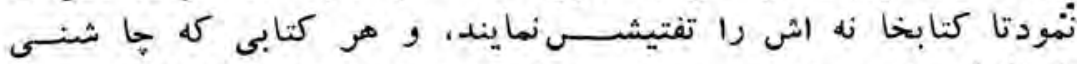

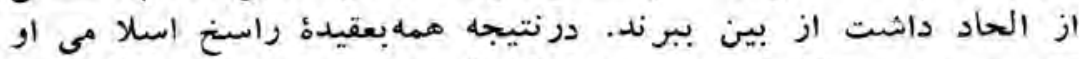

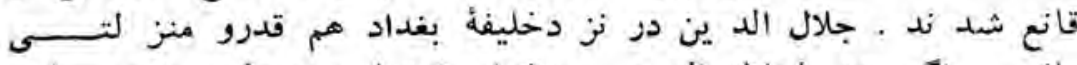

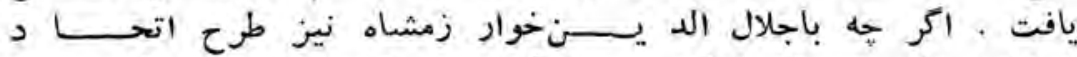

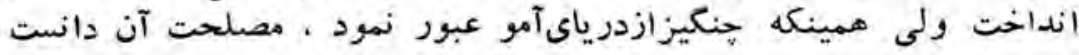

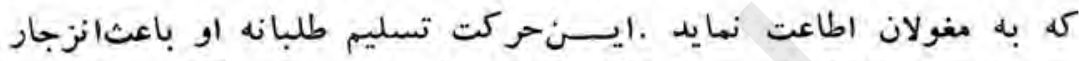

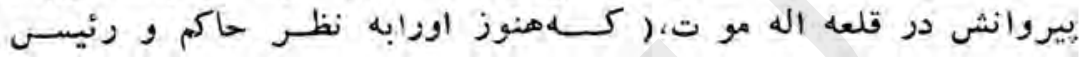

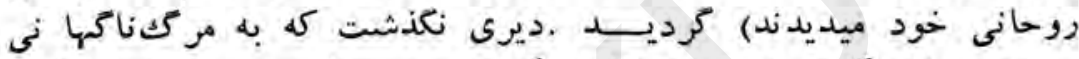
بلدرود حيات كفت مشرد حرمش مسموبم كرديده بود

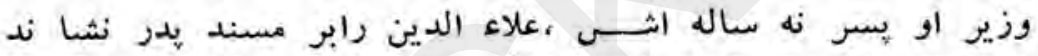

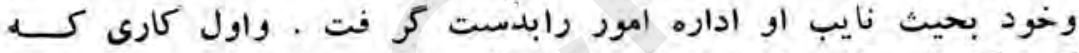

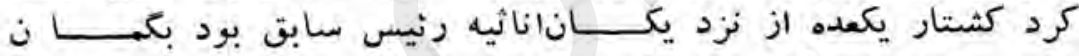

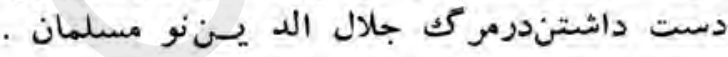

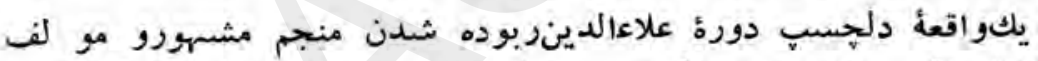

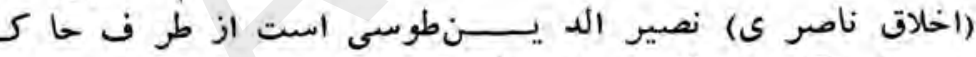

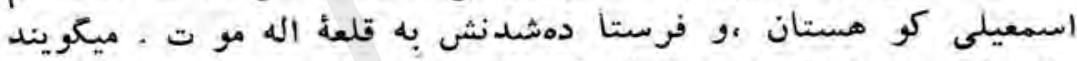

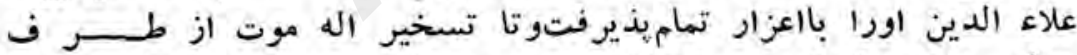

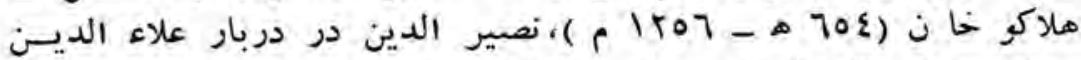

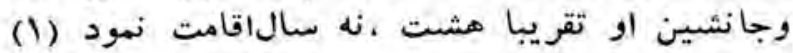

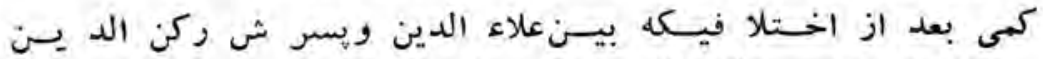

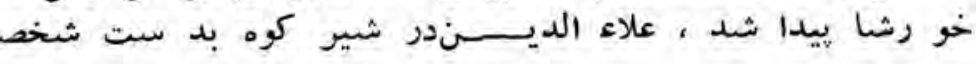

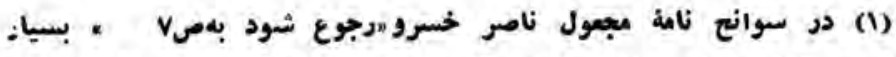

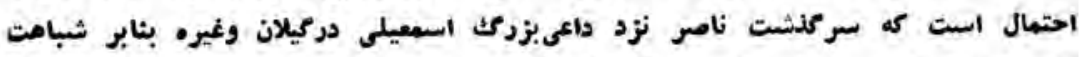

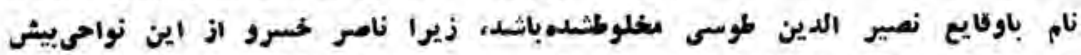

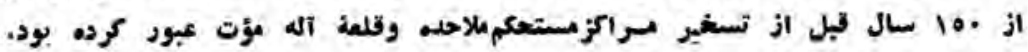




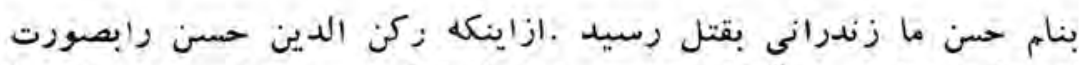

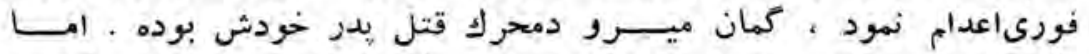

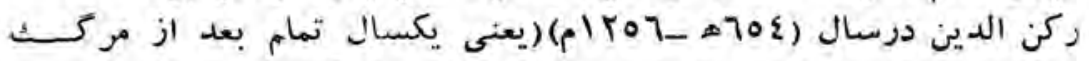

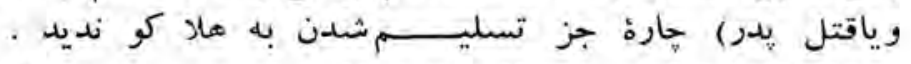

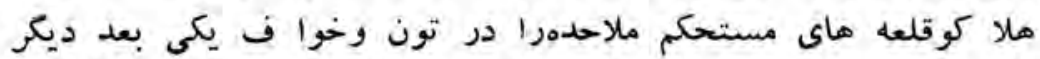

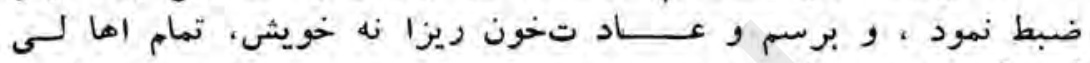

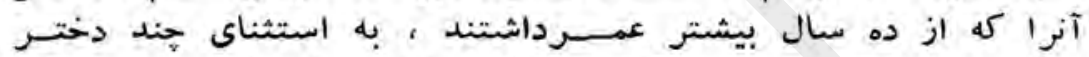

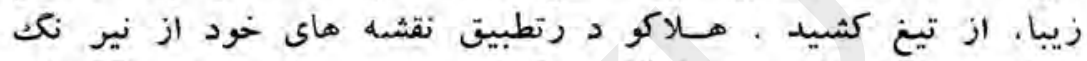

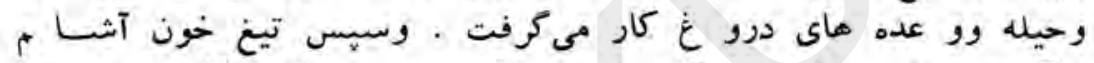

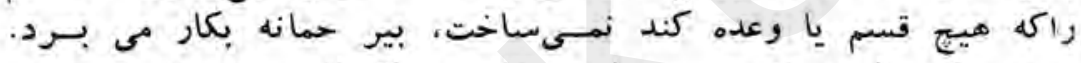

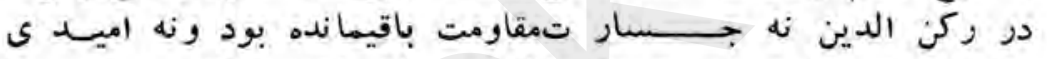

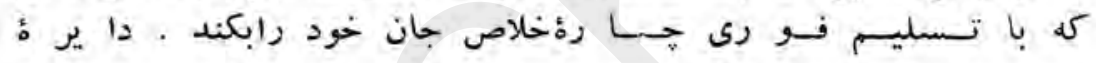

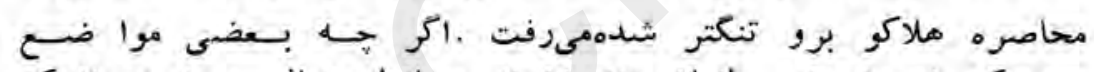

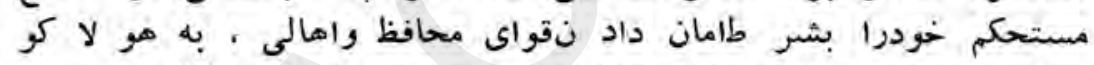

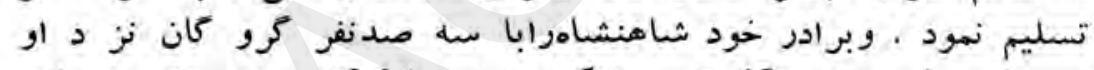

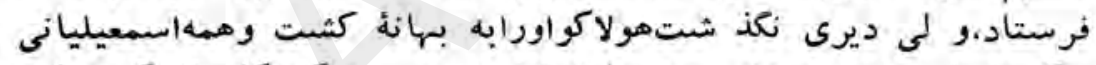

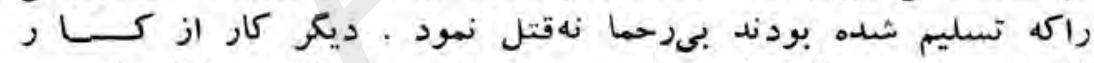

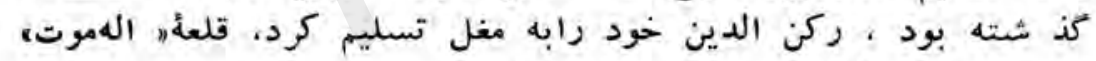

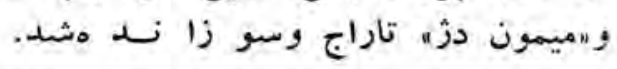

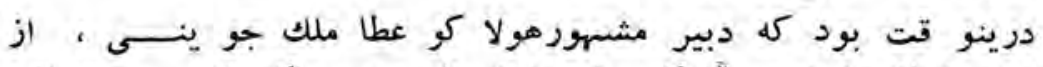

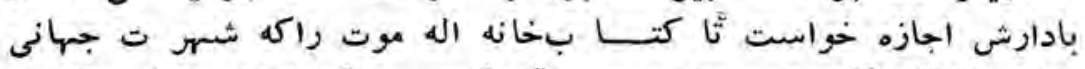

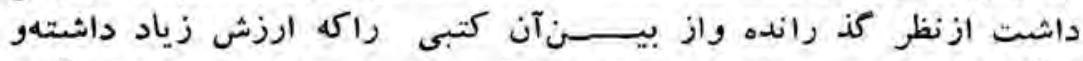

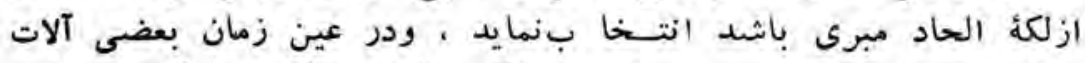

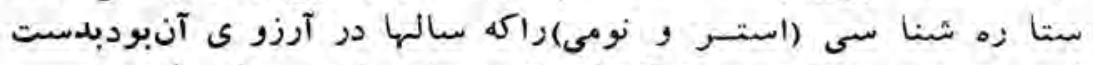

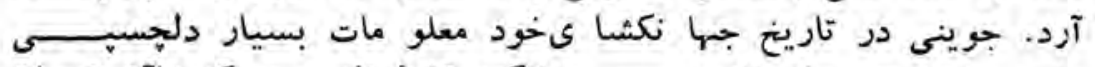

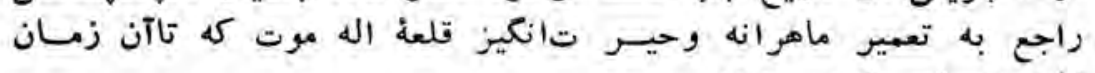

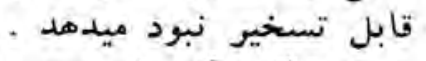
هولا كو ركن الد يسن را تحست الحفظ بدربارمنكوخان به ليقرهوروم، 


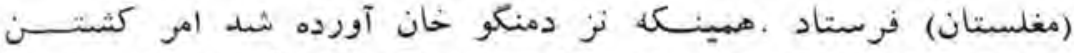

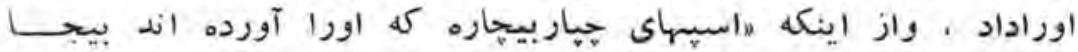

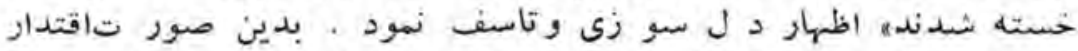

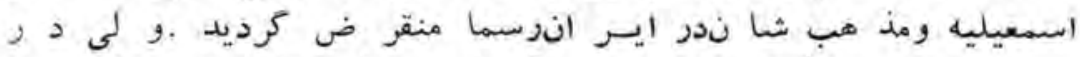

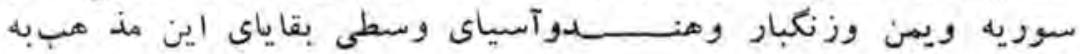

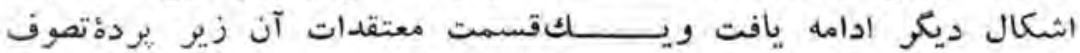

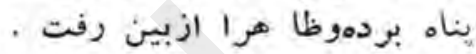

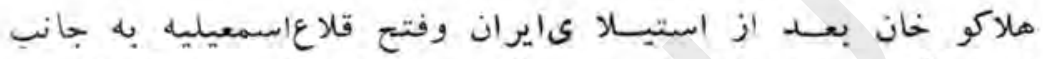

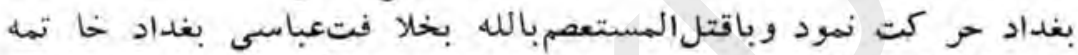

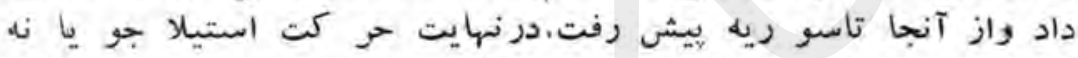

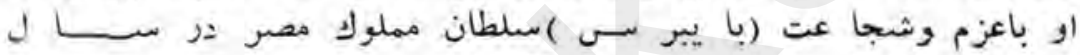

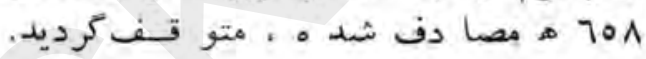

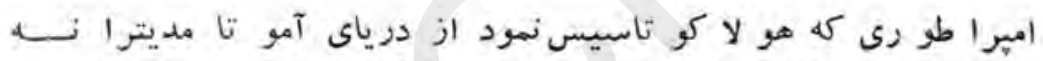

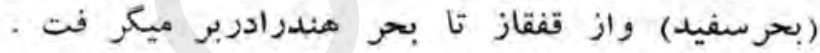

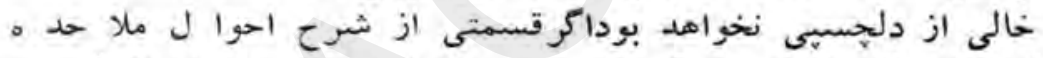

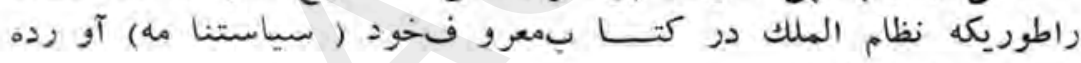

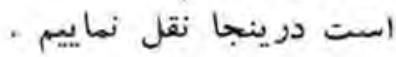

(اندر بيرون آمدن قر مطيـ نوباطنيان در كو هستان وعســر اق

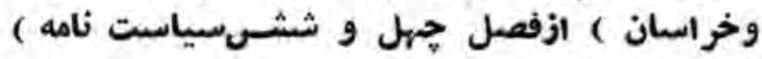

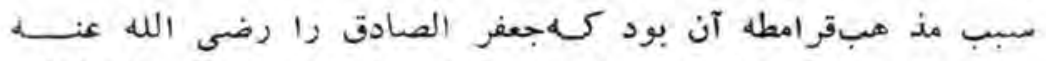

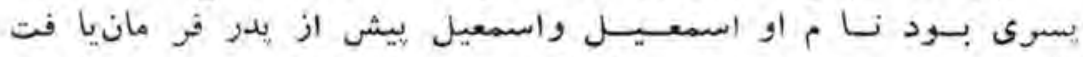

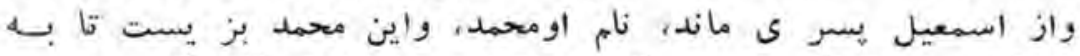

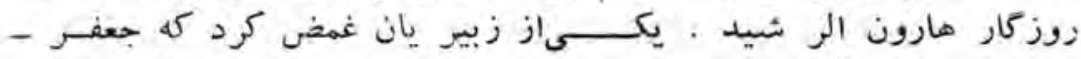

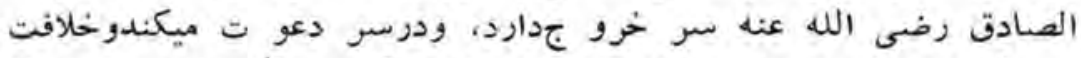

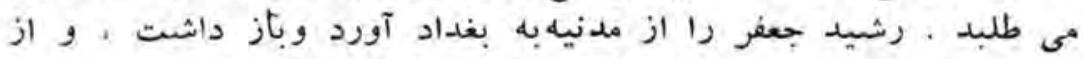

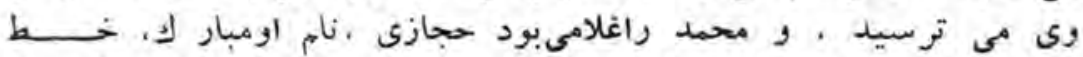

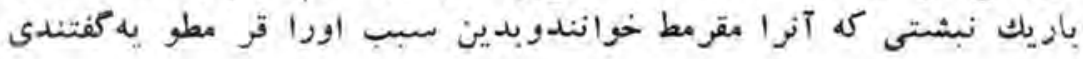




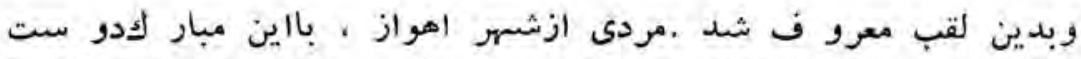

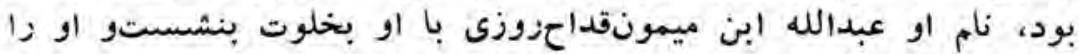

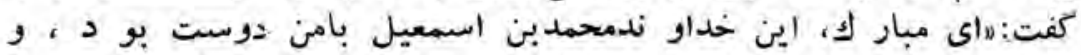

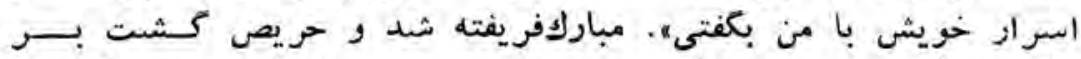

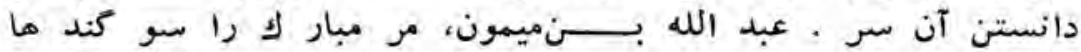

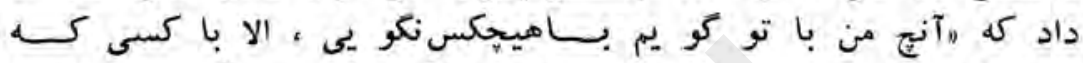

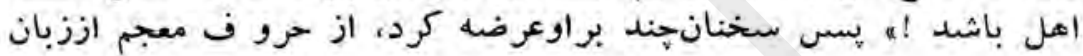

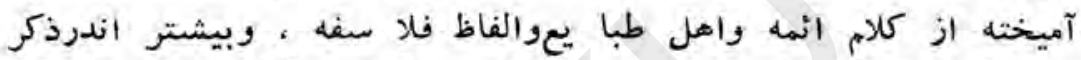

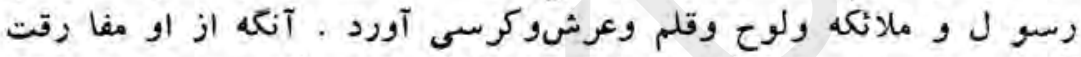

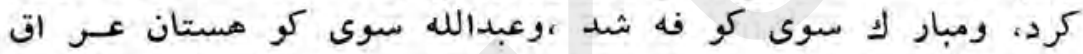

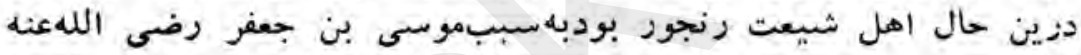

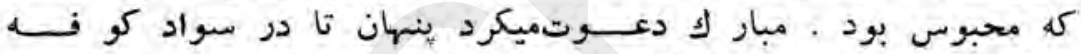

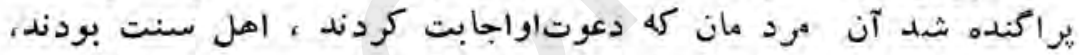

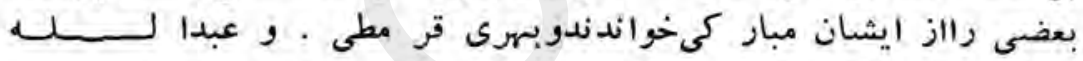

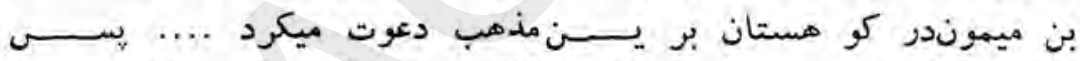

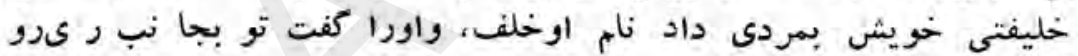

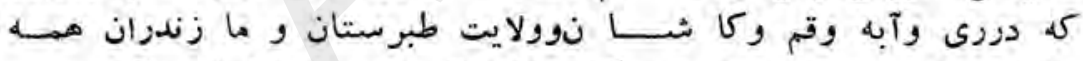

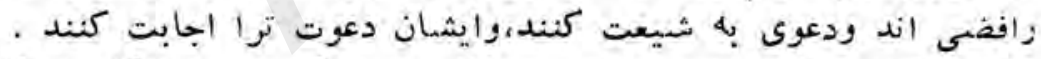

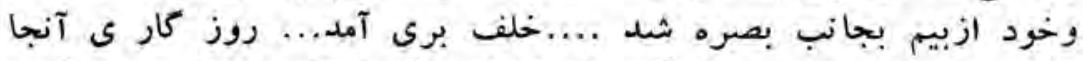

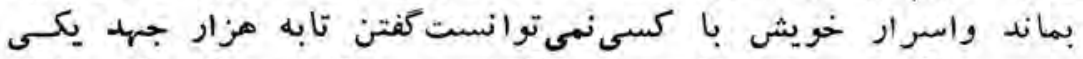

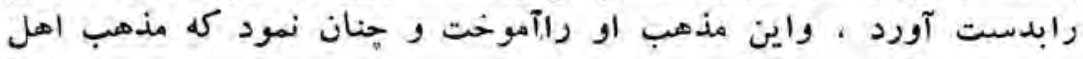

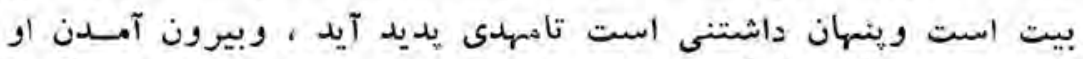

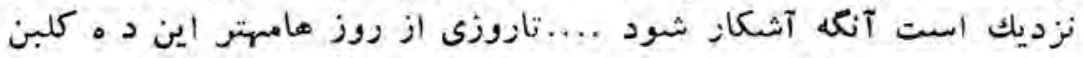

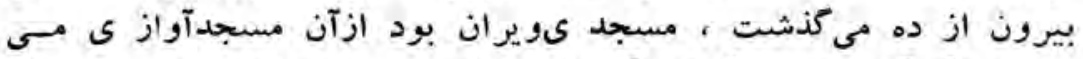

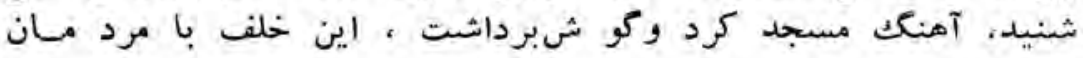

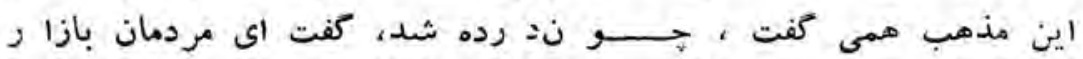

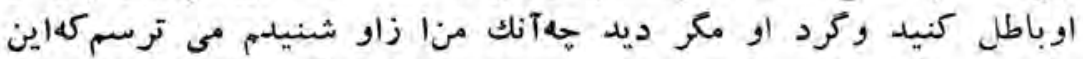

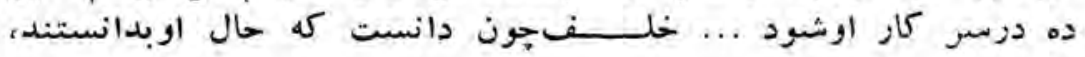


اندر بيوون آمدن قرمطيان وباطنيان

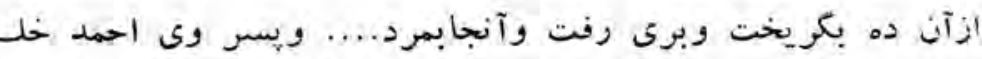

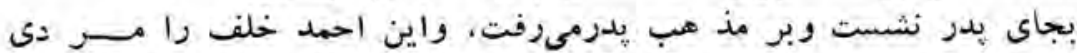

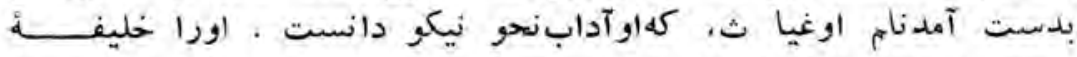

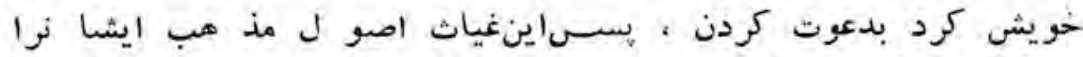

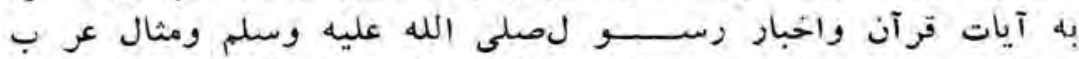

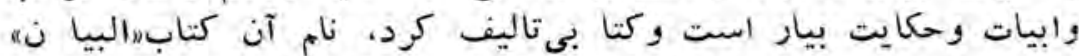

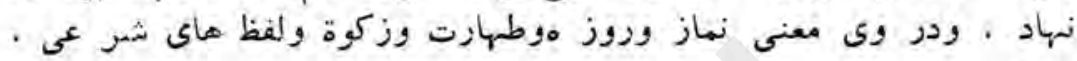

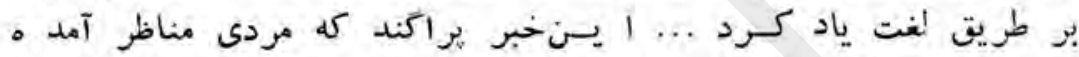

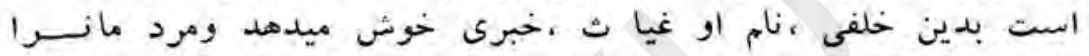

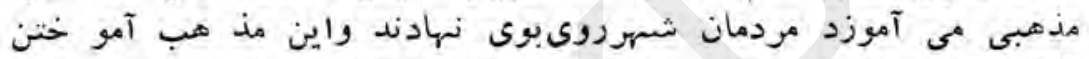

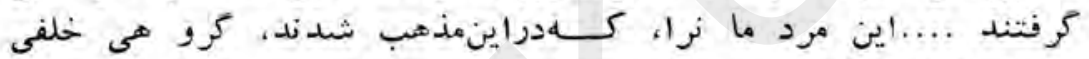

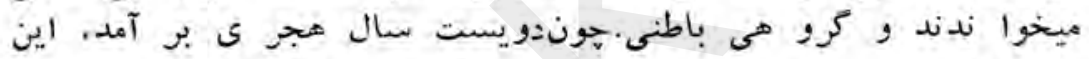

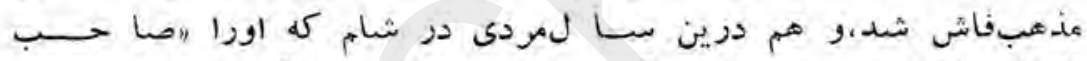

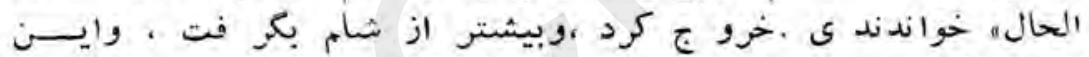

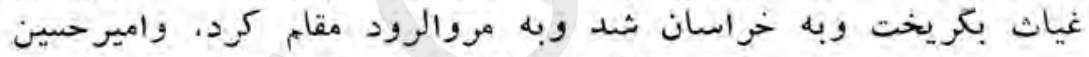

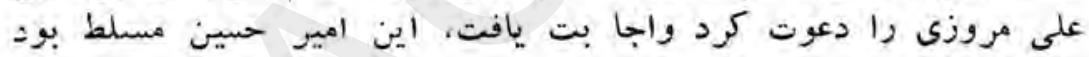

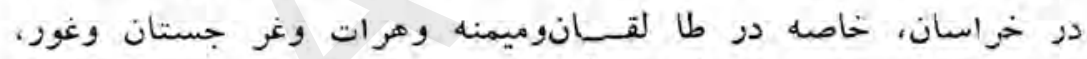

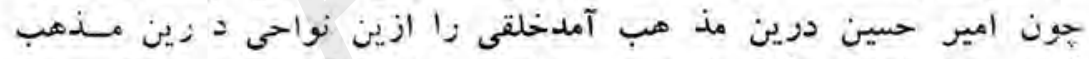

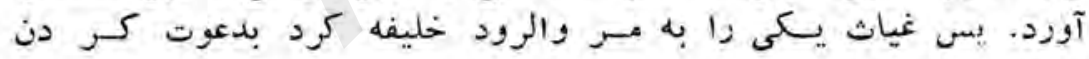

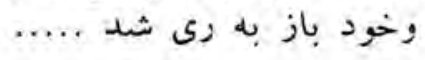

\section{در خروج باطنيان در خراسا نوماوراء النهر

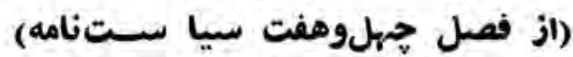

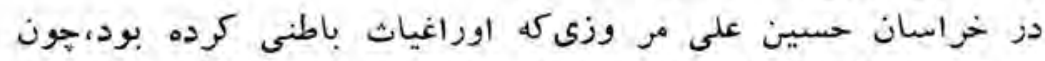

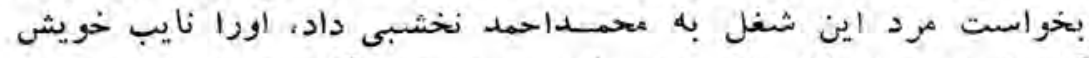

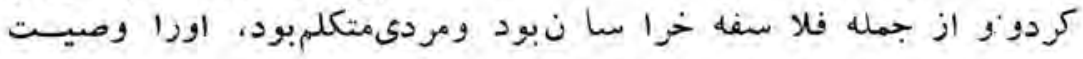

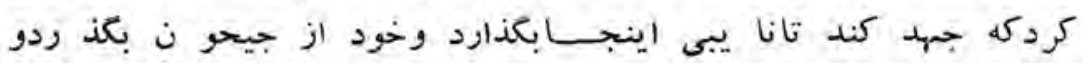

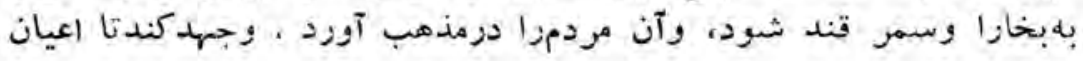




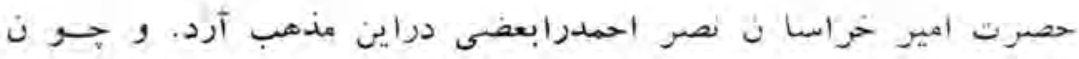

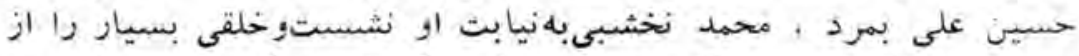

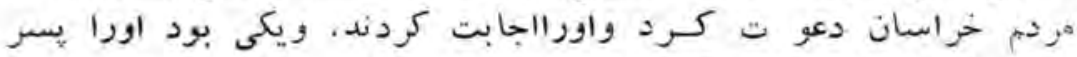

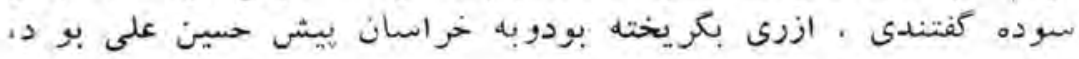

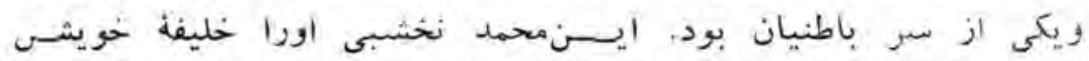

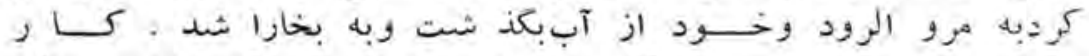

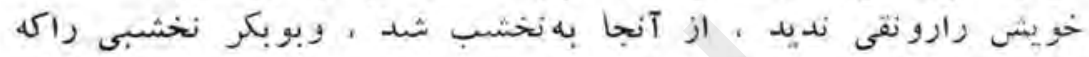

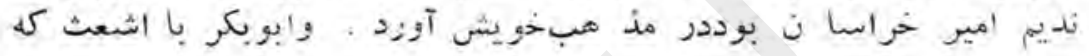

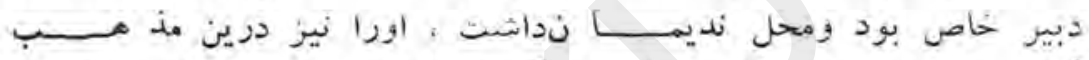

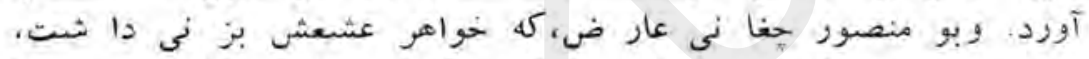

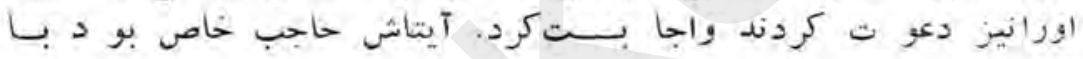

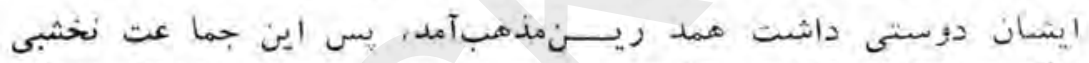

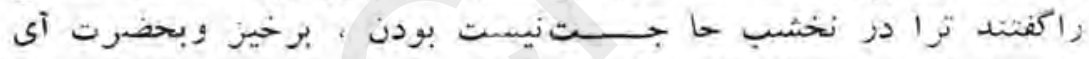

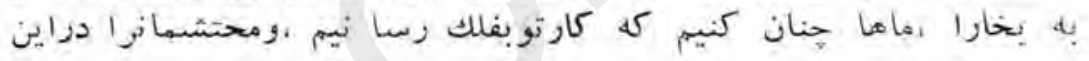

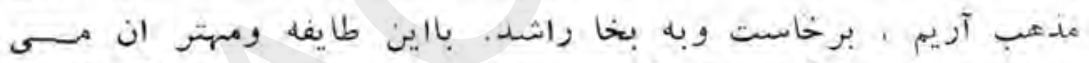

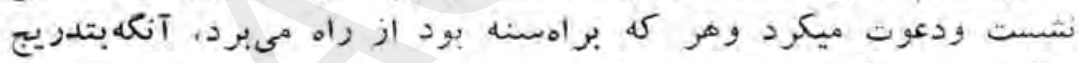

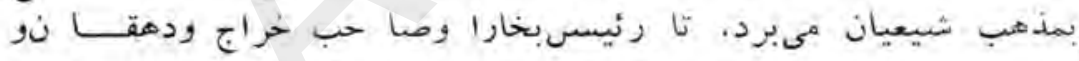

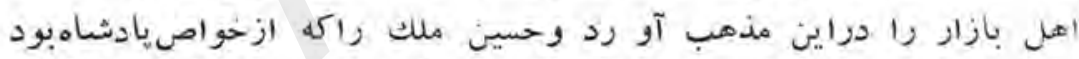

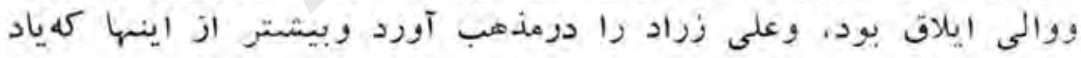

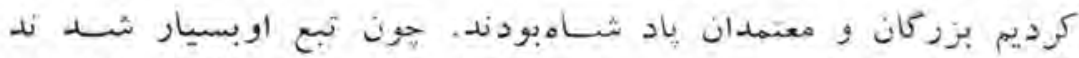

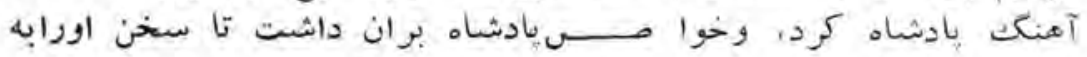

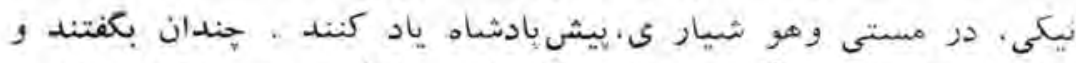

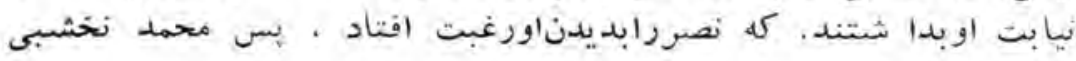

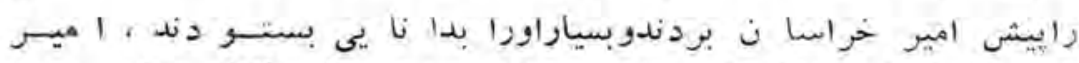

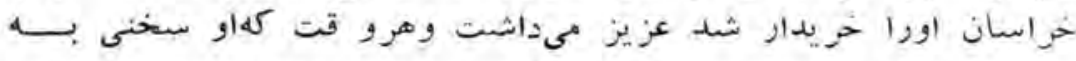

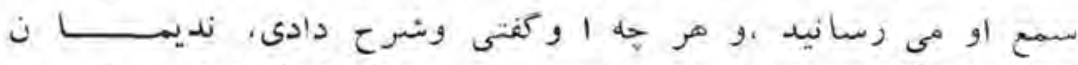

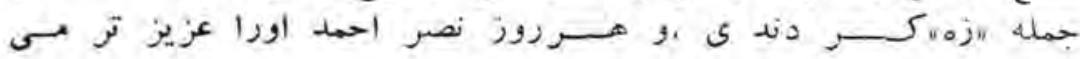


داشت ود عو ت اجابت ميـكر د،وجنان مستو لىكشت كه لهادثاهآن

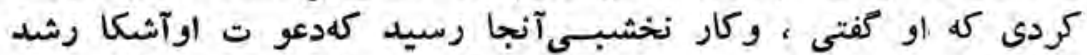

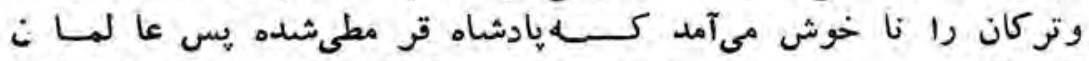

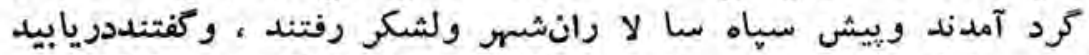

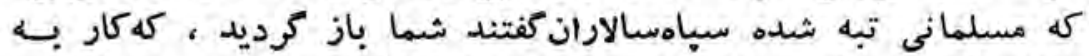

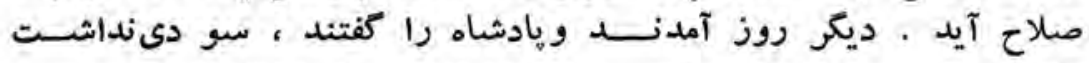

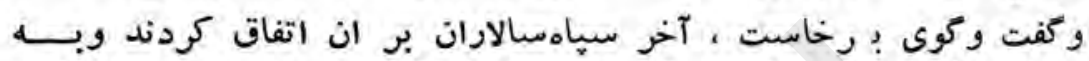

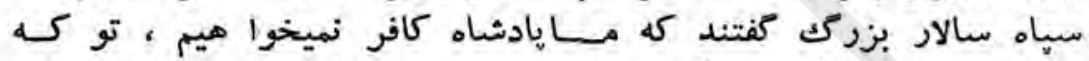

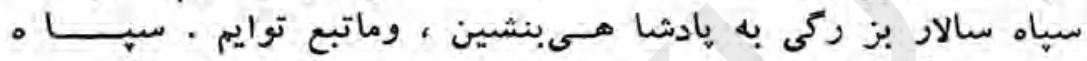

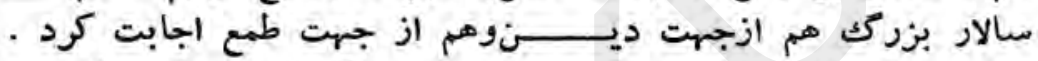

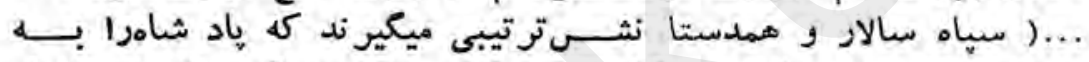

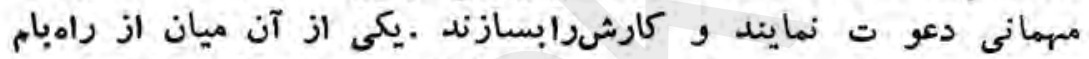

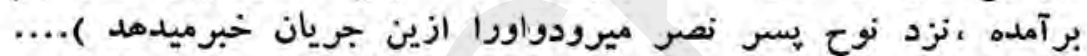

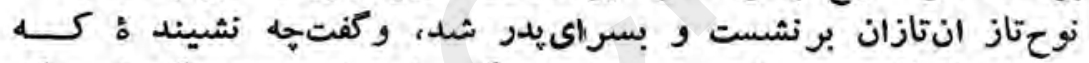

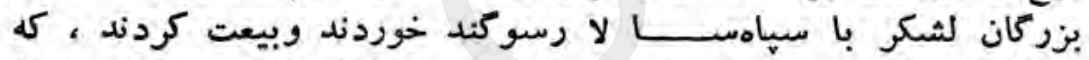

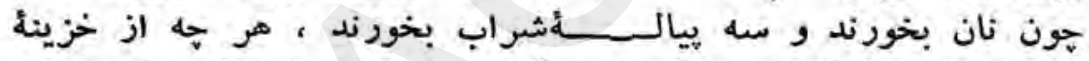

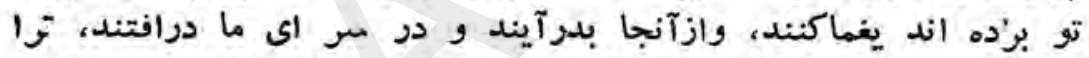

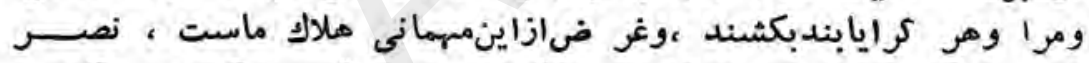

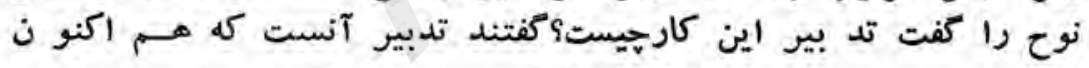

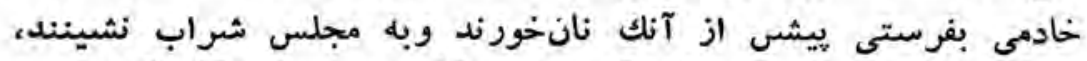

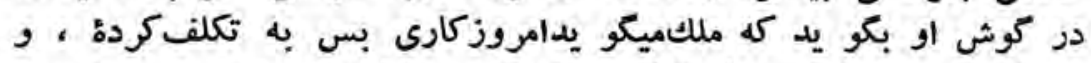

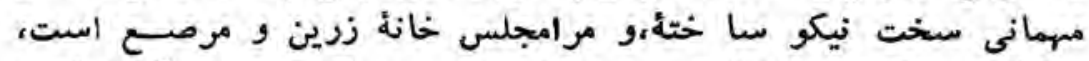

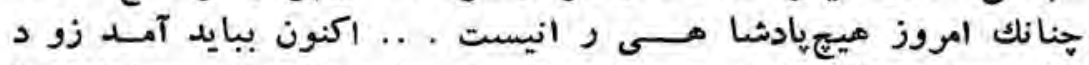

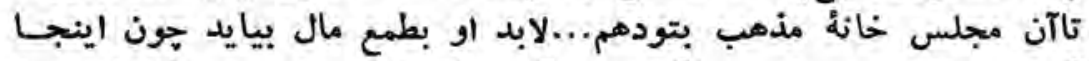

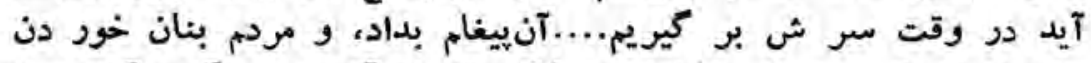

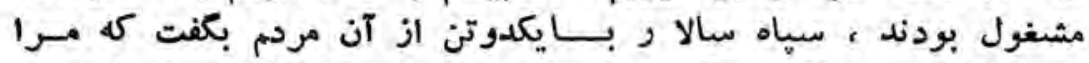

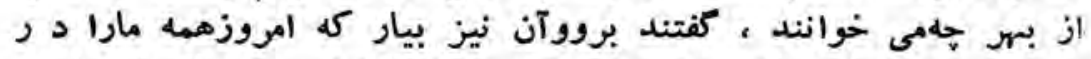

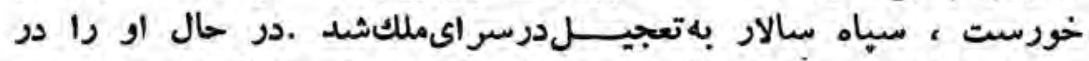

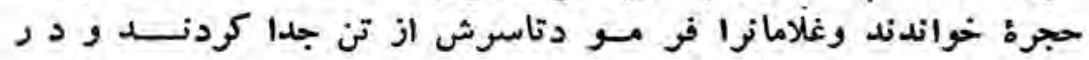




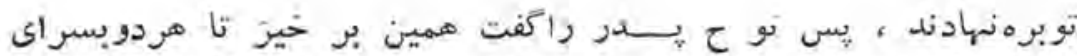

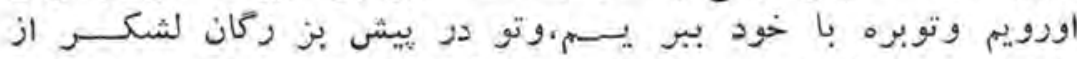

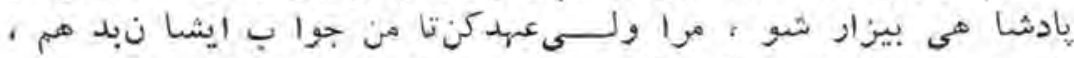

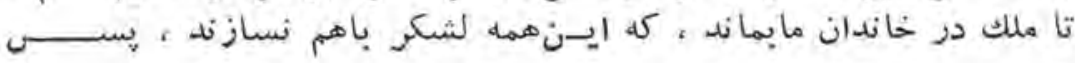

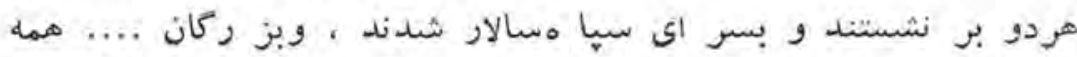

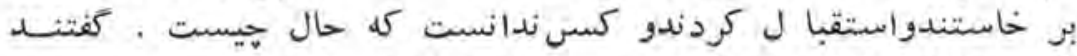

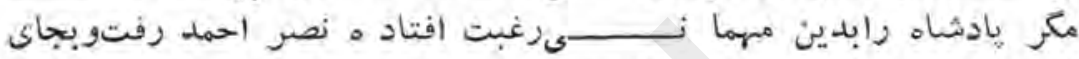

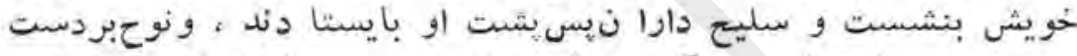

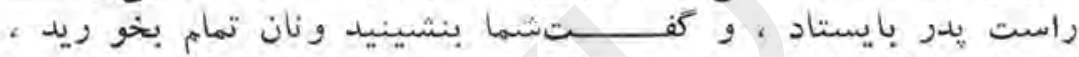

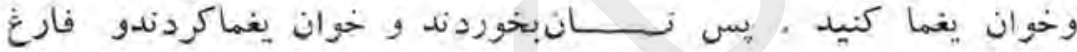

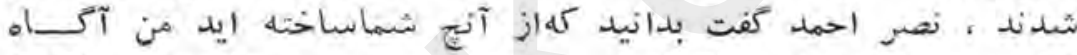

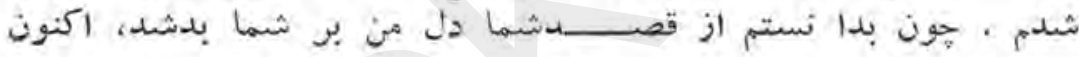

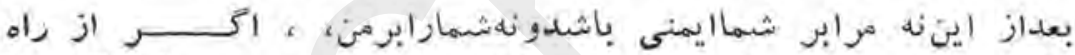

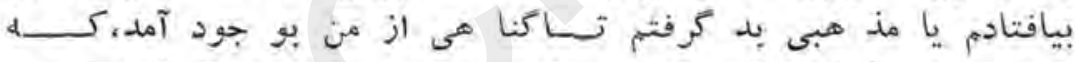

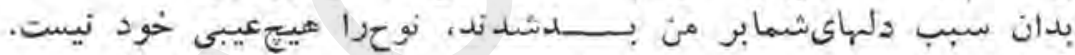

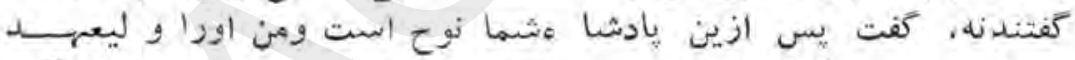

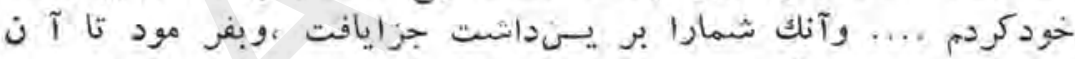

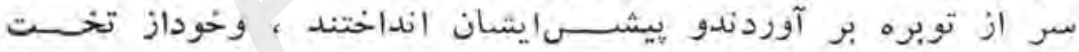

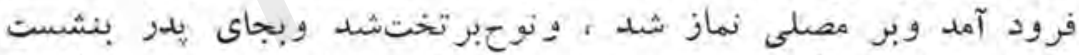

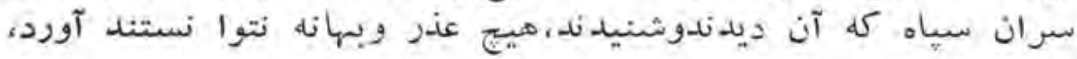

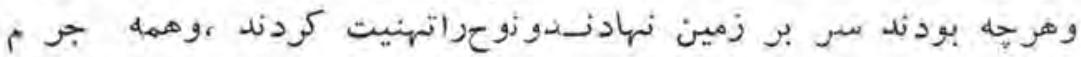

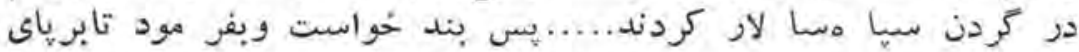

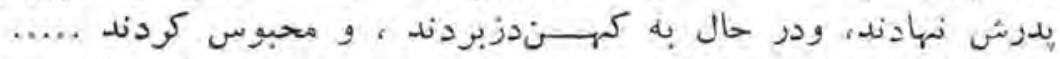

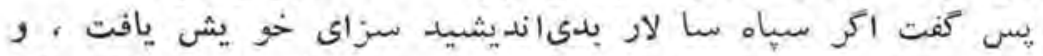

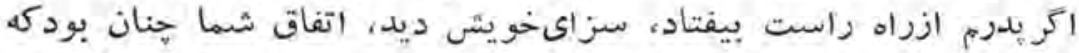

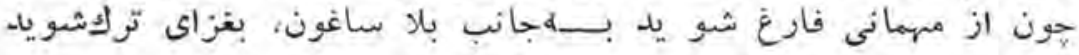

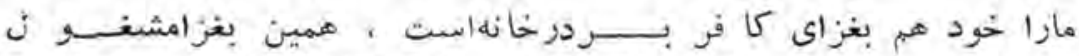

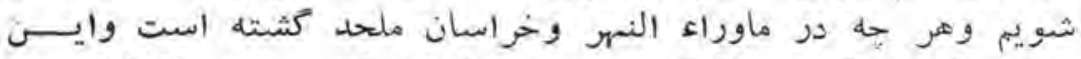

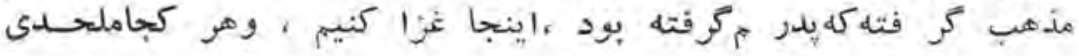




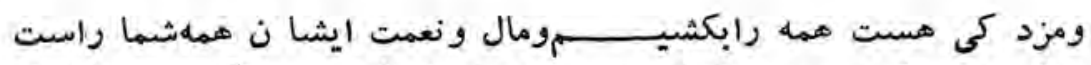

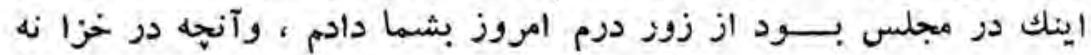

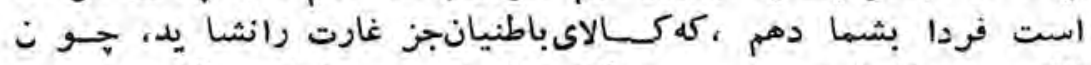

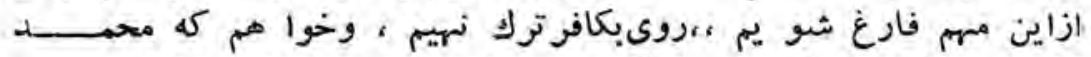

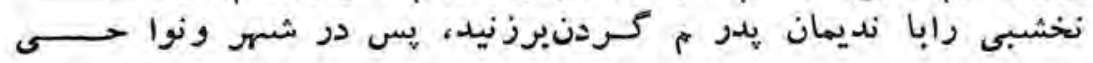

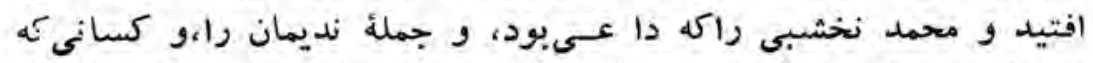

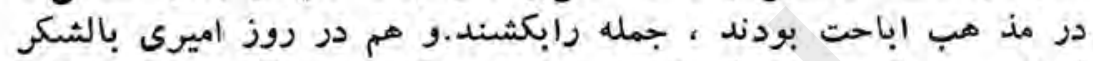

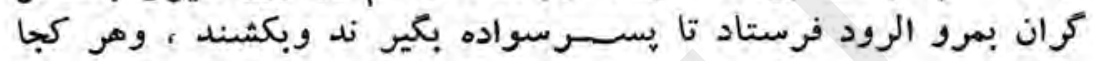

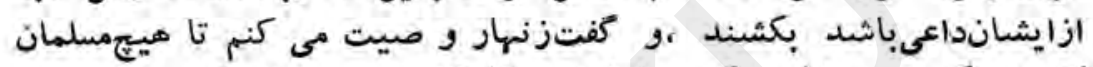

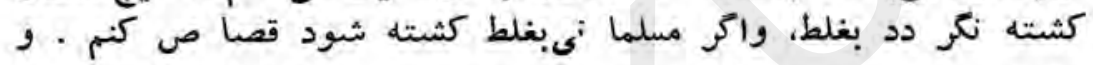

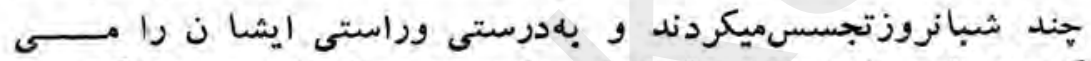

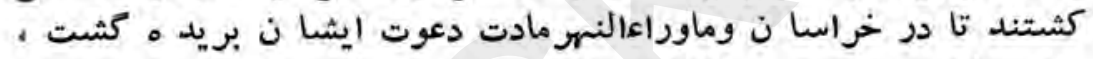

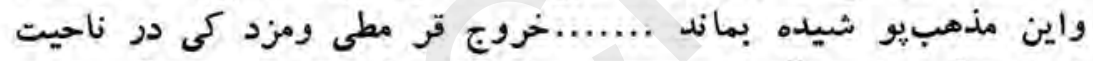

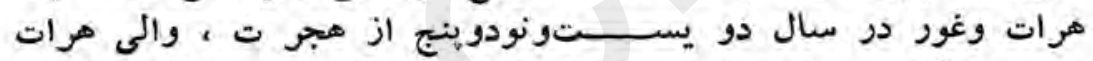

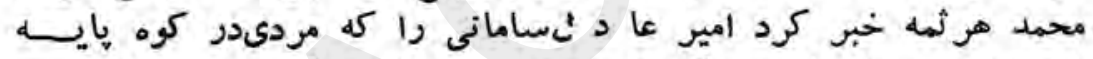

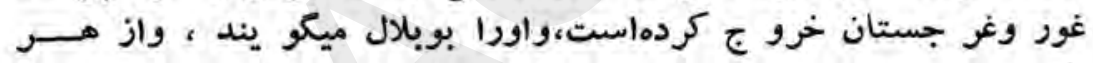

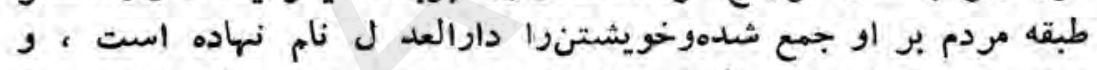

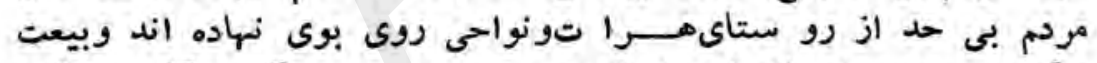

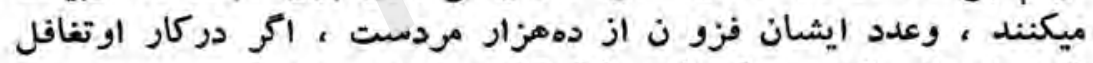

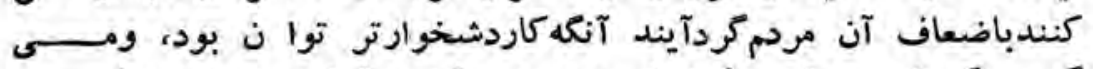

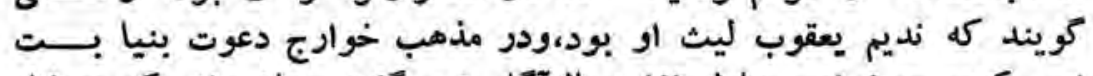

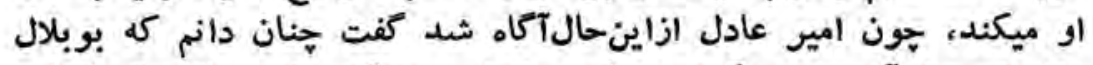

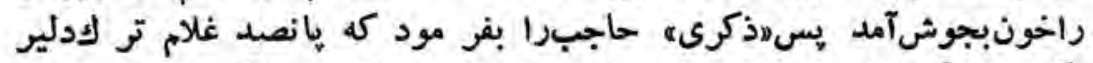

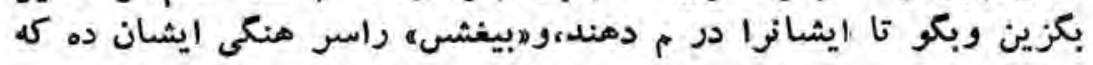

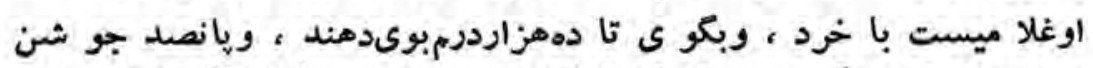

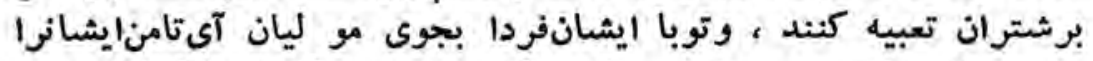

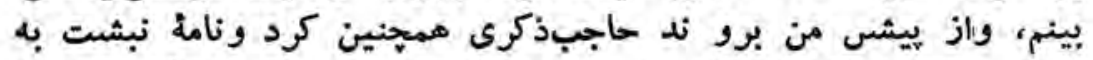

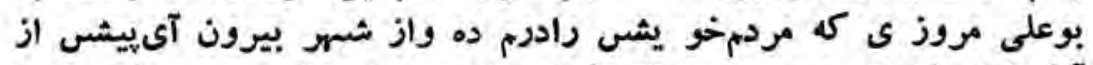

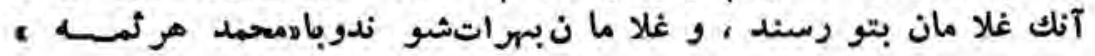




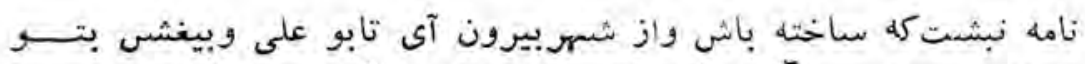

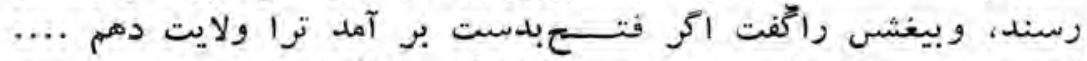

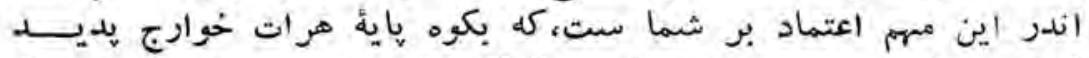

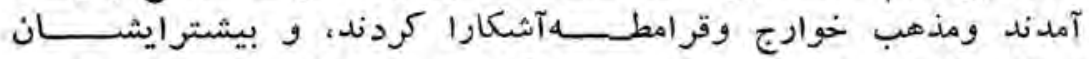

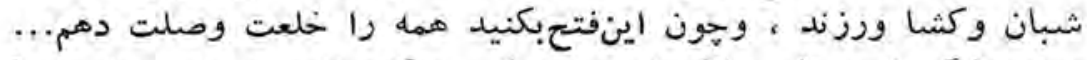

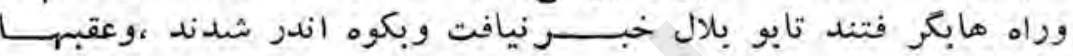

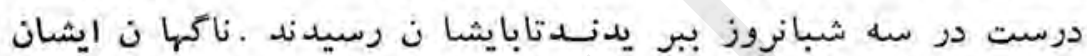

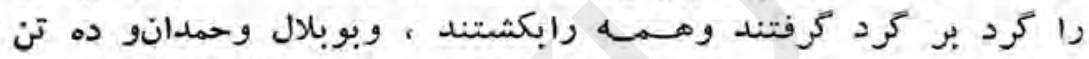

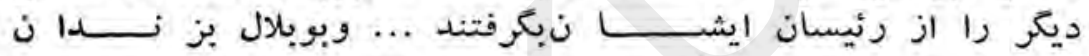

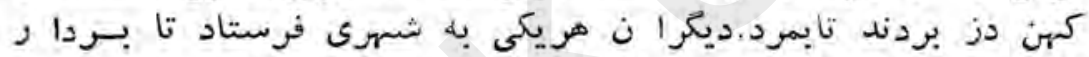

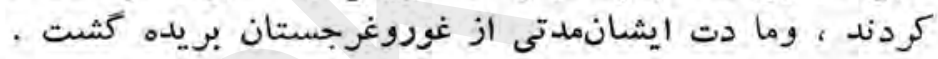

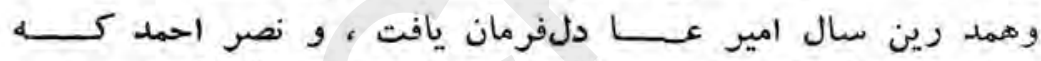

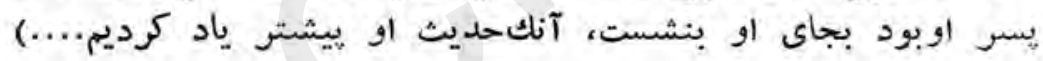

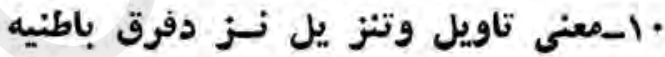

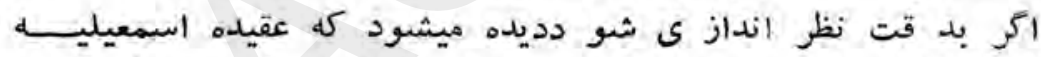

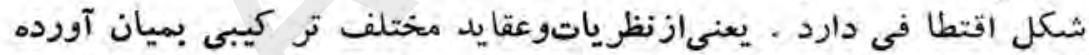

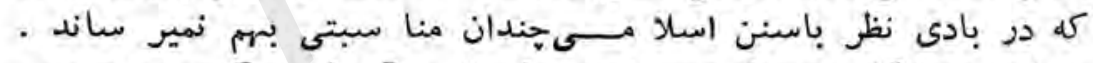
بسيارى از افكار اين مذ هب از دينهاى قدي إيم آسياى مركزى وبخصوص

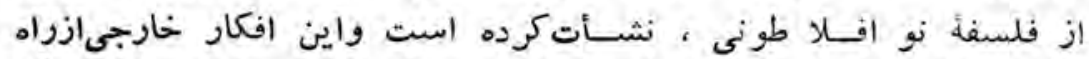

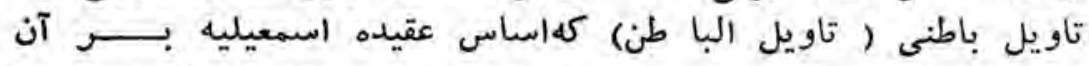

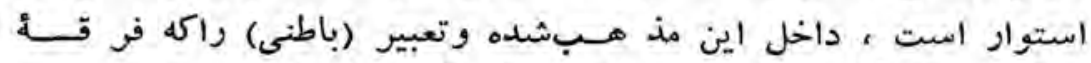

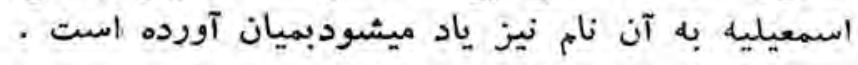

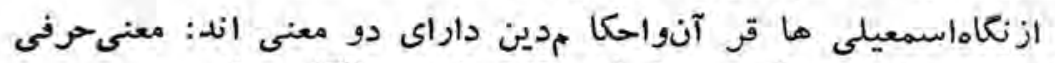

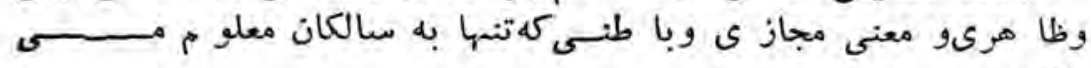
. باشد وطر

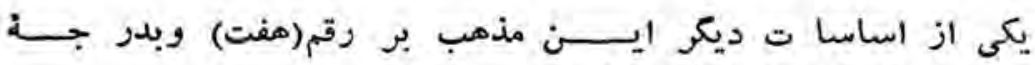

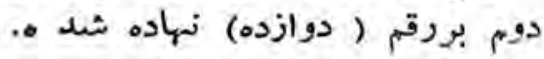


هعنى ناويل وتنزيل نزد فرق باطنيه

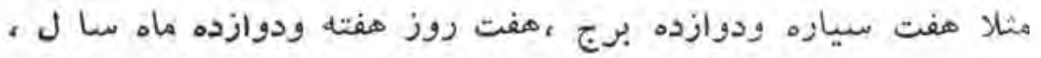

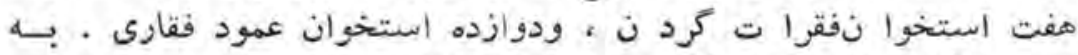

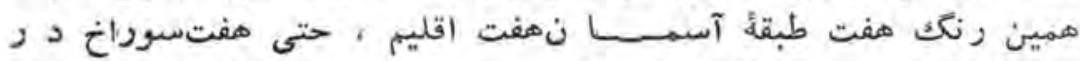

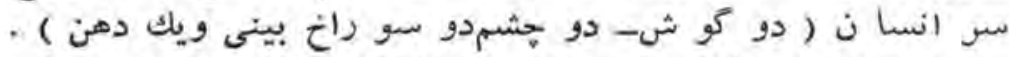

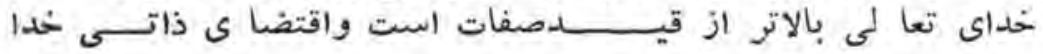

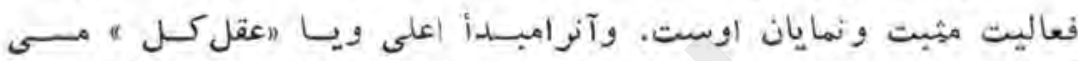

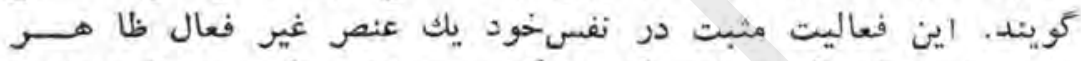

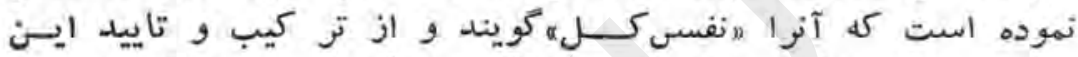

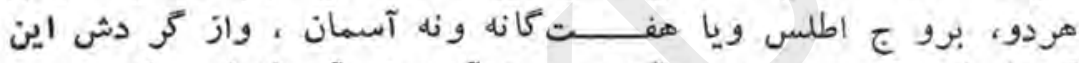

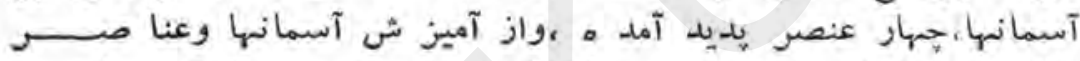

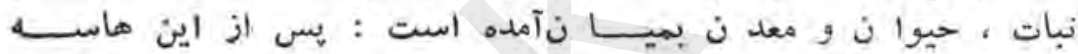

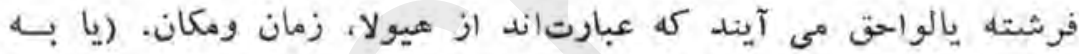

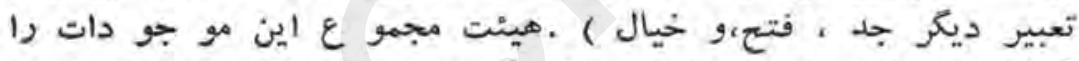

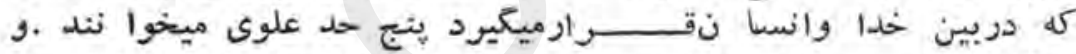

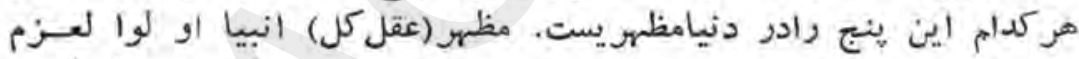

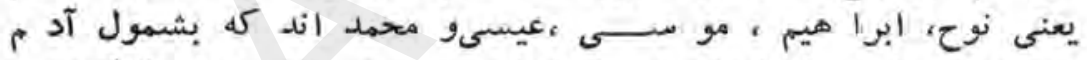

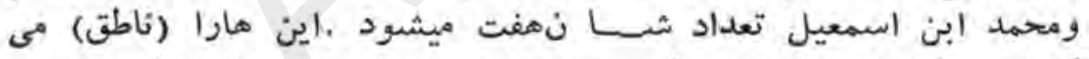

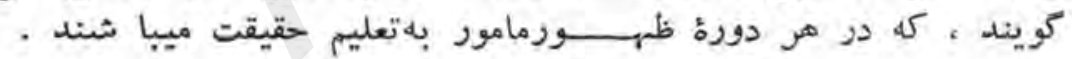

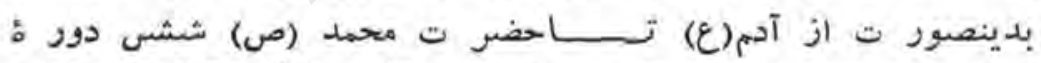

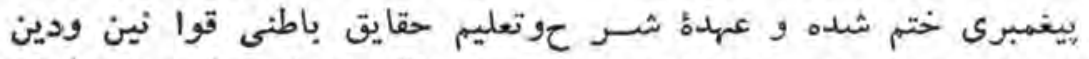

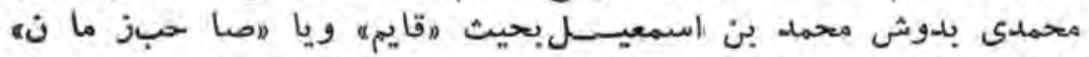

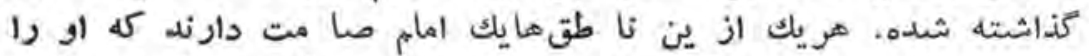

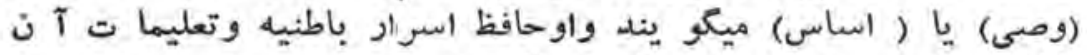

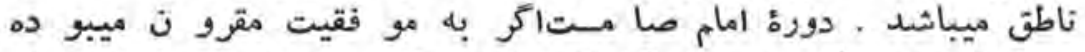

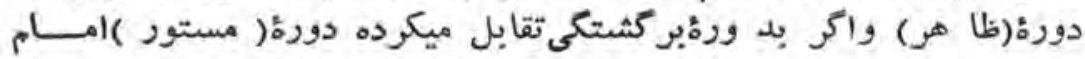

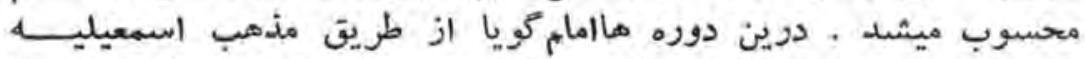

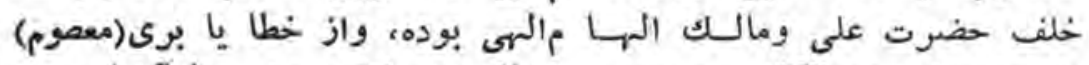

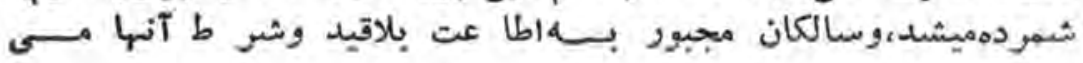




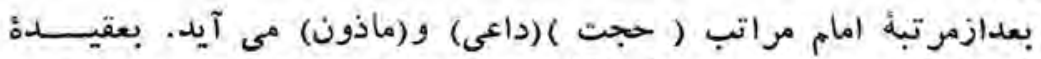

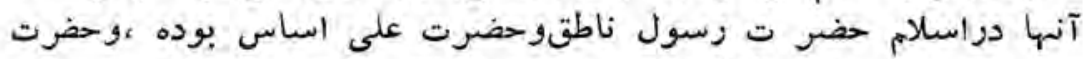

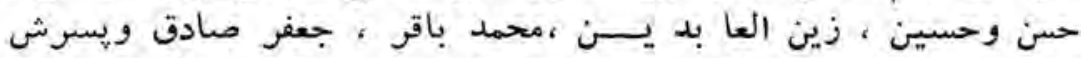

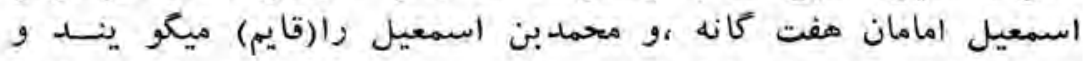

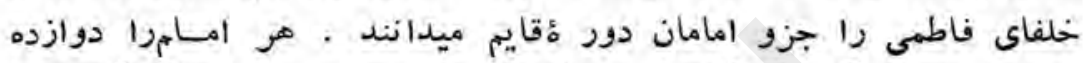

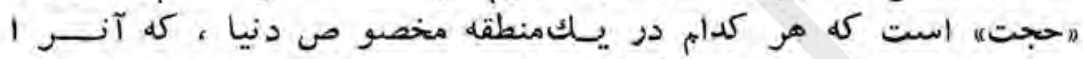

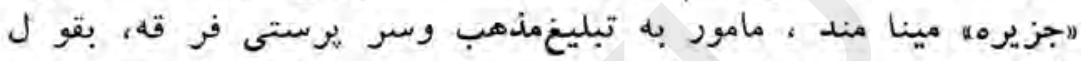

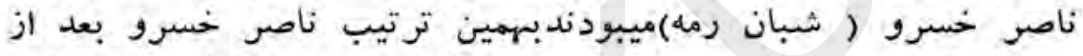

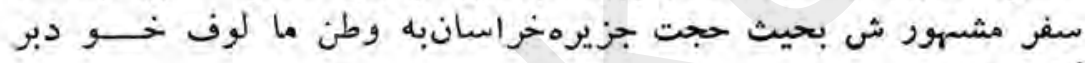

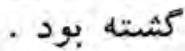

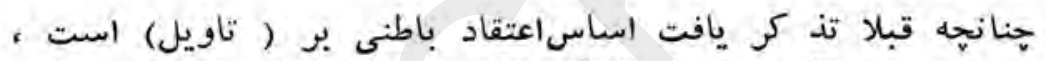

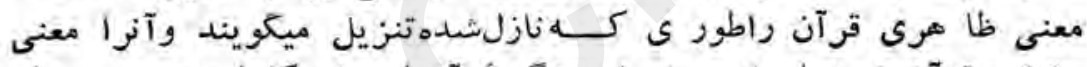

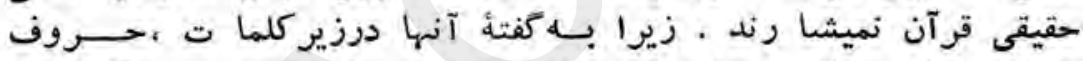

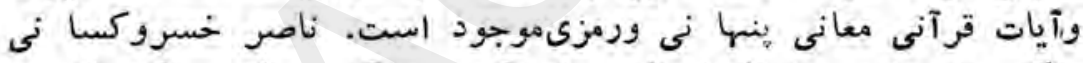

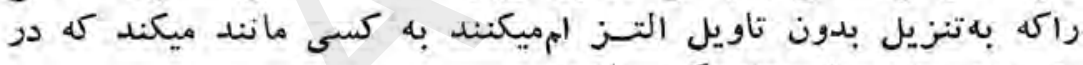

$$
\begin{aligned}
& \text { راه دين جشم را ستشسكور باشد: }
\end{aligned}
$$

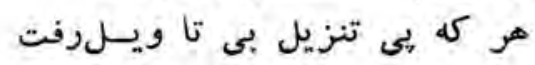

او بحشمراست در دين اعسـور استـت

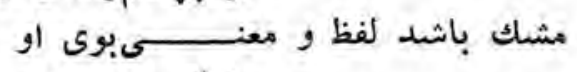

مشك بىبو، اى يسر ، خاو كمتر است

$$
\text { (ะ }
$$

$$
\text { همجنين ،مى كو يد : }
$$

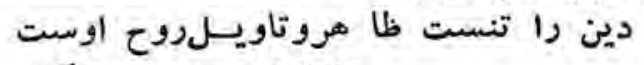

تن زنده جزبروح بكيتى كجاشده است!؟

$$
\text { (د) (د) }
$$

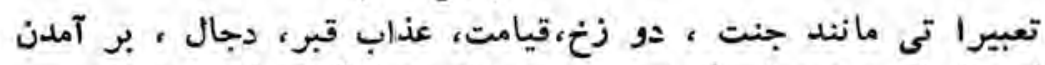

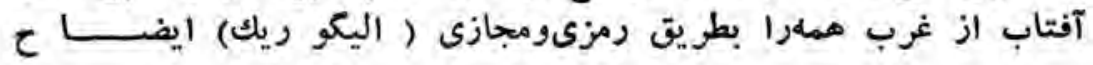




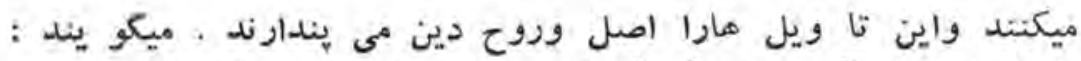

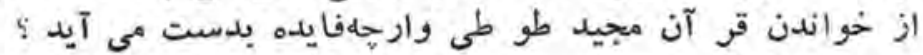

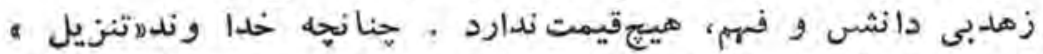

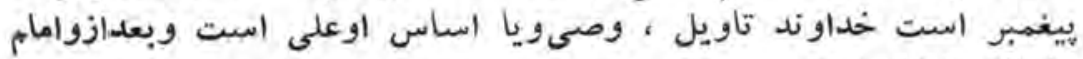

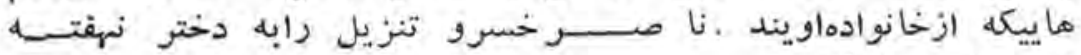

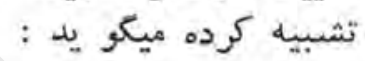

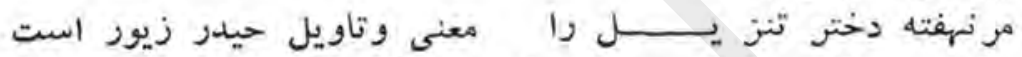

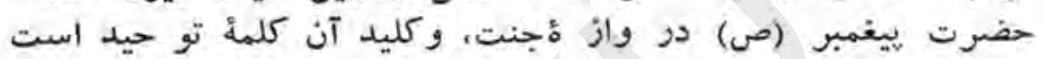

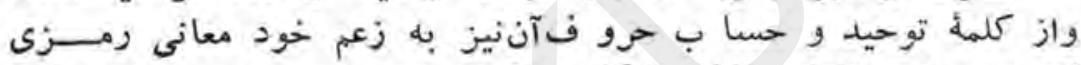

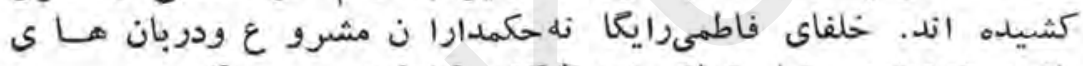

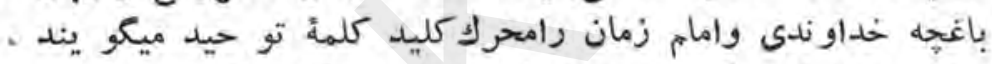

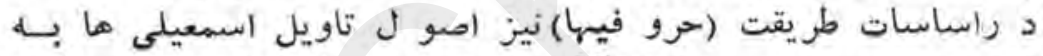

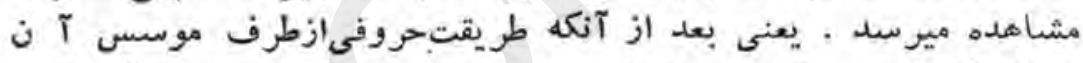

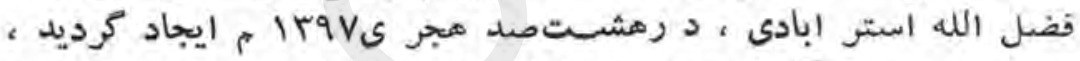

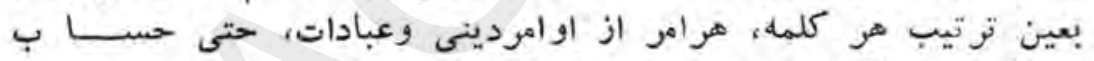

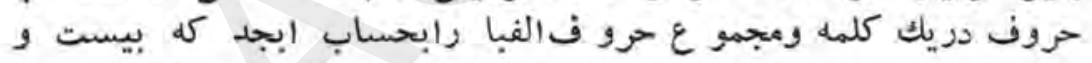

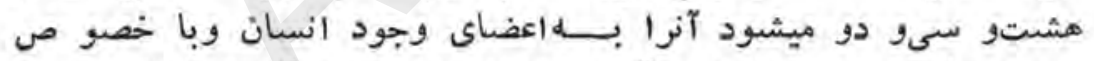

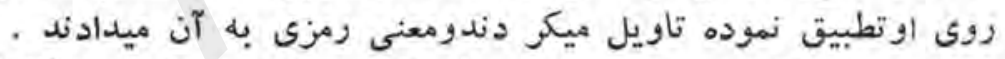

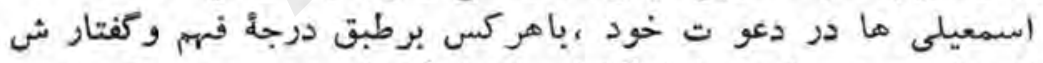

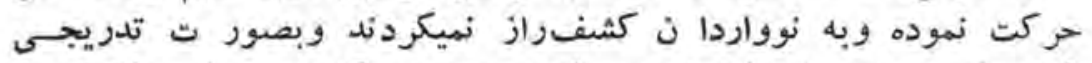

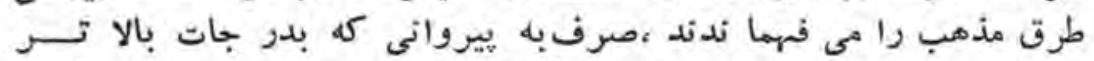

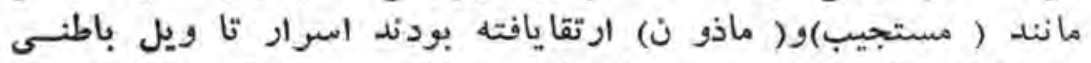

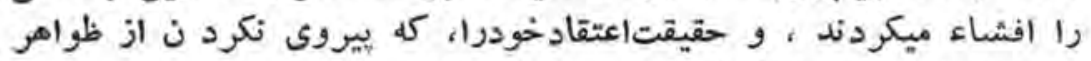

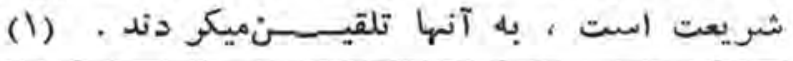

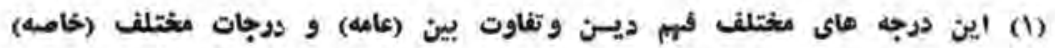

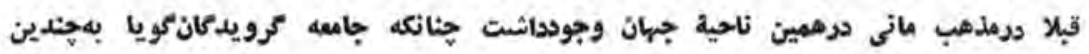

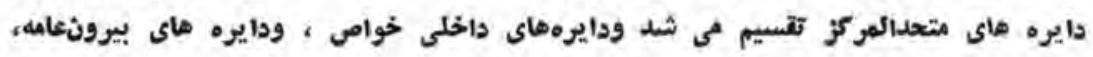

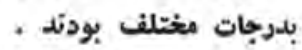




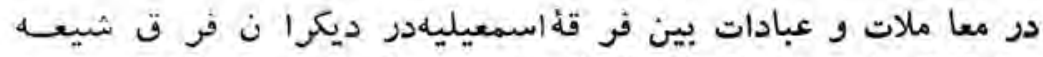

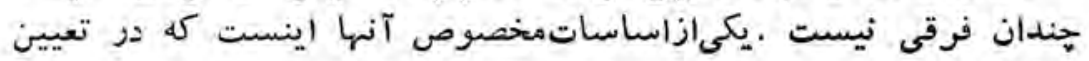

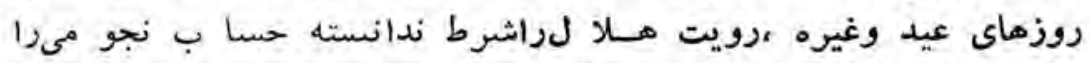

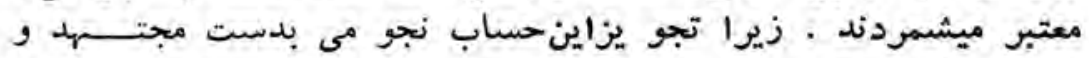

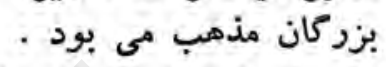

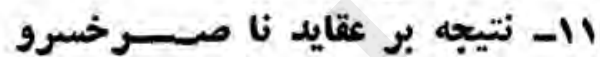

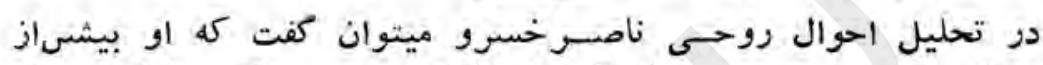

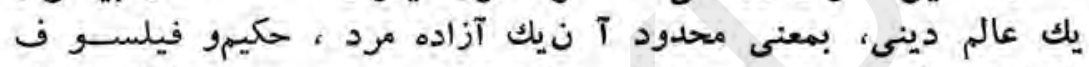

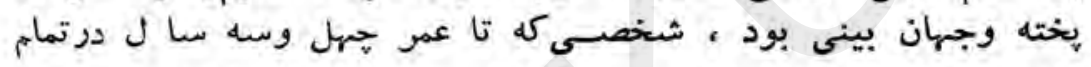

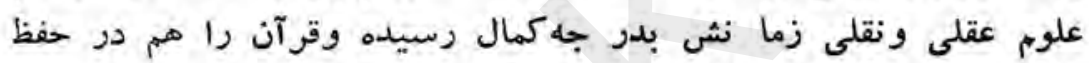

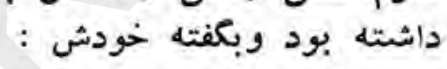

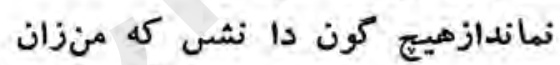

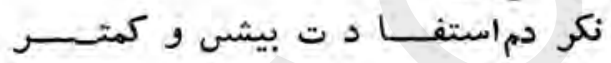

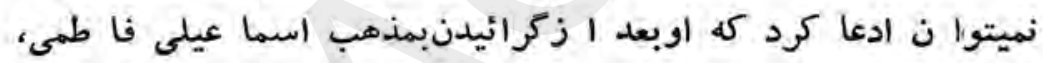

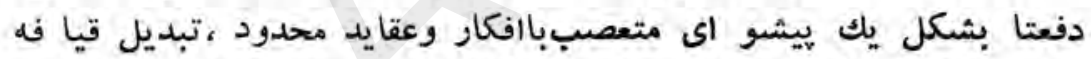

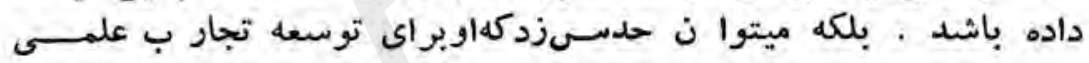

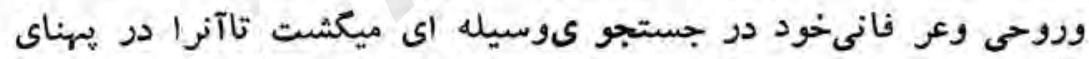

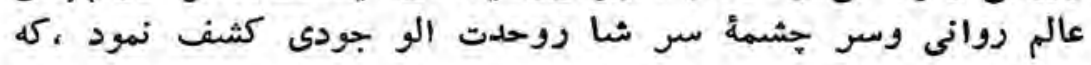

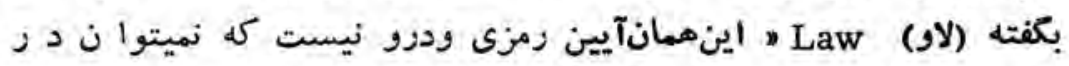

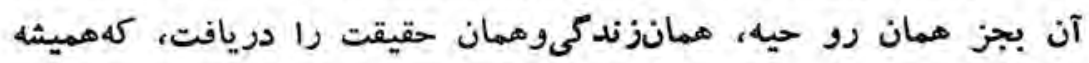

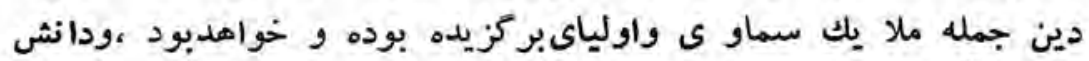

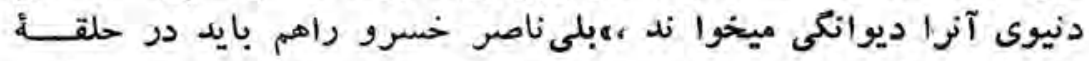

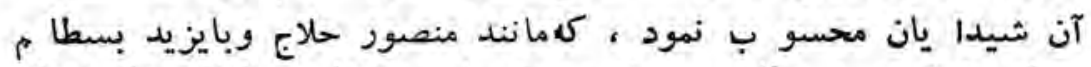

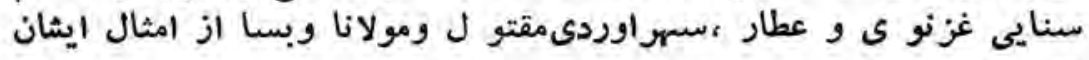

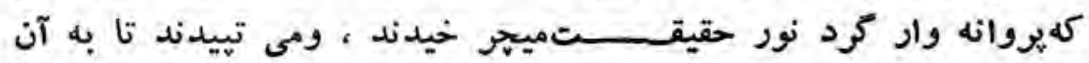

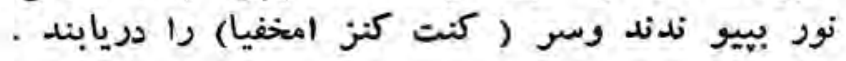


حق كفتش الى مرد زمان ، كنجىبدم من در نهان

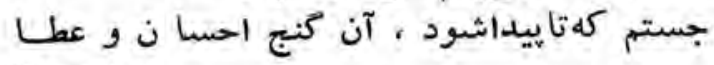

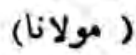

ازنكاه اهل تصو ف هر اختلافىكه در جهان بنظر ميخوردازتجليات مولات

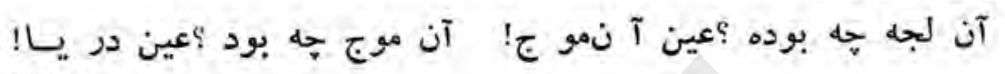

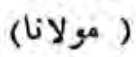

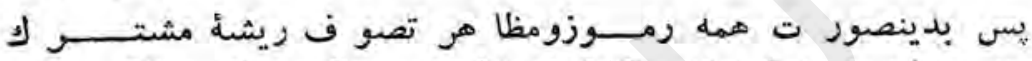

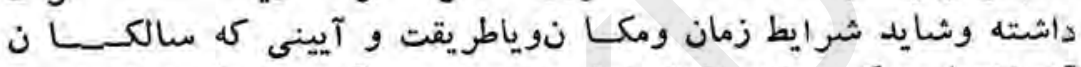

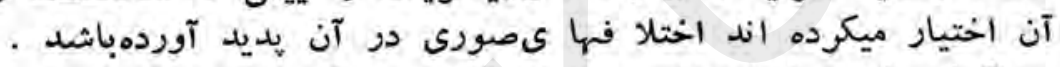

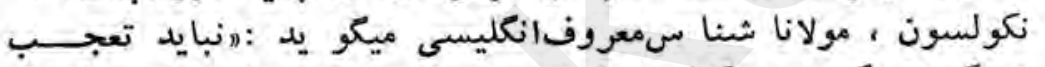

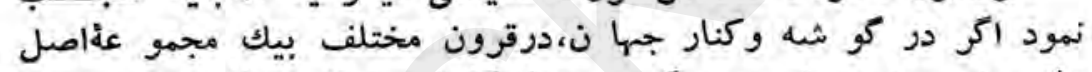

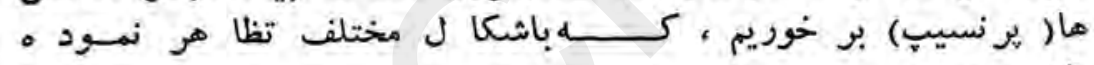

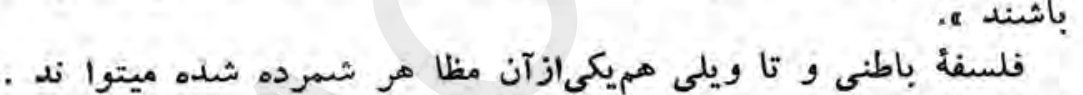

$$
\text { هولانا ميكويد : }
$$
ز يســـــاهر باطنى هم قا هـر است

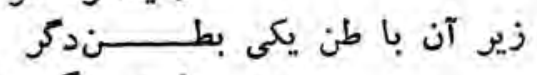

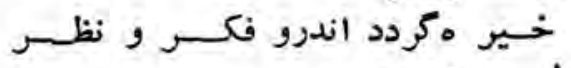

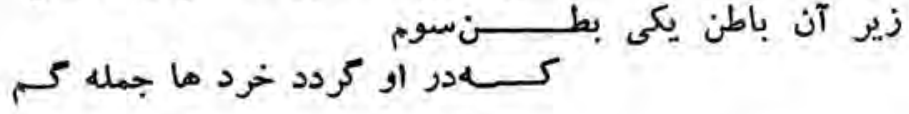

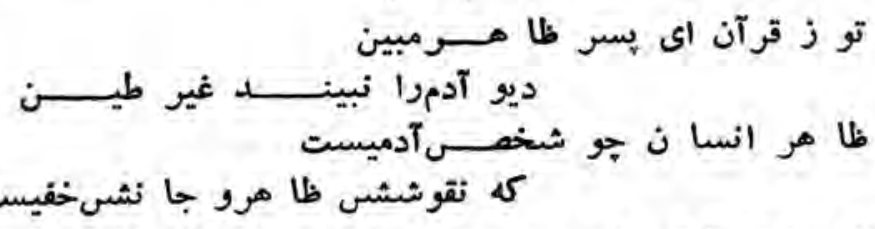

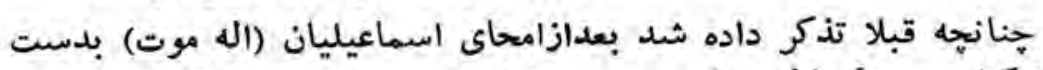

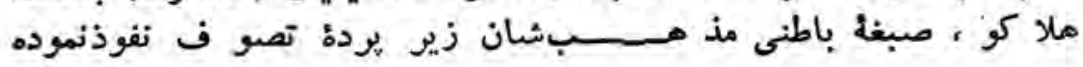




\section{IIE}

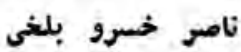

ومائند قطره در دزيـاى و حســــوجود درآميخت وبانغمه آن دمس از كرديد.

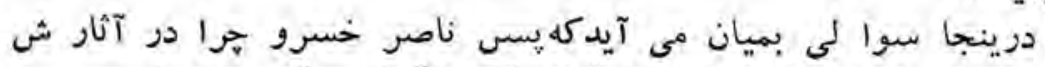

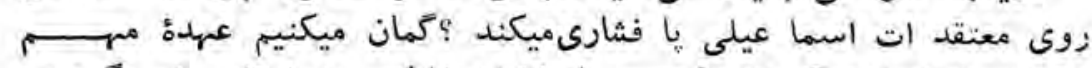

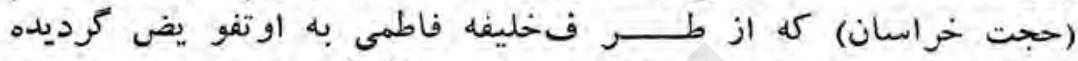

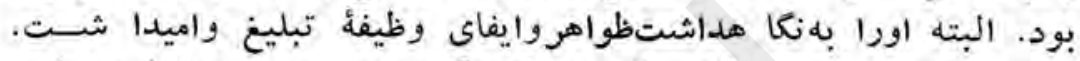

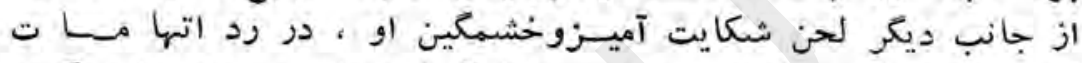

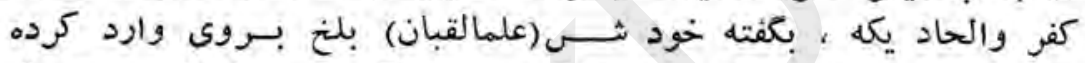

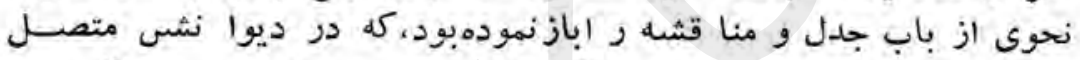

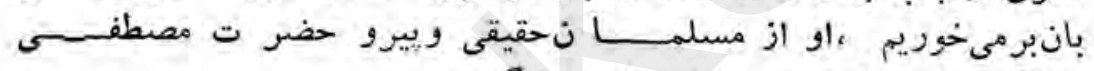

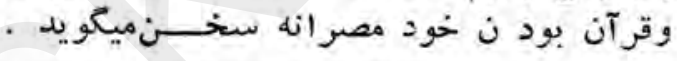

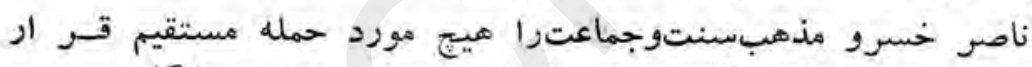

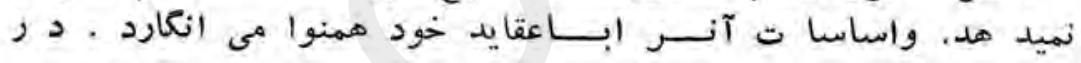

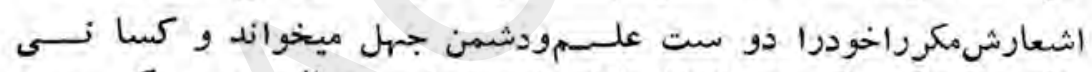

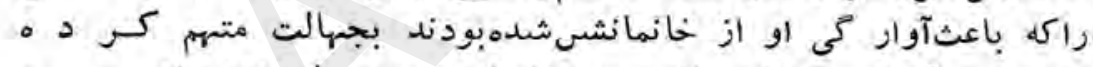

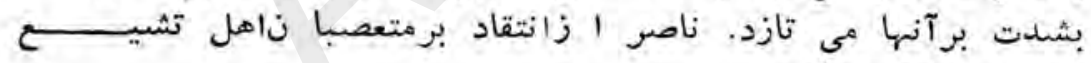

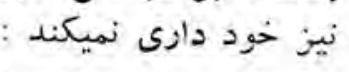
فتنهابجهلوشيفئئ كر بلاشدهاست

$$
\text { اين از بلا كر يخته يعنى كـهنياعيم }
$$




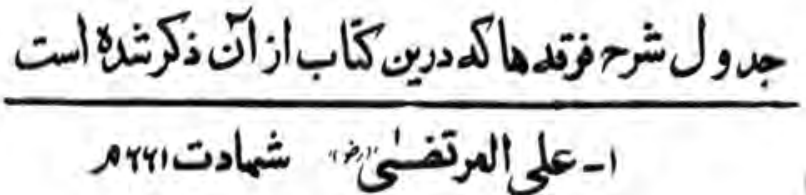

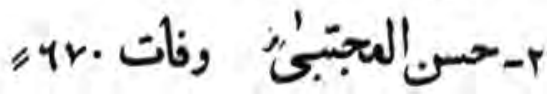

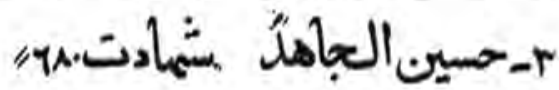

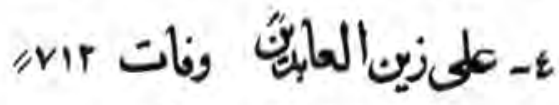

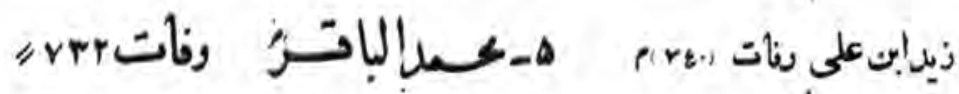

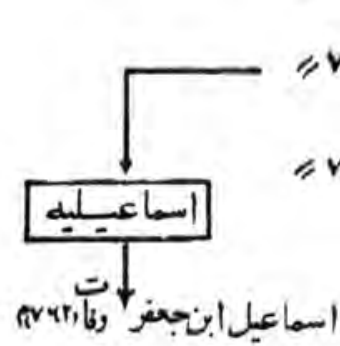

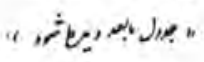

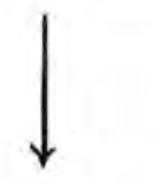

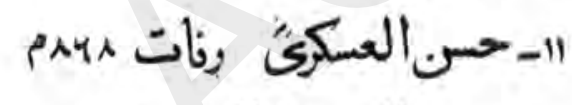

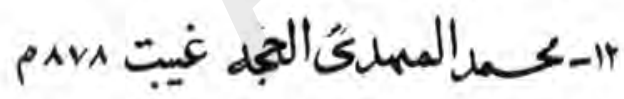

$$
\begin{aligned}
& \text { " امامتختور ). }
\end{aligned}
$$

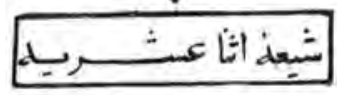

$$
\begin{aligned}
& \text { درعاتِ رابــــات } \\
& \text { وحوالى آن }
\end{aligned}
$$

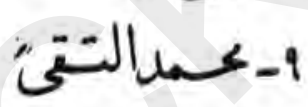

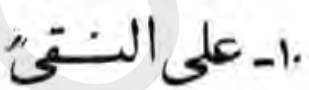
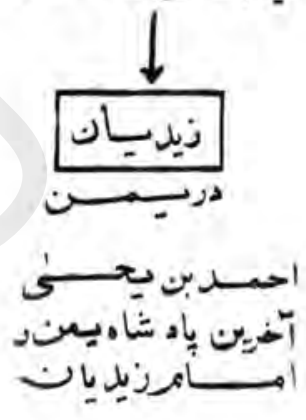

كسمد ابن لفسبربصرى

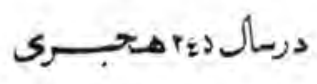

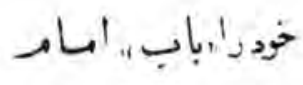
دماعلإِ كــر

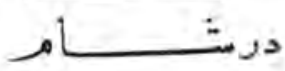




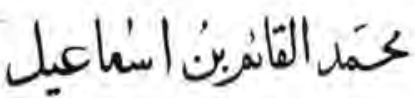

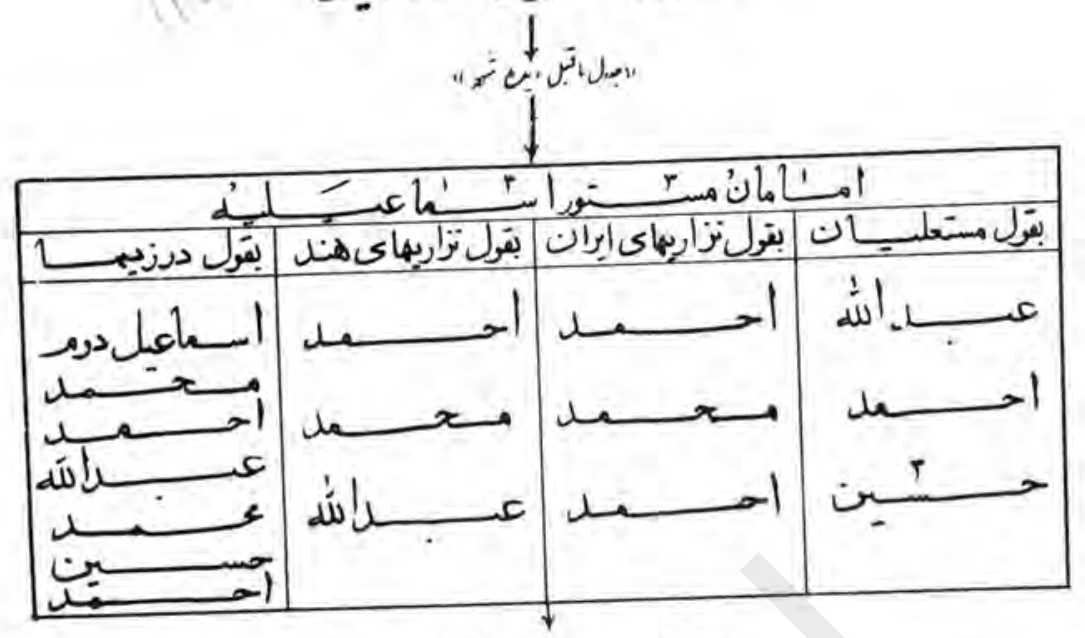

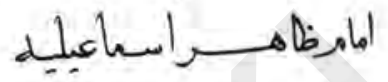

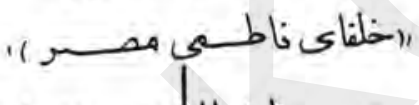

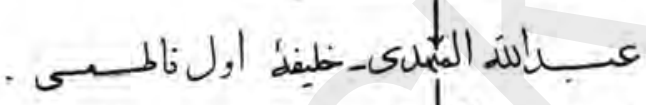

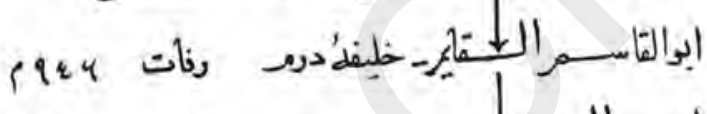

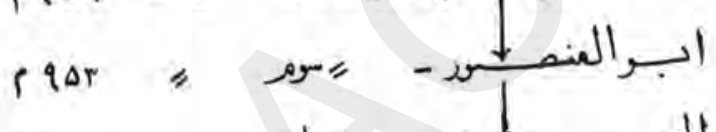

pqua " pla

iq94 "إنس

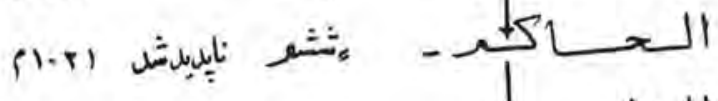

sirr sid

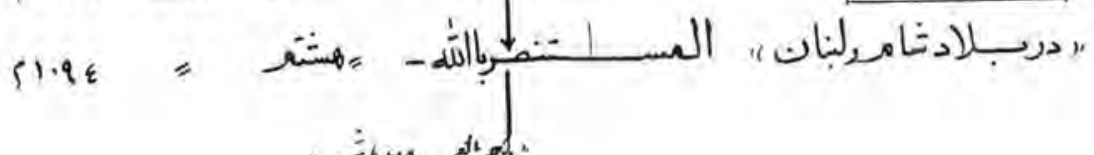
"and 


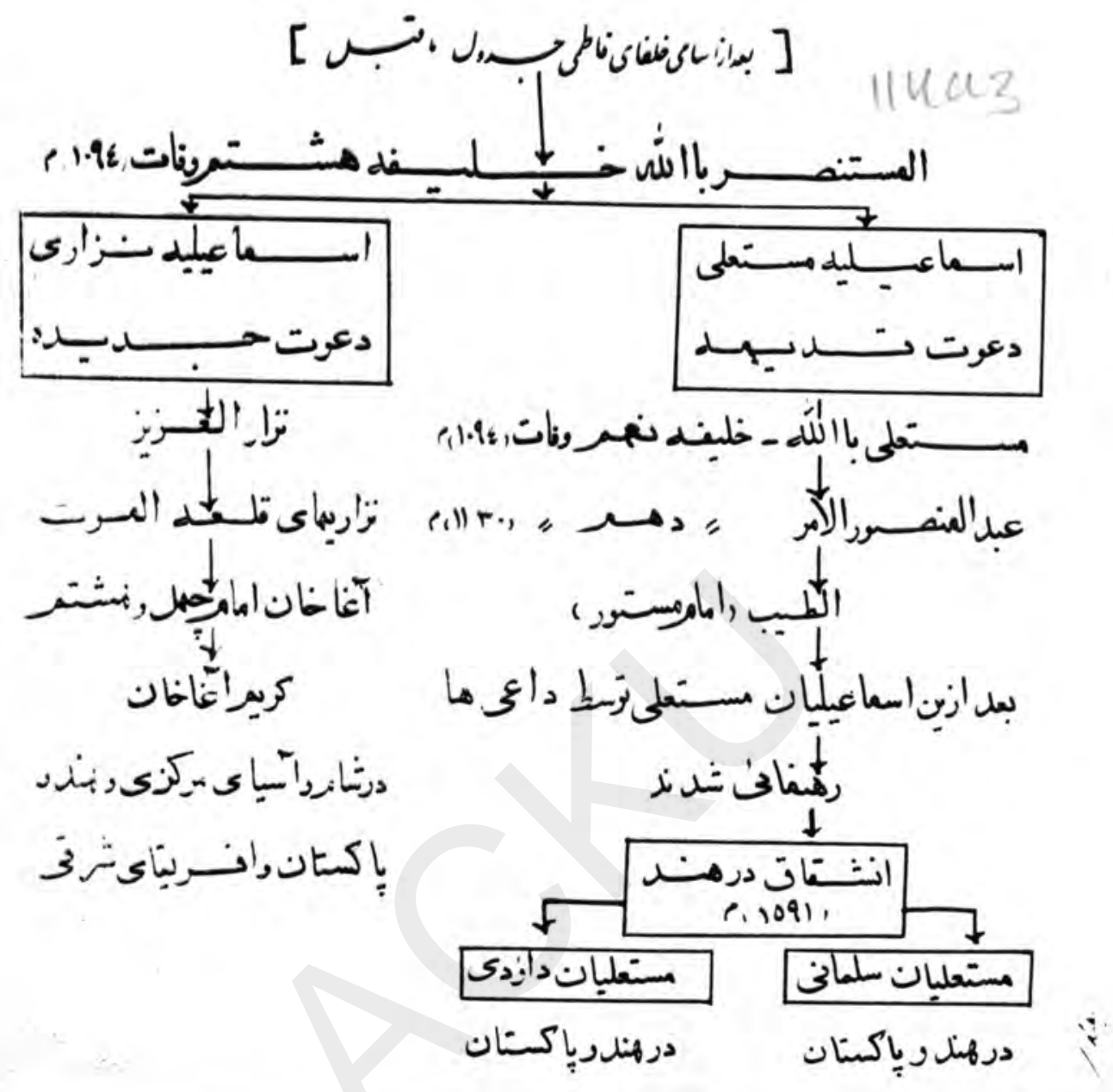

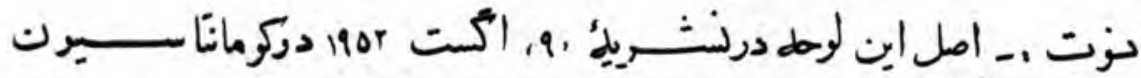

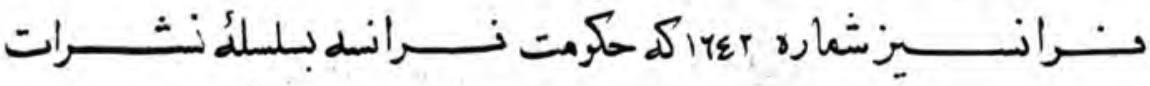

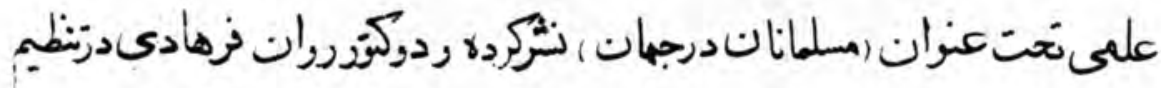

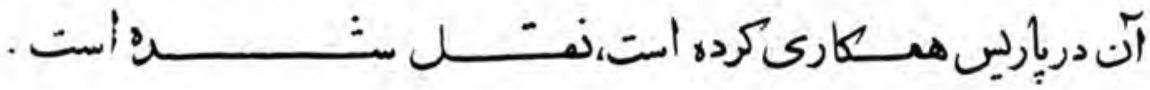




\section{فصلسوم \\ مؤلفات ناصرخسرو بلمخى}

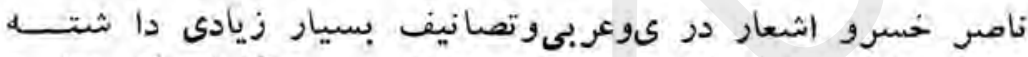

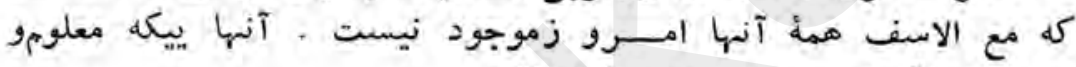
در صحت آن ترديلدى نيست عبارتنداز: آنها

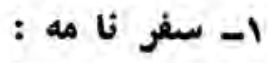

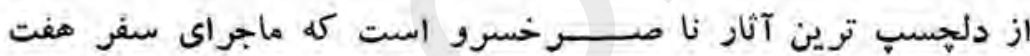

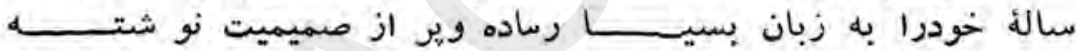

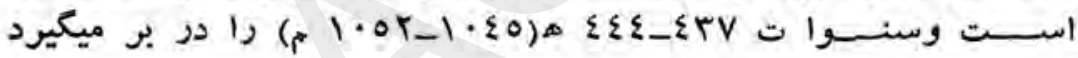

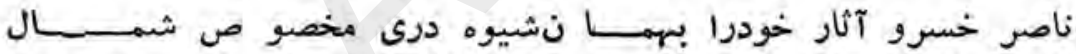

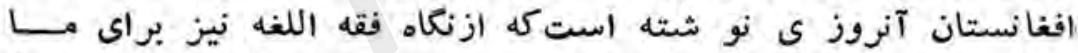

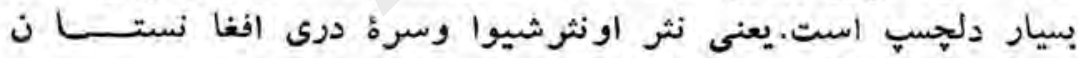

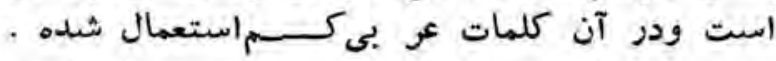

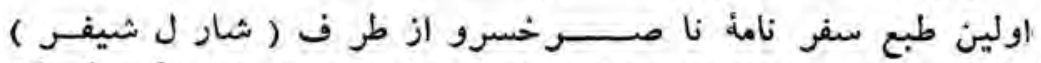
عالم فرانسوى در سنه المن

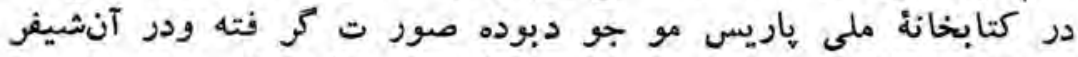

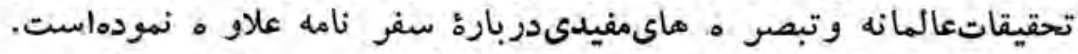

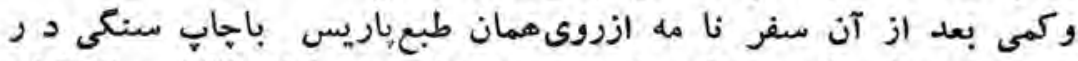

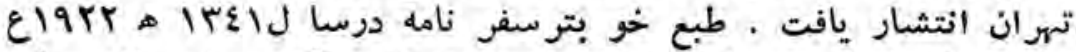

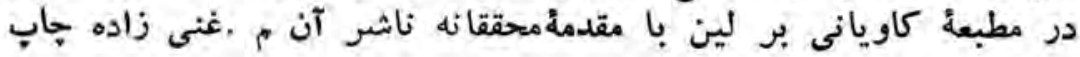




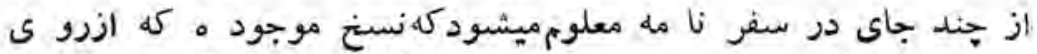

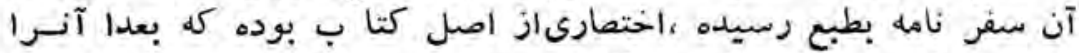

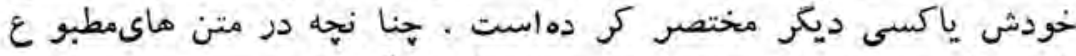

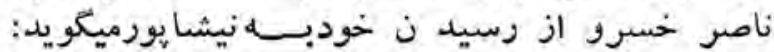

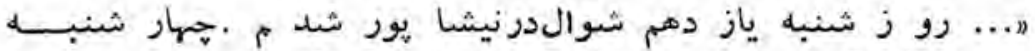

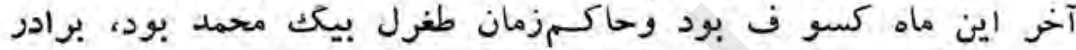

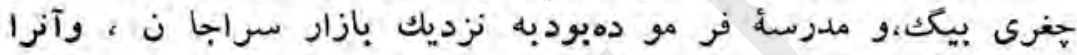

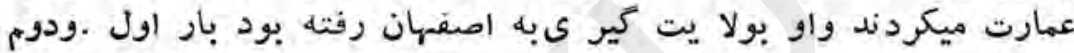

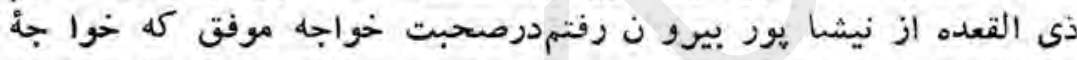

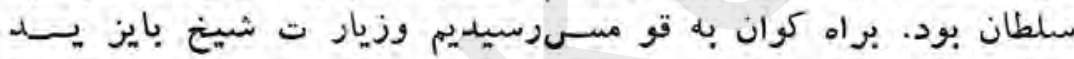

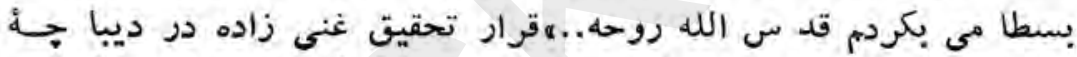

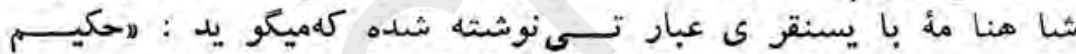

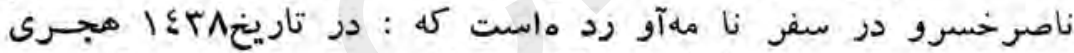

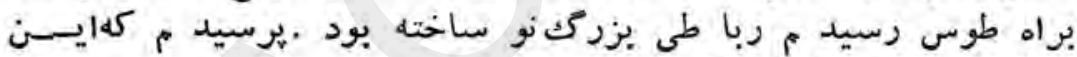

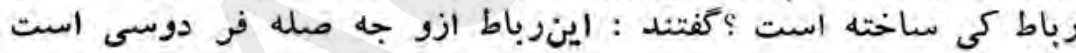

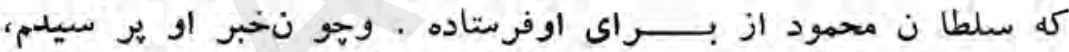

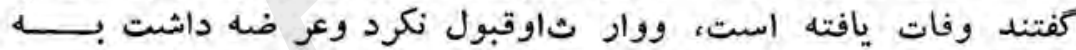

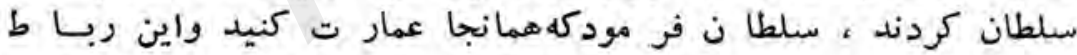

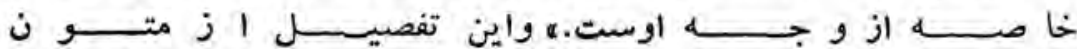

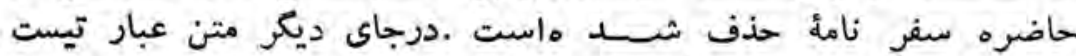

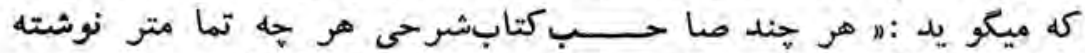

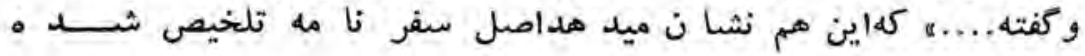
است وفله

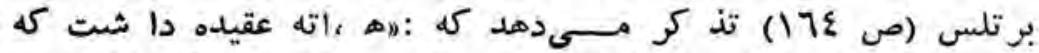

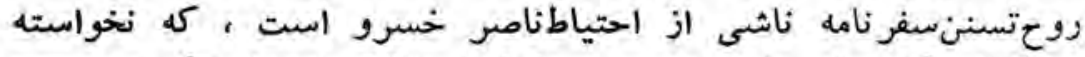

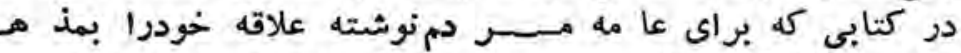

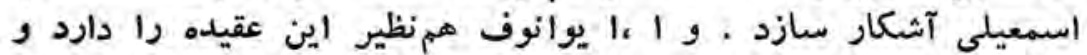

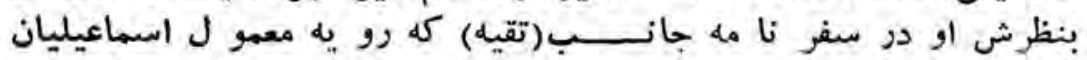




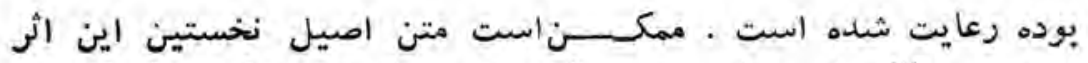

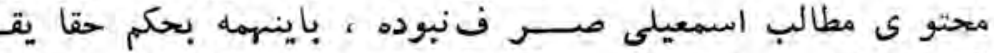

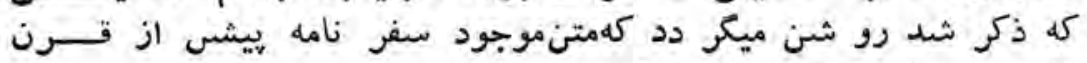

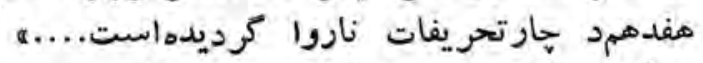

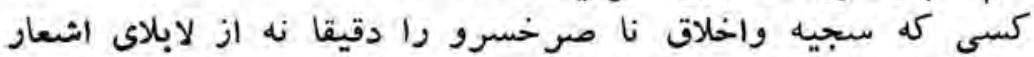

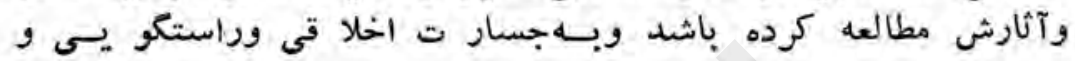

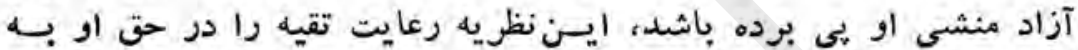

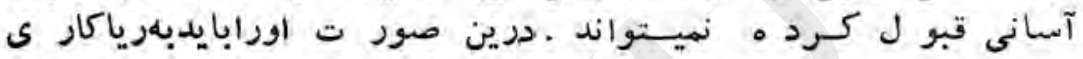

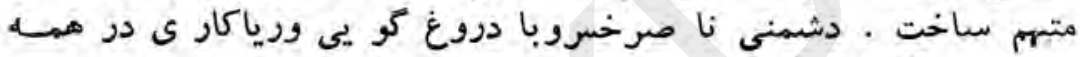

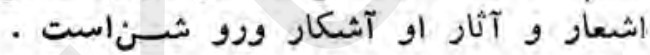

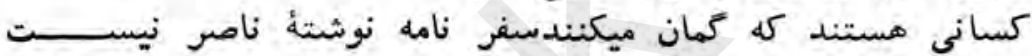

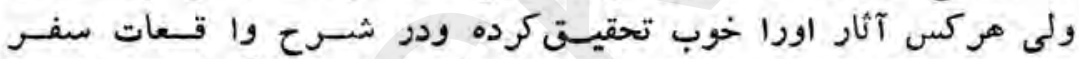

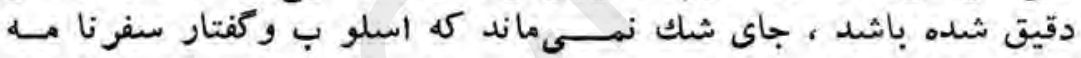

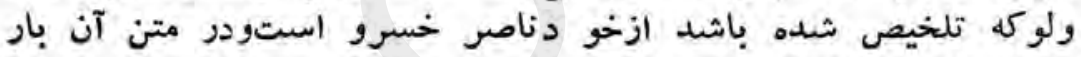

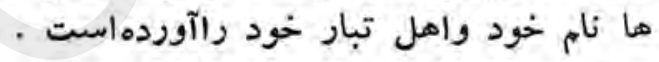
r- آن ديوان اشعار

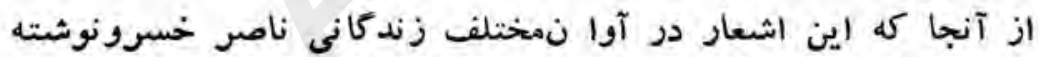

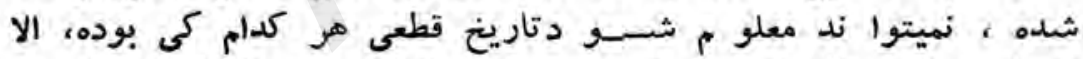

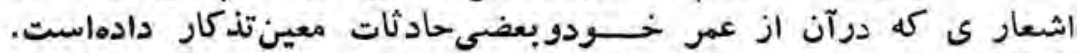

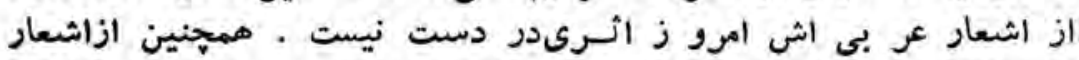

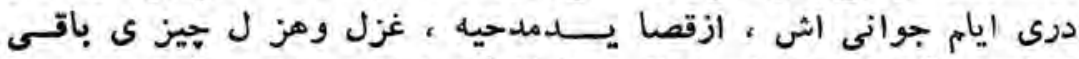

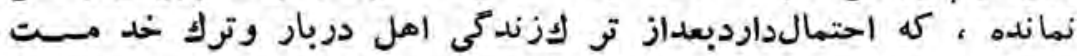

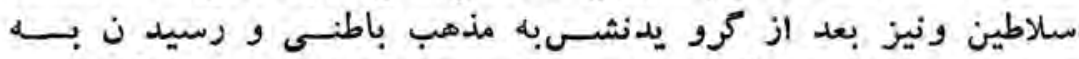

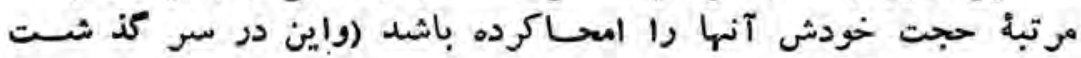

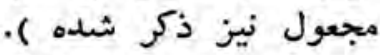

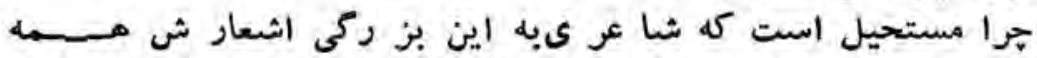

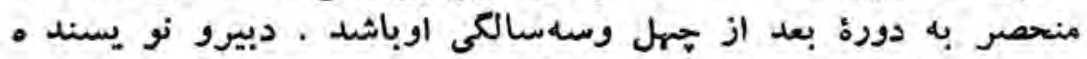

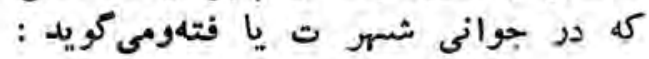




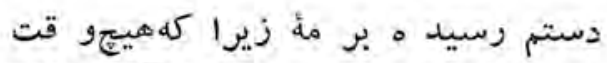

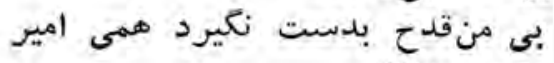

$$
\text { بيشى وزير با خطروحشمتم بدانك }
$$

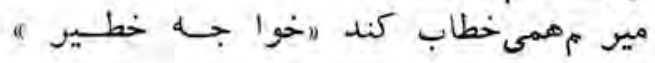

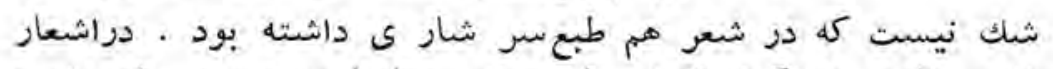

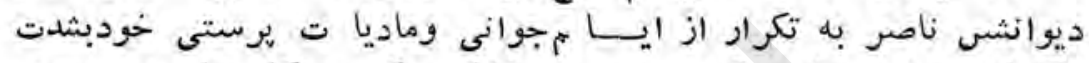

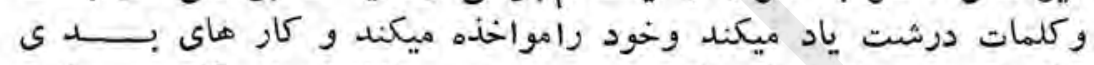

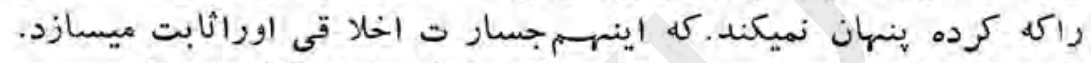

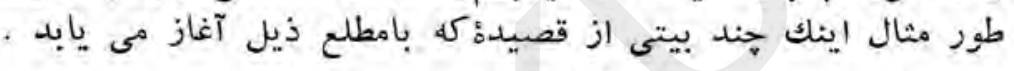
با خو يشتن شمار كن الىهوشياريير: تابر تونوبهار به مايه مايه كذ شت وتير؟

\section{ز اول جنانت بود كمان كاندرين جهان}

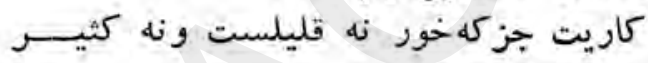

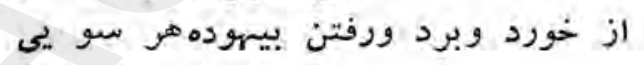

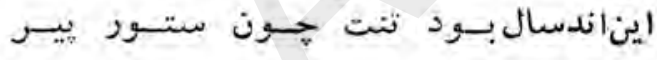

$$
\text { با ناز وبى نيازبيدار ى وبه تواب }
$$

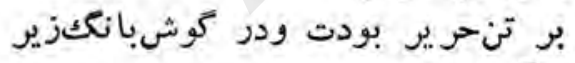

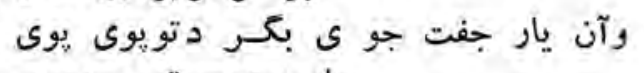

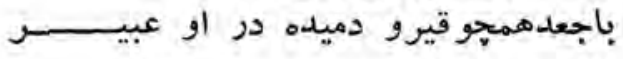

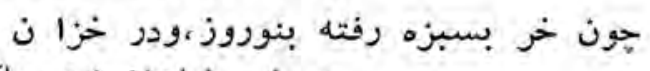

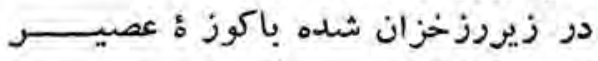

كفتى كه خلق نيست جو من نيز در جهان

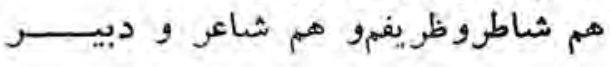

جشمت هميشه مانده بد ست توانكر ان

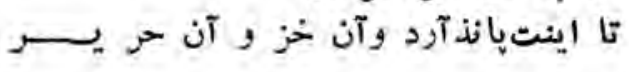


يكسا ل بر كتَ شت كه ز ى تو نيافت بار

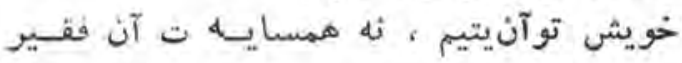

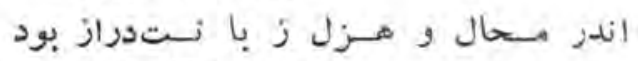
واندر زكاتدستت وانششئكا ن قصيــر

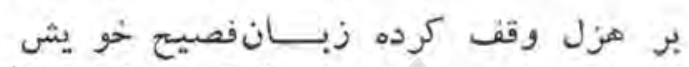

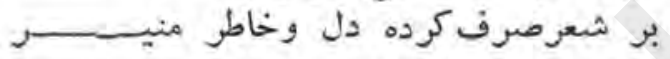
آن كردى از فساد كه كريادت آيد آن كرده رويتسياه كردد وتير مشود ضمثيد

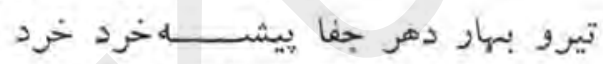

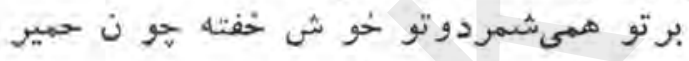

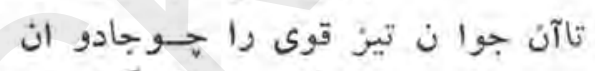

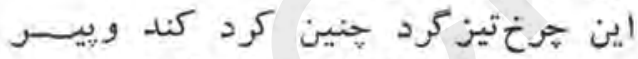

$$
\text { (ديوا ن ص مر كرد (107) }
$$

$$
\begin{aligned}
& \text { در قصيد : ديكى ى ميكو يد : }
\end{aligned}
$$

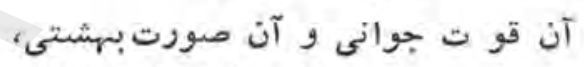

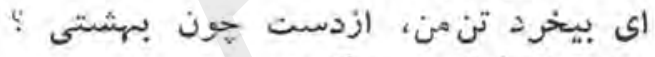

$$
\text { تاصور تت نكو بود ، افعا لز زنشت كردى }
$$

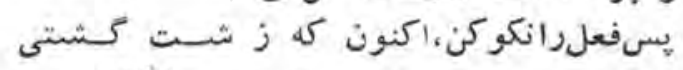

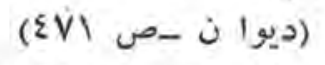

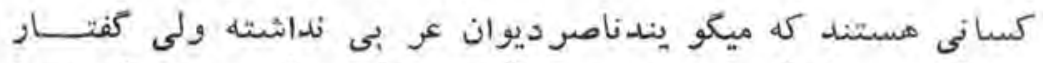

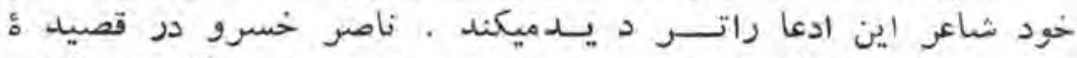

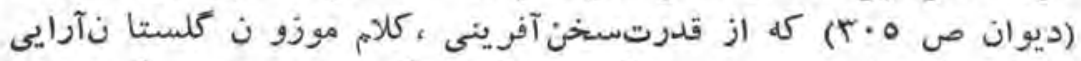

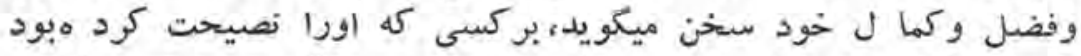

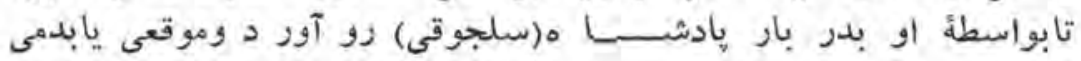

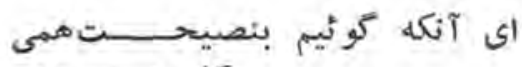

كا ين يير هن بيفكن وفر مان كن 
تاسخت زود من هــو فلا نمرتبـرا

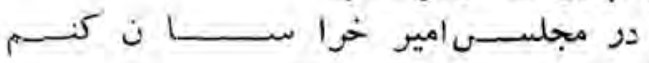

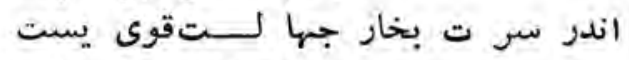

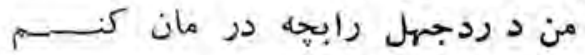

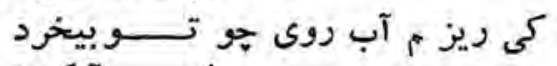

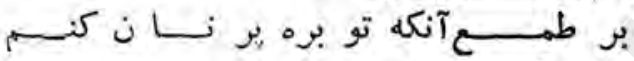

$$
\text { اى بد نصيحتى كل تو كر دي نســرا }
$$

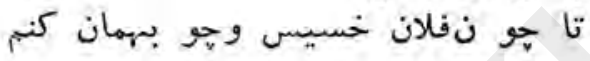

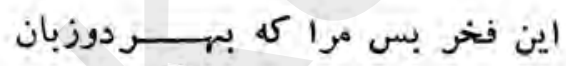

حكمت همى مر تب و دوزيوان

$$
\text { جان را زبهر مد حست آ ل كرول }
$$

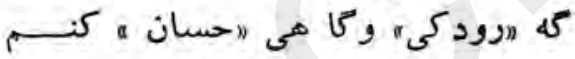

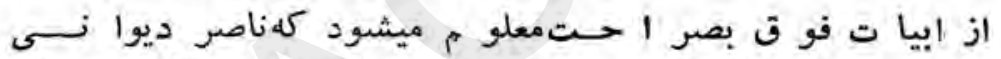

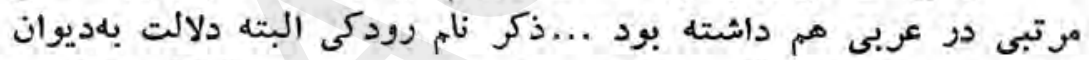

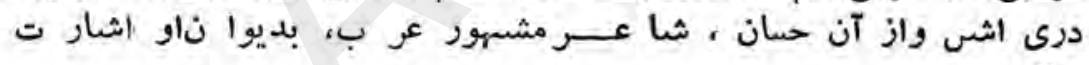

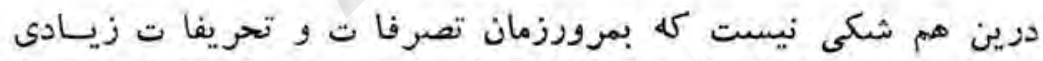

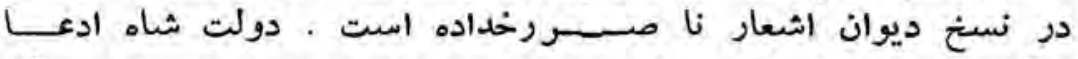

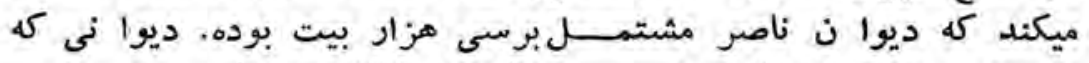

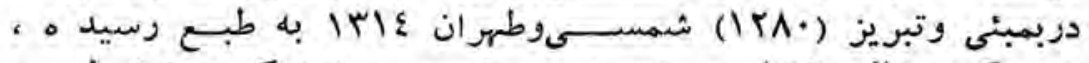

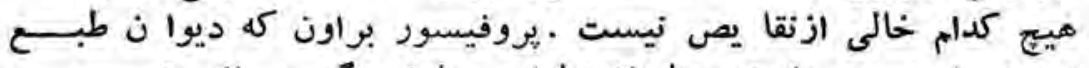

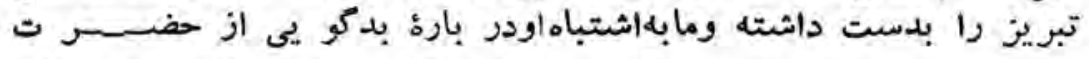

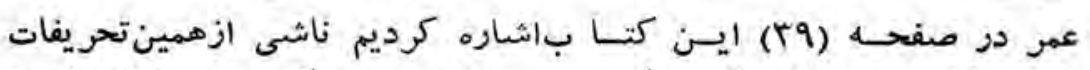

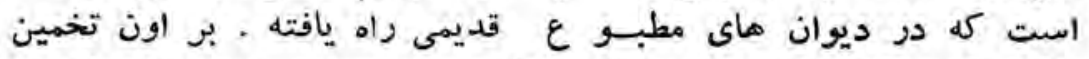

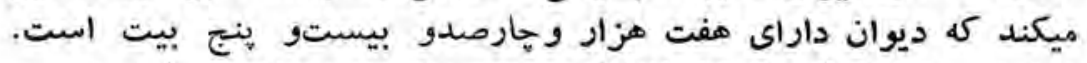

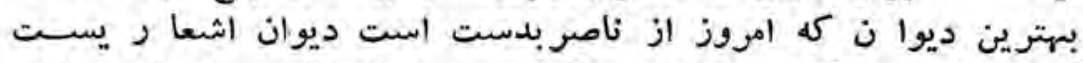

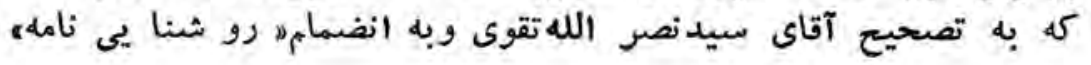




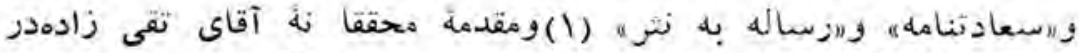

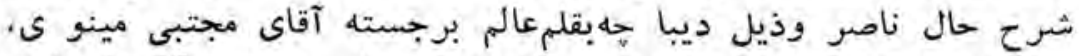

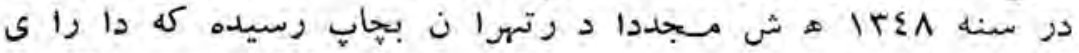

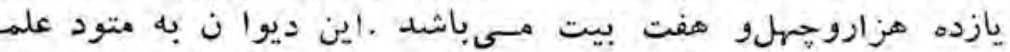

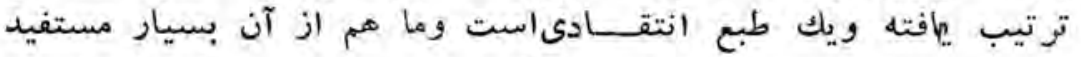

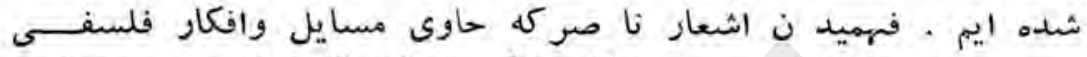

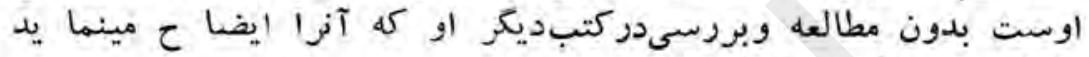

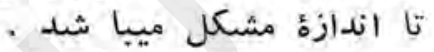

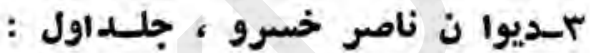

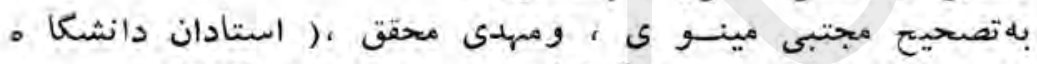

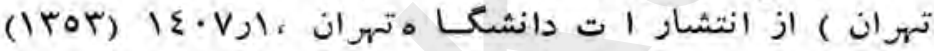

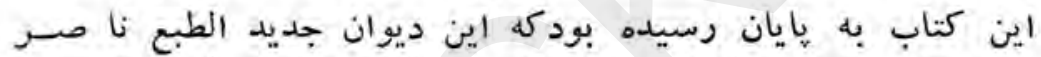

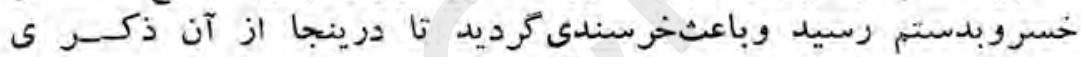

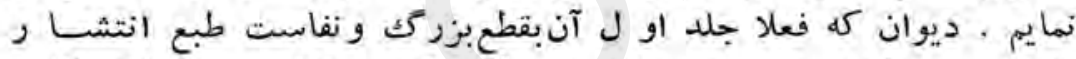

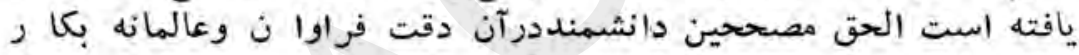

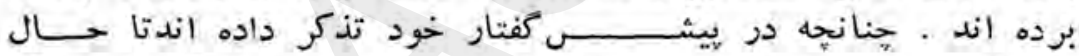

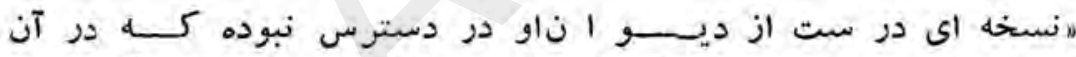

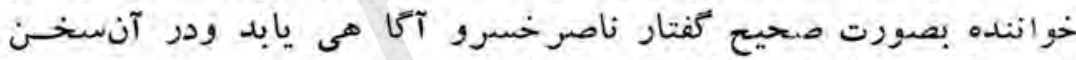

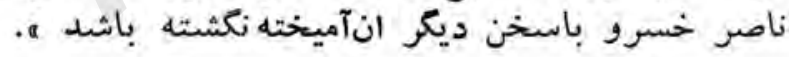

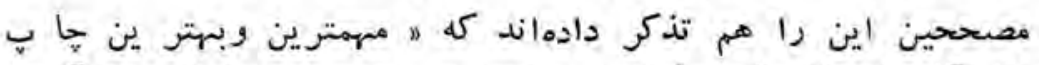

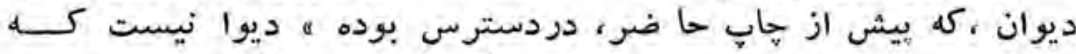

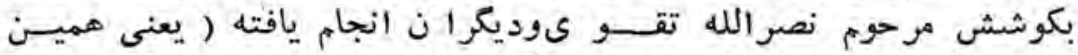

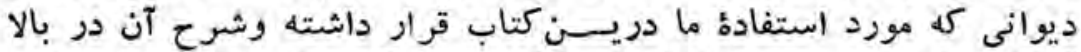

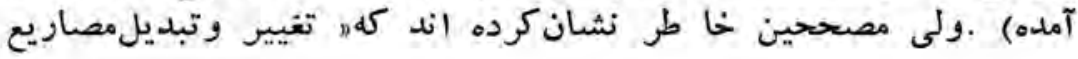

(1) بعدازآنكهآقاى دكتورمعين ويروفيسودكودبن (كتاب جامع العكمتين) ناصر خسرورو

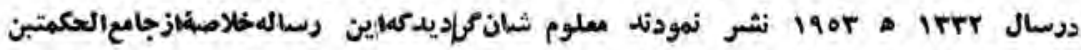

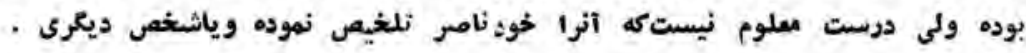




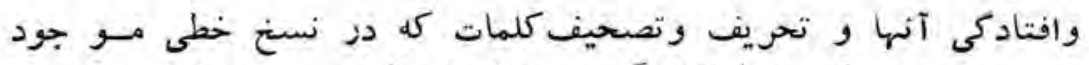

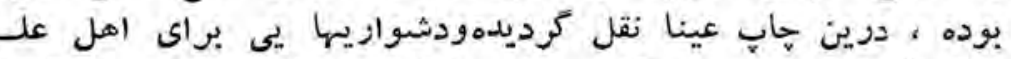

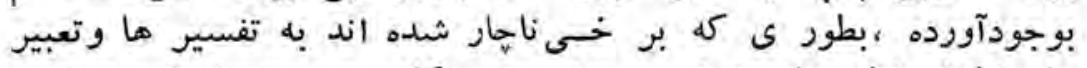

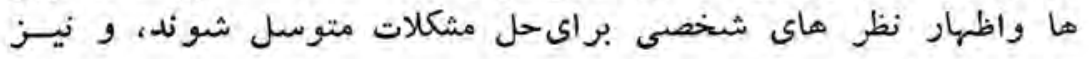

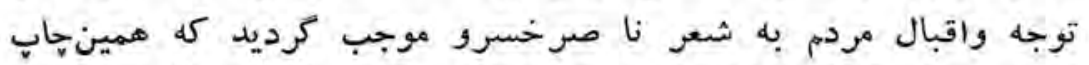

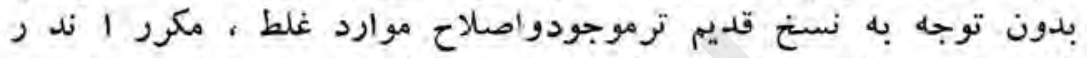

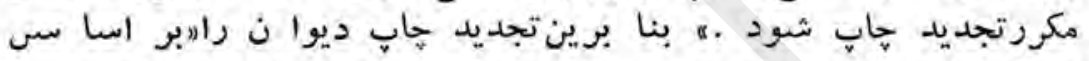

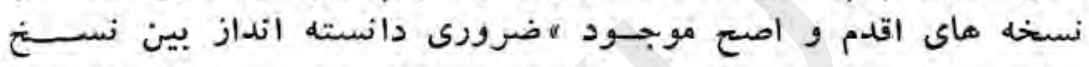

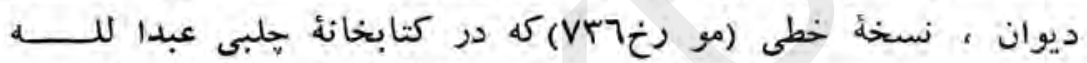

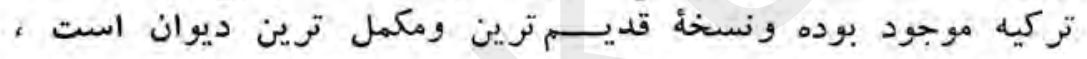

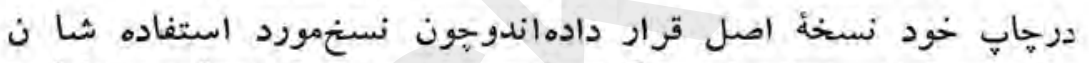

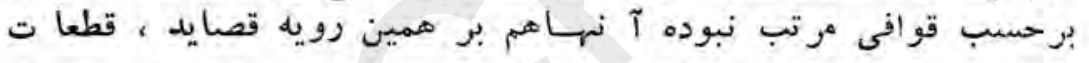

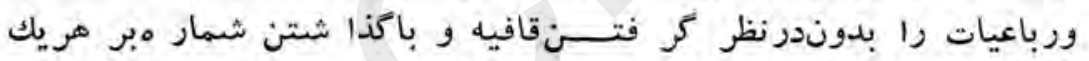

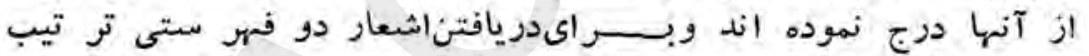

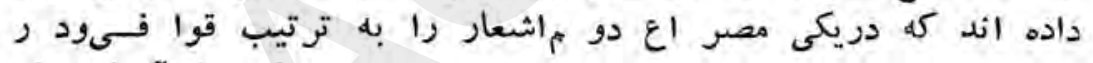

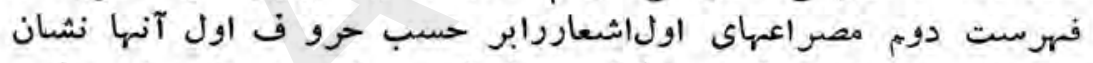

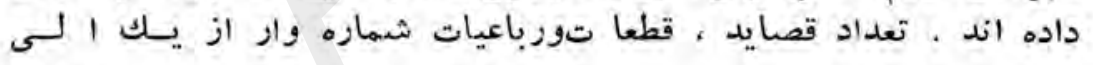

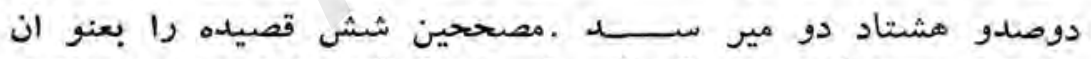

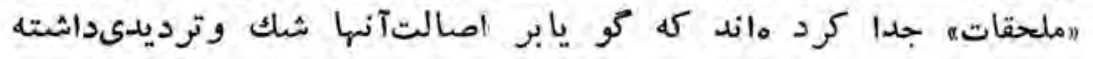

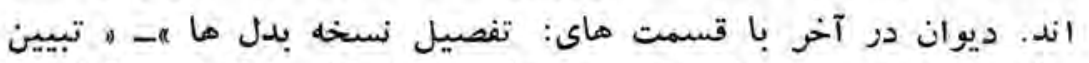

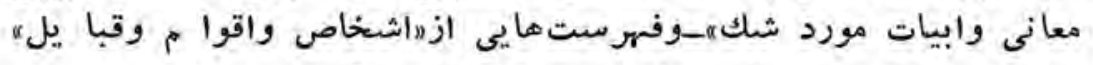

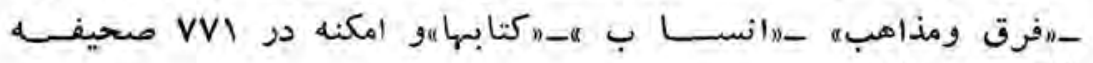
خاتمه مى يابد ومذاصبه

براى اينكه حجم ديوا ناز اندازؤمتناسب بز بز ركتر نشود، مصححين

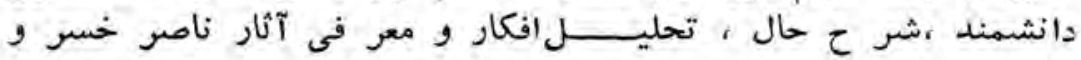

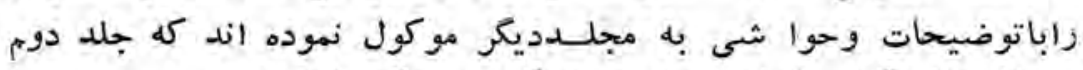

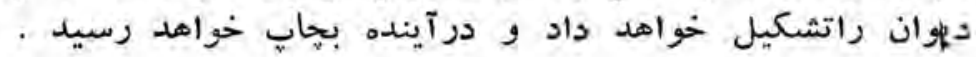


زادالمسافرين - دوشنايينامه

Irr

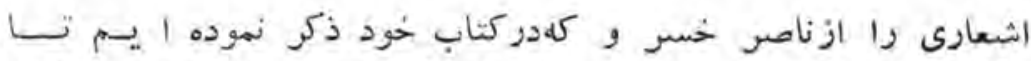

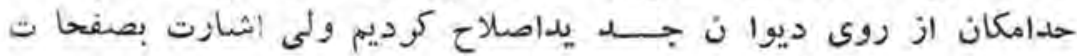

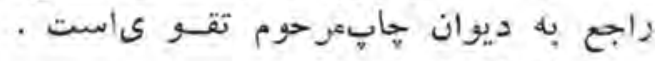

\section{ع-زادالمسافرين}

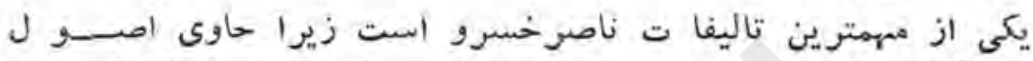

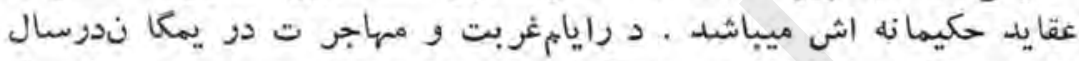

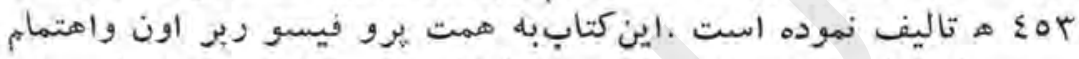

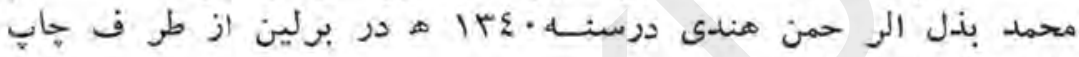

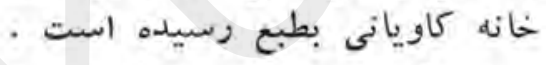

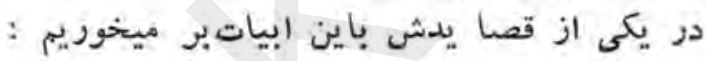

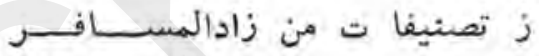

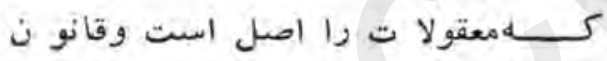

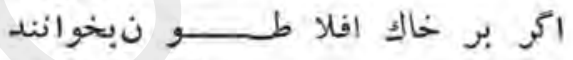

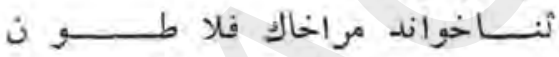

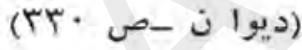

\section{0-رو شنا يى ثامه:}

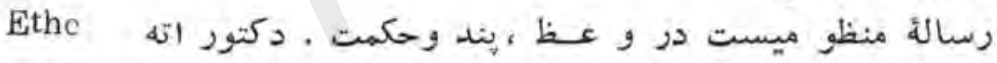

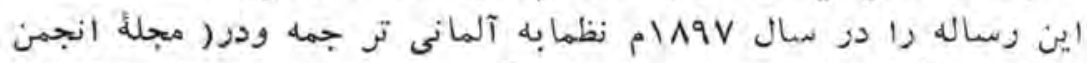

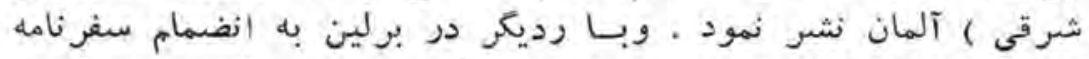

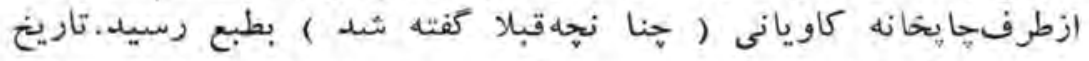

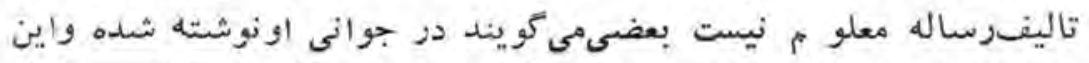

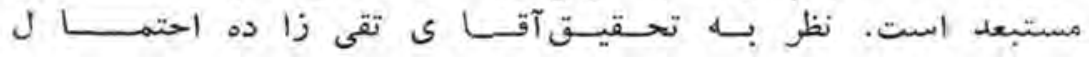

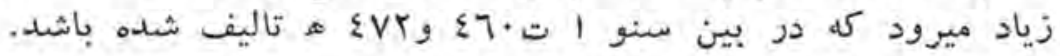

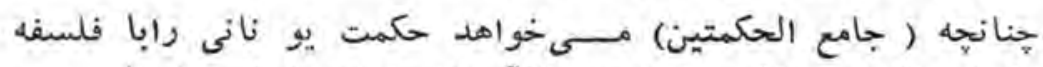

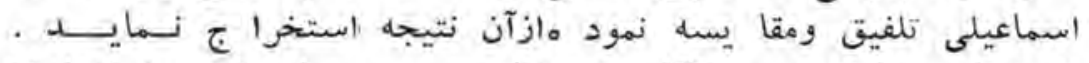

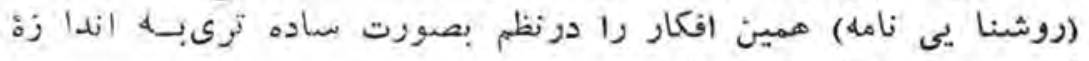

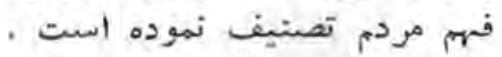




\section{الـوجه دين :}

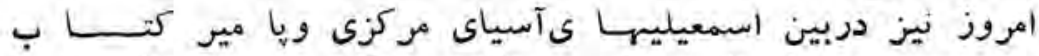

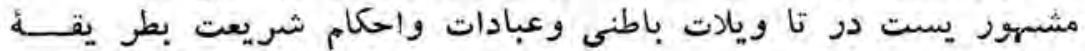

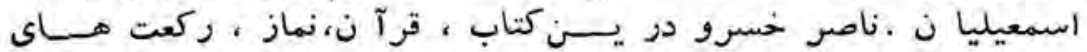

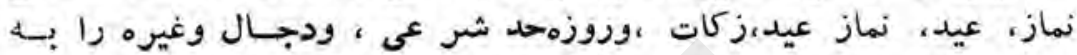

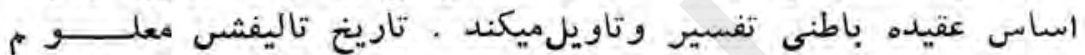

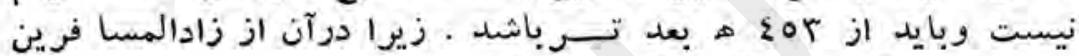

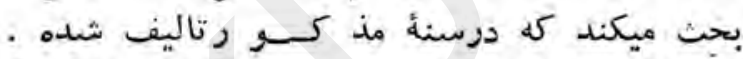

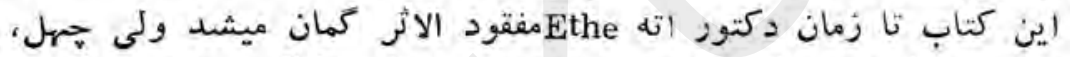

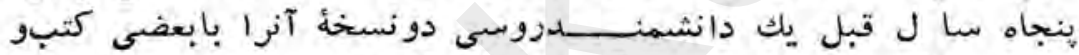

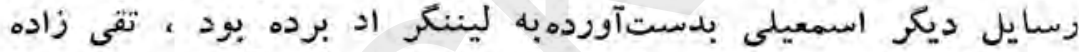

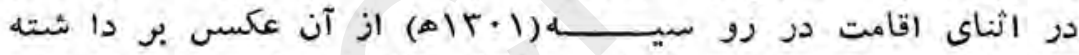

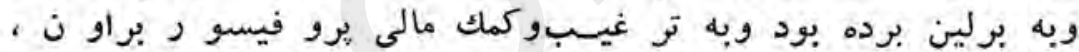

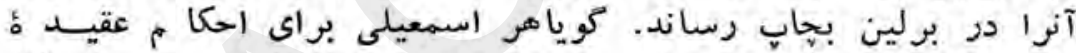

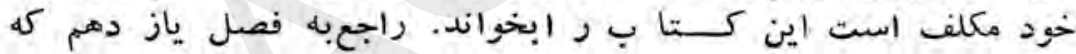

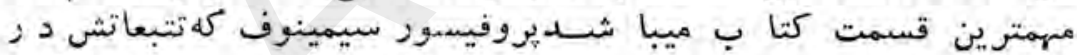

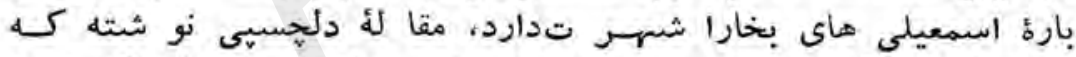

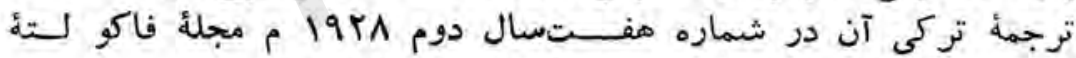

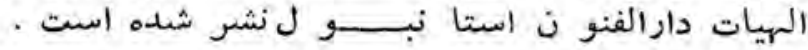

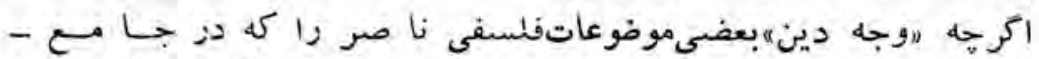

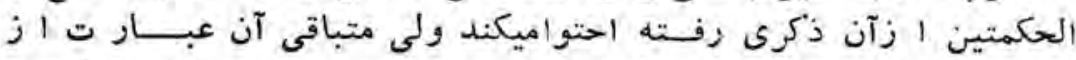

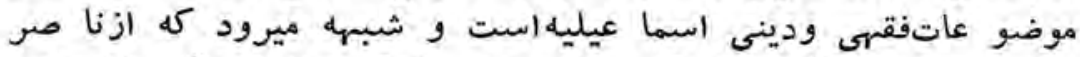

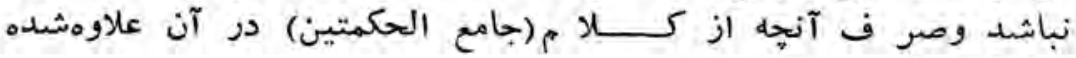

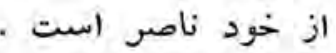

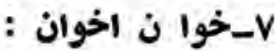

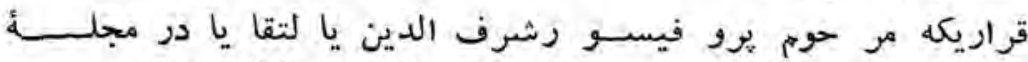

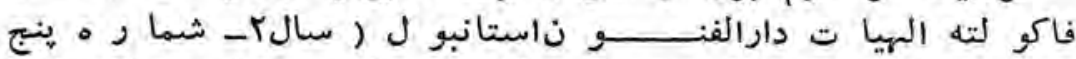

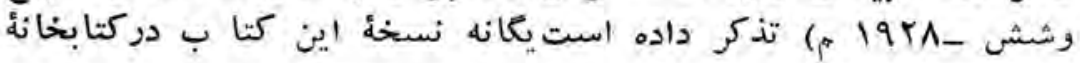




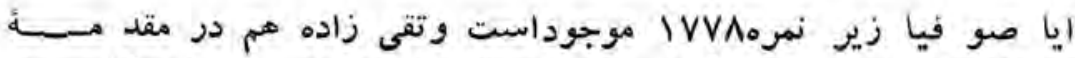

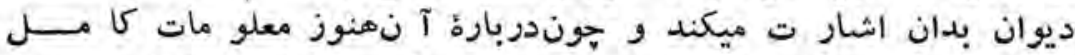

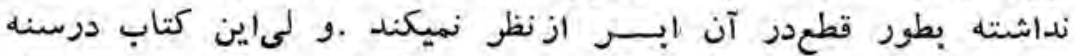

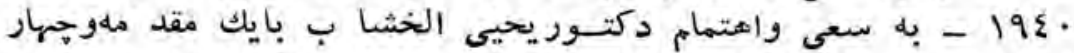

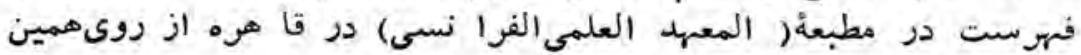

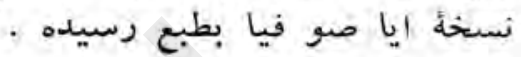

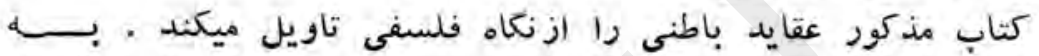

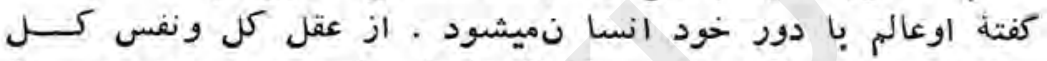

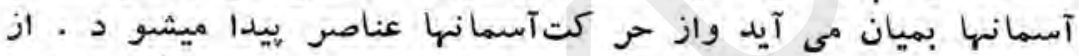

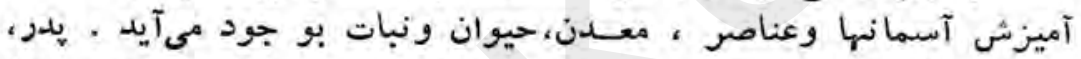

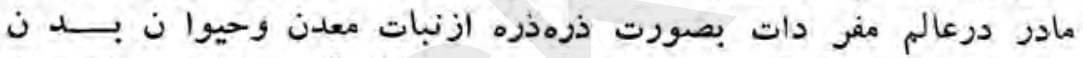

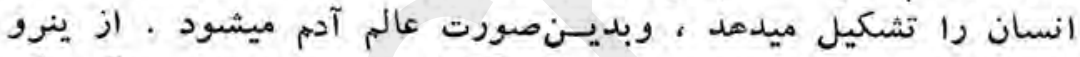

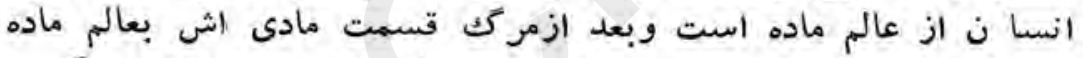

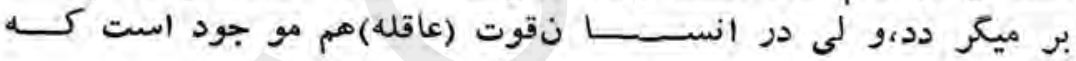

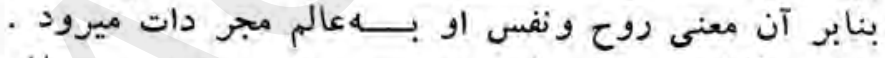

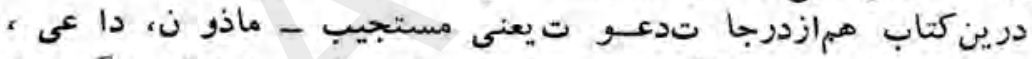

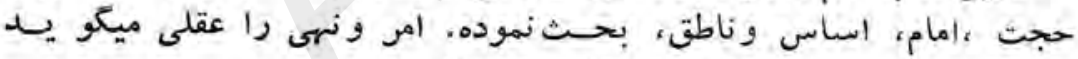

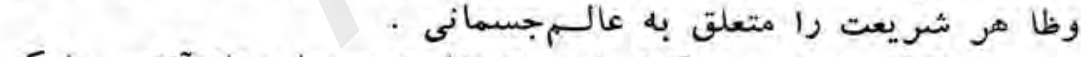

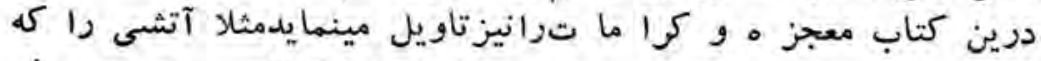

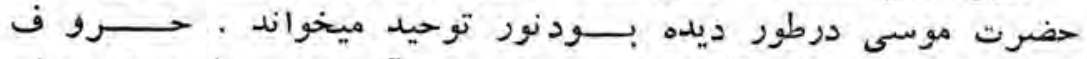

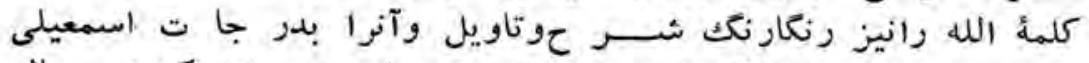

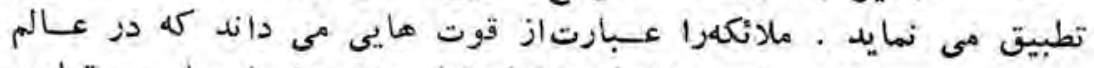

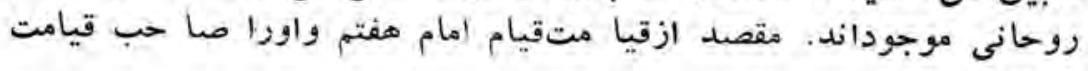

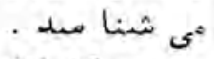

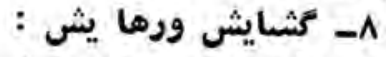

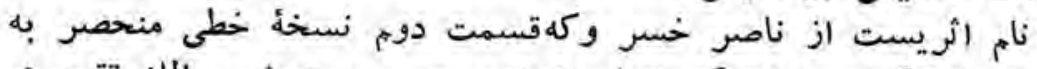

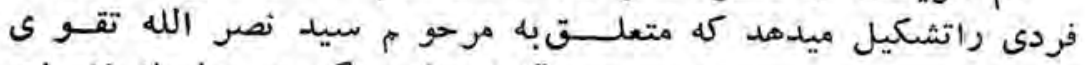

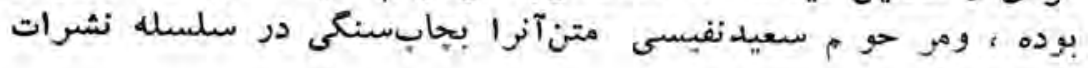




\section{ITT}

\section{نامو خسرو بلغى}

فوق الذكر نشر نموده،و هنـــو زمورد تتبع وتفحصس قــــــر 1 ر

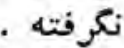

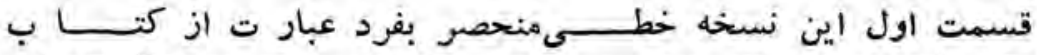

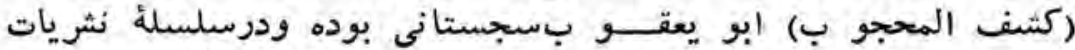

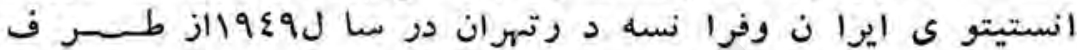

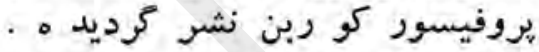

$$
\begin{aligned}
& \text { 9-رو شنا يى نامه به نثر : }
\end{aligned}
$$

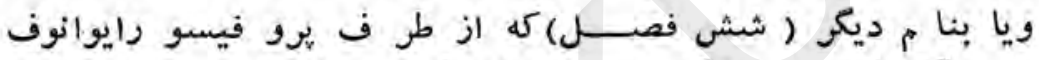

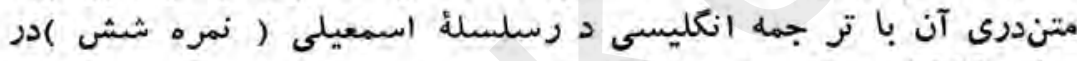

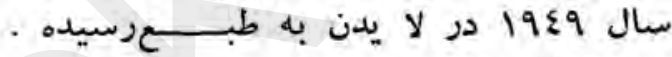

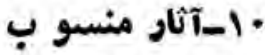

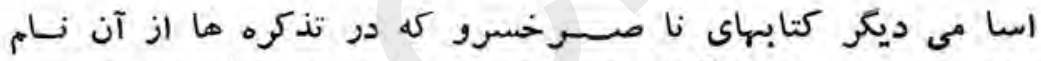

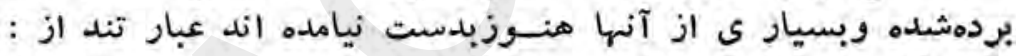

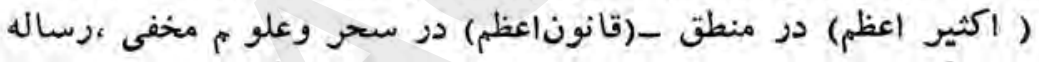

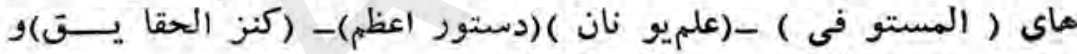

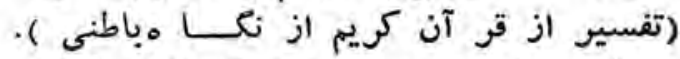

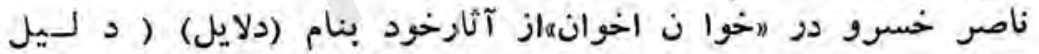

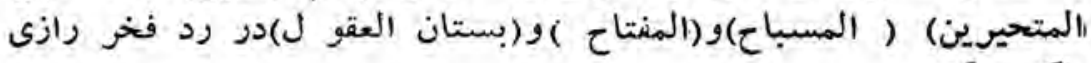
ذكر ميكند .

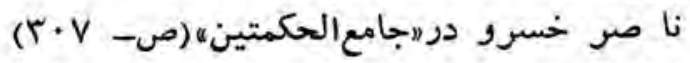

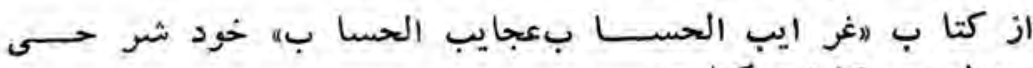

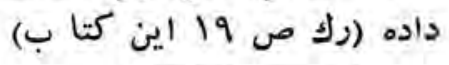

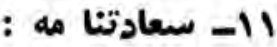

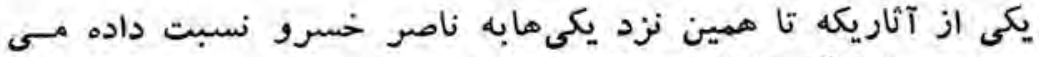

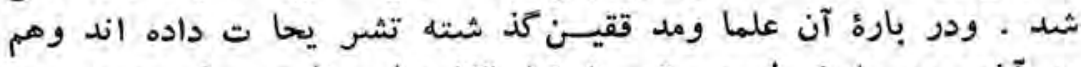

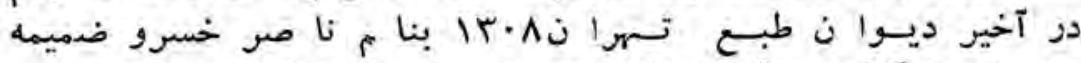

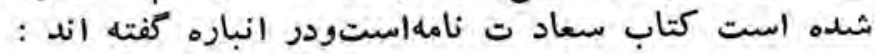




\section{سمادت نامه}

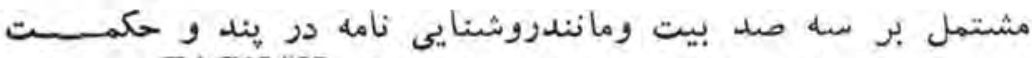

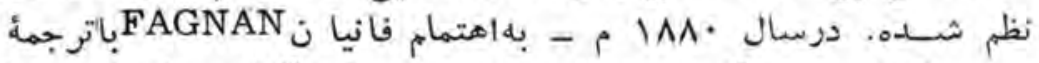

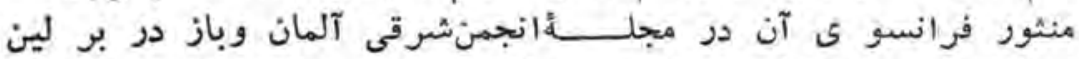

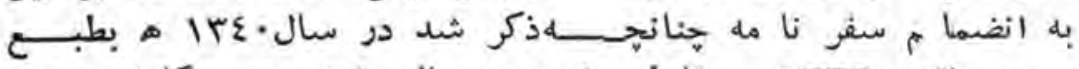

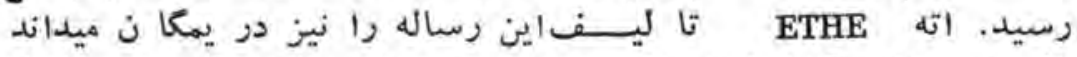

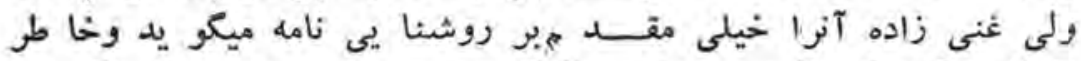

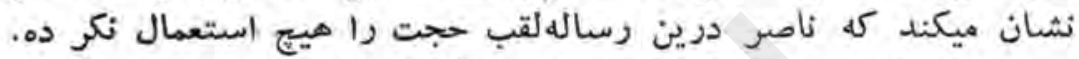

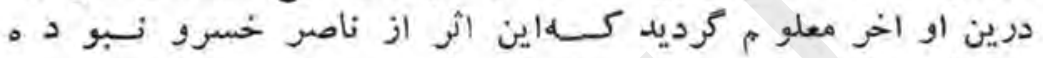

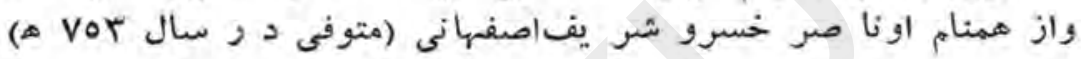
. بودهه

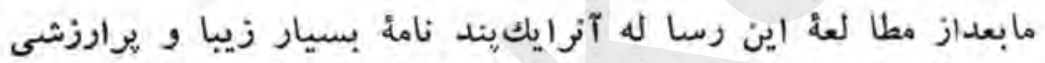

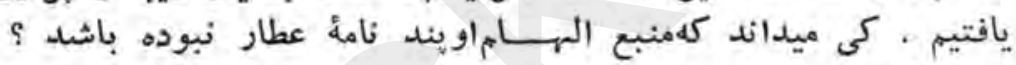

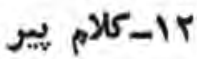

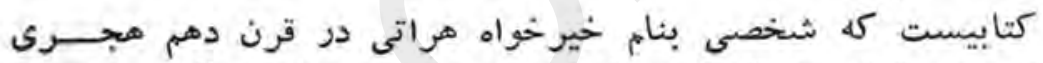

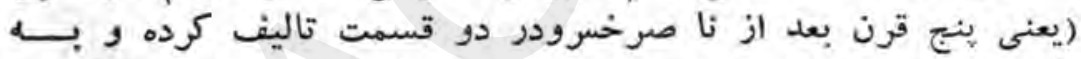

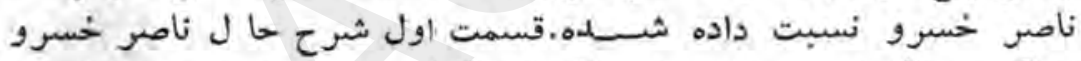

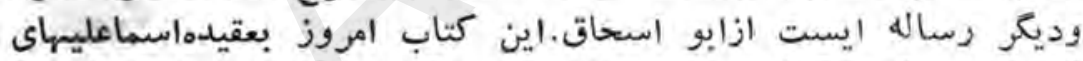

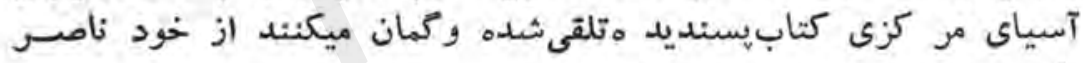

$$
\text { خسرو بوده . آنساي هري }
$$

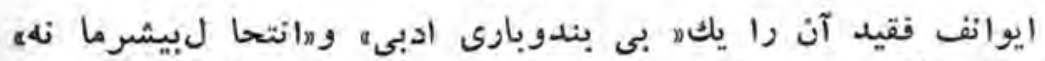

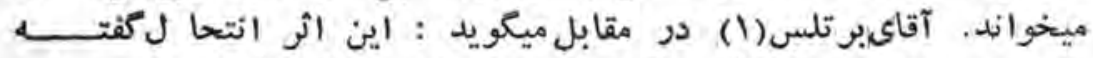

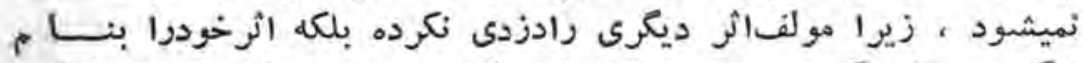

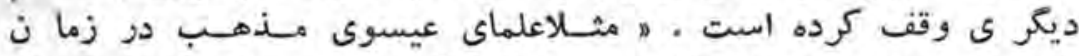

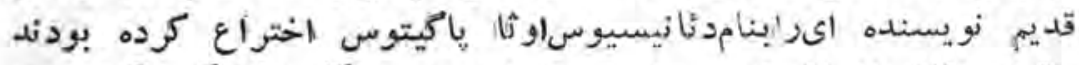

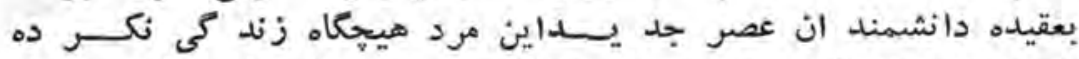

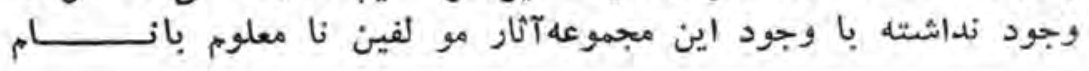

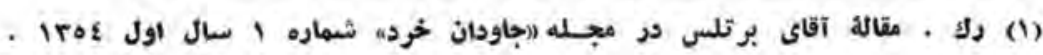




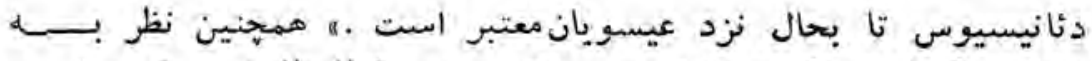

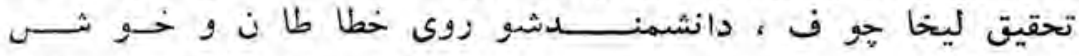

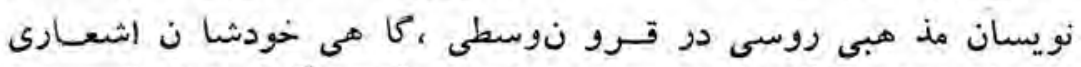

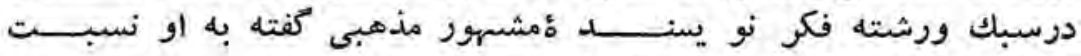

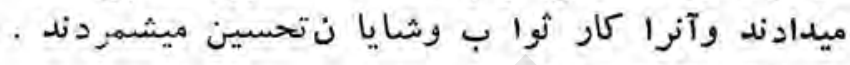

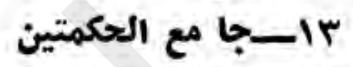

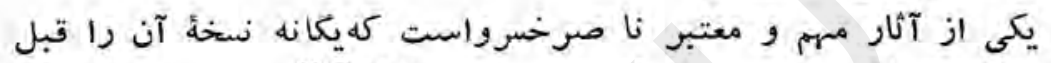

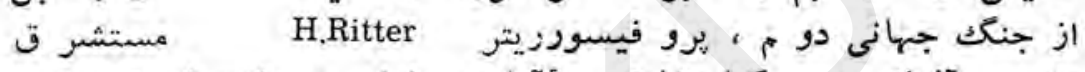

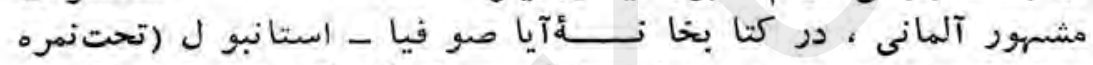

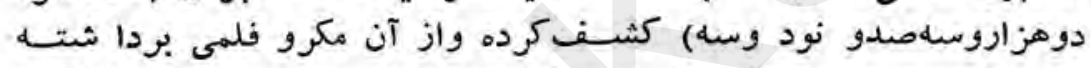

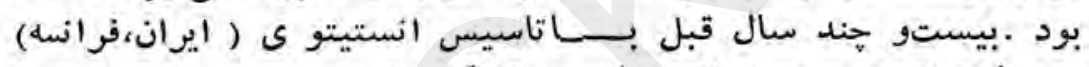

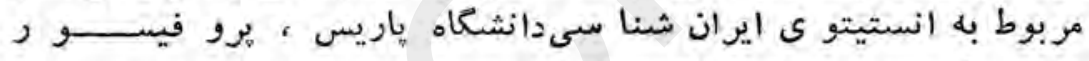

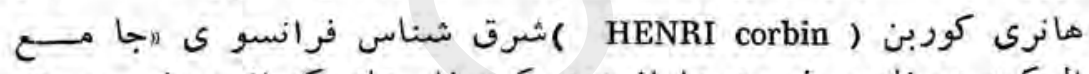

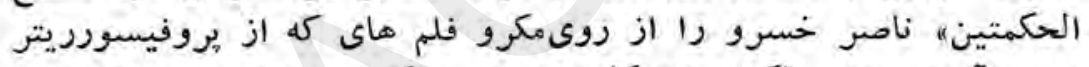

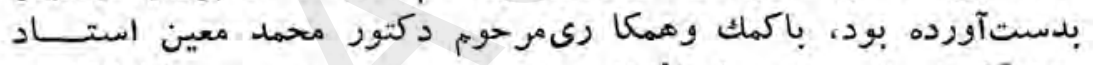

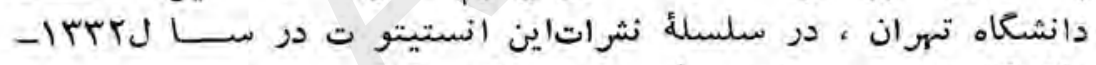

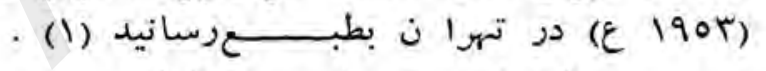

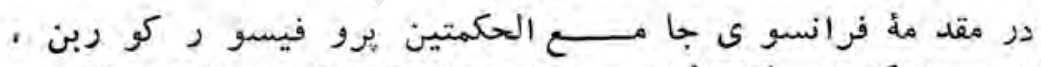

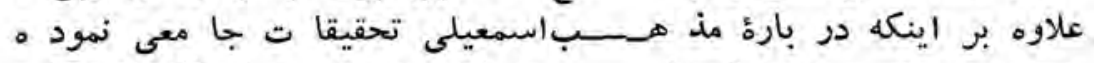

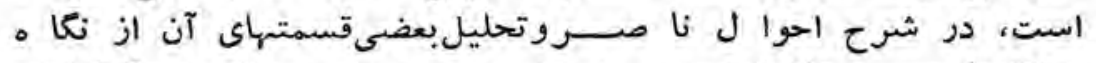

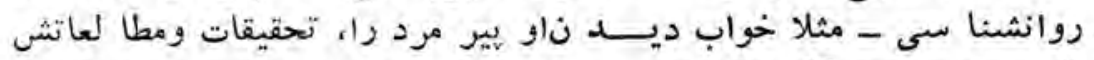

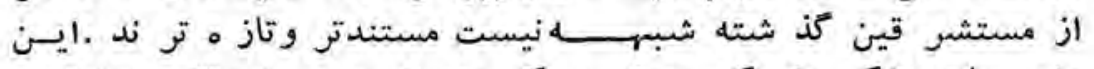

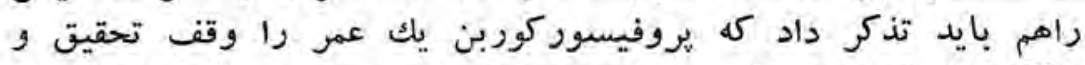

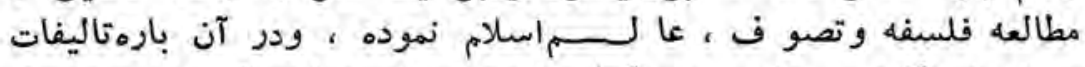

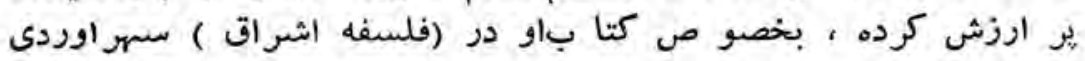

(1) آنجا كه اين كتاب يكىاذ آخريسن آثار ناصر خسرو است ومبين معلوماتوسيع

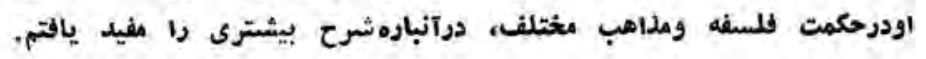




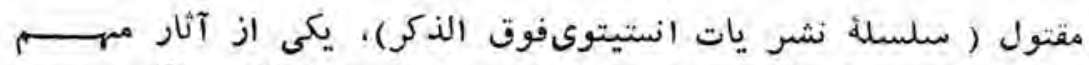

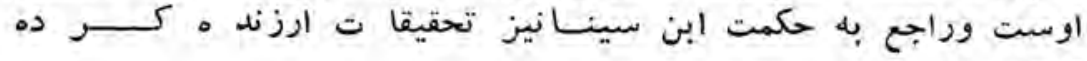

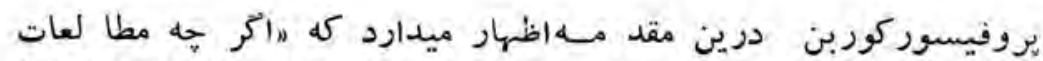

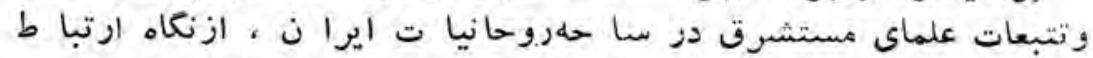

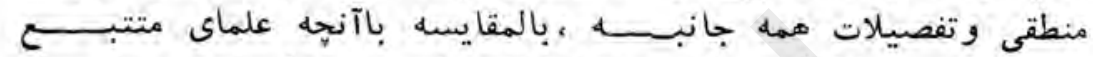

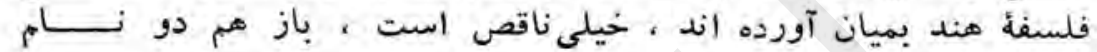

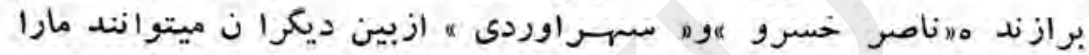

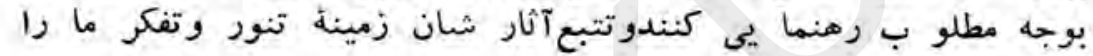

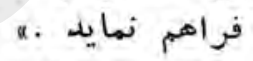

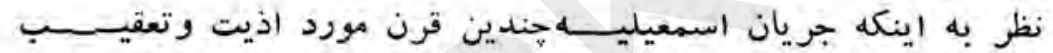

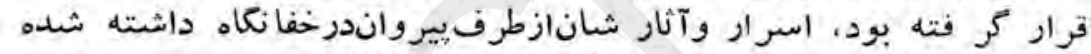

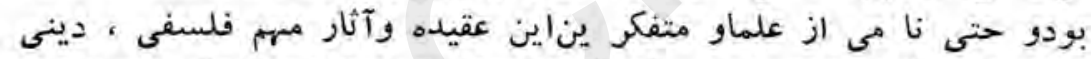

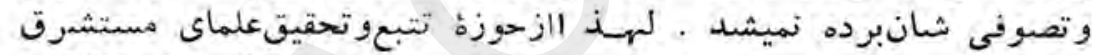

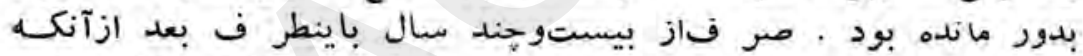

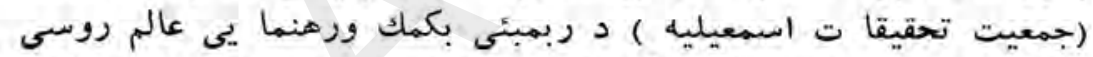

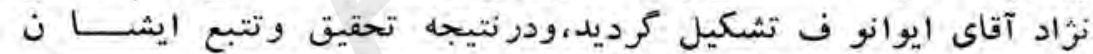

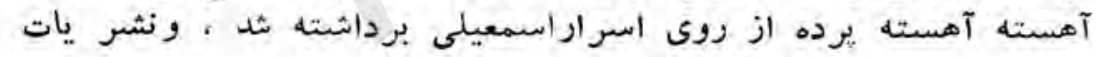

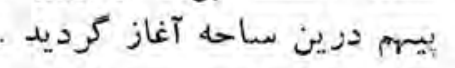

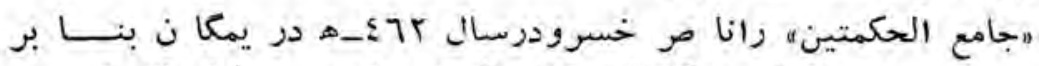

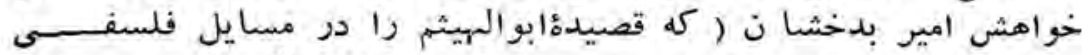

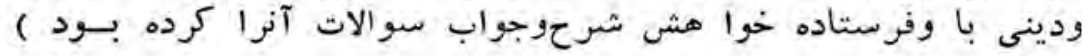

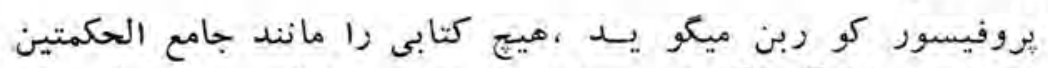

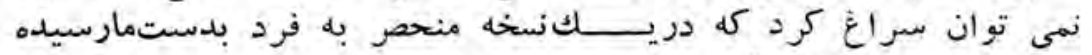

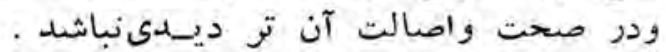

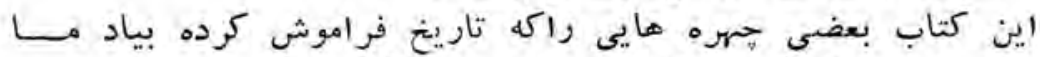

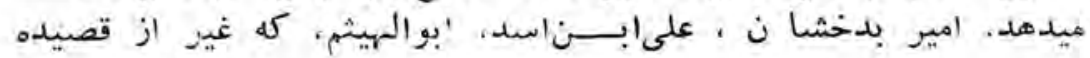




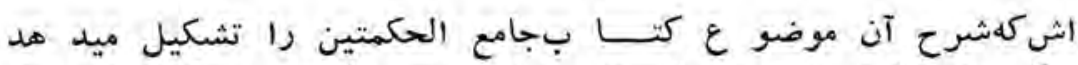

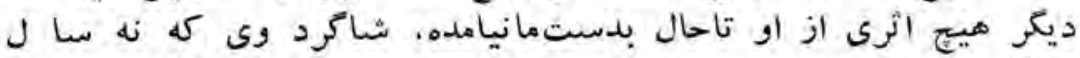

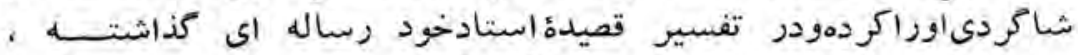

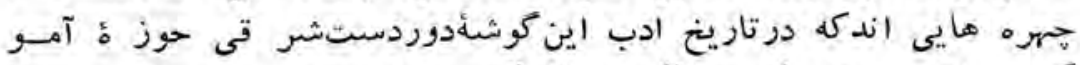

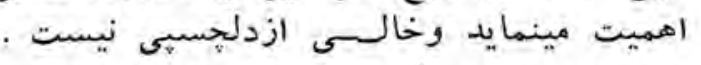

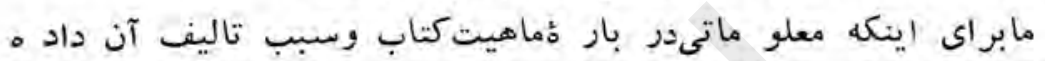

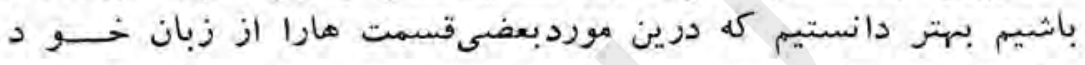

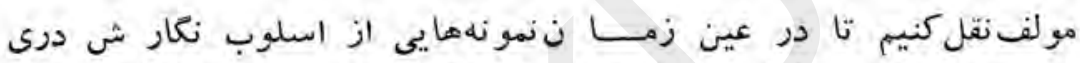

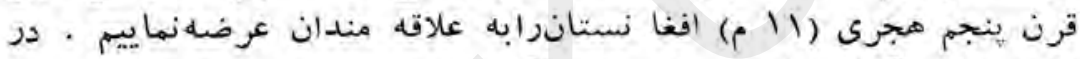
فصل اخير كتاب نا صر خرى خسر ومى النويد :

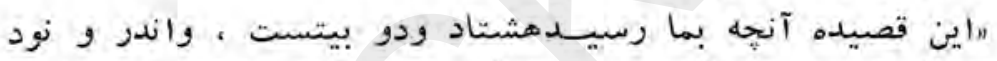

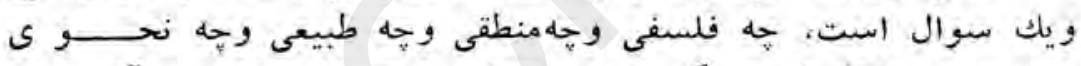

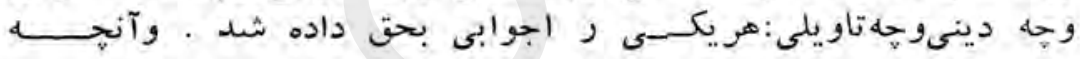

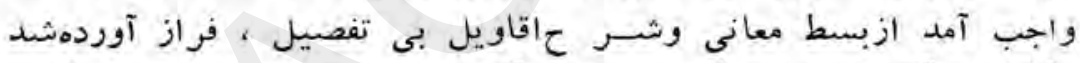

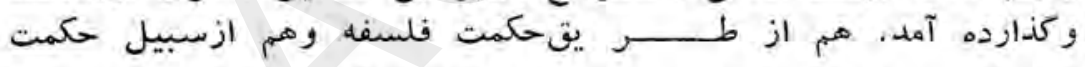

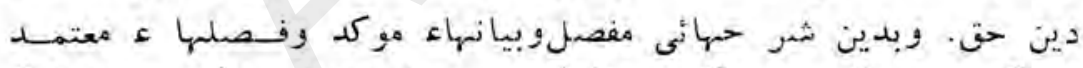

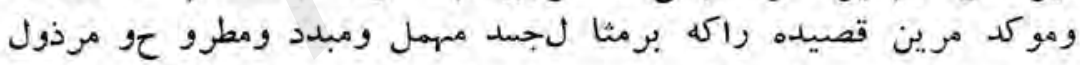

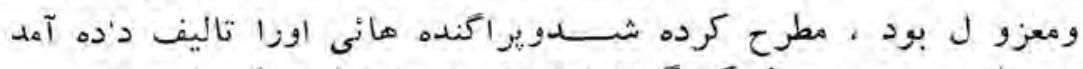

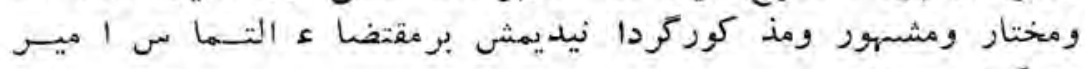
بزركوار (....

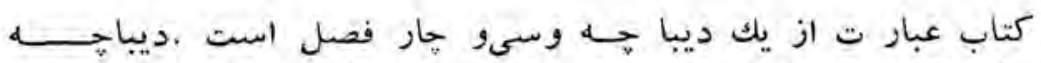

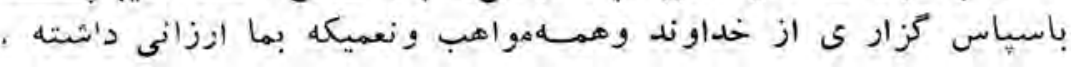

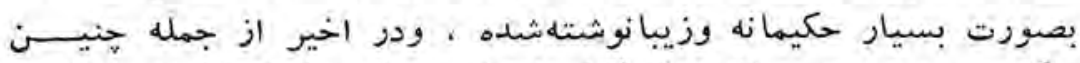

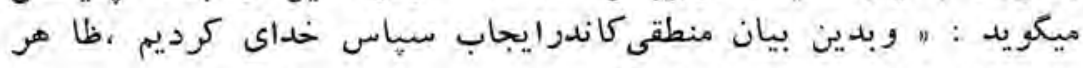

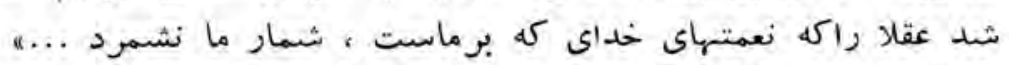

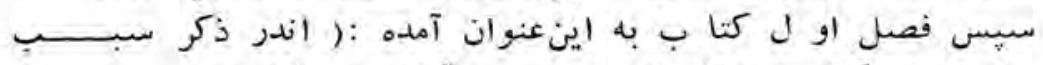

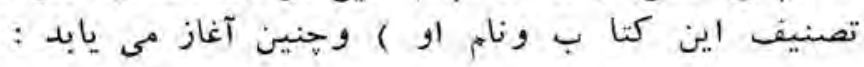




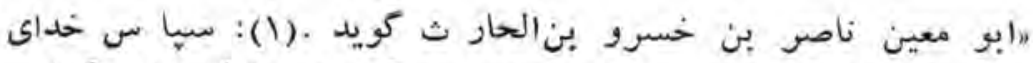

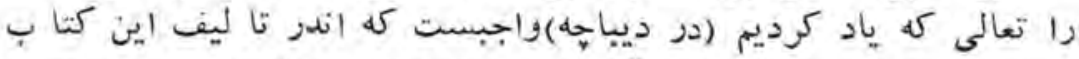

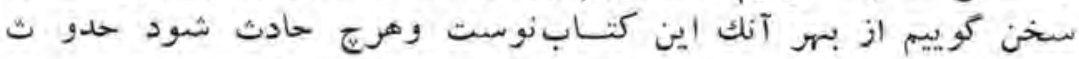

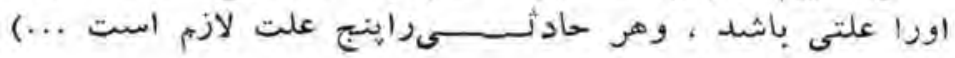

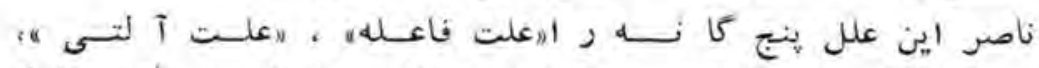

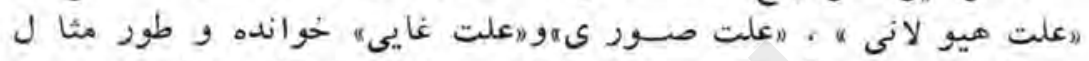

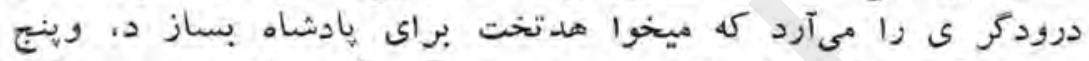

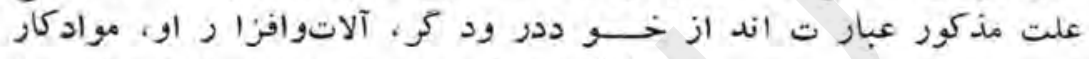

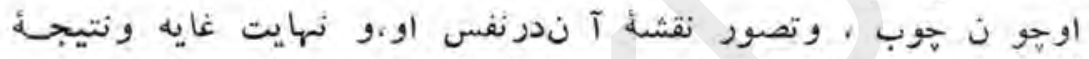

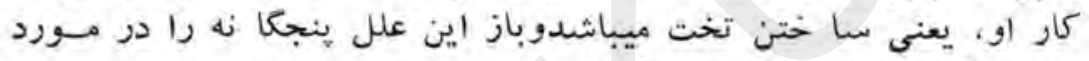

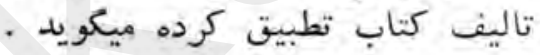

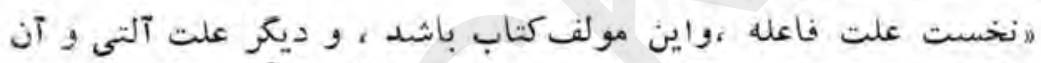

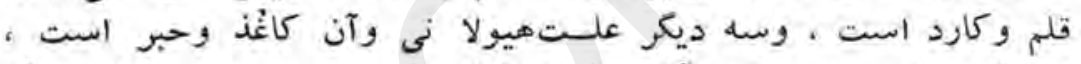

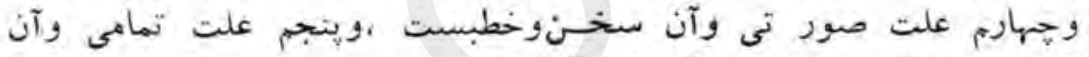

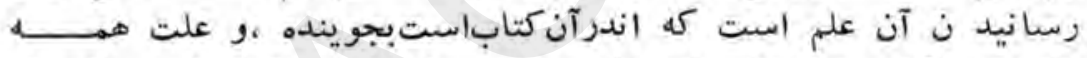

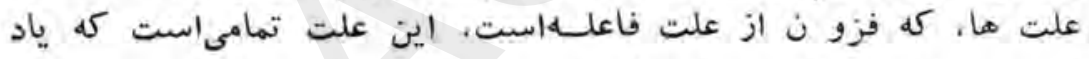

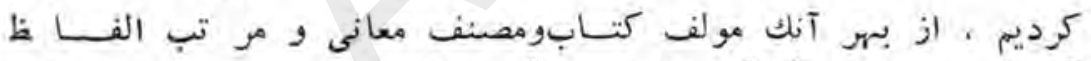

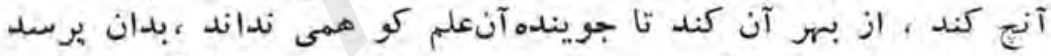

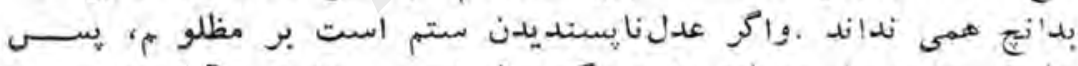

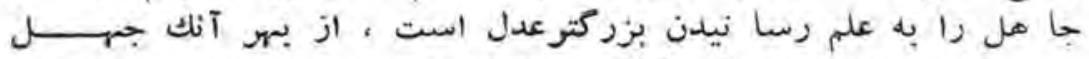

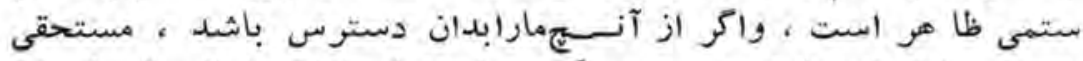

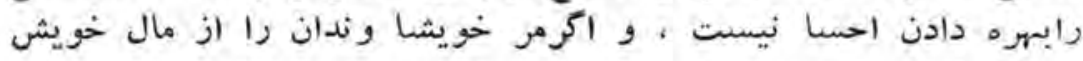

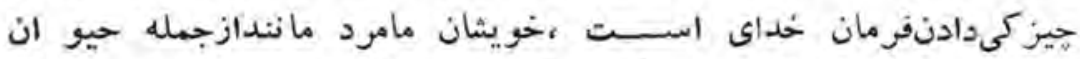

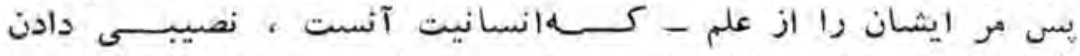

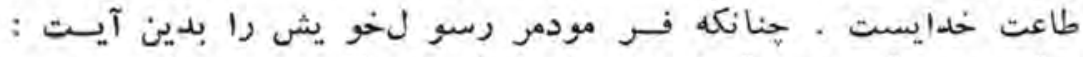

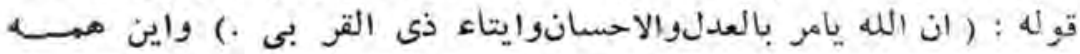

(1) 2دجاى دبعر خودرا ابوعيزنامريسنسرو بزحارث اليهفانى نيزمته است . 


\section{itr}

صفت رسو ل است ، ومارا آكسا مكرد كاين سل كار كه همى كنم مو

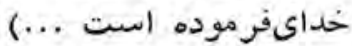

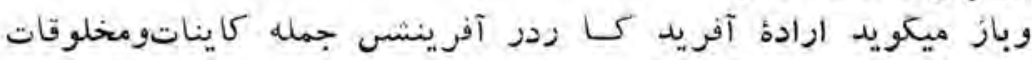

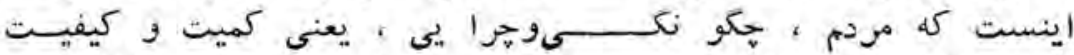

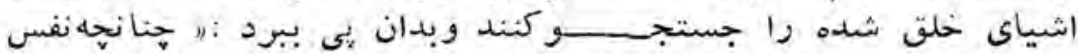

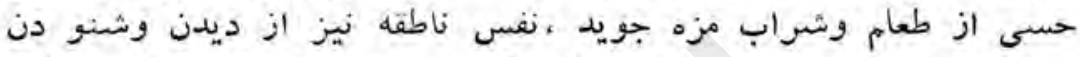

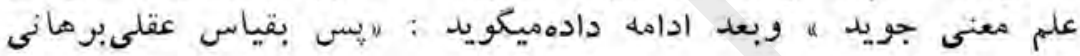

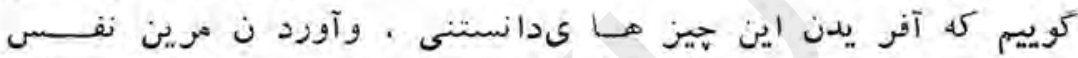

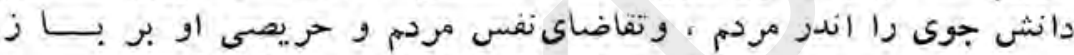

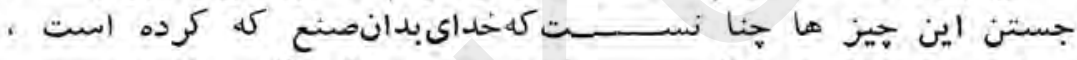

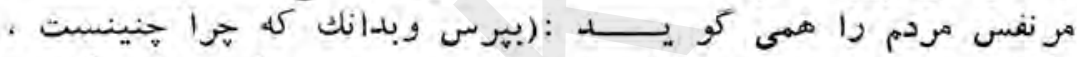

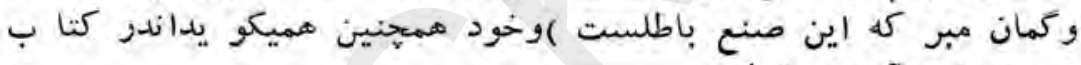

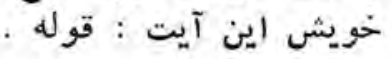

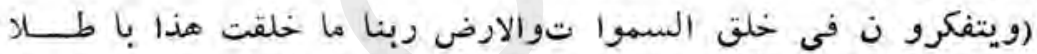

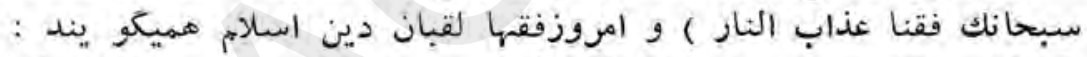

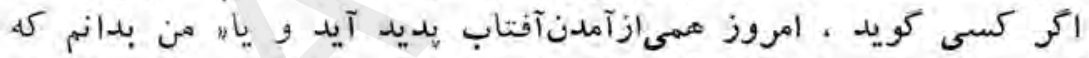

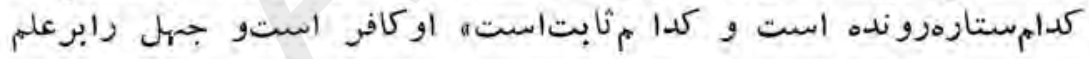

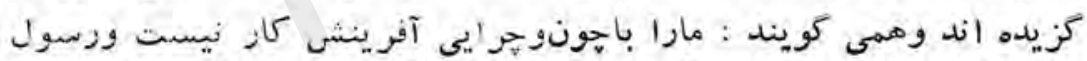

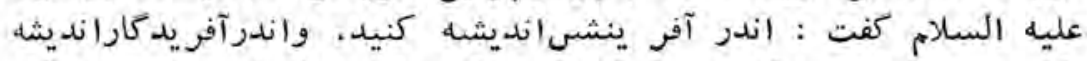

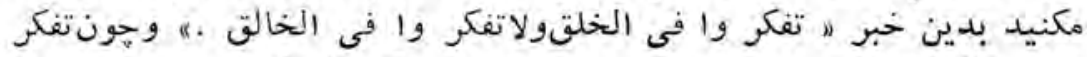

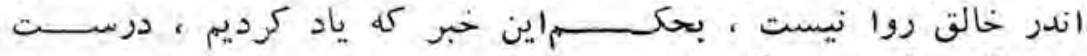

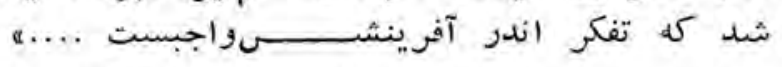

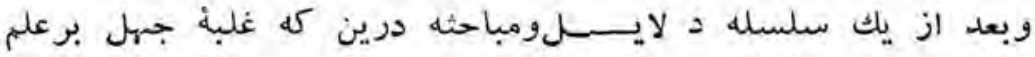

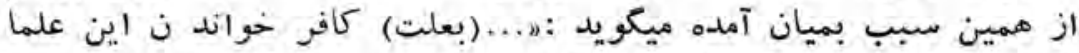

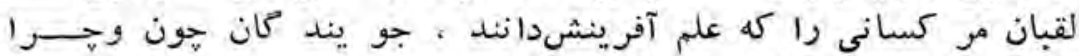

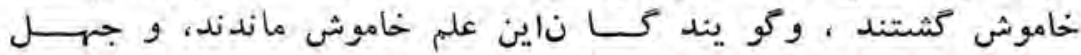

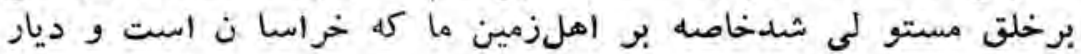




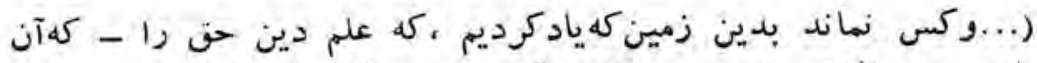

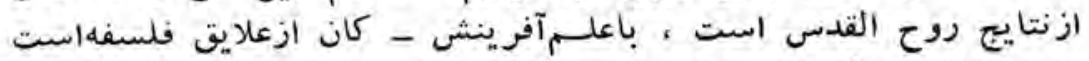

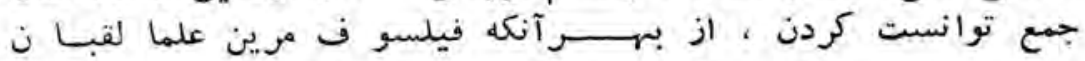

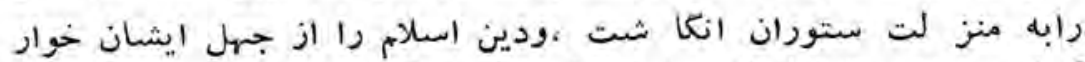

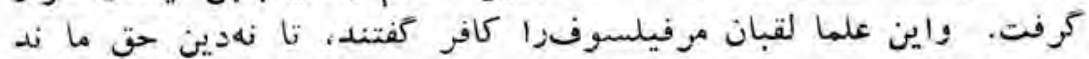

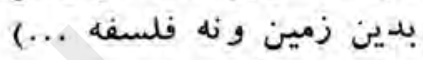

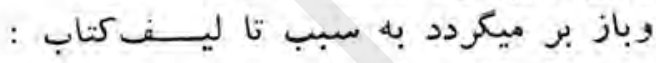

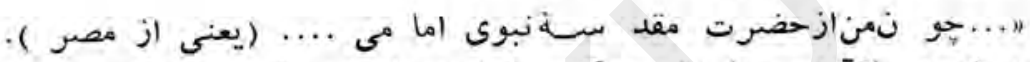

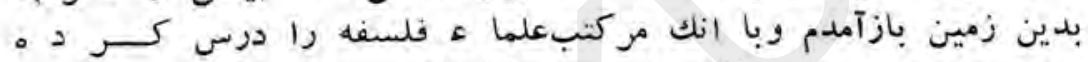

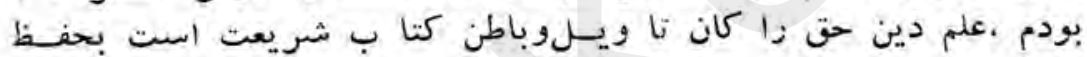

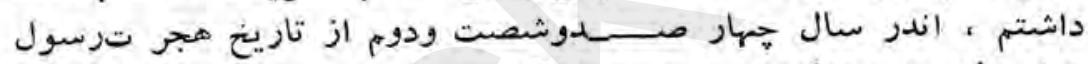

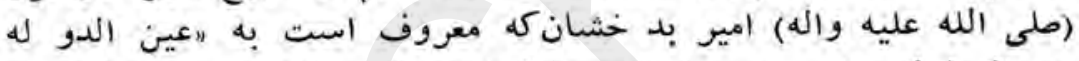

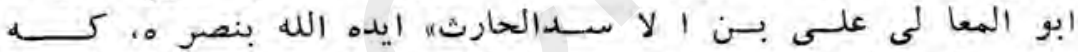

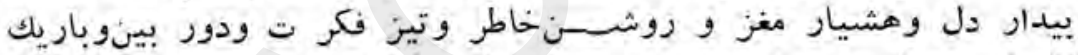

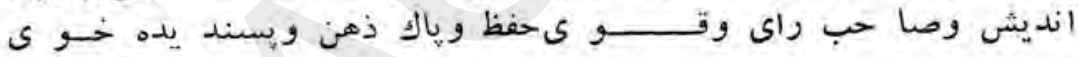

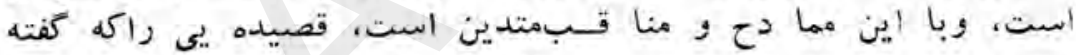

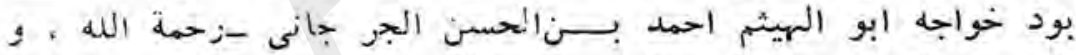

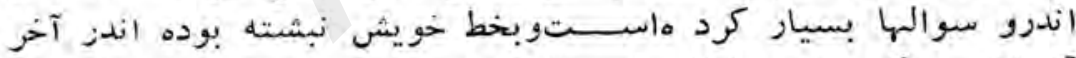

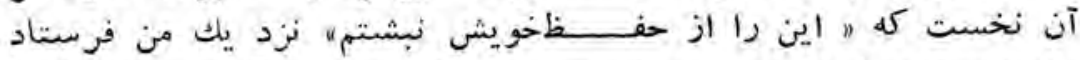

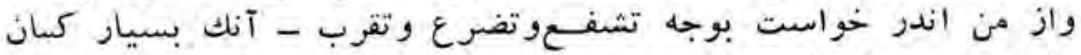

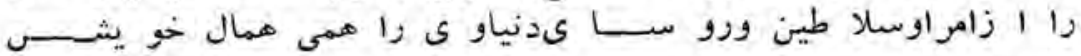

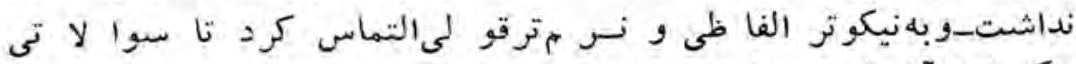

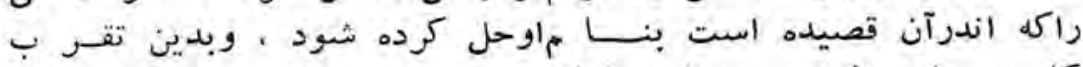

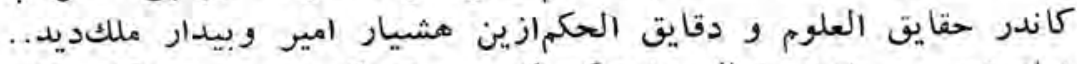

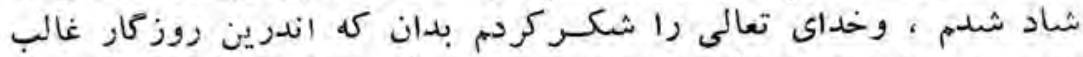

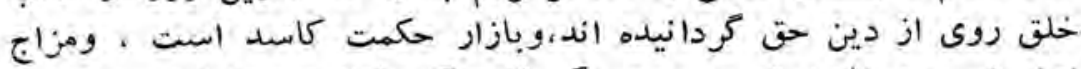

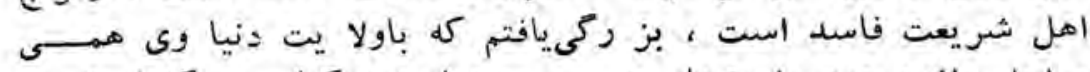

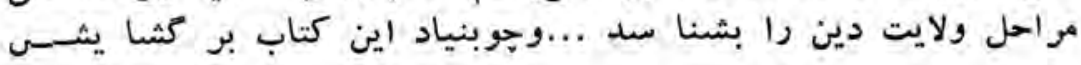




\section{Ire}

ناصر خسرو بلغى

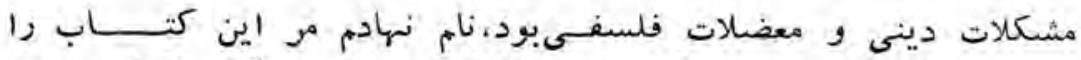

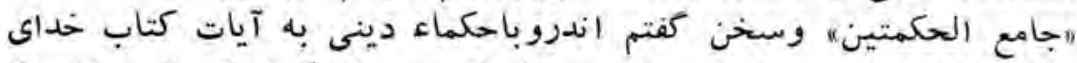

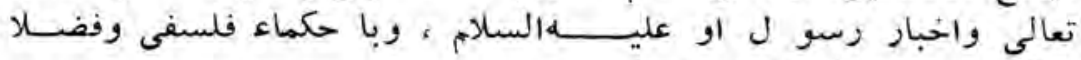
هن......

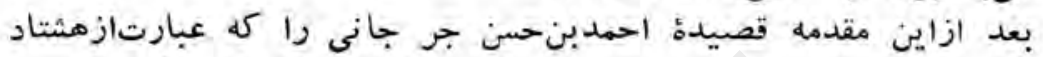

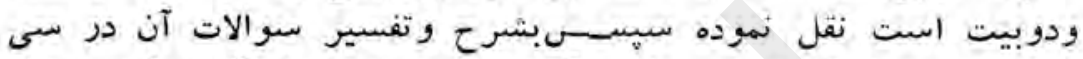

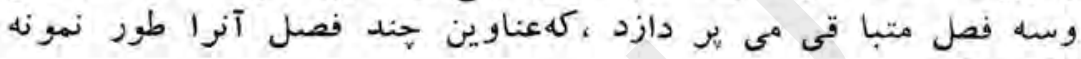
: ذكر ميكنيم فئ

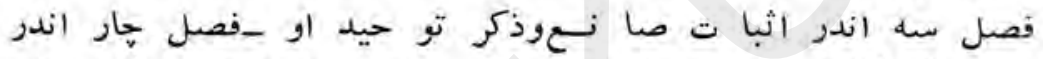

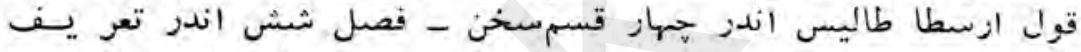

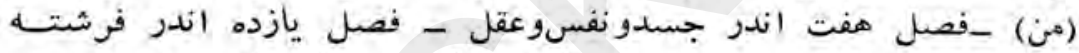

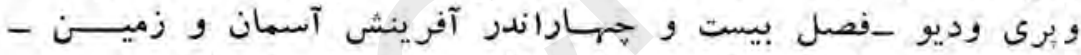

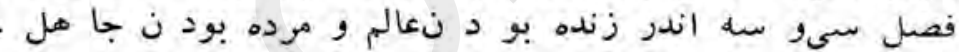

\section{ع ا- در بارة امير بدخشان}

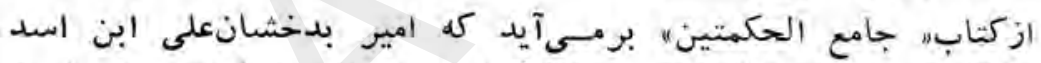

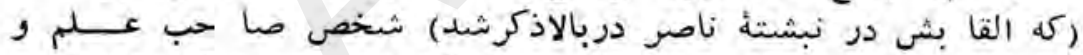

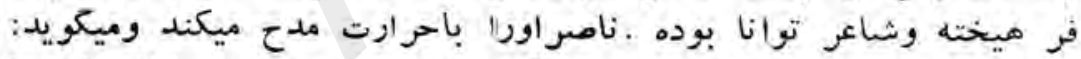

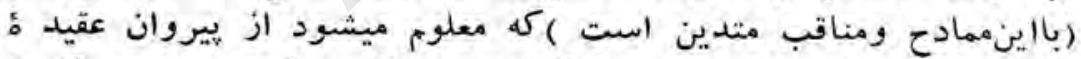

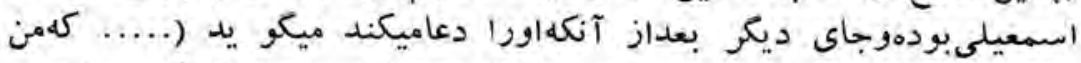

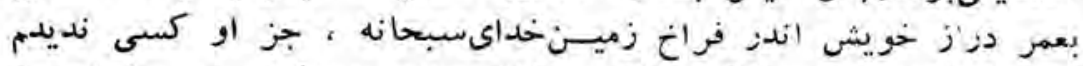

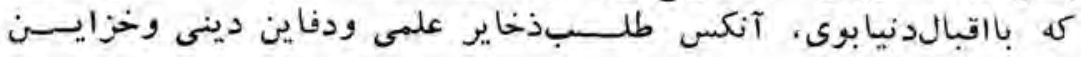

$$
\text { صد قى كند..... }
$$

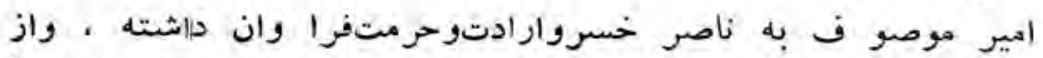

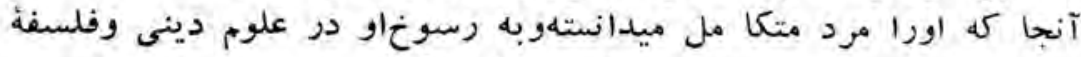

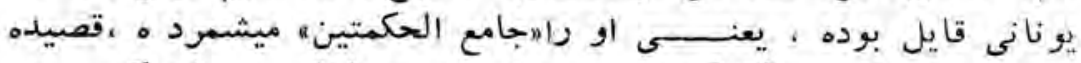

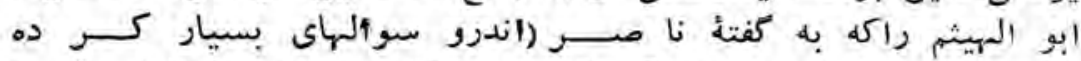

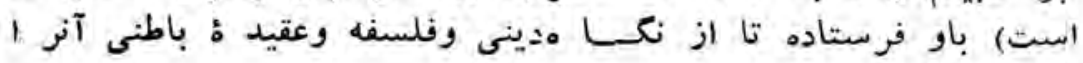
تفسير كند الشيت 


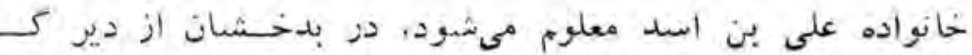

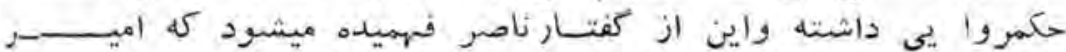

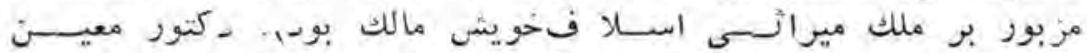

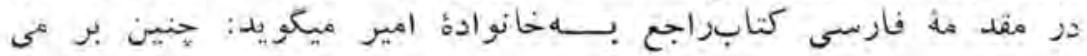

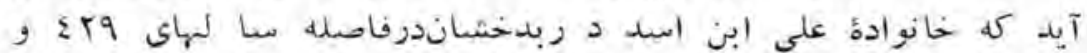
د ع \& \&V

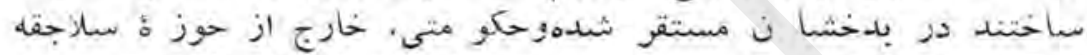

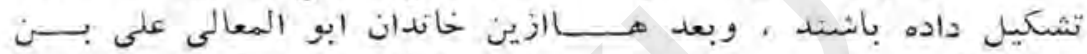

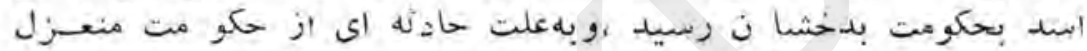

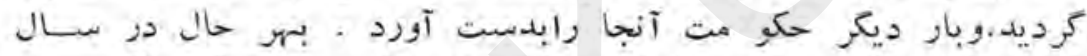

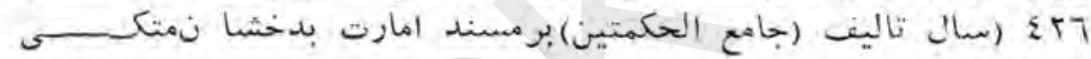

$$
\text { (1) }
$$

ناصر خسرو در (جامعالحكمتين)(ص صل ) ازين حادئل منين ذكر

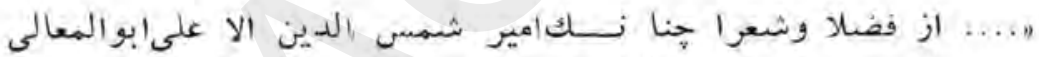

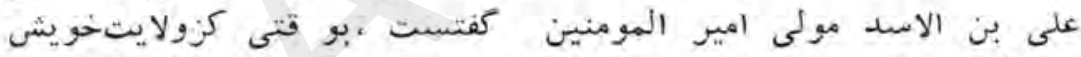

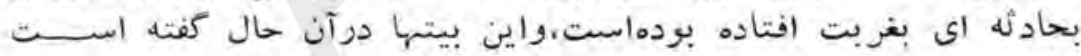

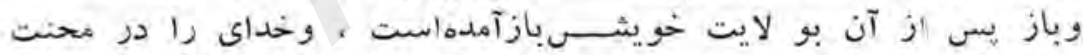

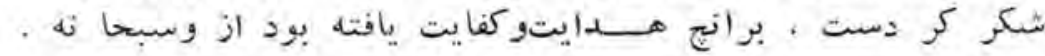

$$
\text { كر بشد از من منال ومـــ الوولايت }
$$

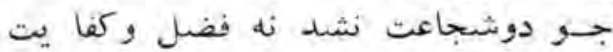

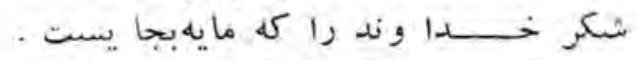

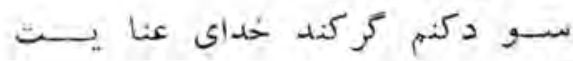

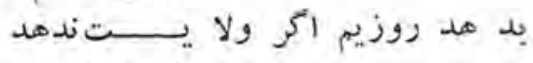

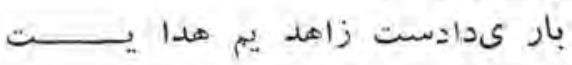

(1)

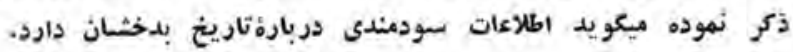




\section{9}

ناصر خسرو بلغنى

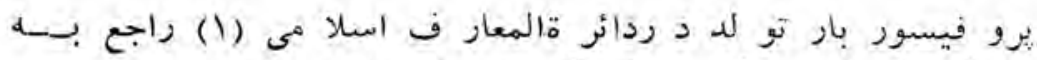

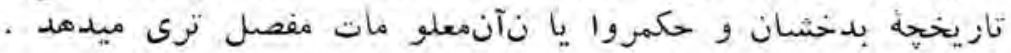

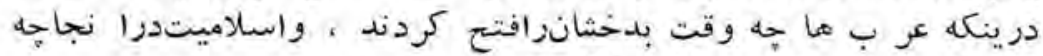

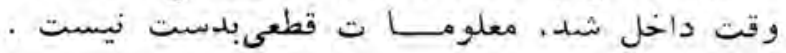

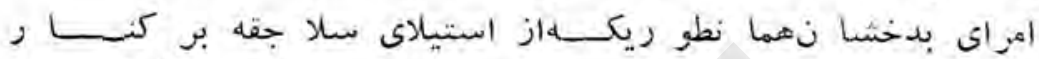

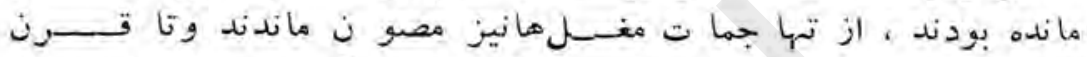

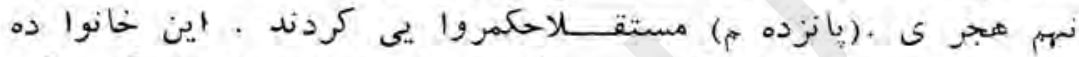

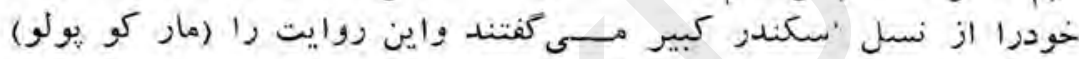

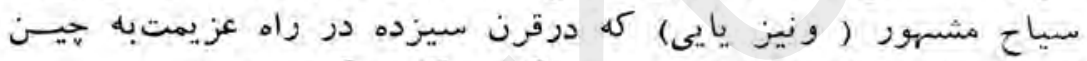

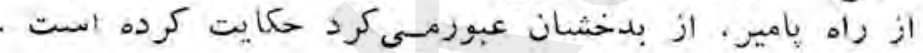

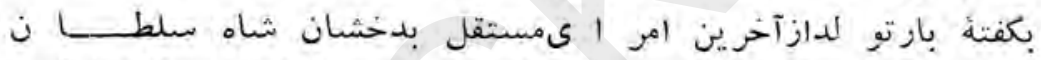

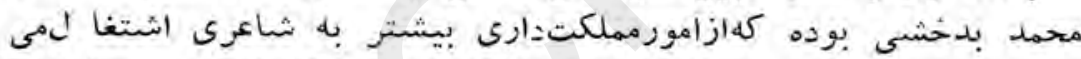

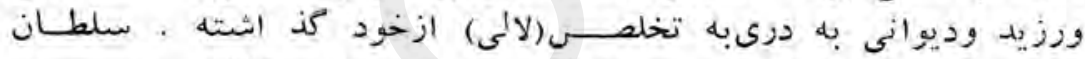

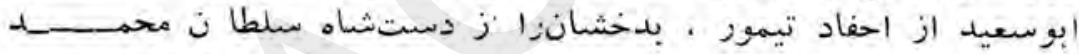

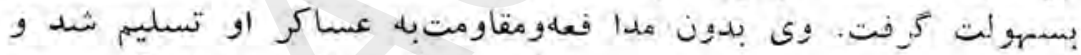

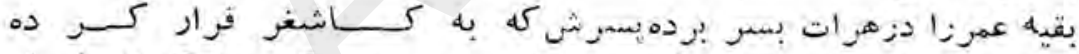

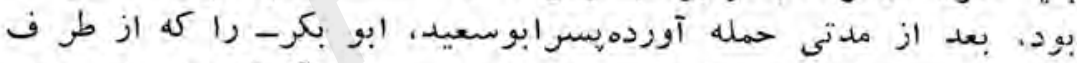

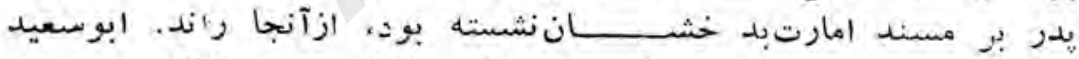

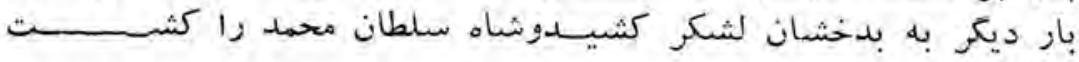
( $\triangle A V I)$

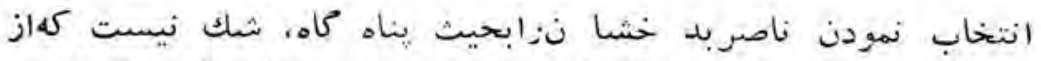

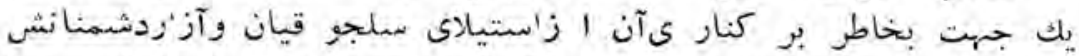

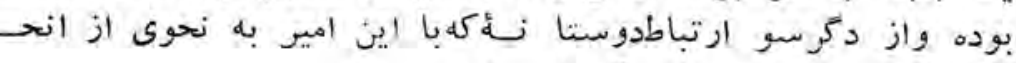

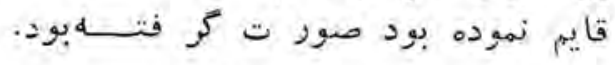

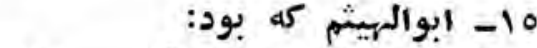

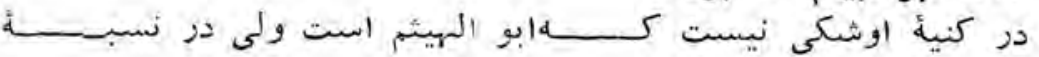




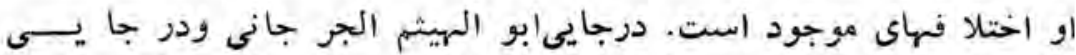

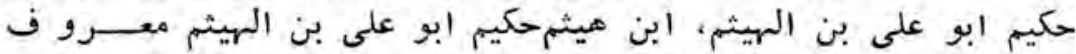

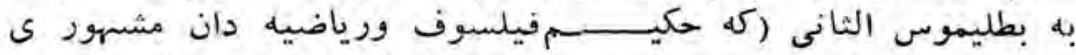

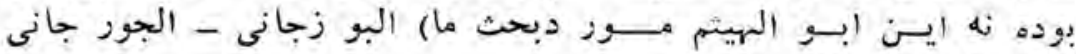

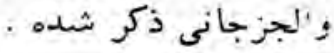

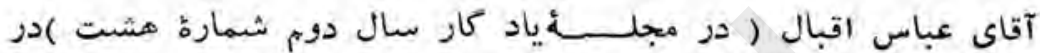

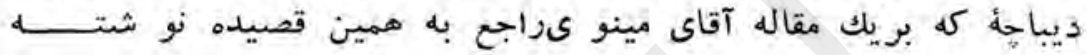

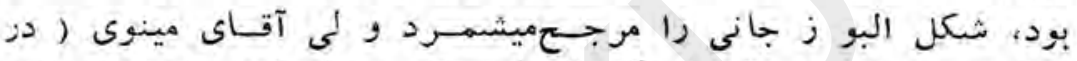

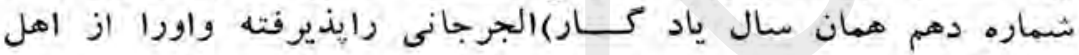

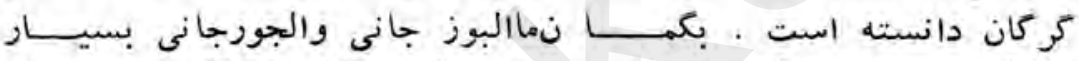

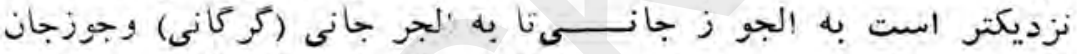

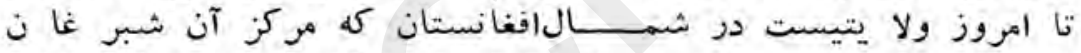

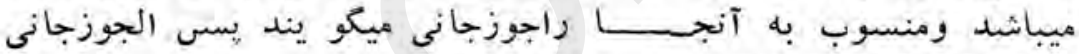

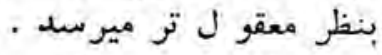

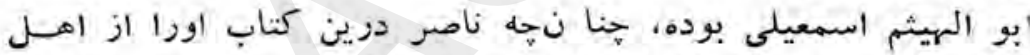

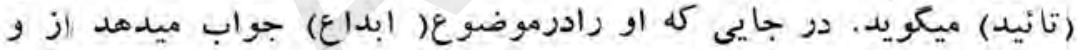

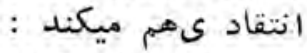

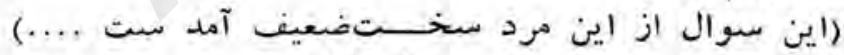

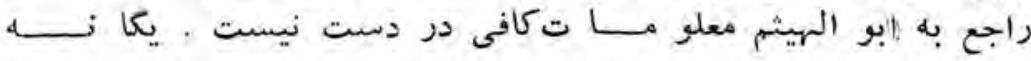

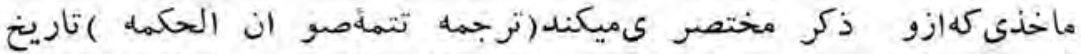

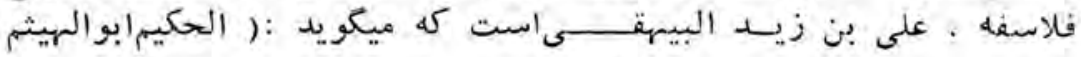

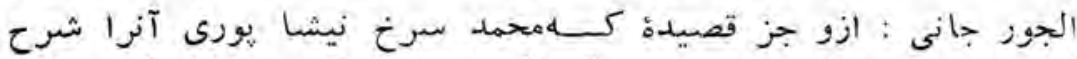

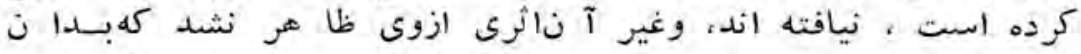

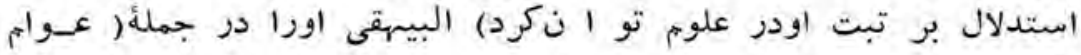

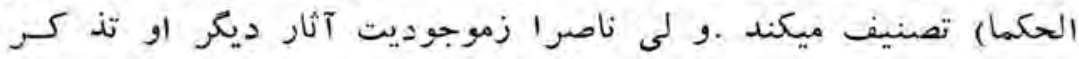

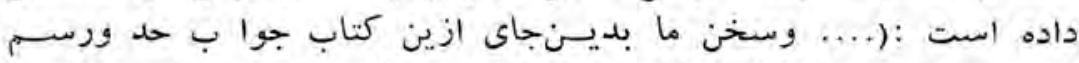

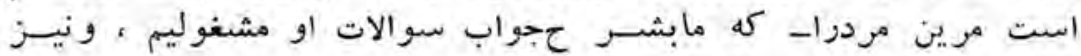




\section{IrA}

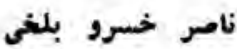

جـايى ديده ايسم از قول اين مرداعنى خواجه ابوالهيشم الجر جانسـى

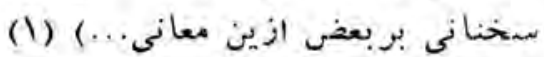

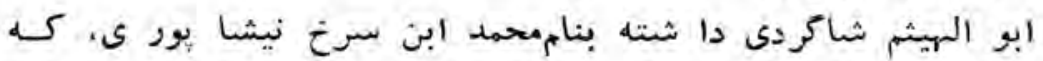

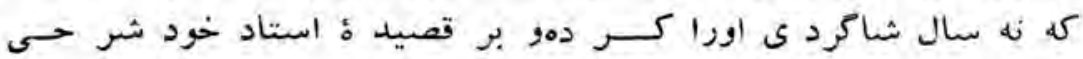

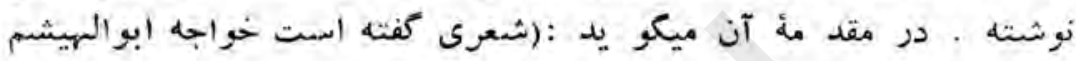

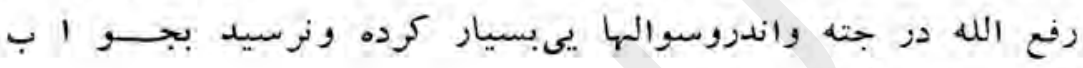

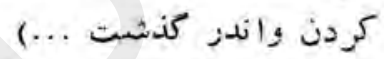

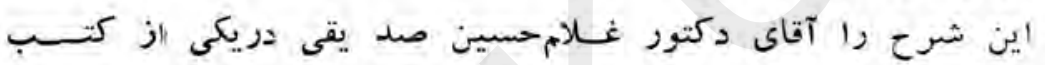

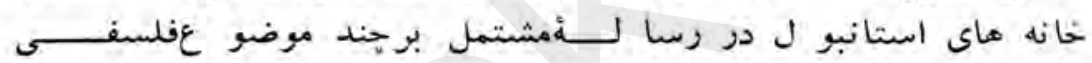

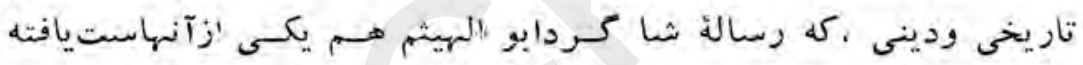

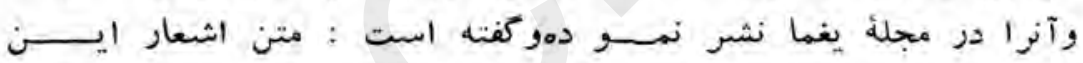

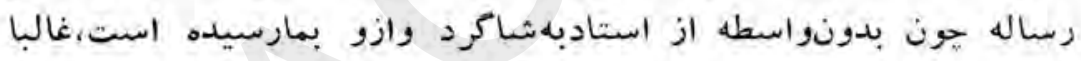

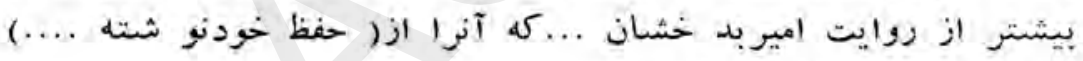

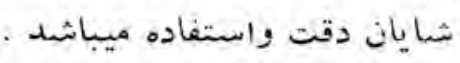

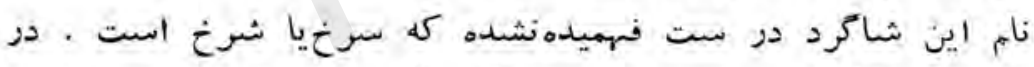

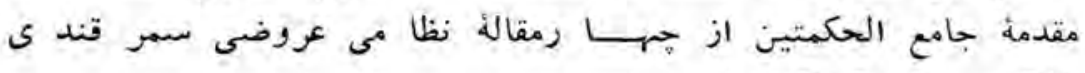

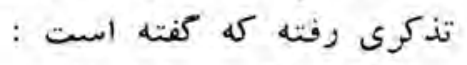

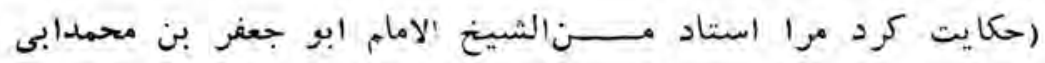

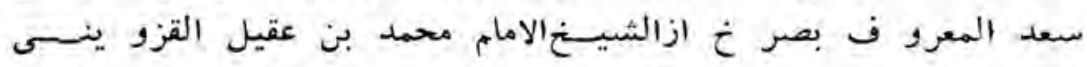

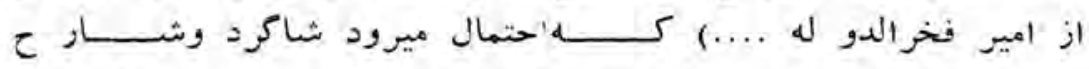

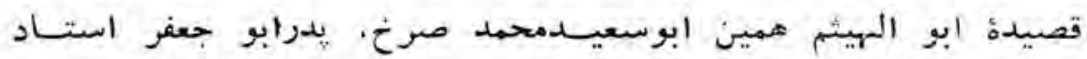

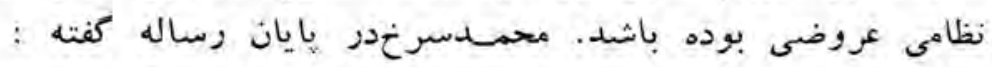




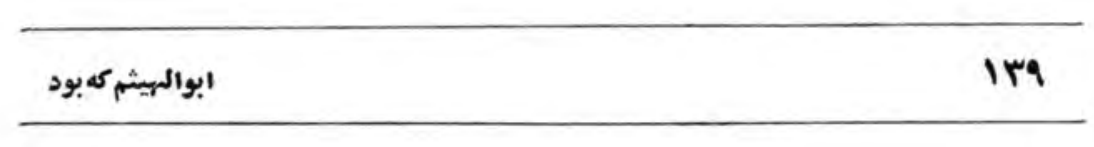

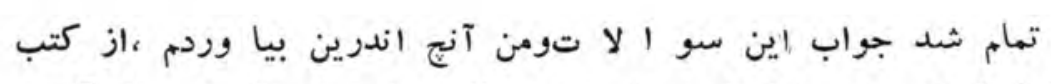

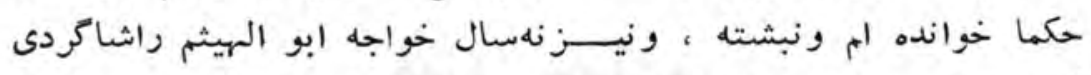

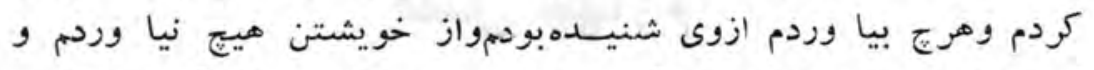

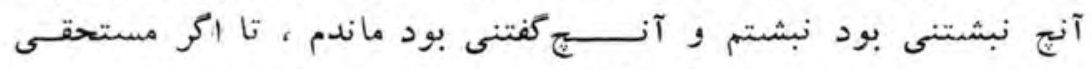

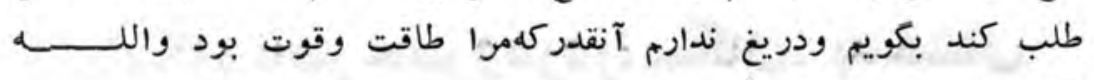

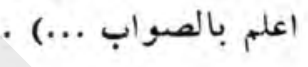




\section{فصل جهارم}

\section{آراسَاه ناصرخسرودردورة يمكان- بدخشان}

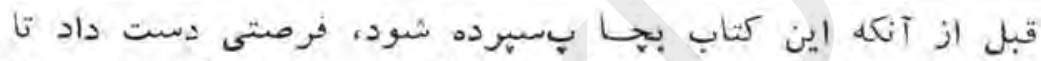

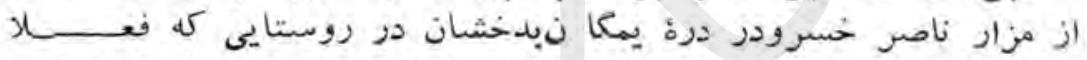

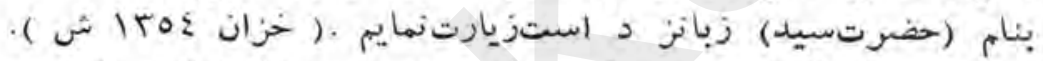

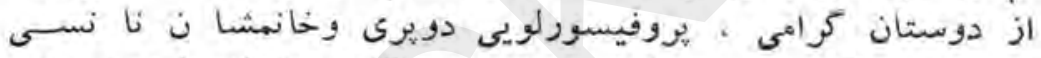

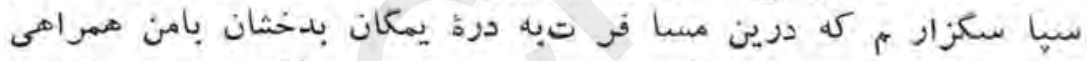

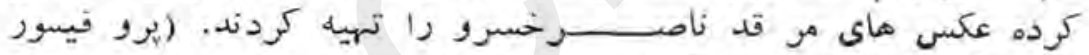

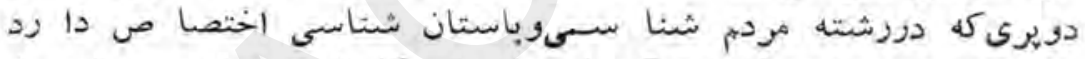

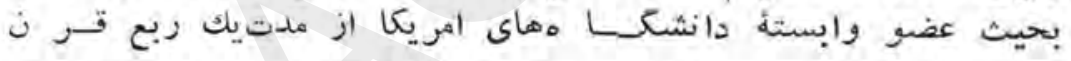

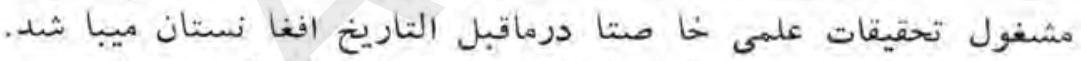

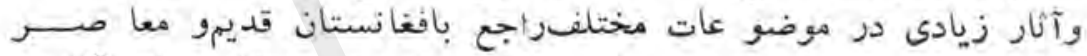

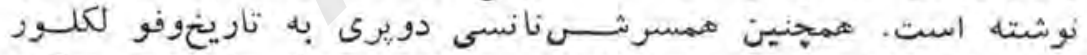

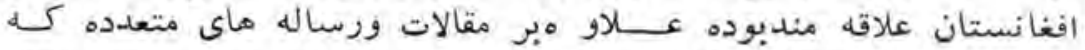

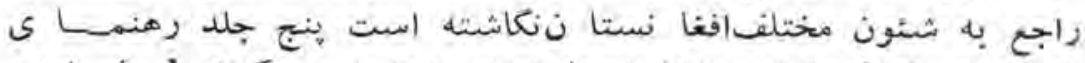

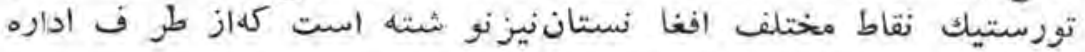

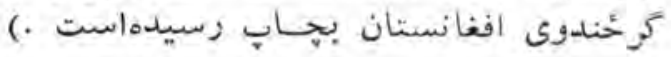

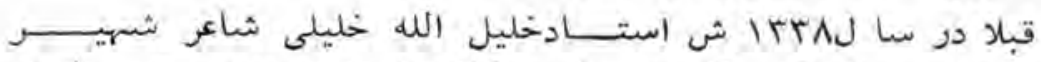

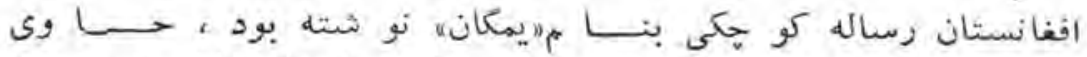

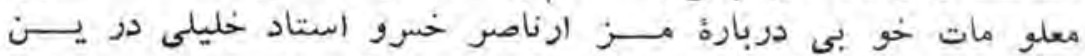

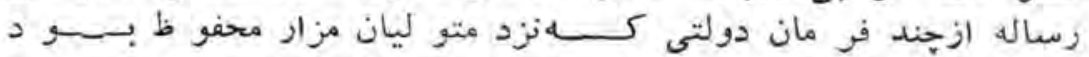

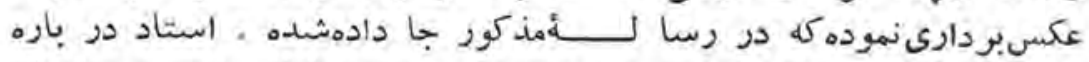

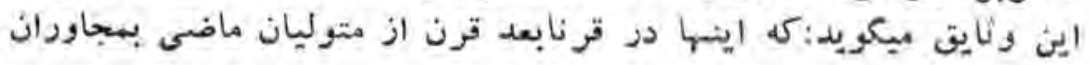




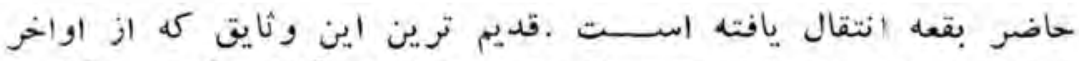

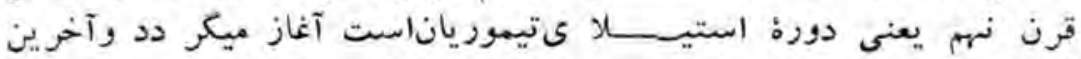

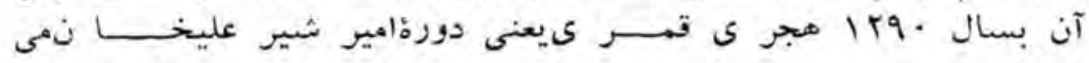

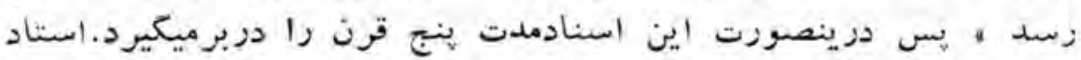

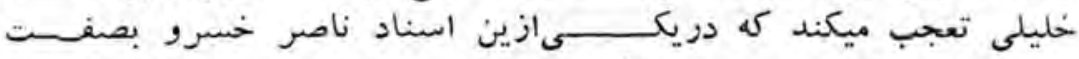

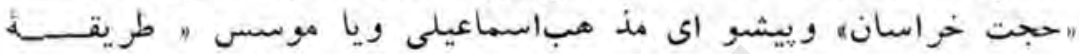

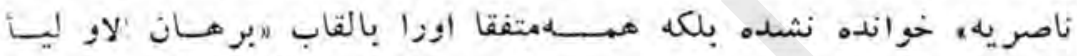

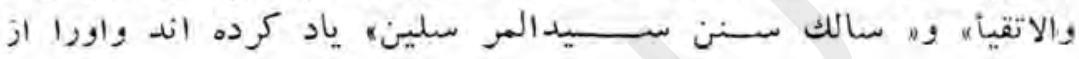

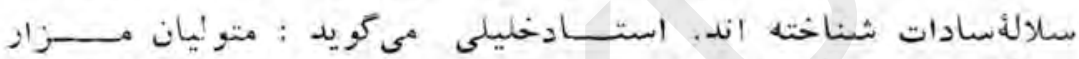

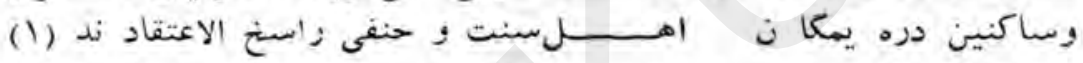

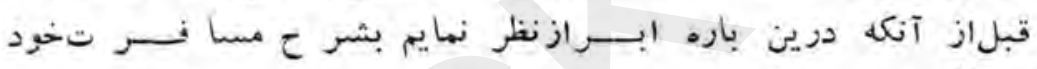

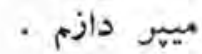

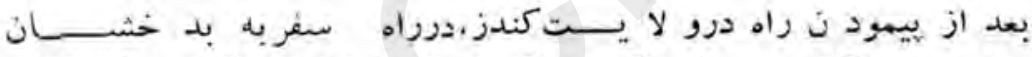

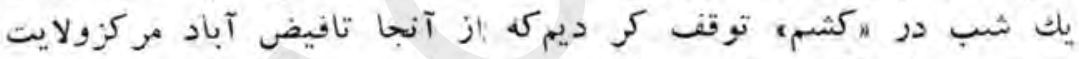

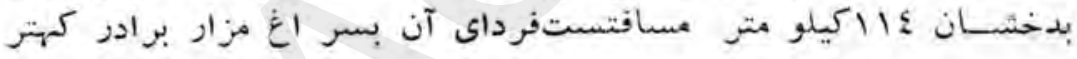

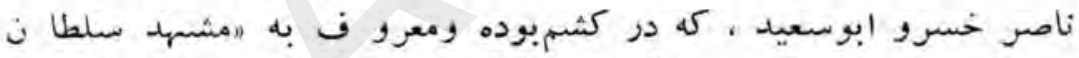

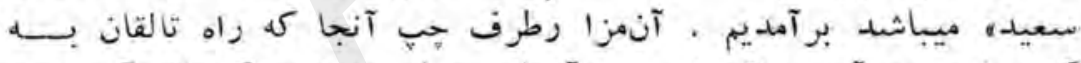

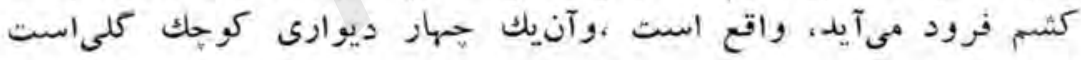

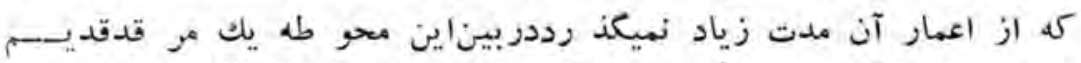

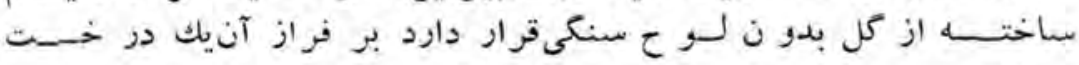

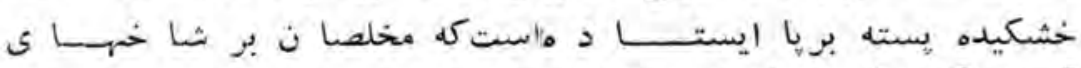

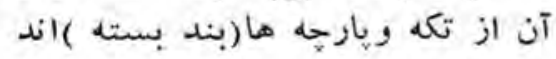

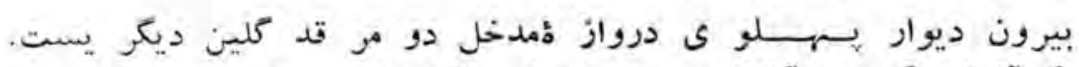

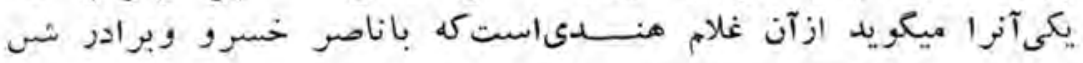

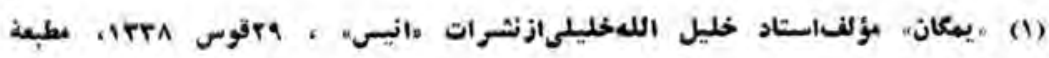
دولتي كابل 


\section{IET}

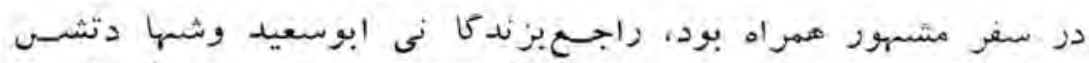

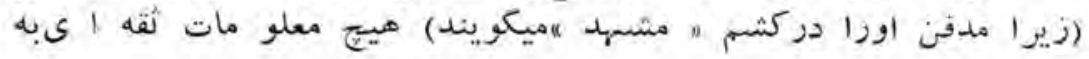

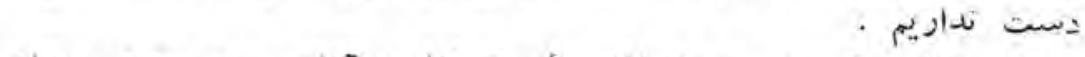

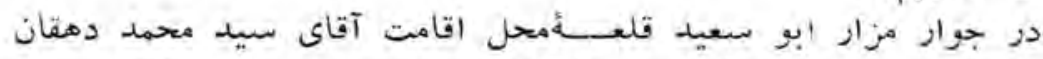

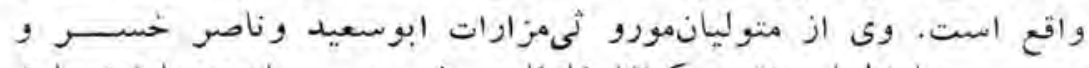

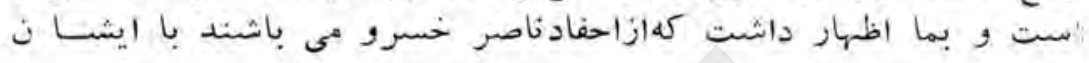

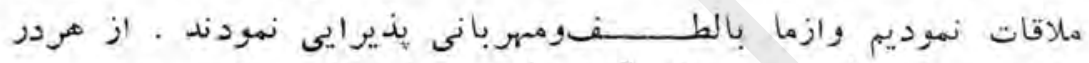

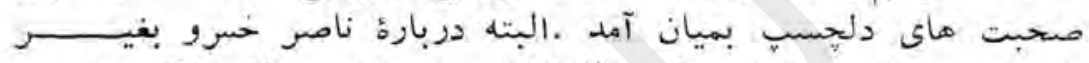

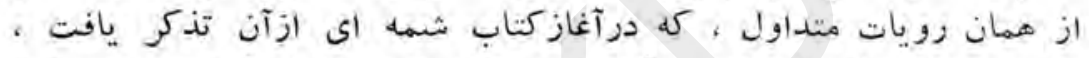

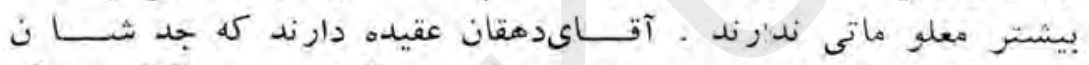

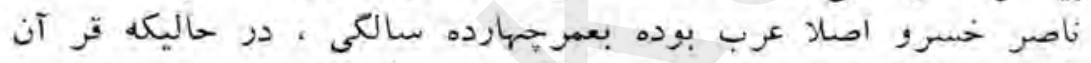

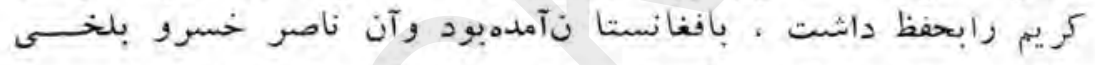

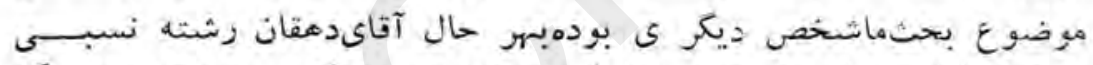

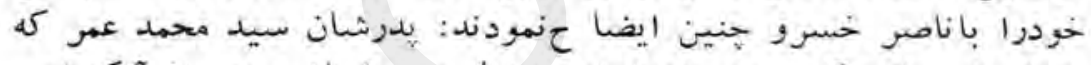

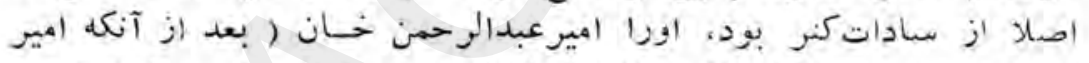

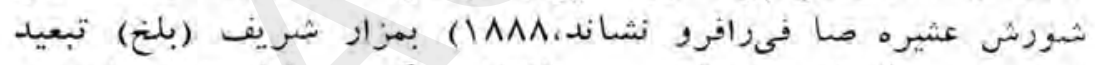

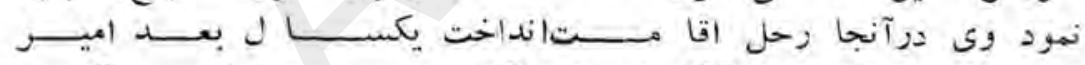

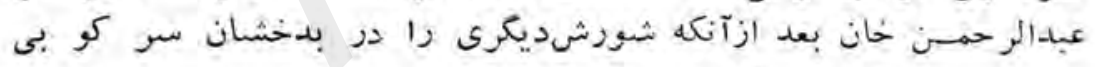

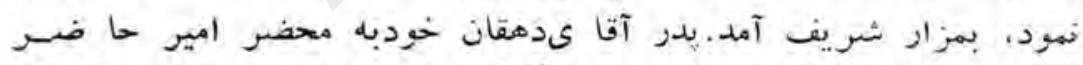

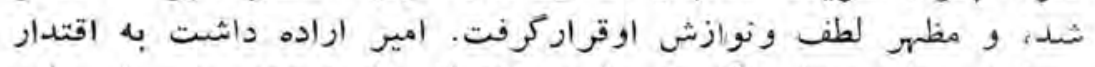

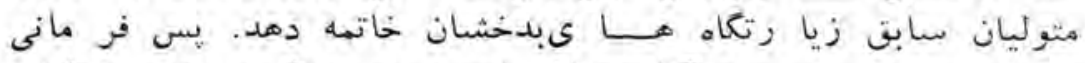

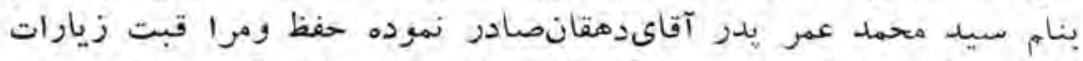

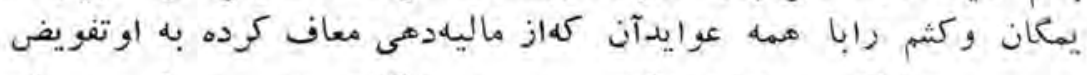

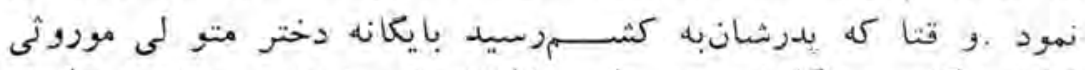

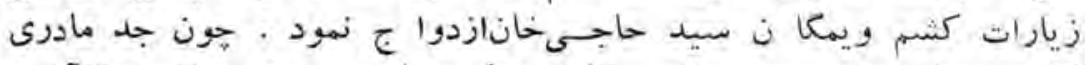

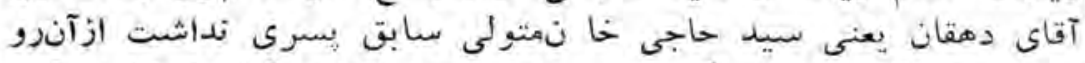

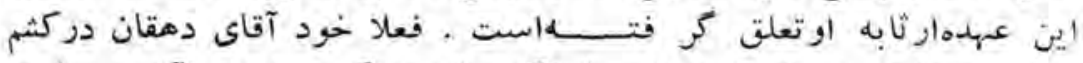

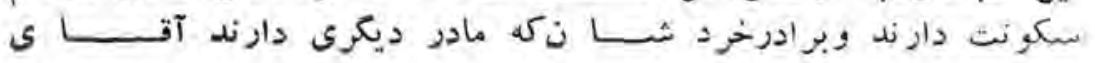




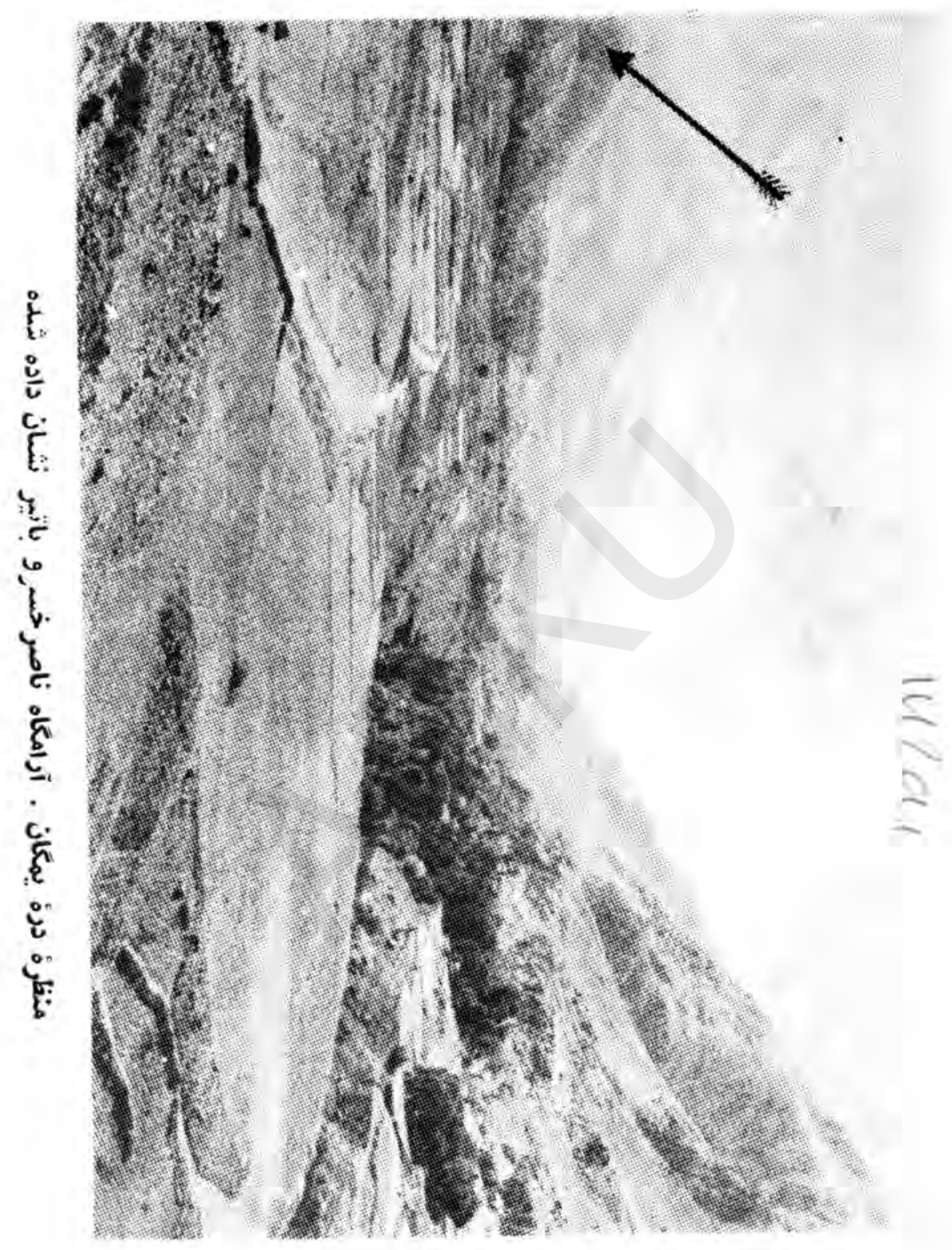


سيد هارون متو لى (حضــــــر تـسيد) آرا مكاه ناصر خسرودريمكان

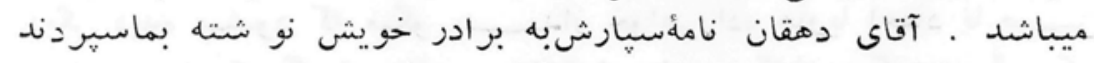

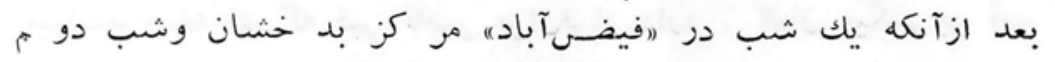

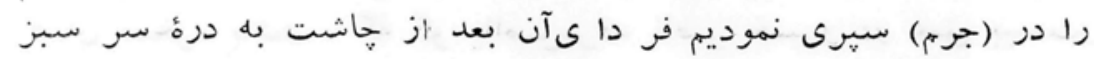

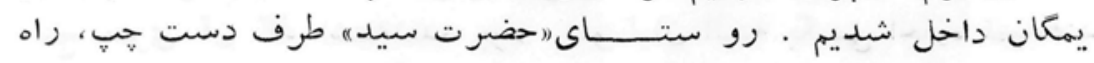

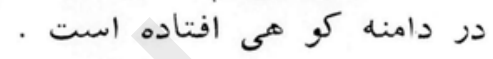

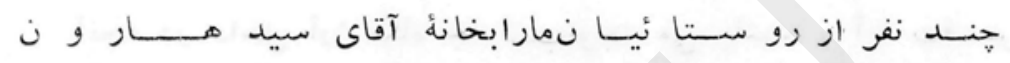

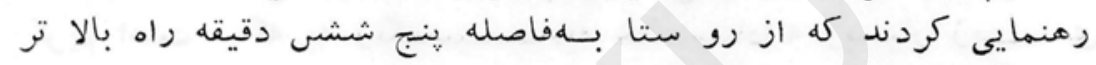

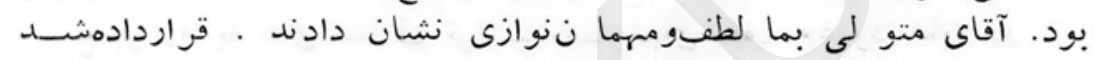

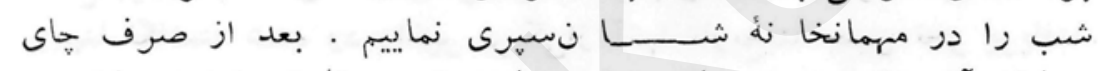

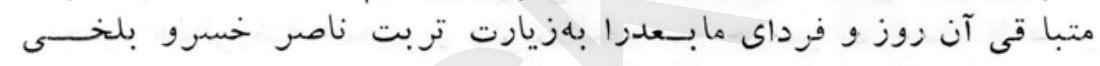
وقن نموديم في آن نوز

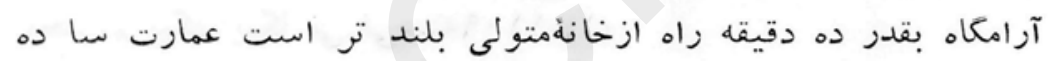

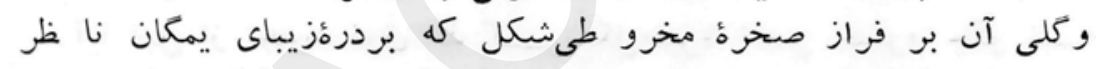

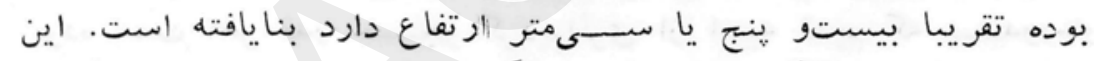

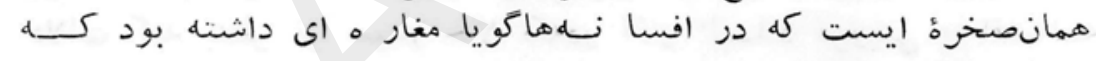

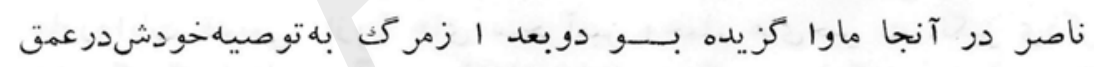

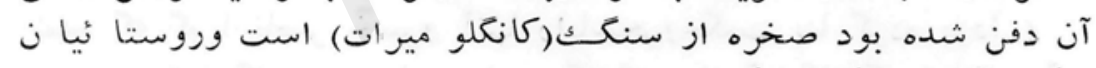

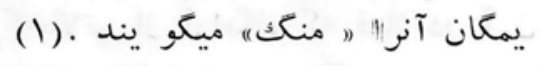

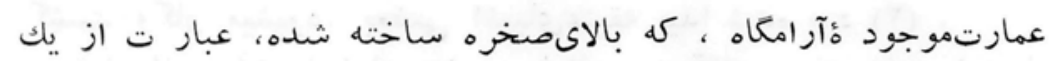

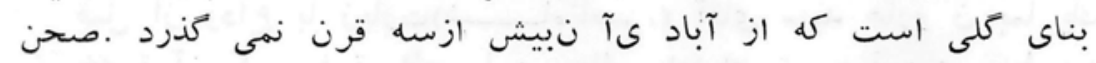

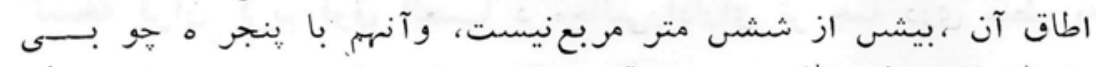

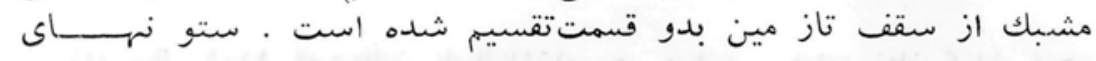

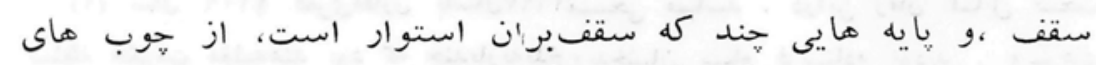

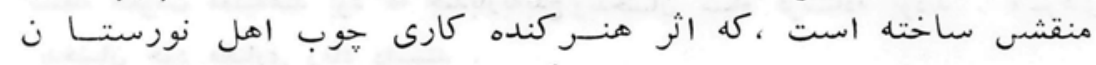

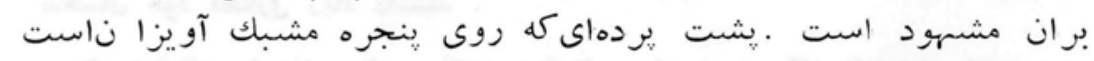




\section{$1 \varepsilon \varepsilon$}

ناصر خسوو بلغى

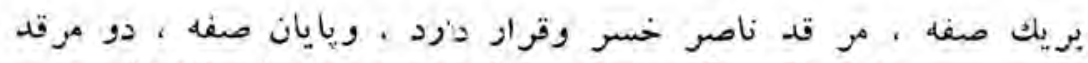

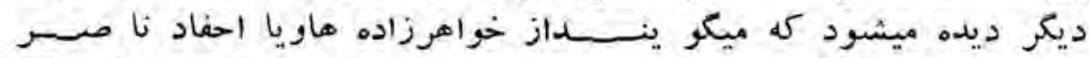

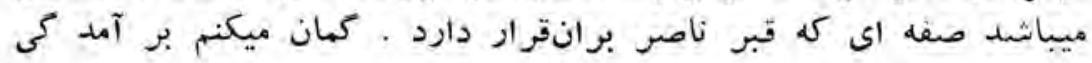

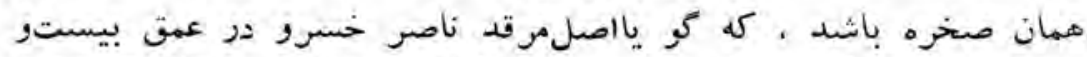

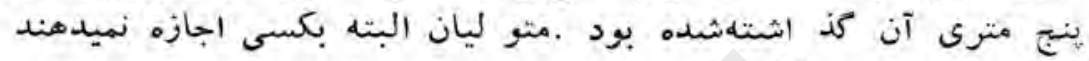

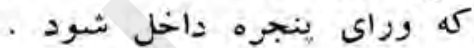

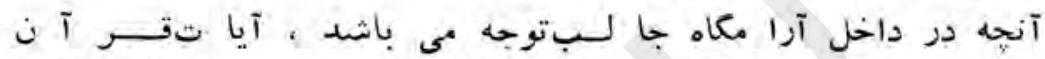

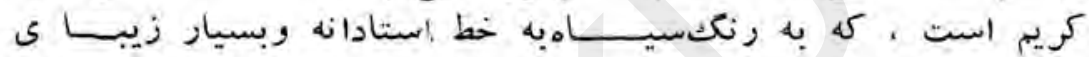

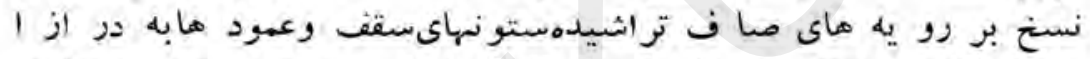

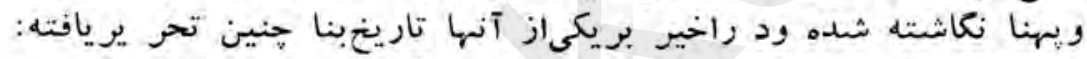

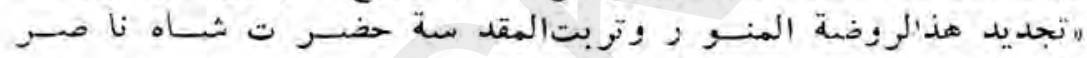

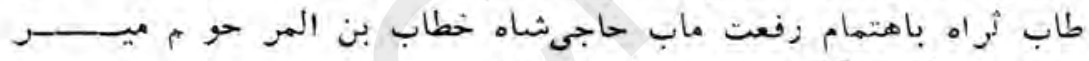

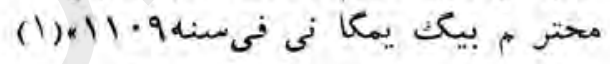

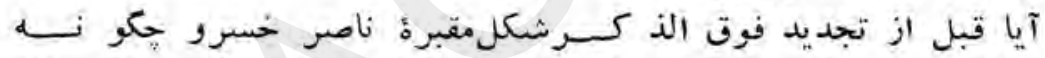

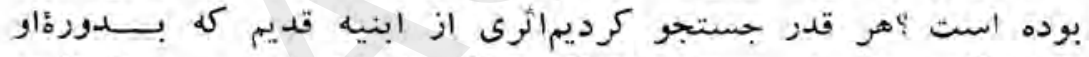

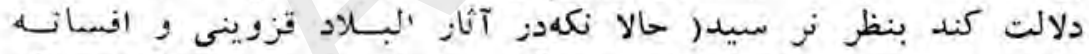

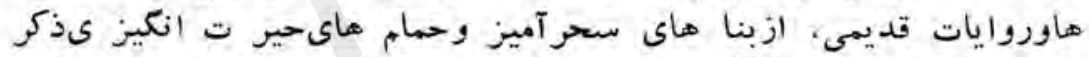

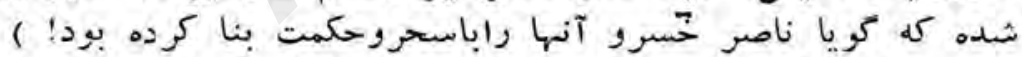

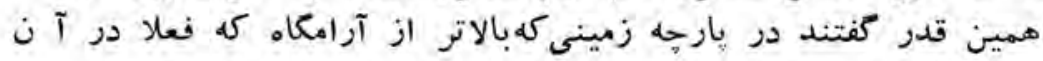

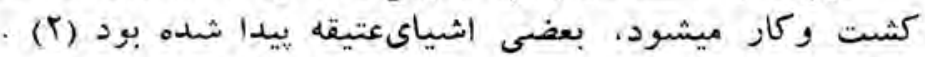

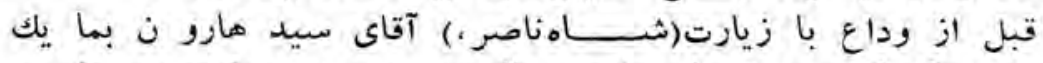

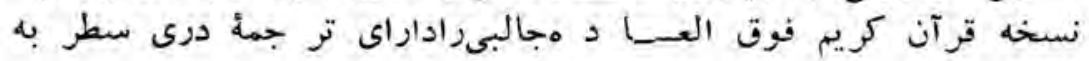

(1)

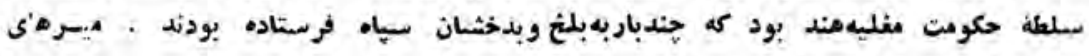

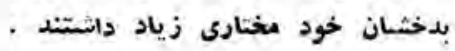

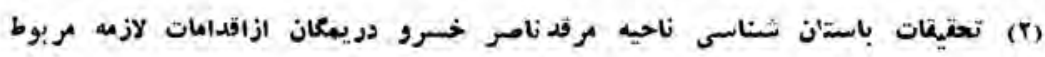
عبد اسلكا مى مى بعقات بالشد. 


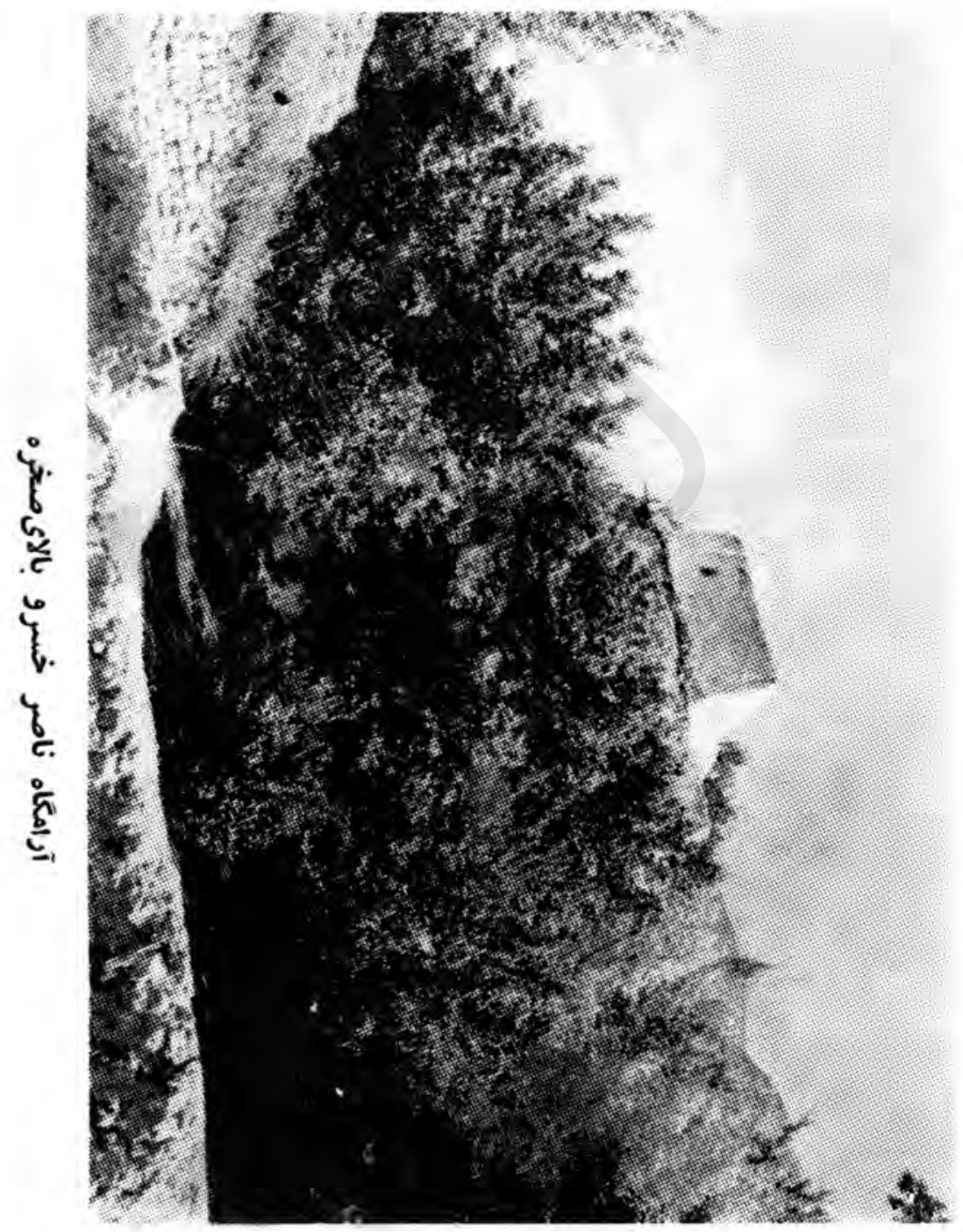




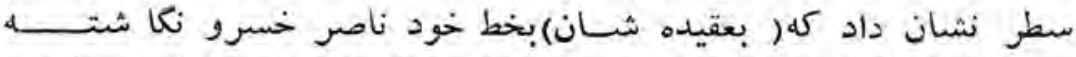

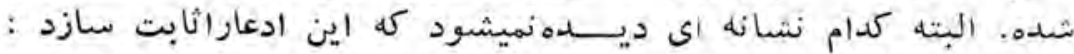

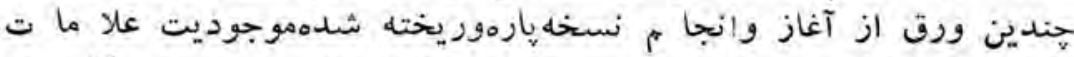

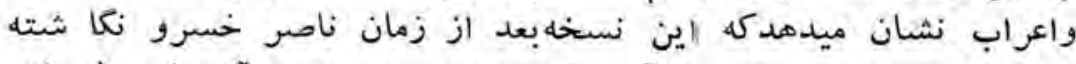

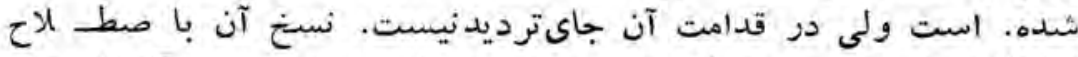

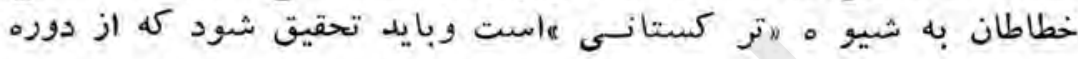

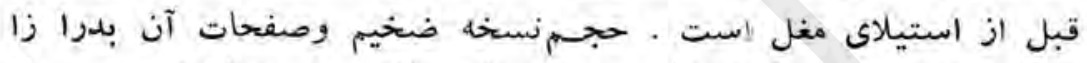

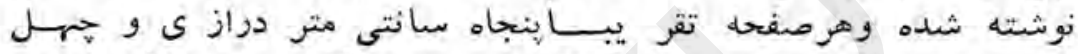

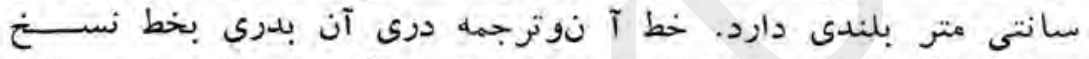

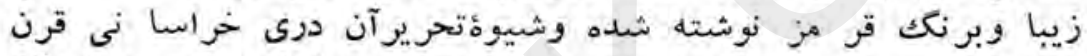

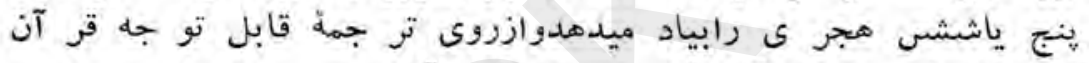

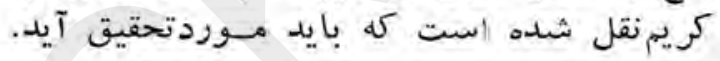

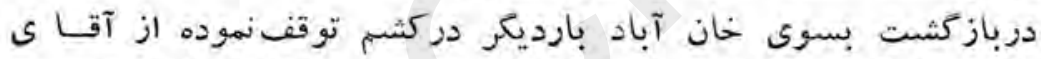

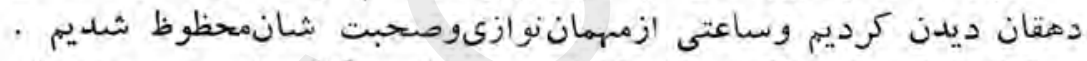

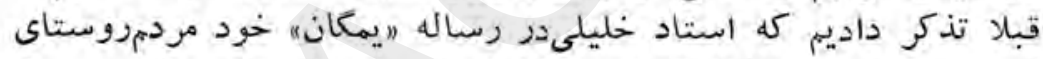

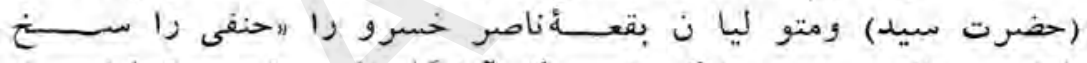

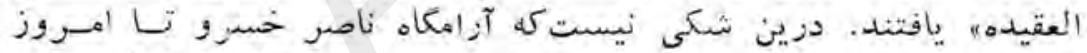

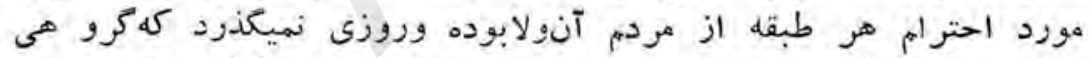

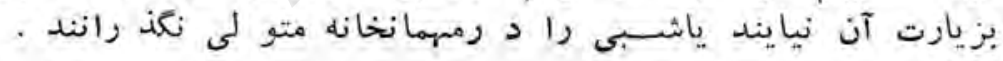

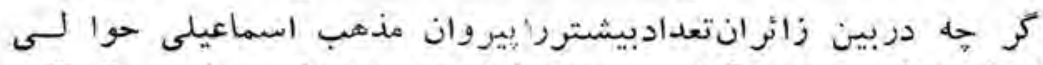

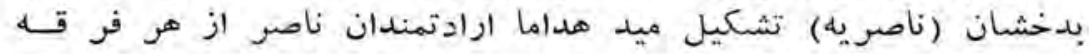

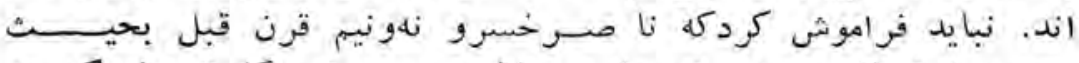

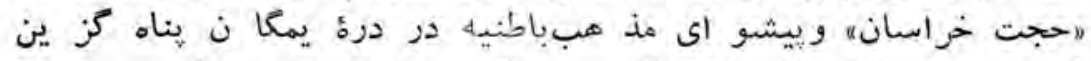

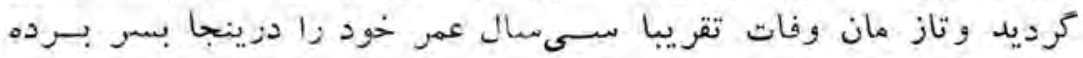

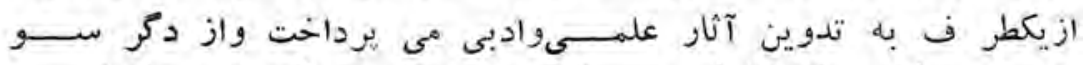

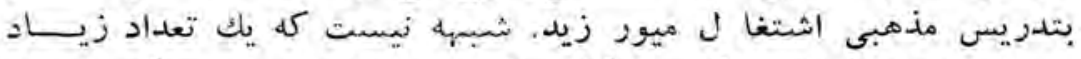

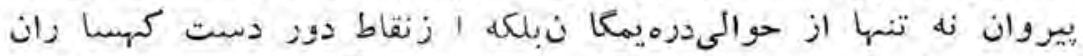

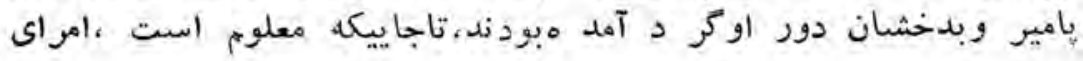




\section{I乏ๆ}

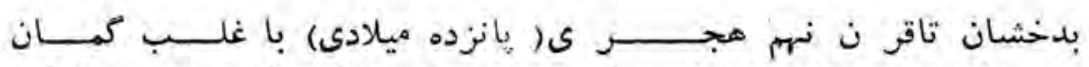

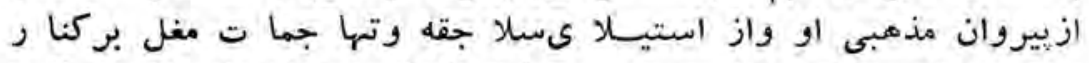

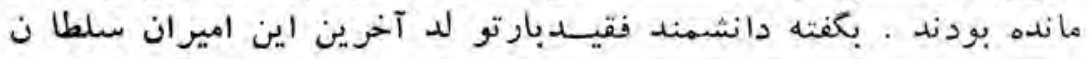

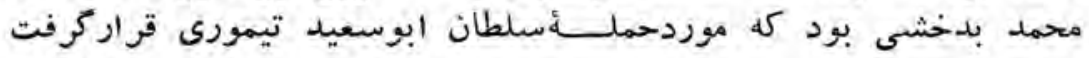

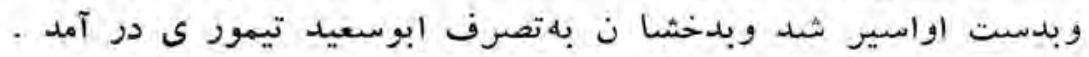

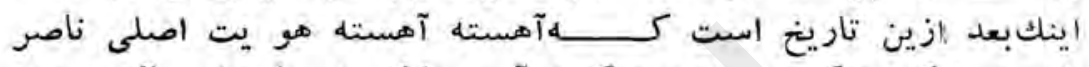

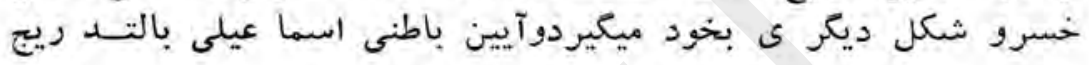

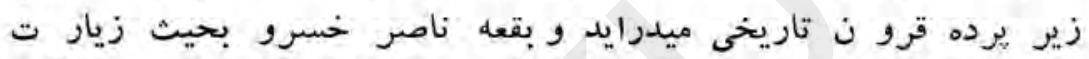

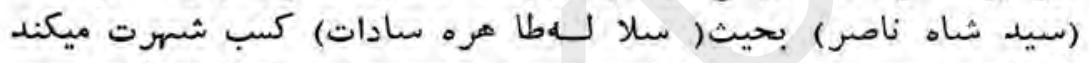

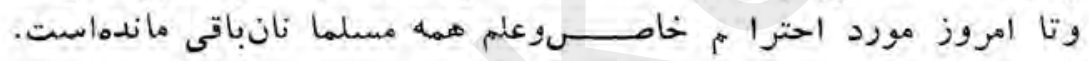




\title{
فصل קنججم
}

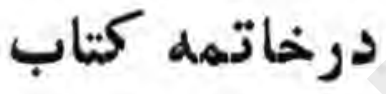

\begin{abstract}
1- افنانستان ونا صر خسـر وبلخى

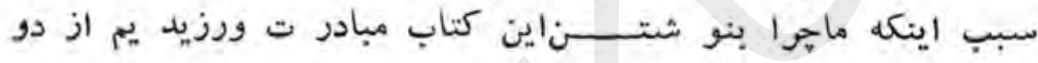

جهت بود م:
\end{abstract}

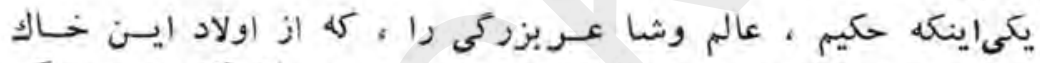

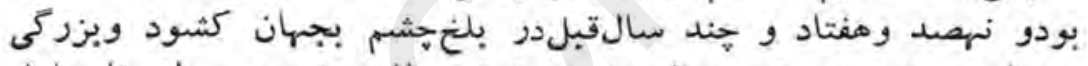

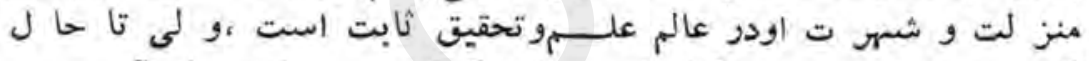

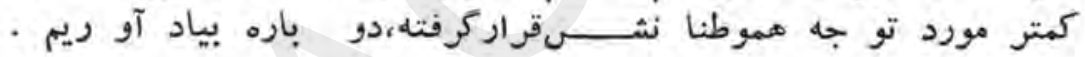

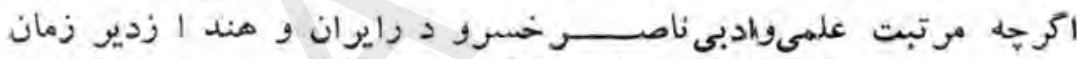

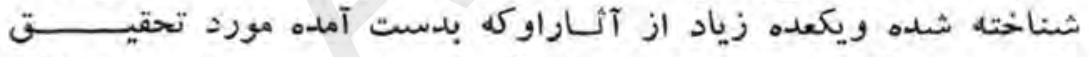

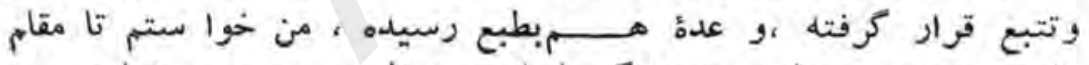

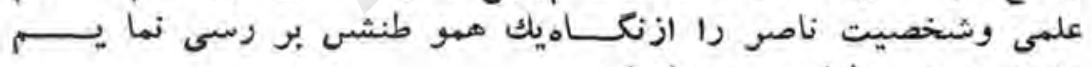

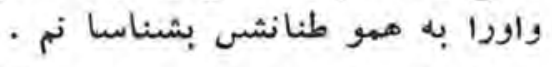

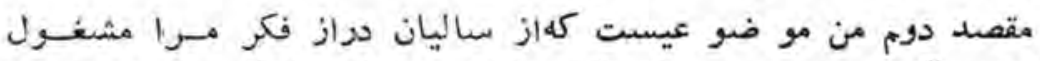

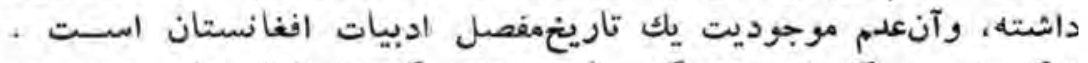

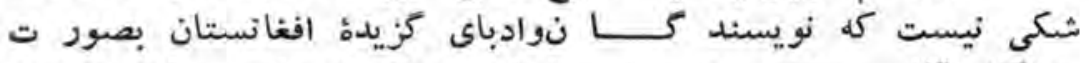

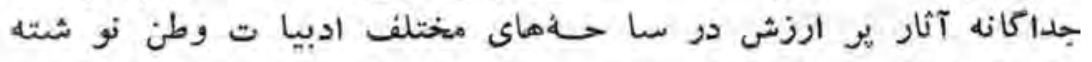

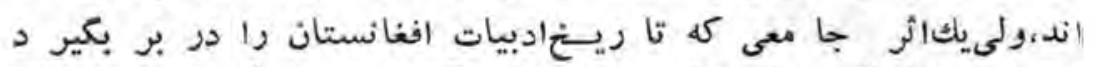

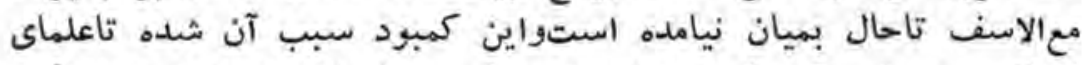

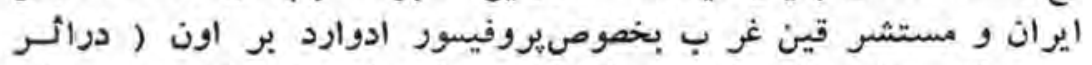

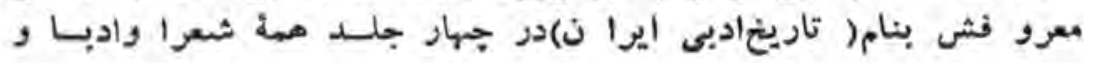




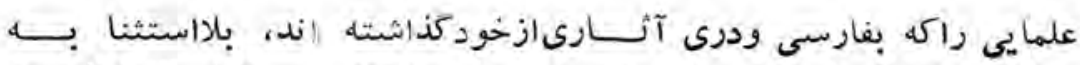

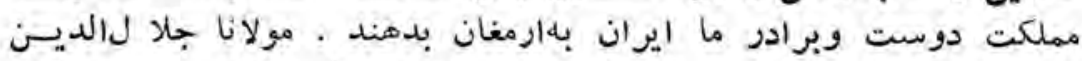

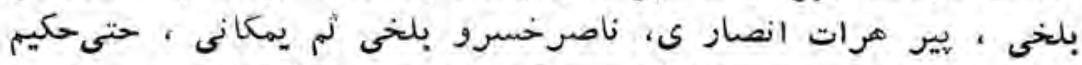

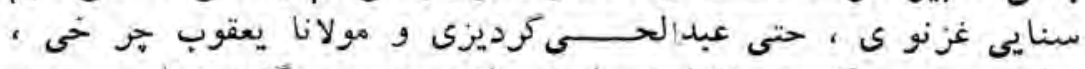

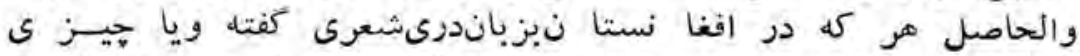

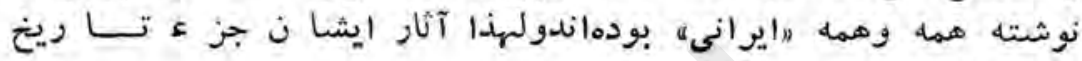

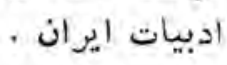

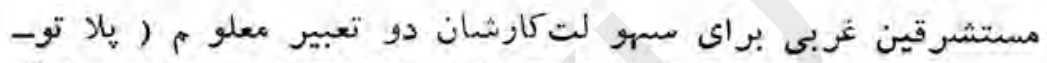

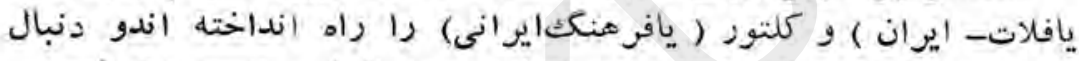

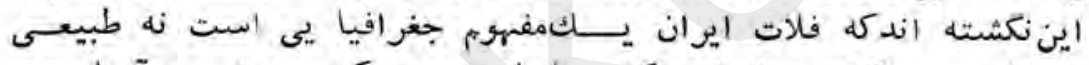

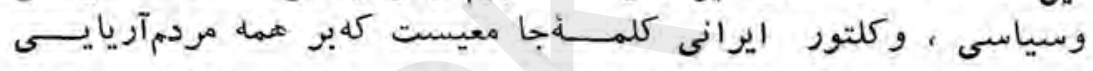

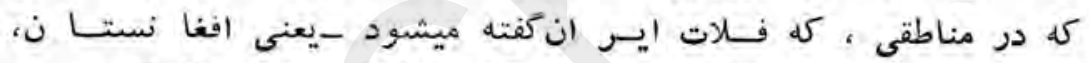

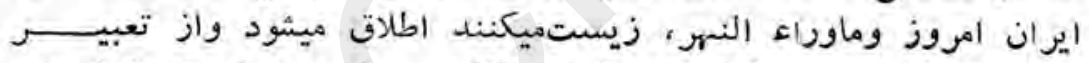

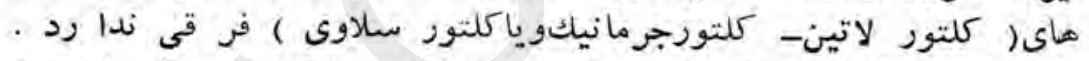

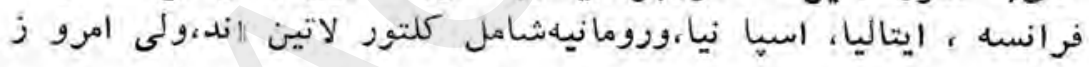

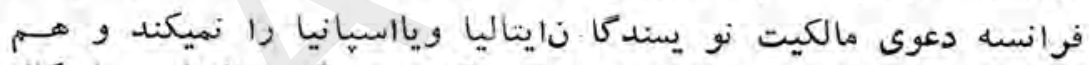

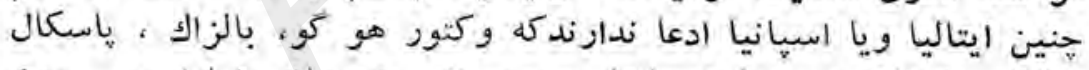

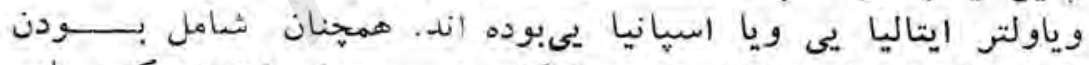

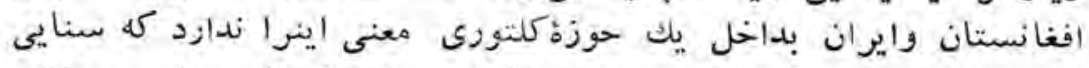

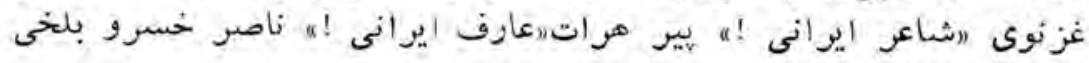

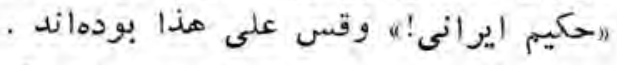

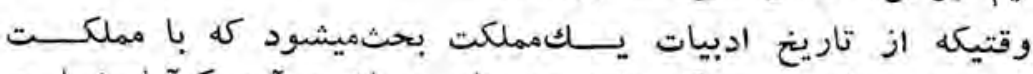

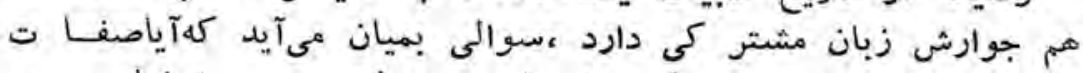

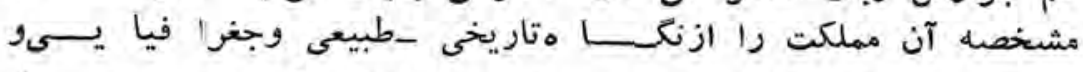

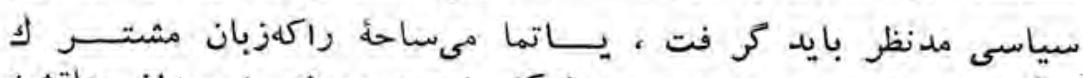

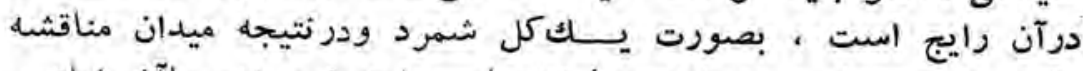

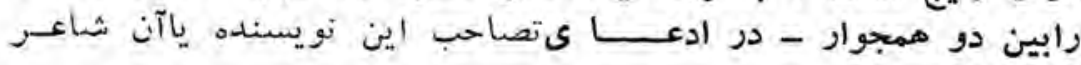




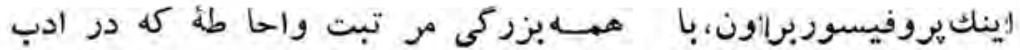

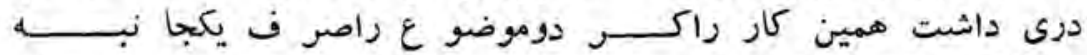

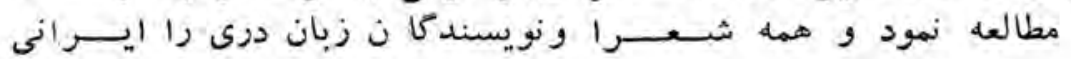

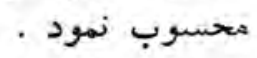

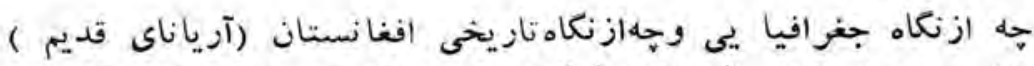

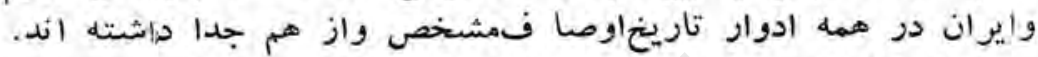

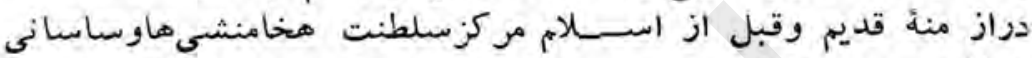

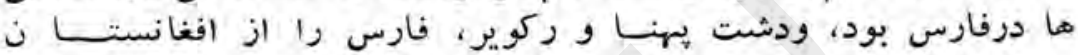

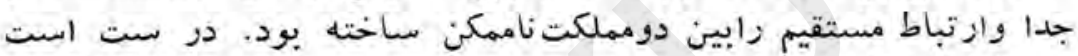

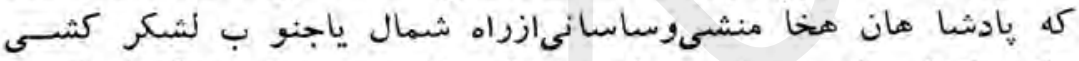

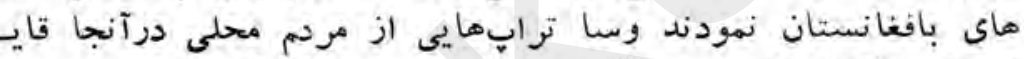

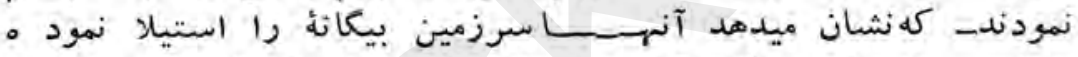

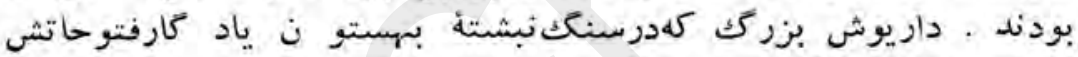
را قيد نموده ميكو يد داريد

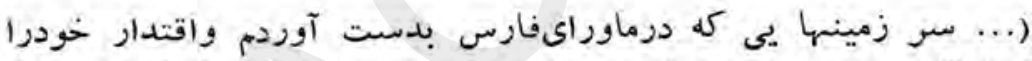

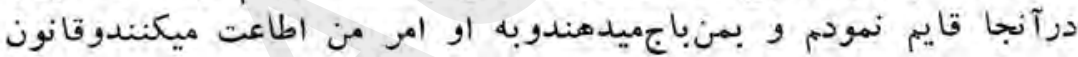

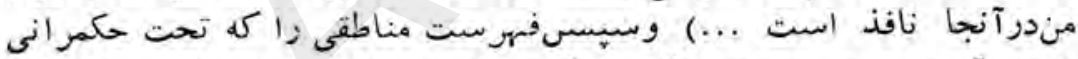

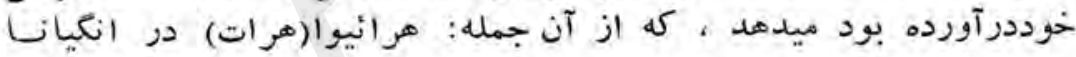

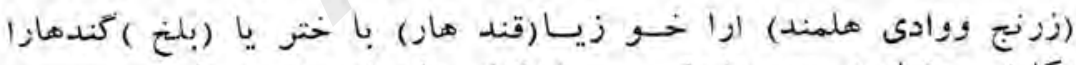

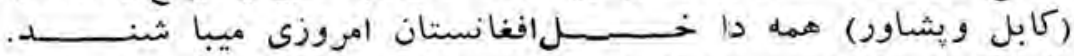

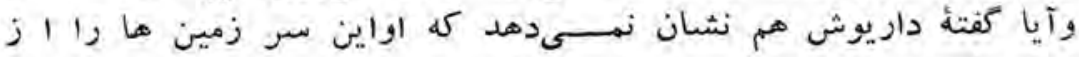

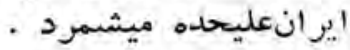

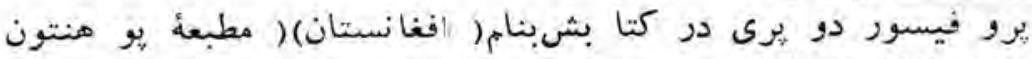

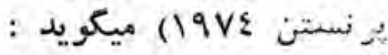

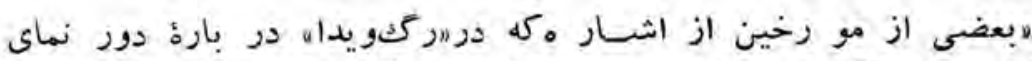

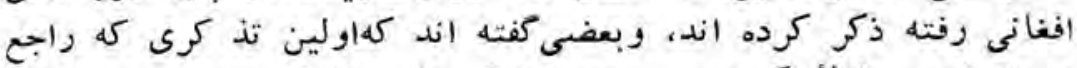

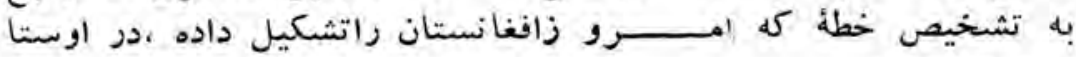




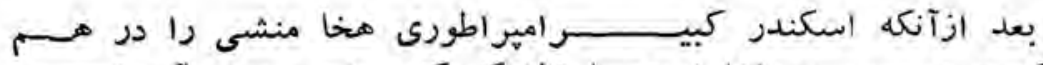

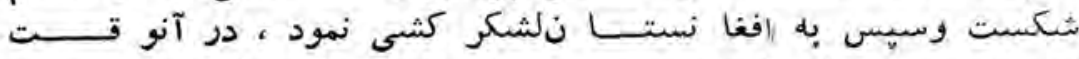

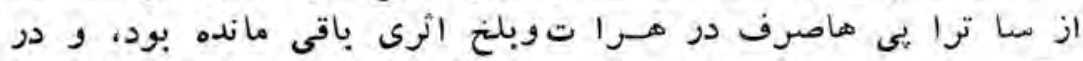

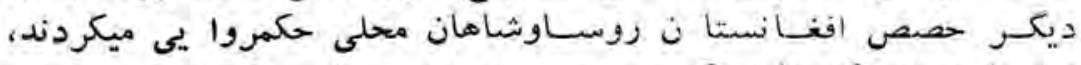

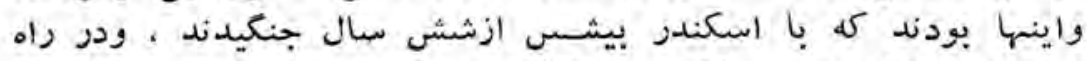

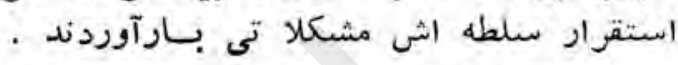

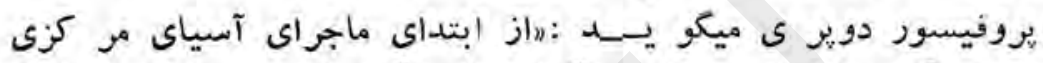

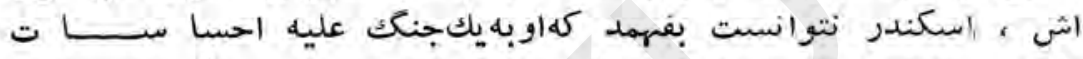

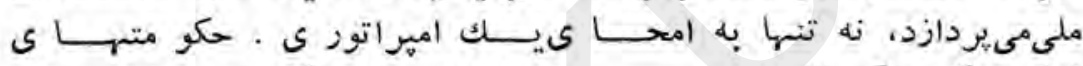

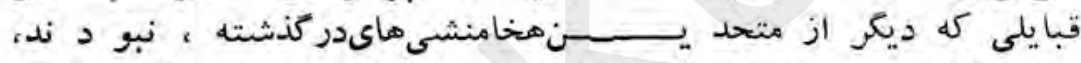

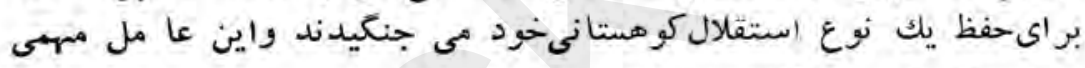

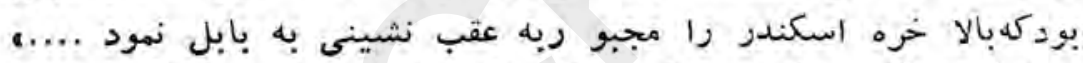

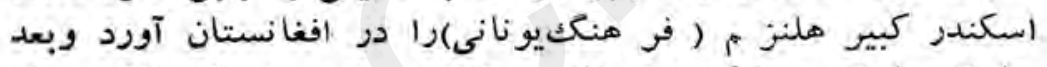

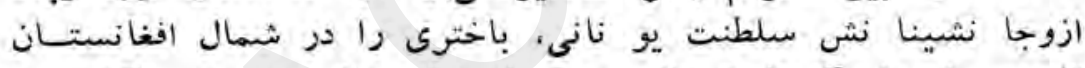

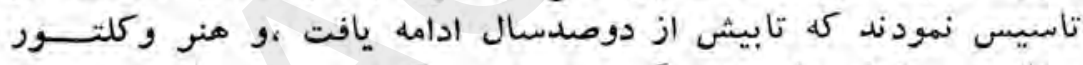

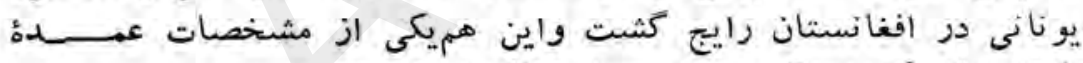

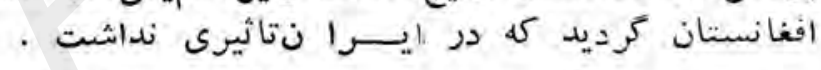

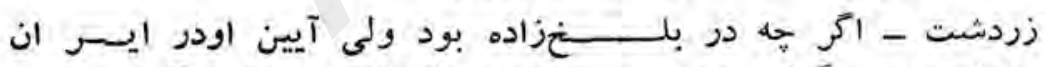

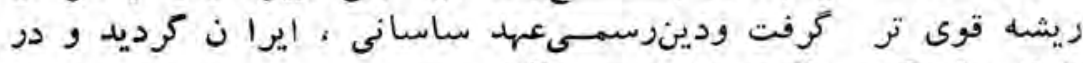

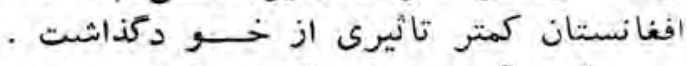

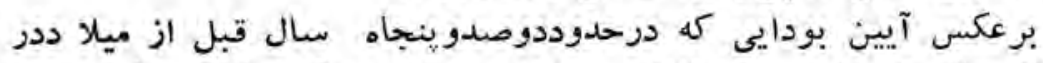

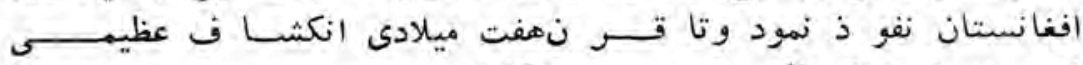

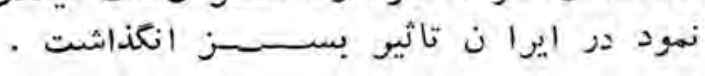

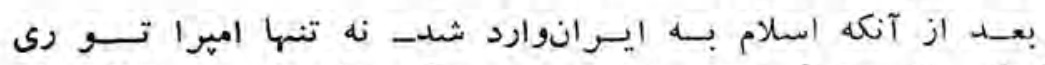

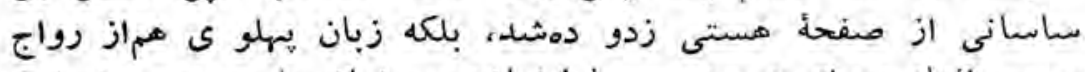

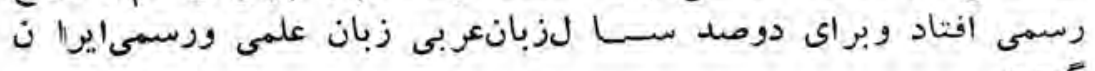
زوريد

زبان هاى آريايى دركو هستا نهاى افغانستان زنده ماندند ،وزبان 


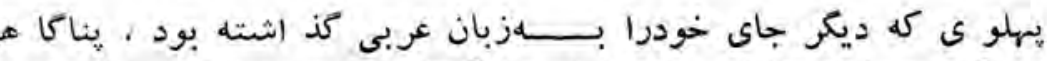

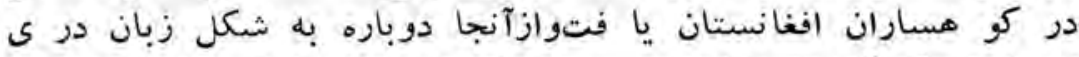

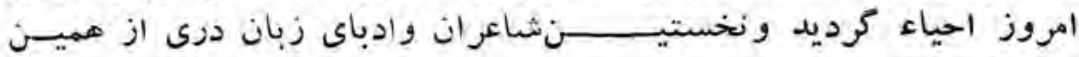

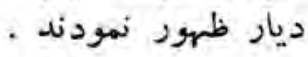

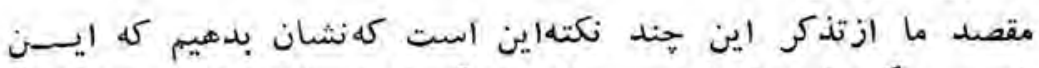

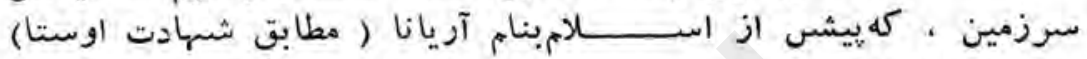

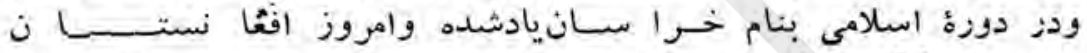

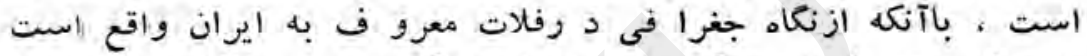

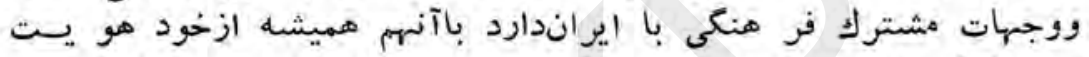

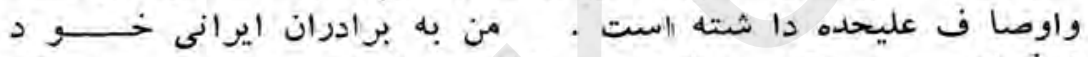

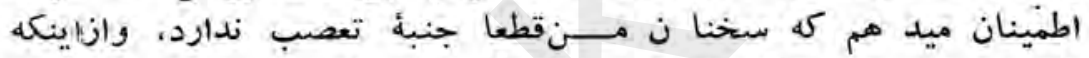

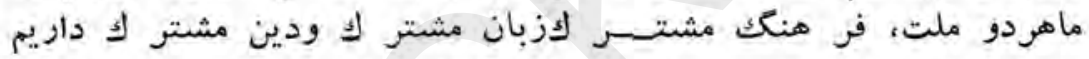

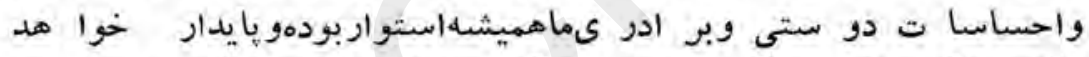

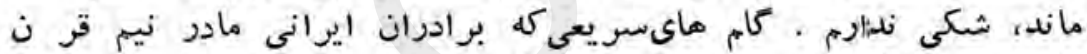

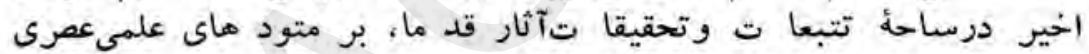

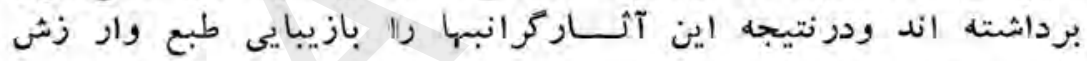

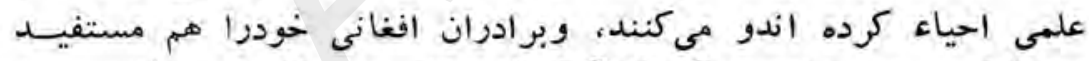

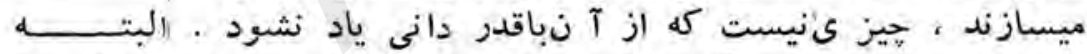

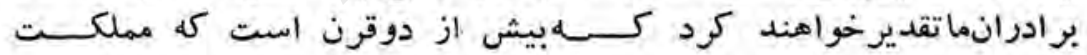

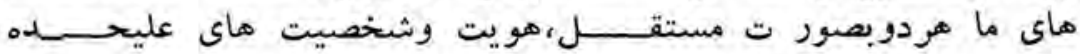

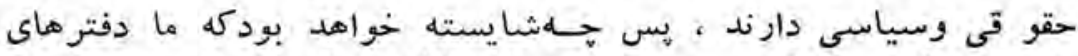

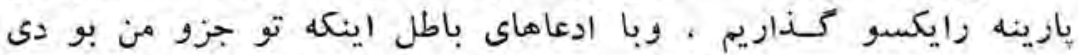

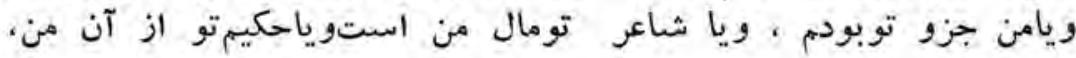

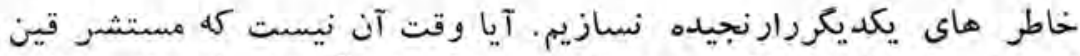

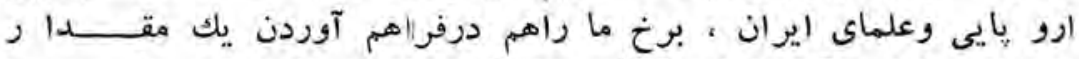

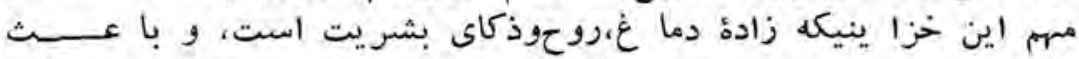

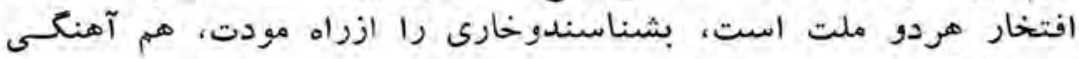

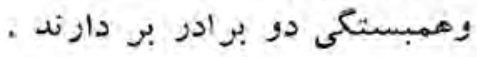




\section{r-نتيجه بو مقام ناصر خسر وبلخى :}

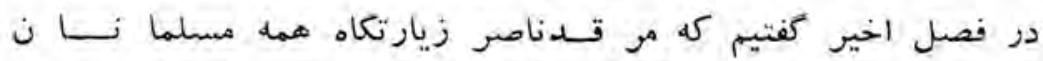

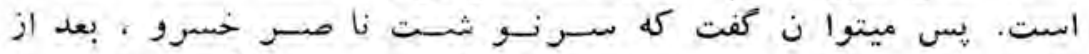

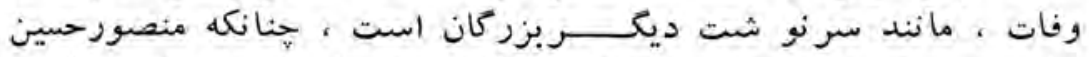

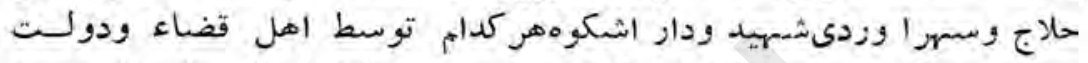

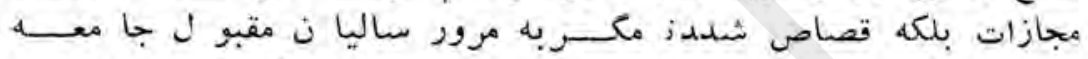

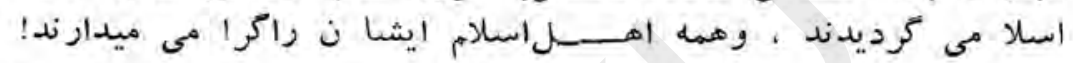

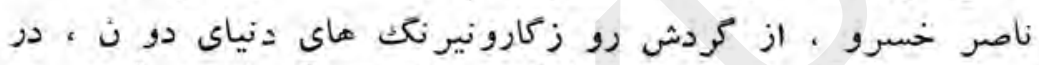

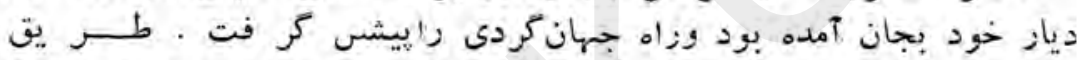

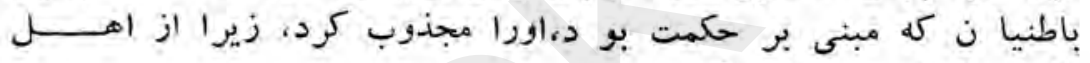

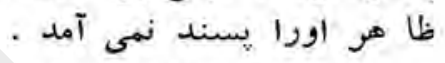

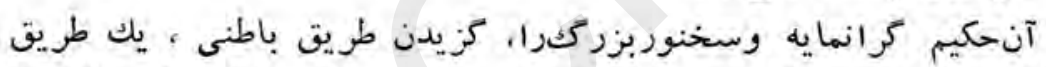

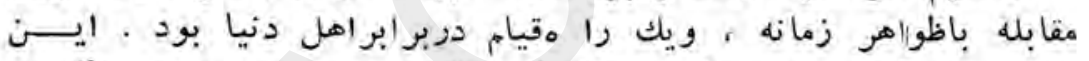

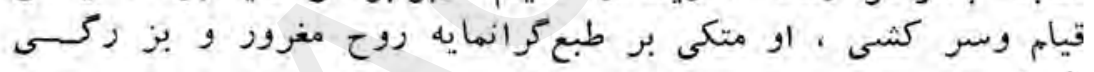
طبع اوبود2.

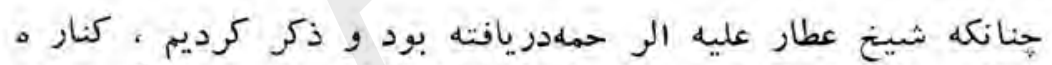

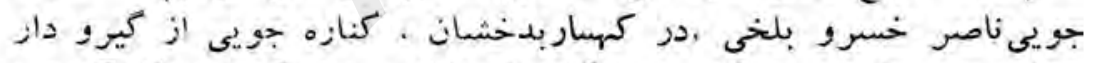

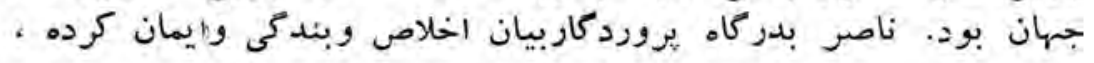

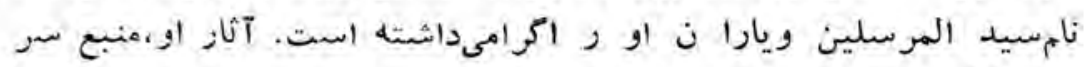

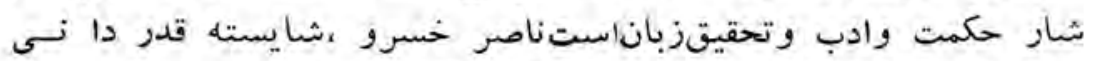

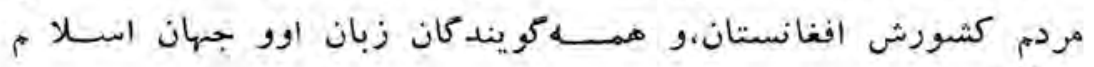
ميباشد مردم 


\section{مـ أخذـ (ببليوكرافى )}

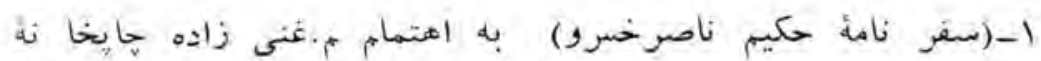

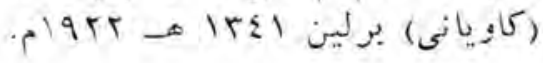

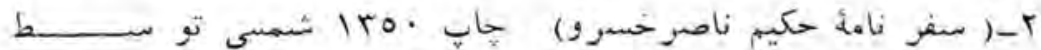

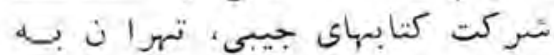
كو شش نادر وزين يون

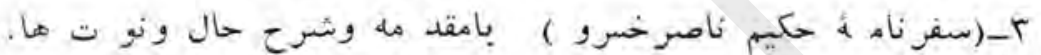

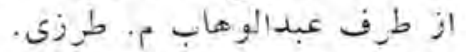

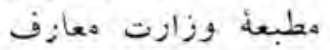

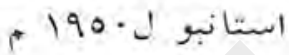

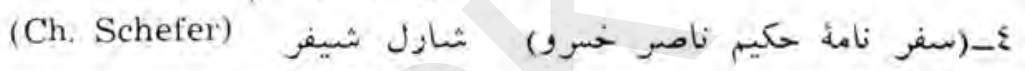

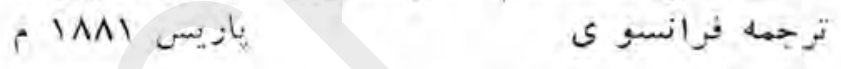

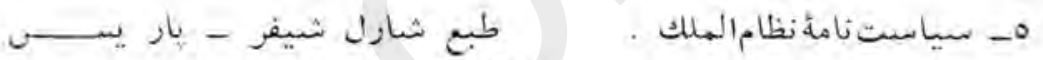

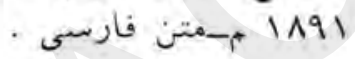

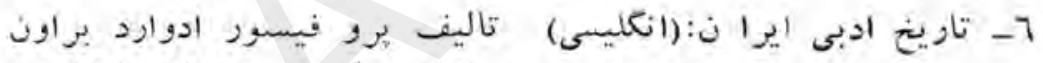

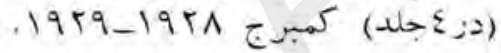

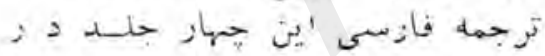

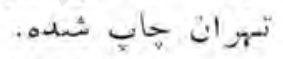

E.G. Brown. literary Histo ry of Persia, 4 Vols,

Camb ridge 1928-1929

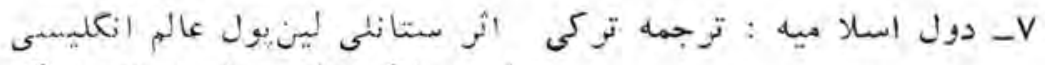

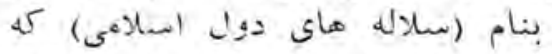

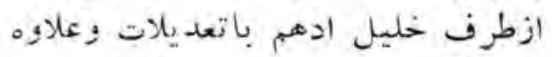

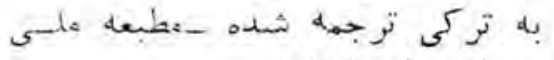

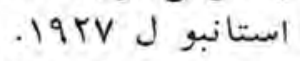

Stanley lane-Pool, Mohammadan Dynasties, London, 1894 


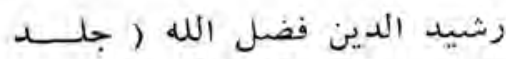

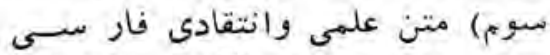

بسعى و الهتمام عبدالكريم على على اوغلى

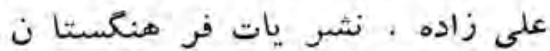

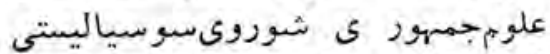

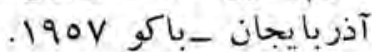

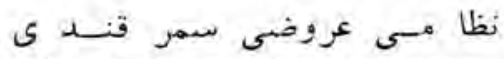

:

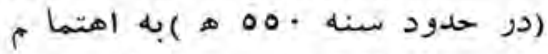

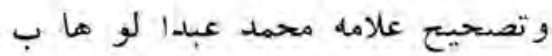

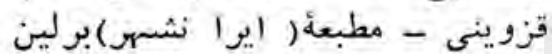

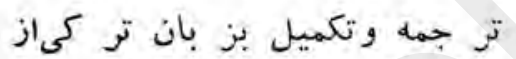

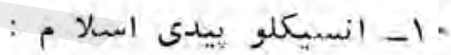

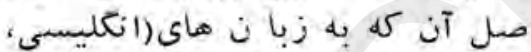

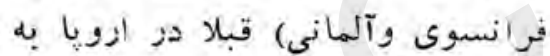
حابت ربسيده

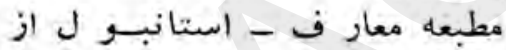

$$
\text { - U 1951 }
$$

ماده هاى : فا طميسها _اسماعيليها،

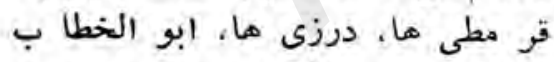

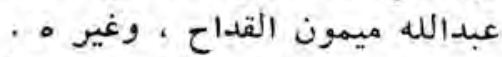
Islam Ansiklopedisi,

(Maarif Basim Evi, Istan-bul.

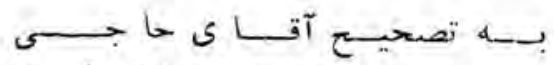

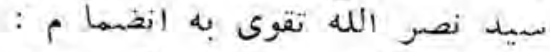

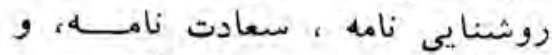

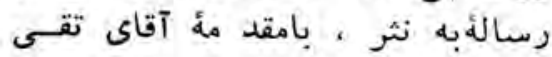

زاده وذيل آقاى مجتبى مينمو ى

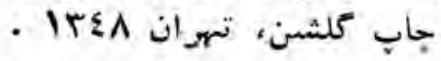

: 11 ابوبعين حميد الدين الدين

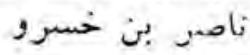
توباديانى 
rا- 2يوان نا صر خسرو (جلداول)

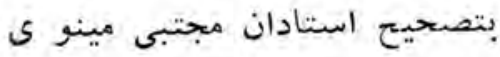

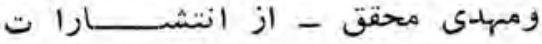

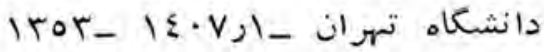

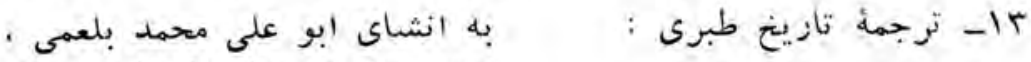

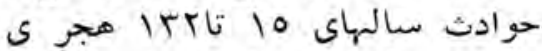

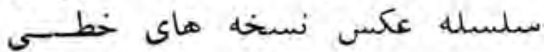

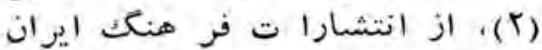

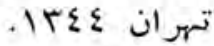

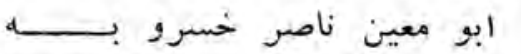
:

تصنيح ومقدمل فارسى وفرا نسوى هنرى كوربن (رئيس قسمت إير 1 ن نوفي

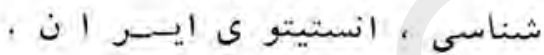

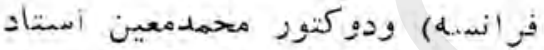

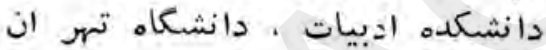
(c) 190r

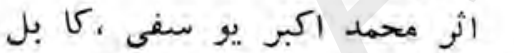
10 - نطبيق سنفوات : ش- $-1+\varepsilon r$

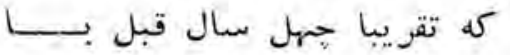

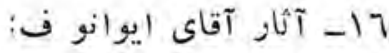

A Guide to Ismaili literature, رهنما ى ادبيات السمعيلى آوانى

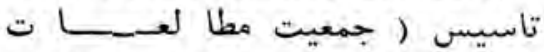

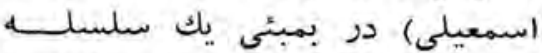

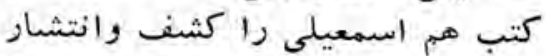
داده است

$$
\text { ا - IV }
$$

The alleged Founder of Ismailism, Bombay, 1946 
Ismaili Tradition concerning:

: 11

The Rise of Fatimids, Oxf ord 1948.

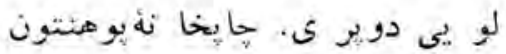

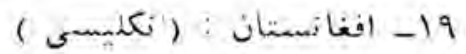

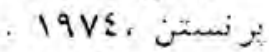

Louis Dupree, Afghanistan.

Princton University Press, 1974

Badakhshan, Historical and Political Gazetteer of Afghanistan, vol. 1

Edited by Ludvice W. Ada mac, Gaz Austria, 1972.

Part II

الب- تاريخ بدخشا ن : :

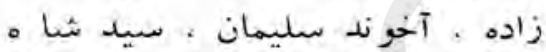

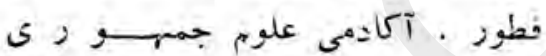

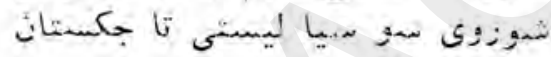

$.19 \mathrm{Vr}$;

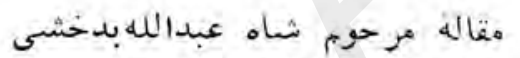

: كابل

نم

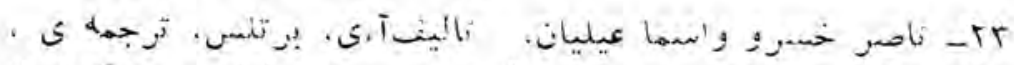

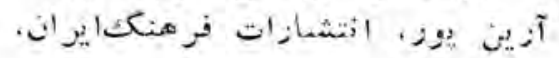

iles - rs

$$
\text { 1rEר it }
$$

زمها'ه بأليف المشتاد خلميل اللهخلينى

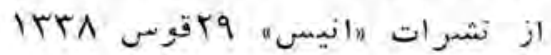

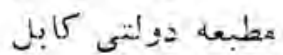

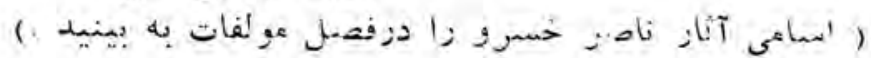




\section{صواب زمابـ}

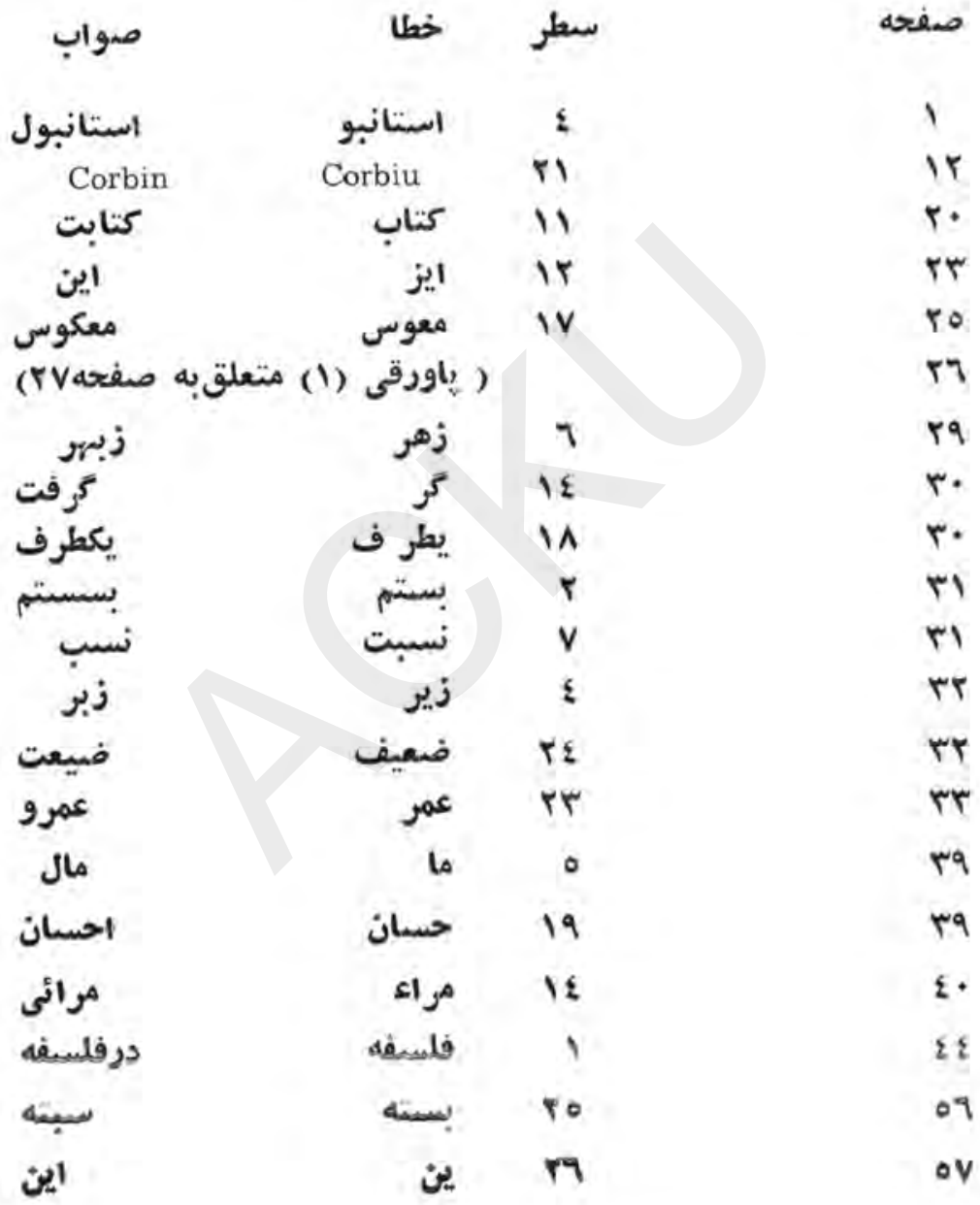




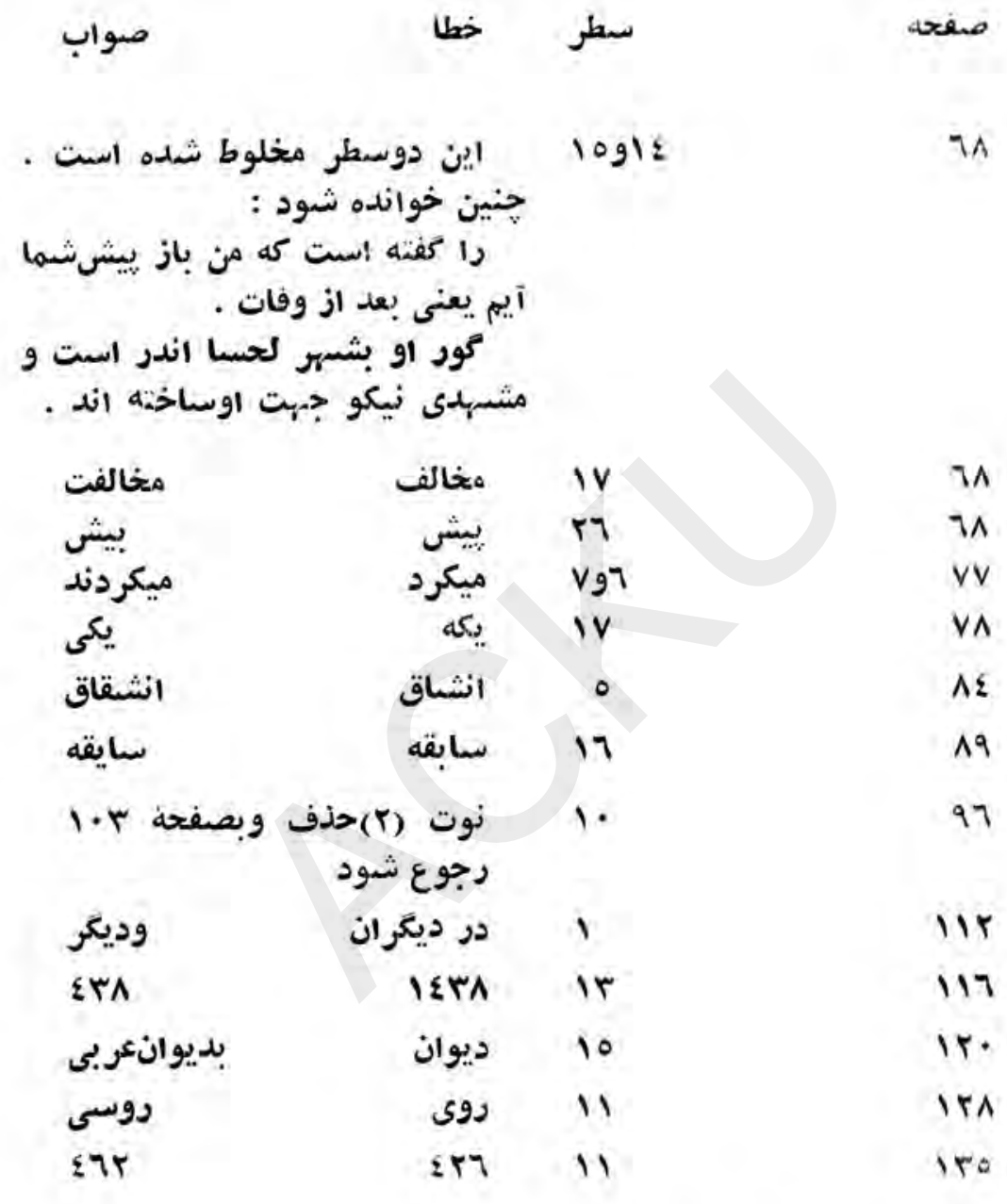




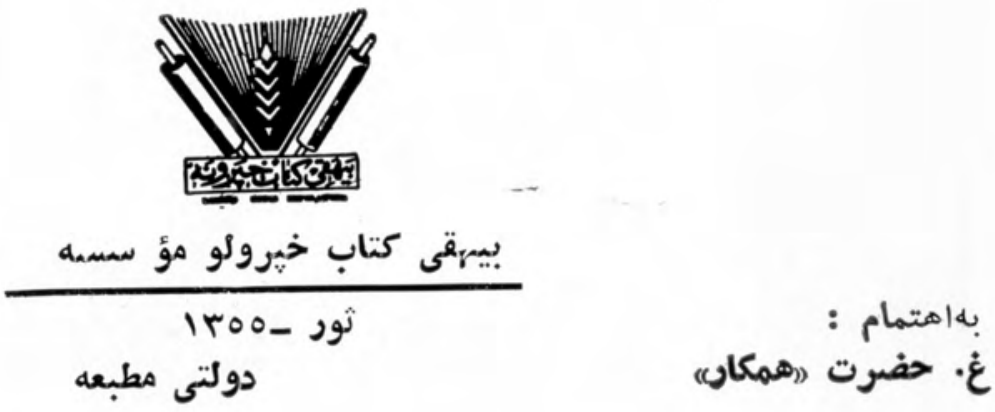


Ministry of Information and Culture

\section{Naser Khosrau of Balkh}

Eleventh Century Philosopher and Poet

of Afghanistan

His life and works

by

\section{Abdul Wahab Mahmud Tarzi}

Baihaqi Book Publishirg Institute

\section{Kabul 1976}

